\title{
PERCORRENDO OS TRILHOS DA FERROVIA RUMO ÀS ASSOCIAÇÕES ENTRE LONGEVIDADE HUMANA E FATORES AMBIENTAIS
}

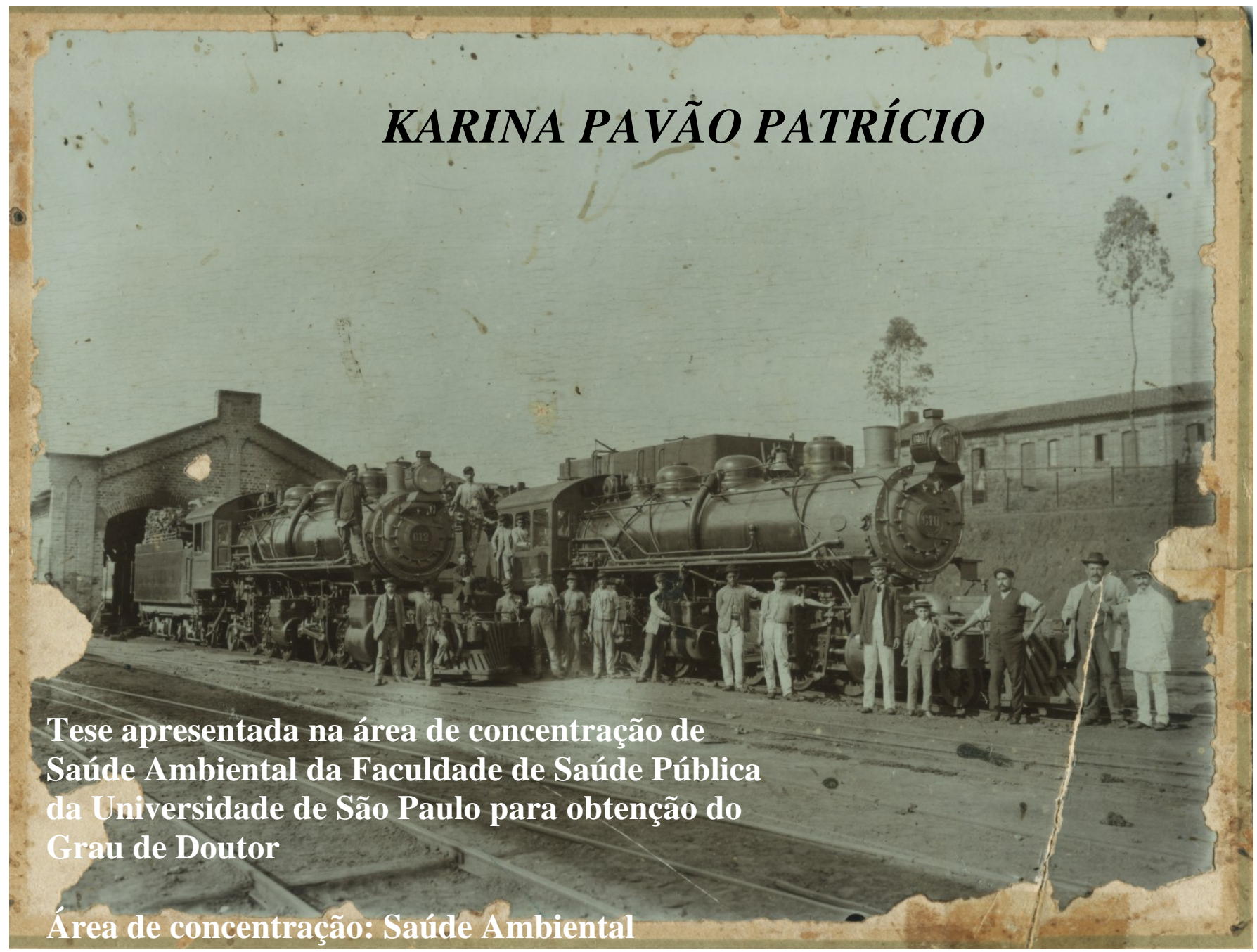

ORIENTADORA: PROFA. DRA HELENA RIBEIRO

São Paulo

2006 
Autorizo, exclusivamente para fins acadêmicos e científicos, a reprodução total ou parcial desta tese, por processos fotocopiadores.

Assinatura:

Data: $07 / 04 / 2006$ 
Estudo subsidiado pela Fundação de Amparo à Pesquisa do Estado de São Paulo (FAPESP), processo no. 03/13580-3 
A todos

$$
\begin{aligned}
& \text { os ferroviários } \\
& \text { da Estrada de } \\
& \text { Ferro Sorocabana } \\
& \text { de Botucatu, pelo } \\
& \text { importante papel } \\
& \text { que desempenharam } \\
& \text { para nossa sociedade, } \\
& \text { hoje esquecido... }
\end{aligned}
$$

Destaco, também, a importância das contribuições à minha formação como pesquisadora, desde a infância (meu querido Pai e historiador: Jaciro Campante Patrício)

até o presente (meu eterno orientador: Katsumasa Hoshino)

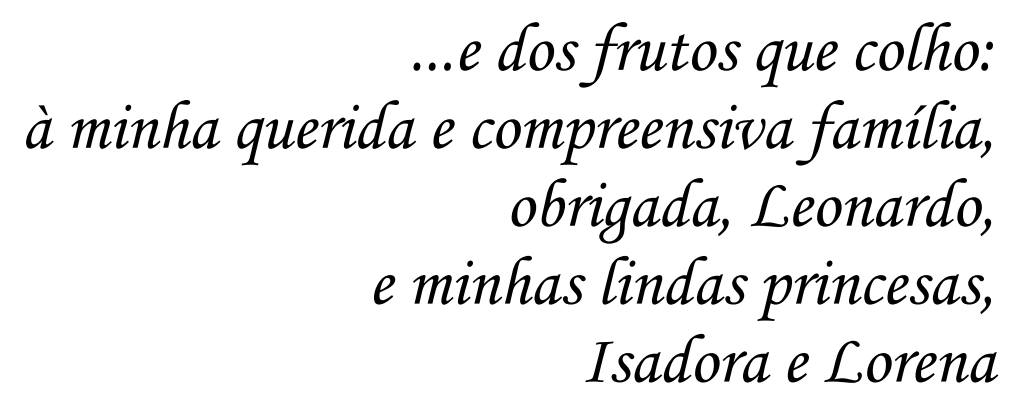




\section{AGRADECIMENTOS}

Esta tese foi, realmente, uma 'gestação científica e biológica'. Ao mesmo tempo em que a delineava, imaginando seu futuro, o mesmo processo se dava em minha vida pessoal, com minha segunda filha, que foi gerada assim que comecei a prestar os exames para conseguir entrar no doutorado, conquistando o primeiro lugar. Hoje, otho para a sua vivacidade, e constato que valeu a pena... Obrigada, queridas filhas, por permitirem, embora às vezes so6 protestos, que a mamãe trabalhasse tanto.

Agradeço aos meus queridos ferroviários, que tive o imenso prazer de conhecer, minha admiração a todos vocês, pelo trabalho importantíssimo que desempenharam (Srs.: Ventura, Catharino, Toninho, Domingos, Biguá, Brasílio, Denadai, João Batista, João Papa, Alexandre, Miguel, Ary, Nestor, Laudelino, Moacyr, Walfredo, Mário Godoy, Coraini, Santini, Mário Massagli, Bonome, Zé Góes, Adipe, Manoel, Benedito, José Mota, José Orsi, José de Oliveira, Romualdo, Natal, Lamartine). E a todos os demais ferroviários da EF Sorocabana, à Associação dos ferroviários aposentados e pensionistas da EFS de Botucatu, na figura do Sr. Orlando de Almeida; e ao Sindicato dos ferroviários, através do Sr. Hélio Masqueti, pelos cadastros e valiosas informações fornecidas.

À CPG, à Faculdade de Saúde Pública, a todo seu corpo docente, e ao Depto. de Saúde Ambiental, por terem me recebido tão bem, compartilhando seu vasto conhecimento. Eà cidade de São Paulo, por ter me acolhido e permitido não vê-la mais com olhos amedrontados.

À querida Profa. Helena Ribeiro, por ter aceito o desafio de me orientar nesta complexa tese, sempre compreensiva frente aos pro6lemas que The trazia ao longo destes 4 anos, meio conturbados, mas procurando entusiasmar-me sempre. Muito Obrigada!

Ao meu departamento de Saúde Pública da VNESP/Botucatu agora, já efetiva no time -, pelo completo apoio para finalizar esta tese. A 
todos os meus parceiros de trabatho e amigos. A Eliana e Toninho Cyrino, pelo eterno apoio pessoal e profissional; a Ivete Dalben, pela prontidão em auxiliar na análise dos dados quantitativos.

A toda a equipe do Noúcleo de Tigilância Epidemiológica, pela compreensão, apoio e coleguismo, dando continuidade ao trabalho eficazmente durante a minha grande ausência - em especial à enfermeira Edna, AMIGA, e ao sempre prestativo Marcos Venícios.

Ao Prof. Katsuma Hosfino, pela incansável busca pela ciência e discussões preciosas durante minha formação.

À Profa. Sífvia Bocchi, por ter aparecido em minha vida em um momento crucial, acolhendo-me pacientemente e enriquecendo minha pesquisa com esta abordagem qualitativa.

À Profa. Alice Moreira Derntl, pelo auxílio e grande estímulo ao projeto desta tese.

Ao amigo e Prof. Newton Madeira pelos 'empurrões' e auxílio no processo de apresentação dos dados aos sujeitos e registro fotográfico, validando a pesquisa.

A toda a minha família: à minha irmã, que sempre procurava ser otimista nos momentos dificeis que enfrentei ao longo deste doutorado; à minha mãe, que faz de tudo para ajudar, e ao meu pai, pelos conhecimentos que sempre nos ensinou, empiricos e científicos.

$\mathcal{A}$ todos os meus amigos, que estão ao meu redor, apoiando, socorrendo e enaltecendo meu trabalho.

Ao meu marido, pelas inúmeras abdicações feitas em nome de minha tese, e às minhas filhas amadas, pela compreensão madura da Isadora e pelas incansáveis reivindicações de Lorena, fazendo-me ver o outro lado da vida. (Agora, poderei cumprir tudo o que prometi a vocês...) 


\section{RESUMO}

Patrício KP. Percorrendo os trilhos da ferrovia rumo às associações entre longevidade humana e fatores ambientais. São Paulo; 2006. [Tese de Doutorado Faculdade de Saúde Pública da USP].

Preocupações com o envelhecimento populacional, que cresce rapidamente nos países em desenvolvimento, aliado à intensa degradação do meio ambiente, levaram ao delineamento desta pesquisa. Inicialmente, procurou-se discutir e compreender o processo de envelhecimento individual e populacional, estudando suas teorias: por que e como envelhecemos e alcançamos a longevidade. Destaca-se os fatores associados positivamente à longevidade: restrição alimentar, genética e hereditariedade, hábitos de vida, engajamento social, entre outros. E condicionantes negativos, situações de exposição opostas a estas, dentre as quais a poluição merece destaque pela morbimortalidade a ela associada, podendo encurtar o tempo de vida. Destaca-se a complexidade dos problemas ambientais e a necessidade de romper com o reducionismo, avançando na Saúde Ambiental e seus indicadores. O objetivo do presente estudo foi compreender as possíveis associações entre fatores ambientais e aumento da longevidade humana, segundo a perspectiva de um grupo de longevos ferroviários. Questionário semi-estruturado foi aplicado a uma população mais homogênea de longevos (30 ex-ferroviários aposentados da Estrada de Ferro Sorocabana de Botucatu). Caracterizou-se a vida desses indivíduos e se resgatou a importante história da ferrovia, buscando evidências de associações entre meio ambiente, saúde e longevidade, por intermédio de metodologia qualitativa (Grounded Theory) e quantitativa. Utilizando a Grounded Theory, emergiram três fenômenos, retratados a partir da experiência dos entrevistados: ANIQUILANDO A VIDA, GERANDO VIDA e FALTANDO CONTROLE SOCIAL E DO ESTADO. Esses longevos percebem o aniquilamento atual do meio ambiente, da ferrovia e até da própria vida, desencadeado pela falta de controle social e do Estado, aliado à falta de consciência coletiva, empreendido pelo movimento da ideologia capitalista do lucro a qualquer custo. Percebem que vários fatores influenciam a longevidade, como: conviver em um ambiente harmônico e sem poluição; adotar estilo de vida saudável e sociável; envolver-se com o trabalho e ter renda para se sustentar; ser e estar tranqüilo e feliz; fatores biológicos e genéticos favoráveis. Por meio desta pesquisa, levantam-se três premissas: a complexidade dos fatores associados ao binômio meio-ambientelongevidade, suas inter-relações, e a necessidade de 'internalização' do meio ambiente no processo de saúde-doença-envelhecimento. Propõem-se nova hipótese nas teorias da longevidade: "valorização das funções desempenhadas"(VFD). A partir da experiência dos longevos, destacando o papel da memória, denota-se a importância em subsidiar a população idosa a empoderar-se para que possa exigir dos governantes ações mais efetivas no sentido de garantir melhor qualidade de vida. Também é importante empoderá-los para que possam lutar contra a degradação ambiental e da própria vida, contra esta cultura do imediatismo e da etnodesvalorização, em um processo dialético histórico que faz o passado representar a vida (ganhos = trabalho, tempo áureo da ferrovia) e o presente a morte (perdas = degradação ambiental, aniquilamento da ferrovia e ferroviários, doenças).

Descritores: Longevidade. Meio ambiente. Ferrovia. Grounded theory. Empoderamento. Teorias do envelhecimento 


\section{SUMMARY}

Patrício KP. Percorrendo os trilhos da ferrovia rumo às associações entre longevidade humana e fatores ambientais. [ Traversing the raiwail route to association between human longevity and environmental factors]. São Paulo (BR); 2006. [PhD Thesis-Faculdade de Saúde Pública da Universidade de São Paulo Brazil]. Concerns with population aging, which grows fast in developing countries, associated with the intense environmental degradation, have led to delineation this research. Initially tried to discuss, and understand individual and population aging process, studying their theories: how and why we age, and reach longevity. Emphasize the factors positively associated to longevity: food restriction, genetics, and heredity, life habits, social engagement, among others. And negative conditioners, situation of exposure opposite to these, especially highlighting pollution because of the morbimortality associated with it, can shorten the life-span. Complexity of environmental problems, and necessity to break up reductionism are outstanding, moving forward in Environmental Health and its indicators. The objective of the current study aim to comprehend the possibility of associating environmental factors with an increase in human longevity, through the perspective of a group of longevity railroaders. A "semi-structured" questionnaire was applied to a homogeneous longevity group (30 retired ex-railroaders from Estrada de Ferro Sorocabana in Botucatu, State of São Paulo). It characterized the lives of these individuals and recovered the importance of railroad history, seeking evidences of associations among environment, health, and longevity through qualitative methodology (Grounded Theory) and quantitative one. Through Grounded Theory, three phenomena emerged, depicted from the experience of the interviewed people: ANNIHILATING LIFE, GENERATING LIFE, and LACKING SOCIAL, AND STATE CONTROL. These longevity individuals detect the current annihilation of the environment, of the railroad, and even of life itself, descending from the lack of social, and State control, allied with lack of a collective conscience, undertaken by the movement of capitalist ideology of 'profit at any cost'. They perceive that various factors have an influence on longevity, such as living in a harmonious environment without pollution, adopting a healthful and sociable lifestyle, involving oneself in work that earns a sustainable income, becoming and staying tranquil and happy; having favorable biological and genetic factors. This research raises three premises: the complexity of factors associated to the "binomial" environment longevity; their interrelations; and the need to "internalize" environment in the healthdisease-aging process. Suggest a new hypothesis of theory of longevity: "Valorization of the Develop Functions' (VDF). From the experience of longevity workers, emphasizing memory's role, it denotes the importance of providing the elderly population and empowering them for what they may demand from more effective governmental actions in the sense of guaranteeing a better quality of life. Also it is important to empower them for their struggle against degradation of the environment and own lives, against this culture of "immediatism", and ethno devaluation, in a historic dialetic process which makes the past represent life (profits=work, golden age of the railroads) and the present signify death (losses=environmental degradation, annihilation of the railroad and railroaders, diseases). Descriptors: Longevity. Environment. Railroald. Gronded theory. Empowerment. Theories on aging. 


\section{LISTA DE QUADROS}

Quadro 1. Categoria A1 - Degradando os recursos hídricos: subcategorias, elementos e

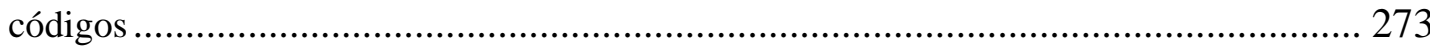

Quadro 2. Categoria A2 - Destruindo a fauna e a flora: subcategorias, elementos e

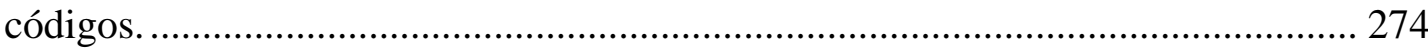

Quadro 3. Categoria A3 - Aumentando a poluição com o tempo: subcategorias, elementos e códigos.

Quadro 4. Categoria A4 - Ocorrendo descontrole ambiental: subcategorias e códigos.

Quadro 5. Categoria A5 - Modificando as propriedades dos alimentos: subcategorias e códigos. 281

Quadro 6. Categoria A6 - Sentindo desprazer em relação ao meio ambiente atual: subcategorias e códigos.

Quadro 7. Categoria B1 - Destruindo todo patrimônio da ferrovia: códigos........... 282

Quadro 8. Categoria B2 - Não sendo bom o desempenho dos novos gestores:

subcategorias e códigos.

Quadro 9. Categoria B3 - Estagnando investimentos e recursos para a ferrovia: subcategorias, elementos e códigos.

Quadro 10. Categoria B4 - Sendo a ferrovia ameaçada pelo crescimento das rodovias:

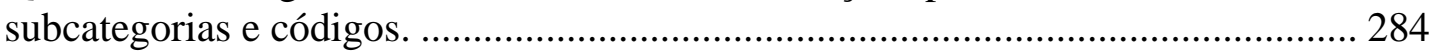

Quadro 11. Categoria B5 - Perdendo prestígio e remuneração: códigos................ 285 Quadro 12. Categoria B6 - Despertando tristeza e saudade: Categoria e códigos. . 285 Quadro 13. Categoria C1 - Adotando estilo de vida saudável: subcategorias e códigos.

Quadro 14. Categoria C2 - Não existindo consenso se habitat harmônico e sem poluição é positivo para a longevidade: subcategorias e códigos........................... 287 Quadro 15. Categoria C3 - Sentindo prazer nas ações realizadas: códigos. ............ 288 Quadro 16. Categoria C4 - Envolvendo-se com o trabalho e tendo renda para se sustentar: subcategorias e códigos. ........................................................................ 288

Quadro 17. Categoria C5 - Crendo no espiritualismo e na sorte: códigos............... 289

Quadro 18. Categoria C6 - Sendo e estando tranqüilo e feliz: códigos. ................... 289

Quadro 19. Categoria C7 - Possuindo fatores biológicos e genéticos favoráveis:

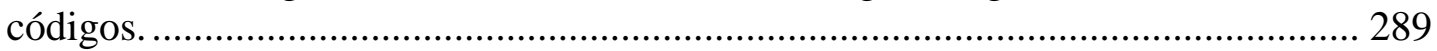

Quadro 20. Categoria C8 - Controlando a própria saúde: códigos. ........................ 290

Quadro 21. Categoria C9 - Percebendo vários fatores associados: códigos. .......... 290

Quadro 22. Categoria D1 - Podendo o meio ambiente influenciar a saúde: códigos.290 Quadro 23. Categoria D2 - Podendo o meio ambiente não influenciar a saúde: subcategorias e códigos.

Quadro 24. Categoria D3 - Poluição e contaminação prejudicando a saúde: categoria e códigos.

Quadro 25. Categoria D4 - Qualidade do ar e da água influenciando a saúde: códigos.

Quadro 26. Categoria D5 - Sendo melhor para a saúde locais com mais área verde: códigos.

Quadro 27. Categoria E1 - Ferroviário alcançando ou não a longevidade: subcategorias e códigos. 292

Quadro 28. Categoria E2 - Tendo um emprego com estabilidade e carreira: códigos.293 
Quadro 29. Categoria E3 - Tendo um bom salário e crédito na cidade: subcategorias e códigos.

Quadro 30. Categoria E4 - Desfrutando de benefícios como ferroviários: códigos.294 Quadro 31. Categoria E5 - Exigindo muita atividade física no trabalho: códigos.. 295 Quadro 32. Categoria E6 - Contando com controle periódico e assistência à saúde:

códigos. 295

Quadro 33. Categoria E7 - Convivendo em um bom ambiente de trabalho: códigos.295 Quadro 34. Categoria E8 - Dedicando-se e sentindo prazer no trabalho: códigos. 296 Quadro 35. Categoria E9 - Orgulhando-se em ser ferroviário: subcategorias e códigos. 296

Quadro 36. Categoria F1 - Desenvolvimento da cidade favorecido pela ferrovia: subcategorias, elementos e códigos. 297 Quadro 37. Categoria F2 - Relembrando o trabalho desenvolvido na ferrovia: subcategorias e códigos.

Quadro 38. Categoria F3 - Sendo a ferrovia importante para o progresso: subcategorias, elementos e códigos. 304 Quadro 39. Categoria 3.1 - Faltando a conscientização de preservar o meio ambiente e a ferrovia: subcategorias e códigos. 306 Quadro 40. Categoria 3.2 - Sendo difícil de definir meio ambiente: subcategorias e códigos. 307

Quadro 41. Categoria 3.3 - Agindo o Estado de forma ineficiente: subcategorias e códigos. 
INTRODUÇÃO

CAPÍTULO 1 - ENVELHECIMENTO, LONGEVIDADE E MEIO

AMBIENTE.

1.1 - O envelhecer da população: por que e como este fenômeno ocorre no contexto individual e populacional? ................................................................................... 5

1.2 - Fatores associados a uma maior longevidade humana....................................... 12

1.3 - Meio ambiente e doenças associadas ................................................................... 23

1.3.1 - Retomando a história do desmatamento e do processo saúde-doença ligado

às condições ambientais....................................................................................... 23

1.3.2 - Os problemas ambientais e seus riscos à saúde............................................ 28

1.3.3 - A complexidade da Saúde Ambiental............................................................ 35

1.4 - Definindo Meio Ambiente e indicadores ambientais ............................................ 41

1.4.1 - Refletindo sobre os conceitos associados a meio ambiente.......................... 41

1.4.2 - Definição e aplicação de indicadores ambientais ........................................ 48

OBJETIVOS....................................................................................................... 52

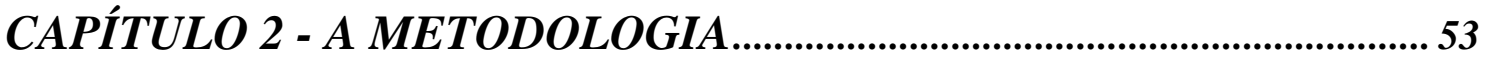

2.1 - A procura de um local adequado para o desenvolvimento do estudo ............... 53

2.2 - Selecionando uma população longeva ................................................................. 59

2.2.1 - Localizando os ferroviários aposentados e elaborando um cadastro ............61

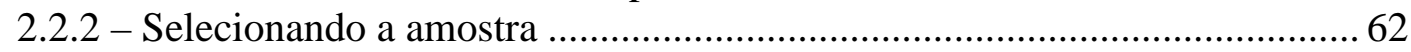

2.3 - Buscando os métodos quantitativos e qualitativos............................................65

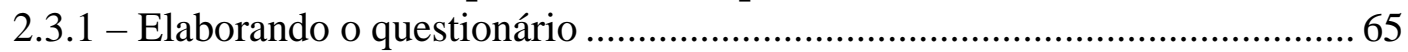

2.3.2 - Selecionando os métodos qualitativos e quantitativos................................... 66

CAPÍTULO 3 - A EXPANSÃO DOS TRILHOS DA ESTRADA DE FERRO SOROCABANA EM DIREÇÃO AO INTERIOR PAULISTA, BOTUCATU: INÍCIO E FIM DE UMA HISTÓRIA..................................... 77

3.1 - Percorrendo a história da Estrada de Ferro Sorocabana ................................... 77

3.2 - Conhecendo um pouco o município de Botucatu.................................................92

Capítulo 4 - CARACTERIZANDO OS FERROVIÁRIOS DA ESTRADA DE FERRO SOROCABANA DE BOTUCATU ENTREVISTADOS....... 96

4.1 - Conhecendo a amostra de longevos ferroviários...................................................96

4.2 - As características da mortalidade dos ferroviários ........................................ 130 
CAPÍTULO 5 - O RETRATO DOS CONHECIMENTOS E DA

HISTÓRIA DOS FERROVIÁRIOS ENTREVISTADOS:

CONTRIBUIÇÕES DO MEIO AMBIENTE PARA A LONGEVIDADE133

5.1 - Os fenômenos identificados 133

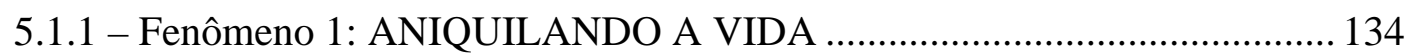

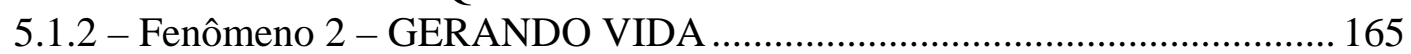

5.1.3 - Fenômeno 3 - FALTANDO CONTROLE SOCIAL E DO ESTADO .... 210

5.2 - Descobrindo a categoria central........................................................................... 220

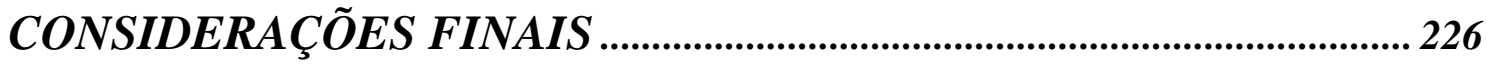

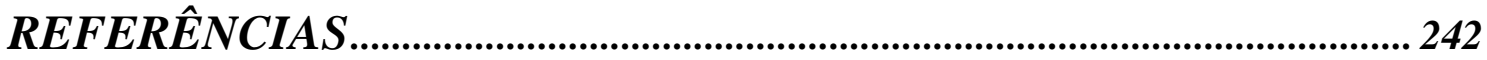

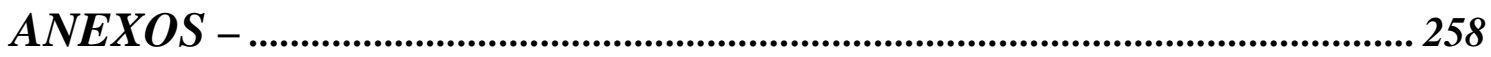

1 - PARECER DO COMITÊ DE ÉTICA EM PESQUISA........................................258

2 - CONSENTIMENTO LIVRE E ESCLARECIDO DE PARTICIPAÇÃO............259

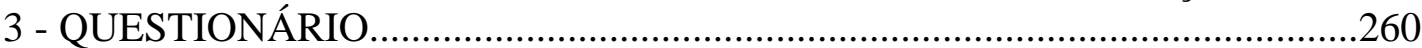

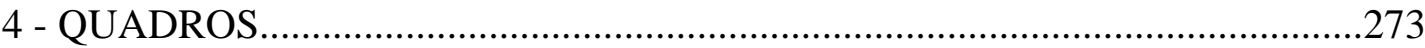



INTRODUÇÃO

As preocupações com o acelerado envelhecimento populacional nos países em desenvolvimento, aliado à intensa degradação do meio ambiente, levaram ao delineamento desta pesquisa.

Inicialmente, procuramos compreender e discutir o processo de envelhecimento individual e populacional, estudando suas teorias, por meio de levantamento bibliográfico. Nota-se que várias teorias têm sido propostas, uma vez que o envelhecimento é um fenômeno quase universal e a expectativa de vida humana vem aumentado. Surgem as perguntas: Por que envelhecemos? Como uma população envelhece? É possível compreender todo este fenômeno? As pesquisas nesta área começaram a se fortalecer nas últimas três décadas, reforçando a importância de se desenvolver estudos neste recente campo.

Além da questão do envelhecimento, propomos abordar a longevidade. Para tanto, realizou-se vasto levantamento bibliográfico, buscando os possíveis fatores determinantes e condicionantes da longevidade. E emergiram outras indagações: Por que umas pessoas vivem mais que outras? Qual segredo para viver bastante? Novamente, nota-se a dificuldade de compreender os mecanismos que levam à longevidade, por se tratar de um fenômeno complexo, com muitos fatores associados. Em termos metodológicos a dificuldade aumenta em face ao grande tempo que as pesquisas demandam e a escassez de indicadores epidemiológicos nesta área. Serão apresentados os vários fatores, discutidos na literatura científica, que promovem a longevidade, como: restrição alimentar, genética e hereditariedade, atividade física intensa, bom relacionamento conjugal e familiar, importância dos avós e da autovalorização, modo de ser e estar feliz e tranqüilo, melhores condições socioeconômicas e saúde. Todos estes serão discutidos ao longo do texto, no capítulo 1 , item 2.

Outro grande tema a ser estudado será o meio ambiente, uma vez que o objetivo do presente estudo é compreender associações existentes entre meio ambiente, longevidade e saúde segundo a vivência de ferroviários longevos. Será percorrida, sucintamente, a história do desmatamento ocorrido no Brasil, evidenciando que a ocupação do território, com o desenvolvimento da agricultura 
canavieira e da cafeicultura, associado ao crescimento das ferrovias, notando-se a forma predatória com que estas ações foram realizadas e aceleradas pela industrialização. No entanto, à época, não eram claros o impacto e os danos futuros que tudo isto poderia causar. A partir da década de 1970, essas preocupações começaram a ganhar o cenário mundial, uma vez que os países desenvolvidos já estavam colhendo os frutos negativos da intensa devastação ocorrida inicialmente lá. Vários projetos e políticas ambientais, inclusive com pactos internacionais, vêm sendo implantados na tentativa de controlar os riscos e problemas ambientais, frutos de produção e consumo cada vez mais acelerados. Com este panorama, a saúde humana vem sendo afetada, direta ou indiretamente. O desmatamento, a agricultura, o desenvolvimento industrial e o próprio crescimento populacional podem gerar contaminação dos recursos hídricos, do ar, dos solos e dos alimentos, prejudicando a saúde humana. Vários estudos científicos serão destacados para exemplificar os impactos negativos que o meio ambiente contaminado pode causar à saúde da população. Ao tentar compreender como se dá esta interação, verifica-se que, assim como é complexo o fenômeno do envelhecimento, também é o da saúde ambiental. Nota-se que à saúde ambiental associam-se muitas variáveis: as ações podem ser sentidas em curto, médio e longo prazo e variam conforme a vulnerabilidade da população exposta, entre outras. A dificuldade encontra-se nas incertezas científicas e epistemológicas que muitas vezes a ciência clássica não consegue responder, sendo necessário superar o reducionismo e adotar práticas transdiscisplinares para a compreensão dos problemas ambientais e a adoção de medidas preventivas e curativas eficazes para a saúde da população.

Verificamos que o meio ambiente pode ser definido de várias formas, conforme o enfoque do pesquisador, havendo uma tendência a 'desnaturalizar a natureza', ou seja, ela é recortada e analisada como algo externo, um cenário onde podem ocorrer doenças. Desde os primórdios das pesquisas em saúde ambiental, adota-se esta 'externalização' do meio ambiente, como nota-se no modelo 'agentehospedeiro-meio', em que o agente e o hospedeiro são concebidos como externos ao meio. Discutiremos, ainda, os indicadores ambientais, evidenciando, novamente, as suas limitações. Questionamos a necessidade de se romper esta visão fragmentada do 
meio ambiente e avançar, utilizando outros instrumentos e modelos, que busquem a globalidade do fenômeno.

Diante de todas estas discussões é que se justifica a presente investigação, buscando associações entre longevidade e meio ambiente, segundo a vivência de um grupo de ferroviários longevos.

A metodologia adotada no estudo será detalhada, descrevendo como foi feita a seleção do município (Botucatu), dos longevos do município (ferroviários aposentados da Estrada de Ferro Sorocabana de Botucatu - EFS), a elaboração de extenso questionário e a opção por trabalhar com a metodologia qualitativa para analisar os fenômenos (utilizando a Grounded Theory) e a análise dos dados quantitativos para auxiliar na descrição do grupo estudado e dos indicadores ambientais.

Para melhor compreensão do universo da pesquisa e dos resultados, apresentaremos um breve capítulo sobre a história das ferrovias e o estabelecimento da Estrada de Ferro Sorocabana (EFS) no município de Botucatu, retratando o cenário do passado e do presente, o início e o fim. Estes percursos históricos são importantes, pois o processo de envelhecimento e a longevidade incluem fatores que aconteceram no passado, inclusive com outras gerações, inserindo-se em processo dialético histórico conjuntural, envolvendo décadas.

Nos resultados, serão apresentados os dados advindos da análise quantitativa do questionário, que descrevem o grupo estudado. Várias aspectos foram investigados: sua caracterização (estado marital, relacionamento familiar, progênie, escolaridade, longevidade familiar, temperamento); procedências; condições e indicadores ambientais; situação profissional pregressa e atual; hábitos de vida; condições de saúde atual e pregressa; alimentação pregressa; grau de satisfação do longevo em relação à sua própria vida e ao meio ambiente em que vive atualmente.

As questões abertas, analisadas através da Grounded Theory, referem-se aos seguintes tópicos: definição de meio ambiente; concepção do meio ambiente pregresso e atual; se acreditavam existir relação entre meio ambiente e saúde; como era trabalhar na EFS; caracterização da cidade naquela época; o segredo para se viver bastante; opinião sobre ferroviários viverem mais que outras pessoas, e sobre a relação entre viver bastante e meio ambiente. Estas últimas questões, analisadas de 
forma qualitativa, são retratadas com base no conhecimento e na história dos ferroviários longevos entrevistados, mostrando associações entre meio ambiente e longevidade. O leitor irá constatar que foram identificados três fenômenos que permitiram chegar à categoria central do processo.

Ao final, na conclusão abarcaremos as discussões colocadas inicialmente, enriquecidas com os resultados que obtivemos na presente pesquisa, contribuindo para avançar nestes campos complexos e envolventes do envelhecimento/longevidade e do meio ambiente.

O leitor é convidado a repercorrer conosco esses intrigantes e emocionantes trilhos da história da EFS, valendo-se da memória e dos relatos dos ferroviários, ora entusiásticos ora desolados, denunciando toda a degradação ambiental e da ferrovia, gerando o aniquilamento da vida, e a falta de controle social e do Estado, responsável por essa situação. O passado passa a representar a vida? E o presente, a morte? 


\section{CAPÍTULO 1 - ENVELHECIMENTO, LONGEVIDADE E MEIO AMBIENTE}

\section{1 - O envelhecer da população: por que e como este fenômeno ocorre no contexto individual e populacional?}

O envelhecimento humano é um fenômeno universal e inevitável. Pode-se considerá-lo como um produto da interação entre fatores genéticos, ambientais e estilo de vida, os quais influenciam a longevidade, tanto entre as espécies como dentro de cada uma (PETROPOULOU e col. 2000). Alguns autores consideram que o processo de envelhecimento ocorre desde os protozoários, entretanto, diversos fatos levam a suspeitar que ele não é universal no reino animal (COOPER 1994). Na espécie humana, envelhecer é uma etapa pela qual todos os indivíduos, a partir de uma determinada idade, passarão. Embora seja um fenômeno comum, o envelhecimento ainda não tem suas bases fisiológicas e seus determinantes bem conhecidos. O que se sabe a respeito do processo de envelhecimento provém de estudos realizados nas últimas três décadas. Na última década, mais de 300 teorias (hipóteses) a respeito dos mecanismos responsáveis pelo envelhecimento foram propostas (MEDVEDEV 1990). É patente que é inviável tentar explicar esse processo por meio de um só mecanismo. As teorias de envelhecimento, até a década de 1990, eram classificadas em dois grandes grupos, de forma geral: a) teorias estocásticas, que supõe o envelhecimento como decorrente de um acúmulo aleatório de desajustes que vão ocorrendo ao longo do tempo; b) teorias não-estocásticas, que supõem o envelhecimento como um processo predeterminado.

Cinco teorias destacam-se entre as estocásticas: 1) a teoria do equívoco, ou erro catastrófico, propõe que a função celular seria prejudicada pelo acúmulo de erros na síntese protéica. Esta teoria não foi comprovada devido à falta de evidências sobre as alterações na seqüência de aminoácidos nas proteínas de animais idosos, comparativamente à de jovens e, tampouco, há evidências de aumento no número de RNA-t defeituosos com o envelhecimento; 2) teoria do "cross-linking”, que supõe, como causa do envelhecimento, a ocorrência deste processo nas proteínas e outras 
macromoléculas. Uma observação pertinente é que o colágeno extracelular torna-se cada vez mais “cross-linked” em humanos e animais de laboratório; 3) a teoria do desgaste e dilaceração parte do pressuposto de que o organismo é constituído de componentes insubstituíveis, que o acúmulo de lesões às partes vitais levaria à morte das células, tecidos, órgãos e organismo. Mesmo a reparação das lesões no DNA poderia ser incompleta, comprometendo as funções celulares; entretanto, estudos laboratoriais sobre o envelhecimento não demonstraram um declínio constante na reparação do DNA; 4) a teoria dos radicais livres estaria ligada à propriedade de estes serem altamente reativos, lesando proteínas, enzimas e DNA, e que o acúmulo destas lesões seria responsável pelo envelhecimento; 5) a teoria do erro primário propõe que a alteração determinante do envelhecimento ocorra no DNA.

As teorias não-estocásticas são representadas por: 1) a teoria do marca-passo, que supõe existir entidades programadoras de envelhecimento dentro dos órgãos e sistemas, ou seja, acredita-se que determinados órgãos ou sistemas sejam os "marcapassos” intrínsecos do envelhecimento, sendo programados geneticamente para involuírem em épocas específicas durante a vida de um organismo; 2) a teoria genética, pela qual as alterações já seriam determinadas geneticamente. Sabe-se que os fatores genéticos são determinantes importantes no processo de envelhecimento, embora os mecanismos envolvidos ainda sejam desconhecidos (ABRAMS e BERKOW 1994; CARVALHO FILHO e NETO PAPALEO 1994).

Atualmente, muitas outras teorias surgiram ou as antigas foram revistas, e esta classificação em estocástica ou não-estocástica tem sido criticada por alguns autores. KIRKWOOD e AUSTAD (2000) discutem a evolução das teorias do envelhecimento. Observando a figura 1, eles destacam quatro teorias e possibilidades. A primeira (fig. 1a) estaria associada à idéia de que a senescência é programada, em parte, para limitar o crescimento populacional ou acelerar a troca das gerações, possibilitando seleção de indivíduos mais adaptados às mudanças ambientais. No meio animal natural, os animais selvagens, sujeitos às intempéries desse meio, dificilmente sobrevivem até se tornarem idosos. Isto acaba ocorrendo somente quando estão em cativeiro ou protegidos (fig.1a). Uma outra teoria, conhecida como "acumulação de mutação", parte do princípio de que existe um progressivo enfraquecimento na força da seleção com o aumento da idade. Quando a 
curva de sobrevivência, no mundo animal, declina para níveis muito baixos, a força da seleção é muito fraca para se opor à acumulação de mutações de genes com efeitos deletérios tardios. Isto levaria ao aparecimento de uma "sombra de seleção" em idades mais avançadas. Esta sombra de seleção permitiria que genes alelos com efeitos deletérios tardios se acumulassem sobre as gerações e fossem responsáveis pelo envelhecimento (fig. 1b). Outra teoria é a da pleiotropia, também conhecida como pleiotropia antagonista, a qual sugere que o envelhecimento decorre de efeitos deletérios tardios de alelos que foram selecionados como bons no início da vida. Desta forma, os genes selecionados como tendo efeitos bons, no início da vida, com o passar da idade, acabariam tendo efeitos deletérios tardios (fig. c). Como exemplo desta teoria, foram realizadas pesquisas com Drosophilas, dentre as quais observouse que populações selecionadas com maior longevidade tinham diminuição da fecundidade, e populações mais resistentes para situações estressoras tinham aumento da longevidade e diminuição da fecundidade (GAWAIN e col. 2000). Esta é a base para outra teoria conhecida como "disposable soma”, que se baseia na ótima alocação de recursos metabólicos entre a manutenção somática e a reprodutiva, ou seja, o envelhecimento seria o resultado entre a alocação de energia na reprodução e na sobrevivência, e os bem- sucedidos teriam uma maior longevidade, que poderia ser passada para as próximas gerações. Por último, KIRKWOOD e AUSTAD (2000) destacam que a manutenção somática efetiva é requerida tanto para as funções fisiológicas diárias como para as adaptações perante às mudanças ambientais, para garantir a sobrevivência. Todos os mecanismos de combate a situações internas deletérias, como reparo de DNA e sistema antioxidativo, exigem recursos metabólicos. O consumo metabólico, diante dessas situações, poderia ir desencadeando o envelhecimento do indivíduo. 

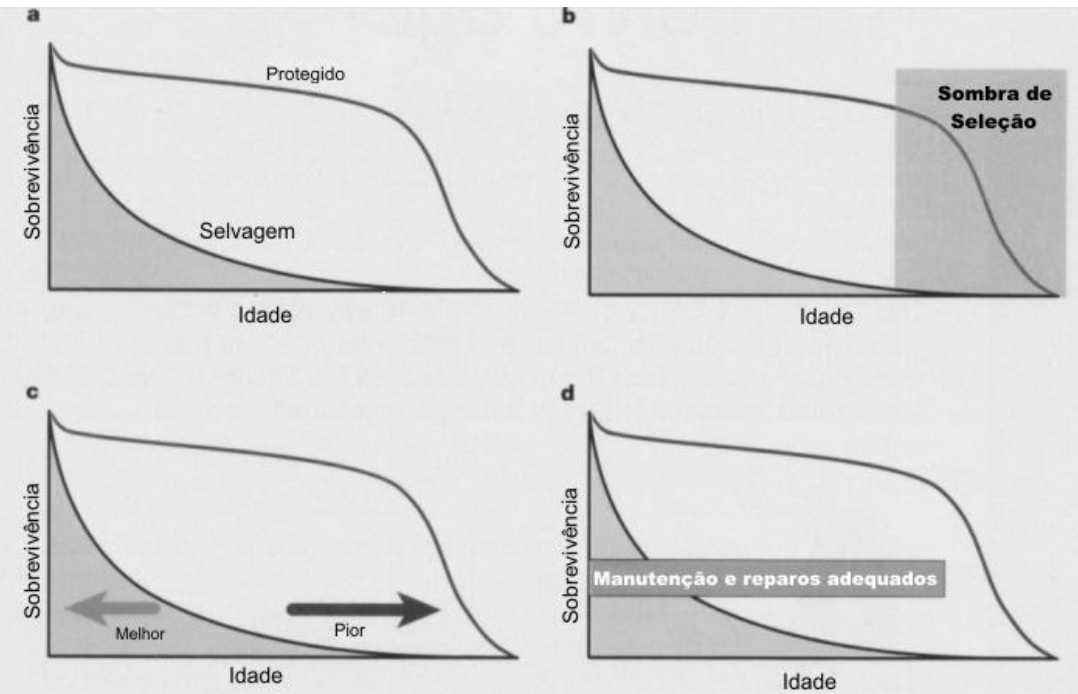

Figura 1: Teorias evolucionárias de envelhecimento. a. Senescência programada;. b.

Sombra de seleção; c. Pleiotropia; d. 'Disposable soma' (Adaptado de: Kirkwood TBL, Austad SN. Why do we age? Nature 2000; 408(6809): p.234).

KIRKWOOD (2002) coloca que ainda não conseguimos desvendar o enigma do envelhecimento, ou seja, explicar por que envelhecemos. Mesmo com os avanços tecnológicos e pesquisas genéticas ainda não conseguimos compreendê-lo completamente. A teoria evolutiva argumenta fortemente contra o envelhecimento programado, referindo que estamos programados para viver, e não para morrer.

As correntes teóricas atuais apontam que o envelhecimento resulta de dois princípios: a força da seleção natural declina com a idade e a longevidade requer investimentos na manutenção somática e reparos que competem contra os investimentos no crescimento, reprodução e atividades que aumentem as aptidões. Além disso, existe um complexo mecanismo celular e molecular que atua no envelhecimento, sendo difícil sua total elucidação (KIRKWOOD 2002).

Já em relação ao envelhecimento em termos populacionais, as principais teorias baseiam-se em estudos recentes sobre longevidade humana, expectativa de vida, mudanças na morbidade, tendências das incapacidades, diminuição da mortalidade e da fecundidade. Devem ser considerados ainda os fatores geográficos, culturais, socioeconômicos e os avanços na tecnologia da saúde. ROBINE e MICHEL (2004) consideram quatro fatores associados à teoria do envelhecimento populacional: 1) o aumento nas taxas de sobrevivência das pessoas doentes, que leva à expansão da morbidade; 2) o controle das doenças crônicas, que pode levar ao 
equilíbrio entre a diminuição da mortalidade e o aumento das incapacidades; 3) a melhoria no estado de saúde e hábitos mais saudáveis, acarretando a compressão da morbidade; 4) o surgimento de pessoas bem idosas e de uma população frágil, levando a uma nova expansão da morbidade.

O envelhecimento, em termos populacionais, transformou-se em um fenômeno mundial que vem rapidamente avolumando-se, inclusive nos países em desenvolvimento. Enquanto nos países desenvolvidos o processo de envelhecimento deu-se de forma progressiva e lenta, no Brasil, a proporção de idosos começou a expressar-se a partir da década de 1960, em decorrência do declínio na mortalidade geral e da diminuição da taxa de natalidade. Este fato também foi observado nos outros países em desenvolvimento, caracterizando a transição demográfica, como é classificada por alguns autores (PEREIRA 1992; KALACHE e col. 1987; CHAMOWICZ 1997). PALLONI e PELAÉZ (2003) apontam que a taxa de crescimento da população idosa depende mais dos progressos ocorridos em relação à mortalidade na faixa etária de 0 a 60 anos, do que da diminuição da fecundidade e das condições da mortalidade em pessoas já idosas.

Estudos demográficos apontam que a população de jovens no Brasil passou de 41,9\% para 34,7\%, de 1970 a 1991. O índice de envelhecimento alcançou 13,9 em 1991, contra 6,4 em 1960, aumento superior a 100\%, em apenas três décadas (CHAMOWICZ 1997). A taxa de fecundidade total, em 2000, estava em torno de 2,3; próximo daquela de reposição, ou seja, que leva ao crescimento nulo da população ao longo dos anos (CARVALHO e GARCIA 2003). Esse declínio levou à desestabilização da estrutura etária, com modificação da conformação da pirâmide etária, promovendo ligeiro estreitamento da base e aumento do ápice, configurando o envelhecimento populacional (CAMARANO 1999; WONG 2001). O número de idosos brasileiros, em 1960, era de 3 milhões, passando para 7 milhões em 1975 e, em 2002, para 14 milhões. Isto corresponde a um aumento de 500\%, em 40 anos. Em países desenvolvidos, como a Bélgica, demorou cem anos para que a população de idosos dobrasse de tamanho (LIMA-COSTA e VERAS 2003). Estima-se que o Brasil, no ano de 2025, alcançará a $6^{\text {a }}$ posição mundial em número de idosos, com 32 milhões de pessoas idosas. Pessoas com 60 anos ou mais representarão 15,1\% da 
população, com um crescimento médio de 6,6\% ao ano, entre 2000 e 2025 (RAMOS e col. 1987; NEUPERT 1987).

O processo de envelhecimento que o Brasil enfrenta, além de estar ocorrendo de forma mais rápida, possui características peculiares. Vivencia-se um contexto institucional instável, aliado a uma situação econômica extremamente desfavorável, o que acaba levando este processo de envelhecimento a ser muito mais complicado, quando comparado a outros países. Comparar a velocidade de envelhecimento da América Latina e do Caribe com a da América do Norte, do Oeste dos EUA e da Europa Ocidental é surpreendente. A velocidade na América Latina e Caribe será ao menos duas vezes maior que nas outras regiões, sugerindo que o impacto nas duas primeiras regiões tende a ser sentido muito mais subitamente, uma vez que possivelmente não estarão prontos para dar todo tipo de suporte a essa população de idosos (PALLONI e PELÁEZ 2003).

Além do aumento populacional de idosos, tem-se observado um acréscimo na expectativa de vida das pessoas. Enquanto, no início do século, a expectativa de vida ao nascer, no mundo, era de 33,7 anos, atingindo 63,5 anos em 1980, estima-se que, até o ano 2025, ela alcance 72 anos. Embora este avanço ocorra em termos populacionais gerais, é importante destacar as grandes diferenças e a influência dos vários fatores que interferem no aumento da expectativa de vida e na longevidade nas mais diversas comunidades. O fator econômico pode influenciar grandemente a expectativa de vida, sendo que os mais ricos tendem a ganhar 15 anos a mais quando comparados aos mais pobres (CARVALHO FILHO e PAPALEO NETO 1994). Desta forma, o número de centenários tende a aumentar, entretanto, este aumento irá depender da melhoria na saúde pública e dos avanços médicos (SMITH 1997). Em países industrializados, o número de centenários tem aumentado de forma extremamente rápida, alcançando até 8\% da população, enquanto anteriormente esta proporção era de, aproximadamente, 1\%. Nos Estados Unidos, existia uma relação de 1 centenário para cada 100.000 habitantes e, atualmente, já prevalece a taxa de 1:10.000. PERLS e col. (2002) discutem que os fatores responsáveis por esse aumento acelerado seriam: as melhorias na saúde desde a fase de infância até o envelhecimento; o melhor controle das doenças infecciosas; a diminuição da mortalidade infantil e materna; tratamentos eficazes em doenças associadas à idade e 
diminuição de suas complicações e seqüelas, frutos do avanço da tecnologia da saúde.

Uma frase tornou-se conhecida e divulgada: "não basta aumentar os anos à vida, é preciso aumentar a vida aos anos”. A Organização mundial de Saúde divulga a idéia de “active ageing”, definindo como um processo de otimização de oportunidades promovendo o bem-estar físico, social e mental ao longo de toda a vida, favorecendo aumento da expectativa de vida com saúde, produtividade e qualidade de vida no envelhecimento (WHO 2001). Na realidade, deve-se tentar caminhar no sentido de garantir uma melhor qualidade de vida a esta população que envelhece rapidamente e que cada vez alcança idades mais elevadas. Os avanços tecnológicos na área da saúde permitem diagnosticar precocemente uma doença (por exemplo, diabetes), intervir e garantir uma grande sobrevida à pessoa acometida pela doença, apesar das possíveis complicações e seqüelas. No entanto, se essa pessoa for aposentada, com um salário mínimo, como a maioria dos idosos brasileiros, tendo dificuldade de acesso aos serviços de saúde e a medicamentos, vivendo em moradia sem adaptações às suas condições, e, às vezes, morando sozinha ou precisando ajudar nas despesas da família, qual a qualidade de vida que essa pessoa idosa pode ter?

O rápido envelhecimento populacional, pelo qual o Brasil passa, traz à tona várias dificuldades, tanto em termos de saúde, quanto de economia (previdência), que precisam ser equacionadas na mesma velocidade do envelhecimento da população, a fim de acolher de forma adequada e humanizada esses idosos em nosso país, diante da maior vulnerabilidade desse grupo. 


\section{2 - Fatores associados a uma maior longevidade humana}

O aumento da expectativa de vida, no século XXI, torna-se uma preocupação e um campo de muitas discussões: demógrafos com previsões alarmantes, políticos preocupados com problemas futuros, cientistas em luta contra bioéticos para testarem fatores que possam aumentar o tempo de vida. No entanto, muitos esforços acabam sendo centralizados em pesquisas voltadas mais para aumentar a longevidade humana do que para compreendê-la (TURNER 2004). Apesar de as pesquisas sobre envelhecimento terem se intensificado há 30 anos, nenhum avanço notável pode ser percebido para compreender o complexo fenômeno do envelhecimento, apenas em relação às patologias associadas com o envelhecer, como critica HAYFLICK (2000).

É importante não confundir envelhecimento com longevidade, são processos diferentes. O primeiro seria um processo mais estocástico, que afeta diretamente o sistema reprodutivo e leva à diminuição da energia disponível para manter o sistema molecular funcionando perfeitamente. Já a longevidade é um processo capaz de estender a capacidade reprodutiva, por meio da seleção natural, garantindo alcançar melhor e maior sobrevivência. Outra diferenciação, adotada por alguns autores, diz respeito à expectativa de vida e ao tempo de vida. Expectativa de vida é a média dos anos totais de vida que espera-se que uma espécie sobreviva. Tempo de vida seria o tempo máximo de sobrevivência que uma espécie pode alcançar. Antes, acreditavase que o tempo máximo de vida do ser humano homem seria de 100 anos, mas, atualmente, considera-se 125 anos (HAYFLICK 2000). Por outro lado, estudos têm demonstrado que o ser humano, em condições ambientais ótimas e tendo comportamentos saudáveis, pode alcançar a idade média, ou expectativa de vida, de 85 anos (PERLS e col. 2002). Para os Estados Unidos, estima-se um aumento de 25 anos na expectativa de vida ao nascer para os próximos séculos (KINSELLA 2005). Entretanto, OLSHANSKY e col. (2001) chamam atenção para o fenômeno da entropia, observado nas tábuas de vida. Analisando as expectativas de vida e as curvas de sobrevivência dos EUA, no período de 1900-1995, e projeções, observaram um grande aumento na expectativa de vida do primeiro para o segundo período (de 48,9 anos para 79 anos). Nos períodos subseqüentes de projeções, passaria para 89,1, aumentando apenas 10,1 anos, não mais 30 anos como nos 
períodos anteriores (figura 2). Isto mostra que a queda da mortalidade não teria mais tanto impacto no aumento da expectativa de vida, como teve no século $\mathrm{XX}$, com o controle das doenças infecto-parasitárias, medidas de saneamento básico e imunizações, entre outros avanços. Enfatizam que "mudanças no estilo de vida, procedimentos cirúrgicos, vitaminas, antioxidantes, hormônios ou técnicas de engenharia genética não terão a capacidade de aumentar a expectativa de vida como ocorreu no século XX” (OLSANSKY e col. 2001).

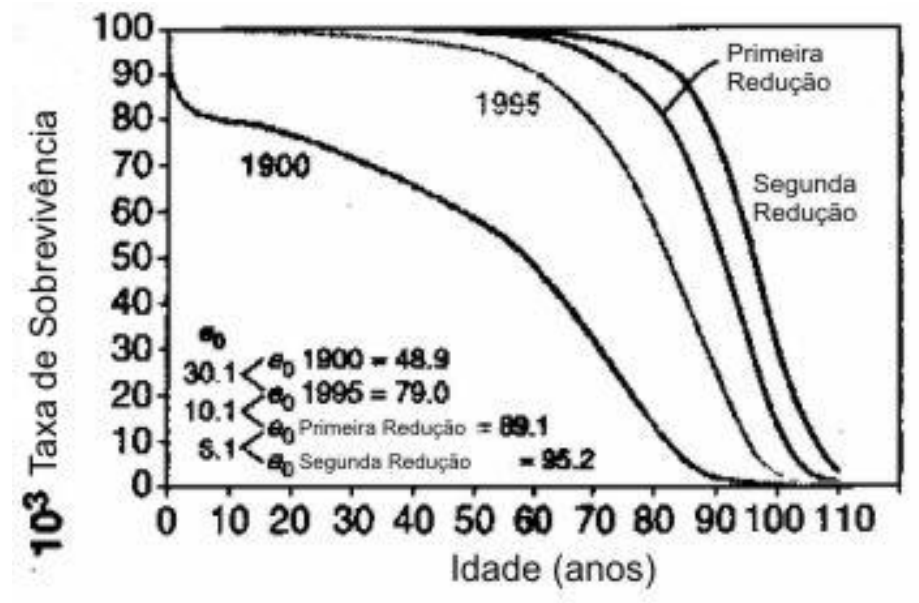

Figura 2 - Curva de sobrevivência e expectativa de vida ao nascimento para mulheres dos Estados Unidos (1900, 1995 e projeções). Adaptado de: Olshansky SJ, Carnes BA, Desesquelles A. Prospects for human longevity. Science 2001; 291(23): p.1491.

No entanto, os modelos matemáticos, de tábuas de vida, não levam em consideração as forças biológicas que influenciam o tempo de vida das pessoas de uma população geneticamente heterogênea. Desta forma, as projeções tornam-se previsões e fica difícil projetar realmente o crescimento acelerado ou mais lento de uma população heterogênea (OLSHANKY e col. 2001).

Frente ao cenário de envelhecimento populacional e aumento da expectativa de vida, a população busca ansiosa por “elixires para se viver bastante” e pesquisadores tentam estudar quais os fatores reais que interferem ou que promovem um aumento da longevidade humana. A questão alimentar tem sido bastante enfatizada. Sabe-se que a ingestão excessiva de alimentos pode estar associada à obesidade e a outras doenças que acabam por encurtar o tempo de vida e, mais recentemente, demonstrou-se, em experimentos laboratoriais, inicialmente com ratos, que a restrição alimentar (redução percentual da quantidade de alimentos ou redução calórica) de 30 a 50\% sobre a oferta de alimentos, nos períodos iniciais da vida, 
aumentava em até $40 \%$ a expectativa de vida desses animais (MCCAY e col. 1935; BERG e SIMMS 1960; ROSS 1966; STUCHLIKOVA e col. 1975; MASORO e col. 1980, YU e col. 1982; WEINDRUNCH e WALFORD 1988, WEINDRUNCH 1996). Entretanto, ainda não se conseguiu comprovar esta propriedade na espécie humana (ROTH e col. 1999). Em estudos mais recentes, observou-se, em ratos, que a restrição alimentar estava associada a uma diminuição da fertilidade total ou parcial no período de restrição. Esta alteração da fertilidade estaria associada à concentração do pouco de energia para manter o metabolismo básico de sobrevivência, prejudicando a fertilidade (SHANLEY e KIRKWOOD 2000). Outro autor faz uma comparação interessante com o fenômeno da restrição, lembrando que a hibernação, que alguns animais fazem, passa por um processo metabólico semelhante à restrição (WALFORD e SPINDLER 1997). PARSONS (1996) coloca que os hábitos dos organismos podem ser expressos como a interação entre: intensidade de estresse, magnitude das flutuações ambientais e a energia dos recursos. Ele afirma que o excesso de alimentos sempre foi visto pelos animais como prejudicial, não respeitando a sua capacidade metabólica. O contexto atual de alimentação humana passou a ser um estresse para o organismo, uma vez que representa alimentação excessiva para várias comunidades, sem ter um gasto adequado de toda essa energia excessiva. Por outro lado, alimentos antioxidantes reduzem o "perigo" dos radicais livres e podem auxiliar no aumento do tempo médio de vida, mas não a longevidade (PARSONS 1996).

Já o papel desempenhado pela genética é fato verificado e, cada vez mais, tenta-se identificar genes responsáveis pela longevidade (KIRKWOOD 1997; JAZWINSKI 2000; PETROPOULOU 2000). PEARL e PEARL (1934) foram os primeiros a verificar a existência de uma forte correlação entre grupos de nonagenários humanos com fenótipos de vida longa de seus ancestrais. Geneticistas chegam a arriscar uma hipótese de que a chance de se viver além dos 100 anos se deva a três fatores: somente ao ambiente, somente à genética ou à inter-relação entre ambos (SCHACHTER 1993). Estudos mais recentes, com centenários, têm demonstrado grande associação com os fatores genéticos familiares. Investigando populações de centenários, conseguiram demonstrar significante associação entre o gen 'REN alelo 10' e o tipo 'haplo $\mathrm{H}$ mitocondrial', como favorecendo a 
longevidade humana. (TAN e col. 2002). A maioria dos estudos com enfoque genético tem demonstrado que, aproximadamente, 25\% do tempo de vida das pessoas são determinados por componente genético. Uma das dificuldades metodológicas de se estudar os fatores genéticos é que a epidemiologia da longevidade envolve um complexo fenômeno, como fatores poligenéticos e mudanças na história da mortalidade (DE-BENEDICTS e col. 2001; GUDMUNDSSON e col. 2000). CHRISTENSEN e VAUPEL (1996) defendem a idéia de que a interação entre os genes associados à longevidade não deve acontecer apenas em um locus, mas necessita ocorrer entre os loci dos genes. E, ainda, afirmam que provavelmente um grande número de fatores ambientais e genéticos interagem na determinação do tempo de vida. BARZILAI e SHULDINER (2000) colocam que, nos últimos 30 anos, têm-se identificado genes e fatores que deterioram ou encurtam o tempo de vida, no entanto, pouco tem-se avançado na descoberta de genes associados à longevidade, que protejam contra doenças comuns ou que posterguem o envelhecimento. A descoberta destes genes poderia ser muito importante para a saúde humana e as doenças associadas ao envelhecimento.

Para analisar a contribuição da hereditariedade, uma pesquisa francesa analisou os anos 700 a 1875 . No período de 700 a 1700, a longevidade do homem mostrou maior associação com a longevidade familiar do que a da mulher, principalmente associada à longevidade paterna. No período subseqüente (1701 a 1875), as mulheres mostraram maior associação com a longevidade familiar e, principalmente, com a idade da mãe. Observou-se que a idade da mulher era sempre dependente da idade de seus pais (WESTENDORP e col. 2001). Um outro estudo, também realizado na Europa, com famílias aristocráticas, mostrou efeito entre o tempo de vida e o sexo, principalmente entre filhas e pais. No entanto, surgiu um fato paradoxal, no qual o tempo de vida foi preferencialmente uma herança do pai, do que da mãe. Eles sugerem que mais estudos sejam realizados para avaliar este achado preliminar (GAVRILOV e GAVRILOVA 2001a). Estudo realizado na Pensilvânia, com uma população ‘Old Older Amish’, analisou 1.655 indivíduos, verificando haver relação entre a idade das pessoas com a longevidade dos pais, tanto paterna como materna. Realizando cálculos estatísticos, chegaram a estimar que a hereditariedade no tempo de vida pode contribuir com $25 \%+/-5 \%$, o que corresponderia a $1 / 4$ do 
tempo de vida dessas pessoas da Pensilvânia (MITCHELL e col. 2001). Raymond Pearl foi o primeiro a sugerir, inclusive, um cálculo matemático, o TIAL (longevidade ancestral imediata total), como um parâmetro para medir quantitativamente a longevidade humana. Para realizar esse cálculo, leva-se em consideração a idade dos seis ancestrais imediatos, a partir dos pais (SRI-KANTHA 2001).

Além disso, a literatura aponta que os filhos dos centenários tinham riscos reduzidos para as doenças associadas com a idade, como infarto, hipertensão e diabetes. Percebeu-se que eles apresentavam um processo de envelhecimento mais lento e estavam menos sujeitos aos riscos das doenças associadas com a idade, ou, quando as tinham, as doenças apareciam em idade bem avançada (PERLS e TERRY 2003).

Acredita-se que pessoas que não fumam têm maior chance de viverem mais, no entanto, um dos homens mais velhos do mundo fumou a maior parte de sua vida. O que torna-se um contra-senso, uma vez que muitos estudos têm demonstrado a ocorrência de doenças associadas ao hábito de fumar, como o câncer de pulmão, que podem encurtar o tempo de vida. Este caso reforça o conceito de que longevidade é multifatorial, ou seja, existem muitos fatores determinantes da longevidade, sendo difícil atribuir somente a um este fenômeno. Estudos com álcool e com atividade física mostraram consistentes associações negativa e positiva, respectivamente, para chegar até idade extrema (BEREGI e KLINGER 1989). Pessoas com hábitos nãosaudáveis podem apresentar envelhecimento prematuro e apresentar doenças crônicas prematuramente, morrendo em idades mais jovens (PERLS e col. 2002).

Observou-se também que mulheres que tinham filhos após os seus 40 anos tinham maior chance de viverem mais. Isto não estava associado simplesmente ao fato de terem filho com esta idade, mas porque seu sistema reprodutor funcionava muito bem e, provavelmente, os outros órgãos também, tendo um processo de envelhecimento mais lento (PERLS e col. 1997).

Com base em trabalhos realizados com população de centenários italianos, notou-se, também, que os idosos que mantinham uma boa atividade mental viviam mais quando comparados aos que apresentavam algum problema, como isolamento e 
falta de atividade intelectual, que tendiam a morrer mais precocemente (MARIGLIANO e col. 1992; RECEPUTO e col. 1995).

Além disso, outros autores afirmam que a atividade física é uma grande aliada da longevidade, além de diminuir o risco de aparecimento de algumas doenças. Entretanto, JONES e EATON (1995) demonstraram que somente exercícios vigorosos teriam a propriedade de aumentar diretamente a longevidade.

A literatura também aponta que a longevidade está associada diretamente com um ótimo funcionamento do sistema imune. Em ratos, observou-se que o complexo maior de histocompatibilidade (MHC), que controla várias respostas imunes, estaria associado com o tempo de vida da linhagem. Nos últimos 25 anos, estudos têm mostrado associação entre o HLA gen (Complexo humano) e a longevidade. No entanto, ainda existem muitos questionamentos, pois enquanto alguns estudos mostram associação, outros não, e, ainda, outros não observaram diferença. Autores dizem que um dos grandes problemas estaria nos erros metodológicos (CARUSO e col. 2001).

Um fato a ser destacado é que os seres humanos são os únicos dentro do reino animal que possuem uma vida longa considerável após o período reprodutivo. Para as demais espécies animais, não é vantajoso manter um indivíduo "velho e improdutivo" na comunidade. Isto sugere que a transmissão de conhecimentos de avós para a progênie pode funcionar como uma força para estender a longevidade humana (LEWIS 1999). A espécie humana, também, é a única que possuí um tempo de vida consideravelmente longo após cessar o período reprodutivo, quando comparada com outros primatas. Considerando um tempo máximo de vida em torno de 100 anos, a mulher acaba tendo quase a metade de seu tempo de vida após a menopausa, enquanto as chipanzés fêmeas têm o tempo máximo de vida em torno de 50 anos, quando também cessa seu período reprodutivo. LEWIS, (1999), coloca que duas hipóteses têm sido propostas para explicar este aumento: 1) "parada precoce” e 2) “efeito da avó”. A primeira sugere que a menopausa seria um processo adaptativo para garantir a extensão do período de cuidados humanos que a infância requer. No entanto, esta hipótese tem sido criticada, pois a menopausa na mulher não ocorre tão cedo, quando comparada com outros macacos e também não explica por que o chipanzé morre após o período reprodutivo, sendo que algumas espécies também 
precisam desenvolver esses cuidados com sua prole. A segunda, "efeito da avó", parte do princípio de que as avós ajudariam os seus netos com a alimentação, ensinando técnicas de forrageamento. No entanto, PACKER e col. (1998) observaram que filhotes de leões e babuínos, que receberam auxílio de suas avós no forrageamento, não tiveram suas curvas de sobrevivência maior quando comparados àqueles filhotes que não tinham avós. Isto, talvez, aponte que, na espécie humana, o tipo de ensinamento ou de cuidado pode exercer uma função mais específica. HAWKES (2004) afirma que realmente existe um efeito benéfico das avós sobre o sucesso reprodutivo de seus filhos e a sobrevivência dos netos. Talvez o que diferencie a espécie humana de outras é que os filhos precisam ser alimentados por um longo período. As crianças não estão aptas a adquirir seu próprio alimento e prepará-lo. Já os chipanzés menores têm esse período muito mais curto e, logo, já estão indo atrás de frutas e outros alimentos. Dessa forma, a avó humana, após cessar seu período reprodutivo, teria um papel importante no auxílio dos cuidados com os netos e com sua alimentação, assim como de influenciar o melhor sucesso de suas filhas na reprodução, por meio de suas experiências já vividas. O problema, ao se analisar esse "efeito da avó”, é que muitas variáveis de confusão podem interferir. Outro estudo, que procurou controlar essas variáveis, chega a afirmar que " $a$ assistência familiar promovida pelas avós é o determinante central da nossa longevidade" (LAHDENPERA e col. 2004). Estes autores estudaram duas populações, uma do Canadá e outra da Finlândia, e demonstraram que as mulheres que têm um período pós-reprodutivo maior possuem maior chance de terem mais netos, uma prole mais numerosa. No entanto, avaliaram famílias que tinham a figura da avó dentro de casa, diferentemente da sociedade contemporânea, na qual prevalecem famílias uninucleares. Observaram, também, uma redução na idade em que os filhos começaram a se reproduzir (netos), e que o intervalo entre um nascimento e outro era menor, assim como o aumento na curva de sobrevivência dessas crianças (figura 3). Desta forma, os resultados apontaram fortemente para a hipótese de que o aumento do período pós-reprodutivo na espécie humana é realmente adaptativo, como sugerido por outros autores (HAWKES e col. 1998; HAWKES e col. 1997). 
a
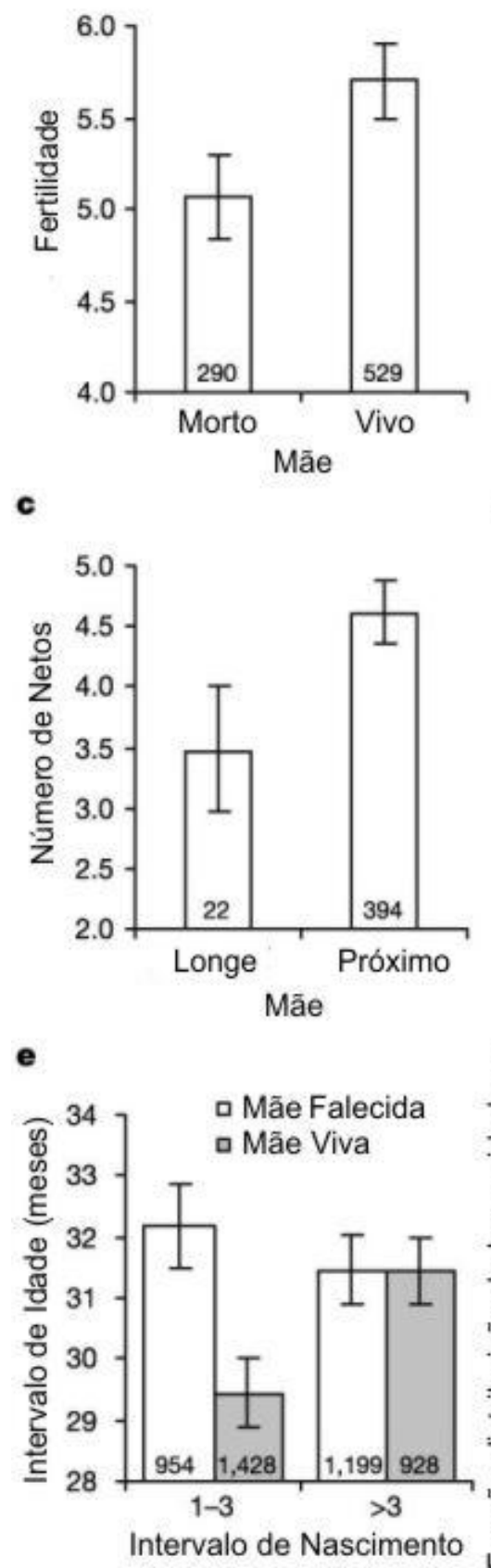

b

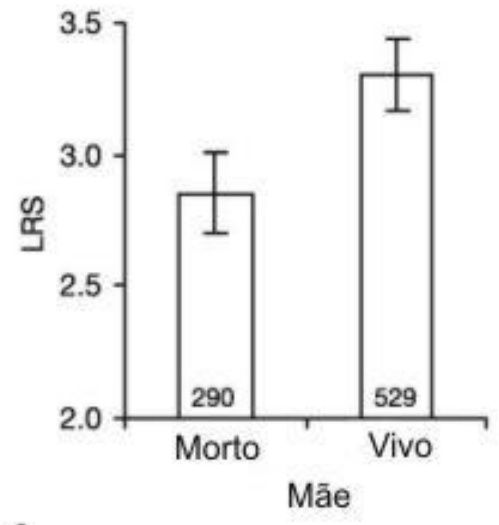

d
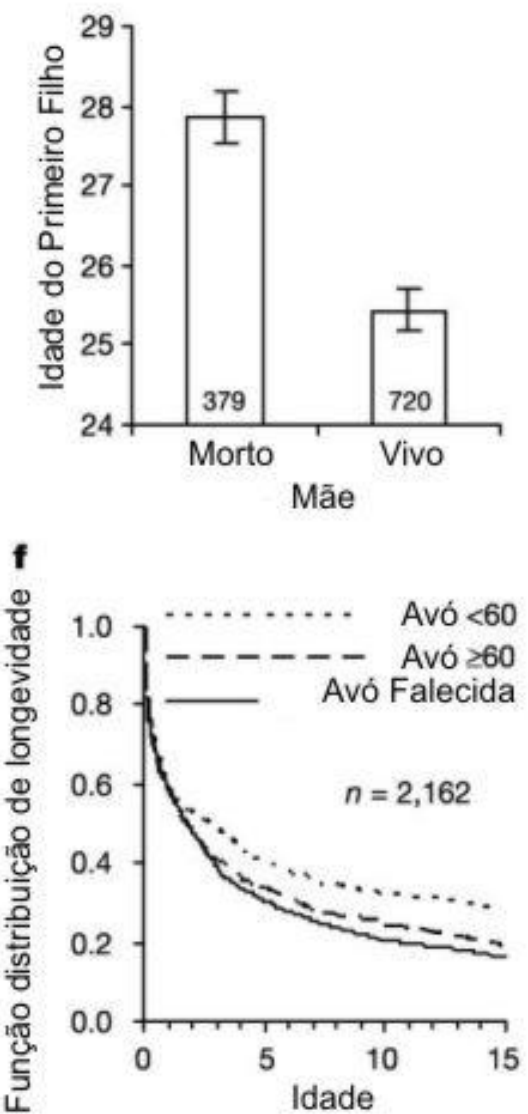

Figura 3 - Presença pós-reprodutiva da mãe e correlações com sua prole. a. aumento do tempo vida da fecundidade da prole $(F 1,607=9,44, p=0,0022)$; b. aumento do tempo de vida do sucesso reprodutivo da prole (LRS) $(\mathrm{F} 1,593=8.23, \mathrm{p}=\mathbf{0 , 0 0 4 3})$; c. aumento do número de netos produzidos quando as avós vivem na mesmo local ou em locais diferentes $(F 1,293=3,98, p=0,047)$; d. redução da idade em que a prole começa a se reproduzir quando a mãe está viva $(F 1,814=52.65$, p<0,0001); e. diminuição do intervalo de tempo entre os três primeiros filhos quando a mãe está viva (F1,977 = 6,45, $\mathbf{p}=\mathbf{0 , 0 1 1})$, mas não depois $(\mathrm{F} 1,711=\mathbf{0 , 8 4}, \mathbf{p}=\mathbf{0 , 3 6})$; f. sobrevivência dos netos antes de quinze anos (log-rank test: [chi]2 $=19,78, p<0,0001)$. (Fonte: Lahdenpera M, Lummaa V, Helle S, Tremblay M, Russell AF. Fitness benefits of prolongel post-reproductive lifespan in women. Nature 2004; 428(6979): p.180). 
Outra hipótese, sugerida por LEWIS (1999), seria a do “educador”. Ele argumenta que a espécie humana tem sucesso muito atrelado ao conhecimento e, desta forma, o conhecimento pode até facilitar um aumento da longevidade, por meio da transmissão deste pelos avós. Os avós possuem uma maior experiência de vida que os pais e conseguem atingir um grupo maior de crianças. Por exemplo, quando reúnem os netos para transmitir conhecimentos, contando histórias ou demonstrando ações. Os pais acabam provendo o alimento para os filhos, enquanto os avós facilitam a obtenção de alimentos, com seus ensinamentos. LEWIS (1999) ainda coloca que os seres humanos são extremamente competitivos e disputam muito por recursos, até chegando a fatalidades. Um grupo que já recebe os conhecimentos de pessoas mais velhas, que alcançaram a longevidade, teria maior chance de ser longevo e de transmitir isto às outras gerações, propagando, inclusive, genes de longevidade. Esta teoria do "educador” atinge ambos os sexos. No entanto, a mulher acaba tendo uma função mais extensa no educar, o que talvez até contribua para ela ter uma expectativa de vida em torno de $8 \%$ maior do que o homem. A mãe e as avós sempre estão mais preocupadas em ensinar, falar o que é mais correto, até mesmo na idade adulta de seus filhos e netos, tentando transmitir isto para todas as gerações que forem possíveis.

PENNINX e col. (1997) relatam até um possível “suicídio programado”, ou seja, aqueles idosos que não se sentem mais úteis acabam sendo influenciados por fatores psicológicos que podem aumentar a mortalidade: falta de suporte emocional e baixo domínio, ou seja, perdem o controle sobre sua vida. A capacidade de administrar sua vida parece representar um controle sobre sua própria vida.

Outra investigação, muito interessante, mostrou que as pessoas que acreditam realmente que elas são importantes têm uma longevidade maior. Como exemplo, a Suprema Corte da Inglaterra é famosa por sua longevidade, assim como pessoas da religião dos Mórmons e Adventistas do Sétimo Dia. Pesquisas têm mostrado que pessoas que passam a ter uma crença, uma religião forte, resgatam esta importância pessoal frente à sociedade, o que é um fator para a longevidade. Elas passam a acreditar que têm uma função e uma missão para com a sociedade e isto aumenta seu suporte emocional e seu domínio, favorecendo a longevidade (MANTON e col. 1991; KARK e col. 1996, KRAUSE 1997; ELLISON e LEVIN 1998). 
Além dos fatores biológicos ou físicos, pode-se destacar a influência dos fatores emocionais, que os próprios idosos associam como fatores responsáveis por uma vida mais longa, destacando a postura perante a vida (modo de ser -“viver bem e ser feliz na vida"; serenidade; autocontrole emocional) e o engajamento social (profissão, sociedade, família e lazer), assim como as condições socioculturais (PATRÍCIO 1998).

Em artigo recente, CASPARI e LEE (2004) trazem uma abordagem diferente, analisando a evolução humana, apontando que o aumento da longevidade representa um dos caminhos da história da vida do ser humano, o que também é uma característica que o difere dos outros animais. Eles chamam a atenção, dizendo que essas mudanças do aumento do tempo de vida começaram a se intensificar já no início do período Paleolítico Superior. Os autores ainda complementam que este aumento tem contribuído para a expansão da população e para as inovações culturais associadas à modernidade.

Uma linha emergente de investigação tem observado associação entre as melhorias na sobrevivência, principalmente nos primeiros anos de vida, e mudanças importantes nas idades mais avançadas. Assim, parece que a exposição a doenças, a contração da morbidade ou condições deletérias no início da vida podem ter contribuições fisiológicas permanentes na vida adulta dessas pessoas. Portanto, a geração do pós-guerra, no mundo todo, deve se beneficiar dos avanços tecnológicos da saúde. Os mesmos autores, PALLONI e PALAEZ (2003), questionam: "Pode essa combinação de eventos aumentar a expressão dos efeitos negativos da exposição precoce a condições deletérias e manifestar-se em uma prevalência mais elevada das doenças e incapacidades das etapas tardias da vida?”

Dessa forma, pode-se notar que o processo de longevidade é o produto da interação de fatores biológicos, psíquicos, sociais e ambientais que atuam ao longo da vida do homem, podendo influenciar na longevidade, tanto positiva quanto negativamente. Vários possíveis fatores ambientais afetam a longevidade humana: ambiente do pré-natal, poluição, radiação, carcinógenos, nutrição, produtos medicinais, estresse, educação, estilo de vida, isolamento, número de filhos, atividade sexual, esporte e atividade física, entre outros. Discute-se que estes fatores ambientais podem, inclusive, agir da mesma forma que os mecanismos celulares 
ocasionados pelos componentes genéticos (CHRISTEN 2003). Em outro artigo, intitulado "O Sol determina a longevidade humana: efeitos teratogênicos da irradiação solar caótica”, os autores tentam fazer a correlação entre alteração no DNA, provocada por irradiação solar, que poderia comprometer as próximas gerações, por meio da transmissão genética (DAVIS e LOWELL 2004).

O aumento no tempo de vida também está muito associado aos avanços da tecnologia da saúde, que diminuíram as taxas de mortalidade. Alguns fatores podem, inclusive, ser potencialmente modificados por tratamento médico, mudanças comportamentais e melhorias ambientais. Um exemplo clássico foi a introdução da antibioticoterapia no tratamento da tuberculose, reduzindo drasticamente a mortalidade e aumentando a sobrevida das pessoas acometidas pelo mal (CRISTENSEN e VAUPEL 1996).

Frente a essa diversidade de pesquisas e fatores apresentados, verifica-se que a longevidade humana é um tema bastante complexo e que muitas perguntas ainda precisam ser respondidas. Pouco se sabe a respeito de todos os mecanismos que controlam a longevidade humana, por se tratar de um complexo fenômeno. O principal obstáculo é a dificuldade de estudá-la diretamente em seres humanos, além do tempo de pesquisa que demanda, resultando em escassez de métodos epidemiológicos para investigação do fenômeno (GAVRILOV e GAVRILOVA 2001a; DE BENEDICTIS e col. 2001).

KIRKWOOD (2002), que tem publicado vários artigos discutindo envelhecimento e longevidade, em um de seus artigos mais recentes coloca: “Feito o progresso para entender a função e evolução dos fatores genéticos e não-genéticos na longevidade humana, são necessários mais detalhes de estudos teóricos sobre como ocorrem as variações dentro das populações, e como fatores socioeconômicos influenciam a seleção de forças que modelam a história de vida”

Por fim, HAYFLICK (2000) chama a atenção para o fato de que os determinantes da longevidade devem ser distinguidos dos do envelhecimento. Ele coloca duas perguntas fundamentais: Por que envelhecemos? Por que vivemos tanto tempo quanto vivemos? 


\section{3 - Meio ambiente e doenças associadas}

\subsection{1 - Retomando a história do desmatamento e do processo saúde-doença ligado às condições ambientais}

O crescimento populacional, aliado ao desenvolvimento tecnológico mundial e ao consumo exacerbado, tem gerado muitos avanços, mas, em contrapartida, tem causado danos ao meio ambiente, chamando a atenção de todo o planeta. O modelo econômico prevalente baseia-se na extração de matéria-prima, sem sustentabilidade, levando a extensa devastação e deterioração de áreas. Além disso, tem-se como subprodutos: poluição e contaminação do solo, da água e do ar (AUGUSTO e BRANCO 2003). Este modelo de desenvolvimento atualmente adotado favorece o aparecimento de riscos para a saúde e o ambiente.

Aliada a esses fatos, há uma distribuição de recursos muito desigual, tanto entre as comunidades de uma mesma localidade, como entre as nações. Os países desenvolvidos acabaram extraindo recursos e poluindo extremamente o planeta, para manter seu intenso desenvolvimento tecnológico. Como exemplo, verifica-se que 20\% da população mundial que habita os países desenvolvidos são responsáveis pelo consumo de $80 \%$ das matérias-primas e da energia produzida. Também são responsáveis por mais de $80 \%$ da poluição global. Somente os EUA consomem 1/3 de toda energia produzida (MINAYO e MIRANDA 2002).

Percorrendo a história de ocupação do território brasileiro, desde os primórdios da colônia, constata-se que a ocupação se deu de forma predatória, devastando as lindas paisagens. No entanto, essas devastações, embora não preocupantes na época, eram percebidas por alguns, que passaram a registrar as possíveis conseqüências dessas ações devastadoras. José Augusto Pádua, em seu livro Um sopro de destruição: pensamento político e crítica ambiental no Brasil escravista (2002), encontrou cerca de 150 textos, escritos por mais de 50 autores, no período de 1786 a 1888, fazendo críticas às ações destruidoras das florestas, sobre o esgotamento dos solos, os desequilíbrios climáticos e outros danos ambientais.

Esse mesmo autor cita que o próprio José Bonifácio, em 1823, redigiu um documento no qual defendia o fim do trabalho escravo, intitulado "Representação à Assembléia Constituinte e Legislativa do Império do Brasil sobre a Escravatura”, em 
que, ao final, faz uma eloqüente defesa da necessidade de conservação dos recursos naturais do país, chegando a ser fatalista:

“A Natureza fez tudo a nosso favor, nós, porém, pouco ou nada temos feito a favor da Natureza. Nossas terras estão ermas, e as poucas que temos roteado são mal cultivadas, porque o são por braços indolentes e forçados. Nossas numerosas minas, por falta de trabalhadores ativos e instruídos, estão desconhecidas ou mal aproveitadas. Nossas preciosas matas vão desaparecendo, vítimas do fogo e do machado destruidor da ignorância e do egoísmo. Nossos montes e encostas vão-se escalvando diariamente, e, com o andar do tempo, faltarão as chuvas fecundantes que favoreçam a vegetação $e$ alimentem nossas fontes e rios, sem o que o nosso belo Brasil, em menos de dois séculos, ficará reduzido aos paramos e desertos áridos da Líbia. Virá então este dia (dia terrível e fatal), em que a ultrajada natureza se ache vingada de tantos erros e crimes cometidos.” (José Bonifácio, 1823, citado por Pádua 2002, p. 27).

As atividades agrícolas no país começaram a ser feitas por meio da queimada da floresta, utilizando as cinzas para adubação do solo, o que o tornava fértil por 2 ou 3 anos. Após este período, o solo ficava totalmente exaurido e as formigas proliferavam. Dessa forma, os senhores das terras reivindicavam novas sesmarias, alegando a baixa produtividade dos solos. Para se produzir açúcar nos engenhos, muita lenha oriunda da mata Atlântica foi queimada. As ferrovias também consumiam, em suas locomotivas a vapor, muita lenha oriunda dessas matas. $\mathrm{Na}$ pastagem, também se utilizavam as queimadas, a fim de que ervas crescessem e o gado pudesse se alimentar. As encostas e os cursos de muitos rios foram modificados às custas de extração de ouro e diamante (PÁDUA 2002). Sérgio Buarque de Holanda, referindo-se aos colonizadores, coloca: “ pelo muito que pediam à terra e o pouco que lhe davam em retribuição”. PÁDUA cita que Frei Vicente Salvador (1564-1636), em sua “História do Brasil”, edição de 1967, criticava os colonizadores que "usam a terra não como senhores, mas como usufrutuários, só para a desfrutarem e a deixarem destruída".

Verifica-se, assim, que as interferências humanas sobre a natureza são 
antigas, desde o início da utilização do fogo e, depois, com a exploração da agricultura. No entanto, essas ações sofreram uma grande aceleração, principalmente após a Revolução Industrial. Por outro lado, ainda não se tinha conhecimento preciso dos impactos ambientais que as devastações e contaminações ambientais poderiam gerar (RIBEIRO 1998).

Os problemas ambientais tornaram-se importantes no cenário internacional, principalmente a partir da década de 1970. Há, desde então, disputas econômicas e por recursos naturais entre os diferentes países. A Conferência das Nações Unidas sobre o Meio Ambiente, realizada em Estocolmo, em 1972, já alertava para o dilema: de uma lado, a busca para adotar-se uma agenda única de compromissos e ações voltadas ao meio ambiente, e, de outro, a pressão do mercado e do desenvolvimento globalizado excludentes. Vinte anos depois, na Conferência das Nações Unidas sobre Meio Ambiente e Desenvolvimento, a Rio-92, o debate se acirrou. Os países em desenvolvimento demonstravam apresentar problemas básicos relacionados à pobreza, distribuição de rendas, acesso à tecnologia, que seriam pré-requisitos para tentarem implantar políticas internacionais a fim de controlar os riscos e problemas ambientais (FUNASA 2003).

Após a Rio-92, uma agenda de ações foi montada visando alcançar um desenvolvimento sustentável. Essa agenda ficou conhecida como “Agenda 21”. Ela enfatizou a importância das necessidades essenciais de saúde da população frente à relação complexa entre fatores ambientais e as inter-relações físicas, biológicas, químicas e sociais. Além disto, ressaltou que é difícil atribuir a causa da doença a um só elemento, uma vez que "a saúde é influenciada não apenas por fatores específicos, mas pela interação entre eles” (CNUMAD 1992; MINAYO e MIRANDA 2002). Na agenda 21, aparece a classificação de riscos tradicionais e modernos:

- Riscos tradicionais: contaminação da água, dos alimentos, ausência de saneamento, maior exposição a vetores e doenças, condições insalubres de moradia, condições de vida associadas a altas taxas de mortalidade infantil e vários tipos de morbidade.

- Riscos modernos: práticas de cultivo intensivo de alimentos e monocultura, uso crescente de energia mineral, poluição do ar, da água, do solo por produtos químicos, doenças cardíacas, dentre outras. 
- Outros riscos decorrentes das mudanças ambientais e sociais: alterações climáticas, destruição da camada de ozônio, aumento demográfico, ampliação dos meios e das formas de comunicação, dos conflitos de território e da exacerbação da violência social.

MINAYO e MIRANDA (2002) apontam que "a emergência e reemergência de doenças no mundo atual estão fortemente potencializadas pela interação dos fenômenos da degradação 'socioecológica', dos interesses econômicos, da deterioração dos programas de saúde pública, dos interesses econômicos, da globalização e da transformação rápida de padrões de comportamentos sociais”. Esta degradação ‘socioecológica’ está associada a intensas transformações sociais, direcionadas pelos interesses econômicos, alicerçada no 'desenvolvimento predatório'. Como resultado, tem-se o aparecimento de novas doenças, recrudescimento de outras e exposição populacional a riscos antes não existentes. Outras características, dentro da dinâmica populacional, podem ser ressaltadas como: envelhecimento populacional, aumento dos moradores de rua, dos migrantes e refugiados das guerras civis, dos usuários de drogas e grupos marginalizados nos grandes centros urbanos, dentre outros (BARATA 1997). Os fatores sociais podem influenciar na ocupação do espaço e na ecologia dos animais e vetores, alterando o ambiente e favorecendo surtos e/ou epidemias (POSSAS 1989). Assim sendo, todos esses novos e antigos fatores, muitas vezes negligenciados, colaboram para desenhar o complexo cenário que envolve a saúde, como exemplificado na tabela 1, a seguir. 
Tabela 1 - Fatores que influenciam na emergência e reemergência das doenças infecciosas

\begin{tabular}{|c|c|c|}
\hline Fator & $\begin{array}{c}\text { Exemplos de } \\
\text { fatores específicos }\end{array}$ & Exemplos de doenças \\
\hline Mudanças ecológicas & $\begin{array}{l}\text { Agricultura, represas, } \\
\text { desflorestamento, } \\
\text { enchentes/secas, fome, } \\
\text { mudanças climáticas }\end{array}$ & $\begin{array}{l}\text { Leishmaniose, Arbovírus } \\
\text { (Sabiá, Rocio, Mayaro), } \\
\text { Hantaviroses }\end{array}$ \\
\hline $\begin{array}{l}\text { Demográfica e } \\
\text { comportamental }\end{array}$ & $\begin{array}{l}\text { Crescimento, migrações, } \\
\text { guerras, deterioração dos } \\
\text { centros urbanos, } \\
\text { adensamento }\end{array}$ & Dengue, Tuberculose \\
\hline $\begin{array}{l}\text { Comércio e viagens } \\
\text { internacionais }\end{array}$ & $\begin{array}{l}\text { Movimento internacional } \\
\text { de bens e pessoas, viagens } \\
\text { aéreas }\end{array}$ & $\begin{array}{l}\text { Malária de aeroporto, } \\
\text { cólera e Dengue nas } \\
\text { Américas }\end{array}$ \\
\hline Indústria e tecnologia & $\begin{array}{l}\text { Globalização de alimentos } \\
\text { e mudanças no } \\
\text { processamento, uso } \\
\text { irracional de antibióticos e } \\
\text { outros }\end{array}$ & $\begin{array}{l}\text { Encefalopaita } \\
\text { espongiforme bovina, } \\
\text { infecções oportunísticas }\end{array}$ \\
\hline $\begin{array}{l}\text { Adaptação às mudanças } \\
\text { dos agentes }\end{array}$ & $\begin{array}{l}\text { Evolução dos } \\
\text { microorganismos, } \\
\text { resistência }\end{array}$ & $\begin{array}{l}\text { Variações de vírus, } \\
\text { bactérias, resistência a } \\
\text { antibióticos, pesticidas, } \\
\text { antivirais }\end{array}$ \\
\hline $\begin{array}{l}\text { Colapso nas medidas de } \\
\text { saúde pública }\end{array}$ & $\begin{array}{l}\text { Saneamento e controle } \\
\text { inadequado de vetores, } \\
\text { cortes nos programas de } \\
\text { prevenção }\end{array}$ & Cólera, Dengue \\
\hline
\end{tabular}

(Fonte: Minayo MCS, Miranda AC, organizadores. Saúde e ambiente sustentável: estreitando nós. Rio de Janeiro: FIOCRUZ; 2002:p. 45. Adaptado de Barreto, 1998 - Emergência e “permanência’ das doenças infecciosas. Médicos, p-19-24, julho/agosto, 1998.)

Nota-se que todas as propostas e medidas sugeridas globalmente não foram colocadas em prática na íntegra. O maior empecilho é a grande força do capital que move o mundo. RIBEIRO (1998) ressalta que, embora não tenham se concretizado mudanças efetivas na lógica do sistema produtivo, algumas transformações positivas puderam ser sentidas:

- Incorporação de aspectos sociais, descentralização de políticas ambientais e, por conseguinte, democratização do poder.

- Maior racionalização da produção, diminuindo prejuízos ambientais. 
- Não mais concentração de indústrias somente em um local, controle de resíduos e depuração de efluentes, uso mais racional de energia elétrica.

- Adoção de política de qualidade nas empresas, diminuindo desperdícios e contaminações, melhorando comunicação e sistema de informação.

- Incorporação do conceito de desenvolvimento sustentável ${ }^{1}$.

Assim sendo, notam-se avanços, mesmo tímidos, mas importantes quando se trata de ações que podem impactar negativamente no setor produtivo, mas em benefício de um ambiente mais saudável para toda a comunidade.

\subsection{2 - Os problemas ambientais e seus riscos à saúde}

As preocupações com doenças advindas de alterações ou contaminações ambientais aumentam exponencialmente. As pessoas podem estar expostas a riscos e contaminar-se em diversas situações e por diferentes vias, podendo ser através do ar, da água, dos alimentos ou do solo. A contaminação, por sua vez, pode se dar no ambiente de trabalho, no ambiente externo geral ou, mesmo, dentro do próprio domicílio (CORVALÁN e col. 1996).

A urbanização e metropolização trouxeram problemas ambientais sérios, que acabaram impactando a saúde das pessoas, principalmente aquelas que moram em periferias onde são inadequadas as condições de saneamento. Há problemas básicos como: a escassez de água potável para 1/4 da população urbana dos países em desenvolvimento; a contaminação da água causada por esgoto não tratado despejado nos rios e córregos; ar contaminado por veículos e indústrias dentro dos grandes centros urbanos, levando ao aumento da mortalidade e morbidade cardiovasculares e respiratórias, óbitos fetais, baixo peso ao nascer, entre outros. O lixo apresenta problemas desde a sua coleta até a disposição final no solo, podendo contaminar o lençol freático. Quando incinerado, pode liberar dioxinas. No Brasil, cerca de 63,9\% dos domicílios estão ligados à rede de abastecimento de água, sendo que, nas regiões

\footnotetext{
${ }^{1}$ Vale ressaltar que este termo é questionado no meio acadêmico, discutindo-se a sua adoção e dúvidas quanto à sua viabilidade
} 
Norte e Nordeste, o serviço alcança, respectivamente, 44,3\% e 52,9\% dos domicílios. Em relação ao esgotamento sanitário, no ano de 2000, 33,5\% dos domicílios eram atendidos por rede geral de esgoto, chegando a 2,4\% na região norte. Quanto à coleta e destinação de lixo, 63,6 \% utilizavam lixões e 32,2 \%, aterros adequados (IBGE 2000). Há extensas áreas contaminadas pelos mais diversos rejeitos industriais abandonados ou mal eliminados. Campos eletromagnéticos espalhados por todas as cidades expõem as pessoas a riscos ainda não muito bem esclarecidos, podendo estar associados a doenças neoplásicas e malformações ou problemas obstétricos. Podem existir, ainda, as catástrofes ambientais relacionadas à ocupação de áreas inadequadas, como encostas e beiras de rios. TAMBELLINI e CÂMARA (1998) apontam que, embora desastres ambientais ocorram naturalmente, os maiores prejuízos para a saúde estão associados às alterações ambientais advindas da exploração ambiental como meio de produção. A Agência de Proteção dos EUA (EPA 1993) ainda alertou para problemas dentro das residências que, muitas vezes, não são valorizados, tais como: os produtos de limpeza inflamáveis, compostos orgânicos como pesticidas, metais pesados, entre outros.

Segundo FUNASA (2003), a partir da década de 1970, os principais problemas ambientais que entraram para o cenário público internacional poderiam ser divididos em:

- Riscos ecológicos globais - gerados pela intensa poluição química, prejudicando o ar, a água, o solo e os alimentos. Destacam-se: o efeito estufa, redução da camada de ozônio, contaminações atmosféricas, do solo, rios e mares, dos alimentos, ameaçando as vidas atuais e futuras.

- Vulnerabilidade social - problemas ambientais afetam mais os excluídos, que são muito vulneráveis devido à falta de infra-estrutura básica e baixas condições socioeconômicas.

- Extinção e destruição - espécies animais e vegetais ameaçadas de extinção devido a grande exploração, a destruição de florestas, redução da biodiversidade, levando, inclusive, a previsões de escassez de recursos naturais.

Constatou-se que ações locais poderiam ter um impacto bem maior, não só 
restrito à área imediata. Entidades ambientalistas promoveram o slogan "Pensar globalmente, agir localmente; agir globalmente e pensar localmente”, em defesa de ações de pessoas, grupos e governos locais. Muitos municípios e governantes locais passaram a adotar práticas ambientalistas; organizações não-governamentais voltaram a interagir com a população, motivando-as para desenvolverem ações nos seus locais de moradia, assim como estudos e pesquisas passaram a ser financiados por entidades internacionais (RIBEIRO 1998). A partir do final da década de 1980, as pesquisas, legislações e ações que visavam a cooperação entre os países, sociedades e cidadãos se intensificaram.

Vários estudos têm demonstrado a associação entre poluição do ar e mortalidade geral (DOCKERY e col. 1992; SCHWARTZ e DOCKERY 1992; TOULOUMI e col. 1994; SARTOR e col. 1994); mortalidade cardio vascular (BALLESTER e col. 1996; WORDLEY e WALTERS 1997; BORJA e col. 1997); mortalidade respiratória (POPE e col. 1992; SCHAWARTZ 1994). A sensibilidade das pessoas para adoecerem ou não devido à poluição seria influenciada por três fatores: o estado de saúde, períodos da vida fisiológica (criança e idosos mais suscetíveis) e o nível de resposta do organismo à poluição (SAMET e WHITE 2004).

Em termos populacionais, pontuam-se três fatores que interferem nos estudos sobre a relação 'adoecimento-poluição': fatores socioeconômicos; a dificuldade de se medirem os efeitos e a relação entre fatores ambientais e saúde; e também a dificuldade de se isolarem os fatores que interferem numa comunidade, que fazem parte de um complexo sistema. Alguns autores alertam que, muitas vezes, atribui-se tudo aos fatores socioeconômicos, que acabam sendo uma variável de confusão (SAMET e WHITE 2004). Já JERRET e col. (2004) e MARTINS e col. (2004) demonstraram que populações com baixo nível socioeconômico são mais vulneráveis e correm maiores riscos de adoecerem por causa da poluição.

Uma revisão realizada por BALLESTER e col. (1995) já demonstrava correlação entre poluição do ar, principalmente partículas pequenas, e mortalidade, mesmo quando os índices de qualidade do ar estavam abaixo dos limites de segurança, adotados tanto em nível nacional como internacional. Em estudo realizado na cidade de Fênix, Arizona, investigando as mortes de idosos, ocorridas de 1995 a 1997, constatou-se uma significativa associação entre mortalidade geral com 
níveis de CO e NO2 (p < 0,05), e mais fracamente com SO2, PM10, PMCF. Já a mortalidade cardiovascular teve significativa associação com CO, NO2, SO2, PM2,5; PM10, PMCF (p < 0,05) e com o carbono (MAR 2000). Outros estudos também demonstraram aumento da mortalidade por doenças respiratórias e cardiovasculares em pessoas com 65 anos ou mais, inclusive no Brasil (SALDIVA e col. 1995; SHWARTZ e MORRIS 1995; VERHOEFF e col. 1996; SANHUEZA e col. 1999; SAHL e col. 2002).

Elevações importantes na temperatura ambiente, como ocorrido na Bélgica em 1994, também favorecem um aumento na mortalidade de idosos (SARTOR e col. 1997). Além disto, poluição aérea das cidades influencia na morbimortalidade da população, principalmente associada a doenças respiratórias e cardiovasculares. Observou-se que, em períodos de elevada poluição urbana, ocorria aumento do número de internações e de óbitos, devido principalmente a grande concentração de Ozônio (SCHWARTZ 1994; BATES 1995; POPE e col. 1995; GOLDBERG 1996; ANDERSON e col. 1996; GRANVILLE e col. 1998; NEVALIANEN e PEKKANEN 1998). Pessoas que moram em cidades com elevada taxa de poluição têm maior risco de mortalidade do que aquelas que moram em locais menos poluídos (ROMM e ERVIN 1996). Tentando quantificar qual o impacto da poluição na saúde, SIGNORELLI e LIMINA (2002), analisando estudos epidemiológicos importantes, pontuaram um aumento de 0,69\% na mortalidade cardiovascular e respiratória associada a PM10 e 0,54\% para a mortalidade geral. Já GOUVEIA e FLETCHER (2000) observaram um aumento de 3 a 4\% na mortalidade geral de idosos na cidade de São Paulo, associado a poluição do ar. MARTINS e col. (2004) realizaram um estudo, no município de São Paulo, analisando indicadores de condições socioeconômicas e mortalidade de causa respiratória em idosos. Demonstraram associação entre estas, principalmente em pessoas que moravam em favelas.

BRIGGS (2003) aponta que 8 a 9\% das causas de uma doença devem-se à poluição, principalmente em países em desenvolvimento e com maiores índices de poluição.

Existem vários estudos mostrando a associação entre internações hospitalares e problemas cardiovasculares e respiratórios, coincidindo com aumento nos índices de poluição. As admissões hospitalares para doença isquêmica do coração mostraram 
associação significativa com as variações diárias da poluição. Além disto, o artigo chama a atenção para o fato de que os idosos sofrem muito a influência da poluição, mesmo quando os níveis de poluição estão abaixo do recomendado (LEE e col. 2003, SIMPSON e col 2003).

A morbidade pode ter ligação direta com os níveis de poluição, principalmente a respiratória. Até 1920, a asma era uma patologia rara e não era considerada como causa de morte importante antes do século XX (MEZA e GERSHWIN 1997). Hoje, ela tem aumentado imensamente, afetando mais crianças e idosos, devido principalmente à poluição (ABERCROMBIE 1953; RIBEIRO SOBRAL 1988; GOUVEIA e FLETCHER 2000). Observou-se um aumento na internação de crianças com asma em épocas com poluição aérea maior. Além disto, pode-se demonstrar que o efeito da poluição é mais grave em crianças pertencentes a famílias com menor situação socioeconômica (NEIDELL 2004). A poluição leva a uma exacerbação dos problemas respiratórios, como a asma e rinites, entretanto, alguns acreditam que a poluição também é capaz de induzir o aparecimento destas patologias (WARDLAW 1995; VERONESE e OORTGIESEN 2001). Além da exacerbação de sintomas respiratórios ou mesmo indução do aparecimento destes em crianças e bebês, estudos mais recentes têm demonstrado a associação entre poluição ambiental e nascimento de prematuros; aumento na mortalidade infantil; déficits no desenvolvimento pulmonar e, possivelmente, o desenvolvimento de asma (COMMUNITY OF ENVIRONMENT HEALTH 2004)

CIFUENTES e col. (2001) analisaram a redução de fatores adversos à saúde, nas últimas duas décadas, nas cidades do México (México), Nova Iorque (EUA), Santiago (Chile) e São Paulo (SP). Eles desenvolveram um modelo matemático para estimar os benefícios que poderiam advir da redução de emissão GHG (gases de efeito estufa). Ressaltaram que não podem assumir que todas as populações serão afetadas da mesma forma. Na figura 4, mostram a projeção para o período de 20012020. 


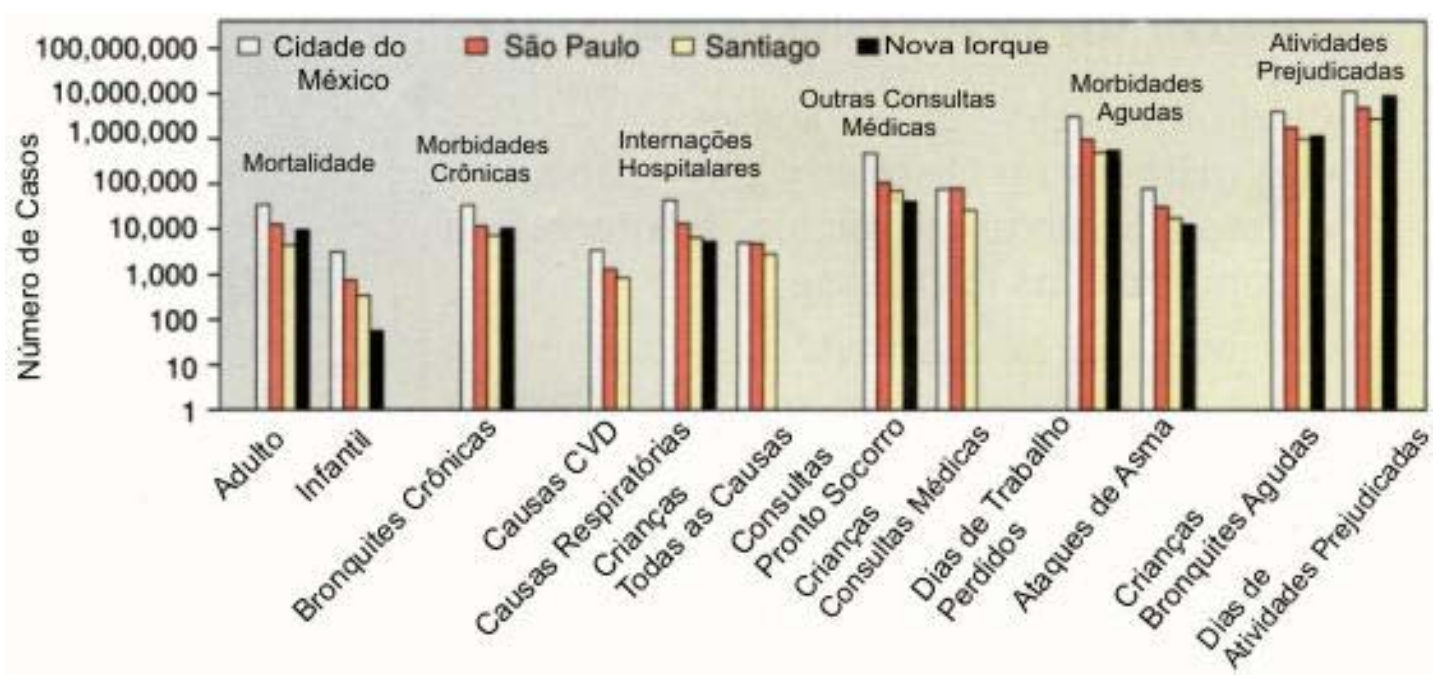

Figura 4 - Potenciais benefícios para a saúde humana por meio da redução de ozônio e material particulado na poluição aérea associada a mensuração de GHG (2001-2020). Adaptado de: Cifuentes L, Borja-Aburto VH, Davis DL, Gouveia N, Thurston G. Hidden health benefits of greenhouse gás mitigation. Science 2001; 293(5533): p. 1257.

Embora existam importantes evidências da associação entre poluição ambiental, aparecimento de doenças e aumento da mortalidade, os mecanismos pelos quais este fenômeno ocorre ainda são obscuros (LIPFERT 1997). Uma hipótese levantada seria relativa à ação direta dos poluentes no sistema cardiovascular e respiratório, aumentando os mediadores inflamatórios, que, por sua vez, afetam a viscosidade do sangue e a homeostase de pneumócitos (IZZOTI e col. 2000). Outra hipótese indica que a substância poluente inicia uma reação inflamatória na via aérea por meio do sistema nervoso sensorial, principalmente via um receptor ácidosensitivo (VR1). Este receptor está localizado nas fibras nervosas que inervam as vias respiratórias e sua ativação resulta na liberação de neuropeptídeos do sistema sensorial terminal das vias respiratórias. Esta interação desencadearia sinais de inflamação (broncoconstrição, vasodilatação, secreção de muco, liberação de histamina, etc.), provocando o aparecimento das doenças (VERONES e OORTGIESEN 2001).

Outras contaminações ambientais foram responsáveis diretamente pela morte de centenas de pessoas, como: as dioxinas que contaminaram Seveso, na Itália, em 1976; o metil-isocianato em Bhopal, Índia, em 1984, e o caso de Chernobyl na Rússia, e no Brasil, o acidente com Césio em Goiânia. O derramamento de óleo sobre os mares, acidente até freqüente hoje em dia, afeta a saúde das pessoas diretamente (quem tem contato com a solução) e indiretamente, por meio do 
consumo de alimentos marinhos contaminados. A contaminação ambiental, por metais pesados (como arsênico, cádmio, chumbo e mercúrio), além dos materiais radioativos, como o caso do Césio em Goiânia, em setembro de 1987, pode levar ao aparecimento de cânceres e de problemas no sistema nervoso central. O aquecimento global da Terra tem gerado alterações bruscas no clima. Elevações intensas de temperatura em certas regiões são responsáveis pela mortalidade de moradores, principalmente idosos, além de estarem associadas ao aparecimento de câncer de pele, desenvolvimento de catarata e linfoma. A utilização de pesticidas na agricultura parece ser causa do desenvolvimento de câncer nos trabalhadores que manipulam diretamente o produto, e também deixa resíduos nas frutas e verduras, podendo contaminar, ao longo dos anos, quem as consome (SINCLAIR 1999)

Com o uso indiscriminado de pesticidas, adubos e outros produtos, a fim de aumentar a produção agropecuária, acabam ocorrendo extensas contaminações ambientais decorrentes do descarte inadequado dos resíduos destes produtos. Como exemplo, temos o caso da “Cidade dos Meninos”, no Rio de Janeiro, Brasil, onde as pessoas ficaram expostas a resíduos de hexaclorociclohexano $(\mathrm{HCH})$ abandonados por uma fábrica de pesticidas. Muitas crianças foram examinadas, e 184 apresentaram-se contaminadas nas amostras de sangue. Esta mesma substância também foi encontrada na Baixada Santista, em Samaritá, colocando em risco uma população de 42.000 pessoas (SILVA 1994). Outro exemplo brasileiro, associado à produção, é o da utilização de mercúrio para a extração de ouro, que ocorria de forma desenfreada até a década de 1990. Estimou-se que 500.000 garimpeiros foram expostos ocupacionalmente ao mercúrio metálico e populações ribeirinhas que consumiam peixes, e pessoas que habitavam os centros onde se comercializava ouro também foram contaminadas, totalizando de 1 a 5 milhões de pessoas expostas (SANTOS 1997).

Muitos outros estudos poderiam ser apontados neste tópico, associando problemas ambientais a interferências na saúde, no entanto, este panorama já é suficiente para o objetivo desta pesquisa. Nota-se que os estudos neste campo, que relacionam meio ambiente e saúde, enfocam problemas decorrentes de um meio ambiente contaminado e poluído, podendo gerar diversas patologias. Não foi possível encontrar estudos que procurassem demonstrar o oposto, ou seja, que 
populações vivendo em ambientes mais equilibrados pudessem ter benefícios em sua saúde e na longevidade. Podemos inferir que, se as pessoas, principalmente crianças e idosos, não convirem em um ambiente poluído, poderão ter menor chance de adoecerem de determinadas doenças associadas a poluição (principalmente cardiorrespiratórias). No entanto, isto é empírico. Não foram encontrados estudos demonstrando associação direta e positiva entre meio ambiente equilibrado e saúde, nem com envelhecimento ou longevidade, que são o foco deste trabalho. Por intermédio deste levantamento bibliográfico, pode-se perceber que a poluição e a contaminação ambientais podem desencadear problemas de saúde (como doenças pulmonares, cardíacas, neurológicas, neoplásicas, entre outras), podendo encurtar, assim, o tempo de vida. Dessa forma, os fatores ambientais negativos parecem interferir na longevidade de maneira inversa e indireta, diminuindo o tempo de vida.

\subsection{3 - A complexidade da Saúde Ambiental}

A intensa intervenção do ser humano sobre o meio ambiente gera uma interação extremamente complexa, colocando a população diante de diversos riscos de exposição, que anteriormente não se tinha noção que pudessem ocorrer. $O$ lançamento da Bomba Atômica em Hiroshima e Nagasaki passou a chamar a atenção mundial, exemplificando que danos de intervenções tão drásticas como estas, ao meio ambiente, podem comprometer várias gerações futuras e não se limitam a territórios geográficos ou políticos. Todos podem ser prejudicados por ações inconseqüentes como esta. A FUNASA (2003) destaca cinco aspectos importantes relativos aos problemas ambientais dentro do contexto global, dos quais, anteriormente, não se tinha noção:

- Tempo e espaço: os problemas ambientais podem se dar em curto, médio e longo prazo, atingindo outras gerações, e não respeitam fronteiras políticas ou geográficas.

- Complexidade: os problemas ambientais são sempre complexos, com muitas variáveis, envolvendo uma dinâmica socioambiental. Surge um grande 
desafio às ciências clássicas, que não conseguem explicá-los e solucioná-los com seus instrumentos, as vezes reducionistas, impossibilitando compreender a essência do problema. Além disto coloca que é necessário desenvolver trabalhos não somente multidisciplinares, mas compor equipes interdisciplinares ou transdisciplinares.

- Incertezas científicas ou epistemológicas: respostas não-precisas da ciência clássica para o diagnóstico e para tomada de ações. Países com menos recursos possuem essas incertezas também associadas à falta de dados, de recursos técnicos para analisá-los e tomarem decisão.

- Exclusão social e desigualdades - países em desenvolvimento são atingidos de forma mais grave pelos problemas ambientais. A heterogeneidade dentro dos próprios países leva os excluídos a habitarem áreas mais vulneráveis às intempéries da natureza.

- Superação do reducionismo e adoção de práticas transdisciplinares - a complexidade dos problemas ambientais leva à adoção de medidas que superem práticas assistencialistas, instrumentos e metodologias adotadas dentro da ciência clássica. “... reforça-se a necessidade de uma redefinição e reorientação do papel do setor saúde frente aos problemas ambientais, pela construção da saúde e numa perspectiva ampliada de vigilância da saúde que supere o modelo hegemônico assistencial-sanitarista. Neste contexto, a intersetorialidade passa a ser um conceito-chave, significa a integração entre os vários níveis e setores de governo envolvidos direta ou indiretamente em torno de problemas de saúde e ambiente. Mais do que somente uma questão de governo e de governabilidade, o enfrentamento dos problemas ambientais e a construção de políticas públicas saudáveis precisa envolver a sociedade como um todo em seu processo de discussão e gestão. Por isso, diz-se que a resolução dos problemas de ambiente e saúde é uma questão de governança, ou seja, ação conjunta e democrática entre governo e sociedade” (FUNASA 2003).

Para ilustrar esta discussão, tomam-se, como exemplo, os Limites de Tolerância, que são instrumentos adotados para quantificar os riscos à saúde do 
indivíduo exposto; no entanto, parte-se do princípio de que estes são verdades ‘científicas’ absolutas. Como AUGUSTO e BRANCO (2003) colocam que “estas posturas têm trazido sofrimento e são fontes de injustiça, principalmente em relação às vítimas da poluição, das más condições de trabalho e das desigualdades sociais”. Estes autores chamam a atenção dizendo que deve-se evitar traçar relações diretas entre exposição e efeito, pois, historicamente, isto tem favorecido apenas o empregador e/ou empresa, não proporcionando justiça ambiental e social, desfavorecendo o trabalhador exposto.

Nota-se que a relação saúde-meio ambiente é extremamente complexa e torna-se impossível tentar compreendê-la sem ter uma visão global das variáveis envolvidas, da realidade na qual está inserida. Nos países em desenvolvimento, isto se torna ainda mais difícil, pois não se tem uma série histórica dos indicadores ambientais, não se investe em tecnologias ambientais e as leis são burladas e não seguidas. Associam-se, também, outros fatores de confusão, como a pobreza e a falta de saneamento básico vigente nesses países, que favorecem as populações carentes a morarem em áreas de maior risco ambiental (BRIGGS 2003). Por isso, tem-se dificuldade em avançar, pois um modelo ou método que englobe todos esses fatores a serem analisados, seria extremamente complexo e certamente difícil de se aplicar.

DIXON e DIXON (2002) propõem um modelo interativo, que seria composto por quatro amplos domínios e contendo suas inter-relações (figura 5). Um deles seria o domínio fisiológico, que poderia ser representado pela seguinte pergunta: “qual é o problema?” Envolveria os processos químicos e fisiológicos pelos quais os fatores ambientais agiriam sobre os organismos expostos. Outro domínio proposto seria o da vulnerabilidade, simplificado com a seguinte pergunta: “quem é afetado?” Este levaria em consideração características individuais e da comunidade que poderiam tornar essas pessoas mais vulneráveis aos riscos ambientais, tais como: componentes nutricionais, genéticos, relativos a gênero e idade, entre outros. Em termos populacionais, fatores culturais e sociodemográficos poderiam favorecer a vulnerabilidade do grupo. Já o domínio epistemológico, seria questionado da seguinte forma: “O que se sabe a respeito disto?” Incluiria o conhecimento científico e popular que se tem para a compreensão dos efeitos do meio ambiente sobre a saúde, assim como as ações que se deveriam adotar. Neste domínio, os autores 
sugerem a utilização de dados da literatura, mas também de investigações com a própria população em risco, envolvendo métodos qualitativos e quantitativos. O quarto domínio seria o da proteção à saúde, investigado pela seguinte questão: “O que as pessoas fazem sobre isto?” Seria o engajamento das pessoas, suas ações, a fim de diminuir os riscos ambientais individuais e populacionais.

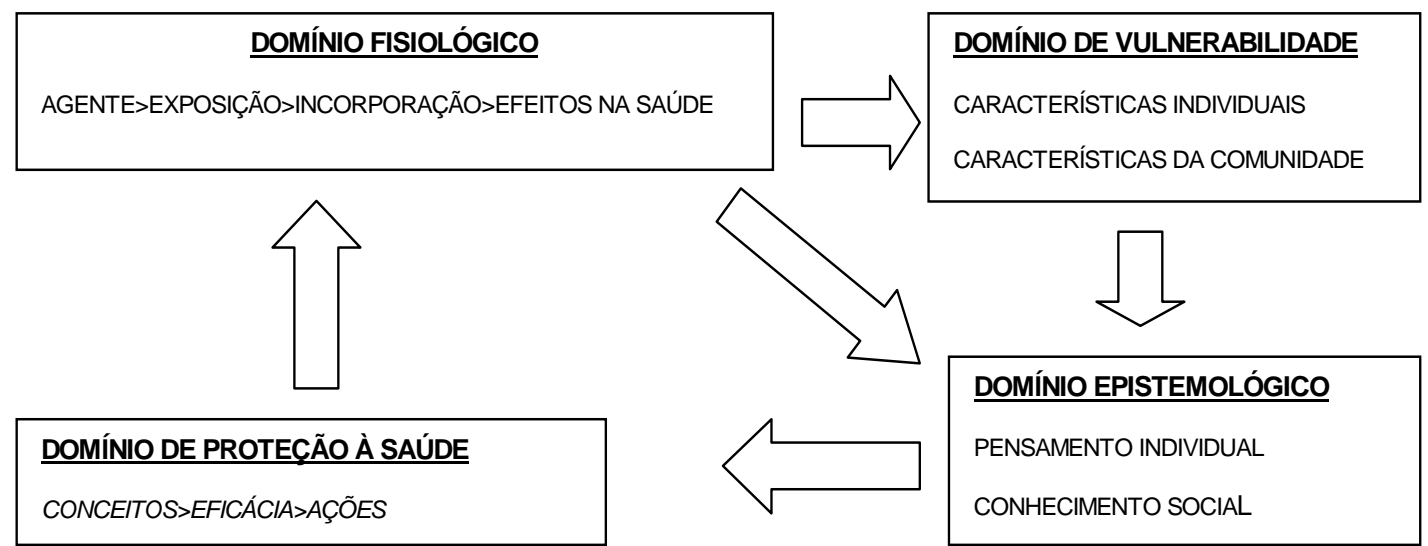

Figura 5 - Retrato gráfico do modelo interativo para a saúde ambiental. Adaptado de: Dixon JK, Dixon JP. An integrative model for environmental health research. Adv Nurs Sci 2002; 24(3): p.44.

MINAYO (2002) apresenta um outro modelo para abordar as relações entre saúde e ambiente, que vem sendo delineado nos EUA e no Canadá, denominada: 'Enfoque ecossistêmico da saúde'. A autora considera que esta proposta: “...apresenta uma forma de resposta à desafiante indagação sobre como fazer a reviravolta do paradigma antropocêntrico e de dominação que, a partir do uso predador dos espaços ambientais, tem provocado a própria destruição dos projetos humanos de vida saudável”. O enfoque ecossistêmico une três dimensões - a da saúde, a do ambiente e da economia (componentes inter-relacionados no processo incluindo análises das condições, situações e estilos de vida de grupos populacionais específicos). Este enfoque também considera alguns marcos positivos, compondo o campo semântico de reflexão, sendo resumidos pela autora em: sustentabilidade ecológica, democracia, direitos humanos, justiça social e qualidade de vida ${ }^{2}$. A qualidade de vida é valorizada nesta abordagem, sendo conceituada com base em um

\footnotetext{
${ }^{2} \mathrm{O}$ termo qualidade de vida, passa por muitas discussões conceituais, ela é utilizada na linguagem cotidiana e no contexto científico. Como não é objetivo direto deste trabalho investigar qualidade de vida, mas ao se trabalhar com populações idosas este termo sempre emerge, partiremos da definição adotada pela OMS, 1995: "percepção do indivíduo sobre a sua posição na vida, no contexto da cultura e dos sistemas de valores nos quais ele vive, e em relação a seus objetivos, expectativas, padrões e preocupações” (The WHOQOL Group. The World Health Organization quality of life assesment (WHOQOL: position paper from the World Health Organization. Soc Sci Med 1995: 41:1403-10).
} 
modelo qualitativo: "Qualidade de vida, dentro do enfoque ecossistêmico, é como um guarda-chuva onde estão ao abrigo nossos desejos de felicidade, nossos parâmetros de direitos humanos, nosso empenho em ampliar as fronteiras dos direitos sociais e das condições de ser saudável e de promover a saúde”.

O enfoque ecossistêmico propõe a construção de nexos entre estratégias de gestão integral do meio ambiente (ecossistemas saudáveis) associada a uma abordagem global e ecológica de promoção à saúde. Tem como objetivo desenvolver novos conhecimentos que esclareçam melhor esta complexa relação saúde/ambiente, procurando se aproximar de realidades mais concretas. Procura implementar ações adequadas, apropriadas e saudáveis para as pessoas que habitam este ambiente. Ressalta que, desta forma, existe a possibilidade de que a ciência e as condições de vida real sejam postas conjuntamente, a fim de garantir qualidade de vida, com uma melhor gestão do ecossistema, com a responsabilidade coletiva e individual de todos sobre a saúde. Na figura 6, pode-se visualizar esta abordagem ecossistêmica da saúde, apresentada por MINAYO (2002), na qual os três componentes estariam imbricados uns aos outros, e a saúde ocuparia uma posição e intersecção central entre a economia, comunidade e ambiente.

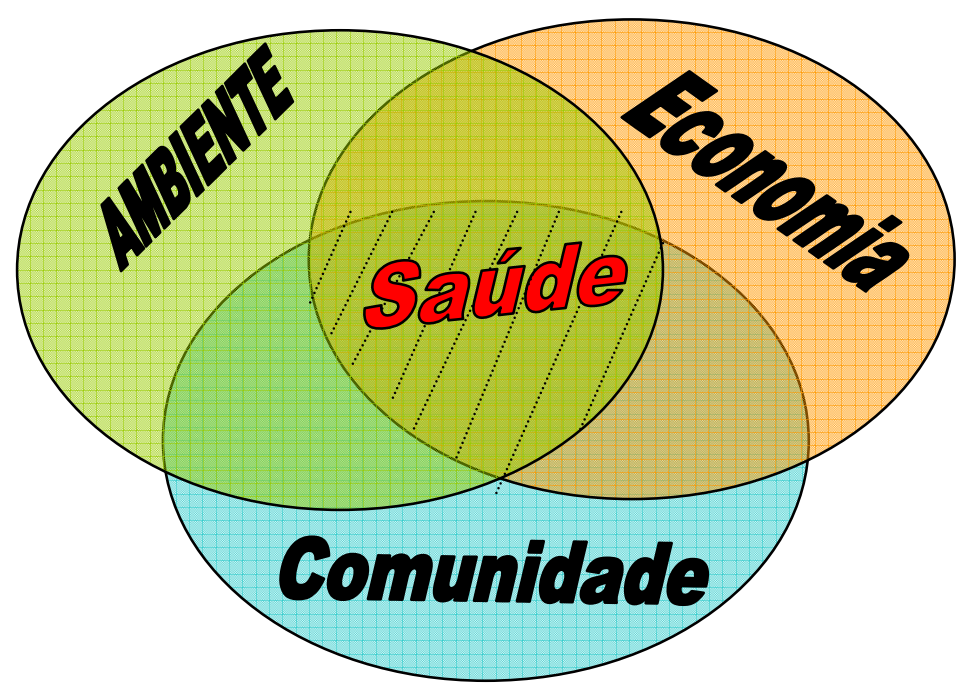

Figura 6 - A abordagem ecossistêmica valoriza igualmente os três componentes. Fonte: Forget e Lebell 2001, apud Minayo MCS. Enfoque ecossistêmico da saúde e qualidade de vida. In: Minayo MCS e Miranda AC, organizadores. Saúde e ambiente sustentável: estreitando nós. Rio de Janeiro: FIOCRUZ; 2002: p.182. 
Por meio destas discussões e destes modelos, começam-se a visualizar caminhos possíveis a serem adotados para conseguir equacionar e compreender melhor a dinâmica entre meio ambiente e saúde. Torna-se necessário rediscutir os padrões estabelecidos pela ciência pré-clássica, seguindo o modelo cartesiano e reducionista, pois, infelizmente, com este modelo nota-se que não está sendo possível compreender e responder aos processos e fenômenos que ocorrem na sociedade pós moderna. Na área da saúde isto pode ser observado, adotando-se medidas muitas vezes ineficientes e até mesmo prejudiciais a estas populações expostas às adversidades do meio ambiente, levando em conta apenas uma avaliação fracionada do processo. 


\section{4 - Definindo Meio Ambiente e indicadores ambientais}

\subsection{1 - Refletindo sobre os conceitos associados a meio ambiente}

Para medir ou avaliar a relação entre saúde e meio ambiente, é fundamental compreender e definir o que é 'MEIO AMBIENTE'. REIGOTA, em seu livro: “Meio Ambiente e Representação Social” (1995), levanta várias definições segundo o ponto de vista de diferentes especialistas. Coloca que, de acordo com o ecólogo RICKLEFS (1973), meio ambiente é: “o que circunda um organismo, incluindo as plantas e os animais, com os quais ele interage”. Refere que o ecólogo DUVIGNEAUD (1984), conceitua o termo da seguinte maneira: "é evidente que o meio ambiente se compõe de dois aspectos: a) meio ambiente abiótico físicoquímico, e b) meio ambiente biótico”. Pesquisa em dicionário de ecologia de TOUFFET (1982), e encontra: “conjunto de fatores bióticos (os seres vivos) ou abióticos (físico-químicos) do habitat, suscetíveis de terem efeitos diretos ou indiretos sobre os seres vivos e, compreende-se, sobre o homem”. Ainda busca a concepção do geógrafo GEORGE (1982): “o meio ambiente é ao mesmo tempo uma realidade científica, um tema de agitação, o objeto de um grande medo, uma diversão, uma especulação”. REIGOTA procura a definição em outro campo, na psicologia, no dicionário Enciclopédico de Psicologia, de SILLIAMY (1980), aparece: “o que circunda um indivíduo ou um grupo. A noção de meio ambiente engloba, ao mesmo tempo, o meio cósmico, geográfico, físico e o meio ambiente social, com suas instituições, sua cultura, seus valores. Esse conjunto constitui um sistema de forças que se exerce sobre o indivíduo e às quais ele reage de forma particular, segundo os seus interesses e suas capacidades”. E, por fim, REIGOTA apresenta a definição que aparece no dicionário do AURÉLIO, no qual não consta o termo "meio ambiente". O autor remete o leitor a "ambiente", onde se lê: (do latim ambiente). Adj. 1) Que cerca ou envolve os seres vivos ou as coisas por todos os lados; envolvente: meio ambiente; s.m. 2. Aquilo que cerca os seres vivos ou as coisas; meio ambiente; 3. Lugar, sítio, espaço, recinto; ambiente mal ventilado; 4. Meio. 5. Arquit. Ambiência. Em versão mais recente deste dicionário, 1999, encontramos já a definição direta de meio ambiente: ' $O$ conjunto de condições 
naturais e de influências que atuam sobre os organismos vivos e os seres humanos. Procurando em outro dicionário mais recente (HOUAISS 2001), encontra-se: 'm.ambiente -conjunto de fatores físicos, biológicos e químicos que cerca os seres vivos, influenciando-os e sendo influenciado por eles’.

A OMS conceitua meio ambiente como sendo "tudo aquilo que é externo ao hospedeiro humano. Podendo ser dividido em físico, biológico, cultural, social. Sendo que qualquer um, ou todos eles, podem influir no estado de saúde da população" (WHO 1995).

Como a definição de meio ambiente nos remete a conceitos de fatores bióticos e abióticos, é importante compreender também esta definição. Buscando no Dicionário de Ecologia, Evolução e Sistemas, de LINCOL e col. (1998), encontra-se: “1) Meio ambiente biótico - o meio ambiente biológico compreendendo todos os organismos que afetam a vida particular de um indivíduo, da população ou das espécies. 2) Meio ambiente abiótico: os componentes não-vivos do ecossistema, fatores físicos e químicos do meio ambiente”. Em livros de ecologia, estes conceitos variam e muitas vezes nem aparecem com esta divisão. Para VAN DER MOLEN (1981), fatores bióticos seriam aqueles relacionados com os seres vivos, e os abióticos relacionados com o meio ambiente (fatores físicos e químicos). Assim sendo, bióticos seriam: alimento, competição, parasitismo, etc.; enquanto os abióticos seriam: chuvas, vento, oxigenação, temperatura, $\mathrm{pH}$, salinidade, composição do solo, umidade do ar. BREWER (1994) cita outros fatores abióticos como: luz, radiação, gravidade, gases, pressão e som, dizendo que os fatores abióticos têm efeito ecológico em muitos organismos e em tempos muito longos. Entretanto, RICKLEFS (1996) critica dizendo que "freqüentemente fala-se do vivo e do não-vivo, como opostos: biológico x físico e químico; orgânico x inorgânico; biótico $x$ abiótico; animado $x$ inanimado, e que, embora possam ser distinguidos com facilidade, eles não existem isolados um do outro. A vida depende do mundo físico”.

TAMBELLINI e CÂMARA (1998) colocam que: “...a idéia do ambiente como elemento importante para o campo da saúde é antiga, porém, sua caracterização em termos técnico-científicos tem sido suficientemente vaga e imprecisa para admitir variadas formas e concepções na elaboração de sua (do 
ambiente) possível relação com a saúde propriamente dita. Invariavelmente, este "ambiente" tem sido visto como "meio externo", muitas vezes considerado como, simplesmente, o cenário onde se desenrolam os acontecimentos ou os processos especiais de uma determinada doença ou grupo delas”. BECKER (1992) denomina este processo como a “desnaturalização da natureza”. Tentar definir o limite entre o espaço e o universo de seres vivos e inertes, que nele se circunscreve, sempre será arbitrário, uma vez que ambos existem em relação aos sistemas que o circundam. Portanto, a noção de ecossistema é usada muito mais como uma unidade analítica do que uma entidade biológica (GOUVEIA 2004³).

Frente a estas várias definições, nota-se que existem muitos elementos envolvidos neste conceito e é difícil chegar a um consenso, em termos teóricos, do que seja meio ambiente. REIGOTA (1995) conclui, nesse livro, que a noção de meio ambiente constitui-se em uma representação social, definindo-o como: "lugar determinado ou percebido, onde os elementos naturais e sociais estão em relações dinâmicas e em interação. Essas relações implicam processos de criação cultural e tecnológica e processos históricos e sociais de transformação do meio natural e construído". O termo representação social (ou coletiva) originou-se na sociologia e na antropologia, como obra de Durkheim e de Lévi-Bruhl (MOSCOVICI 1995). DURKHEIM, que foi a primeiro a adotar esta idéia, conceituando-a como 'representação coletiva'. Em um estudo clássico dele sobre suicídio, mostra que os índices de suicídios são fatos sociais e deveriam ser compreendidos em termos de outros fatos sociais e não individuais de pôr fim a própria vida. No entanto, MOSCOVICI faz uma releitura e emprega o termo de representação social, argumentando que este seria mais adequado diante da sociedade atual moderna. FARR (1995) justifica esta opção de MOSCOVICI dizendo que: “as sociedades modernas são caracterizadas por seu pluralismo e pela rapidez com que as mudanças econômicas, políticas e culturais ocorrem. Há, nos dias de hoje, poucas representações que são verdadeiramente coletivas". Seguindo a teoria das representações sociais, em estudos procura-se levantar as respostas individuais mais como tendências e expressões do grupo que pertence. SPINK, 1995, afirma que as representações sociais são: “...elaboradas a partir de um campo socialmente

\footnotetext{
${ }^{3}$ Gouvea N (Disciplina de Pós-graduação, Epidemiologia Ambiental, oferecida pelo Depto. de Saúde Preventiva da USP). Comunicação pessoal, 2004.
} 
estruturado e são frutos de um imprinting social” e ainda “...as representações são também uma expressão da realidade intra-individual; uma exteriorização do afeto. São, neste sentido, estruturas estruturantes que revelam o poder de criação e de transformação da realidade social”. Assim sendo, meio ambiente sob a óptica das representações sociais traz elementos cognitivo-afetivos pertencentes a realidade vivida pelo grupo analisado, representando não apenas o senso comum, mas uma teia de significados que traduzem efetivamente a realidade (SPINK 1995).

A concepção cotidiana de ambiente refere-se a um "ambiente natural”, no qual ocorrem as inter-relações entre fatores bióticos e abióticos, caracterizando a cadeia alimentar e delimitando ecótopos.

Em termos de políticas públicas, a incorporação e adoção de medidas que relacionassem meio ambiente a saúde só começaram a ser tomadas, efetivamente, com a Reforma Sanitária, que teve início na Inglaterra, no século XIX. Esta reforma obrigava a serem adotadas e cumpridas várias normas, como: fornecimento de água pura ao consumo humano, disposição adequada de lixo e esgoto. No entanto, a teoria dos miasmas ainda predominava, acreditando que as doenças emanavam dos pântanos, que elas tinham ligação com os odores e vapores infecciosos que surgiam da sujeira das ruas (carcaças de animais, lixos, esgotos, etc.) (RIBEIRO 2004).

A visão mais epidemiológica de ambiente passa a incorporar a idéia de "Hospedeiro-Ambiente-Agente”, na qual os seres vivos interagem entre si, no ambiente, estabelecendo diferentes relações, positivas ou negativas, podendo inclusive levar ao aparecimento de doenças. No entanto, esta interpretação ainda concebe o hospedeiro e o agente como fatores externos ao ambiente, observados em esferas diferentes, quando todos interagem num mesmo plano, tornando-se impossível separá-los. Com base nesta concepção, surge o modelo da História Natural das Doenças, proposta inicialmente por LEAVELL e CLARK (1965).

Nas últimas décadas, têm-se incorporado outros elementos à concepção de ambiente, principalmente o componente social e coletivo. A desigualdade social mostra-se inclusive na esfera ambiental, na qual os indivíduos menos favorecidos também acabam usufruindo de ambientes com piores condições, sendo a qualidade da água ruim, muitas vezes com esgoto a céu aberto, ar poluído, locais insalubres para a moradia, entre outros (RIBEIRO 2004; TORRES 1997). A incorporação do 
componente social e coletivo fornece elementos mais globais para compreender e responder às demandas atuais que ocorrem nas comunidades ou grupos populacionais, sendo que a concepção antiga de ambiente não consegue responder a todos os problemas na sua complexidade (TAMBELLINI e CÂMARA 1998). No entanto, ainda adota-se esta idéia de que ambiente é algo externo, principalmente ao ser humano. Uma concepção ainda muito antropocêntrica e unilinear, que não consegue explicar o processo saúde-doença como um todo.

Para a analisar o processo saúde-doença, deve-se partir do princípio de que todos os componentes se relacionam e são interdependentes. Pesquisas e intervenções no campo da saúde e meio ambiente devem considerar este binômio como um sistema aberto e dinâmico, além de incorporar historicidade e subjetividade dos problemas socioambientais. A ciência clássica, buscando explicar os fenômenos por intermédio de suas causas, torna-se limitada. Assim, seus métodos não abarcam a globalidade do sistema (AUGUSTO e col. 2003). Além disso, para que um problema tenha solução, ele tem de estar dentro do sistema, ou seja, internalizado, se estiver fora, não faz sentido intervir no meio (LIEBER 1998). GARCIA (1994) coloca que o sistema tem suas regras lógicas:

- "o todo...sistema, é diferente da soma de suas partes;

- o caráter de um sistema é dado pelas relações de suas partes;

- o ambiente é uma entidade centralizada em um sistema.”

O geógrafo MILTON SANTOS (1997), em seu livro Metamorfose do Espaço Habitado, trabalha o conceito de totalidade, referindo: “... a noção de totalidade é uma das mais fecundas que a filosofia clássica nos legou, constituindo em elemento fundamental para o conhecimento e análise da realidade. Segundo essa idéia, todas as coisas presentes no universo formam uma unidade. Cada coisa nada mais é que parte da unidade, do todo, mas a totalidade não é a simples soma de partes. As partes que formam a Totalidade não bastam para explicá-la. Ao contrário, é a Totalidade que explica as partes”.

O meio ambiente é um exemplo real da totalidade. Para compreendê-lo, não basta juntar seus componentes, pois a simples soma não resultará na sua totalidade ${ }^{4}$.

\footnotetext{
${ }^{4}$ Adotamos a noção de totalidade no sentido da visão de conjunto, que por meio da síntese possibilita compreender o processo significativo da realidade com que se defronta, em uma determinada situação e em um determinado momento.
} 
Ao mesmo tempo deve-se compreender que a totalidade é um momento da totalização, para não se incorrer no erro de julgar ter alçando-a definitivamente, pois não chega-se a uma etapa acabada e definitiva. O conhecimento é um processo aberto e dinâmico e a verdade é sempre relativa. Na visão da dialética marxista considera-se atividade humana como um processo de totalização, que também não alcança uma etapa definitiva e acabada. Ao investigar-se um fenômeno é importante buscar uma visão de conjunto, pois a partir desta visão poderemos analisar melhor o papel de cada parte. Mesmo tendo esta visão de conjunto não se deve pretender esgotar a realidade, uma vez que a realidade é sempre mais complexa do que o conhecimento que se produz a seu respeito (KONDER 1999).

O ser humano se diferencia dos demais animais, entre outros fatores, por tentar modificar a natureza e promover o seu próprio bem-estar (AUGUSTO e col. 2003). Desta forma, o ser humano e as comunidades passam a penetrar o ambiente, tido como natural, explorando-o em seu benefício. TAMBELLINI (1996) coloca que o ambiente passa a ser “... um elemento interativo, por excelência, das relações produção/ambiente/saúde”. A espécie humana é uma parte deste sistema, que interage com elementos bióticos e abióticos, psicossociais, econômicos e políticos, entre outros.

Além dos fatores bióticos e abióticos, que estão contidos no meio ambiente, é necessário incorporar os aspectos psicossociais que a antropologia e a sociologia apontam como essenciais na elucidação dos fatos. Na área da saúde, também sente-se a necessidade de adotar outros preceitos e ações que vão além das médicoassistencialistas, rompendo com o modelo cartesiano ainda arraigado nesta área. TEIXEIRA e col. (1998) apontam a necessidade do desenvolvimento e adoção de novas práticas que levem à promoção e prevenção da saúde, superando o modelo médico-assistencialista e assistencial-sanitarista, hegemônicos na saúde pública brasileira. A lógica de intervenção sanitária clássica não consegue responder todos os problemas de saúde na sua globalidade. Têm-se como exemplos, na esfera ambiental, os problemas do trabalhador associados a causas externas e mesmo a doenças crônico-degenerativas ou a própria AIDS. Não existem “vacinas” contra acidentes de trânsito, nem como higienizar o meio ambiente contaminado por pesticidas que levam ao adoecimento das pessoas (FUNASA 2003). A Vigilância à Saúde, 
implementada pelo Ministério da Saúde em 2003, tenta estabelecer ações que visem superar estes dois modelos e caminhem no sentido da promoção da saúde. Pretende tirar de foco somente a assistência e garantir que ações voltadas às políticas públicas assegurem o controle social, na tentativa de buscar ambientes mais equilibrados e estilos de vida mais saudáveis. Na realidade, busca trabalhar em cima dos princípios doutrinários do SUS, a fim de garantir:

“ saúde é direito de todos e dever do Estado, garantido mediante políticas sociais e econômicas que visem à redução do risco de doença e de outros agravos e ao acesso universal e igualitário às ações e serviços para a sua promoção, proteção e recuperação" (Art. 196).

e que : "todos têm direito ao meio ambiente ecologicamente equilibrado, bem de uso comum do povo e essencial à sadia qualidade de vida, impondo-se ao Poder público e à coletividade o dever de defendê-lo, preservá-lo para as presentes e futuras gerações” (Art. 225).

A Saúde Ambiental ou a Saúde e Ambiente abordam a interface entre ambiente e o padrão de saúde. Segundo a OMS, a Saúde Ambiental incorpora fatores e elementos que potencialmente afetam a saúde, como: exposição a substâncias químicas diretamente, elementos biológicos ou mesmo situações que interferem no estado psíquico do indivíduo, incluindo aspectos negativos do desenvolvimento social e econômico dos países (OPAS, 1990). No campo da saúde pública, incorpora, aos métodos tradicionais quantitativos, os aspectos qualitativos relacionados a fatores psicossocioambientais, inerentes aos problemas ambientais (TAMBELINI e CÂMARA 1998). A FUNASA (2003) define que a saúde ambiental: "integra as dimensões histórica, espacial e coletiva das situações de vida a partir de um compromisso ético com a qualidade de vida das populações e dos ecossistemas em jogo”. Já a OMS a define de forma mais abrangente: “Saúde Ambiental são todos aqueles aspectos da saúde humana, incluindo a qualidade de vida, que estão determinados por fatores físicos, químicos, biológicos, sociais e psicológicos no meio ambiente. Também se refere à teoria e prática de valorar, corrigir, controlar e evitar aqueles fatores do meio ambiente que potencialmente possam prejudicar a saúde de gerações atuais e futuras” (OMS 1993). 
A Vigilância Ambiental no Brasil foi estruturada pela Fundação Nacional de Saúde (FUNASA), recebendo a denominação de Sistema Nacional de Vigilância Ambiental em Saúde (SINVAS), regulamentada em 2001, sendo definida como: "conjunto de ações que proporciona o conhecimento e a deteç̧ão de qualquer mudança nos fatores determinantes e condicionantes do meio ambiente que interferem na saúde humana, com a finalidade de identificar as medidas de prevenção e controle dos fatores de risco ambientais relacionados às doenças ou outros agravos à saúde” (MS 2001).

\subsection{2 - Definição e aplicação de indicadores ambientais}

Perante todas estas dificuldades e diversidade conceituais sobre meio ambiente, envolvido fortemente pela representação social, torna-se mais difícil ainda medir o impacto ambiental sobre a saúde. Até que ponto as mudanças ambientais têm afetado a saúde das pessoas e como avaliar esta relação homem-meio ambiente?

Um instrumento utilizado para avaliar estas relações são os indicadores ambientais. Tem-se avançado em relação aos indicadores ambientais, na tentativa de defini-los e pactuar a respeito de sua adoção. A Organização Pan-americana de Saúde (OPAS) define como indicador ambiental "um valor agregado a partir de dados e estatísticas, transformando em informação para uso direto dos gestores, $e$ deste modo contribuindo para aprimorar o gerenciamento e a implementação de políticas” (BELMAR e col 1993 e CORVALÁN e col. 1996).

Em 1993, a OECD (Organização de Cooperação e Desenvolvimento) definiu e propôs um modelo de indicador ambiental denominado FPEEEA (Forças motrizes/ Pressão/Estado/Exposição/Efeito/Ação), que agrega geração, exposição e efeitos dos riscos ambientais e as ações de controle, de prevenção e promoção de cada etapa (figura 7). A OMS e o próprio Ministério da Saúde do Brasil têm adotado este modelo de indicador, aplicando-o para a saúde e pontuando-o como instrumento que possibilita a análise da relação entre saúde e meio ambiente, facilitando o planejamento de ações e tomada de decisão (AUGUSTO E BRANCO 2003). 


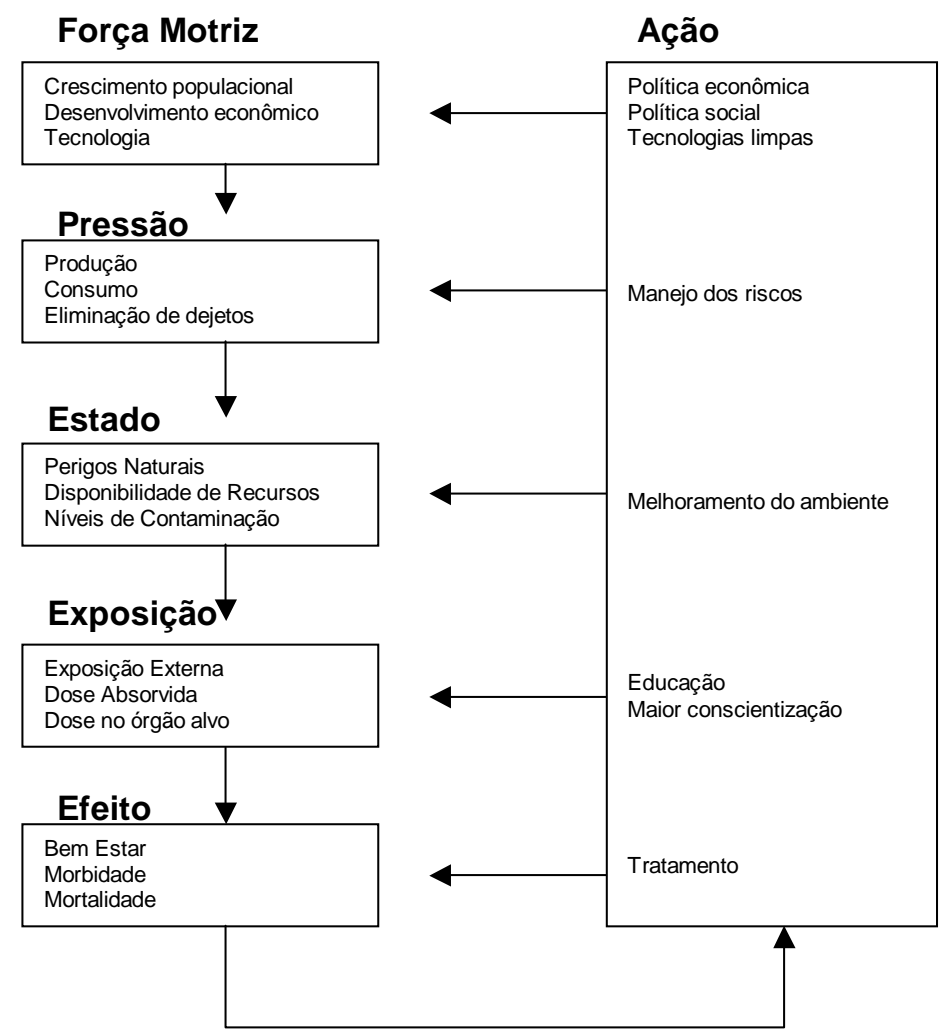

Figura 7 - FPSEEA: um marco conceitual para o desenvolvimento dos indicadores de saúde ambiental. Adaptado de: Corvalán e col. Desarrollo de los indicadores de salud ambiental. Oficina de Salud Ambiental Integral y Global, Organización Mundial de la Salud, Ginebra e Centro Nene para la Investigación, Northampton, Reino Unido; 1995: 14.

AUGUSTO e BRANCO (2003) sintetizaram os componentes deste indicador de forma clara e concisa:

- $\quad$ Forças motrizes - modelo de desenvolvimento adotado, responsável pelas atividades e fontes de poluição e de degradação ambiental.

- $\quad$ Pressão: fontes de pressão sobre o ambiente e sobre a população, estando subordinadas às forças motrizes.

- $\quad$ Estado: condições ambientais gerais submetidas às pressões existentes.

- $\quad$ Exposição: riscos produzidos à saúde ambiental e humana.

- $\quad$ Efeitos: resultado nocivo da submissão à exposição.

- $\quad$ Ações: medidas de proteção da saúde humana e do ambiente. 
Durante o IV Congresso Brasileiro de Epidemiologia, em 1998, foi realizada uma oficina de trabalho sobre indicadores de saúde e ambiente, cujo objetivo foi discutir o tema em questão e propor indicadores para medir e avaliar essa interação (GALVÃO e col. 1998). A oficina foi uma promoção conjunta da Associação Brasileira de Pós-graduação em Saúde Coletiva - ABRASCO, do Centro Nacional de Epidemiologia da Fundação Nacional de Saúde - CENEPI/FNS, da Organização Mundial de Saúde - OMS, e da Organização Pan-americana da Saúde - OPAS. O grupo analisou os indicadores existentes e discutiu sobre a necessidade de se criar novos indicadores para a vigilância ambiental, destacando atenção especial para aspectos de relevância como: “interdisciplinaridade da área, aplicação de indicadores segundo nível de complexidade do sistema de saúde (local, estadual, nacional) e o custo-benefício do uso de indicadores”. Os indicadores discutidos foram os seguintes: água (aferir a qualidade e quantidade de água à população); controle de transmissão de doenças endêmicas por vetores (desenvolver outros indicadores enfocando o ambiente, e não a doença); contaminantes ambientais (objetivar o controle da contaminação ambiental e de prevenção da exposição); ar (aferir qualidade do ar externo e domiciliar também); contaminação do solo (controlar geração e destino final dos resíduos e indicadores de morbimortalidade relacionados); desastres naturais e acidentes com produtos perigosos (monitorar incidência de doenças durante desastres naturais e identificar atividades, fluxo e locais com produtos perigosos).

Nota-se que os indicadores ambientais, na sua maioria, baseiam-se em dados quantitativos. BORJA e MORAES (2001), após uma revisão sobre este tema, notaram que a maioria dos indicadores propostos são quantitativos e com análise matemática. Isto pode se constituir em um empecilho na compreensão dos problemas ambientais, associados a diversos elementos e apresentando grande complexidade, sendo limitante a investigação baseada somente em dados quantitativos.

Outro aspecto muito importante, ligado aos indicadores ambientais, aponta que ao adotar os limites de tolerância como verdades absolutas pode trazer uma falsa idéia do que realmente pode estar acontecendo com o indivíduo ou a população, gerando injustiças e sofrimento, principalmente às pessoas expostas à poluição, às más condições de trabalho e desigualdades sociais (AUGUSTO e col 2003). 
AUGUSTO e BRANCO (2003) destacam que "as respostas aos problemas ambientais devem ser dadas de forma contextualizada, pois a ciência é limitada pelo fato de buscar explicar os fenômenos por 'causas imediatas'. Isto é, os métodos não dão conta da globalidade do problema”. Além disso, os limites de segurança são indicadores quantitativos, determinados a partir da química inorgânica (concentração = massa/volume) e a saúde é um 'indicador biopsicossocioambiental complexo' (NOVAES 1992). Desta forma, nas práticas de saúde, costuma-se cometer o erro de analisar mecanicamente a relação exposição-efeito, somente levando em consideração os limites de tolerância a que o homem foi exposto, já adotando ou dispensando medidas pertinentes para a resolução do caso.

$\mathrm{Na}$ atual pesquisa em foco enfrentamos dificuldades para trabalhar com indicadores ambientais, uma vez que a região escolhida para desenvolvermos o trabalho (Botucatu) não dispõe desses indicadores, nem mesmo em relação a qualidade do ar. Além disso, precisaríamos de uma série histórica desses indicadores, uma vez que pretendíamos observar a relação entre fatores ambientais e longevidade, sendo importante saber como eram as condições ambientais a que estes longevos foram expostos ao longo da vida. Retomando as discussões das limitações destes indicadores ambientais e associando a idéia meio ambiente sob a perspectiva das representações sociais, optamos, para esta pesquisa, por adotar uma abordagem mais qualitativa. 


\section{OBJETIVOS}

\section{OBJETIVO GERAL}

Observando o cenário apresentado, o objetivo da presente tese de doutorado é compreender as possíveis associações entre fatores ambientais e aumento da longevidade, segundo a perspectiva de um grupo de ferroviários longevos.

\section{OBJETIVOS ESPECÍFICOS}

Os objetivos específicos destacados são:

- Estudar possíveis associações entre meio ambiente, saúde e longevidade segundo a vivência de ferroviários longevos.

- Desenvolver um modelo teórico representativo dessas vivências do grupo investigado.

- Caracterizar a amostra de longevos (bio-psico-social), levantando fatores que podem contribuem para a longevidade.

- Investigar as condições ambientais a que esses longevos foram submetidos durante as suas vidas, segundo suas percepções.

- Comparar as causas da mortalidade de idosos ferroviários da Estrada de Ferro Sorocabana de Botucatu e da população geral idosa do município.

- Resgatar aspectos históricos envolvendo a Estrada de Ferro Sorocabana de Botucatu e o próprio município, a partir dos relatos. 


\section{CAPÍTULO 2 - A METODOLOGIA}

\section{1 - A procura de um local adequado para o desenvolvimento do estudo}

Dentre as variáveis das populações a serem estudadas, indaga-se onde estariam os longevos? Será que o número de longevos é percentualmente equivalente em todos os municípios ou a longevidade pode predominar em alguns municípios com características especiais? Um pensamento lógico foi: municípios com maior número de idosos teriam maior chance de possuir longevos.

Buscando maiores informações demográficas, partiu-se para a tabulação e análise dos dados do Censo Demográfico 2000 (IBGE 2000). Em termos de Brasil, observou-se que, em 2000, a população de idosos era de 14.536 .029 pessoas (60 anos ou mais), representando $8,56 \%$ da população geral, sendo $45 \%$ representados por homens e 55\% por mulheres. Além disso, havia uma grande concentração de idosos no meio urbano, 81,4\%, e apenas 18,6\% na área rural. Já a população com 80 anos e mais possuía bem menos representantes, 1.832 .105 pessoas (1,08\% da população). Os centenários representavam 0,01\% da população geral, com 24.576 indivíduos espalhados pelo Brasil. Percorrendo as regiões do Brasil, a que concentrava maior proporção de idosos era a região Sudeste, com 9,30\%, e o Rio de Janeiro era o Estado com maior proporção de idosos, 10,71\%, seguido pelo Rio Grande do Sul, com 10,46\%. Embora a região Nordeste não tivesse se destacado, a Paraíba apresentava 10,18\% de sua população constituída de idosos. O Estado de São Paulo obteve 8,96\% (tabela 2). 
Tabela 2 - Distribuição da população geral e de idosos do Brasil, segundo as grandes regiões e Unidades da Federação, 2000.

\begin{tabular}{|c|c|c|c|}
\hline \multirow{2}{*}{$\begin{array}{c}\text { Grandes Regiões } \\
e \\
\text { Unidades da Federação }\end{array}$} & \multicolumn{3}{|c|}{ População residente } \\
\hline & Total & $\begin{array}{l}60 \text { anos } \\
\text { ou mais }\end{array}$ & $\begin{array}{l}\text { Idosos/população geral } \\
(\%)\end{array}$ \\
\hline Brasil..................... & 169799170 & 14536029 & 8,56 \\
\hline Região Norte................. & 12900704 & 707071 & 5,48 \\
\hline Rondônia... & 1379787 & 72062 & 5,22 \\
\hline Acre........... & 557526 & 30404 & 5,45 \\
\hline Amazonas................................. & 2812557 & 137060 & 4,87 \\
\hline Roraima. & 324397 & 13128 & 4,05 \\
\hline Pará.... & 6192307 & 356562 & $\overline{5,76}$ \\
\hline Amapá... & 477032 & 19443 & 4,08 \\
\hline Tocantins.................................... & 1157098 & 78412 & 6,78 \\
\hline Região Nordeste.......... & 47741711 & 4020857 & 8,42 \\
\hline 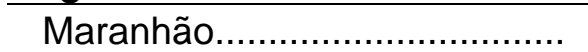 & 5651475 & 405914 & 7,18 \\
\hline Piauí.. & 2843278 & 236954 & 8,33 \\
\hline Ceará & 7430661 & 658989 & 8,87 \\
\hline Rio Grande do Norte.. & 2776782 & 250594 & 9,02 \\
\hline 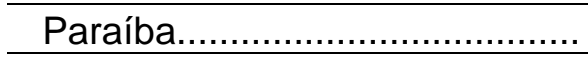 & 3443825 & 350566 & 10,18 \\
\hline Pernambuco.............................. & 7918344 & 704886 & 8,90 \\
\hline Alagoas........................................ & 2822621 & 203882 & 7,22 \\
\hline Sergipe................ & 1784475 & 131171 & 7,35 \\
\hline Bahia.. & 13070250 & 1077901 & 8,25 \\
\hline Região Sudeste............ & 72412411 & 6732888 & 9,30 \\
\hline Minas Gerais......................... & 17891494 & 1624981 & 9,08 \\
\hline Espírito Santo.. & 3097232 & 250196 & 8,08 \\
\hline Rio de Janeiro........................... & 14391282 & 1540754 & 10,71 \\
\hline São Paulo................................... & 37032403 & 3316957 & 8,96 \\
\hline Região Sul..................... & 25107616 & 2305348 & 9,18 \\
\hline Paraná.. & 9563458 & 809431 & 8,46 \\
\hline Santa Catarina.. & 5356360 & 430433 & 8,04 \\
\hline Rio Grande do Sul................. & 10187798 & 1065484 & 10,46 \\
\hline Região Centro-Oeste.. & 11636728 & 769865 & 6,62 \\
\hline Mato Grosso do Sul.............. & 2078001 & 157093 & 7,56 \\
\hline Mato Grosso....................... & 2504353 & 144318 & 5,76 \\
\hline Goiás............................................ & 5003228 & 358816 & 7,17 \\
\hline Distrito Federal.. & 2051146 & 109638 & 5,35 \\
\hline
\end{tabular}

Fonte: Instituto Brasileiro de Geografia e Estatística. Censo demográfico 2000: características demográficas da população e dos domicílios (resultado do universo). Rio de Janeiro: IBGE; 2000.

Tomando-se o Estado de São Paulo, partiu-se à procura de locais com maior concentração de idosos, ideais para a realização deste projeto. Primeiramente, tentouse dividir as cidades conforme o número de habitantes, pois seria inapropriado tentar 
comparar a população de idosos de um município com 500 mil habitantes com a de outro de 5 mil. Desta maneira, os municípios do estado de São Paulo foram classificados em cinco categorias: a) Municípios com população muito reduzida (população inferior a 50.000 hab.); b) Municípios com população reduzida (de 50.000 a 100.000 hab.); c) Porte médio (entre 100.000 hab. a 300.000 hab.); d) Populosos (população entre 300.000 a 500.000 hab.); e) Muito Populosos (mais do que 500.000 hab.) (figura 8). Esta classificação foi criada e adotada para a presente pesquisa, uma vez que não havia padronização na literatura e nem critérios definidos pelos órgãos governamentais. Dentre os municípios com população muito reduzida (total de 531), observou-se uma grande concentração de idosos em cada município, sendo que a cidade com a maior proporção de idosos, de todo o Estado, foi o município de Águas de São Pedro, com 20,5\% da população constituídos por pessoas com 60 anos e mais. Entretanto, esse município, que a princípio parecia o mais adequado para o desenvolvimento do projeto, foi descartado, porque a concentração de idosos foi um fato mais recente. Ou seja, a cidade foi muito divulgada na mídia por oferecer ótima qualidade de vida às pessoas idosas, o que acabou atraindo muitos idosos. Desta forma, provavelmente não foram as características do local que favoreceram o envelhecimento de seus moradores. Além disso, é crença bastante difundida que muitas cidades pequenas do interior têm uma alta taxa de idosos em virtude da migração dos jovens, em busca de oportunidades de trabalho, para os centros urbanos, restando mais idosos nesses municípios, que também apresentam menor movimento migratório. Tendo em vista estes fatores, descartou-se a possibilidade de realizar o estudo em municípios com população muito reduzida. Os municípios com população reduzida (54 no total) apresentaram taxas bem heterogêneas, desde muito elevada até bem inferiores, variando de 13,61\% a 4,01\%. Nesses municípios, também se encontram os agravantes apontados anteriormente, que favorecem a concentração de idosos. Assim sendo, também foram descartadas as cidades com população reduzida para o vigente trabalho. Já os municípios de porte médio (43 no total) pareciam ser promissores, uma vez que, aproximadamente, 50\% dos municípios apresentavam uma proporção de idosos superior à média para o Brasil e para o Estado. O que mais se destacou foi São Caetano do Sul, com 16\% de idosos (22.429 pessoas), entretanto, verificou-se que esse município também 'atraiu’ 
os idosos da região metropolitana, após suas aposentadorias, pela qualidade de vida oferecida pela cidade. As cidades que possuíam mais de $11 \%$ de idosos eram: Araraquara (11,43\%), Barretos (11,39\%), Botucatu (11,21\%), Catanduva (12,37\%), Jaú $(11,37 \%)$ e Rio Claro (11,34\%). Estas se mostraram, à primeira análise, adequadas ao estudo. Partiu-se para analisar os municípios populosos (11 no total). Observou-se que eles não despontavam muito em termos de idosos, apenas Santos apresentou uma taxa mais elevada (15,60\%). Novamente aqui (Santos) também se pôde descobrir o 'fenômeno atrativo' de idosos em busca de melhor qualidade de vida, após a aposentadoria, e tendo imóveis litorâneos a preços mais atrativos. Nos municípios muito populosos (somente 8) também não havia grande concentração de idosos. Santo André foi o que apresentou a maior taxa, 10,33\% de idosos.

\section{Figura 8}

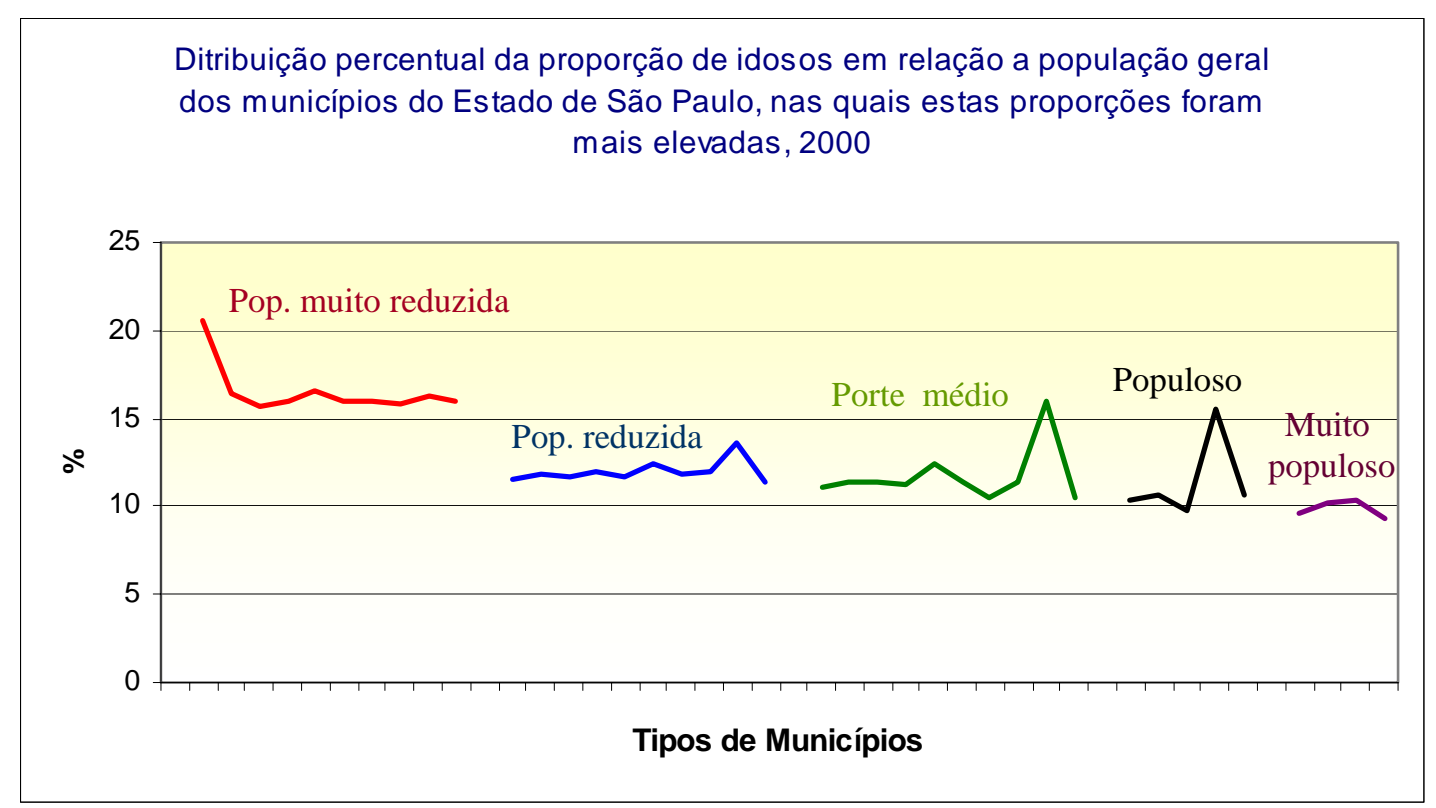

Fonte: Censo Demográfico IBGE, 2000.

Nos censos de 1996 e 1991, as cidades de Rio Claro, Jaú, Botucatu e Bragança Paulista destacavam-se pela elevada proporção de idosos. Em estudo anterior, PATRÍCIO (1998) relatou que estes municípios tinham algo em comum. Todos tiveram seu desenvolvimento associado historicamente com a ferrovia (a ferrovia passava por estes locais) e esta havia contribuído em demasia para o crescimento destes municípios. No caso específico de Botucatu, existem estudos e 
livros relatando a importância da ferrovia Sorocabana no desenvolvimento, tornando a cidade um grande pólo comercial e cultural do Planalto Ocidental até a década de 1930. No caso dos outros municípios de porte médio, que também obtiveram taxas elevadas de idosos, segundo o último Censo, como Araraquara, Barretos e Catanduva, também verificou-se a presença e a importância das ferrovias no século XIX e XX. Em Araraquara, iniciava-se a ferrovia Araraquarense, sendo a cidade um centro importante de ferroviários, empregando muitas pessoas e qualificando-as. Era referência para as outras ferrovias. Já em Barretos e Catanduva, a estrada de ferro que passava por ali era a E.F. Mogiana, entretanto, nestas duas cidades havia Estações Intermediárias, desempenhando papel fundamental para o crescimento destes municípios (ALMEIDA 2003) ${ }^{5}$. Estas cidades são apontadas no mapa esquemático da malha ferroviária da FEPASA, 1987 (figura 9).

Figura 9 - Malha ferroviária do Estado de São Paulo e localização das cidades de porte médio com maior proporção de idosos, 1987.

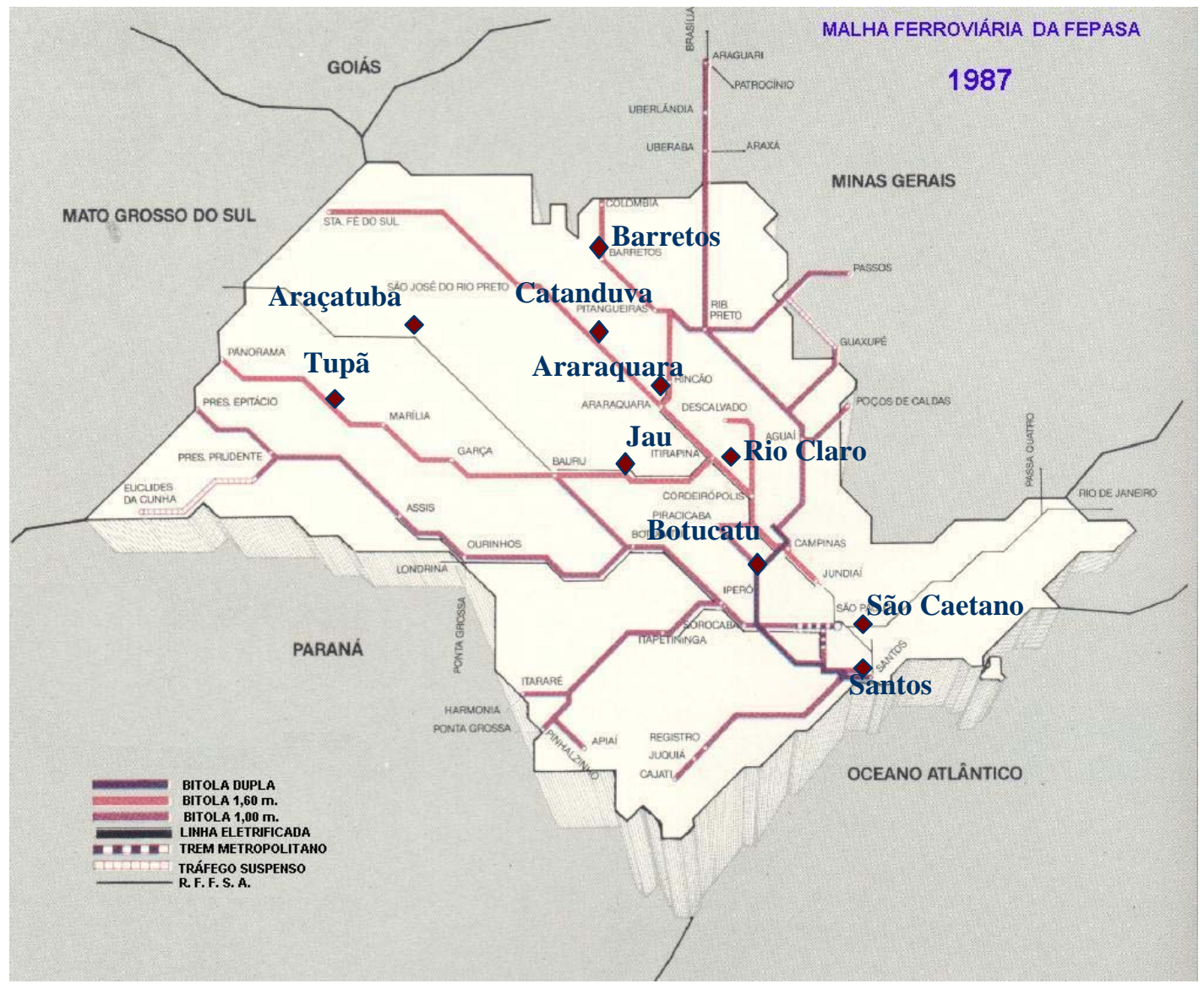

\footnotetext{
${ }^{5}$ Almeida O. Presidente da Associação de Ferroviários Aposentados e Pensionistas da Estrada de Ferro Sorocabana de Botucatu, Botucatu. Comunicação pessoal, 2003.
} 
Muitos fatores interferem positiva e negativamente no envelhecimento humano, como foi apontado inicialmente. Portanto, seria adequado selecionar um grupo de idosos e longevos que tivessem características não muito discrepantes, um grupo mais homogêneo. Desta maneira, correria-se menor risco de se trabalhar com variáveis de confusão associadas à longevidade. Assim sendo, o grupo de ferroviários aposentados mostrou-se bem adequado ao estudo. São pessoas idosas e muitos longevos, com uma história de vida semelhante, com condições socioeconômicas não muito discrepantes, que vivenciaram as mesmas influências ambientais, com pequenas variações perante o trabalho desempenhado, sendo, portanto, um grupo homogêneo e adequado para se investigar a longevidade associada às condições ambientais. A localização e acesso a esses ferroviários também seria outro ponto favorável, uma vez que existe a Associação de Ferroviários Aposentados e Pensionistas da Estrada de Ferro Sorocabana de Botucatu e do Sindicado dos ferroviários, que têm fichas cadastrais dos associados.

Dentre todos os municípios de porte médio e com elevada proporção de idosos, o município de Botucatu apresenta uma literatura de apoio favorável, com dados sobre a história do município e da ferrovia (AGUIAR 2001; DELMANTO 1990, 1993, 2000; DONATO 1985; GODOY 2000; IYDA 1979; PINTO 1994); pesquisas e trabalhos com a população geral e idosa do município (CARANDINA e col. 1986; RUIZ 1996; CORDEIRO 2001), além de contar com uma boa rede de saúde e hospital universitário, onde dados de condições de saúde e de morbimortalidade dos longevos poderiam ser encontrados. Em face a estes fatores, elegeu-se o município de Botucatu como o mais adequado e promissor para a execução deste projeto. 


\section{2 - Selecionando uma população longeva}

A proposição de projetos de pesquisa de grande envergadura necessita o conhecimento das principais variáveis envolvidas no tema de estudo, sem o qual corre-se o risco de chegar a conclusões errôneas e perder-se o alto investimento despendido. Além das dificuldades de natureza teórica, o tema a respeito da longevidade na espécie humana envolve o conhecimento das variáveis das populações a serem estudadas. Dentre as várias questões analisadas, destaca-se, inicialmente, o critério para definição de idoso e de longevo.

A OMS, em julho/agosto de 1982, promoveu uma Assembléia Mundial a fim de discutir o tema do envelhecimento, tendo a participação de diversos paísesmembros e de entidades não-governamentais. Procurou-se discutir a situação do envelhecimento e dos idosos em todo o mundo, enfatizando a necessidade de se criar uma política comum visando a melhoria das condições de vida das pessoas idosas (NAÇÕES UNIDAS 1982; CANÇADO 1994). Após amplo debate, chegou-se a um consenso, considerando idoso todo indivíduo com idade igual ou superior a 60 anos, em países em desenvolvimento, e com 65 anos ou mais aqueles residentes em países desenvolvidos, em vista da diferente expectativa de vida destes dois blocos de países (NAÇÕES UNIDAS 1982). Mesmo com esta delimitação etária definida mundialmente, é difícil definir o momento real em que as pessoas passam a pertencer à categoria de idoso, podendo ter um envelhecimento mais precoce ou tardio. De certa maneira, em nossa sociedade, as pessoas passam a ser consideradas idosas quando encerram suas atividades profissionais, ou seja, quando se aposentam. Segundo outra classificação popular, idoso é aquele que começa a depender de outras pessoas para realizar suas atividades diárias. Portanto, seja qual for a delimitação adotada, a definição deste grupo etário, estará sempre carregando uma razoável taxa de arbitrariedade (SAAD 1990).

Em relação à definição de Longevo, as dificuldades e contradições ampliamse em demasia. Alguns trabalhos elegem longevos como sendo os indivíduos com 80 anos e mais, mas somente para facilitar o estudo, sem nenhum critério de legitimidade. Outros, estudando a possibilidade de herança genética, apontam que 85 anos poderia ser a idade de demarcação da longevidade humana feminina e 75 anos a 
da masculina (GAVRILOVA e GAVRILOV 2001b). A inexistência de uma referência etária para a espécie humana torna vaga a noção de longevo, que é socialmente sintetizada como “os velhos muito velhos”. Em trabalhos experimentais, é definida em comparação ao tempo de vida de animais tidos como controle, enquanto em trabalhos americanos, o longevo é definido como “old old”. PATRÍCIO (1998), buscando um critério mais preciso para longevo, elaborou algumas possíveis definições etárias levando em consideração a expectativa de vida nas diversas regiões. No caso do Brasil, se considerasse longevo o indivíduo com idade superior a 80 anos, encontraríamos muitas pessoas na região Sudeste, mas um número bem menor na região Norte. Provavelmente, o longevo da região Norte poderia ser classificado como tal com idade inferior ao da região Sudeste, diante à diferença na expectativa de vida dessas regiões. PATRÍCIO, baseando-se na expectativa de vida, propôs inicialmente que se distribuísse a população de idosos do município a ser investigado e considerasse longevas as pessoas pertencentes ao último quartil. Outra possibilidade apontada seria considerar os indivíduos cujo tempo de vida fosse maior que a idade mediana dos que ultrapassou a expectativa da população, ou seja, a metade mais idosa das pessoas que ultrapassaram a expectativa de vida da população. Caso um critério mais rigoroso fosse preciso, a autora aponta que poderia se estabelecer como longevos aqueles indivíduos com tempo de vida real pertencentes ao último quartil (Q4) das pessoas que ultrapassaram a expectativa de vida. Quando se usa a expectativa de vida para a definição de longevo, ressalta-se a diferença etária importante existente entre o sexo masculino e feminino, ao contrário do que ocorre quando se usa o critério estático de idoso, definido como 60 anos, independente do sexo ou local de moradia. Isto torna os critérios propostos como elegíveis e aplicáveis. Dentre estas possibilidades, optou-se por adotar o critério de longevo, para esta pesquisa, como sendo todos aqueles indivíduos com idade superior ao último quartil da população acima de sessenta anos (idosa) do município a ser pesquisado.

Com base nos dados de uma amostra populacional da cidade de Botucatu, realizada em outubro de 2001 (26.000 pessoas), por CORDEIRO, e adotando o critério de longevo como sendo o indivíduo com idade superior ao último quartil da população de idosos, definiu-se a faixa etária para longevo em Botucatu: 
- População Geral: 75,6 anos

- Homens: 74,8 anos

- Mulheres: 76,1 anos

\subsection{1 - Localizando os ferroviários aposentados e elaborando um cadastro}

A fim de localizar os ex-ferroviários aposentados da Estrada de Ferro Sorocabana de Botucatu, recorreu-se a alguns locais para se conseguir o nome e endereço dessas pessoas, elaborando um cadastro. Recorreu-se a Associação dos Ferroviários Aposentados e Pensionistas da Estrada de Ferro Sorocabana de Botucatu (AFAPEFSB) e, após o consentimento do Presidente, as fichas de cadastro desses idosos puderam ser consultadas. Essas fichas são utilizadas pela Associação apenas com o objetivo de ter o controle do pagamento da mensalidade, sendo feito manualmente a cada mês. Elas continham poucas informações, e muitas estavam incompletas. Foram anotados os seguintes dados: nome completo do ferroviário, data de nascimento (quando existia), endereço e telefone. Até maio de 2003, existiam 681 pessoas cadastradas, das quais 325 eram viúvas dos ferroviários falecidos e 356 eram aposentados vivos.

Depois, também se conseguiu o consentimento do Presidente do Sindicato dos Ferroviários, para que as suas fichas de cadastro fossem consultadas. O grande trabalho foi que tudo teve de ser feito de maneira manual, pois não havia nada informatizado. As fichas eram consultadas, transcritas para papel e, depois, digitadas, o que demandou bastante tempo. Pelo sindicato, conseguiu-se registrar 761 ferroviários aposentados, sendo que existiam cerca de 1.800 cadastros, mas muitos referentes às viúvas ou dependentes de ferroviários falecidos. Foram anotadas as mesmas informações que da Associação, entretanto, muitas dessas fichas estavam desatualizadas, contendo dados de ferroviários que já haviam falecido há tempo. Ao todo, foram cadastrados 1.013 ferroviários. Para chegar ao fim desse cadastro, o trabalho perdurou por três meses. 


\subsection{2 - Selecionando a amostra}

Utilizou-se a figura de um informante-chave, que havia trabalhado durante muitos anos na ferrovia e, depois, no sindicato, conhecendo a maioria dos ferroviários. Dessa forma, foi marcado um encontro com o informante, o presidente e a secretária atual do sindicato, para rever todos os nomes cadastrados pela pesquisadora e para tentarem lembrar quais estavam vivos, bem de saúde (principalmente a parte mental), qual a função que desempenharam na ferrovia, se teriam condições de serem entrevistados e quais seriam ferroviários informanteschave (ativos na história da ferrovia).

De posse das informações, foram excluídos 15,3\% nomes da lista que foram descobertos com já tendo falecido (atestado de óbito e dados informais). Além disso, 13 pessoas foram excluídas por morarem em outros municípios. Mais 20 nomes de ferroviários foram retirados do universo por apresentarem patologias que os impossibilitavam de serem entrevistados, como demência ou outras doenças incapacitantes, além de um desaparecimento. Esses casos foram descobertos por meio de informantes. Então, dos 1.013 cadastrados inicialmente, ficou-se com 828 nomes de ex-ferroviários.

Por fim, partiu-se para analisar a idade desses ferroviários cadastrados, uma vez que somente pessoas longevas, com idade igual ou maior que 74 anos e 8 meses poderiam entrar para a amostra desta pesquisa. Em 76 casos, a idade foi ignorada e 251 com idade igual ou superior a 74 anos e 8 meses, idade adotada como longevo. Destes, 20 eram aqueles que apresentavam doenças que impossibilitavam a entrevista, reduzindo a amostra de longevos a 231 (tabela 3). 
Tabela 3 - Distribuição etária dos ferroviários cadastrados para esta pesquisa, 2003.

\begin{tabular}{l|c|c}
\hline Dados dos ferroviários & No. & $\%$ \\
\hline 25 a 29 anos & 4 & 0,4 \\
\hline 30 a 34 anos & 0 & 0 \\
\hline 35 a 39 anos & 1 & 0,1 \\
\hline 40 a 44 anos & 1 & 0,1 \\
\hline 50 a 49 anos 54 anos & 8 & 0,8 \\
\hline 55 a 59 anos & 19 & 1,9 \\
\hline 60 a 64 anos & 89 & 8,8 \\
\hline 75 a 69 anos 74 anos & 126 & 12,4 \\
\hline 75 a 79 anos & 125 & 12,3 \\
\hline 80 a 84 anos & 152 & 15,0 \\
\hline 85 a 89 anos & 109 & 10,8 \\
\hline 90 a 94 anos & 78 & 7,7 \\
\hline 95 a 99 anos & 50 & 4,9 \\
\hline 100 ou mais & 6 & 0,6 \\
\hline Ignorado & 3 & 0,3 \\
\hline Óbito & 1 & 0,1 \\
\hline Reside em outro município & 13 & 1,3 \\
\hline
\end{tabular}

Fonte: Associação dos Ferroviários e Pensionistas da Estrada de Ferro Sorocabana de Botucatu e do Sindicato dos Ferroviários de Botucatu, 2003.

Com um total de 231 nomes e os devidos endereços, as entrevistas começaram a ser agendadas pela própria pesquisadora, selecionando aqueles que foram indicados como informantes-chave e que haviam desempenhado diferentes funções na ferrovia (maquinista, foguista, chefe de estação, camareiro, engenheiro, entre outros). Primeiramente, entrava em contato via telefone, apresentando a pesquisa e questionando se o ferroviário gostaria de ser entrevistado. Desta forma, agendava-se um dia, horário e local mais adequados para o ferroviário, e a pesquisadora se dirigia até lá.

Para se definir o tamanho da amostra, utilizamos o princípio da saturação da metodologia qualitativa. Ou seja, o pesquisador vai entrevistando os sujeitos e quando as respostas começam a se repetir, seguindo um mesmo padrão de resposta e não acrescentando novos elementos aos pontos investigados, isto significa que atingiu-se a saturação da amostra (STRAUSS e CORBIN 1998). Para a presente pesquisa esta saturação foi atingida com 30 entrevistas, uma vez que se tinham 
muitos e diferentes dados a serem coletados, dificultando atingir uma saturação global em todas as questões. Desta forma foram entrevistados 30 ferroviários longevos, com idade igual ou superior a 74 anos e 8 meses, corte etário definido para esta pesquisa como longevo (idade igual ou superior ao último quartil da população acima de 60 anos do município de Botucatu).

As entrevistas eram gravadas em fitas cassete e as respostas às questões fechadas anotadas pela entrevistadora no próprio questionário. O tempo médio gasto em cada entrevista foi de 2 horas e 30 minutos, variando de 1 hora e 45 minutos até 4 horas. As entrevistas eram realizadas por meio de uma visita domiciliar (apenas um entrevistado preferiu ser entrevistado na antiga estação e outro em uma unidade básica de Saúde). Houve duas recusas entre o grupo selecionado e 3 entrevistas foram perdidas, pois não foi possível transcrever a fita (timbre e tom de voz dos longevos). Uma entrevista foi refeita, pois o informante permitiu ser entrevistado novamente e era o único que tinha um engajamento histórico-político peculiar (excomunista). As fitas foram transcritas na íntegra e conferidas pela pesquisadora (conferência de fidelidade) e realizou-se a limpeza do texto (copidesque), com pequenas correções gramaticais e coloquiais, sem alterar o sentido das falas.

Outro recurso utilizado foi a captura de imagens fotográficas, antigas e novas. Durante as entrevistas perguntava se o entrevistado tinha alguma foto da época da ferrovia. Poucos foram os que tinham. O que auxiliou muito foi que em Botucatu existem várias pessoas preocupadas com a ferrovia e em preservar o passado. Entre elas um grupo de pessoas ${ }^{6}$ montou uma exposição fotográfica denominada: Museu Histórico Itinerante: “Lá vem o trem”, que é composto por mais de 100 fotos da história da EF Sorocabana e poucas de outras ferrovias. Por meio deste acervo foi possível visualizar como era no passado e comparar com o hoje, que também foi registrado pela pesquisadora, fazendo este retrato dialético entre o passado e o presente da EF Sorocabana, enriquecendo ainda mais a pesquisa.

\footnotetext{
${ }^{6}$ Os responsáveis por este acervo fotográfico são: Luiz Roberto Coelho Gomes (Zulu); o médico Joel Spadaro e o fotógrafo Marcelino Dias, que foi elaborado no ano de 2000, após longa busca a registros fotográficos da antiga EFS.
} 


\section{3 - Buscando os métodos quantitativos e qualitativos}

\subsection{1 - Elaborando o questionário}

O questionário foi elaborado de forma a abranger vários possíveis fatores ligados à longevidade na vida das pessoas e as questões ambientais associadas à saúde e à longevidade, baseando-se nos dados encontrados na literatura cinetífica. Desta forma, foi estruturado em nove partes contendo 86 perguntas (Anexo 3). A primeira parte consistia na apresentação do entrevistador, do objetivo da pesquisa e do termo de consentimento (Anexo 2). A segunda destinava-se à caracterização do longevo: sua identificação, estado marital, relacionamento com família, progênie, escolaridade, pessoas que viveram bastante na família, temperamento. Na terceira parte, havia questões sobre a procedência: onde nasceu, locais onde morou e períodos, migrações, condições e indicadores ambientais (a - Condições de abastecimento de água a que foram expostos ao longo de suas vidas; b - Situação de poluição atmosférica; c - Coleta e disposição final de resíduos sólidos que tiveram disponíveis; d - Condições de esgoto; e - Área verde das regiões onde moraram; f Condições sonoras a que estavam expostos; g - Condições de poluição visual; h Umidade; i - Variações de temperatura; j - Se já vivenciaram algum desastre ambiental; k - Se já haviam passado por situações de contaminação ambiental, l - Se já haviam morado em algum local onde tivesse ocorrido algum tipo de contaminação dos solos). Questionava-se, com questões abertas, como se obtinha lenha para a ferrovia, e seu papel no desmatamento da região. Também se investigou como a informação chegava naquela época e se tinham conhecimento a respeito dos agrotóxicos. Foram inseridas quatro questões abertas abordando a temática meio ambiente: como definiam meio ambiente, como era o meio ambiente na época em que trabalhavam na ferrovia e como consideram que está hoje, e, ainda, se achavam existir relação com a saúde. Na quarta parte, foi investigada a questão profissional, indagando-se sobre: início do trabalho, locais de trabalho, funções e período, acidentes de trabalho, manipulação de produtos tóxicos, benefícios, jornada de trabalho, remuneração atual, quadro familiar do domicílio. Mais três perguntas 
abertas apareceram: como era trabalhar na EFS de Botucatu, quais as funções exercidas, e como era a cidade na época da ferrovia. Na quinta parte, foram discutidos os hábitos de vida e vícios desses longevos: fumo, uso de bebidas alcoólicas, atividade física, lazer, amizades. As condições da saúde foram questionadas na sexta parte: condição atual de saúde e pregressa; uso de medicamentos, serviços de assistência à saúde a que tem direito e quais usa; grau de satisfação com atendimento; se adoeceu no último ano e precisou de internação; qual e como era a assistência na época da ferrovia. Na sétima parte, perguntava-se a respeito da alimentação: consumo de carne, verduras e frutas; locais de obtenção de alimentos; quantidade e qualidade do hábito alimentar. Na penúltima parte, foi investigada a questão da longevidade. Tomou-se o cuidado de colocá-la mais ao final do questionário para evitar vieses com as outras perguntas. Inseriram-se três perguntas abertas: qual era o segredo para viver bastante; se achavam que os ferroviários viviam mais que outras pessoas, e se viver bastante tinha relação com o meio ambiente. No último tópico, era questionado o grau de satisfação do longevo em relação à sua própria vida e ao meio ambiente em que vivem atualmente.

\subsection{2 - Selecionando os métodos qualitativos e quantitativos}

Ao se refletir a respeito de qual metodologia e instrumentos adotar para esta pesquisa, foi necessário aprofundamento nos estudos acerca das abordagens metodológicas, suas características e aplicações. Dentro da metodologia quantitativa, são muitos os caminhos e instrumentos que auxiliam na análise, fornecendo vastos resultados. No entanto, o pesquisador deve ter clareza de seus objetivos e utilizar os dados adequados para testar realmente a sua hipótese inicial. Em relação à metodologia qualitativa, esta vem ganhando espaço cada vez maior no meio científico e visibilidade, não cabendo mais discussões equivocadas de que ela não tem cientificidade ou é inferior. Na verdade, ambas podem se complementar. Como coloca HAGUETTE (2000): 'o problema sob investigação é que define o método de investigação'. MINAYO (1996) ressalta que a metodologia é, ao mesmo tempo, o caminho e o instrumento que se deve adotar para estudar a realidade e SPINK (1995) 
complementa: "No debate corrente é freqüente referir-se a estas diferenças contrapondo dicotomicamente as metodologias quantitativa e qualitativa. Partindo do truísmo de que qualidade e quantidade são qualificações desprovidas de sentido de valor, vale uma pequena digressão buscando situar historicamente a conotação valorativa desta falsa dicotomia na noção de rigor científico".

Desta forma, voltou-se a refletir sobre os objetivos da pesquisa atual. Para compreender as possíveis associações entre fatores ambientais e aumento da longevidade, segundo a perspectiva de um grupo de ferroviários longevos, a metodologia qualitativa responderia melhor, uma vez que possibilita captar e compreender as experiências vividas pelos sujeitos (o processo, o movimento) a serem investigados.

Entre os objetivos específicos buscava-se investigar as condições ambientais a que estes longevos foram expostos durante a vida. Desta maneira, era preciso levantar também as características do ambiente em que esses longevos viveram. Os indicadores ambientais, como discutidos no capítulo1, item 4.2, não estavam disponíveis na época e nem existiam medições para o município de Botucatu, que pudessem ser acessadas atualmente. Para favorecer alcançar uma maior longevidade, é importante a ação de fatores no início da vida, como também foi discutido no capítulo 1, item 2, portanto, não adiantava trabalhar com os indicadores ambientais atuais. Assim sendo, inseriram-se questões fechadas no questionário, na tentativa de descrever estes indicadores ambientais (qualidade da água, do ar, área verde, poluições, temperatura, umidade, lixo, esgoto, desastres ou contaminações ambientais), mas percebeu-se que somente estas medidas não seriam suficientes para alcançarmos nossos objetivos. Além disto, era muito importante conhecer um pouco mais da experiência de vida que essas pessoas tinham percorrido para chegarem até a longevidade. Isto facilitaria a compreensão e discussão dos possíveis fatores que colaboraram para a longevidade, e, dentre eles, elucidar o papel ambiental, se interferia ou não, por meio da percepção desses longevos. Optou-se por investigar com base nos relatos dos próprios ferroviários, partindo da idéia de que meio ambiente pode ser definido como uma representação social, como eram as condições ambientais a que foram expostos ao longo de suas vidas. Vale lembrar que o estudo do conhecimento do senso comum rompe com as teorias clássicas do conhecimento, 
trazendo inquietação e discórdia em relação a objetividade e a busca da verdade. SPINK, 1995, enfatiza que esta ruptura caminha no sentido de “... uma ampliação do olhar de modo a ver o senso comum como conhecimento legítimo e motor das transformações”.

Diante de todos os conceitos e dados discutidos até agora, a metodologia qualitativa é adequada para o recorte que esta pesquisa se propõe. Sendo que a metodologia quantitativa auxiliará na descrição do grupo de longevos entrevistados e dos indicadores ambientais referidos.

STRAUSS e CORBIN (1998) destacam que existem vários motivos para se trabalhar com a metodologia qualitativa. Um seria porque este método vai ao encontro da natureza do problema a ser pesquisado. Além disto, é possível obter detalhes do fenômeno que se quer estudar, como sentimentos e emoções, que são difíceis de se extrair ou estudar por meio de métodos de pesquisas tradicionais. No entanto, é necessário ter rigor na coleta de dados para que as emoções e opiniões do investigador não interfiram no processo como um todo. Para tanto, a entrevista, principal instrumento utilizado nas pesquisas qualitativas, deve seguir os parâmetros estipulados pela metodologia científica, tentando captar ao máximo o real, a visão global do problema. HAGUETTE (2000) chama a atenção para três pontos essenciais, a fim de se descrever e compreender o fenômeno real que se quer investigar: lembra que a história da ciência mostra que ela não tem sido construída de forma neutra, mas sempre busca a objetividade; no entanto, esta objetividade torna-se um parâmetro inatingível, mas mesmo assim não se deve perdê-lo de vista. E, por último, acredita que não é possível descrever o real como uma imagem perfeita, como se fosse um espelho. Esta idéia aparece reforçada por DEAN e WHYTE (1969), os quais referem que não se deve perder de vista que as informações do entrevistado representam meramente suas percepções, captadas e modificadas segundo suas reações cognitivas e emocionais, relatadas por intermédio de sua capacidade pessoal de verbalização. DEMO (1985) discute de modo veemente esta questão, de uma forma comparativa muito interessante, dizendo que, com base na pesquisa, obtemos mais uma pintura que um retrato dos fenômenos sociais. Pensando nesta pintura, é possível compreender que a realidade é captada com cores e nuances particulares, vislumbradas pelo pintor, inserindo objetos e pessoas segundo sua 
reinterpretação e criação artística. Não se pode afirmar que aquela pintura é um retrato fidedigno da realidade, embora busque ser. É apenas uma dimensão dentre muitas possíveis, na qual o pintor introduz métodos e técnicas, mas acaba predominando sua visão sobre o real e sobre o impacto que lhe causa. Ele insere imagens que são realmente visíveis e também suas emoções, na tentativa de descrever a realidade. Por fim, MINAYO (1996) ressalta que: "É preciso aceitar que o sujeito, das ciências sociais, não é neutro ou então se elimina o sujeito no processo de conhecimento. Da mesma forma o objeto, dentro dessas ciências, é também sujeito e interage permanentemente com o investigador”.

Pensando em todos estes pontos levantados é que se elegeu a Grounded Theory como uma metodologia qualitativa adequada ao estudo, seguindo o rigor científico, possibilitando um grande grau de aprofundamento dos fenômenos a serem investigados e produzindo um modelo teórico representativo das questões analisadas. Esta metodologia é uma das com maior rigor e credibilidade científica (CRESWELL 1998). PATTON (2001), citando DENZIN e LINCOLN (2000), coloca que a Grounded theory é o mais influente paradigma para a pesquisa qualitativa nas ciências sociais na atualidade. Ainda ressalta que GLASER e STRAUSS (1967) fizeram uma revolução dentre as metodologias qualitativas: “foi a precursora de um método rigoroso e chegou a uma teoria, pois a falta de rigor tornava, às vezes, a pesquisa qualitativa ilegítima, sendo meramente descritiva”.

Esta teoria foi lançada por Barney G. Glaser e Anselm L. Strauss, por meio do pioneiro livro: “The Discovery of Grounded Theory”, em 1967, na escola de sociologia de Chicago. Esta proposta foi ganhando cada vez mais adeptos e estudiosos, e, posteriormente, Juliet Corbin e Anselm L. Strauss, em 1990, incorporam novos elementos à técnica e lançam novo livro: "Basics of Qualitative Research”, aprimorando mais essa técnica. PATTON (2001) coloca que este método foi se difundindo, levando a pesquisa qualitativa às universidades onde não se adotava esta metodologia. Ele acredita que isto pode ter acontecido pelo fato de esta teoria ser mais 'objetiva'.

E o que vem a ser então esta metodologia? Como os próprios autores a definem, trata-se de uma teoria que é derivada de dados, sistematicamente coletados e analisados ao longo do processo da pesquisa. Neste método, coletânea de dados, 
análise e eventuais teorias estão em relação próxima, uma com a outra, e vão ocorrendo simultaneamente. É um método de indução sistemático, desde a coleta de dados até a análise, para construir um modelo teórico que explique os dados coletados. Ou seja, hipóteses e teorias emergem durante o procedimento de coleta e análise de dados, gerando categorias analíticas com base nos dados, chegando a um modelo teórico que explique todo o processo investigado. O processo pode ser comparado a uma música, onde você irá descobrindo o compasso, o ritmo, as pausas, interrupções e as variações no movimento que levam a uma seqüência de ações/interações, gerando uma melodia com significado complexo (STRAUSS e CORBIN 1998).

A Grounded preconiza um rigor sistemático desde o desenho, a coleta de dados e a análise, culminando com a teoria. Todos os passos, todas as etapas são feitas de forma sistemática, sendo possível saber exatamente o que foi feito até chegar à teoria, permitindo que a mesma pesquisa seja reproduzida, no sentido de ser reavaliada e validada. As hipótese testadas por meio da Grounded permitem confirmar ou descartar a teoria que emergiu.

A base central da Grounded é fazer comparações - comparações teóricas, de forma sistemática e criativa, levantando questões e descobrindo propriedades e dimensões que podem estar nos dados (PATTON 2001). É um método de comparação constante: comparando diferentes pessoas (seus pontos de vista, situações, ações, opiniões e experiências); comparando dados do mesmo indivíduo com eles mesmos; diferentes pontos de vista; comparando incidente por incidente; categoria com categoria, e comparando categoria com outra categoria (CHARMAZ 1983; GLASSER 1992).

Os passos iniciais da Grounded são semelhantes a outras metodologias, ou seja, as entrevistas são transcritas na íntegra e, depois, passam por uma microanálise, linha por linha, realizada desde a primeira entrevista, para ir gerando as categorias e os códigos iniciais. Deve-se ter senso analítico, não somente descritivo. Desta forma, as falas são quebradas em pequenos pedaços, para se entender a lógica do processo. Depois, faz-se uma organização conceitual (organizando os dados em categorias de acordo com suas propriedades e dimensões). Enquanto se estudam os dados, vão sendo criadas categorias. O processo de se criar categorias é feito por meio do exame 
de cada linha de dados e definindo-se ações ou eventos dentro destes - linha por linha. Estas análises de linha por linha nos levam a pensar o que nossos dados significam, levantando perguntas para nós mesmos sobre isto, apontando nexos e guiando em direção ao foco, durante a coleta subseqüente dos dados. Ao longo da análise, vai se trabalhando com diagramas, que são artifícios visuais que retratam a relação entre os conceitos e auxiliam a descobrir as categorias, subcategorias, elementos, chegando a uma matriz axial condicional, que é um diagrama analítico que mapeia as mudanças de condições e conseqüências relativas ao fenômeno ou categoria. Esta matriz contém vários círculos que representam ações e interações, desde as mais distantes até as mais próximas, podendo identificar fenômenos (idéia central dos dados que representa os conceitos), temas, e chegando à categoria central (fig11).

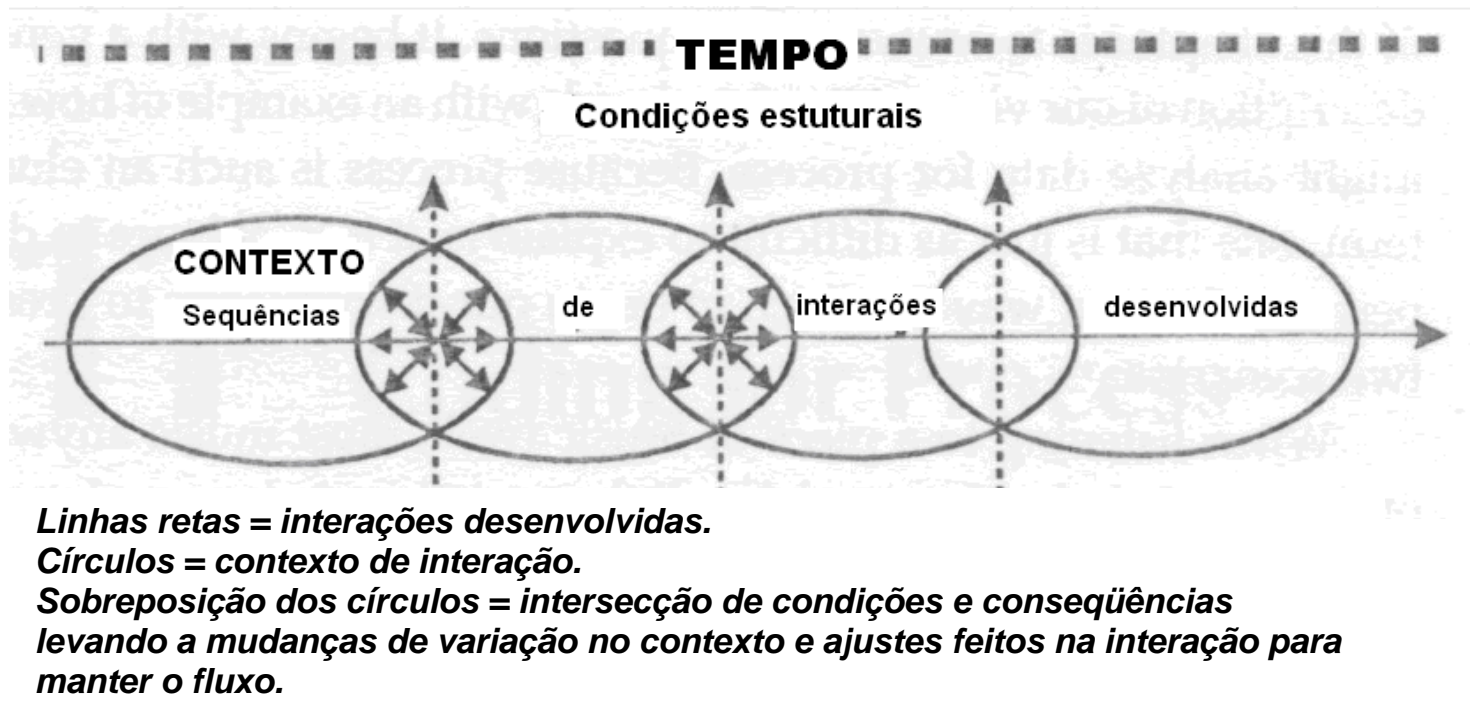

Figura 11 - O processo (fonte: Strauss AL, Corbin J. Basics of qualitative research: techniques and procedures for developing grounded theory. $2^{\text {nd }}$ ed. California: SAGE Publications; 1998: 167)

Para melhor compreensão, descrevemos as fases da análise dos dados, apresentada por BOCCHI (2001), segundo CHENITZ e SWANSON (1986):

- Descobrindo categorias. O passo inicial consiste em quebrar os dados em pequenos pedaços para se entender a lógica do processo, embora não seja um processo natural fazer isto, mas é necessário. Para isso, os dados 
são analisados linha por linha, e parágrafo por parágrafo, identificando suas dimensões e propriedades. Cada incidente é codificado como um conceito ou abstração do dado, procurando-se ter senso analítico, não somente descritivo.

- Ligando categorias - depois de identificadas as categorias, é feita nova comparação, desta vez entre categorias, estruturando melhor o conceito. Deste modo, reduzem-se as categorias iniciais, identificando-se a idéia que melhor explicou o fenômeno ou o tema daquele grupo de categorias. São, então, identificadas as categorias e seus componentes (subcategorias e elementos). O processo que leva às categorias a partir das subcategorias é organizado em torno de um eixo, para encontrar as categorias que se ligam por intermédio de propriedades e dimensões semelhantes. No início da análise, o pesquisador não consegue saber o que é categoria ou subcategoria, mas durante o processo de codificar, isto começa a se evidenciar. Não é somente uma descrição de causa e efeito, isto é muito simplista. Existem múltiplos fatores operando em várias combinações para criar um contexto.

- Desenvolvendo memorandos - são registros escritos da análise que podem variar em tipo e forma. O processo de construção da teoria implica o registro do processo analítico desde o seu início, de forma que se pode perceber o desenvolvimento do conceito, quase que passo a passo. Eles devem ser feitos desde o começo da pesquisa, com as análises iniciais, e continuar ao longo de todo o processo. Eles são importantes documentos, porque retratam o processo, pensamentos, sentimentos e as direções da pesquisa e do pesquisador, facilitando a construção da abordagem analítica do processo.

- Identificação do processo. Depois de identificadas as categorias e seus componentes, deve-se ordená-las de maneira a identificar uma que seja central, ou melhor, aquela categoria com a qual todas se relacionam: a categoria central. Para chegar a ela, são elaborados esquemas e aplicados aos dados (novo retorno aos dados, de modo a verificar qual deles parece melhor expressar as experiências dos informantes). A categoria central 
representa o principal tema da pesquisa, ou seja, ela consiste na condensação de todos os produtos da análise em poucas palavras, que tentam explicar: “esta pesquisa é sobre”. Ela tem poder analítico.

Este tipo de análise qualitativa demanda grande energia por parte do pesquisador, examinando e discutindo detalhe por detalhe, ao mesmo tempo pensando, abstraindo e generalizando, indo do particular para o geral (STRAUSS e CORBIN 1998). Isso causa muita ansiedade no pesquisador, que agrupa e reagrupa diversas vezes seus dados, sem saber ao certo o que é categoria, tema, elemento, para só, ao final, construir este complexo quebra-cabeça.

Ao final emerge a categoria central e chega-se a um modelo teórico representativo que procura explicar a maioria das experiências. Para fazer a validação deste modelo existem algumas técnicas. Uma é voltar aos dados, as falas e verificar se este modelo explica a maioria delas. Outro seria apresentar estes resultados aos sujeitos entrevistados e averiguar se eles julgam que este modelo representa a maioria de suas vivências.

As questões do questionário analisadas por esta metodologia qualitativa foram as seguintes: definição de meio ambiente; como era o meio ambiente na época em que trabalhava na ferrovia; como ele vê o meio ambiente atual; se acha que meio ambiente tem relação com a saúde e de que forma; como era trabalhar na EFS; quais as funções desempenhadas; como era Botucatu antigamente; utilização de agrotóxicos em alimentos; problemas atuais com a atenção à saúde; como era obtida a lenha para a ferrovia; papel da ferrovia no desmatamento; como a informação chegava naquela época; se tinham conhecimento dos malefícios dos agrotóxicos; qual era o segredo de viver bastante; se os ferroviários viviam mais que outras pessoas, e se viver bastante tinha relação com o meio ambiente. Para melhor identificação e compreensão destes itens e partes, vide item 2.3.1 (elaborando o questionário) e o próprio anexo 3 (questionário na íntegra, no qual estão destacadas, grifadas e em itálico, estas questões). 


\section{A METODOLOGIA QUANTITATIVA}

O questionário foi composto por 86 questões, sendo que 74 foram analisadas quantitativamente. A maioria das questões fechadas apresentavam cinco opções de resposta ao longevo entrevistado. Foram analisadas os seguintes aspectos, utilizando o pacote estatístico SPSS: caracterização do longevos (item II), procedência e as respectivas condições ambientais (item III), profissões (quarta parte), hábitos de vida (item V), saúde (parte VI), alimentação (parte VII) e grau de satisfação com a vida (item IX). Para melhor identificação e compreensão destes itens e partes, vide item 2.3.1 (elaborando o questionário) e o próprio anexo 3 (questionário na íntegra). Estes dados foram colhidos a partir da entrevista dos 30 ferroviários longevos.

Procurou-se descrever o grupo de longevos analisando os dados quantitativos do questionário. Vale ressaltar que, no questionário, foram colocadas questões referentes àqueles fatores apontados na literatura que favorecem a longevidade, como discutido no capítulo 1, subitem 1.2, e que sempre era necessário contar com a memória desses longevos, para retratarem as condições a que foram expostos ao longo de suas vidas.

Não era objetivo deste estudo quantificar o impacto de cada um desses fatores na longevidade, portanto, não foi estabelecido um grupo controle para se fazer as devidas comparações. Sugere-se que seria interessante desenvolver outros estudos na tentativa de estabelecer uma relação causal, estabelecendo um grupo controle ou fazendo um estudo de coorte. Poderia-se também comparar com um grupo que já foi a óbito antes de se tornar longevo, mas a dificuldade seria obter todos esses dados, com detalhes, dos familiares. O que poderia se tornar uma lembrança muito dolorosa, recordar todos os detalhes da vida de um ente próximo já falecido. Para investigar a questão específica da longevidade e do meio ambiente, poderiam ser estudados os óbitos de pessoas que sempre viveram em um município com melhores condições ambientais e de outras que não tiveram essas condições. No entanto, seria necessário controlar muito bem os vieses associados, uma vez que temos vários fatores agindo e interagindo no organismo humano de forma simbiótica ou antagônica.

Para conseguir aplicar testes estatísticos de correlação, um caminho seria realizar estudo longitudinal prospectivo, de coorte, podendo acompanhar e medir constantemente as variáveis associadas a possível longevidade de uma população. 
Temos, como exemplo, o estudo de "Framingham", em Massachusetts, uma grande pesquisa com desenho longitudinal prospectivo de base populacional (coorte), que tinha como objetivo analisar fatores de risco ligado, principalmente, a doenças cardiovasculares (FRIEDMAN e col. 1967). No Brasil, temos um estudo de base populacional que está sendo realizado com uma população de idosos de um pequeno município de Minas Gerais, Bambuí, que possui cerca de 20.000 habitantes. Esse estudo prospectivo foi desenhado em 1996, iniciando-se o seguimento de toda a população idosa do município (n=1742) a partir de 1997, fazendo-se os seguimentos e análises anualmente. Vários estudos têm sido publicados sobre essa importante pesquisa, inclusive, com abordagem antropológica e qualitativa da saúde (UCHOA 2003; LIMA -COSTA e col. 2003; VORCARO e col.. 2004; FIRMO e col. 2004b; LIMA-COSTA et col. 2004; FIRMO e col. 2004a).

Existe outro estudo de coorte que vem sendo realizado em um município do Sul do País, em Veranópolis, RS. Esse pequeno município chama atenção pela longevidade de seus moradores. Segundo o censo de 1996 (IBGE), a expectativa média de vida nesse local era de 77,7 anos, sendo que para o Estado do RS era de 71,8, e para o Brasil, de 67,7 anos, nessa época. Pesquisadores da Pontífica Universidade Católica do Rio Grande do Sul têm desenvolvido vários estudos, desde 1996, para investigar as variáveis associadas ao envelhecimento bem-sucedido, mais especificamente com pessoas de idade igual ou maior que 80 anos, acompanhando esta coorte longeva (MARAFON e col. 2003; SCHWANKE e col. 2002).

Outros dados que receberam análise quantitativa foram os referentes a mortalidade dos ferroviários e da população idosa masculina de Botucatu. Estudou-se o período de 1999 a 2003. Analisou-se somente o sexo masculino, uma vez que a quase totalidade dos ferroviários era do sexo masculino e a amostra entrevistada só incluiu os homens. Para isto, o banco de dados do SIM (Sistema de Informação de Mortalidade) foi consultado, tomando toda a população do município de Botucatu que tinha ido a óbito com 60 anos e mais; no entanto, para descobrir quem eram os ferroviários foi necessário fazer outras investigações. Na Associação, recorreu-se aos arquivos buscando atestados de óbitos que estavam guardados. Poucos atestados foram achados, cerca de 100. Descobriu-se, no Sindicato, que ofícios mensais eram encaminhados com o nome do ferroviário que tinha ido a óbito, a fim de pedir 
complementação de pensão para os dependentes/viúva. No entanto, essa prática era mais recente e não havia cópia do atestado. Foram encontrados mais 84 nomes nesse período. Para complementar essas informações, todos os atestados de óbitos dos idosos do município de Botucatu, do período, foram consultados manualmente. Verificava-se a casela referente à profissão, uma vez que o programa do SIM não permite que seja inserido o tipo de profissão, apenas "aposentado". Desta forma, tomou-se nota dos atestados nos quais havia registro de “ferroviário aposentado". Entretanto, nem sempre quem preenche o atestado tem este cuidado ou, muitas vezes, a família também só diz: “Aposentado”. Com base na pesquisa dessas três fontes obteve-se 193 óbitos de ferroviários no período de 1999 a 2003, e na população idosa masculina de Botucatu: 1.321 óbitos de idosos. 


\section{CAPÍTULO 3 - A EXPANSÃO DOS TRILHOS DA ESTRADA DE FERRO SOROCABANA EM DIREÇÃO AO INTERIOR PAULISTA, BOTUCATU: INÍCIO E FIM DE UMA HISTÓRIA}

\section{1 - Percorrendo a história da Estrada de Ferro Sorocabana}

Assistindo ao sucesso da linha férrea que ligava Liverpool a Manchester, na Inglaterra, em 1830, o governo imperial brasileiro motivou-se, por meio do regente Diogo Antonio Feijó, a sancionar a Lei Geral no. 101, de 31 de Outubro de 1835, que concedia carta de privilégio a uma ou mais companhias, de forma a construírem estradas de ferro que unissem a capital do Rio de Janeiro às Províncias de Minas Gerais, Rio Grande do Sul e Bahia. Após várias tentativas, o Barão de Mauá, conseguiu fechar um contrato em 1852, vindo a inaugurar a primeira linha férrea no Brasil em 30 de Abril de 1854, ligando o Porto Mauá à Raiz da Serra, com 14,5 km de extensão.

Nessa época, a Província de São Paulo se desenvolvia às custas do café e também sentia necessidade de escoar a produção até o porto de Santos, assim, em 1867, inaugurou-se o trecho de Santos-Jundiaí (VALADÃO 1991).

Em 1869, os Ituanos lideram uma reunião para a construção de uma linha que ligasse Itu a Jundiaí, mas como o custo seria muito alto chamam capitalistas Sorocabanos para entrarem como acionistas da "Companhia Ytuana", a fim de construir a linha. No entanto, consta que esses acionistas não foram bem aceitos, pois queriam a extensão até Sorocaba. Entre eles, estava Luiz Matheus Maylasky, um húngaro muito empreendedor, que logo formou um outro grupo, somente de Sorocabanos, e rapidamente conseguiu levantar o capital necessário para a construção da ferrovia. Assim, em 1871, formou a "Companhia Sorocabana”, com intuito de construir uma linha férrea de Sorocaba a São Paulo. Já em 10 de julho de 1875, conseguem inaugurar esse trecho. Mais tarde, Maylasky foi agraciado por Dom Pedro II com o título de "Visconde de Sapucahy", frente aos grandes empreendimentos relevantes realizados no Brasil. Em 1877, essa estrada de ferro atinge Piracicaba, às margens do Rio Piracicaba, integrando o transporte a vapor ao fluvial, atingindo o porto de Lençóis, no rio Tietê. Em 1889, chega, então, ao 
município de Botucatu, ponto importante no interior de São Paulo (foto 1). Em 1892, ocorre a fusão da Cia Ytuana à Sorocabana, originando a 'Companhia União Sorocabana e Ituana’, transformando-se na maior rede ferroviária do Estado, com 820 km, com mais 222 km de vias fluviais no Rio Piracicaba e Tietê, pertencentes a Ituana. Em 1900, a rede paulista de ferrovias tinha $3.393 \mathrm{~km}$, sendo que 86 pertenciam à 'Paulista', 905 à 'União Sorocabana e Ituana' (GIESBRECHT 2005; GIMENEZ 2005; ESTAÇÕES DA ESTRADA DE FERRO SOROCABANA 2005).

Assim foi crescendo essa rede ferroviária:

$\begin{array}{ll}\text { Anos } & \text { Quilômetros } \\ 1867 & 139 \\ 1877 & 1.007 \\ 1887 & 1.973 \\ 1897 & 3.110\end{array}$

Fo to de Arquivo - Museu Historico Itinerante " L"a vem o Trem" - Botucatu - SP Zulu - M. Dias - J. Spadaro

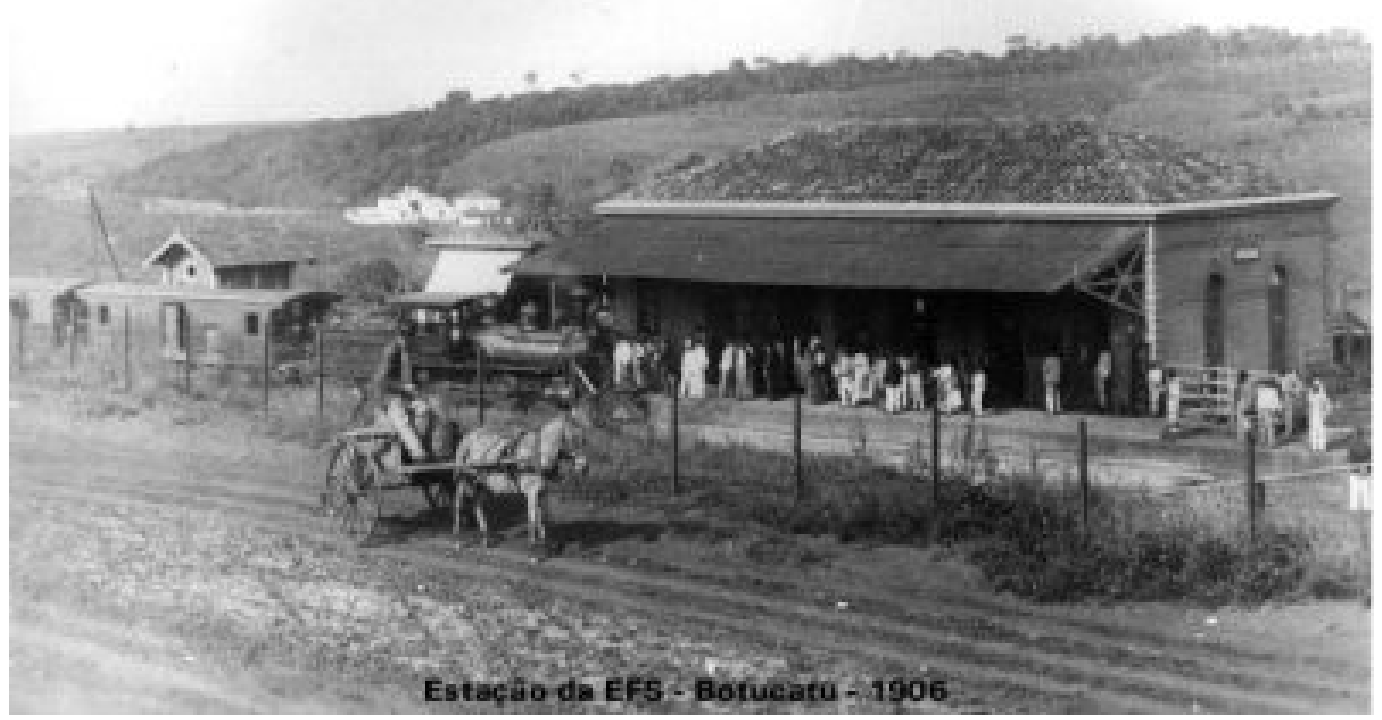

Foto 1 - A plataforma da pequena estação primitiva de Botucatu, 1906. (Foto: arquivos do Museu Histórico Itinerário "Lá vem o trem”, Botucatu). 


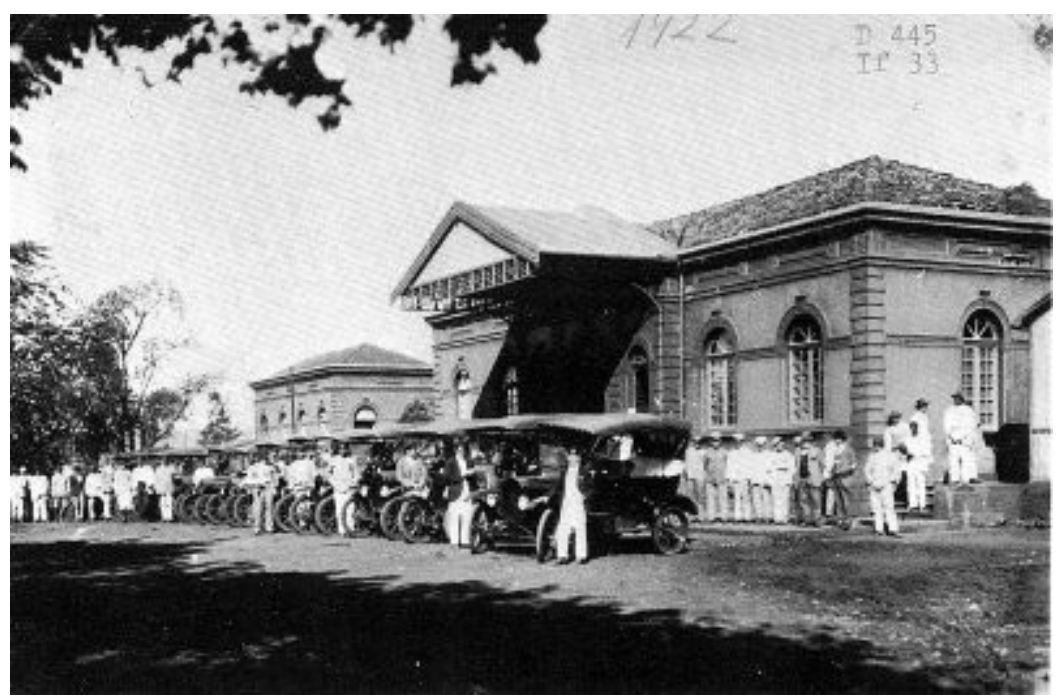

Foto 2 - A segunda estação de Botucatu, em 1922, muito movimentada com os vários táxis da época. (Foto: arquivos do Museu Histórico Itinerário “Lá vem o trem”, Botucatu).

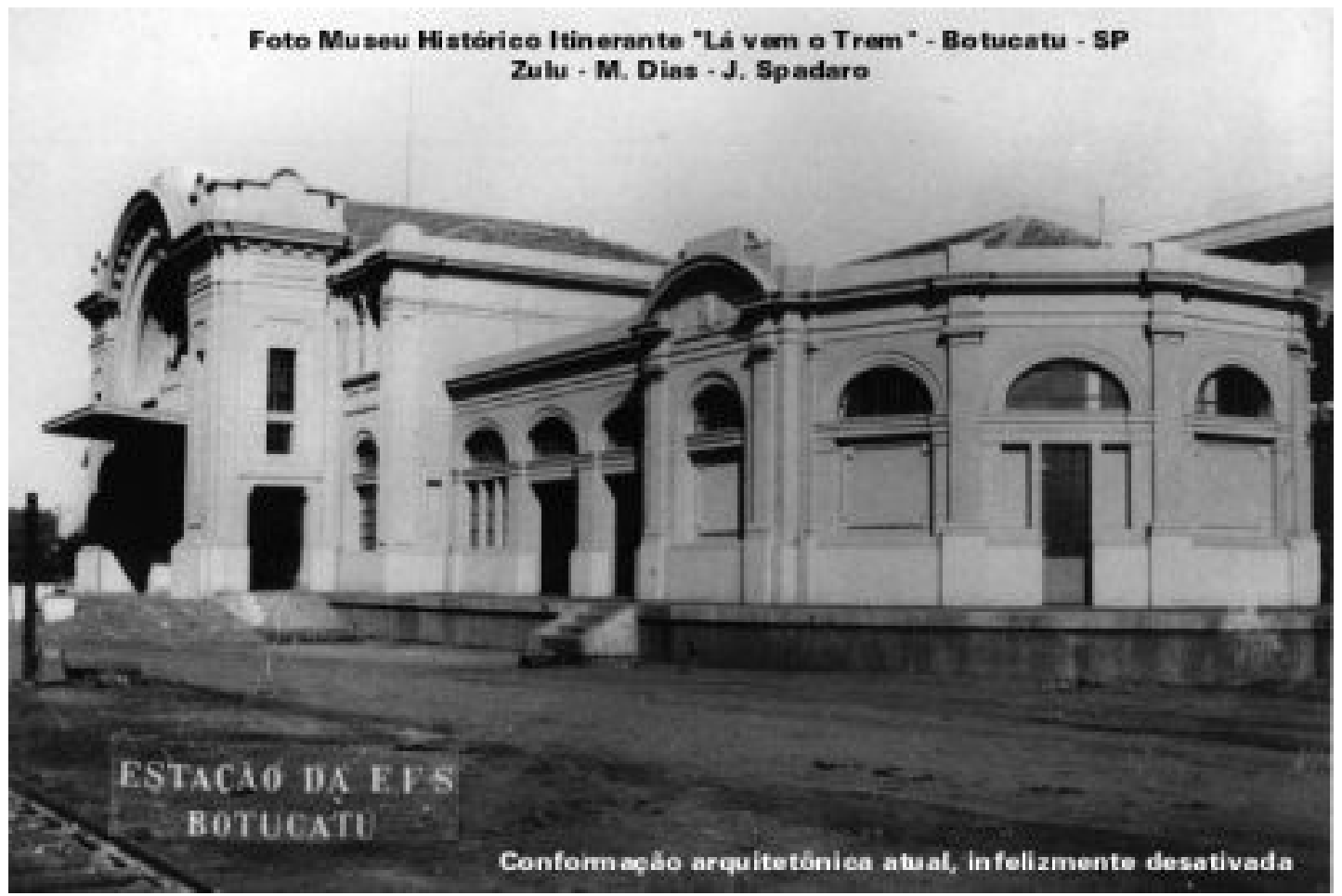

Foto 3 - A estação de Botucatu em 1934, recém inaugurada. (Foto: arquivos do Museu Histórico Itinerário “Lá vem o trem”, Botucatu).

A Companhia Sorocabana e Ituana não parava e foi avançando no sentido do Paraná e Mato Grosso, mas frente aos grande empreendimentos não agüentou e faliu. Em 1904, o governo federal encampou a empresa, mas no ano seguinte, já passou para a administração do Estado de São Paulo. Em 1905, estendeu as linhas até Bauru, tornando-se muito importante para a ligação com Mato Grosso, partindo dali a 
Noroeste, ligando o mais remoto centro-oeste ao mar. Entre 1907 a 1919, foi arrendada por um consórcio franco-americano, chamado Trust Farqhuar. Nessa época, a Sorocabana recebeu o nome de Sorocabana Railway Company, e chegou até as margens do Rio Paraná, em Presidente Epitácio. No entanto, entra em crise novamente e o governo paulista passa a administrá-la outra vez (GIESBRECHT 2005)

Entre 1927 e 1937, a Sorocabana constrói uma enorme e belíssima obra, transpondo toda a serra, a Linha Mayrinque-Santos, que desafiava o monopólio do acesso ao Porto de Santos pela empresa inglesa São Paulo Railway (GIMENEZ 2005, ESTAÇÕES DA ESTRADA DE FERRO SOROCABANA 2005).

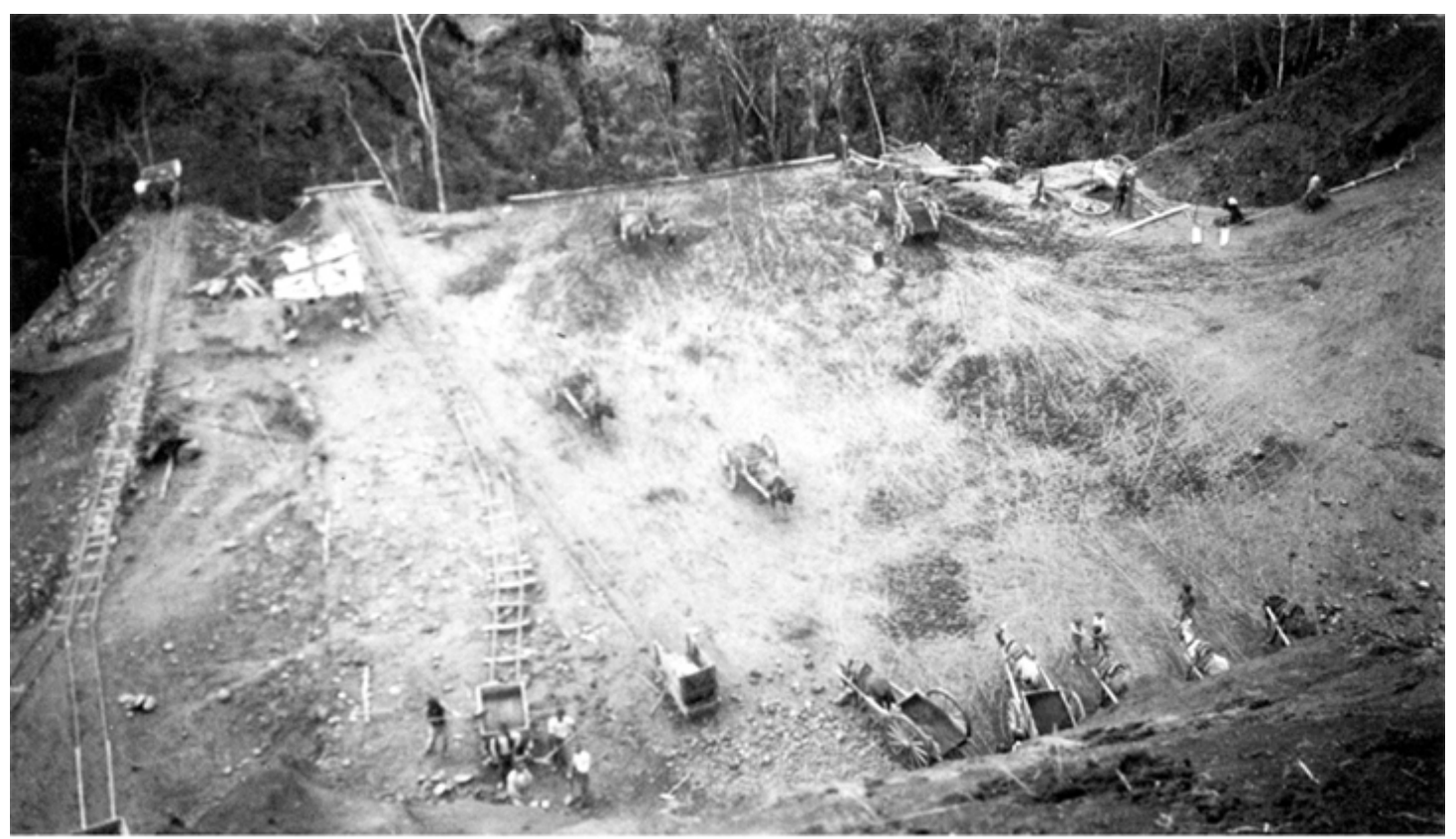

Construção da Mayrink-Santos,1928 - Dr. Múcio Drummond Murgel

Foto: www.efbrasil.eng.br

Foto 4 - Construção da Mayrink -Santos, em 1928, desafiando todos os conhecimentos tecnológicos da época, exigindo muitos esforços para vencer as dificuldades impostas pela serra do mar. 


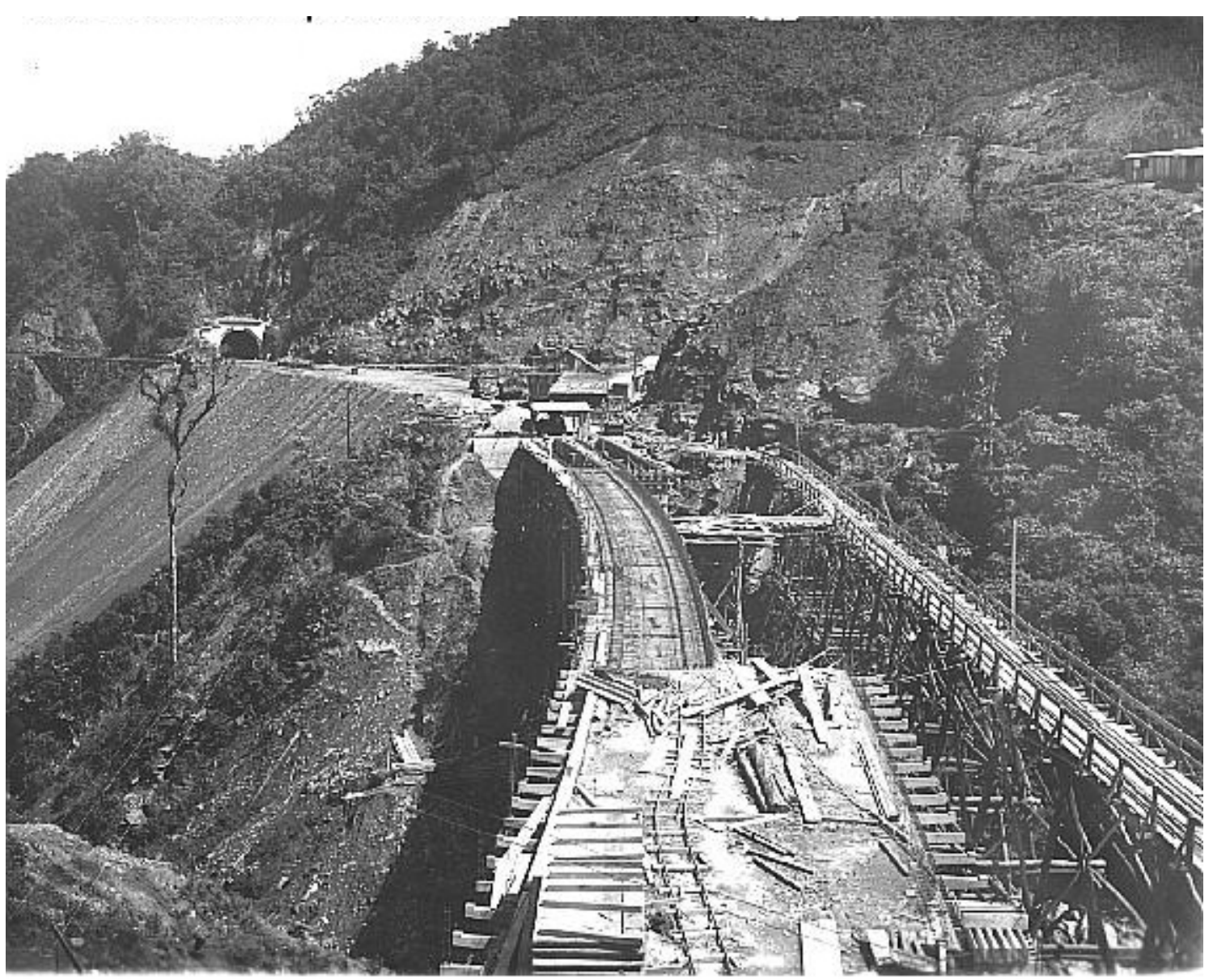

E.F.S. - Mayrink-Santos - Col. Nílson Rodrigues

Foto: www.efbrasil.eng.br

Foto 5 - Ponte sendo construída sobre a Serra do Mar, em 1930.

Desta forma, a E.F. Sorocabana extrapolou em demasia seus objetivos iniciais, integrando a região sul do Estado de São Paulo, pela linha-tronco, até Presidente Epitácio (porto fluvial no Rio Paraná), e integrou o norte do Paraná, conectando-se com a Estrada São Paulo-Paraná em Ourinhos. Além disso, através de Bauru, viabilizou conexão direta com a E.F. Noroeste do Brasil, ligando o estado de São Paulo à região sul do Mato Grosso e Bolívia (GORNI 2005).

A estrada de ferro Sorocabana, desde a sua fundação em 1871, tinha suas locomotivas movidas a vapor, por meio da queima de muita lenha e carvão. Essas locomotivas eram conhecidas como 'Maria Fumaça', devido à fumaça que produziam. Muitas vezes, os passageiros tinham suas roupas queimadas pelas fagulhas lançadas pela chaminé da Maria Fumaça, sendo que os funcionários 
costumavam trabalhar de guarda-pós, para proteger um pouco a roupa (GIMENEZ 2005).

Sob a administração do Estado, a EFS passou por amplo programa de melhoramento em suas linhas e modernização. Além disto o consumo de lenha estava desenfreado, levando a desmatamento de grandes áreas e dificultando a obtenção de lenha. Viu-se que era necessário implantar a eletrificação da linha férrea, como atesta este depoimento do engenheiro Acrísio Pais Cruz, o então diretor da Sorocabana, em 24 de fevereiro de 1939:

"O problema dos combustíveis necessários à Estrada de Ferro Sorocabana para o seu crescente transporte está tomando um aspecto alarmante.

No ano de 1937, gastou a Sorocabana nada menos de 27.400 contos com combustíveis, o que equivale a $28,2 \%$ da sua despesa de custeio. No ano passado (1938), essa despesa subiu acima de 33 mil contos, mantendo mais ou menos aquela mesma porcentagem sobre a despesa de custeio.

Mas não é esse, o financeiro, o lado alarmante do problema. Tal despesa, embora tão elevada, é conseqüência natural da intensidade do tráfego da Estrada (que atua no fator quantidade) e do encarecimento geral da vida no Brasil (que atua no fator

preço). O que alarma é a dificuldade, cada vez maior, na obtenção dessa tão

grande quantidade do nosso combustível mais econômico que é a lenha.

Em 1937, consumiu a Sorocabana nos seus trens $1.296 .000 \mathrm{~m}^{3}$ de lenha, além de

70.200 toneladas de carvão estrangeiro e 4.700 toneladas de carvão nacional.

Em 1938, o consumo de lenha atingiu a $1.580 .000 \mathrm{~m}^{3}$, além de quase 60.000 toneladas de carvão estrangeiro e 15.400 toneladas de carvão nacional.

Se nos tivesse sido possível só queimar lenha nos trens, o consumo de lenha nesses dois anos ter-se-ia elevado a $1.880 .000 \mathrm{~m}^{3}$ em 1937 e a $2.137 .000 \mathrm{~m}^{3} \mathrm{em}$ 1938.

A não ser no $5^{\circ}$ Distrito (de Bernardino de Campos a Presidente Epitácio) e em poucos trechos, nas margens da linha Sorocabana raras matas ainda existem, e a nossa lenha é obtida de ramais especialmente construídos, com extensões até 23 quilômetros e de elevados custos. Já temos em serviço ou em construção nada menos de oito desses ramais.

E com essa escassez de lenha ao longo da linha muito se alonga, também, a distância média de transporte. Tudo isso vem agravar e onerar o problema do combustível, pois normalmente temos mobilizadas, para esse transporte, cerca de 25 locomotivas e 360 gôndolas, isto é, 8\% do nosso material de tração e $20 \%$ de nossas gôndolas, que são assim desviadas do transporte remunerado da estrada. Urge, pois, uma providência para resolver esse problema."

(Acrísio 1939, Comunicação pessoal ${ }^{7}$ )

Este problema da lenha era muito sério e, infelizmente, para o desenvolvimento e progresso do Estado muitas matas foram completamente

\footnotetext{
7 Comunicação pessoal de Acrísio Pais Cruz, 1935, citada por GORNI AA, Disponível em URL:http://www.efbrasil.eng.br [2005 nov 05], sobre a Eletrificação nas ferrovias Brasileiras - EFS, p. 4).
} 
devastadas. Outro texto retrata exatamente esta problemática: "De fato as ferrovias nacionais não mais podiam depender da lenha: não só elas estavam ameaçadas de se tornarem economicamente inviáveis como também a devastação ambiental estava ficando muito grave. Por exemplo, áreas de mata virgem da Serra do Mar, na região de Evangelista de Souza, por onde passava a Mayrink-Santos, foram totalmente devastadas pela E.F. Sorocabana ao longo das décadas de 1930 e 1940" (GORNI 2005)

Perante esta problemática, foram realizados vários estudos a respeito da eletrificação da Sorocabana, entre 1924 e 1939, no entanto, nada foi efetivado. Somente em 27 de outubro de 1939, abriu-se concorrência para eletrificar os primeiros 140 km, de via dupla, entre São Paulo e Iperó. Em 12 de outubro de 1940, o então Interventor do Estado de São Paulo, Adhermar Pereira de Barros, assina contrato com a Cobrazil - Eletric Export Co., empresa criada para esta empreitada, por intermédio da união entre a International General Eletric, Westinghouse International Company e a Companhia de Mineração e Metalúrgica BrasilCOBRAZIL. Foi especificado que as locomotivas teriam de ser capazes de fazer o percurso de São Paulo-Iperó em duas horas e meia, rebocando um trem de passageiro de doze carros, pesando 475 toneladas. Este trecho tinha $140 \mathrm{~km}$, então, a velocidade comercial seria de $56 \mathrm{~km} / \mathrm{h}$ e a máxima de $70 \mathrm{~km} / \mathrm{hora}$. Já para o transporte de cargas teria de tracionar 20 vagões, sendo 600 toneladas no sentido exportação e 450 no sentindo importação, com velocidade máxima de $50 \mathrm{~km} /$ hora. O primeiro trecho a ser eletrificado foi de São Paulo a Sorocaba, mesmo sob as restrições impostas pela Segunda Guerra Mundial. Nos anos que se seguiram, a eletrificação foi atingindo outros trechos, como mostra a tabela a seguir. 
Tabela 4 - Evolução da eletrificação de cada trecho da malha ferroviária da EF Sorocabana, no período entre 1944 e 1954.

\begin{tabular}{|c|c|c|c|}
\hline Trecho & $\begin{array}{c}\text { Extensão do } \\
\text { Trecho } \\
{[\mathbf{k m}]}\end{array}$ & $\begin{array}{c}\text { Extensão } \\
\text { Total } \\
{[\mathbf{k m}]}\end{array}$ & $\begin{array}{c}\text { Data da } \\
\text { Inauguração }\end{array}$ \\
\hline São Paulo-Sorocaba & 104,342 & 104,342 & 08.12 .1944 \\
\hline Sorocaba-Iperó & 35,130 & 139,472 & 14.08 .1945 \\
\hline Iperó-Cerquilho & 24,718 & 164,190 & Janeiro 1947 \\
\hline Cerquilho-Laranjal Paulista & 24,148 & 186,388 & 15.12 .1947 \\
\hline Laranjal Paulista-Juquiratiba & 30,863 & 217,201 & 01.05 .1949 \\
\hline Iperó-Tatuí & 18,575 & 235,776 & 30.07 .1950 \\
\hline Tatuí-Morro do Alto & 42,833 & 278,609 & 1951 \\
\hline Juquiratiba-Botucatu & 50,707 & 329,316 & 16.10 .1951 \\
\hline Botucatu-Rubião Júnior & 5,772 & 335,088 & 1952 \\
\hline Rubião Júnior-Pátio 3 & 30,210 & 365,298 & 1953 \\
\hline (Itatinga) & 37,444 & 402,742 & 1954 \\
\hline Pátio 3 (Itatinga)-Bernardino & de Campos & & \\
\hline
\end{tabular}

Fonte: Disponível em URL:http://www.efbrasil.eng.br [2005 nov 05]

Para eletrificar o trecho entre Botucatu e Rubião Jr, em 1952, foi necessário o uso de uma subestação portátil de 2000 Kw, que ficou localizada em Apuãs, mas depois recebeu uma subestação retificadora definitiva

O custo da tração elétrica era bem mais barato que o da tração a vapor, segundo os cálculos da própria E.F. Sorocabana, de 1951; o custo da tração elétrica era de Cr\$ 4,24/1000 ton./km; Cr\$ 10,84/1000 ton./km o da tração diesel-elétrica, e o da tração a vapor, Cr\$ 42,00/1000 ton./km. Então, nota-se que, além de todo o problema com a devastação, o custo do transporte com máquinas a vapor era 10 vezes maior que com a tração elétrica, justificando por demais a eletrificação.

Este processo de eletrificação se deu até a década de 1970, no entanto, a partir da década de 1960, uma grande crise atinge as ferrovias, frente à incorporação do diesel. Mas mesmo assim, em 1967, a eletrificação chega a Samaritá, na baixada Santista, e em Assis, em 1969, conseguindo traçar uma extensa linha férrea eletrificada (Figura 12). 
Nesse período, já tramitava na Assembléia Legislativa um projeto de Lei para unir todas as ferrovias do Estado de São Paulo em uma única. Em outubro de 1971, foi votado na câmara legislativa do Estado e, através do decreto 10.410, o governador Laudo Natel sancionou a criação da nova ferrovia, incorporando as cinco: EF Sorocabana, Companhia Mogiana de Estradas de Ferro, Companhia Estrada de Ferro Araraquara, Cia. Paulista de Estrada de Ferro, e a Estrada de Ferro São Paulo e Minas. Essa nova ferrovia unificada recebeu o nome de Fepasa Ferrovia Paulista S/A. Sua sede passou a ser em São Paulo, coordenada por um presidente, uma diretoria, com sete unidades Regionais: Sorocaba (UR 1), Botucatu (UR2), Bauru (UR3), Araraquara (UR4), Campinas (UR5), Ribeirão Preto (UR6) e Santos (UR7). 


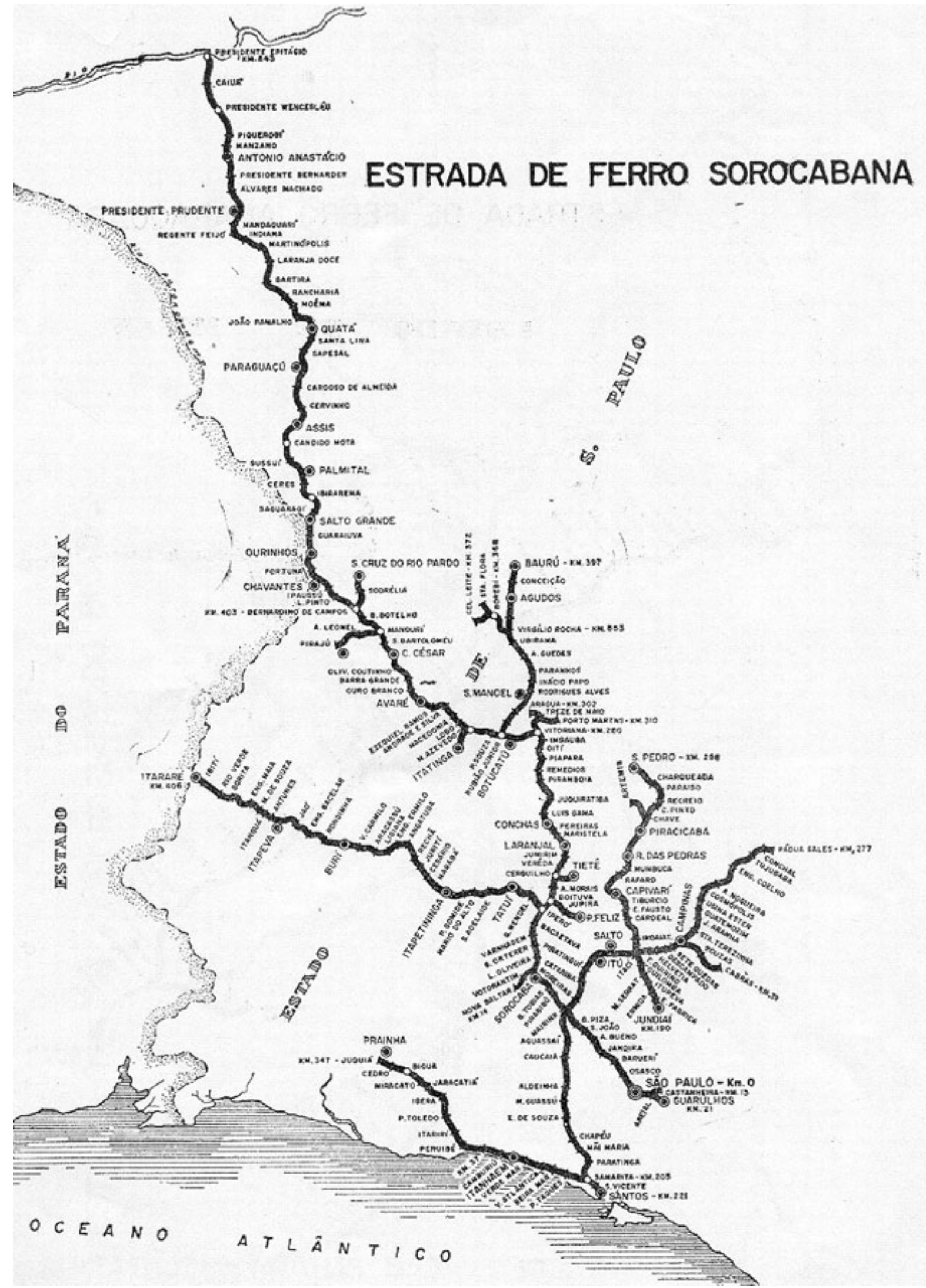

Figura 12 - Este mapa representa o traçado da E.F. Sorocabana em 1961, nos bons tempos. ( Texto original de um suplemento da Revista Ferroviária, 1961. Fonte: www.efbrasil.eng.br, cortesia de Hermes Yoiti Hinuy, de São Paulo, SP). 
A década de 1970 foi marcada pela crise do petróleo, provocada pela crise no Oriente Médio, mas ao mesmo tempo acontecia o Milagre Brasileiro, aumentando em demasia a produção e, por conseguinte, o escoamento dessa produção, feita ainda em grande parte pelas ferrovias. No entanto, a Fepasa começou a mostrar uma incapacidade para transportar tamanho volume e com rapidez. Foram necessários estudos para a remodelação da ferrovia. Entre 1975 e 1977, a antiga Sorocabana recebeu várias locomotivas diesel-elétricas da General Eletric U20C, para substituir as mais antigas. No entanto, a crise no transporte ferroviário era certa, sendo ameaçada pelo crescimento das rodovias, que transportavam em menor tempo e recebiam mais incentivo do governo que as ferrovias. Começou-se, novamente, a pensar em privatizar, e desta forma nenhum novo grande investimento foi feito e nem modernizações, ficando as ferrovias estagnadas por longo período. Somente em 1995, com a posse do Governador Mário Covas, é que a privatização se consolidou. Em 1998, por conta de uma enorme dívida do Banco do Estado de São Paulo BANESPA, junto ao governo federal, a Fepasa é transferida para a Rede Ferroviária Federal S.A - RFFSA, como parte do pagamento da dívida. E, em 1999, finalmente acaba sendo privatizada, fulminando todo o seu patrimônio e crescimento. Somente a linha férrea é privatizada ficando todo o patrimônio imobiliário para a União. A FERROBAN - Ferrovias Bandeirantes assume a privatização e de imediato rompe a eletrificação e o transporte de passageiros, atuando somente com carga e locomotivas a diesel. Mesmo sob protestos, essa ação é tomada e, somente em maio de 2000, a empresa se manifesta publicamente, como apareceu no jornal 'O Estado de São Paulo’, em 29 de Maio de 2000: 
ALL APOSENTA AS LOCOMOTIVAS ELÉTRICAS"

Concessionária optou por máquinas a óleo diesel, que oferecem um custo menor Aurélio Alonso ${ }^{8}$

OURINHOS - Depois de 55 anos, o sistema de eletrificação para transporte de carga desaparece na malha ferroviária do Oeste paulista. As locomotivas movidas a energia elétrica foram retiradas de circulação no trecho da antiga Fepasa, entre Rubião Júnior e Assis, para cortar custos. Essa é a explicação da América Latina Logística (ALL), a operadora do trecho paulista que foi arrendado junto à Ferrovias Bandeirantes (Ferroban).

(...)

Outro problema que gerou o desligamento da rede de alta tensão é uma onda de furto ao longo da linha. O cabo por onde passava a energia elétrica é de cobre puro. Os ladrões conseguem bom preço na venda a ferro-velho. A Supervisão de Operações de Ourinhos da ALL admite que será necessária a retirada da fiação, o que a RFFSA já autorizou."

E quais foram as causas para que a ferrovia chegasse a este ponto? No livro 'Nos trilhos da Memória: trabalho e Sentimento', existe uma série de depoimentos de funcionários de Estrada de ferro Noroeste, que passava por Bauru, e eles apontam que foram várias as causas: os desregramentos administrativos das empresas; administração do estado; o mal uso político da ferrovia, que culminou com a Fepasa; a diminuição significativa do número de funcionários que trabalhavam na linha, e o fim do plano de carreira e de tempo de serviço; a hipervalorização do serviço rodoviário, e o encerramento da rede elétrica da ferrovia com a privatização (LOSNAK 2003).

Após a desativação de toda a rede elétrica da EFSorocabana, esta ficou ao desalento, totalmente abandonada e sujeita a roubos e ações de vândalos. No entanto, existiam materiais perigosos, como o mercúrio e o óleo ascarel, que é sabidamente cancerígeno, mas a população desconhecia a existência destes produtos na eletrificação da ferrovia. Com o completo abandono, todo o patrimônio da ferrovia passou a ser saqueado, uma vez que os fios utilizados para a eletrificação continham cobre, ficando a população exposta ao risco de também adoecer. No jornal 'O Estado de São Paulo', de 18 de Agosto de 2001, uma reportagem chama a atenção para esses graves problemas que estavam acontecendo devido ao abandono irresponsável das ferrovias:

\footnotetext{
${ }^{8}$ Comunicação pessoal Aurélio Alonso ao Jornal ‘O Estado de São Paulo’, em 29 de Maio de 2000, citada por GORNI AA. Disponível em URL:http://www.efbrasil.eng.br [2005 nov 05], sobre a Eletrificação nas ferrovias Brasileiras - EFS.
} 


\section{“SUBESTAÇÕES DA RFFSA PÕEM POPULAÇÃO EM RISCO José Maria Tomazela9}

SOROCABA - Seis meses depois de constatados vazamentos de substâncias tóxicas, como mercúrio e ascarel, em subestações elétricas desativadas da Rede Ferroviária Federal S/A (RFFSA), os moradores próximos continuam sob o risco de contaminação. Terra, lixo e sucata impregnados por esses produtos ainda não foram retirados das subestações de Mairinque, Sorocaba, Iperó e Itapetininha, onde ocorreram vazamentos. O material estava em transformadores arrebentados por ladrões de sucata. Na subestação do Pantojo, em Mairinque, dez adolescentes manusearam o mercúrio, depois que um grupo deles levou a substância para a escola.

Esse elemento acumula-se no organismo e causa danos irreversíveis ao fígado, pâncreas e sistema nervoso central. O mercúrio foi recolhido, mas o óleo que continha ascarel, substância cancerígena proibida no País há mais de 15 anos, impregnou o solo. A terra ainda não foi removida. Na subestação de Varnhagen, em Iperó, onde ocorreu o vazamento de 40 mil litros de óleo mineral com ascarel, contaminando uma área da Floresta Nacional de Ipanema (Flona), também nada foi feito.

A Rede foi multada em $R \$ 20$ milhões pelo Instituto Brasileiro do Meio Ambiente e dos Recursos Naturais Renováveis (Ibama), mas ainda não retirou a sucata contaminada, nem removeu a terra. A assessoria de imprensa informou que os técnicos realizaram todos os estudos no local e aguardam que a Companhia de Tecnologia de Saneamento Ambiental (Cetesb) defina o local para onde o lixo será removido. As duas subestações ficam dentro de vilas e continuam sendo freqüentadas pelos moradores.

Em Sorocaba, no distrito de Brigadeiro Tobias, também houve o vazamento do conteúdo de quatro transformadores. Segundo vizinhos, os equipamentos foram roubados e o óleo despejado nos arredores. No Distrito de Morro do Alto, em Itapetininga, crianças brincam nas duas subestações que foram depredadas. O óleo que pode conter ascarel escorreu no terreno.

Outras 60 subestações da antiga Ferrovia Paulista S/A estão equipadas com transformadores que contêm essas substâncias. Praticamente não há vigilância e muitas continuam sendo saqueadas. A RFFSA informou que a sucata e equipamentos que representam risco serão retirados, mas a remoção depende de autorização dos órgãos ambientais."

E assim foi o fim da E.F. Sorocabana, uma época áurea, de apogeu e contribuição para o progresso, transformada em completo esquecimento e descaso. Uma grandiosa história é engolida pela cultura do imediatismo e da

\footnotetext{
${ }^{9}$ Comunicação pessoal José Maria Tomazela ao Jornal 'O Estado de São Paulo', em 18 de agosto de 2001, citada por GORNI AA. Disponível em URL:http://www.efbrasil.eng.br [2005 nov 05], sobre a Eletrificação nas ferrovias Brasileiras - EFS.
} 
etnodesvalorização ${ }^{10}$. Todo o vultoso patrimônio é rapidamente saqueado por cidadãos comuns e não comuns. O patrimônio investido ao longo de 128 anos foi depredado em praticamente 1 ano. Essa depredação pôde ser assistida em praticamente todas as estações que compunham a E.F. Sorocabana.
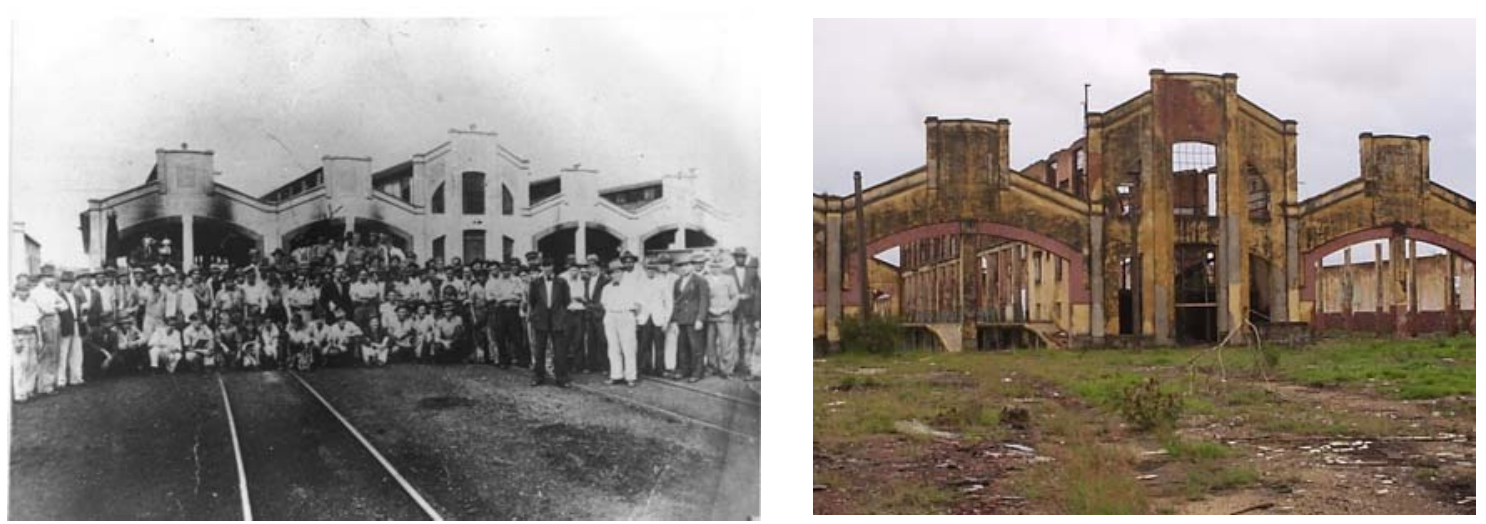

Fotos 6 e 7 - Fotos do depósito de Botucatu, antes no seu tempo áureo (do Museu Histórico Itinerário, Lá vem o trem, de Botucatu), e as ruínas atuais que sobraram, após saques constantes e depredação (Foto: Karina Pavão Patrício, Junho de 2005)

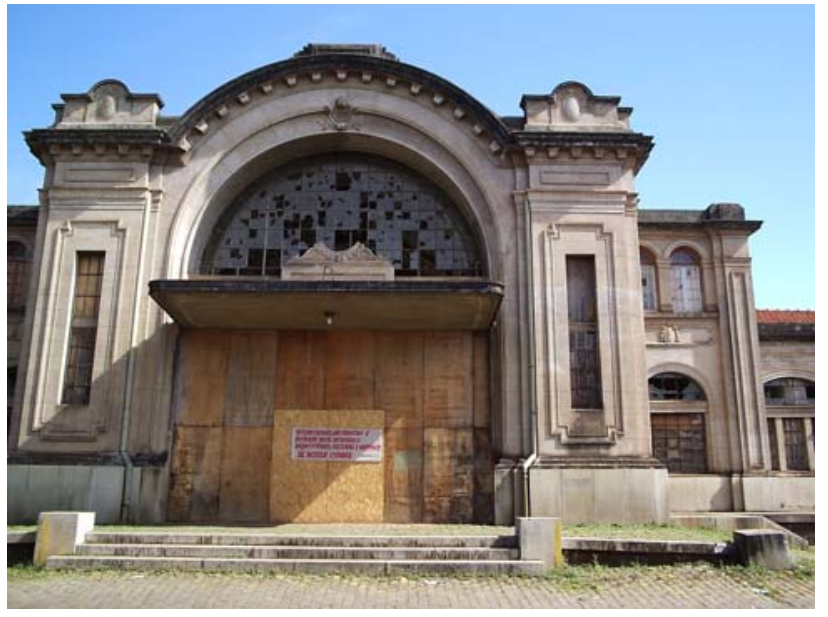

Fotos 8 - A bela estação ferroviária de Botucatu, com as imponentes portas esculpidas em imbuia maciça, após serem destruídas, foram substituídas por tapumes para evitar mais depreciações. O Relógio, de 2 toneladas, que ficava na parte superior, logo na entrada, também sumiu (Foto: Karina Pavão Patrício, Maio de 2004)

\footnotetext{
${ }^{10}$ A etnodesvalorização é um termo que deriva dos preceitos estudados e discutidos em etnobiologia, que por sua vez pode ser definida como "o estudo do conhecimento e das conceituações desenvolvidas por qualquer sociedade a respeito da biologia” (Posey DA. Introdução - Etnobiologia: teoria e prática. In: Suma Etnológica brasileira. Edição atualizada do Handbook of South Americans Indians. Darcy Ribeiro et alli, 1987). Desta forma etnodesvalorização seria a desvalorização de todos os conhecimentos adquiridos e conceitos de um grupo especifico, neste caso os ferroviários.
} 

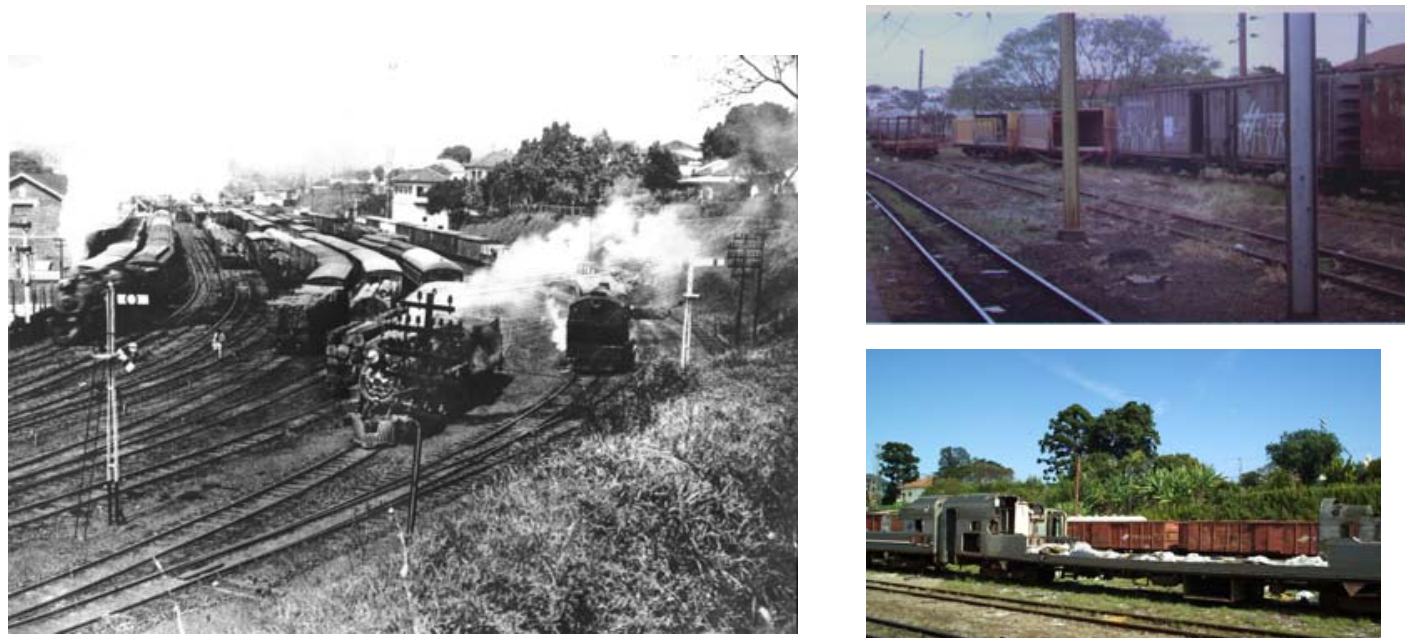

Foto 9, 10 e 11 - Foto antiga ilustrando o intenso moviment de trens (foto: Museu H.I. "Lá vem o trem”, de Botucatu).

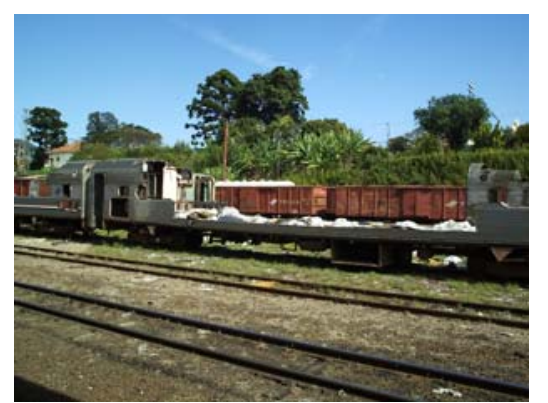

A direita, hoje, os vagões completamente destruídos pelo vandalismo e saques - após retirarem todo o material interior, agora roubam, em plena luz do dia e a machadadas, pedaços dos vagões para serem vendidos ao ferro velho (Foto: Karina Pavão Patrício, Maio de 2004). 


\section{2 - Conhecendo um pouco o município de Botucatu}

O município de Botucatu está localizado a 224,8 km da Capital do Estado e a 898 km da Capital Federal. A cidade possui clima ameno (temperaturas médias de $22^{\circ} \mathrm{C}$ ) e altitude relativamente elevada, que varia de $756 \mathrm{~m}$ na baixada (antigo matadouro) a 920 m no Morro de Rubião Júnior (ponto mais alto). Possui uma área de 1.496 km2, com uma população de 117.305 habitantes, com densidade demográfica de 78,41 hab/km2, sendo o índice de envelhecimento de 50,69\%, e a população maior de 60 anos representando 11,57\% do total de habitantes (SEADE 2005; IBGE 2000).

Botucatu nasce como uma fazenda administrada pelos jesuítas, em 1719, destinada a abastecer o Colégio de São Paulo com carne e comercializando gado para todo o interior do sertão. Em 1846, o Governador da Província, sancionou a Lei que criava "uma freguesia no distrito de cima da serra de Botucatu”. É da tradição oral que o povoado se originou a partir do núcleo de comércio clandestino de cavalos e gado no cimo da serra, fora do alcance da lei, por temor aos índios que ainda aí habitavam. Livre dos rigores do fisco, que oprimia o comércio legalizado na feira regional de Sorocaba, e com o lucro alto na venda de animais, às vezes roubados, houve prosperidade e aumento populacional. A elevação à categoria de cidade se deu em 1855, quando contava com cerca de 83 habitações, sendo 40 de telhas. Por volta de 1870/80, o café chegou a Botucatu, sendo que, nessa época, predominava o regime de grandes propriedades, movimentadas pelo elemento escravo, assim como, arrendatários e agregados. Após a abolição da escravatura, várias mudanças se processaram no município, levando a transformações, favorecendo um extraordinário surto econômico e social. Com a imigração subvencionada pelos governos federal e estadual, muitos estrangeiros vieram se fixar ali, principalmente os italianos. Em 1866, Botucatu é elevada à categoria de Comarca (Lei Provincial nº 61). Dava-se início ao $1^{\circ}$. ciclo Industrial, com expansão econômica e demográfica do município. Com a política monetária favorável e o crescente interesse de investimentos estrangeiros, era necessário a implantação de uma estrutura viária mais eficiente para o escoamento da produção, diminuindo seu custo. Desta forma, em 1889, a Estrada de Ferro Sorocabana, proveniente de São Paulo, foi estendida até a cidade de 
Botucatu, que se tornou o último posto da civilização "na boca do sertão", que se prolongava até as barrancas do Rio Paraná-Paranapanema. Em função desse crescimento populacional, da diversificação da agricultura e intensificação da pecuária, Botucatu desponta como um importante centro comercial e de abastecimento, além de funcionar como centro cultural de referência para toda a região. Passou a ser centro irradiador de produtos industrializados provenientes de São Paulo e Sorocaba, devido à sua localização estratégica como ponto de ocupação e desenvolvimento da Sorocabana e por ser entroncamento ferroviário entre a Noroeste e a Sorocabana, até a década de 1930. Botucatu e São Manuel constituíam as cidades mais populosas do Planalto Ocidental em 1920 (IYDA 1979; DONATO 1985; DELMANTO 1990; PATRÍCIO 1998).

Fazendeiros, comerciantes, lavradores, ferroviários e funcionários públicos foram se estabelecendo na região e fixando família ao longo dos anos. A população foi crescendo rapidamente, ocupando os empregos oferecidos pela cidade, não sendo necessário o deslocamento à procura de emprego em outras áreas. As boas e várias escolas (Grupo Escolar Cardoso de Almeida, Escola Italiana Dante Alighieri, Instituto Santa Marcelina, Escola de Comércio Nossa Senhora de Lourdes, entre outras) ofereciam subsídios necessários para a formação de bons alunos e profissionais, que não precisavam ser mandados pelos seus pais para outras localidades, a fim de continuarem seus estudos. Essa situação de grande atividade econômica e prestígio político se confirma pelo número de órgãos administrativas sediados em Botucatu até a década de 1940, destacando-se, entre eles: Diretoria Regional dos Correios e Telégrafos ( $3^{\circ}$ do Brasil); Delegacia Regional de Polícia (desde Anhembi até Palmital); $4^{\circ}$ Distrito do Departamento de Transportes; Delegacia Regional de Saúde; Inspetoria dos Serviços de Combate à Febre Amarela, com influência até o Paraná (IYDA 1979). Outro grande empregador foi a Estrada de Ferro Sorocabana, que tornou-se oficina mecânica de referência para esta região, tendo um grande número de funcionários, destacando-se entre as demais ferrovias do Estado de São Paulo e por ter uma localização estratégica, próximo ao centro do Estado.

A estrada de Ferro Sorocabana, após seu novo traçado, entre Botucatu e Bernardino de Campos, possuía $2.200 \mathrm{~km}$, ocupando o $6^{\circ}$ lugar em ferrovias 
nacionais, e se sobressaía das demais por realizar o maior trabalho expresso em ton./km em serviço retribuído - mercadorias e animais (1.854.374.801 ton. $/ \mathrm{km}$ em 1952). A prosperidade levou ao estabelecimento de indústrias e, junto ao pioneirismo apresentado pela região, resultou na instalação da primeira usina hidrelétrica particular da América do Sul no município, por Petrarca Bacchi (DONATO 1985).

O período de 1930 a 1970 caracterizou-se pela concentração das propriedades agrícolas, envelhecimento dos cafezais, geadas, erosão dos solos e as sucessivas crises (1929-30), culminando com a grande quebra da Bolsa de Nova Iorque. Esta constelação de fatores foi responsável pela grande evasão de recursos e de mão-deobra, que partiu em direção a regiões mais dinâmicas, como São Paulo e Sorocaba, em fase de expansão industrial importante, ou para novas fronteiras produtoras de café na Alta Sorocabana, Noroeste e norte do Paraná. A partir de 1940 muitas sedes administrativas regionais do governo, que funcionavam em Botucatu, foram extintas ou transferidas para outras localidades e, com elas, uma parte dos trabalhadores foi obrigada a se mudar. No período de 1950 a 1960, o crescimento populacional caiu a 0,60\%/ano, índice mais baixo desde 1900. Essa época coincide com a construção da rodovia SP-270, ligando o norte do Paraná a São Paulo, através de Itapetininga, desviando a rota comercial da região de Botucatu. A cidade entrou em declínio, perdeu sua importância e se estagnou junto aos velhos trilhos da Estrada de Ferro Sorocabana, que agonizava com o advento da indústria automobilística no país (DONATO 1985, PATRÍCIO 1998).

O $2^{\circ}$. ciclo de crescimento ocorre nos anos 1960, quando se estabeleceu no município a Faculdade de Ciências Médicas e Biológicas de Botucatu (FCMBB), compreendendo os cursos de Medicina, Medicina Veterinária, Agronomia e Biologia. Em meados da década de 1970, Botucatu entra em seu $3^{\circ}$. ciclo industrial , restabelecendo um pólo industrial com várias indústrias, como: fábrica de aviões (Neiva, implantada em 1956), de ônibus (CAIO), de plásticos reforçados para indústria automobilística e ferroviária (Hidroplás, 1974), de chapas de fibra de madeira prensada (Duratex, 1973), de Confecções (Staroup), metalurgia (Petrac e Moldimix), entre outras.

Atualmente, o município conta com essas indústrias e poucas outras, sendo que algumas delas passam por crise econômica, como a CAIO. A antiga FCMBB foi 
desmembrada em Faculdade de Medicina, Faculdade de Agronomia, Faculdade de Medicina Veterinária e Instituto de Biociências, tornando-se grande e importante centro empregador; aumentando, de forma provisória, a população botucatuense com um grande número de alunos, que movimenta o setor imobiliário e de todo o comércio local. O comércio também tem se desenvolvido de forma promissora. Em termos culturais, atualmente, conta somente com um cinema e dois teatros, mas são realizadas várias festividades típicas ao longo do ano (o Festival Nacional do Saci, as Festas da Mandioca, do Milho, das Nações, e a Semana Angelino de Oliveira, entre outras).

Em meio a esta retomada de crescimento, ouve-se ao longe o tímido e fraco apito de alguns trens de carga que atravessam a cidade, em situação muito precária, não mais movimentando a cidade e as pessoas para se emocionarem e sentirem-se orgulhosos daquele progresso. O prédio da estação, glorioso, mostra ainda a sua força, conseguindo se manter de pé apesar de todos os ataques dos vândalos que vem sofrendo, porém, todos os outros prédios ao redor não estão agüentando mais. As telhas foram roubadas, o madeiramento e a fiação saqueados, o resto queimado e, agora, os tijolos que sobraram são vendidos pelos ladrões a elevado preço, sem contar os dormentes que, de um dia para o outro, foram levados por vários caminhões, sem que a polícia descobrisse. O movimentadíssimo prédio do depósito agoniza. O leitor pode perguntar: - Mas nada está sendo feito para preservar esse patrimônio? A Prefeitura apenas ocupou os prédios da administração, que ficam do outro lado da estação. A Associação dos Ferroviários Aposentados da E.F. Sorocabana, na figura do Sr. Orlando de Almeida, atual diretor, mantém um pequeno museu, com o pouco que conseguiu salvar; e o Sr. Góes, que, todos os dias, voluntariamente, pega o ônibus do outro lado da cidade, vai até a estação, de manhã e de tarde, para varrê-la e cuidar daquilo que um dia representou a sua vida e de muitos ferroviários, que foram completamente esquecidos pela sociedade, assim como a sua tão amada ESTRADA DE FERRO SOROCABANA. 


\section{Capítulo 4 - CARACTERIZANDO OS FERROVIÁRIOS DA ESTRADA DE FERRO SOROCABANA DE BOTUCATU ENTREVISTADOS}

\section{1 - Conhecendo a amostra de longevos ferroviários}

A análise dos dados quantitativos, utilizando o programa estatístico SPSS, permitiu caracterizar a amostra e o meio ambiente a que esses longevos foram expostos ao longo da vida. A seguir, serão apresentados estes dados numéricos, de forma a caracterizar as condições de vida dessa amostra de longevos ex-ferroviários da Estrada de Ferro Sorocabana e os aspectos do meio ambiente a que eles foram expostos ao longo de sua vida, segundo seus depoimentos.

\section{IDADE}

A idade média da amostra foi de 82,87 anos (tabela 5), tendo o mais velho 96 anos e o mais novo 75. A moda foi de 79 anos e a mediana de 82,50. Lembrando novamente que, para fazer parte da amostra, o longevo precisava ter acima 74 anos e 8 meses.

Tabela 5 - Distribuição etária dos entrevistados

\begin{tabular}{llr}
\hline \hline & Válidos & Número \\
& Sem informação & 30 \\
Média & & - \\
Mediana & 82,87 \\
Moda & 82,50 \\
Desvio padrão & 79 \\
Mínimo & 4,637 \\
Máximo & & 75 \\
\hline \hline
\end{tabular}

\section{SITUAÇÃO MARITAL}

Dos 30 entrevistados, 22 (73,3\%) eram casados, com tempo médio de casamento de 51,50 anos, demonstrando uma relação bem estável. 88,4\% responderam que o relacionamento era ótimo ou bom. Observou-se, em outros estudos, que idosos que têm parceiros(as) têm maior sobrevida quando adoecem de 
alguma patologia, por receberem mais auxílio destes possíveis cuidadores (BERKSON 1962, CHANDRA e col. 1983, GOODWIN e col. 1987, GOLDMAN e col. 1995).

A qualidade e o tempo do relacionamento também podem influenciar na saúde, principalmente na saúde mental. A literatura aponta que o estado mental e de saúde são melhores principalmente nas mulheres que têm bom relacionamento marital (LEVENSON e col. 1993).

Tabela 6 - Situação marital e de relacionamento dos entrevistados.

\begin{tabular}{llcr}
\hline \hline & & $\mathrm{N}$ & $\%$ \\
\hline Situação marital & Casado & 22 & 73,3 \\
& Viúvo & 6 & 20,0 \\
& Solteiro & 1 & 3,3 \\
& Amasiado & 1 & 3,3 \\
Relacionamento & Ótimo & 9 & 34,6 \\
& Bom & 14 & 53,8 \\
& Médio & 2 & 7,7 \\
& Ruim & 1 & 3,8 \\
\hline \hline
\end{tabular}

Tabela 7 - Tempo de casamento e de viuvez dos entrevistados.

\begin{tabular}{lccc}
\hline \hline & Tempo de casamento & Tempo de viuvez \\
\hline $\mathrm{N}$ & Válidos & 24 & 6 \\
& Sem informação & 6 & 24 \\
Média & 51,50 & 11,52 \\
Mediana & 56,00 & 10,50 \\
Moda & 56 & $0,12 \mathrm{a}$ \\
Desvio padrão & 13,45 & 8,75 \\
Mínimo & 0 & 0,12 \\
Máximo & 68 & 23,00 \\
\hline \hline
\end{tabular}

a.Várias modas existem. O menor valor foi mostrado.

\section{PROGÊNIE}

Esses ferroviários, na sua grande maioria, deixaram descendentes: filhos (96,7\%), netos (93,3\%) e bisnetos (60\%). Além disso, os entrevistados apontaram que o relacionamento com a família era ótimo ou bom na grande maioria dos casos (96,3\%) e que conviviam quase que diariamente com seus filhos (85,3\%). Tendo, portanto, uma rede de apoio familiar próxima, muito importante durante o envelhecer, o que também pode favorecer a longevidade, tanto na parte emocional (afeto, diálogos, etc.) como na saúde (cuidados freqüentes, atenção à saúde, levando às consultas médicas, auxiliando na alimentação, etc.). 
Tabela 8 - Distribuição do número de filhos, netos e bisnetos dos entrevistados.

\begin{tabular}{llrr}
\hline \hline \multirow{4}{*}{ Nilhos } & & $\mathrm{N}$ & $\%$ \\
& Não & 1 & 3,3 \\
\multirow{2}{*}{ Bisnetos } & Sim & 29 & 96,7 \\
& Não & 2 & 6,7 \\
& Sim & 28 & 93,3 \\
& Não & 12 & 40,0 \\
& Sim & 18 & 60,0 \\
\hline \hline
\end{tabular}

Tabela 9 - Qualidade do tipo de relacionamento com a família.

\begin{tabular}{rlcc}
\hline & & Freqüência & Percentual \\
\hline Válidos & Ótimo & 12 & 44,44 \\
& Bom & 14 & 51,85 \\
Médio & 1 & 3,7 \\
Total & 27 & 100 \\
Sem informação & 3 & \\
\hline \hline
\end{tabular}

Tabela 10 - Convívio dos entrevistados com seus filhos.

\begin{tabular}{llcc}
\hline \hline & Freqüência & Percentual \\
\hline Válido & Diariamente & 14 & 51,85 \\
& Varias vezes/semana & 9 & 33,33 \\
Uma vez semana & 2 & 7,41 \\
Algumas vezes/mês & 2 & 7,41 \\
Total & 27 & 100,0 \\
Sem informação & 3 & \\
\hline \hline
\end{tabular}

\section{OS FATORES HEREDITÁRIOS}

Foi perguntado se havia pessoas longevas na família, ou seja, que tinham falecido com idade avançada. As respostas foram favoráveis para esta variável.

As idades médias de óbito das tias foram as mais elevadas dentre as indicadas, sendo dois casos relatados (103 e 98 anos). Em termos de maior freqüência, foi a lembrança de o pai ter vivido bastante, em 17 casos, sendo a idade média de 87 anos. No entanto, todas as figuras do sexo feminino se destacaram pelas idades mais elevadas, quando comparadas com seu par masculino (mãe, avó, irmã e tia). Também a idade média de óbito da mãe, que foi de 89,46 anos, é mais elevada que a dos pais. A contribuição familiar como mais um fator na longevidade humana tem sido estudada por meio da construção de pedigrees de centenários e demonstra que existe um componente familiar importante associado a longevidade extrema (PERLS e col. 1998; GUDMUNDSSON e col. 2000; KEBER e col. 2001; PERLS e col. 2002). 
Tabela 11 - Idade de óbito dos ancestrais dos entrevistados.

\begin{tabular}{l|cccccccc}
\hline & & & & & & & & \\
& Mãe & Pai & Avó & Avô & Irmão & Irmã & Tio & Tia \\
\hline Idade média & 89,5 & 87,4 & 86,2 & - & 90,2 & 91,5 & 92 & 100,5 \\
& & & & & & & & \\
Número de casos & 13 & 17 & 4 & - & 5 & 4 & 1 & 2 \\
\hline
\end{tabular}

\section{LOCAL DE MORADIA}

Entre os ferroviários entrevistados, 46,7\% tinham morado apenas em duas cidades, sendo que 26,7\% somente em Botucatu, 16,7\% em quatro cidades e $10 \%$ em três. Além disso, na última cidade de moradia, o tempo médio foi de 66,6 anos. Dessa forma, observou-se que este grupo mantém o perfil relatado na literatura, na qual observa-se uma menor mobilidade com o envelhecimento (VERAS e col.1987; RAMOS e col. 1987; VERAS 1994).

\section{ESCOLARIDADE E IDADE DE INÍCIO DE TRABALHO}

Embora os ferroviários exercessem uma profissão muito reconhecida e bem remunerada, isto não estava associado à escolaridade, diferentemente do que ocorre nos dias atuais. O tempo médio que eles freqüentaram a escola foi de 4,07 anos, o que correspondia ao estudo "primário" da época. Eles relataram a dificuldade de estudar, pois muitos moravam em zona rural, quando crianças, e cedo já era necessário começar a trabalhar, ajudando o pai. Era muito freqüente a criança, com uns 10 anos, ao terminar o "primário”, começar a trabalhar na lavoura. Botucatu era famosa pelas boas escolas, mas esses ferroviários nem chegaram a desfrutar delas, pois logo entravam para a ferrovia e faziam carreira lá dentro, sem serem cobrados para ter maior escolaridade. Bastava ter alguns anos de estudo ou saber ler e escrever, isto já era suficiente. Quem acabou se beneficiando dessas boas escolas foram os filhos dos ferroviários, já que seus pais tinham um emprego estável e ganhavam relativamente bem para a época, não exigindo que seus filhos fossem trabalhar precocemente, priorizando o estudo para os filhos. É comum vermos filhos de ferroviários ocupando bons serviços e com formação universitária. 
A idade média em que essa amostra de ferroviários longevos começou a trabalhar em alguma atividade foi de 14,33 anos, sendo o mais novo com 7 e o mais velho com 33 anos. Para se efetivar na ferrovia, exigia-se um pouco mais de experiência e, muitas vezes, eles entravam como aprendizes, sem receber salário. Mostrando bom desempenho, depois, eram chamados e tinham carteira assinada. Assim sendo, a idade média para entrar na ferrovia, dessa amostra, foi de 19,33 anos.

Tabela 12 - Tempo em anos de escolaridade dos entrevistados.

\begin{tabular}{lcc}
\hline $\mathrm{N}$ & Válidos & 28 \\
Média & Sem informação & 2 \\
Mediana & 4,07 \\
Moda & 4,00 \\
Desvio padrão & 4 \\
Mínimo & 2,64 \\
Máximo & 2 \\
\hline \hline
\end{tabular}

Tabela 13 - Idade em que os entrevistados começaram a trabalhar e quando iniciaram na ferrovia.

\begin{tabular}{lrc}
\hline \hline & $\begin{array}{c}\text { Idade de início } \\
\text { de trabalho }\end{array}$ & $\begin{array}{c}\text { Idade de início } \\
\text { de trabalho na ferrovia }\end{array}$ \\
\hline $\mathrm{N}$ & 28 & 30 \\
Sem informação & 2 & 19,3 \\
Média & 14,4 & 19,0 \\
Moda & 14 & 6,06 \\
Desvio padrão & 5,34 & 11,0 \\
Mínimo & 7 & 38,0 \\
Máximo & 33 & \\
\hline \hline
\end{tabular}

\section{ACIDENTE OCUPACIONAL}

Em relação à ocorrência de acidentes de trabalho, 57\% referiram já ter tido algum tipo de acidente de trabalho e os outros $43 \%$ não. O trabalho na ferrovia expunha os trabalhadores a vários riscos, mas também a exposição era ligada à função que desempenhavam. As pessoas da carreira (que exerciam funções diretamente na locomotiva) ou os trabalhadores (ligados à linha férrea) estavam mais expostos e, na época, não utilizavam equipamentos de proteção. Já os ferroviários que ocupavam cargos mais administrativos estavam menos expostos a esses acidentes. Alguns diziam que a ferrovia era muito segura, pois tinha tudo controlado por um aparelho chamado stafe, que procurava evitar a colisão entre as locomotivas a vapor. Posteriormente, as locomotivas elétricas passaram a ter o controle pelo CTC 
(Controle de Tráfego Central). No entanto, outros ferroviários disseram ser freqüentes os acidentes, inclusive, com vítimas fatais.

"É, eram dois aparelho, um de um lado da estação e outro pra outro. Então, a estação pegava, é... e a estação pegava e pedia pro despachador, posso ir em frente? Pode, solta... agora já foi terminado. E fora quando tinha acidente né, nossa senhora, inclusive eu tenho dois elogios, dois acidente que eu salvei." (18.2)

"É... o gráfico era, era tudo medido, pra 0 hora até as 24 horas. As estações eram em Laranjal, Maristela, Pereira, Conchas, até Botucatu... então a gente pegava os trens de passageiro, tinha horário, a gente pegava fazia os pinguinhos, estação por estação, horário do trem, chegada e partida. A de chegada e de partida? É... de lá pra cá. Aí pelos pingo que a gente controlava pros carga correr. Tinha que estar com o percurso na cabeça aqui né, pra controlar todo o movimento, pra num atrasar ninguém. E aquele tempo era uma beleza que era difícil ocorrer acidente né" (18.5)

"Isso, as primeiras locomotivas se processavam por meio de Stafes, né. O trem só podia circular um trecho portando um bastãozinho, né. E tinha uma máquina, por exemplo, entre Botucatu e Rubião né, ia parti um trem daqui pra Bofete, então o chefe da estação daqui pedia pro chefe da estação de Rubião acionar uma alavanca lá, pra liberar o bastão aqui em Botucatu que ia partir tal trem. Ele acionava, saia o bastão, estava lá em Botucatu e em Rubião né, entregava pro maquinista, o maquinista já ia pra Rubião, chegava lá a operação pegava o bastão e esse aí punha na máquina, e quando esse bastão estava em circulação, você não conseguia tirar outro bastão. Então a segurança era máxima né. Depois veio o CTC que já modifico, eliminou esse bastão. Você liberava os trens por sinal, como se faz nos cruzamentos aqui rodoviários né." (24.4)

Em relação aos tipos de acidentes que essa amostra mais sofreu, o que teve maior ocorrência foi o referente à colisão de veículo e tombamentos. Este fato talvez esteja associado por ser um acidente mais grave e, desta forma, muito mais lembrado. Em segundo lugar, aparecem os seguintes acidentes: prensado, atingido por objeto em movimento, e queda de veículo em movimento. Acidentes estes decorrentes dos riscos a que estavam expostos, principalmente no depósito (oficina) e na própria locomotiva (cair e prensar membros superiores na fornalha ou caldeira).

"eu estava vendo o tombamento da locomotiva 1010. Ele falou o ano, mas eu não lembro mais o ano, agora. Foi quando morreu o maquinista, o foguista e o graxeiro. Essa locomotiva tombou na saída de Laranjal, o ano eu num lembro, ele me falo lá mas... num guardei. Aí a locomotiva, essa aí, foi recolhida pra Sorocaba né, pra fazer um serviço geral nela, tombou, tombou, matou os três, morreu os três, mais se não me engano isso aí, acho que foi... se não me engano, foi lá por 45,44 por aí". (28.4) 
"Tive sim, tive um acidente muito grave, na serra de Santos, eu trabalhei ali de... no km 11, perto de Domingos de Moraes, em São Paulo, descendo a serra de Santos. Eu caí de cima de um poste num dia de chuva. Lá chovia muito na serra de Santos e eu caí de cima de um poste, em dia de chuva, lá chove muito na serra né.

Caí de cima de um poste, caí sentado em cima de uma pedra assim, abriu tudo aqui". 19.1

Tabela 14 - Distribuição dos tipos de acidentes sofridos pelos entrevistados no trabalho da ferrovia.

\begin{tabular}{l|c|c}
\hline Tipo de acidente & No. de ocorrência & Percentual \\
\hline Colisão/tombamento de veículo & 6 & 33,3 \\
Ficou prensado & 3 & 16,6 \\
Atingido por objeto em movimento & 3 & 16,6 \\
Caiu de veículo em movimento & 3 & 16,6 \\
Queda da pessoa & 1 & 5,5 \\
Manipulação de ferramentas cortantes ou perfurantes & 1 & 5,5 \\
Outro & 1 & 5,5 \\
\hline
\end{tabular}

\section{MANIPULAÇÃO DE SUBSTÂNCIAS QUÍMICAS}

Investigou-se o fato de os ferroviários transportarem e manipularem substâncias químicas. Inicialmente, aventou-se a possibilidade de os agrotóxicos serem transportados a granel e serem manipulados pelos ferroviários sem nenhum tipo de proteção. Durante as entrevistas, relataram que os agrotóxicos, quando começaram a ser utilizados no Brasil, eram importados. Chegavam pelo porto de Santos, eram colocados em gôndolas especiais da ferrovia (pois o ferro era corroído mais rapidamente pelos agrotóxicos), e não manipulados pelos ferroviários. Vinham para Botucatu e depois iam para Avaré, onde existia uma empresa que embalava o produto. Quem retirava o produto das gôndolas e trabalhava com ele eram os funcionários dessa empresa de agrotóxicos. Alguns relataram também que, naquele tempo, eles não sabiam que os agrotóxicos faziam mal, pois seu uso não era disseminado. Disseram que nas lavouras era utilizado, freqüentemente, apenas o esterco.

“Não! Naquele tempo, naquele tempo não falava nem isso! Nem usava? Nem falava nisso aí. Não tinha não! Inclusive, inclusive aí, aqui tinha uma fazenda que era do Fisco né, fazenda de café aonde eu passei uma parte da minha infância aí né, e não tinham essas coisa, não tinha preocupação com essas coisas, produto químico, não existia né..." (2.3) 
"Transportava. Porque, principalmente adubo essas coisa, aquele calcário, acho que não era aquele calcário não, aquele enxofre, aqui passava muita Gôndola de enxofre né. Passava, passava a granel e ensacado né.(...) Mexiam, agora esses a granel acabaram com milhares de vagões da ferrovia, enferrujou tudo que não teve conserto mais. Aquele Ultrafertil tinha um depósito em Avaré. Aqueles vagões não deram pra aproveitar nada, está tudo encostado nesses pátios por aí, apodreceram

tudo. É, aquele adubo vinha a granel, acabou com tudo, porque o depósito da Ultrafertil ele é feito de madeira, ele é feito de madeira porque não agüenta. Se você pegar um punhadinho e pôr em cima do capô do carro, dali uns dias fura o

carro, acaba com a tinta, acaba com tudo. E as pessoas não ficava doente,

nada? Isso até pensei viu, eu acho que boa coisa não pode se não, o cheiro era forte. Antigamente num exigiam tanto, ou a pessoa que era mairs forte antigamente, não sei, pode ser que seja isso também né. Não isso era o próprio funcionário do depósito mesmo, porque lá eles ficavam nos depósitos, de lá que iam ensacando,

os caminhão levavam pras fazenda. E era gente da ferrovia mesmo, da

Sorocabana? Não, não, nada, da Sorocabana não, eles punham no depósito, então o trabalho da Sorocabana era só levar os vagão lá. Em Avaré, em Avaré, os

vagões passavam direto aqui e ia tudo pra Avaré, e tinham outros em Assis

também. Deixava lá...? Deixava o vagão lá e eles que descarregavam, os funcionários dessa empresa lá que descarregavam. Mas eles não usavam máscara não, eu tenho certeza, eu via quando ia trabalha por vagão né... E vinha da onde essas coisas? Se não me engano vinha direto de Santos, não tenho bem certeza, mais acho que vinha direto de Santos. Era importado, aquilo lá era material importado". (5.8)

“...não existia química, ninguém usava adubo, nem na lavora, nem em lugar nenhum usava química não, na lavora trabalhava com adubo, com esterco de cavalo e só isso, não tinha. Agora depois que veio tudo, naquele tempo não tinha coisa". (8.4)

Investigou-se a utilização de outros produtos químicos durante o trabalho da ferrovia, mas apenas 5 relataram já os terem manipulado. As substâncias que relataram foram: soda caústica, BHC, óleo isolante e extintor de incêndio. O caso do óleo isolante foi o que mais chamou a atenção, pois o ferroviário, para trabalhar na instalação da via elétrica, precisava ter o corpo totalmente envolto por essa substância, ficando dentro de um grande tanque. Nenhum tipo de proteção era utilizada, apenas trocava a roupa comum.

"A elétrica começou, acho que mais ou menos em 40, por aí, lá em São Paulo né. Vinha de São Paulo a Sorocaba, depois de Sorocaba era Iperó, era aquela Santo Antônio antigamente. Depois de Iperó passou por, passou por Laranjal, Boituva, pra saí lá em Laranjal, Laranjal, Pereira, Conchas, depois de Conchas veio uma subestação americana, e umas par de subestações nacionais e umas par delas Americanas, junto com americano, junto com americano, porque o americano, o americano já ia com os desenho da América, dos Estados Unidos, então ia dentro do transformador, cheio de óleo de óleo...? De óleo isolante, tinha que entrar lá 
dentro pra tirar aquilo lá e americano ficava em cima e nós já fazíamos o serviço lá embaixo, e ele não confiava em outra pessoa, era só eu que tinha que entrar lá dentro. Eu costumava tirar toda a roupa, usava o calção deles, deles mesmo e camisa, uma camiseta deles, era tudo, era tudo roupa deles mesmo, num usava de nossa roupa, ia trabalhar de terno né, é... Não, nada de elétrico, tudo desligado. Então ele falava que o que faltava e ia completar né, e dava pra nós se entender mais ou menos. Eu fiz de Iperó até Assis, é a rede, depois foi a linha de transmissão pra solta os 3 mil volts pra rede. Da linha de transmissão soltava 88 mil volts pra Sorocabana e soltava pra rede 3 mil pras máquinas elétricas" (19.1)

SITUAÇÃO ATUAL DE REMUNERAÇÃO, TRABALHO E APOSENTADORIA

Perguntou-se aos ferroviários sobre a situação profissional atual, se estavam aposentados, em que categoria, e se tinham alguma outra remuneração. A totalidade respondeu que estava aposentada por tempo de serviço e recebendo aposentadoria. Apenas um tinha outro emprego, trabalhando em tempo parcial, e outro que fazia trabalhos autônomos esporádicos. Somente um referiu ter investimentos (uma fazenda).

Em relação à questão sobre se recebiam ajuda dos filhos, apenas cinco disseram que sim. No entanto, ao longo da entrevista, questionando-se outros fatores, complementavam dizendo receber ajuda dos filhos no pagamento de planos de saúde, para a aquisição de medicamentos e mesmo alimentos. Isto pode estar associado ao fato de se envergonharem em afirmar que precisavam receber auxílios dos filhos, pois a aposentadoria é insuficiente.

Tabela 15 - Distribuição dos aposentados segundo as categorias de aposentadoria em que se encontravam.

\begin{tabular}{lcccc}
\hline & \multicolumn{2}{c}{ Sim } & \multicolumn{2}{c}{ Não } \\
\cline { 2 - 5 } & $\mathrm{N}^{-}$ & $\%$ & $\mathrm{~N}^{0}$ & $\%$ \\
\hline Aposentado por tempo de serviço & 29 & 96,7 & 1 & 3,3 \\
Aposentado por invalidez & - & 0 & 0 & 0 \\
Trabalha em tempo parcial & 1 & 3,3 & 29 & 96,7 \\
Trabalha como autônomo & - & 0,0 & 30 & 100,0 \\
Recebe salário & 1 & 3,3 & 29 & 96,7 \\
Recebe aposentadoria & 30 & 100,0 & - & 0,0 \\
Tem investimentos & 1 & 3,3 & 29 & 96,7 \\
Recebe ajuda dos filhos & 5 & 16,7 & 25 & 83,3 \\
Recebe de outras fontes & 1 & 3,3 & 29 & 96,7 \\
\hline
\end{tabular}




\section{BENEFÍCIOS RECEBIDOS NO TRABALHO}

Em relação aos benefícios que eles recebiam durante o trabalho desenvolvido na ferrovia, elencaram: décimo terceiro, direito a férias e a assistência médica. Disseram que nunca receberam cesta básica, no entanto este benefício não existia ainda na ocasião, mas eles tinham a cooperativa da EF Sorocabana. Por meio desta cooperativa podiam comprar vários produtos alimentícios e de limpeza que eram descontados em folha de pagamento, mas tinham um preço melhor que o do praticado no mercado, na ocasião. Apenas um disse ter recebido vale- refeição. Estes benefícios foram conquistados pela classe trabalhadora mais recentemente. Lembraram que passaram a ter direito às férias com o Governo de Getúlio Vargas, pois antes não tinham nada, assim como a jornada de trabalho não era regulamentada e nem os descansos semanais. Antes disso, trabalhavam de segunda a segunda, sem descanso, e no início desfrutavam de 15 dias de férias anuais e, depois, foram aumentando até chegar a 1 mês. A assistência médica conveniada pela EF Sorocabana foi referida apenas por dez entrevistados. Entretanto, mais adiante no questionário, a grande maioria referiu que sempre que precisavam tinham atendimento no posto médico, mantido pela ferrovia, com três médicos, e também no Hospital Sorocabana ${ }^{11}$.

Tabela 16 - Distribuição dos entrevistados segundo benefícios recebidos na época em que trabalhavam na ferrovia.

\begin{tabular}{lcccc}
\hline & \multicolumn{2}{c}{ Sim } & \multicolumn{2}{c}{ Não } \\
\cline { 2 - 5 } & $\mathrm{N}^{-}$ & $\%$ & $\mathrm{~N}^{-}$ & $\%$ \\
\hline Vale-refeição & 1 & 3,3 & 29 & 96,7 \\
Décimo terceiro & 27 & 90,0 & 3 & 10,0 \\
Assistência médica de convênio & 10 & 33,3 & 20 & 66,7 \\
Férias anuais & 27 & 90,0 & 3 & 10,0 \\
Outros benefícios & 2 & 6,9 & 27 & 93,1 \\
Cesta básica & 0 & 0 & 30 & 100,0 \\
\hline
\end{tabular}

${ }^{11}$ O Hospital Sorocabana foi construído com o auxílio dos ferroviários, que davam um dia por mês de seus serviços, em benefício da construção do hospital. 


\section{CLASSIFICAÇÃO DA SITUAÇÃO FINANCEIRA PREGRESSA E ATUAL}

Observou-se, nas respostas, que em relação à situação financeira, a pregressa foi considerada boa (63,3\%) ou média (36,7\%). Enquanto 20\% consideraram a atual situação financeira ótima ou boa, 56,7\% avaliaram como média, e 16,7\% como ruim ou péssima. A justificativa para a situação financeira pregressa foi agrupada em algumas categorias: alguns acharam que o salário que recebiam realmente era melhor, mas que existiam variações conforme a função que exerciam, sendo que os da "linha” (maquinista, foguista, ajudantes) e os que podiam fazer hora extra ganhavam mais. Além disto, destacaram que os ferroviários tinham crédito em todos os lugares, o que facilitava bastante a parte financeira, e que até conseguiam investir ou guardar o dinheiro que sobrava, construindo a casa própria.

Já a justificativa para a situação financeira atual como ruim vem atrelada à queixa de que eles não têm aumento há 8 anos $^{12}$. Também alegam que, se não fosse a ajuda dos filhos, o benefício não daria, e também gastam muito com remédios. Outros dizem que a situação não está fácil para ninguém e o que ganham dá para passar o mês e não devem nada para ninguém. Já têm a casa própria e alguns até carro, mas lembram que não dá mais para guardar e nem para passear.

Na pesquisa "New England Centenarian Study”, analisando os pedigrees dos centenários, observou-se que as famílias que viviam mais também tinham outros fatores associados, como melhores condições socioeconômicas (PERLS e col. 2002). Os idosos com melhor poder aquisitivo podem ter um envelhecimento, em parte, mais ameno, porque, pelo menos, podem pagar os gastos referentes à saúde, à boa moradia com adaptações, à alimentação adequada e ao lazer.

Tabela 17 - Classificação da situação financeira pregressa e atual dos ferroviários.

\begin{tabular}{lcccc}
\hline & \multicolumn{4}{c}{ Situação financeira } \\
\hline & \multicolumn{2}{c}{ Anterior } & \multicolumn{3}{c}{ Atual } \\
\cline { 2 - 6 } & $\mathrm{N}^{-}$ & $\%$ & $\mathrm{~N}^{-}$ & $\%$ \\
\hline Ótima & - & 0 & 1 & 3,3 \\
Boa & 19 & 63,3 & 5 & 16,7 \\
Média & 11 & 36,7 & 17 & 56,7 \\
Ruim & - & 0,0 & 5 & 16,7 \\
Péssima & - & 0,0 & 2 & 6,7 \\
\hline
\end{tabular}

\footnotetext{
${ }^{12}$ Dizem receber uma parte do salário pela antiga `Fepasa` (governo do Estado) e outra do governo Federal. Se a `Fepasa` dá algum pequeno aumento, o governo federal desconta isto da outra parte.
} 


\section{LAZER}

Pode-se notar que as atividades de lazer desses idosos, nos dias atuais, são bem reduzidas. Em média, têm apenas 1,5 atividade de lazer e 4 disseram não ter atividade alguma. O que predominou foram as outras atividades - como cuidar da chácara, caminhar no mato, caçar, viajar, tocar sanfona ou violão, jantar fora -, mas cada um apontava apenas uma destas atividade. Pescar e jogar (bocha e baralho) também foram atividades de lazer apontadas por 6 pessoas. Um até relatou que fazer “nada” era sua atividade de lazer atual, outro disse que era “dormir”, e apenas um se referiu à atividade que a sociedade reserva aos idosos: “o velho banco da praça”. Isto reflete a falta de estímulo ou, mesmo, de opções de lazer para essa faixa etária.

$\mathrm{Na}$ época em que trabalhavam na ferrovia, gostavam de desenvolver outras atividades: pescar, freqüentar bailes e cinemas, jogar bola, correr, atividades sociais e descansar. Até a década de 1940, Botucatu destacou-se por ser um grande centro cultural para todo interior paulista e, principalmente, para o centro-oeste. Existiam três cinemas na cidade e todos os filmes eram distribuídos através da EF Sorocabana. Os filmes saíam de São Paulo e vinham para Botucatu, que tinha o controle na distribuição dos filmes. Além disso, existia um grande nome em Botucatu: Emílio Pedutti, que era dono de uma extensa rede de cinemas em todo o Estado de São Paulo e mesmo fora dele. Emílio Pedutti também foi Prefeito da cidade de Botucatu e foi muito lembrado durante as entrevistas, recebendo elogios dos ferroviários pelo bom trabalho que realizou no município.

"O cinema! Aqui, aqui era a capital do cinema aqui! Aqui chegou a ter, parece que 4 ou 5 cinemas, aqui! Toda a distribuição de filmes para o Estado de São Paulo, Mato Grosso e tudo era feito por aqui, entendeu? Todas as companhias de filmes:

Paramon, e todas elas, entendeu? Tinha o escritório aqui e aqui cedo vinha aquele monte de latas de filmes, entendeu? Entregava a noite. Tudo pela ferrovia, entendeu? E aqui, aqui tinha cinema, tinha 4 ou 5 como já falei, 4 ou 5 cinema, entendeu? Era...hoje tem um e olhe lá (risos)". (2.2)

"O Emílio Pedutti tinha 25 cidades com cinema... ele então é exibidor. Então eu ia pra fiscaliza a renda, quanto deu, metade dele, metade da companhia... e... e fui muito conhecido dele, me dei muito com ele então me dava um apartamento, o cinema ele me dava apartamento... Há em várias cidades, Paraná, São Paulo e Mato Grosso... levei os melhores filmes que existia naquela ocasião... O Tubarão, Os Dez Mandamento, isso foi até $87 . .$. em 87 chegou a... veio a anistia, veio anistia, me chamaram voltei outra vez... " (17.5) 


\section{ATIVIDADE FÍSICA}

Investigou-se a respeito das atividades físicas desenvolvidas pelos ferroviários atualmente e na época da ferrovia. O que eles praticam mais freqüentemente, nos dias de hoje, é a caminhada (13 relataram), sendo que as demais atividades, como capinar, jogar bocha, fazer esteira, andar de bicicleta e arrumar a casa, foram referidas individualmente. No entanto, quase a metade não faz nenhum tipo de atividade física atualmente. Relataram que fazem essas atividades de forma freqüente, quase todos os dias da semana (50\%). A outra metade dos que relataram fazer atividade física a exercem: 4 vezes por semana (12,5\%), somente um dia por semana (12,5\%), e 25\% praticam 2 ou três vezes por semana.

Tabela 18 - Atividade física atual dos entrevistados.

\begin{tabular}{llll}
\hline \hline & & \\
& & Freqüência & Percentual \\
\hline Válidos & Não & 14 & 46,7 \\
Sim & 16 & 53,3 \\
& Total & 30 & 100,0 \\
\hline \hline
\end{tabular}

Tabela 19 - Distribuição da freqüência da atividade atual.

\begin{tabular}{llcc}
\hline \hline & & & \\
\hline Válidos & Todo o dia ou quase todo dia & Freqüência & Percentual \\
& Mais de 4 vezes pro semana & 2 & 50 \\
& 2 a 3 vezes por semana & 4 & 12,5 \\
& Um dia por semana & 2 & 25 \\
& Total & 16 & 12,5 \\
\multirow{3}{*}{ Sem informação } & & 14 & 100,0 \\
& & & \\
& & & \\
& &
\end{tabular}

Em relação às atividades físicas pregressas, 12 ferroviários referiram que não faziam atividade física, mas destes, 4 disseram que o trabalho que desenvolviam exigia muito esforço físico. Dentre os que referiram fazer atividade física, destacouse jogar futebol e, depois, o próprio trabalho. Outras atividades que apareceram foram: jogar basquete, tênis, caçar, caminhar e nadar. Considerando-se a freqüência das atividades, observou-se que $60 \%$ referiram que praticavam a atividade quase todos os dias, o que está associado ao fato de trabalharem diariamente e ser exigido esforço físico constante e vigoroso na ferrovia. $23 \%$ relataram que faziam essas 
atividades duas a três vezes por semana, $11 \%$ faziam quatro vezes por semana e $6 \%$ 1 dia por semana.

"Era ajudante em geral, jogava a lenha na frente. Eu pegava junto e punha na fornalha e abastecia a fornalha e controlava a água na caldeira também né. Enchia todos os dois lados da locomotiva, o maquinista tinha um e o foguista tinha outro.

Então quando baixava a água lá, lá o manômetro lá que marcava, era um calor hein!" (4.2)

"Dava porque fazia força né, porque a locomotiva a vapor, tem um negócio, você pra, pra você fazer fogo nela, a lenha não era só você jogar a lenha dentro dela de qualquer jeito, você tinha que jogar ela enfiada assim (mímica), uma em cima da outra, certinho, porque senão ela não produzia vapor suficiente. Se você ver a boca da fornalha é assim (mímica), em pé as laterais, você tinha que jogar pelas laterais, não podia deixar lugar sem lenha, era trabalhoso viu." (5.6)

“Trabalhava, principalmente quando eu entrei no lenheiro lá. Roupa, roupa não tinha roupa que aguentasse, enroscava, rasgava, se deixasse, ficava pelado. Meu pai, coitado, fez esforço pra eu entrar na Sorocabana, o dia que eu cheguei todo rasgado em casa eu vi que ele até chorou". (22.6)

Tabela 20 - Atividade física no tempo em que os entrevistados trabalhavam na ferrovia.

\begin{tabular}{llcc}
\hline \hline & & & \\
Válidos & Não & 12 & 40,0 \\
& Sim & 18 & 60,0 \\
& Total & 30 & 100,0 \\
\hline \hline
\end{tabular}

Tabela 21 - Classificação do esforço exigido pelo trabalho na ferrovia.

\begin{tabular}{llcc}
\hline \hline & & & \\
& & Freqüência & Percentual \\
\hline Válidos & Muito pouco & 8 & 26,7 \\
& Pouco & 8 & 26,7 \\
& Médio & 2 & 6,7 \\
& Muito & 4 & 13,3 \\
& Muito mais & 8 & 26,7 \\
& Total & 30 & 100,0 \\
\hline \hline
\end{tabular}

\section{CONDIÇÕES DE SAÚDE}

Verificou-se a morbidade atual referida, ou seja, perguntava-se aos longevos se eles tinham alguma doença, trabalhando somente com o que era dito por eles. Seis longevos referiram não ter nenhuma doença e, entre os que tinham algum tipo de 
doença, a hipertensão foi a mais referida: 13 casos (54\% dos casos). Depois, apontaram os problemas de próstata, alguns referindo câncer, outros apenas de forma genérica, dizendo ter "problema de próstata” (6 casos - 25\%). As demais doenças referidas foram: catarata (4 casos - 17\%), problemas osteoarticulares, infarto agudo do miocárdio, diabetes melitus (3 casos - 12,5\%), depressão, problemas pulmonares e circulatórios (2 casos - 8\%).

O tempo médio de apresentação de todas essas doenças foi de 11,5 anos, variando de 1 mês (início de hipertensão) a 70 anos (asma desde a infância).

Quando se questionou sobre terem adoecido no último ano, 80\% disseram que não, reafirmando a higidez dessa população.

Tabela 22 - Problemas crônicos de saúde referidos pelos entrevistados.

\begin{tabular}{cccc} 
& & Freqüência & Percentual \\
\hline Válidos & Não & 6 & 20,0 \\
& Sim & 24 & 80,0 \\
& Total & 30 & 100,0 \\
\hline \hline
\end{tabular}

Em relação ao número de doenças referidas pelo grupo investigado, a maioria possuía poucas doenças crônico-degenerativas, típicas do envelhecimento. De forma geral, eram idosos mais hígidos, considerando a idade avançada dessa amostra. 46\% dos casos apresentavam apenas uma doença, 32\% duas e 22\% três.

Um estudo retrospectivo realizado em New England, de base populacional, mostrou que $88 \%$ das centenárias mulheres e 100\% dos centenários homens tinham independência funcional até 92 anos em média, o que aponta a teoria da compressão da morbidade associada com a longevidade (PERLS 1995; VITA e col. 1998; PERLS e col. 2002)

Pediu-se para que eles comparassem a sua saúde atual com a de outras pessoas da mesma idade. A maioria, 58,62\%, disse estar com saúde melhor ou muito melhor do que os outros, enquanto somente 3,45\% responderam estar pior. Foi feito o mesmo questionamento referindo-se à época em que ainda trabalhavam, e responderam que a saúde era igual, comparando com a dos outros colegas da ferrovia 
(53,5\%); apenas 30\% disseram ser melhor. Relataram que muitos ferroviários bebiam em demasia e não tinham "saúde muito boa”.

"Não! Normal, normal. Depende da pessoa né, o estado de saúde, o estado da pessoa, assim isso. Tinha uns que bebiam né, tinha quem bebesse viu,....uhhhhhhhh, mas também hoje num tem mais nenhum vivo, nenhum, nenhum. Todos esses daí morreram, mais ou menos na idade que nem o meu irmão. Os ferroviário daquele tempo do meu irmão, foi tudo, todos eles foram embora, não tem mais nenhum aí...aqui, nenhum, tudo mundo já morreu. A bebida prejudica muito a saúde, a vida da pessoa né, e o cigarro também ajuda né". (8.9)

Tabela 23 - Autocomparação da saúde atual dos entrevistados com outras pessoas da mesma idade.

\begin{tabular}{llcc}
\hline \hline & & & \\
\hline Válidos & Pior & 1 & 3,45 \\
& Igual & 11 & 37,93 \\
& Melhor & 13 & 44,83 \\
& Muito melhorência & Percentual \\
& Total & 4 & 13,79 \\
\multirow{2}{*}{ Sem informação } & & 29 & 100,0 \\
& & 1 & \\
\hline \hline
\end{tabular}

Em relação ao número de medicamentos utilizados, chamou a atenção que 8 longevos referiram não usar utilizar nenhum tipo de medicação, sendo que tinham idades bem avançadas, incluindo o mais longevo da amostra, com 96 anos. Os demais tinham de 80 a 87 anos e não referiram apresentar patologias crônicas que exigissem o uso de medicação. Apenas um disse estar com hipertensão há 1 ano e fazendo acompanhamento e tratamento não-medicamentoso. O número médio de medicações utilizadas foi de 1,68 e a mediana 1,5. Este é um número até baixo, uma vez que existe o problema de supermedicação de idosos. Tratam o processo de senescência (processo fisiológico normal de envelhecimento) como senilidade (patologias decorrentes do envelhecimento), intervindo em todo sinal ou sintoma que não se enquadra no esperado para um adulto. A geriatria é uma ciência nova que tem tentado demonstrar que não é necessário medicalizar todo idoso. Um grave problema que ocorre com freqüência com essa população é a interação medicamentosa e reações adversas, que podem inclusive levar a óbito. Não se tem dados sobre a gravidade do que pode estar realmente acontecendo com essas interações e reações, 
uma vez que não são notificadas de forma sistemática pelos profissionais de saúde, sendo impossível medi-las e implementar melhorias.

Em relação aos convênios de saúde, a grande maioria os tem (76,7\%). Muito embora vários idosos não tenham condições financeiras de adquiri-los, devido ao seu elevado valor, principalmente para essa faixa etária. Assim, os filhos auxiliam no pagamento. Como os idosos apresentam maior risco de ter várias patologias crônicodegenerativas, demandar internações e/ou intervenções de custo mais elevado, os planos de saúde para eles são extremamente onerosos. O convênio que mais referiram foi a UNIMED (43,3\%), seguido de um convênio mais local - PREVER (13,3\%). Além disso, Botucatu conta com um hospital universitário terciário (Hospital das Clínicas da Faculdade de Medicina de Botucatu - UNESP) e um Centro de Saúde que oferece ambulatório de geriatria cinco vezes por semana. A área de abrangência dessa unidade básica de saúde concentra a maioria dos exferroviários aposentados.

Pediu-se para que eles atribuíssem uma nota ao serviço de saúde atual, e ela foi de 7,96 , sendo que $60 \%$ não se queixavam de problemas. Isto pode estar relacionado à cultura do idoso, de pessoas mais velhas, na qual o médico era extremamente respeitado e tido como "semideus”. Dessa forma, não se questionavam as condutas e a qualidade do serviço. Possivelmente, ainda ostentam esta concepção e ficam envergonhados de criticar. Outro viés que pode ter-se criado é o fato de a entrevistadora ser médica e ter vínculos com estes dois serviços, como era explicado no início da entrevista.

O Hospital Sorocabana, um hospital que atende o setor secundário do município, foi construído e extremamente utilizado pelos ferroviários. Segundo texto de um ferroviário que administrou por muito tempo esse hospital, ele relata que:

"O Hospital Regional de Botucatu teve sua pedra fundamental lançada em 13/11/1949, em terreno de 6.400 m2, doado pela família Barbosa de Barros, na gestão do governador do Estado de São Paulo, Dr. Adhemar Barbosa de Barros, Secretário de Viação e Obras Públicas, Engo. Lucas Nogueira Garcez e Diretor da Estrada de Ferro Sorocabana, Engo. Álvaro de Souza Lima. A Inauguração de seu Hospital Central deu-se no ano de 1955, completamente equipado. As atividades do Regional de Botucatu, entretanto, se deram a $1^{\circ}$. de janeiro de 1951, no prédio da ex-Casa de Saúde, de propriedade do Dr. Humberto Gianella, situado na Av. 
SANTANA no. 323. Portanto, meio século de existência, servindo a comunidade de Botucatu e região". (comunicação pessoal de Henriques 2000) ${ }^{13}$

Os ferroviários relataram que deram muitos dias de serviço para a construção do hospital, ou seja, alguns dias de trabalho do mês eram descontados na folha de pagamento e o dinheiro era revertido para a construção do hospital. Era como uma mensalidade. Atualmente, o hospital está em uma situação muito precária, com muitas dívidas e sem conseguir investimentos, dificultando mais ainda o acesso dos ferroviários aos serviços de saúde que eles poderiam utilizar mais facilmente. Em uma comemoração ao dia do Hospital (2 de Julho), uma professora, filha de exferroviário engenheiro responsável pela construção do Hospital Sorocabana escreveu uma história à imprensa escrita de Botucatu:

"Certa vez, meu pai, Luiz Bandeira Leite de Mello, me contou este fato: estava na sala da chefia da estação Júlio Prestes, juntamente com o diretor da Sorocabana, Dr. Acrísio Paes Crus, quando vieram Ihe dar uma triste notícia - Um ferroviário, vindo de Assis, e por falta de socorros médicos acabara de falecer. Dr. Acrísio imediatamente se levantou e disse aborrecido: - Ferroviário não é um indigente e isto não irá acontecer mais. Imediatamente, ligou para o Dr. Lamartine Navarro consultor jurídico - e pediu-lhe que desse andamento à formação de uma entidade médica para socorrer os doentes da tão querida estrada de ferro Sorocabana.

Quando uma vida se apagava, uma centelha de amor ao próximo se ativava. Dr. Acrísio , Dr. Cavalcanti, Dr. Bandeira se juntaram, irmanados por uma força maior e partiram para a luta. Primeiramente, conseguiram com o governador um terreno no bairro da Lapa, em São Paulo, e ali ergueram um hospital. A seguir, vieram também os hospitais de Assis e o de Botucatu".

(Comunicação pessoal de Marins 2000) ${ }^{14}$

Os ferroviários relataram que sempre tiveram assistência à saúde na época em que trabalhavam na ferrovia. Antes da construção do hospital Sorocabana, existia o Posto Médico que atendia somente as pessoas ligadas à ferrovia, com médicos que consultavam em horário comercial, mas podiam ser chamados para prestar atendimento em casa em outros horários.

\footnotetext{
${ }^{13}$ Comunicação de Sr. Romeu Francisco Henriques, diretor administrativo na época do Hospital Sorocabana, como parte inicial de um relatório do hospital, 2000.

${ }^{14}$ Comunicação de Elvira Bandeira de Mello Marins, 2000 - texto mimeo do Hospital Sorocabana em comemoração ao dia do Hospital, 2 de Julho de 2000.
} 
"Porque antes, doutora, que já vai longe, a parte do ferroviário, vamos falar assim, os médico atendiam na casa, que era, vamos falar do INPS, na época num era mais vamos... 3 médicos, tinham 3 médicos, Arnaldo Moura Reis, João Reis, Doutor Araújo, depois veio o Doutor Darvi, aí veio o Vino. Mais na época, doutora, da saúde, vamos dizer, a parte da empresa que era ferroviário tinha mais assistência, assistência na casa. Vamos supor, um exemplo: Jordina ficava doente, telefonava pro médico: - Doutor estou com a minha senhora assim doente, assim, assim, dá pro senhor vim? - Pois não. Se ele tinha carro, tudo bem, se não você que tinha que mandar o carro. Vinha, examinava tudo direitinho ia embora, tudo bom, nada mais. Lá acontecia a mesma coisa, fora daqui, por exemplo aí em Vitoriana, esses

lugares, Avaré, por aí. Lá o empregado, o chefe de trem, o chefe da estação, paravam, o chefe, naquela época, era chefe de distrito, é como se diz, requisitava ou um carro ou uma locomotiva pra levar o médico a Avaré, ou nesse postinho pra ele examinar o doente ou trazer se fosse um caso de parturiente. Se fosse um caso de parturiente, então já alugava um carro ou um vagão, vamos dizer assim, pra trazer, uma coisa ou outra. Quer dizer que então essa parte estava tudo bem, lá ficava um doente lá, eu já telefonava pro médico, o médico já ia lá, mas tinha um pormenor, o médico que não tinha carro na época, como dizia um médico pobre (risos), um médico pobre na época. Então falava, falava pro dono do doente lá: mande um carro, o senhor aluga aí, o senhor me manda o carro pra mim ver o doente. Eu não posso ir aí, não tenho carro. Alugava e dava um jeito, (...) o bom, virou, uma coisa e outra, que o senhor acha doutor? Está assim, assim, assim, vai tomar esse remedinho aqui tal... curou, está muito bem, estou muito bem, não mais agora, tem o carro pra pagar. - Não! O senhor não tem carro! Não! Não vou pagar não doutor, o senhor aí coisa... não, não vou pagar o carro não, o senhor já ganha, vou pagar o carro? O médico tinha que pagar o carro pra vim né". (13.5-6)

"Era, era. Então doutor Jorge, doutor Arnaldo, doutor João Reis. Mais era uma beleza o atendimento viu. Você ia lá, nossa, atendia na hora. Nós sempre tirávamos licença né. Então ia lá com o doutor João Reis, o doutor João Reis é que dava mais licença pra nós, ficava lá... o doutor já: - quantos dias você quer?: - Ah! dá uns 3 dias". (10.4)

“... dava, principalmente o João Reis, dava licença até no meio da rua... Foi, aquele foi um médico bom pra essas coisas, pros ferroviários ele foi uma mãe, pra mim tudo eles foram bom, Doutor Peres, tinha o Doutor Luís." (30.6)

Os ferroviários que precisassem de serviço mais especializado eram encaminhados para SP, sendo que os maquinistas e outros profissionais de carreira faziam exames anuais em SP. Existia também uma farmácia da Sorocabana, onde os ferroviários retiravam a medicação, cujo valor era descontado do ordenado, no final do mês. No entanto, 83,3\% referiram que raramente tinham que ir ao médico, durante o ano, na época em que trabalhavam. 
"A farmácia funcionava ali na..., em frente ao antigo Lunardi. Ali, que era aquela farmácia de fórmula. Eu entrei ali... Aí, por exemplo, se houve a receita médica, porque ali em anexo, tinham 3 médicos na época, e o posto médico era anexo, junto. (...) Não, não, não só quem era da..., só quem era ferroviário, fora disso não, não tinha fornecimento nenhum. Só exclusivamente sob fatura, dinheiro não, quer dizer que o ferroviário vinha com a receita, ele tinha uma caderneta, ele tinha uma caderneta né, trazia a receita, fazia o débito, entregava a caderneta com uma cópia com a caderneta né, a original ia pra São Paulo e a cópia ficava na farmácia pra depois entrar em desconto de folha pra eles lá". (13.2)

\section{PATOLOGIAS ASSOCIADAS DIRETAMENTE A PROBLEMAS AMBIENTAIS}

Procurando visualizar a ligação entre problemas ambientais ou poluição ambiental e saúde, questionou-se sobre a manifestação de doenças cardiorrespiratórias (asma, rinite, problemas cardíacos) e o tempo de aparecimento, como aponta a literatura e foi discutido na introdução da atual pesquisa. Esta última variável (tempo) foi difícil de colher, uma vez que muitos não se lembraram especificamente quando o problema havia ocorrido ou começado a se apresentar.

Em relação aos problemas respiratórios, 80\% referiram não apresentar nada. Entre os que apresentaram algum problema, relataram: bronquite, rinite, enfisema, congestão e tosse.

Tabela 24 - Problemas respiratórios apresentados pelos entrevistados ao longo de suas vidas.

\begin{tabular}{lcc}
\hline \hline & & \\
& Freqüência & Percentual \\
\hline Bronquite & & \\
Congestão (pus no pulmão) & 1 & 4,17 \\
Enfisema & 1 & 4,17 \\
Rinite & 1 & 4,17 \\
Tosse com catarro & 1 & 4,17 \\
Tosse do cigarro & 1 & 4,17 \\
Sem problemas & 1 & 4,17 \\
Total & 24 & 75,98 \\
\hline \hline
\end{tabular}

Perguntou-se também e diretamente se já tinham apresentado quadros de asma. Apenas 3 relataram já terem apresentado, sendo o tempo de aparecimento há mais de 70 anos (apenas um lembrou-se). Problema de coração também não foi 
freqüente, 70\% referiram não apresentar nada, no entanto, o tempo de aparecimento médio foi mais recente, de 12 anos.

\section{FUMO E BEBIDA}

Dessa amostra de longevos, 33,3\% referiram nunca ter fumado, sendo que 13,3\% dos restantes ainda fumavam ou já haviam sido fumantes anteriormente (53,3\%). O tempo médio do hábito de fumar dos ex-fumantes foi de 33,7 anos e dos 5 que ainda fumam foi de 43,2 anos. A quantidade média de maços fumados ao dia foi de 1 , variando de $1 / 6$ a 3 maços.

Tabela 25 - Hábito de fumar dos entrevistados ao longo da vida.

\begin{tabular}{llcc}
\hline \hline & & Freqüência & Percentual \\
\hline Válidos & Não, nunca & 10 & 33,3 \\
& Sim & 4 & 13,3 \\
& Já fumei & 16 & 53,3 \\
& Total & 30 & 100,0 \\
\hline \hline
\end{tabular}

PERLS e col. (2002) alertam para o fato de que os americanos acabam perdendo em média 10 anos em seu tempo máximo de vida devido a hábitos nãosaudáveis, como: fumar, não praticar atividade física regularmente e serem obesos (2/3 da população desse país apresenta sobrepeso e 20\% são obesos), terem uma dieta inadequada (gordurosa e calórica), que representa fator de risco para doenças coronarianas. Os autores ainda ressaltam que se a população americana tivesse hábitos saudáveis, além de aumentar seu tempo de vida, cada indivíduo e a própria população estaria ganhando muito com isto no futuro.

Em relação à bebida, notou-se que alguns não gostavam de referir que bebiam bastante. Isto foi descoberto durante as entrevistas entre colegas, que acabavam relatando que o outro ferroviário entrevistado tinha o hábito de beber bastante. Talvez, por isto, encontrou-se uma grande percentagem de pessoas $(55,17 \%)$ que responderam nunca ou raramente terem ingerido bebida alcoólica. Além disto, existe o preconceito social em relação a pessoas que são rotuladas como 'alcoólatras', inibindo-os nesta resposta. 
Em relação à quantidade, foi muito variável e difícil de analisar, pelo fato de os entrevistados fazerem uso de diferentes bebidas, como pinga, uísque, vinho e vodca. Todos disseram ingerir apenas um ou dois cálices. Inclusive o longevo com maior idade dentro dessa amostra (96 anos) referiu que sempre gostou de beber e que até hoje faz uso de uísque.

Tabela 26 - Hábito de beber dos entrevistados ao longo da vida.

\begin{tabular}{llcc}
\hline \hline & & Freqüência & Percentual \\
\hline Válido & Não, nunca & 5 & 17,24 \\
& Raramente & 11 & 37,93 \\
& Mais de um dia por semana & 10 & 34,48 \\
& Já utilizei & 3 & 10,34 \\
& Total & 29 & 100,0 \\
& & 1 & \\
\hline \hline
\end{tabular}

\section{ATIVIDADES E AMIZADES}

Investigou-se a respeito de outro fator que pode contribuir para a longevidade: o engajamento social. O que chamou a atenção foi que 57,14\% referiram que eram muito ativos antigamente, trabalhavam na ferrovia e faziam outras atividades. Era comum o fato de eles próprios construírem suas casas. Disseram que, após chegarem em casa, retornando do trabalho, viravam pedreiros. Compravam materiais de construção a um preço bem acessível na própria ferrovia, que trazia tijolos, areia, pedra, cimento, madeira e vendia aos ferroviários. Além dessa atividade, também capinavam o quintal de suas casas e cuidavam da horta e pomar. Alguns ainda mantinham outro emprego ou faziam "bico” para aumentar a renda.

"É, o da estrada ia até às 19 horas, então eu descia pro cinema. E quando terminava a sessão, às 23 horas, eu já deixava o aparelho limpo, tudo, porque eu chegava, no outro dia em cima da hora no cinema e a primeira sessão era às 19 horas, ia até às 21 horas, depois começava outra sessão que ia até às 23 horas. Eu trabalhei, num tive tempo pra bagunçar." (29.3) 
Tabela 27 - Autoclassificação em relação às atividades que os entrevistados faziam durante a época em que trabalhavam na ferrovia.

\begin{tabular}{llcc}
\hline \hline & & Freqüência & Percentual \\
\hline Válidos & Muito ativo & 16 & 57,14 \\
& Médio, com algumas atividades & 5 & 17,86 \\
& Pacato, só com atividades do trabalho & 7 & 25,0 \\
& & & 100,0 \\
\multirow{2}{*}{ Sem informação } & Total & 28 & \\
& & 2 & \\
& & & \\
\hline \hline
\end{tabular}

Tabela 28 - Amizades que os entrevistados possuíam.

\begin{tabular}{llcc}
\hline \hline & & Freqüência & Percentual \\
\hline Válido & Muitas amizades & 21 & 75,0 \\
& Algumas amizades & 5 & 17,86 \\
& Poucas & 2 & 7,14 \\
& Total & 28 & 100,0 \\
Sem informação & & 2 & \\
& & & \\
\hline \hline
\end{tabular}

A grande maioria dos ferroviários disse que tinha muitas amizades (75\%) outro fator que aparece na literatura como provedor da longevidade. A literatura aponta que o suporte social é um componente importante na morbimortalidade. Em relação à mortalidade, existem estudos indicando menor risco de morrer entre as pessoas que têm grande suporte social (HO 1991; OLSEN 1993; SEEMAN e col. 1993; HOUSE e col. 1988). Duas teorias tentam explicar este fenômeno. A primeira afirma que haveria um efeito direto, ou seja, a pessoa com maior suporte social teria maiores benefícios diretos sobre sua saúde. A segunda diz que os efeitos seriam indiretos, advindos desta relação, na qual os efeitos maléficos dos fatores estressantes poderiam ser amenizados através de apoio social, dos amigos (PENNIX e col. 1997).

\section{ALIMENTAÇÃO}

Investigou-se o hábito alimentar dessa amostra, levantando as seguintes variáveis: número de refeições por dia, ingestão de leite e derivados, ingestão de carnes, ovos e leguminosas, frutas, verduras e líquidos. Era solicitado que relatassem como estes itens anteriores eram consumidos na época em que ainda trabalhavam. Para este estudo, era importante descobrir como era a ingestão ao longo da vida, pois 
a literatura aponta que a alimentação, principalmente nos primeiros anos de vida, provavelmente interfere na longevidade, como demonstrado em ratos (MACCAY e col. 1935; BERG e SIMMS 1960; ROSS 1966; MASORO e col. 1980, YU e col. 1982; WEINDRUNCH e WALFORD 1988). Desta forma, optou-se por tentar caracterizar como havia sido a ingestão na maior parte da vida do longevo. A média do número de refeições foi de 3 ao dia, sendo o consumo de verduras maior (duas vezes ao dia) que de frutas, pois diziam que antigamente era mais difícil de se obter frutas do que hoje, só existia a fruta da época. Chupavam mais laranjas, que às vezes pegavam pelo caminho da ferrovia ou no quintal de casa. Não costumavam ingerir carnes todos os dias, mas 3 ou quatro vezes por semana, principalmente, frango e lingüiça. O consumo de ovo era muito freqüente, assim como de feijão, praticamente todos os dias.

As mulheres eram muito importantes nesse processo de alimentação dos ferroviários. Elas acordavam de madrugada para fazer a marmita, para que o ferroviário pudesse levar para o trabalho; ou faziam durante o dia e mandavam até a estação pelos filhos ou elas próprias. Lá existia um pequeno vagão que saía distribuindo a comida ao longo dos trechos da ferrovia que eram possíveis de se alcançar. Mas, mesmo assim, tinham problemas, pois às vezes demorava muito e, quando a comida chegava, estava azeda, ou ela se "perdia pelo caminho”. Os ferroviários relataram ter problemas referentes à sua alimentação na época em que trabalhavam na ferrovia, como falta de alimento durante o trabalho. Existem relatos de passarem fome e ficarem muitas horas sem comer.

"as mulheres, elas quantas vezes de madrugada no fogão a lenha fazendo comida pra mim levar, é.... a gente levava ou então mandava na linha pra mim, levava a pé, a gente morava perto.... mandava levar na estação. A mulher de ferroviário, dos

ferroviários da carreira - maquinista e foguista, sofreram barbaridade - de madrugada estava fazendo comida no fogão a lenha. Nós chegávamos, ... que nem para ir para São Paulo, que saía daqui e levava comida. Tinha uma folha de zinco cheia, em cima cheia de areia, embaixo era o fogo e esquentava aquela....e punha a vasilha de comida ali pra esquentar (risos)" (12.6-7)

“... cantinho nosso, comprava no armazém. Mais era coisa tudo de primeira, não tinha nada de falsificado. Verdura, verdura era na horta nossa mesmo, nada de químico. Você regava a horta com a água do poço, era uma beleza. Sua comida era arroz, feijão, uma lingüicinha frita. Matava o porco, fazia em casa mesmo, a carne de frango, frango criado em casa. Era difícil come carne de lá, difícil, era ovo frito, lingüiça frita, essas coisinha, era tudo do porco". (22.6) 
"Tinha um trem que saía às 10 horas de Botucatu, o trem de passageiro saía as 10:30, aquele trem levava comida pra turma, aquele trem... locomotiva, tinha um lugar separado da locomotiva que mandava fazer pra caber a comida, lá cabia, lá cabia 20, 25 comidas. Aí a esposa levava na estação? Levava na estação, e na estação tinha o responsável que pegava as comidas. Aquele responsável era um portador que era o responsável, tinha o lugarzinho onde levava pra o ... a área lá que levava a comida. Depois punha num carrinho, quando encostava a locomotiva no trem punha o carrinho a parte, aí colocava na locomotiva. Então, tinha um trem parado lá em Pirambóia, ai chegava lá com trem. O foguista, o pessoal de máquina

sabia que a comida dele tinha vindo naquele trem. Então eles já esperavam a comida, tudo com rótulo né, com os rótulos, fulano de tal... Iperó, né, falava o trem Iperó, falava o trem Iperó, então eles já chegavam na locomotiva, já pegavam a comida, é pegava. É eu era já acostumado já com isto" (16.9)

Foi pedido para que eles fizessem uma auto-avaliação da qualidade de sua alimentação, na época da ferrovia, sendo que 60,87\% classificaram-na como sendo boa ou ótima.

Tabela 29 - Qualidade da alimentação pregressa dos entrevistados.

\begin{tabular}{llcc}
\hline \hline & & Freqüência & Percentual \\
\hline Válidos & Ótima & 3 & 13,04 \\
& Boa & 14 & 60,87 \\
& Média & 6 & 26,09 \\
& Total & 23 & 100,0 \\
Sem informação & & 7 & \\
& & &
\end{tabular}

Perguntou-se, também, onde eles compravam as mercadorias e a quase totalidade respondeu que retirava os alimentos no armazém da ferrovia. Eles possuíam uma caderneta, na qual anotavam o que desejavam e deixavam no armazém. No final do mês, a compra era entregue, através de carroças, em suas próprias casas. Todos disseram que esse armazém era muito bom, tendo de tudo, menos verduras e frutas, e que a qualidade do produto era excelente (elogiaram muito a qualidade do bacalhau, que dava para o mês todo). Além do armazém, 63\% possuíam horta e/ou pomar, de onde retiravam o que necessitavam, sem utilizarem adubos artificiais, somente esterco de gado.

Questionou-se a respeito da quantidade de alimento ingerido ao longo da vida. Era explicado para que eles se comparassem com outros colegas, da mesma idade e mesmo porte. $46,7 \%$ responderam que comiam a mesma quantidade e $40 \%$ 
disseram comer menos que os outros e apenas 13,3\% mais. Este é outro componente pesquisado na literatura, com possível associação com a longevidade. Em ratos, comprovou-se que diminuindo a quantidade de alimentos, restrição calórica, podia-se estender o tempo de vida (MACCAY e col. 1935; BERG e SIMMS 1960; ROSS 1966; STUCHLIKOVA e col. 1975; MASORO 1998, YU e col. 1982; WEINDRUNCH e WALFORD 1988, WEINDRUNCH 1996).

Tabela 30 - Auto-avaliação da quantidade de alimento consumido, em tempo pregresso, pelos entrevistados.

\begin{tabular}{llcc}
\hline \hline & & Freqüência & Percentual \\
\hline Válido & Muito menos & 6 & 20,0 \\
& Menos & 6 & 20,0 \\
& Igual & 14 & 46,7 \\
& Mais & 3 & 10,0 \\
& Muito mais & 1 & 3,3 \\
& Total & 30 & 100,0 \\
\hline \hline
\end{tabular}

\section{GRAU DE SATISFAÇÃO EM RELAÇÃO À VIDA}

Ao final do questionário, perguntou-se qual o grau de satisfação que eles tinham em relação à vida que haviam construído. A grande maioria $(93,4 \%)$ disse que estava satisfeita ou muito satisfeita, assim como feliz (96,29\%), e apenas um disse estar insatisfeito: "sinto-me derrotado” (morava sozinho e a mulher havia sido levada para uma casa de repouso por ter fraturado o fêmur). Também questionou-se se eles tinham algum problema atual que gostariam que fosse diferente ou que não existisse. 53,3\% disseram não apresentar problemas importantes e relevantes; 23,3\% queixaram-se da situação econômica; outros, de problemas familiares, isolamento e problemas de saúde.

Tabela 31 - Grau de satisfação dos entrevistados em relação à vida.

\begin{tabular}{llcc}
\hline \hline & & \\
\hline Válidos & Muito satisfeito & 17 & 56,7 \\
& Satisfeito & 11 & 36,7 \\
& Insatisfeito & 2 & 6,7 \\
& Total & 30 & 100,0 \\
\hline \hline
\end{tabular}


Tabela 32 - Grau atual de felicidade dos entrevistados.

\begin{tabular}{llcc}
\hline \hline & & & \\
\hline Válidos & Muito feliz & Freqüência & Percentual \\
& Feliz & 12 & 44,44 \\
& Indiferente & 14 & 51,85 \\
& Total & 1 & 3,70 \\
\multirow{2}{*}{ Sem informação } & & 27 & 100,0 \\
& & 3 & \\
& & & \\
\hline \hline
\end{tabular}

Investigou-se se eles tinham algum plano para um futuro próximo, algo que gostariam de fazer e ainda não haviam feito. A maioria disse que não, que 'o tempo já estava acabando e já tinham feito bastante’, mas 9 disseram que ainda tinham o que fazer. Foram bem variados os planos: andar de avião, passear, viajar com a mulher, ver os filhos dos netos, ter saúde, voltar a trabalhar, viver o restinho de vida e continuar sendo feliz.

\section{QUESTÕES ASSOCIADAS AO MEIO AMBIENTE}

Tentou-se caracterizar o meio ambiente a que esses idosos foram expostos ao longo da vida. Baseou-se nos indicadores ambientais adotados pelo Ministério da Saúde e pela oficina de trabalho realizada durante o IV Congresso Brasileiro de Epidemiologia - EPIRIO-98 ${ }^{14}$. Os indicadores propostos apontaram para alguns tópicos: a) qualidade da água para consumo humano; b) controle dos fatores condicionantes do risco de transmissão de doenças endêmicas por vetores; c) contaminantes ambientais; d) qualidade do ar; e) contaminação do solo; f) desastres naturais e acidentes com produtos perigosos. (GALVÃO e col. 1998).

Para a presente investigação, era importante levantar os indicadores ambientais pregressos, ou seja, da época da infância e adolescência desses ferroviários. Uma vez que os fatores associados à longevidade podem começar a agir desde os primeiros anos de vida. Desta forma, tentou-se caracterizar como era a

\footnotetext{
${ }^{14}$ Essa oficina tinha como objetivo central a discussão do tema e propor indicadores para a vigilância de problemas da esfera ambiental que afetam a saúde.
} 
qualidade da água e de onde era adquirida; a qualidade do ar; disposição do lixo; condições do esgoto da residência; área verde; ruídos; poluição visual; condições de umidade/temperatura e mudança brusca de temperatura; se havia vivenciado algum desastre ambiental, contaminação ambiental ou contaminação dos solos. Todas estas questões eram investigadas, pedindo-se ao longevo que tentasse lembrar como eram estes itens em cada lugar que ele havia morado e nos respectivos tempos. Uma tabela era preenchida com todas as características ambientais de cada local. Alguns problemas podem advir desta metodologia adotada, como dificuldade de memória e avaliações questionáveis (por exemplo: água limpa visivelmente não é sinônimo de água de boa qualidade), no entanto vale ressaltar que não existem dados de órgãos especializados que retratem como eram estes indicadores ambientais para o município de Botucatu no período investigado.

\section{QUALIDADE DA ÁGUA}

Em relação à água, no primeiro local de moradia predominou a água de poço (39,29\%), sendo classificada por eles como limpa e muito limpa (82\%), e, depois, apareceu a água de mina (25,0\%), também classificada como limpa e muito limpa (86\%).

Tabela 33 - Tipos de captação de água relatados pelos entrevistados nos locais de moradia.

\begin{tabular}{llcc}
\hline \hline & & Freqüência & Percentual \\
\hline Válidos & Encanada & 6 & 21,43 \\
& Mina & 7 & 25,0 \\
& Poço & 11 & 39,29 \\
& Outro & 4 & 14,29 \\
& Total & 28 & 100,0
\end{tabular}

Sem informação

2

A partir do segundo local de moradia, começou a predominar a água encanada (56,7\%), caindo a água de poço para 23,3\% e de mina para 3,3\%, mas continuaram referindo que ambas eram limpas, apenas um disse que a água de seu poço era suja. A partir do período em que a companhia de água se estabeleceu no município (no caso a SABESP), as pessoas foram obrigadas a fecharem os poços de 
suas casas. Em relação à autoclassificação da água encanada, mais da metade referiu que ela era limpa e muito limpa (59\%), um referiu ser média, e outro, suja.

\section{QUALIDADE DO AR}

Em relação ao ar, indagou-se se havia poluição do ar no local onde moravam. No primeiro local de moradia, a totalidade respondeu não existir, e consideraram o ar como sendo puro e muito puro. No segundo local de moradia, apenas um referiu ter poluição, sendo o ar considerado como puro e muito puro $(77,8 \%)$ e médio (22,3\%).

\section{RESÍDUOS SÓLIDOS}

Ao se questionar a respeito do lixo, que destino era dado a este, os entrevistados não se lembraram tão bem quanto dos outros elementos anteriores. Desde o primeiro local de moradia, predominou a referência da coleta municipal. Diziam que Botucatu sempre teve um serviço de coleta. Uma carroça passava pela cidade recolhendo o lixo. Outros disseram que enterravam e, em terceiro lugar, apareceram os que jogavam em terrenos baldios. Para tentar caracterizar melhor, foi indagado se a região onde moravam era limpa ou não, se tinha lixo jogado e sujeira pelas ruas. Esta questão não pôde ser analisada, uma vez que a metade dos entrevistados não sabia informar.

“... então o que eles faziam, o lixo que vinha jogavam tudo naquele buraco que tinha. Chego um ponto que hoje... está certo que puseram terra por cima, mais no fim da rua, no fim da rua Rangel Pestana, a Rua do Sapo, que tinha um buraco e eles jogavam, a carroça jogava lixo lá, depois jogavam terra por cima porque num

tinha como hoje já tem a prefeitura, já está cada vez mais providenciando né. Naquele tempo não tinha disso aí não. Era tudo, jogado lá e punham terra por cima, chegou um ponto que se ficou cheio. Hoje, quando eu passo aí lembro né, quando é aqui hoje eu passando em cima, estou passando em cima do lixo, entendeu?"

\section{ESGOTO}

Referindo-se ao esgoto, no primeiro local de moradia, predominou o uso de 'casinhas' (fossa) - 73,3\%, diminuindo, depois, para 23,3\%. Em contrapartida, o esgoto passou de $6,7 \%$ para $60 \%$. Um fato muito interessante, relatado por um ferroviário, foi o de que Botucatu, já na época da ferrovia, dispunha de um sistema de tratamento de esgoto: 
“...você vê que o pessoal antigamente tinha também inteligência, eram antigo, mais sabiam fazer as coisa. Esse tubo que trazia toda água da cidade do esgoto, ele caía aqui na rede pública, sabe aonde é a rede pública? Sei, sei, alí do lado do sindicato. Ali era a Caixa Sete, assim ali caiam as sete caixas, um, dois, três metro. Em cima dela tinha um cano dessa grossura (mímica). O resíduo ficava todo ali e água saía por aquele cano. Tinha 6 ou 7 caixas automáticas, que nem a caixa de descarga. A água enchia a caixa e ela descarregava, caía num piso, em baixo de pedra, todos com encanamento de 2 polegada, tudo mais ou menos assim (mímica). Era dia e noite aquilo... essa baixava, aquela levantava, era até bonito pra vê viu, ninguém punha a mão em nada. A água saía da cidade, e o resíduo a prefeitura tinha, naquela época, uma carrocinha de mão que pegava pra por no jardim. Só isso que fazia, o resto era tudo automático, fazia tudo sozinho, ninguém punha a mão em nada, hoje... Em vez de melhorar, piora." (4.4)

\section{ÁREA VERDE}

Questionou-se se, próximo à casa dos ferroviários, havia área verde. No primeiro local de moradia, 60,71\% relataram ter muita área verde e, já na segunda residência, este fato não ocorreu, mas infelizmente, praticamente a metade não respondeu essa questão. No entanto, poucos moravam em sítio ou áreas mais afastadas, onde pudesse ter mais arborização. Eles referiram que próximo a Botucatu era tudo pasto ou plantação de café.

"Aqui! Da linha, do começo da linha aqui até quase Rubião, era uma mata fechada! Que nós, época de jabuticaba, nós íamos buscar jabuticaba no meio do mato. Nós pegávamos o falecido pai, subia no pé, derrubava, nós catávamos. Agora você vê,

destruiram tudo, a linha passou quase no meio, por fim aí derrubaram tudo, derrubaram tudo. A linha passava dali pra lá um pouco né, fazia a volta, mas aí com o progresso pra fazer, pra encurtar as quilometragens, fizeram ela passar quase no meio da mata, mas acabaram com tudo. Até o lado da chácara nossa aí, pra nós ir até a linha, meu pai comprou uma quilha de terra de 3 metros. Acho que ele fez um caminho, porque nós passávamos por dentro da mata pra sair na linha, depois foram derrubando tudo" (5.3)

"O mato era um pouco mais denso... e a exploração assim da vegetação era mais café. Café em todo o canto. Tudo café, ali na chácara, logo depois dali da ferrovia né, era cafezal. Quer dizer, a fazenda chegava até quase que 300 mil pés de café" (24.6)

Tabela 34 - Classificação das áreas verdes do primeiro local onde os entrevistados moraram.

\begin{tabular}{llcc}
\hline \hline & & Freqüência & Percentual \\
\hline Válidos & Muita mata & 17 & 60,71 \\
& Pouca mata & 9 & 32,14 \\
& Nenhuma mata & 2 & 7,14 \\
& Total & 28 & 100,0 \\
Sem informação & & 2 &
\end{tabular}


Tabela 35 - Classificação das áreas verdes do segundo local onde os entrevistados moraram.

\begin{tabular}{llcc}
\hline \hline & & Freqüência & Percentual \\
\hline Válidos & Pouca mata & 13 & 81,25 \\
& Nenhuma mata & 3 & 18,75 \\
& Total & 16 & 100,0 \\
Sem informação & & 14 & \\
& & & \\
\hline \hline
\end{tabular}

POLUIÇÃO SONORA

Perguntou-se se, no local onde moravam, existia barulho que os incomodava. Em média, 70\% negaram barulho e apenas dois falaram ter muito barulho.

\section{POLUIÇÃO VISUAL}

Em relação à poluição visual, as referências atuais para este indicador são muito diferentes das remotas, como outdoors, pichações, cartazes, panfletos, etc. Optou-se por perguntar como achavam o local onde moravam, classificando em lindo, bonito, normal, feio ou horroroso. A maioria disse que o local era lindo (33,3\%) e bonito (40\%). Isto pode ter relação com a memória “idílica”, ou seja, o fato de sempre valorizarem o passado, dizer que antes tudo era bom e bonito e que, agora, tudo está pior (BONILLA 2003).

\section{UMIDADE E TEMPERATURA}

Solicitou-se para que eles classificassem o grau de umidade do local de moradia em cinco categorias. Classificaram como normal, ou seja, nem com muita chuva e nem seco $(57,69 \%)$. Outros disseram que era mais úmido $(38,46 \%)$ e apenas um disse ser mais seco. Já para a temperatura, vários referiram ser normal (43,3\%) e $36,6 \%$ frio ou muito frio. Nestas questões eles acabaram se referindo somente a Botucatu, comparando a umidade e a temperatura anterior com as atuais. Não se lembravam muito dessas características dos outros municípios ou locais que moraram.

Uma resposta unânime foi a não-existência de mudança brusca de temperatura. Todos disseram que isto não costumava acontecer antigamente, que as estações do ano eram mais bem definidas do que hoje. A mudança brusca de 
temperatura acaba interferindo na saúde das pessoas, principalmente crianças e idosos podem vir a adoecer (ABERCROMBIE 1953; RIBEIRO SOBRAL 1988; SALDIVA e col. 1995; SHWARTZ e MORRIS 1995; VERHOEFF e col. 1996; SANHUEZA e col. 1999; GOUVEI e FLETCHER 2000; SAHL e col. 2002).

Tabela 36 - Classificação do grau de umidade dos locais de moradia dos entrevistados.

\begin{tabular}{llcc}
\hline \hline & & Freqüência & Percentual \\
\hline Válidos & Seco & 1 & 3,85 \\
& Normal & 15 & 57,69 \\
& Úmido & 7 & 26,92 \\
& Muito úmido & 3 & 11,54 \\
& Total & 26 & 100,0 \\
& & 4 & \\
\hline \hline
\end{tabular}

"Eu acho que a natureza, como se diz - ela é variável, né, variável como se diz, uma ora é calor, outra ora frio, não tem aquela temperatura certa né" (10.7)

"Bom, como tinha bastante verde, eu acho que a natureza era bem melhor do que hoje né, pelo menos é a impressão que eu tenho. Às vezes, conversando com a minha esposa, que o tempo está mudando, é está mudando, por exemplo, a gente achava que as estações parece que vinham mais certas do que hoje né, mesmo o ciclo lunar parece que era mais certo né, isso é impressão que a gente tem né, num sei se é..." (25.8)

"A natureza era boa, chovia no tempo certo, ventava no tempo certo, num era muito variado, num tinha essa... Eu calculo que essas ventanias, essas coisas, esse, esse ressecamento da terra, eu calculo que essas grandes indústrias de coisa elétrica, calculo que seja isso, calculo comigo, num estudei essas coisas, num estudei nada, nada, falo mais ou menos o que, o que está acontecendo..." (27.8)

Tabela 37 - Classificação da temperatura dos locais de moradia dos entrevistados.

\begin{tabular}{llcc}
\hline \hline & & Freqüência & Percentual \\
\hline Válidos & Quente & 1 & 4,0 \\
& Normal & 13 & 52,0 \\
& Frio & 10 & 40,0 \\
& Muito frio & 1 & 4,0 \\
& Total & 25 & 100,0 \\
Sem informação & & 5 &
\end{tabular}




\section{DESASTRES E CONTAMINAÇÕES AMBIENTAIS}

Ao se questionar se já tinham passado por alguma situação de desastre ou contaminação ambiental ou de solo, a totalidade negou ter tido alguma experiência deste tipo. Já haviam passado por situação de descarrilhamento de trens, no qual vagões tombaram, mas estavam transportando bens alimentícios, animais de criação, madeira ou lenha. Somente um ferroviário relatou ter ouvido falar de um derramamento de algum produto químico, mas que não havia sido nesta região.

\section{GRAU DE SATISFAÇÃO COM O MEIO AMBIENTE}

Foi solicitado aos ferroviários entrevistados que classificassem o grau de satisfação que tinham com a situação do meio ambiente atual, de forma geral. 64\% responderam estar satisfeitos e apenas $28 \%$ insatisfeitos, reclamando de poluições sonoras, das águas e do ar.

Tabela 38 - Grau de satisfação dos entrevistados em relação ao meio ambiente atual.

\begin{tabular}{llcc}
\hline \hline & & Freqüência & Percentual \\
\hline Válidos & Muito satisfeito & 1 & 4,00 \\
& Satisfeito & 15 & 60,0 \\
& Insatisfeito & 7 & 28,0 \\
& Não sabe & 2 & 8,0 \\
& Total & 25 & 100,0 \\
& & 5 & \\
& & & \\
\hline \hline \multirow{3}{*}{ Sem informação } & & & \\
& &
\end{tabular}




\section{RESUMO GERAL SOBRE QUEM SÃO E COMO VIVEM OS FERROVIÁRIOS LONGEVOS}

Resumindo todas as características aqui apresentadas por essa amostra de longevos ferroviários, podemos retratá-la como apresentando idade média de 82,87 anos. A maioria casada, 73,3\%, em média com 51,5 anos de casamento e 88,4\% com bom relacionamento marital. A quase totalidade teve filhos (96,7\%) e netos (93,3\%) e com bom relacionamento familiar (96,7\%), convivendo quase que diariamente com filhos (85,2\%). O tempo médio de escolaridade foi de 4,07 anos, iniciando o trabalho com 14,33 anos, sendo o mais novo com 7 anos e o mais velho com 33. A idade média para iniciar o trabalho na ferrovia foi de 19,33 anos. A longevidade familiar apareceu em 83,3\% dos entrevistados, associada mais à figura feminina (mãe, avó, tia, irmã). Apresentavam estabilidade residencial, sendo o tempo médio, na última cidade, de 66,6 anos. O grau de satisfação com o trabalho desempenhado na ferrovia foi considerado ótimo em 100\%. Quase a metade (53,3\%) fazem atividade física atualmente. A situação financeira pregressa foi considerada boa em 63,3\% e atual como boa (20\%), média (56,7\%) e ruim (23,4\%), sendo os motivos atuais de insatisfação ligados à perda salarial com a aposentadoria, sem aumento há 8 anos e defasagem do salário. Referem ter atualmente assistência à saúde (93,3\%) e 76,7\% possuía algum convênio de saúde. A nota que atribuíram à assistência à saúde atual foi de 7,96 e 60\% disseram não ter queixas. A alimentação foi considerada como boa ao longo da vida em 56,7\% e a quantidade de alimento ingerido, comparada com a de outros colegas durante toda a vida, foi considerada igual (46,7\%) e menor em $40 \%$ dos casos. A maioria, 80\%, referiu possuir alguma patologia, embora 56\% referiram ter saúde melhor que outras pessoas da mesma idade hoje, e somente 3,4\% disseram estar pior. Em relação aos vícios, 53,3\% já haviam fumado e 13,3\% ainda eram fumantes. Disseram ser pessoas bem ativas sempre (53,3\%) e com muitas amizades (70\%). Em relação ao lazer, fazem poucas atividades atualmente, em média 1,5 atividades, e 4 disseram não fazer nenhuma atividade. Referem ser felizes atualmente (86,7\%), satisfeitos com a vida que construíram (93,4\%), sem problemas atuais muito relevantes $(53,3 \%)$ e fazendo planos para o futuro (63,3\%), como andar de avião, continuar tendo saúde e sendo feliz. 


\section{2 - As características da mortalidade dos ferroviários}

Em relação à mortalidade investigada, no período de 1999 a 2003, para a população ferroviária e idosa masculina do Município de Botucatu, pode-se observar que a idade média de óbito dos ferroviários ao longo dos cinco anos sempre foi um pouco maior que a da população comparativa, como mostra a tabela 38, alcançando significância estatística em 2001 e 2002. O que vem ressaltar a idéia de que os ferroviários provavelmente vivem mais do que a população em geral do município. No entanto, pode existir viés, pois não se sabe realmente se foi possível descobrir todos os ferroviários que foram a óbito nesse período, como foi relatada, na parte da metodologia deste trabalho, a dificuldade em se obter esta referência: quais seriam os nomes dos ferroviários que realmente faleceram? Por isto é que buscou-se três fontes de dados: Associação, Sindicato e Atestado de óbito.

Tabela 39 - Idade média e desvio padrão referentes aos ferroviários e idosos em geral segundo ano, 1999 a 2003.

\begin{tabular}{lccc}
\hline Ano & Ferroviários & Idosos em geral & Valor $p$ \\
\hline 1999 & $75,7 \pm 7,8$ & $75,1 \pm 8,7$ & 0,63 \\
2000 & $76,7 \pm 7,7$ & $74,4 \pm 9,1$ & 0,15 \\
2001 & $79,3 \pm 7,2$ & $75,5 \pm 9,5$ & 0,04 \\
2002 & $78,7 \pm 7,9$ & $76,0 \pm 8,7$ & 0,05 \\
2003 & $77,2 \pm 6,8$ & $74,7 \pm 8,9$ & 0,14 \\
\hline
\end{tabular}

Fonte: Atestados de óbitos e SIM, 1999 a 2003, Botucatu. Calculados e analisados com a ajuda da Profa Dra. Lídia Raquel de Carvalho, do Depto de Estatística do IB da UNESP/Botucatu.

Vale ressaltar que podemos considerar esta população de ferroviários em 'extinção', uma vez que resta um pequeno grupo de representantes desta categoria e que não está mais sendo reposta. Partindo do número de ferroviários cadastrados no município de Botucatu, por meio desta atual pesquisa, teríamos 848 indivíduos vivos em 2003 e se o ritmo de falecimento permanecer semelhante ao ocorrido nos anos entre 1999 a 2003, teríamos uma média de 43,6 mortes/ano, independente da idade. Este cálculo simplificado permite dizer que só teremos por volta de mais 19 anos esta população viva, sem considerar que a maioria (63,2\%) possui mais que 70 anos, aumentando sua probabilidade de óbito em mais curto prazo. Desta forma, este grupo de ferroviários, detentores de um conhecimento e experiências particulares, esta 
ameaçado realmente de 'extinção' e com ele parte deste grande e rico conhecimento. $^{15}$

Tendo disponível o nome dos ferroviários e descobrindo-se o ano de óbito, pôde-se comparar as causas básicas de óbitos dos idosos do município de Botucatu com as dos ferroviários (tabela 39).

Assim sendo, a principal causa de óbito dos ferroviários foram as doenças contidas no Capítulo IX da CID 10, “Doenças do aparelho circulatório”, representando 41,45\%. Da mesma maneira, esta causa de óbito também destacou-se em primeiro lugar para a população idosa do sexo masculino de Botucatu (42,11\%). A segunda causa de óbito esteve relacionada às patologias do capítulo II, “Neoplasias (tumores)”. Para os ferroviários, ela foi responsável por 26,42\% dos casos e para os idosos masculinos de Botucatu 22,96\%, apresentando uma diferença um pouco maior. Em terceiro lugar, apareceram as doenças contidas no capítulo X, "Doenças do aparelho respiratório”, que foram responsáveis por 8,81\% das causas de óbito dos ferroviários, também sendo maior nos botucatuenses, (12,15\%). A partir da quarta causa mais frequente de óbito algumas diferenças chamam a atenção. Para o grupo de ferroviários a quarta causa foi a relacionada com o capítulo IV "Doenças endócrinas nutricionais e metabólicas” com 6,74\%, enquanto para o município ela foi de apenas $1,15 \%$, valendo a pena novos estudos para averiguar melhor esta diferença. Outra que chama a atenção são as causas de “Algumas doenças infecciosas e parasitárias”, que na população geral foi de 2,57\% e nos ferroviários apenas um caso ocorreu no período estudado.

Desta forma, pode-se concluir que a distribuição das causas de óbito dos ferroviários segue o padrão de distribuição do município de Botucatu, que por sua vez não difere do que se tem no Estado de São Paulo e mesmo no Brasil (DATASUS 2004). Maiores análises ficam comprometidas pelos números pequenos da amostra e pelas dificuldades metodológicas na coleta das informações.

\footnotetext{
${ }^{15}$ Em 1999, resolvi resgatar, com a ajuda de alguns ferroviários, documentos da EF Sorocabana que acabara de ser privatizada, pois já se iniciava um rápido processo de depredação. Para nossa surpresa, o responsável pelo prédio, uma vez que só a linha férrea foi privatizada, referiu que os documentos foram levados para Sorocaba e como ‘não havia local para armazenamento adequado', foram ‘jogados’ e depois ‘queimados’. Como estes documentos não foram resgatados até hoje, esta informação pode ser pertinente. Além disto, em visita recente ao Museu Histórico Sorocabano, em Sorocaba, a atual responsável pelo museu disse não descartar esta possibilidade, uma vez que para montar parte do acervo deste museu foram buscar em lixões e dentro de vagões documentos e peças abandonadas.
} 
Tabela 39 - Distribuição dos óbitos da população masculina com 60 anos e mais de Botucatu e de ferroviários 1999 a 2003

\begin{tabular}{|c|c|c|c|c|c|c|c|c|c|c|c|c|c|c|}
\hline & \multicolumn{2}{|c|}{1999} & \multicolumn{2}{|c|}{2000} & \multicolumn{2}{|c|}{2001} & \multicolumn{2}{|c|}{2002} & \multicolumn{2}{|c|}{2003} & \multicolumn{2}{|c|}{ TOTAL } & \multicolumn{2}{|c|}{ \% Total } \\
\hline & Btu* & $\mathbf{F r} * *$ & Btu & Fr & Btu & Fr & Btu & Fr & Btu & Fr & Btu & Fr & Btu & Fr \\
\hline I. Algumas doenças infecciosas e parasitárias & 4 & $\mathbf{0}$ & 7 & 1 & 9 & $\mathbf{0}$ & 4 & $\mathbf{0}$ & 5 & $\mathbf{0}$ & 29 & 1 & 2,57 & 0,52 \\
\hline II. Neoplasias (tumores) & 47 & 14 & 50 & 13 & 58 & 7 & 54 & 10 & 50 & 7 & 259 & 51 & 22,96 & 26,42 \\
\hline $\begin{array}{l}\text { III. Doenças do sangue e de órgãos } \\
\text { hematopoéticos e alguns transtornos imunitários }\end{array}$ & 0 & 0 & 1 & 0 & 1 & 0 & 2 & 0 & 0 & 0 & 4 & 0 & 0,35 & 0 \\
\hline $\begin{array}{l}\text { IV. Doenças endócrinas nutricionais e } \\
\text { metabólicas }\end{array}$ & 9 & 4 & 12 & $\mathbf{0}$ & 8 & 3 & 7 & 3 & 8 & 3 & 44 & 13 & 1,15 & 6,74 \\
\hline V. Transtornos mentais e comportamentais & 0 & 1 & 4 & $\mathbf{0}$ & 2 & $\mathbf{0}$ & 4 & $\mathbf{0}$ & 2 & $\mathbf{0}$ & 12 & 1 & 1,06 & 0,52 \\
\hline VI. Doenças do sistema nervoso & 5 & 3 & 3 & 2 & 4 & $\mathbf{0}$ & 7 & $\mathbf{0}$ & 8 & 1 & 27 & 6 & 2,39 & 3,11 \\
\hline VII. Doenças do olho e anexos & 0 & $\mathbf{0}$ & 0 & $\mathbf{0}$ & 0 & $\mathbf{0}$ & 0 & $\mathbf{0}$ & 0 & $\mathbf{0}$ & 0 & $\mathbf{0}$ & 0 & $\mathbf{0}$ \\
\hline VIII. Doenças do ouvido e da apófise mastóide & 0 & $\mathbf{0}$ & 0 & $\mathbf{0}$ & 0 & $\mathbf{0}$ & 0 & $\mathbf{0}$ & 0 & $\mathbf{0}$ & 0 & $\mathbf{0}$ & 0 & $\mathbf{0}$ \\
\hline IX. Doenças do aparelho circulatório & 99 & 22 & 85 & 20 & 89 & 12 & 87 & 16 & 115 & 10 & 475 & 80 & 42,11 & 41,45 \\
\hline X. Doenças do aparelho respiratório & 31 & 7 & 29 & $\mathbf{0}$ & 21 & 4 & 27 & 2 & 29 & 4 & 137 & 17 & 12,15 & $\mathbf{8 , 8 1}$ \\
\hline XI. Doenças do aparelho digestivo & 6 & 2 & 17 & $\mathbf{0}$ & 17 & 2 & 8 & 4 & 17 & $\mathbf{0}$ & 65 & 8 & 5,76 & 4,14 \\
\hline XII. Doenças da pele e do tecido subcutâneo & 0 & $\mathbf{0}$ & 0 & $\mathbf{0}$ & 0 & $\mathbf{0}$ & 0 & $\mathbf{0}$ & 1 & $\mathbf{0}$ & 1 & $\mathbf{0}$ & 0,09 & $\mathbf{0}$ \\
\hline $\begin{array}{l}\text { XIII. Doenças sistema osteomuscular e do tecido } \\
\text { conjuntivo }\end{array}$ & 0 & $\mathbf{0}$ & 0 & $\mathbf{0}$ & 1 & $\mathbf{0}$ & 1 & $\mathbf{0}$ & 1 & 1 & 3 & 1 & 0,27 & 0,52 \\
\hline XIV. Doenças do aparelho geniturinário & 6 & $\mathbf{0}$ & 1 & $\mathbf{0}$ & 4 & 1 & 6 & 2 & 2 & $\mathbf{0}$ & 19 & 3 & 1,68 & 1,55 \\
\hline $\begin{array}{l}\text { XVII. Malformações Congênitas, deformidades e } \\
\text { anomalias cromossômicas }\end{array}$ & 1 & $\mathbf{0}$ & 0 & $\mathbf{0}$ & 0 & $\mathbf{0}$ & 0 & $\mathbf{0}$ & 0 & $\mathbf{0}$ & 1 & $\mathbf{0}$ & 0,09 & $\mathbf{0}$ \\
\hline $\begin{array}{l}\text { XVIII. Sintomas, sinais e achados anormais de } \\
\text { Exames clínicos e laboratoriais, não classificados } \\
\text { em outra parte }\end{array}$ & 4 & 1 & 3 & 1 & 0 & $\mathbf{0}$ & 7 & 2 & 2 & 1 & 16 & 5 & 1,42 & 2,60 \\
\hline XX. Causas externas de morbidade e mortalidade & 6 & 1 & 12 & $\mathbf{0}$ & 4 & $\mathbf{0}$ & 8 & 5 & 6 & 1 & 36 & 7 & 3,19 & 3,63 \\
\hline TOTAL & 218 & 55 & 224 & 37 & 218 & 29 & 222 & 44 & 246 & 28 & 1128 & 193 & 100,00 & 100,00 \\
\hline
\end{tabular}

Fonte: SIM

$*$ Btu $=$ Botucatu

** $\mathrm{Fr}=$ Ferroviários 


\section{CAPÍTULO 5 - O RETRATO DOS CONHECIMENTOS E DA HISTÓRIA DOS FERROVIÁRIOS ENTREVISTADOS: CONTRIBUIÇÕES DO MEIO AMBIENTE PARA A LONGEVIDADE}

\section{1 - Os fenômenos identificados}

A análise dos dados adotando Grounded Theory possibilitou compreender a interação entre meio ambiente, saúde e longevidade sob a visão e experiência dos ferroviários longevos entrevistados. Essa experiência mostra que esses longevos percebem o aniquilamento atual do meio ambiente, da ferrovia e até da própria vida, desencadeado pela falta de controle social e do Estado, aliada à falta de consciência coletiva, ambas decorrentes do movimento da ideologia capitalista do lucro a qualquer custo.

Os fenômenos serão apresentados em forma de diagramas e quadros, descrevendo os conceitos que emergiram da vivência dos ex-ferroviários longevos, segundo os componentes que formam o processo: temas, categorias, subcategorias e elementos, permitindo, assim, chegar, ao final, na categoria central que liga todas estas peças e dá movimento a esta rica história. Em cada categoria e subcategoria são apresentados recortes das próprias falas dos longevos, sendo que as partes coloridas de azul são falas de suas esposas e em negrito da entrevistadora. As falas desses ferroviários longevos encontram-se codificados nos quadros em anexo, para que o leitor possa acompanhar e compreender todos os passos que foram sendo realizados.

Seguindo os passos do referencial metodológico, foi possível identificar três fenômenos: - ANIQUILANDO A VIDA (fenômeno 1), - GERANDO VIDA (fenômeno 2), - FALTANDO CONTROLE SOCIAL E DO ESTADO (fenômeno 3). 


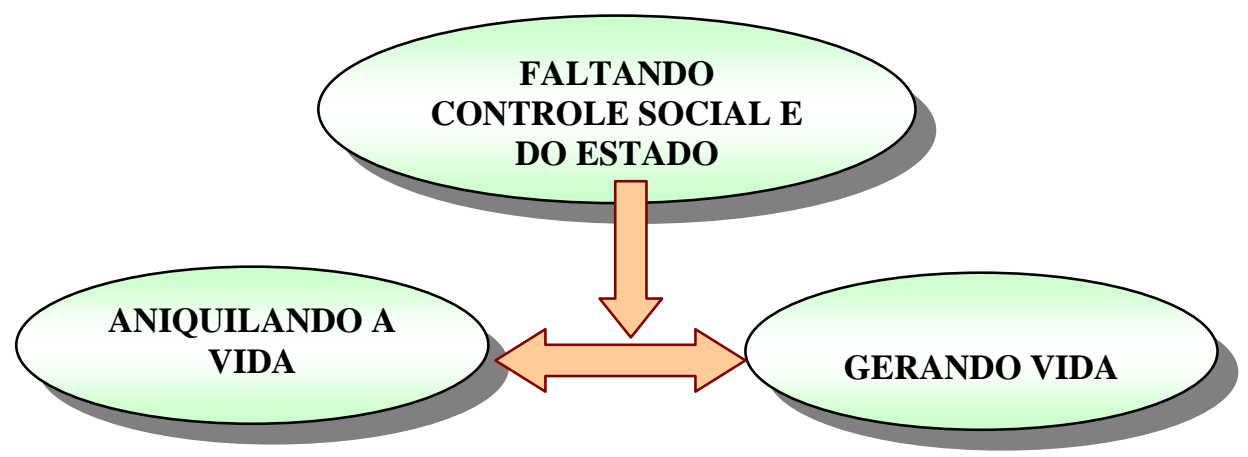

Diagrama 1. Fenômenos identificados: - Aniquilando a vida, - Gerando vida, - Faltando controle social e do Estado.

\subsection{1 - Fenômeno 1: ANIQUILANDO A VIDA}

O primeiro fenômeno a ser apresentado é: ANIQUILANDO A VIDA (fenômeno 1).

Este fenômeno reúne as percepções dos ferroviários a respeito da degradação do meio ambiente (incluindo a própria vida) e da ferrovia. Eles denunciam a degradação dos recursos hídricos, a destruição da fauna e da flora, o aumento da poluição ambiental, gerando descontrole ambiental e modificando as propriedades dos alimentos. Tudo isto faz com que essas pessoas sintam desprazer em relação ao meio ambiente atual, valorizando e hipervalorizando o passado, quando não existia essa destruição. Além disto percebem a degradação das relações humanas, com aumento da violência, da perda de respeito entre as pessoas e da liberdade. Notam que a ferrovia também foi aniquilada na atualidade e os ferroviários ficam desolados com toda esta situação atual, tentando entender os fatores que levaram a todo este mórbido cenário (diagrama 2).

Temos dois temas associados a este fenômeno: - DEGRADANDO O MEIO AMBIENTE (Tema A), - ANIQUILANDO A FERROVIA E DESOLANDO OS FERROVIÁRIOS (Tema B).

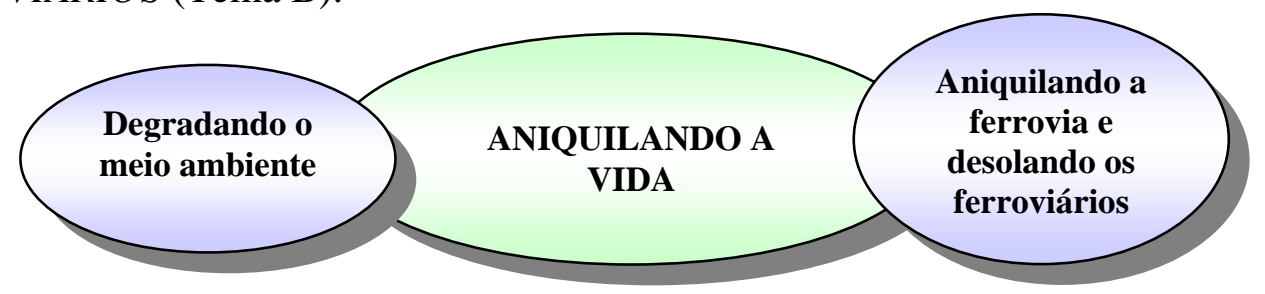

Diagrama 2. Fenômeno 1 - Aniquilando a vida: temas. 


\section{TEMA A - DEGRADANDO O MEIO AMBIENTE}

Comparam o meio ambiente atual e o do passado, observando a sua degradação. Criticam a degradação dos recursos hídricos, a destruição da fauna e da flora, o aumento intenso da poluição nos dias atuais. Todos estes fatores contribuem para um descontrole ambiental, inclusive, a modificação das propriedades dos alimentos, que perdem seu sabor e qualidades. Estas degradações ambientais acabam gerando um desprazer nos ferroviários longevos em relação ao meio ambiente atual, os quais desaprovam a violência e falta de respeito atuais, ficando tristes e sentindo saudade das boas sensações despertadas pela natureza antigamente. Desta forma, hipervalorizam o passado, que representava a época em que podiam desfrutar dessa natureza mais viva e equilibrada.

Este primeiro tema agrega as seguintes categorias: - Degradando os recursos hídricos, - Destruindo a fauna e a flora, - Aumentando a poluição com o tempo, Ocorrendo descontrole ambiental, - Modificando as propriedades dos alimentos, Sentindo desprazer em relação ao meio ambiente atual (diagrama 3).

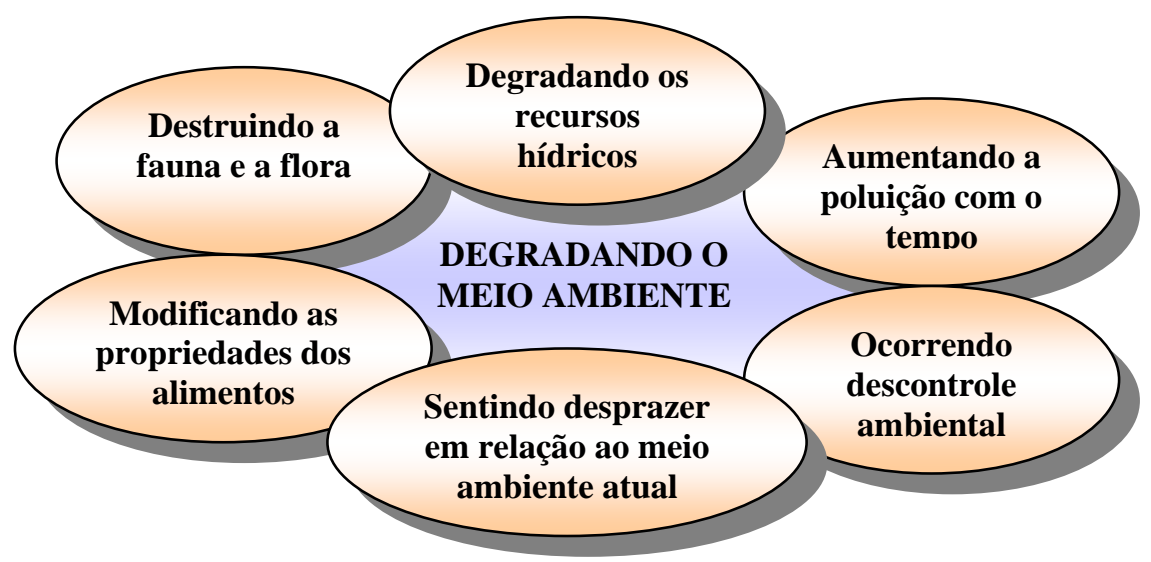

Diagrama 3 - Tema A - Degradando o meio ambiente: categorias

\section{Categoria A1 - Degradando os recursos hídricos}

Significa que as ações humanas predatórias (como o desmatamento em torno das nascentes e da mata ciliar, o desperdício de água, bem como a poluição dos rios com produtos químicos, o lixo e o esgoto, o qual é desprovido de tratamento) vêm piorando a qualidade da água dos rios que abastecem as cidades, impedindo que o próprio ser humano continue a desfrutar dos seus benefícios. 
Congrega as seguintes subcategorias: - Desmatando a mata ciliar e provocando riscos à população e às nascentes, - Desperdiçando água, - Poluindo rios, - Piorando a qualidade da água, - Não podendo desfrutar dos benefícios hídricos (diagrama 4).

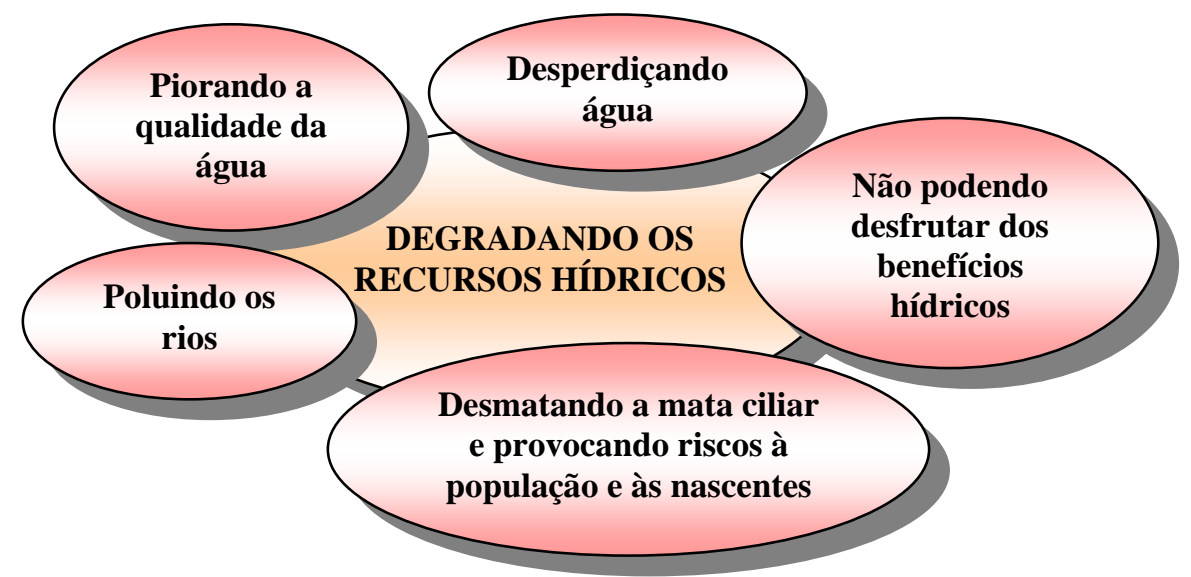

Diagrama 4 - Categoria A1 - Degradando os recursos hídricos: subcategorias

\section{$\underline{\text { Desmatando a mata ciliar e provocando riscos à população e às nascentes }}$}

Os entrevistados associam que o desmatamento em torno das nascentes, principalmente acabando com a mata ciliar, leva as nascentes a irem secando. Criticam também a ocupação das encostas e beiras de rios, que, aliada ao processo de desmatamento da mata ciliar, coloca em risco a vida dos próprios moradores (quadro 1).

“...que estão destruindo, estão destruindo totalmente a natureza. É, tem uma grota de mata ali, se tem uma nascente de água ali, o nego derruba aquilo ali, aquilo vai secar, vai secar, isso não é uma judiação que estão fazendo com a natureza? "

“...vão desmatando as mata, as nascente vão secando e vai diminuindo...” (7.4)

"Eu, eu entendo que esse tempo está mudando por causa do homem estar destruindo a natureza viu, principalmente lá (nt), a mata ciliar (nt), tudo né, vão destruindo tudo né. ... que lixo essas coisas..." (18.4)

"Que nem aquele de São Paulo, a margem do rio é 30 metros de cada lado, respeitado, mas nego vai fazer casa lá, depois morre afogado, diz que é... começa reclamar. Eu, eu principalmente, nunca morei em lugar baixo (...) Porque eu tinha medo da água. Óia, nego, 30 metros de cada lado, o nego vai fazer na margem do rio, quando vem enchente o rio, entendeu? Num sei que cidade aí que o rio lá subiu 100 metros, 100 metros subiu o rio, 100 metros, o rio tomou conta da casa, invadiu

casa, invadiu tudo. 100 metros. Agora... morreu o que? Morreu uns 30. Nego vai fazer casa no rio.... outro vê barranco lá, vai fazer casa debaixo do barranco lá. Nós que prejudicamos a natureza." (1.3) 


\section{Desperdiçando água}

Criticam o desperdício e uso inadequado de água tratada, que é utilizada, por exemplo, para lavar calçadas (quadro 1).

"O pessoal faz uso muito inadequado da água, um trabalhão pra você fazer tratamento de d' água né, o pessoal fica lavando, lavando calçada aí é..." (24.8)

Poluindo rios

Os ferroviários longevos lembram que, antes, os rios eram mais limpos e, hoje, estão muito poluídos por receber esgoto, produtos químicos e lixo. Criticam o despejo nos rios de grande quantidade de esgoto gerado pelas cidades, que os desprezam sem nenhum tratamento, comparando que, no município de Botucatu, antigamente, havia um processo eficaz de tratamento de esgoto. Observam que os rios acabam recebendo também produtos químicos de forma acidental ou por meio dos agrotóxicos utilizados na lavoura, chegando até os rios. Outro poluidor é o lixo que as pessoas jogam nos rios, sendo o plástico importante componente associado a enchentes (quadro 1).

Os elementos que compõem a subcategoria são: - Desprezando esgoto sem tratamento, - Contaminando os rios com produtos químicos, - Jogando lixo nos rios.

"As águas nossas aqui, antigamente o rio era bem melhor do que hoje, ...... poluição desse rio aí, ninguém resolve nada".

"Tudo, tudo, tudo, é uma sujeira inteira, o rio todo, nossa! Ninguém vive. Agora, éh! naquele tempo sim! É outra coisa, Karina, você vê que o pessoal antigamente tinha também inteligência, eram antigo, mais sabiam fazer as coisas. Esse tubo que trazia toda água da cidade do esgoto, ele caía aqui na rede pública, sabe aonde é a rede pública? Sei, sei, ali do lado do sindicato. Ali era a Caixa Sete, assim, ali caiam as sete caixas, um, dois, três metros em cima dela tinha um cano dessa grossura (mímica), o resíduo ficava todo ali e água saía por aquele cano, tinha 6 ou 7 caixas automáticas, que nem a caixa de descarga. A água enchia a caixa e ela descarregava, caía num piso embaixo de pedra, todos com encanamento de 2 polegadas, tudo mais ou menos assim (mímica). Era dia e noite aquilo. Essa baixava, aquela levantava, era até bonito pra ver viu, ninguém punha a mão em nada. A água saía da cidade e o resíduo a prefeitura tinha, naquela época, uma carrocinha de mão que pegava para por no jardim. Só isso que fazia, o resto era tudo automático, fazia tudo sozinho, ninguém punha a mão em nada, hoje... Em vez de melhorar, piora " (4.4)

"Ah! Era boa, é que eu estou falando, nós íamos pra nadar no Rio Lavapés, aquele tempo tinha peixe no rio né, aqueles cascudos, quantas vezes nós iamos lá brincar pra pegar cascudo, hoje acabou tudo né, tudo, judiação" (15.5) 
“... a natureza, o rio, tinha árvore por ali, a água era cristalina, a gente bebia água do rio. Não tinha esgoto, nada disso. Depois o bairro passou a ter casa por lá e despejava esgoto no rio. Então aquilo foi estragando tudo..." (29.2)

“...chegou acontecer tombamento de tanques com produtos e derramar no rio, chegou numa escala, por que depois com o tempo, todo e qualquer transporte desse tipo ele era circundado de providencias especiais né, então tinha toda segurança. Não era um, era um, tinha uma turma especial pra isso vinha acompanhando o trem, vinha em horário especial, trem especial." (24.14)

“... agora hoje está muito ruim de pescaria assim, no rio esse negócio, aquele tempo, tempos atrás, a gente saía pescar por esses riozinhos aí pegava, hoje num tem mais nada, esse negócio de adubo que eles põem nas plantas também, vai acabando né..." (23.7)

“É... agora tem um pouco também de nós, que também não sabemos conservar também muita coisa, que nós não sabemos conservar né, negócio de lixo essas coisa, que jogam nos rios..." (5.4)

“...né, naquele tempo não tinha isso, está tudo, está poluído, poluição está muito grande, está muito grande, acabaram com as ferrovias, você vê o Rio Tietê (NT), pegava dourado, pintado, acabou tudo, está podre o rio, você nem vê mais peixe, né Cida. Tudo sujo as beiradas tudo. Mais o que eu mais fico, mais fico nervosa é por causa dos plásticos viu, que nem São Paulo fala que tem inundação, se já pensou em São Paulo, o que tem lá de coisa..." (9.4)

$\underline{\text { Piorando a qualidade da água }}$

Avaliando que antigamente as águas dos rios eram limpas e cristalinas, e as pessoas podiam beber água direto dos rios, assim como de poços e minas. Atualmente, observam a degradação da qualidade da água dos rios, sendo impraticável utilizá-la para consumo humano direto (quadro 1).

"As águas nossas aqui, antigamente, o rio era bem melhor do que hoje ..." (4.3)

"Então todo mundo ia pegar água lá. Da mina, e todo mundo pegava aquela água lá pra beber, pra cozinhar. E era limpinha? Limpinha...uuuuuuu...um cristal viu." (10.5)

“... quando eu estava com sede tomava do rio mesmo, mesmo do Titê na década de 50, que a gente ia pescar lá. Naquele tempo a gente bebia água do rio, a água era limpa, tomava do rio. Agora, depois aí, então a gente já levava água porque a água já não era mais boa pra toma (nt)... mais naquela época na década de 50, nossa, tomava a água do rio..." (30.12).

"a gente ia pescar aqui e ali, era limpo, né! E tinha, podia pescar onde quisesse que era peixe. O rio era o Tietê. Então, meu avô Bateri estava com sede, bebia água do rio. Veja que, que...que é água hoje: se bebe, morre, né." (2.5) 


\section{Não podendo desfrutar dos benefícios hídricos}

Relembram que antigamente os rios eram fontes de lazer, onde as crianças se divertiam, fonte de alimentação, sendo muito piscosos e com água de boa qualidade para o consumo. Além disso, eram úteis às mulheres que os utilizavam para lavar as roupas. Lamentam que hoje não se pode desfrutar mais desses benefícios, tendo inclusive que comprar água mineral para beber (quadro 1).

"No meu tempo de criança tinha o riozinho ali, um corregozinho ali, a gente ia nadar ali. Era a diversão da molecada." (29.1)

"Quando nós viemos morar aí embaixo, o rio que passava no fundo do nosso quintal, você podia pegar um copo d'água e beber aquela água de limpa que era. Você enxergava o fundo do rio, pescava tudo, agora vê se pega um peixe pra lá, não tem mais nada, acabou tudo em nada." (5.4).

"Ah tinha, aquele tempo num tinha represa, aquele tempo tinha o rio Tietê, que a gente ia pescar né, dava peixe que nossa senhora, nós tínhamos o rancho da amizade, eram 6 sócios, e...(nt), pegava de saco... hoje num tem nada, num tem mais nada... quanto Corimbatá, trazia ensacado, dava pra todo mundo, todo mundo comia peixe..." (28.4).

“... eu compro água, água mineral porque, porque essa outra água que vem, vem lá do rio, podre... num é?" (26.7).

\section{Categoria A2 - Destruindo a fauna e a flora}

Esses ferroviários julgam que os avanços tecnológicos, aliados ao progresso, têm contribuído para a destruição da fauna e da flora, piorando a qualidade do meio ambiente atual e dificultando o acesso das pessoas aos alimentos; tornou-se necessária a construção de parques artificiais e hortos, pois no passado existia maior área verde para o ser humano desfrutar. Observam que o desenvolvimento da ferrovia também contribuiu para a destruição, devido ao intenso e enorme consumo de madeira, carvão e areia.

Esta categoria congrega as seguintes subcategorias: - Avanço intenso da tecnologia e do progresso, - Tendo menos área verde atualmente, - Piorando o meio ambiente atual, - Não vendo diferença no meio ambiente atual, - Sendo o acesso mais difícil aos alimentos atualmente, - Tendo de construir parques artificiais e hortos, Desenvolvimento intenso da ferrovia (diagrama 5). 


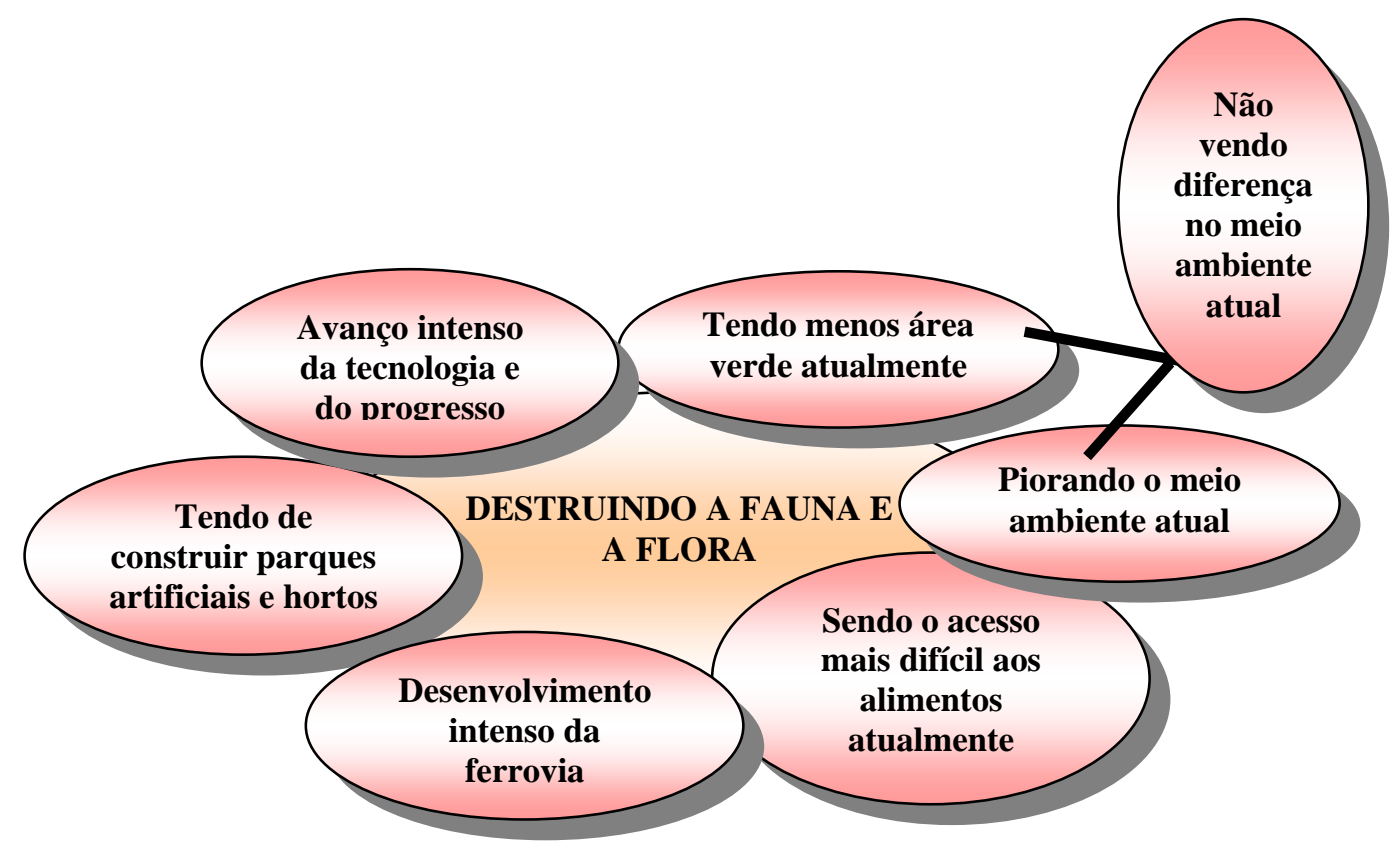

Diagrama 5 - Categoria A2 - Destruindo a fauna e a flora: Subcategorias.

\section{$\underline{\text { Avanço intenso da tecnologia e do progresso }}$}

Acreditam que o desmatamento é o preço do progresso, que pode gerar benefícios, mas, ao mesmo tempo, trazer a destruição. Relatam que, em poucos minutos, derruba-se uma árvore que demorou centenas de anos para se formar (quadro 2).

“...pode ser progresso né... mas pode ser destruição, quem que pode saber? Isso infelizmente é nosso..." (26.4)

"Acho que eles vinham, alguém cortava, ou eles compravam num sei também né, mas vinha aqueles trens de lenha, lá passava aqueles trens de lenha que... aí... por isso que desmataram tudo, aí veio desmatando tudo e agora tão desmatando por outras coisas também. Antes era pra carregar progresso, porque levava tudo por transporte, agora não..." (11.3)

"Eu acho que, já acho que o governo devia tomar uma providência mais séria, porque eu vejo aquelas motoserras derrubando aqueles monstros daquelas árvores, me dá um aperto no coração, eu fico com dó, fico com dó mesmo, de ver o que eles fazem. Uma árvore daquela que levou uns 300, 200 anos pra formar, 5 minutos está no chão, eu acho que o governo tem que tomar uma providência séria, por que isso aí é o que nós estamos vendo, e o que estão tirando que ninguém vê, isso é, é coisa, é coisa de louco viu!" (5.3) 
Tendo menos área verde atualmente

Os ferroviários longevos lembravam que antes existia mais área verde, com matas em torno das cidades e, inclusive, lindas matas 'virgens', e que tudo foi sendo derrubado para dar lugar, inicialmente, ao café. Observam que esta diminuição de área verde atinge desde o Brasil como um todo até as residências, nas quais as pessoas passaram a cimentar os seus próprios quintais e jardins (quadro 2).

"... porque mato num existe mais, num é verdade? Brasil inteiro tem bem pouco mato, o mais é eucalipto né, mais é eucalipial, o eucalipto não tem o aroma que tem o mato legítimo..." (28.7)

“Eu, quando estava trabalhando, ia trabalhar lá em... no Paraná ficava no (nt) de Cornélio Procópio, então depois passou tempo parou de mandar o pessoal trabalhar lá. Aí precisou mandarem eu e me escalaram pra ir lá, e eu estava só pensando que pra lá de Maringá tem um rio, Rio da Cinza e a margem do rio era, uma margem, uma coisa mais linda que tinha viu, mas aquela mata que sumia de vista, era só mata, e eu louco de vontade pra ver aquela mata, só pensando naquela mata, aquela mata verde, mais aí quando eu ia passando lá, eu vi: não tinha mais, tinham cortado tudo pra plantar café, é tava tudo cheio de café, aí eu falei: - puxa vida eu pensando, não via a hora de passar lá pra ver aquela mata, a mata estava tudo... não existia mais... mas era coisa linda viu, imagina aquele riozão, aquela mata, ah coisa mais linda viu!" (12.17)

"Não existia uma casa que não tivesse horta ou jardim, por ai você já começa a ver a diferença, né. Eu tinha um jardim enorme, horta, mas de repente eu pensei, ai meu Deus, eu planto um canteiro inteiro de alface, pego um pé e o resto eu dou, melhor comprar. E assim nós fomos cimentando, que é o que todo mundo fez."

$\underline{\text { Piorando o meio ambiente atual }}$

Classificam o meio ambiente do passado como sendo melhor que o atual e associam que onde tem mais mata é mais benéfico, ao viver melhor. Como exemplo, julgam que a vida no sítio é melhor que a da cidade (quadro 2).

"Bom isso aí, é... infelizmente está acabando tudo, foi muito bom..." (9.3)

"Eu acho que não está muito bom que nem era antigamente, né. Hoje está mais duro, tá." (3.4)

“... por exemplo, se você tivesse a oportunidade por exemplo de ir num sítio, num lugar, numa água cristalina que a água, água corrente, acho que tem possibilidade de você viver mais, acho que tem sim, acho que deve ter... porque ali (nt) tem mais possibilidade, tem mais possibilidade..." (27.13) 
$\underline{\text { Não vendo diferença no meio ambiente atual }}$

Aparecem falas que consideram que já não existia tanta área verde antigamente, que já existiam muitas plantações de café por todos os lados e que a natureza era semelhante à atual (quadro 2).

“... é...natureza é quase... quase que a mesma de, de hoje, viu” (2.5)

"O mato era um pouco mais denso (nt) e a exploração assim de... vegetal era mais café... Café em todo o canto." (24.6)

$\underline{\text { Sendo o acesso mais difícil aos alimentos atualmente }}$

Acreditam que, antes, o acesso aos alimentos era mais fácil, uma vez que existiam mais árvores frutíferas nas residências e nas matas ao redor das cidades. Relatam que era possível pescar e caçar com maior facilidade e mesmo não tendo muito dinheiro, existia fartura em alimentos (quadro 2).

“...antigamente, na cidade, ninguém comprava uma laranja de caminhão, todo mundo tinha no quintal, abacate, manga então nossa senhora..." (28.4)

"A gente tinha pomar nos quintais, todos os quintais. Minha mãe tinha horta, a terra era boa, tinha abobrinha, cheiro verde, tinha tudo. Remédio, como camomila, tinha tudo aqui. O pessoal vizinho ia tudo buscar em casa com minha mãe." (29.4)

"Olha... olha no meu tempo, eu sempre gostava de caçar e pescar, a gente ia correr no mato, caçar, ia em rio pra pescar, tudo o mais. Tinha bastante mato. Hoje a lei também não permite né, proibiu a caça, então eu me afastei disso ai." (30.8)

"Agora você vê, antigamente, por exemplo, havia miséria, mais não era uma miséria, não é que nem agora, era falta de dinheiro mais tinha fartura, e era tudo puro. A minha mãe fazia lingüiça, tinha o fogão a caipira, é lenha, e fazia aquela, fazia o pão, na fornalha o pão, eu trocava lá na escola com o pão de padeiro, fazia fila comigo: - não, troca comigo. Eu era enjoado de ver. Café era torrado em casa, eu ficava lá, torrando e moendo lá em casa, era tudo, leite era cru, manteiga, não existia margarina. Óleo não tinha, era banha e nós não tínhamos geladeira, então minha mãe tinha a lata de óleo, lembra? Era banha, eu punha a carne lá né, pra

conservar, era assim..." (9.4)

\section{Desenvolvimento intenso da ferrovia}

Relatam que a ferrovia foi uma das grandes responsáveis pelo intenso e acelerado desmatamento, tanto consumindo lenha como combustível para as locomotivas a vapor, quanto para a construção da linha férrea, que cortava pelo meio das grandes matas, sendo que muita mata foi destruída antes da construção dos 
hortos. Contam, também, que existiam os arrendatários, que arrendavam propriedades para cortar toda a mata existente e vender a lenha para a Sorocabana (quadro 2).

"Eu também até culpo a estrada de ferro por ter destruído as matas virgens, porque chegava lá, quem mediu a lenha comprava aquela lenha lá, chegava lá cortava tudo, então vinha aquelas gôndolas de lenha, queimavam tudo né. Queimou tudo, por exemplo, foi destruidora a estrada de ferro a vapor... porque consumia lenha né... então (nt)foi queimando, foi queimando, foi queimando... foi longe..." (26.5)

"É vinha é, vinham cortando tudo, essa devastação de mata que tem aí, a maior parte foi tudo queimado nas locomotivas da ferrovia." (12.14)

"lam acabando, só de Paula Souza foram anos e anos derrubando matas, aí depois que formaram esse horto de Itatinga aí, de eucalipto..." (5.1)

"Aqui! Da linha, do começo da linha aqui até quase Rubião, era uma mata fechada! Que nós, época de jabuticaba, nós íamos buscar jabuticaba no meio do mato. Nós pegávamos o falecido pai, subíamos a no pé, derrubávamos, nós catávamos. Agora você vê, destruiram tudo, a linha passou quase no meio, por fim aí derrubaram tudo, derrubaram tudo. A linha passava dali pra lá um pouco né, fazia a volta, mas, aí com o progresso pra fazer, pra encurtar as quilometragens, fizeram ela passar quase no meio da mata, mas acabaram com tudo." (5.3)

"Ele comprava o mato de pé e depois punha lá empregado pra derrubar, picar, cortar." (7.3)

"Não, os empreiteiros que cortavam e forneciam à Sorocabana né, eles traziam a lenha tudo cortado no metro certo, faziam as pilha lá no depósito, depois nós dávamos pras máquinas." (28.1)

Nesta categoria, associam-se os seguintes elementos: - Sendo intenso o consumo de madeira, - Sendo a lenha transportada por caminhões ou ramais provisórios, - Empilhando lenha no depósito, já cortada no tamanho certo, Utilizando todo tipo de madeira, - Vindo lenha de diversas áreas e provocando desmatamento, - Consumindo carvão importado e areia dos rios.

Como existem muitos componentes importantes dentro destes elementos, optamos por descrevê-los também neste tópico, pois são importantes para a compreensão do objetivo desta pesquisa. Em relação ao primeiro elemento - sendo intenso o consumo de madeira -, os longevos ferroviários procuram caracterizar o enorme consumo diário de lenha pelas locomotivas a vapor, relatando que o tender 
das máquinas comportava cerca de 20 metros2 de lenha, e que ainda era necessário abastecer novamente para completar o percurso (quadro 2).

“Daqui a Iperó, só daqui lá, gastava 40 metros de lenha, 40 até 50 metros de lenha. Uma locomotiva grande, ela gastava 50 metros de lenha e pra vim mais 50, fica 120 quilômetro (Botucatu-Iperó-Botucatu). Queimava lenha daquele jeito (...) a locomotiva a vapor tem um tender, o tender é que enche de lenha, cabe 25 metros no tender de lenha. Então quando a locomotiva saia daqui, a locomotiva ela saia com trem e o tender com 25 metros de lenha, lotado de lenha, né tudo bem empilhadinho, é tudo bem empilhadinho assim (...), então esse tender de lenha, a turma queima viu, é queimava muita lenha, o consumo de lenha era bastante, bastante." (16.8)

“...se pega um trem, vamos supor, em Laranjal, subi Laranjal, tudo se queimava mais de 20 metros de lenha, essas locomotivas grande que tinha antigamente, as fornalha dela era 4 metros de lenha que ia numa fornalha numa vez, 4 metros de lenha, fora o carvão que usava né. Tinha locomotiva que gastava menos, mais era mais ou menos essa base, se fazia, se queimava, eram 3 horas de viajem. Você tinha que fazer, principalmente quando de Vitoriana pra Botucatu, que era serra, subia a serra e era, ali era dureza viu. Aí tinha que pôr mais madeira? Muito mais! Era dobrado, era seguida." (5.2)

Interagindo com o primeiro elemento, temos outros fatores. Em relação ao fator, sendo a lenha transportada por caminhões ou ramais provisórios, contam que a lenha cortada do mato era transportada por meio de caminhões ou da construção de ramais provisórios da ferrovia, que chegavam até a beira da mata para poder colocar a lenha nas gôndolas do trem e transportar para o depósito (quadro 2).

"É, eles cotavam a mata, então eles transportavam um caminhão, e os caminhões deixavam nas estações, então tinha o trem de lenha que carregava e distribuía depois a lenha, e tinham vários depósitos aqui em Botucatu, Bernardino de Campos, Assis, Santo Anastácio, ia pra todos esses lugares, ia o trem de lenha, carregava um colosso de gôndolas, carregadas de lenha." (7.3)

"Fazia até, a Sorocabana até fazia trabalho provisório pras locomotiva levar as gôndola para um local. Pra pegar a lenha? Pra pegar a lenha, outra que nem, Virgílio Rocha (nt), você não conhece? Não. É pra lá de Lençóis, é Lençóis, Virgílio Rocha depois tinha... Borebi é uma cidadinha de lá, e tinha coronel eleito naquela fazenda e lá tinha o lado de Quatá, tinha uma parte as esquerda, saiu muita lenha de lá. Tinha um ramal de 40 quilômetros, pra pegar lenha, um ramal grande que entrava até lá, o nome era horto, de ramal ia pra horto de Borebi, tinha estrada de ferro..." (16.7) 
“...tinha um lugar nu... nu... não era longe, que nem Santa Cruz mesmo, cortava lenha perto de Santa Cruz, deixava na beira da linha, depois carregava nas gôndola, né..." (11.3)

Um segundo fator que interage com o primeiro elemento (intenso e acelerado consumo de madeira) é: empilhando lenha no depósito, já cortada no tamanho certo. Descrevem a imensa quantidade de lenha que era empilhada nos grandes depósitos da ferrovia, e que toda a lenha deveria ser cortada no tamanho correto para ser colocada na fornalha e produzir pressão de forma adequada às locomotivas (quadro 2).

“Já vinham as gôndola de lenha, descarregavam... carregavam, tinha depósito de lenha, tinha depósito de lenha aí, tinha um depósito de lenha aí, tinham mais de cinqüenta mil metros de lenha." (6.1)

“...então aí, num sei se a senhora conhece, o depósito aqui tem um pátio enorme lá traz né, aquilo ali era fechado de lenha né, pilhas de lenhas, pilhas altas, mais altas que isso aqui, pra gente pode trabalhar, né." (25.5)

“... aqui no depósito tinha um lenheiro que era fim de mundo, ele tinha 5, 6, 6 metros de altura a pilha de lenha, tudo bem enfiadinho, bem no jeito, então a máquina chegava e ia pegando aquela lenha, pegava de trecho, trecho de lenha mais seca..." (27.9)

"O ferroviário abasteci a caldeira. Essa máquina funcionava à vapor. E a lenha para ela era cortada por metro. Era de 6 a $22 \mathrm{~cm}$ de espessura e eu era que recebia essa lenha. Os fornecedores de lenha das fazendas cortavam a lenha e mandavam a lenha cortada por metro. E a espessura era de 6 a $22 \mathrm{~cm}$ para poder trabalhar, para a fornalha. A lenha fazia combustão e aquecia a água da caldeira e a máquina funcionava." (29.1)

"Misturava com lenha, na fornalha, aí punha lenha na fornalha aí jogava o carvão em cima da lenha pra ajudar a aquece mais né. Uma locomotiva é 200 libra de pressão, ela tem que está a 200 pra puxar trem pesado, se ela vêm pra 100 não puxa o trem, tem que estar nas 200 pra puxar trem pesado. Eu, a locomotiva a vapor da grande, sempre conservava uma fornalha de locomotiva grande a vapor, se for encher ele parado tem 4 metros, cabe 4 metros, mas sempre trabalhei com 2 metros assim, com o fogo pela metade, conforme a pressão é que manda né. Aí vai pondo mais? É, a pressão é que manda, a gente ... é capricha, capricha muito pra fazer fogo, não pode jogar lenha, jogar lenha na fornalha não, na fornalha tem que jogar lenha empilhadinha, assim, pro fogo ter força, num deixar buraco, tendo o

buraco entra ar e não faz pressão, então tem que fazer o fogo bem feitinho, caprichar no fogo, e... pra não deixar buraco se não... porque a fornalha tem grelha, grelha é assim, num é fechada, é assim pra ter respiração né, era bem assim né, ela chama grelha né, é assim, e... agora o fogo tem que estar forte pra receber aquela respiração e... dá, dava fogo forte viu, se jogar de qualquer jeito... por isso que o maquinista é o responsável, o maquinista vai perto do foguista pra caprichar no fogo, eu gosto de fogo bem feito se não não vai, assim não vai, assim não vai." 
Outro componente que interage com este primeiro elemento é: utilizando todos os tipos de madeira para a ferrovia. Os ferroviários longevos revelam que cortava-se todo tipo de madeira para servir como lenha para a ferrovia, desde árvores inapropriadas, como as do cerrado, por serem finas e tortas, até madeiras de lei que eram queimadas. Para a fabricação de dormentes, utilizavam madeiras melhores e mais fortes, como peroba, favero, aroeira, angico e cabreúva (quadro 2).

"Nossa Senhora, até essa lenha de cerrado, eles cortaram por muito tempo essa lenha de cerrado, que era duro pra você trabalhar, que era tudo torta, tinha dificuldade pra colocar na fornalha, né." (5.1)

"O que tivesse no mato, não interessava se o pau era fino ou se o pau era grosso, era cortar o mato, vinha tudo aí, agora acontece se o pau fosse grosso esse era aparado e tinha uma machado que partia ele pro meio, era um machado a ar." (8.1)

“... pinho, peroba, canela, vinha toda madeira boa, vinha pra fornalha..." (22.4)

"Só pros dormentes que era madeira selecionada, porque tinha que ter resistência né, colocava o trilho pro trem passar em cima, e não apodrecia logo né." (7.3)

"É, o dormente era pesado pra chuchu, o dormente de peroba, favero né, pesado." (12.7)

"Tinha a linha era diversa viu, Aruera, tinha Cabreúva, tinha Peroba também, e tinha o Angico também. Tudo pra fazer os dormentes? Pra fazer dormente."

Outro fator associado ao intenso consumo de madeira é que vinha madeira de diversas áreas, provocando desmatamento também nessas regiões. Lembram que a madeira utilizada na ferrovia era proveniente de vários locais, desmatando toda a redondeza em torno da ferrovia até chegar a lugares mais distantes, como Mato Grosso e Paraná (quadro 2).

"Ela vinha de... aqui de Virgílio Rocha, vinha também lá de cima do Mato Grosso, também vinha" (8.1)

"Vinha de toda a redondeza aí, chegou vir lenha aqui, chegou vir lenha aqui lá de... de onde tinha mata ia fornecendo, derrubava a mata e ..." (16.6) “... é lenha aqui, Barra Grande, Vitoriana, Bernardino, em todo lugar tinha um lenheiro."

(18.4) 
"Até Presidente Epitácio, na beira do rio (nt)não tem mais árvore, não tem mais árvore... queimaram tudo, não é isso?" (26.5)

Outro elemento associado ao desenvolvimento intenso da ferrovia é o consumo de carvão importado e de areia dos rios. Lembram que o carvão utilizado nas locomotivas era importado da Inglaterra e descarregado no Porto de Santos, uma vez que o nosso carvão não era tão bom. Contam que existiam carros especiais de passageiros que eram movidos somente a carvão, por produzir mais pressão. Na locomotiva a vapor, também se utilizava areia, que era retirada do rio Tietê (quadro 2).

“O carvão vinha... o carvão vinha dos estrangeiro, era carvão estrangeiro, o carvão nacional nunca foi bom, nunca descobri um carvão bom nacional, daí não gostava do carvão, depois começaram a descobrir o carvão nacional, era um carvão fraco, um carvão só fazia sujeira, nunca foi bom, só se agora, acho que mina muito nova, o carvão que vinha do estrangeiro, vinha muito, vinha navio de carvão, e... desembarcava no porto de Santos o carvão, era carvão, principalmente o lá na Barra Funda, os trens de passageiro eram feitos só no carvão, era carvão muito bom, carvão que dava caloria forte mesmo, era carvão estrangeiro..." (16.8)

“...dizer se a senhora sabe... mais a senhora sabe que a locomotiva é... depende muito de areia pra poder andar, então vinha gôndolas e gôndolas de areia, areia grossa do... do Rio Tietê, depois peneirava ela, pra tirar aquelas pedrinha, pra por no areiero da máquina pra... pra quando ela está rodando tinham duas pontas de ferro assim, socava areia ali, pra ir calçando pra ela não virar em falso, senão não saía do lugar depois." (30.11)

\section{Tendo de construir parques artificiais e hortos}

O desmatamento produzido, principalmente, pelo grande consumo de lenha para a ferrovia, obrigou-a a começar formar hortos para retirar a madeira e, depois, foi necessário partir para o plantio de eucalipto, pois a lenha do mato foi acabando. Esse desmatamento tornou-se tão intenso e geral que, como os longevos ferroviários observam, atualmente, só existem matas bonitas em locais mais isolados e afastados, sendo necessário a construção de jardins botânicos para que as pessoas voltem a apreciar uma bela natureza (quadro 2).

“...porque a Sorocabana plantou muito horto florestal, Sorocabana tinha horto florestal, tinha horto de Andrade Silva, Andrade Silva era antigamente, estrada de ferro, que em Andrade Silva, lá já tinha um horto florestal que a Sorocabana comprou, até hoje deve ter. Comprou um terrenão, a Sorocabana, um terreno grande, a Sorocabana era muito rica, comprou um terreno grande, tinha lá 
plantação de eucalipto. Em Itatinga a Sorocabana também tinha um horto florestal em Itatinga, aquilo era terreno que a Sorocabana comprou, eu até vou dizer, eu era foguista, eu era foguista... e... Piraju também tinha um horto da Sorocabana, e...tinha outro horto grande também em Salto Grande, não cheguei a conhecer, mas está pra lá do rio, diz que era uma fazenda bem grande, era da Sorocabana também." (16.7)

"É, tinham muitos lenheiros, por exemplo, aqui em Itatinga tinha um horto florestal

de eucalipto, tinham muitos alqueires de eucalipto, bastante, perdia de vista, e vinha lenha (nt) tem outra vinha outro em Itapetininga, Itapetininga a Iperó, grande lenheiro, grande também que fornecia lenha, então esse lenheiro fornecia lenha pra Soro... lenha de eucalipto..." (27.9)

“...está ficando desativado né, está ficando... não é mais bonita assim a mata, só no Amazonas, no Mato Grosso né, no estado de São Paulo já não tem, por isso que tem esses jardim Britânico né." (16.10)

\section{Categoria A3 - Aumentando a poluição com o tempo}

Significa para eles que o aumento da poluição com o tempo decorre do incremento da frota de carros e de caminhões; da utilização abusiva de produtos químicos; do aumento da produção de lixo gerado por maior utilização de produtos descartáveis, associado ao maior poder aquisitivo das pessoas e crescimento populacional. Os longevos entrevistados consideram que essa intensa poluição é pior em cidades de maior porte e menor altitude. Percebem que, antes, não havia poluição ou ela não atingia níveis tão elevados como os atuais, a ponto de prejudicar a saúde e o bem-estar das pessoas, contaminando todo o ambiente (quadro 3)

As subcategorias que emergem aqui são: - Aumentando a frota de carros e caminhões, - Utilizando abusivamente produtos químicos, - Aumentando a produção de lixo, - Prejudicando a saúde e o bem-estar, - Sendo pior a poluição em cidades de maior porte e menor altitude (diagrama 6).

“... era bem, não tinha, num, não tinha, nem, nem existia essa palavra poluição viu, não existia essa palavra. É depois que veio a poluição..." (2.5)

"Eu acho que isso aí nunca teve né, nunca teve, estou vendo essas coisa agora depois de velho, mas no meu tempo de moço, mocinho nunca vi, nunca vi fala nisso..." (28.8)

"Ah! Era sim e depois tinham lugares que o ar não tinha poluição nenhuma, tinha coisa nenhuma, a gente ia pescar aqui e ali, era limpo, né?" (2.5) 
“É...poluição, é... poluição sempre teve. É...tinha é, quer dizer, ninguém ligava pra...pro." (6.4)

"Já tinha um pouco de poluição, os veículos, era fumaça de caminhão." (7.4)

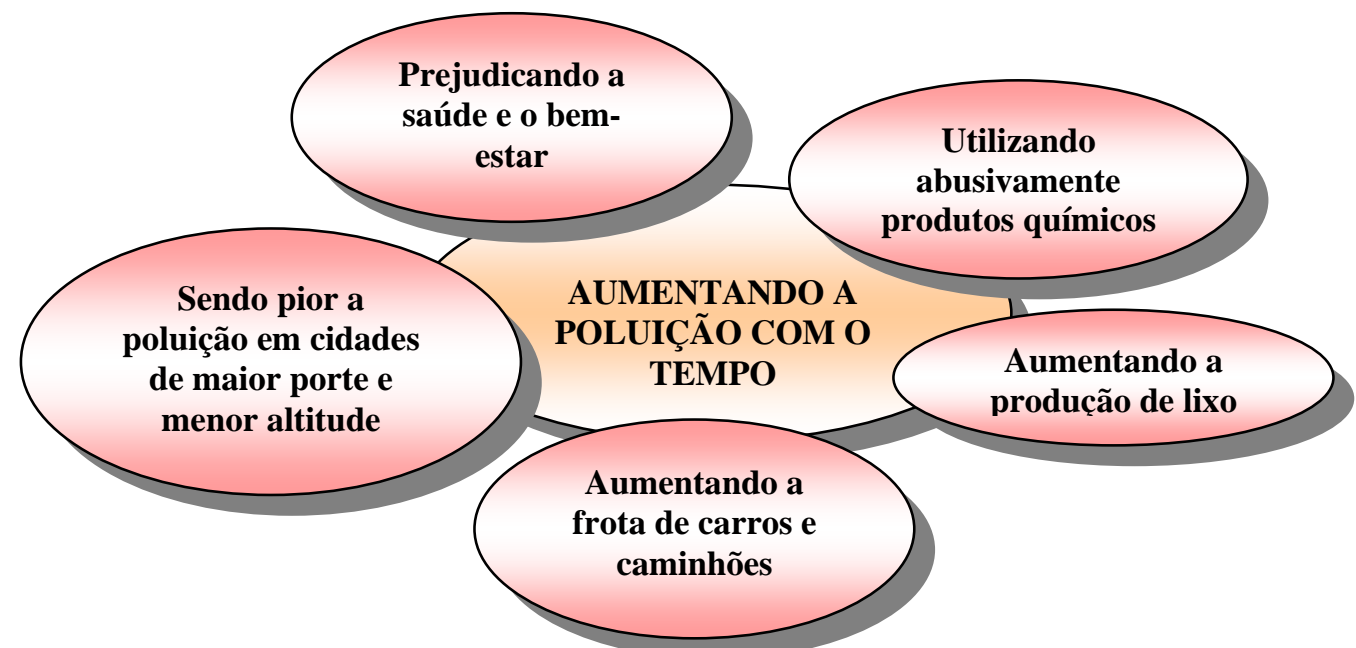

Diagrama 6 - Categoria A3 - Aumentando a poluição com o tempo: Subcategorias.

\section{Aumentando a frota de carros e caminhões}

Associam a poluição atual ao aumento da frota de veículos, como carros, ônibus e caminhões, que circulam muito hoje em dia. Contam que os trens geravam menor poluição (quadro 3).

"Não tinha poluição não. Não tinham carros também né. Você, você andava na cidade aí, não tinha carro nenhum quase." (10.5)

"Tinha movimento mas não é que nem hoje, principalmente de carro, hoje Botucatu está super lotado de carro, de ônibus, muitos ônibus aqui em Botucatu, têm muitos ônibus, tem mais ônibus que chega de fora do que tem aqui, se anda, se calcular quantos ônibus tem aqui em Botucatu e que chega aqui em Botucatu viu..." (8.3)

“...era mais limpo o ar, agora é tudo poluído, muito carro, muita condução, o trem não poluía tanto como essas caminhãozadas." (23.4)

\section{Utilizando abusivamente produtos químicos}

A própria ferrovia passou a transportar adubo, que inicialmente era importado e descarregado no porto de Santos. Contam que o adubo era transportado nos vagões dos trens, que iam sendo corroídos pelo produto. No entanto, os ferroviários não manipulavam esses produtos. Criticam a utilização abusiva de agrotóxicos e adubos em todos os produtos, contaminando solos, rios e tudo o mais (quadro 3). 
“...agora esses a granel acabaram com milhares de vagões da ferrovia, enferrujou tudo, que não teve conserto mais. Aquele Ultrafertil tinha um depósito em Avaré, aqueles vagões não deram pra aproveitar nada, está tudo encostado nesses pátio por aí, apodreceram tudo.

...Deixava o vagão lá e eles que descarregavam, os funcionários dessa empresa lá que descarregavam. Mas eles não usavam máscara não, eu tenho certeza, eu via quando ia trabalhar com vagão né" (5.8).

“...tempos atrás, a gente saía pescar por esses riozinhos aí pegava, hoje não tem mais nada, esse negócio de adubo que eles põem nas plantas também, vai acabando né..." (23.7)

“...a terra está muito contaminada minha filha, muito contaminada, aquele tempo num era assim, eu trabalhava, eu trabalhei uns tempo no cafezal, trabalhei um tempo, bastante tempo na lavora..." (27.7)

\section{Aumentando a produção de lixo}

Observam o aumento da produção de lixo, associando à utilização de produtos descartáveis, como latinhas e, principalmente, plásticos, os quais julgam ser mais prejudiciais ao meio ambiente. Associam o crescimento populacional à maior quantidade de lixo, assim como ao poder aquisitivo das pessoas, ou seja, quanto maior o poder aquisitivo mais lixo se produz. Percebem uma piora no comportamento das pessoas, jogando mais lixo em locais inadequados (quadro 3).

Os elementos que aparecem associados a esta categoria são: - Utilizando mais produtos descartáveis, - Crescimento populacional, - Tendo maior poder aquisitivo.

"Que nem o ambiente, uma coisa assim que eu fico nervosa, que você vai em qualquer lugar vem aquelas sacolas ridículas, eu acho que aquilo é uma coisa terrível viu, terrível, que aquilo vai destruindo a terra, destruindo água, destruindo tudo, e não há o que, não há o que chegue. Você pode ver, em filmes americanos, não sei se o você notou, tem a, que vai assim os artistas lá comprarem coisas no mercado, eles saem com saco de papel, eles não saem com saco de plástico." (9.3)

"Hoje não, hoje tem uma parte de operário e a outra parte dos burguês. Tem mais lixo." (7.4)

"O povo parece que era mais educado, eu não sei se é porque tinha menos gente

né, a gente andava lá na rua onde hoje é o calçadão, a gente não via sujeirada assim, a cidade também era menos gente, menos coisa né, bem menos

Prejudicando a saúde e o bem-estar movimento..." (11.3)

Percebem que todo o tipo de poluição pode interferir na saúde e prejudicar diretamente o sistema respiratório, prejudicando a respiração e, até, o pulmão (quadro 3). 
"Um exemplo é a poluição dos ônibus do Roger, aquilo faz mal pra gente, acho que até pro pulmão faz mal." (4.4)

"A natureza, a natureza está muito poluída, por exemplo a poluição daqueles ônibus de São Paulo, eles jogam a fumaça pra cima, aquilo lá dá problema na garganta da gente..." (19.4)

\section{$\underline{\text { Sendo pior a poluição em cidades de maior porte e menor altitude }}$}

Notam que existe uma variação na intensidade da poluição em relação ao porte das cidades, à ventilação e altitude (quadro 3).

"Eu acho que a água está boa, o pior é a poluição do ar. A gente aqui nem tanto, mais em São Paulo o nego está envenenado" (1.3)

"Aqui pra nós não, ainda não. Eu acho que ainda não, apesar que é muito caro aqui em Botucatu viu. São Paulo é pior ainda viu. Porque aqui é uma vila alta né. Não! Isso é na cidade toda Dirce, porque nós estamos em cima do morro, né, da cidade , de repente tem ventilação. Ah! Em São Paulo por exemplo é terrível né. É fumaça,

é fuligem... São Paulo não dá mais pra viver de jeito nenhum." (4.4)

\section{Categoria A4 - Ocorrendo descontrole ambiental}

Percebem que ocorreram alterações ambientais, julgando que as estações do ano estão maldefinidas atualmente, com indefinição do ciclo da florada, e as terras tornaram-se menos produtivas hoje. Embora o clima de Botucatu sempre tenha sido classificado como bom. Notam que o meio ambiente e a natureza estão modificados, diferentes, sendo o ser humano responsável por estas alterações (quadro 4)

As subcategorias que aparecem: - Sendo as terras mais ressecadas hoje, Morando em local com clima privilegiado, - Indefinição do ciclo da florada, Estando as estações do ano maldefinidas (diagrama 7).

"Eu... eu entendo que esse tempo está mudando por causa do homem estar destruindo a natureza viu... " (18.4) 


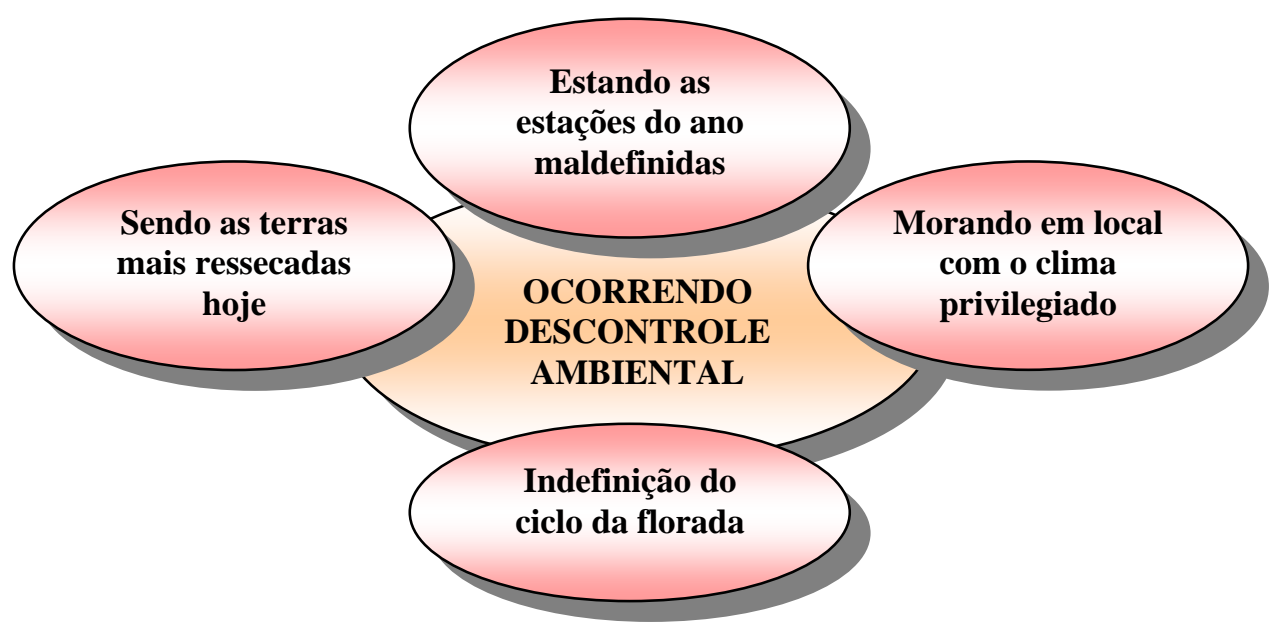

Diagrama 7 - Categoria A4 - Ocorrendo descontrole ambiental: Subcategorias.

\section{$\underline{\text { Sendo as terras mais ressecadas hoje }}$}

Acreditam que a terra está mais ressecada e que, antes, todas as pessoas podiam ter horta em seus quintais. Julgam que o eucalipto, a bananeira e a cana ajudam a ressecar a terra (quadro 4).

“...o eucalipto, (nt) ele puxa água, eucalipto, bananeira, cana, a cana também, a cana puxa um pouco de água, mais o pior de tudo é o eucalipto, você num vê que o eucalipto está ressecando, ele puxa água, ele puxa água..." (27.9)

\section{$\underline{\text { Morando em local com clima privilegiado }}$}

Classificam o clima de Botucatu como sendo muito bom sempre, inclusive, a cidade é referência como estância de "bons ares”, além de possuir um dos céus mais claros do mundo, o que dificulta saber se, em Botucatu, está ocorrendo descontrole ambiental (quadro 4).

"O clima de Botucatu sempre foi bom né, mesmo com tudo isso que tem hoje assim, ainda continua sendo bom né." (15.6)

"Botucatu diz que é uma das cidades, não sei se é verdade, uma das cidades mais bem iluminadas do mundo, iluminação natural de sol né, dias que faz de sol, por isso que tem muita granja aqui, por isso que se instalou a fábrica de aviões, por causa que o... o que tem de céu aberto aqui é muito grande né. Acho que a proximidade da cuesta, tem sempre um vento, predominante que limpa as nuvens né..." (24.11/12)

“....só que eles residiam em Rubião Junior, aquele hospital que tem, que vocês trabalham, aquele hospital foi feito pra...pra...pro...pulmão, o Ademar de Barros,.... o pessoal já tinha casa aqui, mas morava em São Paulo, morava em Campinas, só gente que podia, mais eles tinham casa aqui, eles passavam temporada aqui, que nem passa ná....que nem passa lá ainda em Campos de Jordão..." (8.9) 
Indefinição do ciclo da florada

Relatam que o próprio ciclo da florada sofreu alterações, pois antes as flores floresciam em período mais definido, perfumando tudo (quadro 4).

"Há era bom, a natureza tinha outro aroma né, era diferente, agora você não vê cheirar flor de nada,(nt) aquele tempo quando florescia o cafezal, então nossa senhora, florescia laranjeira, mexeriqueira, tudo as coisas floresciam na época certa né, era tão gostoso né. A gente sentia o cheiro da... da flor né, hoje num tem mais nada, mais nada" (28.4)

\section{$\underline{\text { Estando as estações do ano maldefinidas }}$}

Percebem que, no passado, as estações do ano eram mais definidas e que, agora, não é possível prever a temperatura ou as chuvas, associando esta indefinição ao desequilíbrio ambiental (quadro 4).

"Bom, como tinha bastante verde, eu acho que a natureza era bem melhor do que hoje né... pelo menos a impressão que eu tenho. Às vezes, conversando com a minha esposa que o tempo está mudado, é está mudado, por exemplo, a gente achava que as estações parece que vinham mais certas do que hoje né, mesmo o ciclo lunar parece que era mais certo né, isso é impressão que a gente tem né, num sei se é. "(25.8)

"Porque ... eu acho que tem o descontrole da natureza, porque hoje em dia, antigamente, eu me lembro que o frio chegava naquela época de frio, ia frio certo pra aquele tempo, chuva era sempre dezembro, janeiro e fevereiro os meses que mais chovia, este ano choveu, mais os anos passados, os outros anos... eu acho que tudo isso é tudo descontrole..." (5.4)

\section{Categoria A5 - Modificando as propriedades dos alimentos}

Acreditam que as propriedades dos alimentos se modificaram, modificando o sabor e suas características, tornando-os menos saudáveis devido à utilização de rações e produtos químicos, e incorporando abusivamente produtos químicos nas plantações.

Subcategorias: - Modificando o sabor e as características dos alimentos, Substituindo o adubo orgânico por químico e uso abusivo de agrotóxicos (diagrama 8).

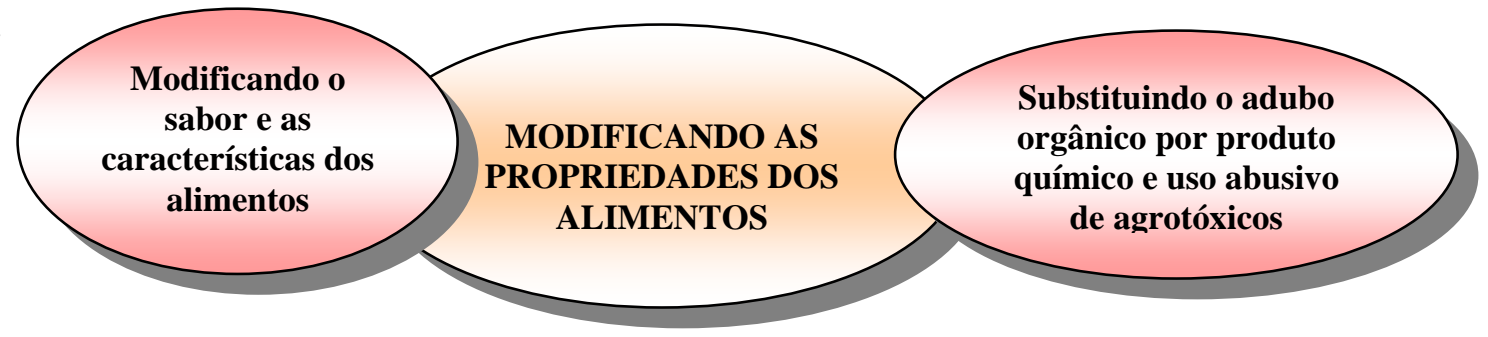

Diagrama 8 - Categoria A5 - Modificando as propriedades dos alimentos: Subcategorias 


\section{Perdendo o sabor e as características dos alimentos}

Sentem que os alimentos perderam suas propriedades, como a beleza, o sabor, a pureza, devido à utilização de produtos químicos, que até fazem os alimentos serem maiores, mas sem sabor. Relembram como os alimentos eram mais saborosos no passado (quadro 5).

“...almerão também, tinha tudo essas coisas viu, principalmente a hortaliça num era muito... muito coiso...é que nem o porco, a carne de porco, aquele tempo o porco comia milho, milho só, milho é abençoado, abobora é abençoado, mandioca é abençoado, é o que o porco comia, um porco de engorda, esse porco de engorda só milho só, num é aquela... aquelas fezes do porco num era tão, tão brava que nem agora né. Então você fritava um pedaço de carne de porco, uma costela chegava, chegava ( $n t)$, num tem mais nada... você pega uma carne de frango de supermercado, você esquece da panela ele cola tudo na panela, gruda, aquele outro não..." (27.7)

“...antes tinha cada abacaxi gostoso doce, aquelas melancias que era barbaridade de gostosa, num tem mais. Você compra aí não tem doce nenhum.... não tem terra, terra destruíram tudo. (nt).. essas coisas aí num tem gosto mais, você comia um pepino, a que gostoso que era o pepino, agora..." (26.5)

\section{$\underline{\text { Substituindo o adubo orgânico por produto químico e uso abusivo de agrotóxicos }}$}

Contam que, no passado, utilizavam esterco nas plantações e que, depois, passaram a utilizar de forma abusiva e indiscriminada os agrotóxicos, adubos e rações para produzir os alimentos (quadro 5).

"Nada, nada, nada. Era só esterco normal, tinha criação de coelho, nós tínhamos cocheira, a gente usava bastante capim na cocheira pro gado ficar, depois tirava aquele esterco, colocava pra ele curti, aí ia pra horta plantar. Pra dizer, a gente tinha uma plantação de repolho lá embaixo que tinha dificuldade de vender lá no Fávero. Eles compraram duas vezes de mim, não quiseram mais, por causa do tamanho que deu, eles diziam que era muito difícil de vender, o repolho chegou a dar de 4 a 5 quilos cada um, era isso aqui (Mímica), só com esterco. As verduras eram tudo bonitas, as verdura, verdinhas. Plantava vagem, plantava couve-flor, plantava, tinha de tudo, tudo. Eu tinha um capricho na horta, era que nem esses riscos aqui (mímica), era tudo retinho, tudo reto. $E$ eu, pra conservar a terra úmida, pra não precisar estar regando muito, eu punha pó de serra e aquela barbatimão, mas eu tinha o capricho de por uma tábua assim, vamos supor, a tábua aqui, outra aqui, e eu punha cada um... o pó de serra era claro e a barbatimão escuro, até as pessoas iam lá falar se aquilo era horta ou era jardim. Eu tinha esse capricho comigo. Agora, sempre quando aprendi trabalhar numa coisa, de um jeito eu sempre mantive, desde quando eu trabalhava de foguista, procurava sempre fazer a coisa de acordo mesmo, do jeito que, que era preciso." (5.4/5)

"Mais forte a saúde era... se você comia uma carne de porco, tinha gosto de carne de porco, num é que nem hoje que tem gosto de ração e injeção até carne de vaca num, já não tinha aquele gosto que tinha antigamente, que matava lá no matadouro né. Tinha um matadouro lá embaixo no, na Vila Maria né, açougueiro matava 4, 5 boi lá, e a carne era pura né, agora não, agora vêm (nt) a carne já faz uns 3 meses que está congelada né... num tem gosto de nada, você vê, você frita ela parece uma borracha né... num é verdade?" (28.4) 
“...não existia química, ninguém usava adubo, nem na lavora, nem no...lugar nenhum usava química não, na lavora trabalhava com adubo, com esterco de cavalo e só isso, não tinha, agora depois que veio tudo, naquele tempo não tinha coisa." (8.4)

\section{Categoria A6 - Sentindo desprazer em relação ao meio ambiente atual}

Sentir desprazer em relação ao meio ambiente atual está relacionado às más sensações geradas pelas vivências atuais, como: aumento da violência, perda do respeito entre as pessoas e da liberdade, aumento da miséria. Julgam que todos estes fatores levam as pessoas a se sentirem tristes, fracas e insatisfeitas. Sentem falta de prazeres despertados pela natureza no passado, embora, outros julgem o meio ambiente atual como sendo melhor.

Subcategorias: - Aumentando a violência, - Perdendo o respeito e a liberdade entre as pessoas e a liberdade, - Sentindo falta das boas sensações despertadas pela natureza, - Deixando as pessoas tristes, fracas e insatisfeitas, - Sendo o meio ambiente atual melhor (diagrama 9).

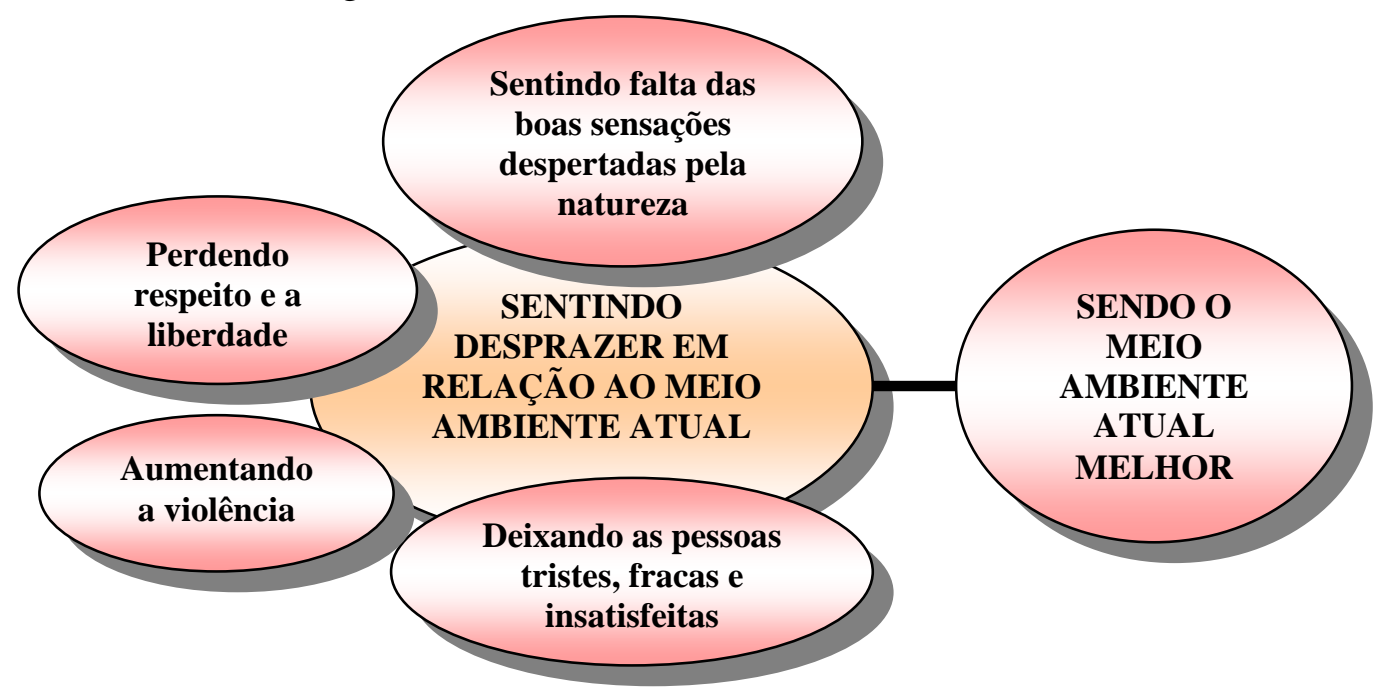

Diagrama 9 - Categoria A6 - Sentindo desprazer em relação ao meio ambiente atual: Subcategorias.

\section{Aumentando a violência}

Percebem o aumento da violência e da maldade entre as pessoas, não podendo mais ter tranqüilidade nas ruas e nem mesmo na própria casa, como antigamente. Essa violência atinge, inclusive, as crianças, prejudicando-as e não permitindo que desfrutem de uma infância saudável (quadro 6). 
"Você vê, eu pego aí o Datena, é todo dia morte, morte, mata um sujeito que nem mata um porco." (9.4)

"O movimento era bem diferente do que é agora, agora está muito movimentado, antigamente não tinha bandidismo, você não ouvia falar em bandido, você dormia, saía de casa e deixava a janela, porta aberta que não tinha perigo nenhum. Hoje não pode sair, hoje você é prisioneiro da sua casa, naquele tempo era uma beleza..." (22.2)

“... criançada brincando de roda, acabou tudo, estão tudo pra cidade, na cidade fazendo o que? Vício, bebendo. Você vê uma menina, uma menina, uma menina, por exemplo de 10 anos, era uma coisinha, num sabia de nada, sabia só trabalhar..." (27.8)

Perdendo o respeito entre as pessoas e a liberdade

Sentem falta da privacidade, da liberdade e do respeito que existia antes entre as pessoas e relatam que, hoje, estes valores se perderam, aumentando a miséria (quadro 6).

"Olha, Botucatu naquela época, vou falar pra você, era sossego aqui, era um sossego, não se via falar em assalto, não se via falar em... em... era um respeito todo mundo, com chefe também. Hoje não, hoje é... eu sempre respeitei meu chefe viu, eu sempre respeitei, portanto se você encontrar com o chefe que trabalhou comigo e perguntar pra ele, ele vai confirmar..." (10.1)

“Tinha mais liberdade né, hoje em dia está, hoje está mais duro..." (3.4)

$\underline{\text { Sentindo falta das boas sensações despertadas pela natureza }}$

Sentem falta das sensações agradáveis que a natureza proporcionava, como: o bom aroma exalado pelo mato, o perfume das flores, de poder admirar a beleza da natureza, apreciar o canto dos passarinhos e os animais silvestres. Percebem que, atualmente, a natureza perdeu sua beleza e vivacidade, influenciando negativamente a vida das pessoas (quadro 6).

"Muito... a natureza é muito bonita né, é muito bonita a natureza, é a coisa mais linda que tem né, num tem coisa que substitui a natureza, é muito linda. E de primeira era, parece que, até era mais bonita, porque a gente, que nem a gente, vê a mata né bastante, vê o passarinho cantar, então é muito bacana viu, que nem lá, lá na fazenda quando, quando era nova, era mata virgem, era uma beleza viu..." (16.10) 


\section{Deixando as pessoas tristes, fracas e insatisfeitas}

Ficam tristes e penalizados ao verem a destruição da natureza, o desmatamento e a poluição dos rios. Acreditam que essa destruição afeta diretamente os sentimentos das pessoas, deixando-as tristes, aborrecidas e fracas, como se estivessem morrendo junto com a natureza (quadro 6).

"a gente se sente é, mais, mais aberto mais alegre né. É assim, a natureza que manda, a natureza é fora de série viu (...) Ah hoje está feio, parece que está morrendo, é, parece que está tudo triste.(...) Interfere sim viu, e muito viu.(...) Ah! Faz a pessoa ficar triste, aborrecida. É esses sujeitos tudo aí, parecem que estão morrendo, num é verdade?" (12.13/14)

"A natureza, sem dúvida, interfere no modo que a pessoa vive. Olha que a, a nutrição né, quando ela é bem, come bem, tem boas amizades, ele se sente

satisfeito... mas a humanidade, hoje né, satisfeitos somos poucos, são os comandantes, os proprietário das coisas..." (26.5)

"Ah! Sim, eu acho que é uma judiação que estão fazendo, estão destruindo tudo né!" (4.3)

“... porque eu vejo aquelas motoserras derrubando aqueles monstros daquelas árvores, me dá um aperto no coração, eu fico com dó, fico com dó mesmo, de ver o que eles fazem, uma árvore daquela..." (5.3)

\section{Sendo o meio ambiente atual melhor}

Avaliam o meio ambiente atual como bom e melhor do que no passado, existindo mais assistência à população e cuidado maior com o meio ambiente (quadro 6)

"Era, a natureza era boa. Agora também, está melhor, agora também, porque agora esta, está cuidando, antes não cuidava nada né....ninguém cuidava da, da natureza de primeiro..." (6.4)

"Eu acho que está melhor, está melhor. Porque a gente vê mais limpeza né, entendeu? Essas rua aí mesmo quase, aqui na Vila Maria não tem, mais aí pra cidade, quase todo lugar tem pessoa limpando, num é verdade? Naquele tempo não tinha isso não, num tinha." (21.3)

“É em parte está melhor, tem mais assistência..." (12.13) 
O outro tema associado ao fenômeno 1, ANIQUILANDO A VIDA, é: ANIQUILANDO A FERROVIA E DESOLANDO OS FERROVIÁRIOS (TEMA B).

O tema “Aniquilando a ferrovia e desolando os ferroviários” está associado ao fim da ferrovia e ao abandono e depredação atual do patrimônio da ferrovia. Acreditam que o que levou a este fim foi a estagnação de investimentos e de recursos para a ferrovia, por não ser bom o desempenho dos governantes, e a valorização das rodovias, que ameaçavam as ferrovias. Os ferroviários passaram a perder o prestígio e ter menor remuneração, ficando tristes e sentindo saudade do passado, tendo vontade de voltar a trabalhar se tudo fosse como antes e se tivessem cuidado até hoje do que restou da ferrovia.

As categorias que compõem este tema são: - Destruindo todo o patrimônio da ferrovia, - Estagnando investimentos e recursos para a ferrovia, - Perdendo prestígio e remuneração, - Despertando tristeza e saudade, - Não sendo bom o desempenho dos novos gestores, - Sendo a ferrovia ameaçada pelo crescimento das rodovias (diagrama 10)

"Mas, mas na maioria já foi tudo, já foi tudo embora. Então até o Governo fica preocupado em querer tirar essa complementação da gente, entendeu? Mas não precisa de tirar! Eu estou com 88 anos, 85 anos, daqui a pouquinho eu...3, 4 anos aí, acabou né. E assim, e assim os demais, não é verdade? Então não precisa tirar nada de ninguém! Deixa aí!" (2.4/5)

“E agora, os ferroviários estão acabando tudo." (9.7)

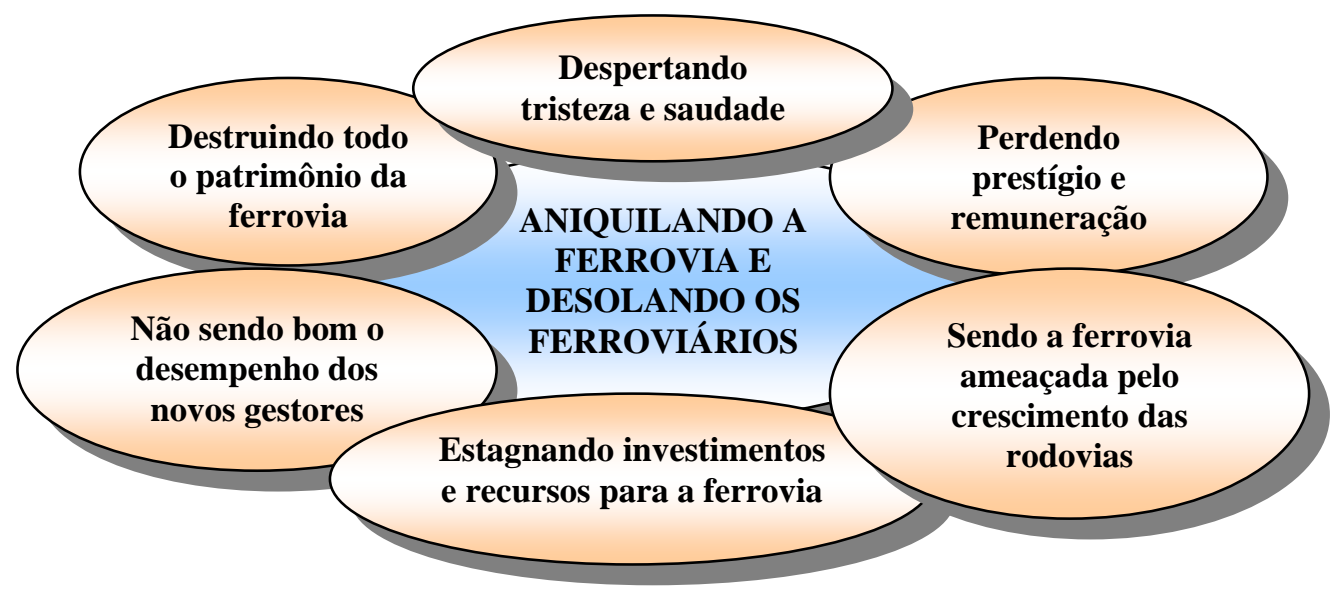

Diagrama 10 - Tema B - Aniquilando a ferrovia e desolando os ferroviários: Categorias. 


\section{Categoria B1 - Destruindo todo o patrimônio da ferrovia}

Comparam todo o cuidado que se tinha com a ferrovia antes e denunciam que, hoje, está tudo abandonado, destruído, que até os fios dos trens elétricos foram roubados (quadro 7).

"Gostava! Gostava da locomotiva bem limpa, bonita!" 12.3

“...pica aí tudo e vende pro ferro velho, aproveita o dinheiro. agora fica aí ladrão fazendo bagunça, aí" (19.5)

"O movimento era grande, só nesse depósito... que judiação tá as traça, lá" (5.2)

\section{Categoria B2 - Não sendo bom o desempenho dos novos gestores}

Culpam o péssimo desempenho dos governos do Estado de São Paulo, como responsável pelo fim da Estrada de Ferro Sorocabana, desempenhando uma má administração conjuntamente com a corrupção (quadro 8).

Subcategorias: - Aumentando desnecessariamente o número de funcionários, Difamando a ferrovia (diagrama 11).

"Má administração, porque olha, essa ferrovia quem viu como a gente viu, que era isso e deixar morrer como deixaram, é tudo má administração, os nossos governantes enterraram isso aí pra poder restabelecer ou sustentar as companhias de ônibus, né." (25.10)

"Foi em 70... não, eu aposentei em 71, é acho que foi em 73, 74 por aí foi caindo, caindo, caindo, acabou tudo." (12.17)

“... depois começou fracassar o negócio, mais aí começou o roubo, o roubo, começou com aquele lá de Campinas: Quércia. O Quércia começou a roubar (...) quem ajudou muito a ferrovia foi o Ademar de Barros e o Getúlio Goulart, esses dois ajudaram muito a ferrovia, se eles estivessem vivos hoje num estava desse jeito aí como você está vendo, estava tudo funcionando..." (19.4)

“... quem acabou com as ferrovia mesmo foi o Covas, é o Covas aí. Onde já se viu esse patrimônio, um patrimônio desse aí, o patrimônio da Sorocabana num tinha o que pagasse..." (12.17)

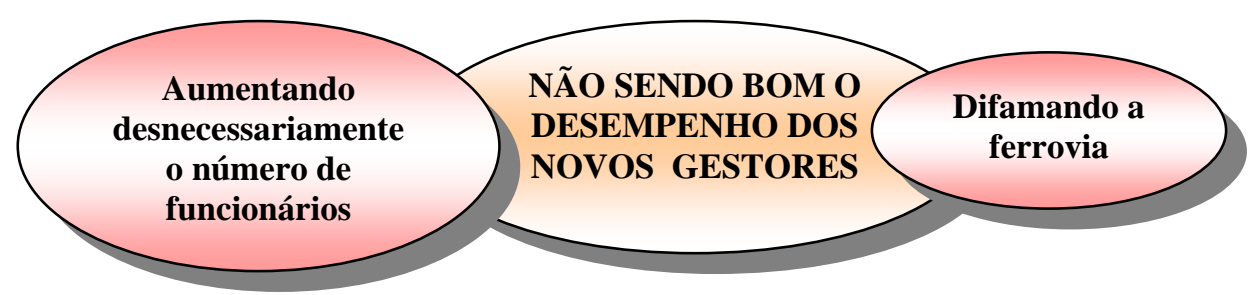

Diagrama 11 - Categoria B2 - Não sendo bom o desempenho dos novos governantes: Subcategorias. 


\section{Aumentando desnecessariamente o números de funcionários}

Relatam que foram criando muitos cargos e chefias, funcionários entrando por politicagem, e aumentando excessivamente o número de empregados de forma desnecessária, principalmente após a transformação em FEPASA (quadro 8).

“. não tinha aquela imensidade que nem quando criou aí na Fepasa, encheu de chefe, gente aí que não sabe o que é ferrovia, é aposentado como chefe de

licitação aí da ferrovia. No tempo da Sorocabana não, quando uma pessoa pra ir a chefe era que estava necessitando de um chefe pra aquele cargo ali mesmo. Aí depois encheu aí, aquilo acabou com a gente ..." (12.17)

“... e um dia eu fui em São Paulo e precisei ir na Barra Funda, naquele tempo ainda, ainda estava na estrada. Cheguei lá, fiquei num lugar ali, entra gente, entra gente, entra gente, entra gente, entra gente...Fiquei 2 horas vendo passar gente, ai custou ver um conhecido meu de Botucatu, aí conversei com ele, fomos tomar café no bar, perguntei pra ele: escuta, tem lugar pra todo essa gente trabalhar? Ele disse:

Mário, não tem, eles rasgam um papel, olham uma gaveta, as vezes tornam a rasgar, e assim é, levanta vai no mictório, vai fumar, vai aqui pra li... é mais fácil dispensar um de nós daqui do que qualquer um desses um aí que entraram por política. (...) Isso já nos dia quase atuais viu, 83, por isso que eles recolheram tanta gente. Um dia apareceu a comissão dos ferroviários lá: - escuta a folha não vai dá... Vai recolhendo, vai recolhendo... Eles recolheram gente até, até acabar o nome, até acabar o nome de ferrovia né." (17.11/12)

\section{Difamando a ferrovia}

Referem que existia uma difamação política da ferrovia, dizendo que a EFS não era rentável e acarretava prejuízo, mas os entrevistados discordam desta afirmação (quadro 8).

“... eles achavam que a ferrovia estava dando prejuízo, mas num estava dando prejuízo coisa nenhuma, a ferrovia além do frete ser mais barato, né, entregava certinho na casa..." (19.4)

“... porque fala que a Sorocabana dava prejuízo (nt), o que acontecia no meio da Sorocabana era muita política, entendeu, muita política. Por exemplo, havia muito interessado em acabar com a ferrovia..." (15.3)

\section{Categoria B3 - Estagnando investimentos e recursos para a ferrovia}

Relatam que começaram a investir menos na ferrovia, recebendo menor verba e tendo menos propaganda, em comparação com a rodovia. A ferrovia continuou utilizando uma tecnologia ultrapassada, demorando mais o transporte, sua construção e podendo ter acidentes, sendo atualmente subtilizada e sem manutenção. 
As subcategorias que compõem esta categoria são: - Recebendo menor verba e tendo pouca propaganda, - Sendo subtilizada a ferrovia atualmente e sem manutenção, - Utilizando tecnologia ultrapassada e demorando o transporte, Gerando menos emprego (diagrama 12).

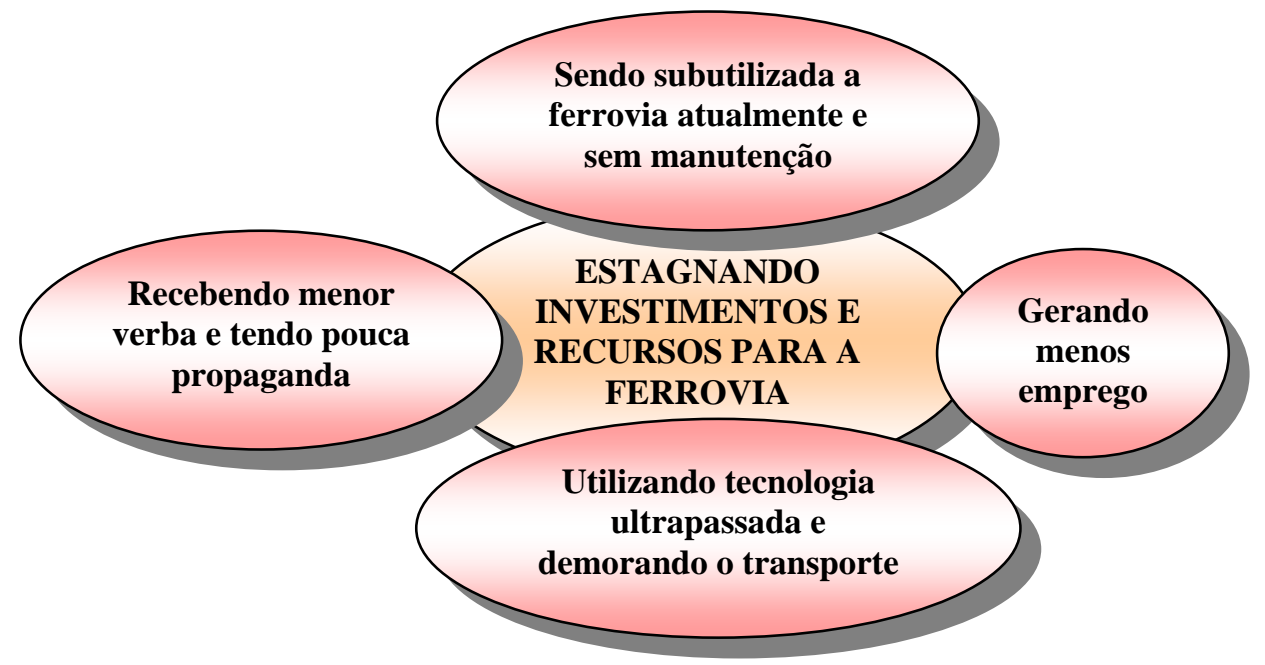

Diagrama 12 - Categoria B3 - Estagnando investimentos e recursos para a ferrovia: Subcategorias.

$\underline{\text { Recebendo menor verba e tendo pouca propaganda }}$

Observaram que a verba recebida pelas ferrovias era menor, prejudicando seu desenvolvimento. Além disto, a ferrovia nunca foi alvo de muita propaganda, deixando-a pouco visível (quadro 9).

“... mas sempre ficou a quem do que poderia ter sido por falta de investimentos, ferrovia desenvolveu em todo o mundo, mas aqui não..." (24.15)

“Infelizmente a ferrovia, ela, ela não tem assim um... que tem por exemplo a rodovia, no tocante a propaganda aqui, que o governo faz na rodovia todo mundo vê e a ferrovia ninguém sabe de nada o que foi feito pra ferrovia né! Então a ferrovia era tida por centro de despesas, uma incógnita né!" (24.6)

“... problema político porque se faz na rodovia todo mundo vê, na ferrovia não...” (24.10)

$\underline{\text { Sendo subtilizada a ferrovia atualmente e sem manutenção }}$

Revelam que a ferrovia está sendo subutilizada atualmente, transportando só cargas, e sem receber manutenção, representando até risco para o transporte (quadro 9).

"É, agora... aquele tempo transportava tudo, mais agora, agora ficou mais só carga..." (17.11) 
“... passei aí na linha do... eram todos podres os dormente, um perigo está lá viu, descarrilhar trem." (11.2)

“...aí está completamente abandonado né, porque né, eles não zelam pela linha nem nada. Num sei se está correndo trem, mais corre na sorte né, porque conservação de linha num tem..." (23.6)

\section{Utilizando tecnologia ultrapassada e demorando o transporte}

Julgam que a tecnologia atual utilizada nas ferrovias é semelhante a do passado, necessitando modernizar as ferrovias. Outro fator negativo para a ferrovia era o transporte muito demorado, por haver muitas curvas no trajeto, adotando-se um traçado da linha férrea muito antigo; no entanto, a viagem era prazerosa, tendo carro restaurante e orquestra. Além disto, havia problemas freqüentes com a locomotiva a vapor, atrasando ainda mais, e também acidentes, como tombamentos e descarrilhamentos (quadro 9).

Aparecem os seguintes elementos: - Demorando no transporte e na construção, - Existindo acidentes e problemas no transporte ferroviário.

“...até hoje é assim mesmo, aquele subúrbio que trabalha, que trabalha lá Júlio Preste, que é na paulista. Aquele subúrbio era aquilo lá mesmo, se vê nove, nove carros né, (...) quer dizer que nove carros, é três carros que comanda, é isso aí, cada um comanda três."

“... as firmas ganhavam por quilômetro de ferrovia construída né, é lógico que ganhavam por, por quilômetro de ferrovia construído, então eles diziam que procuravam esticar o máximo fazendo sinuosidade, mas num era por isso, era pra evitar grandes aterros né, então se desenvolvia mais em curva de nível, (nt) pra evitar cortes e aterros, pra não ter que por maquinário pra fazer corte e aterro, por isso que aconteceu isso né. Então formaram uns traçado muito antigos, ao contrário da rodovia..." (24.7)

“... porque, olha a senhora vê, nós saíamos de São Paulo com o trem lotadinho, ia a Porto Alegre. Esse trem, levava 72 horas, mais era uma viajem de alegria, ninguém achava ruim. Olha, tinha vez que no restaurante tinha até orquestra, e era uma verdadeira festa..." (25.10)

"Para que você veja, a locomotiva, ela fazia $30 \mathrm{Km} / \mathrm{h}$, depois quando vieram umas locomotivas novas, é americana, aí ela passou 35, e o trem de passageiro passou a 40, de 35 passou a 40, o de passageiro, aí diminuiu, porque dava 8 hora de Botucatu a São Paulo, levava 8 horas pra você ir a São Paulo, depois passou a 6 hora e 15 minuto, com as locomotivas novas, depois chegou a máquina elétrica, a elétrica mudo tudo." (8.4) 


\section{Gerando menos emprego}

Com os avanços da tecnologia, relatam que a necessidade de mão-de-obra na ferrovia foi diminuindo, podendo uma pessoa transportar e controlar sozinha a máquina, sendo desnecessário também o serviço de outros setores (quadro 9)

“... e eles queriam, agora, deixar um homem só na direção pra, pra... como que chama... como que chama... maquinista? É maquinista só, tal pessoa né, para economizar. Um aparelho controla (nt) 100 vagões. Antigamente era 10 vagões, 15 vagões carregados desciam, outro subia com 30 de carga, agora querem por 100 vagões, pra economiza, não adianta..." (26.7)

\section{Categoria B4 - Sendo a ferrovia ameaçada pelo crescimento das rodovias}

Percebem que o avanço das rodovias representou uma grande ameaça às ferrovias, pois havia muito interesse político para que as rodovias avançassem, além do transporte rodoviário ser mais rápido, assim como sua construção, embora mais perigoso.

As subcategorias que constituem esta categoria são: - Avanço das rodovias prejudicando as ferrovias, - Tendo interesse político nas rodovias, - Sendo o transporte e a construção da rodovia mais rápidos, mas perigosos (diagrama 13).

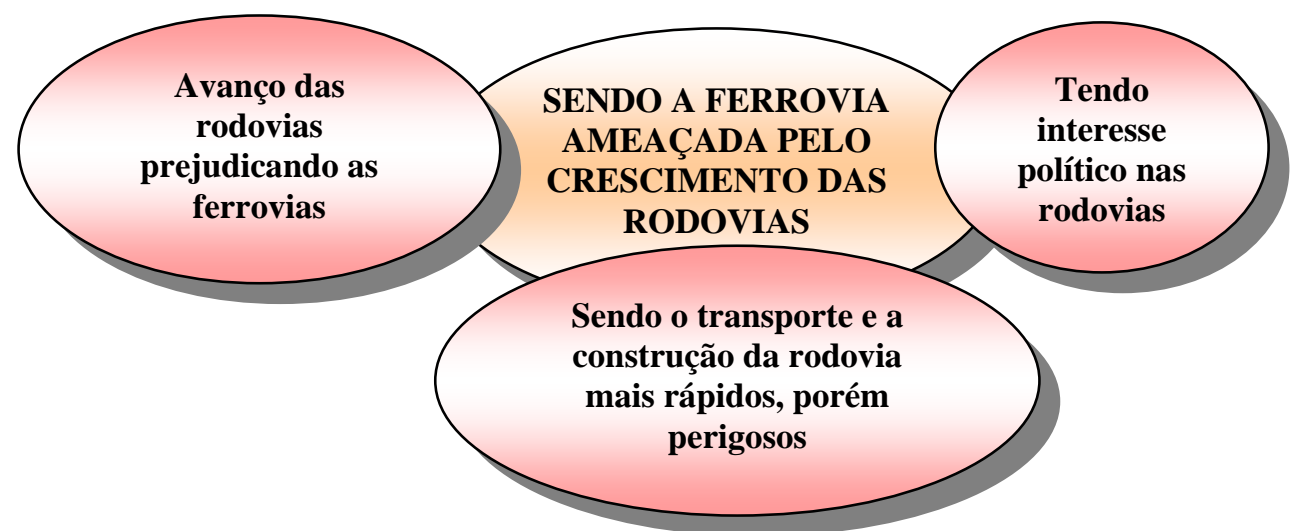

Diagrama 13 - Categoria B4 - Sendo a ferrovia ameaçada pelo crescimento das rodovias: Subcategorias.

Avanço das rodovias prejudicando as ferrovias

Culpam as rodovias por serem responsáveis pelo fim das ferrovias, não podendo mais competir com as indústrias automobilísticas e ônibus, que ganharam velocidade (quadro 10).

"É, a rodovia começou a correr mais que a ferrovia e a estrada de ferro acabou." 
Tendo interesse político nas rodovias

Revelam que existia muito interesse político e pessoal, interno e externo, para que as rodovias crescessem, como envolvimento de políticos donos de frotas de caminhões e a pressão do mercado externo de petróleo (quadro 10).

“... problema econômico internacional, cujo petróleo comanda né. É interessante você circular caminhões em vez de trens, você paga roialts pra fora..." (24.10)

“...o que acontecia no meio da Sorocabana era muita política, entendeu, muita política. Por exemplo havia muito interessado em acabar com a ferrovia (...) A primeira coisa que eles fizeram foram fechar Porto Epitácio, Porto Epitácio transportava muita mercadoria para São Paulo, fecharam Porto Epitácio por quê? Alguém que tinha cota de caminhão pra transportar isso aí, a verdade é isso ai..."

Sendo o transporte e a construção da rodovia mais rápidos, porém perigosos

Alegam que o transporte rodoviário é mais perigoso que o ferroviário, podendo ter acidentes mais graves e roubos. A rodovia tem a vantagem de ser construída mais rapidamente e de forma planejada (quadro 10).

“... os caminhões, esses monstros de caminhões aí nas estradas aí, vão estragando as estrada porque o asfalto não agüenta, e os acidentes, horror de acidentes que morre gente aí, ônibus lotado acaba morrendo tudo aí..." (12.17)

"Pega o traçado, por exemplo da Castelo Branco né, moderníssimo né, e a ferrovia não. Por exemplo, entre São Manuel e Rodrigues Alves, aqui no, no ramal de Bauru, tem no trecho de 10 quilômetros tem 44 curvas, fechadíssimas, em 130 metros, pra você ter uma idéia, as curvas rodoviárias tem na ordem de 1000 metros, 1000 e poucos metros né, então a velocidade está limitada por causa da curva, então você não tem como concorrer, o transporte de passageiro daqui a São Paulo você não consegue competir com a rodovia, porque você leva, quanto, daqui lá a São Paulo, 3 horas e pouco, de ferrovia você num consegue menos que isso, de carro vai bem menos né." (24.7)

\section{Categoria B5 - Perdendo prestígio e remuneração}

Comparam que, antes, o ferroviário tinha prestígio, era valorizado e tinha status social, hoje, perdeu-se tudo. Inclusive, o salário, que ficou muito defasado após a aposentadoria e há anos contam que não têm aumento (quadro 11).

“... quando eu aposentei, o meu salário era aquele lá, agora você soma o que a ferrovia paga e o INPS paga, se passa do limite que está ali, eles cortam aqui, pra ficar sempre naquele mesmo nível. E outra coisa, foram conversar com um governador lá pra ele não descontar mais isso aí que, sabe o que ele respondeu pro deputado que foi lá? Que o estado num tem ferrovia... estado num tem ferrovia, e de fato num tem mesmo né? "(30.14) 
“... a gente tinha uma, como se fala uma, uma posição boa. É o ferroviário naquela época era o seu fulano, hoje, agora, não é mais nada né. Você vê como é que está acabando tudo né, mais nós tivemos nossa época de, de ouro vamos falar, a gente chegava num lugar qualquer dizia que ia fazer uma compra, dizia que era ferroviário (nt), tinha crédito em tudo. A gente ganhava, o dinheiro tinha valor, a gente ganhava bem, então tinha aumento normal, quer dizer, a gente fazia greve... tudo essas coisa, achava que vinha de graça?" (30.12)

\section{Categoria B6 - Despertando tristeza e saudade}

Sentem tristeza e dó ao ver a situação em que se encontra a ferrovia atualmente, tudo acabado e abandonado. Hoje, sentem muita saudade da época em que trabalhavam, querendo voltar a trabalhar se tudo ainda fosse como antes. Um ferroviário relatou que vai todos os dias da semana, no período da manhã e no de tarde cuidar até hoje do que restou da estação, onde tem uma sala que guarda seus apetrechos de limpeza (quadro 12).

“... acabou tudo e a gente que viveu isso não acredita..." (12.15)

"Até hoje tenho saudades, e sonho com meu serviço, sonho com o serviço, o serviço sempre embaralhado, mas quase toda noite eu sonho com meu serviço, sonho..." (22.2)

“É... Sorocabana foi, foi uma mãe... dá dó de vê aquilo lá tudo acabado né! Nossa senhora!" (28.2)

"Pra quem trabalhou 30 anos ali e vê hoje do jeito que está, olha...é judiação viu." (10.7)

"Eu acho que sim, sabe que hoje, por exemplo, encontro muitos funcionários da época que eu trabalhava né, e sempre que a gente se encontra, naquele momento, fica com saudades da ferrovia né, e a gente batendo papo com eles, a gente vê que eles gostavam muito da ferrovia, por exemplo, gozado, um negócio meio místico viu. Você não observou isso conversando com o pessoal? Gostam da ferrovia que é uma loucura, parece que a ferrovia é deles." (24.11)

“... se a Sorocabana não tivesse morrido, se o governo não tivesse acabado com a Sorocabana, com a Fepasa, eu estaria até hoje lá, aí eu ia trabalhar uns 40 anos lá, estava trabalhando até agora." (22.3)

"Todo dia nesse horário eu estou aqui, quando for 11:00h pego o ônibus e vou embora pra casa. E volto a tarde (para a estação)" (19.5)

\subsection{2 - Fenômeno 2 - GERANDO VIDA}


O segundo fenômeno, GERANDO VIDA, emerge em oposição ao primeiro, que aniquilava a vida.

Neste fenômeno 2, GERANDO VIDA, aparecem os fatores que favorecem alcançar uma maior longevidade, segundo a concepção dos ferroviários longevos entrevistados. Entre eles, temos: adotando um estilo de vida saudável e sociável; convivendo em um habitat harmônico e sem poluição; envolvendo-se com o trabalho e tendo renda para se sustentar; sendo e estando tranqüilo e feliz; apresentando fatores biológicos e genéticos favoráveis. Pontuam também fatores que podem ter contribuído para a longevidade dos ferroviários, que vêm reforçar os anteriores. Também descrevem como a saúde pode ser influenciada pelo meio ambiente, sendo a poluição prejudicial à saúde e sendo esta melhor em locais com maior área verde. Outro tema dentro deste fenômeno trata das riquezas geradas pela ferrovia, levando o desenvolvimento e progresso às cidades.

Existem quatro temas associados a este segundo fenômeno: - Favorecendo alcançar maior longevidade, - Meio ambiente influenciando a saúde, - Ferrovia gerando riquezas, - Observando fatores que podem ter contribuído para a maior longevidade do ferroviário (diagrama 14)

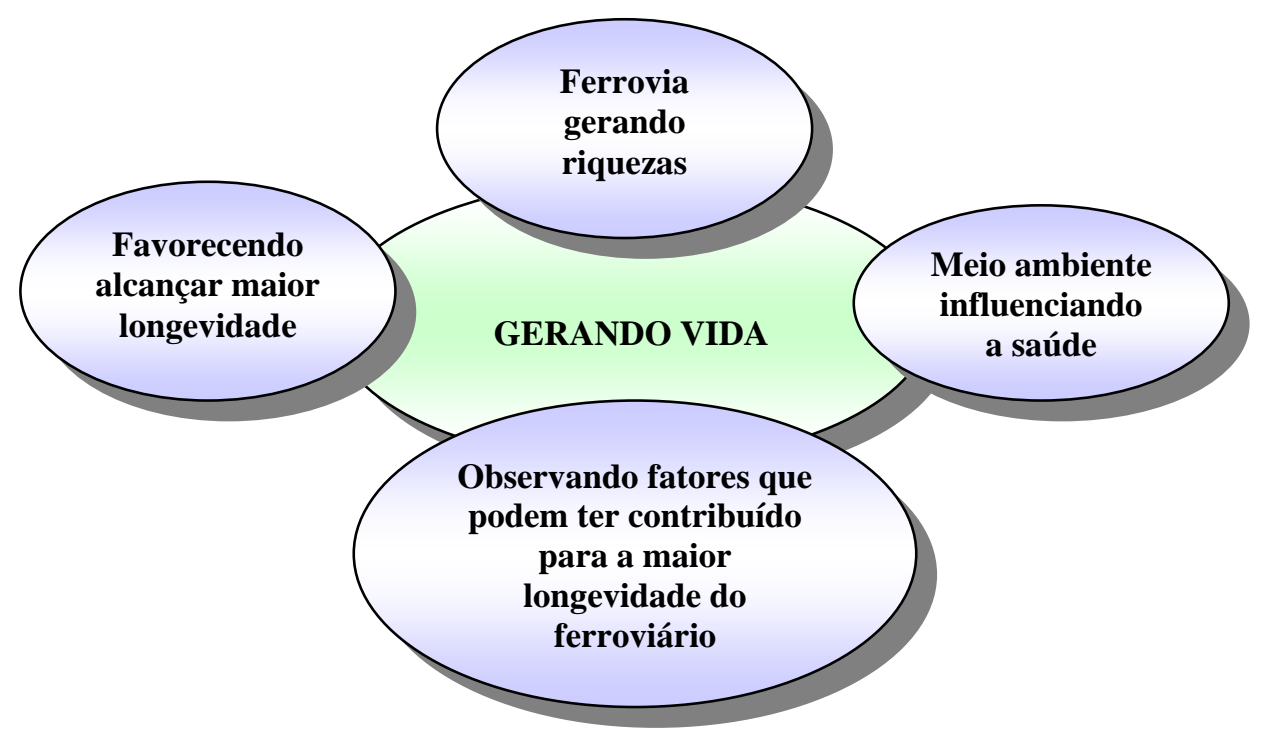

Diagrama 14. Fenômeno 2 - Gerando vida: temas.

O primeiro tema que aparece associado a este segundo fenômeno, GERANDO VIDA, é: - FAVORECENDO ALCANÇAR MAIOR LONGEVIDADE (Tema C) 
Os entrevistados acreditam que o segredo para se alcançar uma maior longevidade é adotar um estilo de vida saudável e sociável: mantendo-se ativo física e mentalmente, com pensamentos positivos; tendo um sono regrado; não tendo vícios e não sendo extravagante; tendo hábito alimentar saudável, e relacionando-se bem com as pessoas e a família. Outros fatores apontados como importantes são: crendo no espiritualismo; sendo e estando tranqüilo e feliz; possuindo fatores biológicos e genéticos favoráveis; envolvendo-se com o trabalho e tendo renda para sustentar-se, sendo a aposentadoria um desestímulo à vida. Além disto, são fatores positivos: convivendo em um habitat harmônico e sem poluição da água, do ar, com estabilidade climática, apreciando os bons estímulos da natureza, assim como sentindo prazer nas ações realizadas.

Existem várias categorias associadas a este tema: - Adotando estilo de vida saudável e sociável, - Não existindo consenso se habitat harmônico e sem poluição é positivo para a longevidade, - Sentindo prazer nas ações realizadas, -Envolvendo-se com o trabalho e tendo renda para se sustentar, - Crendo na espiritualidade e na sorte, - Sendo e estando tranqüilo e feliz, - Possuindo fatores biológicos e genéticos favoráveis, - Controlando a própria saúde, - Percebendo vários fatores associados (diagrama 15).

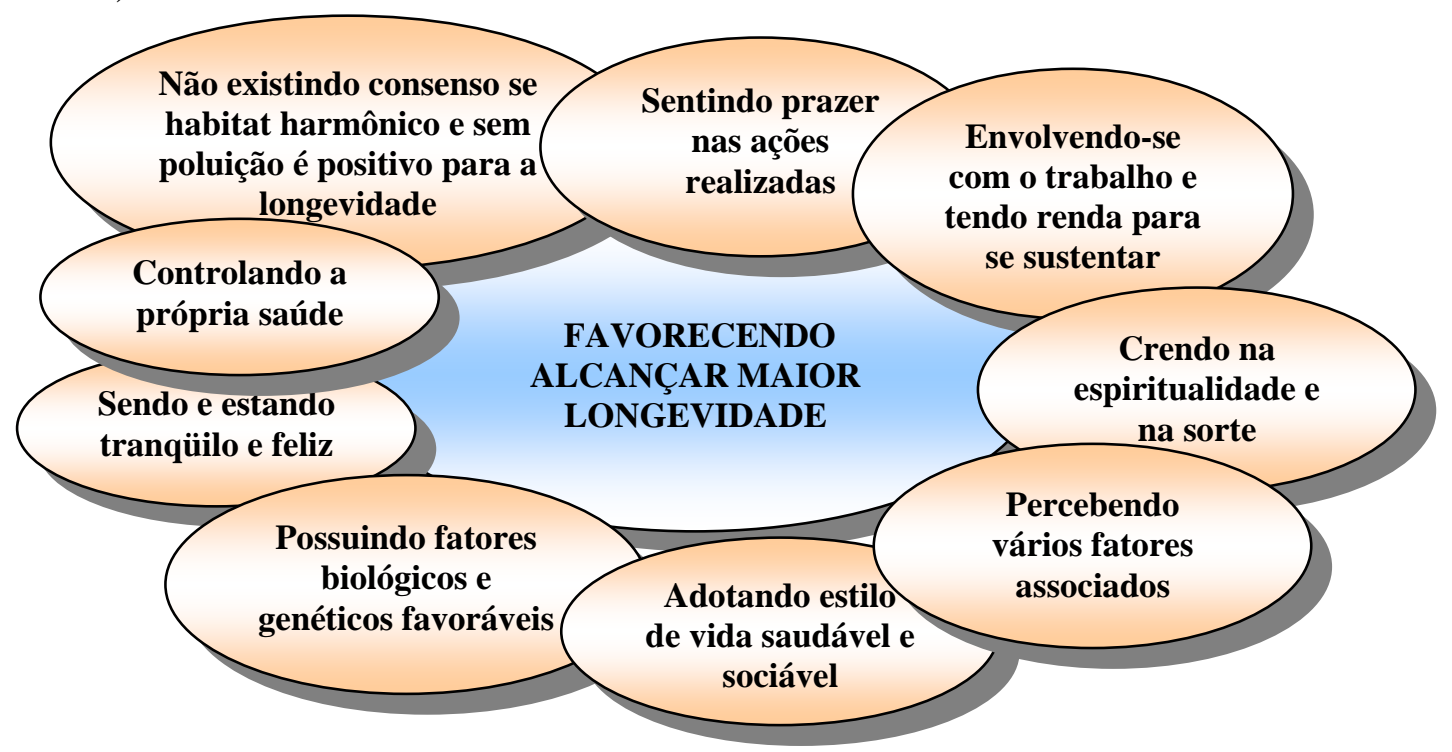

Diagrama 15. Tema C - Favorecendo a alcançar maior longevidade: Categorias. 


\section{Categoria C1 - Adotando estilo de vida saudável e sociável}

Os entrevistados acreditam que é necessário manter-se ativo física e mentalmente e com pensamentos positivos, relacionando-se bem com as pessoas e a família. Além disto, consideram importante ter um sono regrado, adotar um hábito alimentar saudável e, principalmente, não ter vícios e não ser extravagante (quadro 13).

As subcategorias que apareceram foram: - Mantendo-se ativo física e mentalmente e com pensamentos positivos, - Tendo um sono regrado, - Não tendo vícios e não sendo extravagante, - Tendo hábito alimentar saudável, - Relacionandose bem com as pessoas e com a família (diagrama 16).

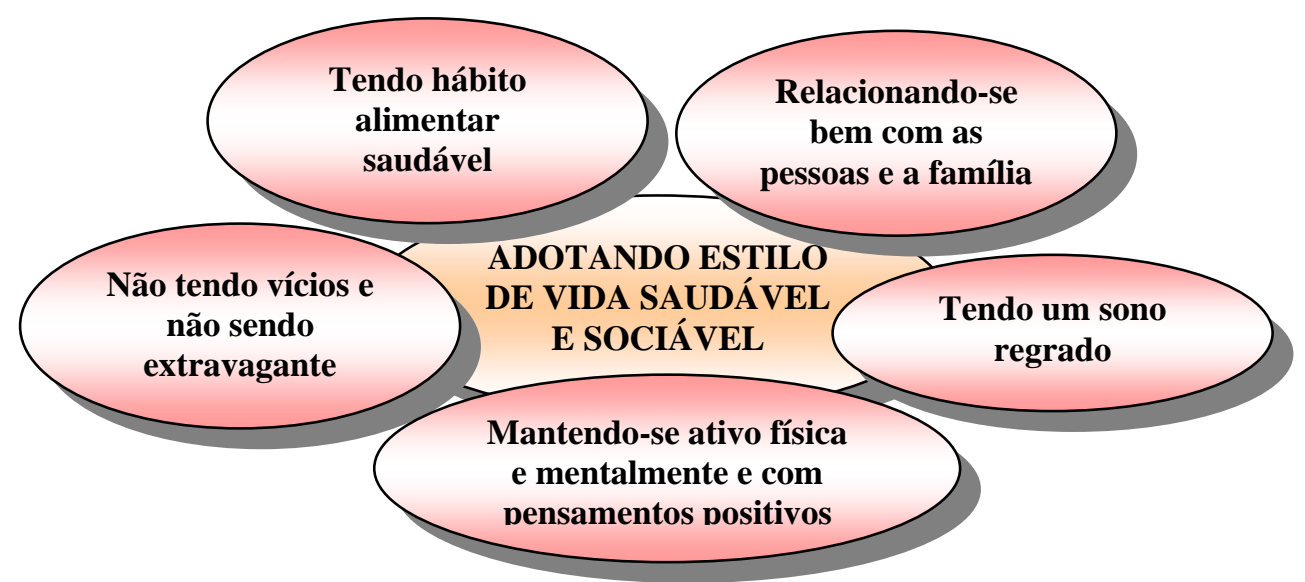

Diagrama 16. Categoria C1 - Adotando estilo de vida saudável: Subcategorias.

Mantendo-se ativo física e mentalmente e com pensamentos positivos

$\mathrm{O}$ primeiro fator remete à atividade física e mental, assinalando que é importante a pessoa manter-se sempre ativa, fazendo atividade física, como caminhadas, e nunca ficar parada dentro de casa, procurando sempre estar disposta a fazer outras atividades. Os ferroviários longevos destacam a importância da atividade mental, dizendo que o segredo para se viver bastante é sempre exercitar a mente, mas não com pensamentos ruins ou preocupações que prejudicam (quadro 13).

“... e outra, fazer os exercícios físicos também que é importante, né..." (15.8)

"Acho que tem que movimentar as coisa, tem que andar, não pode parar, sempre tem que ter uma preocupação para o cérebro funcionar. Minha paixão é o Palmeira, quando Palmeira perde é uma tristeza." (18.7) 
"É usar a mente eu acho, uma vida sadia (nt) atividade física né, e a mente, eu acho que a mente influi barbaridade, pelo menos, (nt) sem pensar em doença né, mais se você pensar em ficar doente você fica, você sem pensando num fica viu. Eu acho que deve existir uma relação muito estreita entre ambiente e o corpo que funcionando harmoniosamente daí tudo bem e vice versa né, por motivo assim, a mente pode ser afetada e vice versa. E outra, ficar tranqüilo, num esquentar muito a cuca não, tem gente que se preocupa com tudo né, nunca vi coisa igual né, eu não me preocupo com as coisas não." (24.11)

"Ter consciência... imaginação da gente, se você nunca pensar em mal, você vive um século, o que deixa a gente fracassado na vida é o pensamento..." (28.6)

\section{Tendo um sono regrado}

Eles valorizam a importância de dormir bem, indo cedo para a cama e não perdendo noites de sono em passeios (quadro 13).

“... agora você vê, tem que dormir cedo, dormir cedo. Essa noite não, não é a noite, eu gosto muito de calor, muito calor eu durmo a vontade na minha cama. Então dorme sempre cedo o máximo aí 9 horas eu já estou deitado, agora amanhã cedo 6 horas eu já estou acordado, já ponho o café pra ferver, já saio na padaria..."

"Nunca fui em noite, nada dessas coisa, sempre só no trabalho, em casa, trabalho, em casa, só." (3.6)

"Quando era mocinho, 9 horas meu pai colocava a gente para dormir, nem esperava chegar para falar, senão dava surra..." (29.2)

\section{Não tendo vícios e não sendo extravagante}

Associam a maior longevidade ao fato de não terem vícios e não serem extravagantes. Julgam que o vício, como beber e fumar, prejudica a saúde e pode encurtar a vida. Colocam que ser extravagante (fazer bagunça, jogar, fumar, beber) estraga a vida e faz viver menos, deve-se ter disciplina e comportar-se bem. Justificam isto apontando que os ferroviários que tinham vícios ou vida extravagante já morreram todos (quadro 13).

“Não fumar, nem beber, dormir cedo, não fazer besteira... difícil né?” (29.2)

“... eu acho que evitar coisas né, por exemplo: cigarro, a bebida forte, eu acho que isso aí, estraga tudo com a saúde da gente. Agora, essa droga que não conhece porque veio depois né, no meu tempo não existia nada disso, graças a Deus, mas a bebida e o cigarro sempre, sempre fez mal, mas as pessoas não ligavam né, hoje já está evitando mais, né." (4.5) 
“...mais tem uns que, já lá no começo, começa a beber, começa a estragar a vida, o sujeito estraga a vida porque quê, num é mesmo, estraga a vida porque... nós, nós sim estragamos nossa vida porque nós queremos..." (27.11)

"Depende, depende, porque desses indivíduos que eu falei com a senhora que entraram comigo, a maioria morreu tudo novo, porque nunca se cuidaram, está entendendo? Bebiam, fumavam, então, a maioria morreu tudo...novo, entendeu? Bebiam demais, então, o que estraga a pessoa é a bebida e o cigarro, eu acho que pra...eu penso assim: o que debilita uma pessoa é a bebida e o cigarro, e a extravagância que o sujeito faz né, agora, o sujeito sendo, sabendo se comportar, sabendo.... então." (3.6)

\section{Tendo um hábito alimentar saudável}

Relacionam que ter uma alimentação de qualidade - com frutas, leite e alimentos bem selecionados, conforme a escolha da pessoa, evitando gordura - e não faltando comida, garantem uma maior longevidade (quadro 13).

"Porque quem morre primeiro são os mais gordos, os mais gordos deviam ir primeiro. Deviam ser primeiros, eles se aposentavam e não se mexiam, e porque... era que nem porco, ia engordando, morriam mais cedo e a gordura prejudica o coração né." (4.6)

“... era tudo bom né, o alimento daquele tempo era bom, arroz, feijão, tudo, tudo as coisas eram, eram melhores. Na cooperativa a gente tirava Bacalhau, carne seca, lingüiça de todo o tipo tinha, a gente tirava né, tirava dava pro mês inteiro, sempre comia bem né... sempre comia, fora a mistura da horta, comia repolho, tomate, cebola, pimentão." (28.7)

"Eu acho que a primeira coisa é comer bem... Comer a comida que você gosta, que não faz mal, tem coisa que faz mal comigo, não faz mal pra você, não é verdade?"

\section{$\underline{\text { Relacionando-se bem com as pessoas e com a família }}$}

Acreditam que é importante não fazer ou não desejar o mal ao próximo e não se preocupar com a vida alheia. É importante procurar ter um bom relacionamento social e familiar, tendo boas amizades (quadro 13).

"Acho que tem que ser uma pessoa, não se preocupar com nada de mais, se não puder fazer o bem pra uma pessoa não fazer o mal. Andar sempre com a consciência tranqüila, sossegado, de encontro com as pessoa, se a pessoa passar perto e num olhar pra mim, eu também não ligo, não faço conta, não levo a sério, se me tratar bem eu trato bem também. Eu acho que é isso aí e evitar o máximo de arrumar encrenca, arrumar encrenca..." (12.15/16)

“...começou pensa mal, desejar mal pros outros, essas coisas, num presta (nt) se eu não puder fazer o bem, mal também não faço para ninguém..." (28.6) 
“... eu acho que a vida, o segredo de viver bem é a gente não ligar pra vida do outro e ver a da gente né, o que eu estou fazendo de bem, de mal, procurar se emendar também,né." (25.9)

“... ter uma, participar de uma boa sociedade, pra conversar...” (26.6)

“... boas amizades, é muito importante, convivência com a família também, né” (15.8)

\section{Categoria C2 - Não existindo consenso se habitat harmônico e sem poluição é positivo para a longevidade}

Um grupo dos entrevistados acredita que existe associação entre meio ambiente e longevidade, percebendo que o ambiente mais controlado e o modo de criação interferem, sendo que a contaminação do ambiente leva ao envelhecimento precoce. Destacam que as pessoas que têm mais contato com a natureza, como quem mora no sítio, têm possibilidade de viver mais. Vale ressaltar que alguns julgam não ter associação entre meio ambiente e longevidade, justificando que a longevidade depende de cada organismo ou que a idade é predestinada, além de se classificarem como leigos e não podendo opinar (quadro 14).

As subcategorias que aparecem são: - Sendo difícil avaliar, pois condições ambientais no município sempre foram boas, - Associando instabilidade climática ao adoecimento, - Bons estímulos da natureza gerando vida, - Achando que a longevidade não sofre influencia do meio ambiente (diagrama 17).

"Eu acho, dúvida nenhuma, dúvida nenhuma, o ambiente é o principal da vivência da vida de qualquer pessoa, isso... o principal disso é o ambiente, não é mesmo, esse é o primeiro passo, número um, eu acho que é, né. Que a alimentação põe em segundo plano, eu acho que o primeiro, pra mim no meu entender, primeiro é... eu acho que é o ambiente." (15.9)

“... o meio ambiente é o viver né, é as pessoa que vivem, agora tem....tem pessoas que vivem melhor e tem outras pessoas que vivem mais ou menos, isso depende da.....do modo da família que cria os filho, isso já vem dos modo que se...que a gente vê né..." (8.5)

“... daqui 10 anos uma moça de 30 anos, ia pro hospital com 30 anos, é bem velhinha, já é bem velha, porque a natureza está muito, muito fracassada minha filha, a natureza está muito difícil, as coisa estão muito difíceis, muita contaminação, em todos os sentidos, não é contaminação de água, nem de comida não, em todos os sentido, contaminação..." (27.12) 
“... por exemplo, se você tivesse a oportunidade, por exemplo, de ir num sítio, num lugar, numa água cristalina, que a água, água corrente, acho que tem possibilidade de você viver mais, acho que tem sim, acho que deve ter... porque ali (nt) tem mais possibilidade, tem mais possibilidade, porque num sabe, e que nem contaram o caso da... da Unesp de novo, meu médico falo: se o você olhar naquele canto no microscópio pra você vê, você vê quanta coisa ruim que tem aqui. Num sítio não, num sinto ruim não, eu sinto a terra, a terra devolve tudo, a terra devolve tudo, devolve tudo, a terra absorve... absorve tudo, ela absorve tudo, absorve coisa ruim e coisa boa, o que caí na terra ela absorve, até ferro ela dissolve, tudo. Então no sítio acho que é melhor do que aqui, no sítio acho que é melhor, tem, tem condição

(nt)... se lembra que as pessoa antigas viviam aí 100 anos, 90 anos." (27.13)

"Num sei, num posso fala pra senhora, nessa parte eu num... eu sou meio leigo... leigo não, eu sou inteiramente leigo nessa parte..." (30.14)

"Não... não a natureza, a natureza é pra você, por exemplo, se você tiver um destino de viver 80 anos, ou 90 anos, você vive 80 anos... (nt) agora se você começar estravagar aí você num chega aos 80 , num chega nem os 60 . Muitos colegas meus num chego nem aos 60..." (27.12)

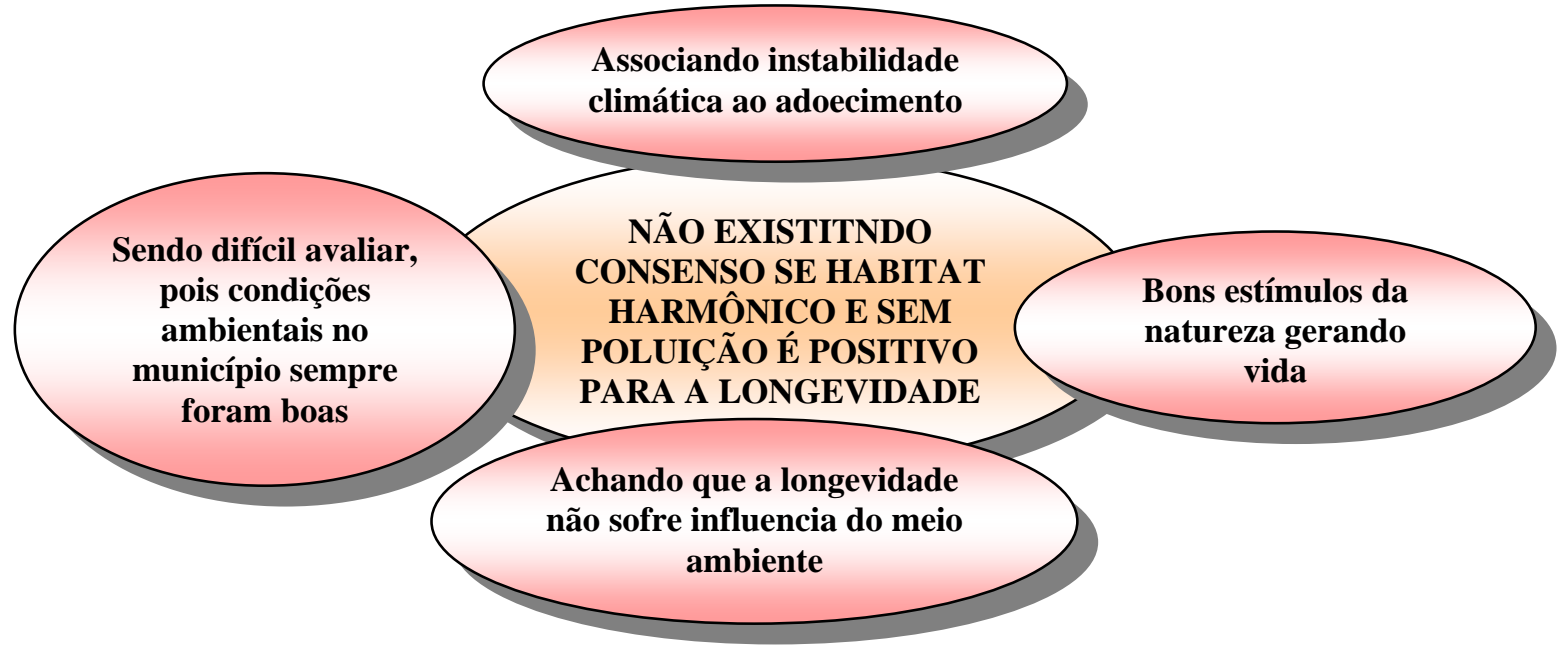

Diagrama 15. Categoria C2 - Convivendo em habitat harmônico e sem poluição: Subcategorias.

$\underline{\text { Sendo difícil avaliar, pois as condições ambientais do município sempre }}$

$\underline{\text { foram boas }}$

Acreditam que o ar puro e a água limpa são componentes importantes para a longevidade. Refletem que, para Botucatu, é difícil fazer esta comparação, porque a água e o clima da cidade sempre foram bons (quadro 14).

"A água ajuda muito viu, a água é... O ar puro não tem uma coisa melhor na vida da gente, tem que ser ar puro, você desce em São Paulo, você vê o ar de São Paulo, poluição, você vai no sítio é outra coisa." (14.7) 
"Porque tem que distrair, ter distração né,(nt) o meio ambiente, na mata, aí você vê o ar é outro, respira já é outro, do que na cidade, você nota a diferença, pode frequentar um lugar aí que o você vai notar a diferença, (nt)você mora ali no Jardim Paraíso, saí da cidade, saí um pouquinho pra você ver que gostoso."

"Aqui em Botucatu, eu acho que não. Eu acho que não, porque nosso clima é muito bom, né Dirce? É, aqui é ótimo. A água também é muito boa, a água daqui mesmo, que era poço, era água tudo de pedra embaixo... É o que estou dizendo, nós estamos sentados em cima de pedra (risos). Por isso que a água é boa! A água é muito boa! (4.6/7)

\section{Bons estímulos da natureza gerando vida}

Destacam que apreciar os bons estímulos que a natureza nos proporciona pode contribuir para uma maior longevidade. Consideram como bons estímulos o aroma do mato e da terra, as belezas da natureza, o conforto proporcionado pela mata, o som dos passarinhos, que trazem alegria, distraem as pessoas e aumentam a possibilidade de viver mais (quadro 14).

"Não por exemplo, que nem esse negócio das matas, tudo que eles estão cortando, a mata trazia mais, mais conforto pra turma e tudo né, e... ao passo do jeito que estão cortando, acabando com tudo, então vai, vai piorando a situação de todo mundo né." (23.6)

"Eu acho que sim, quando eu vou, entra no meio do mato, escuta o passarinho cantar, esquece até que é vivo, é uma beleza, aquele cheiro de mato, passarinho catando. Isso ai que dá a vida pra gente, viu. È uma maravilha, viu." (18.7)

"Faz viver mais sim, faz viver mais. Por que o senhor acha? Ah! Fica mais alegre, as árvores bonitas e você fica prestando atenção aquele ar puro, vem aquele cheirinho do mato, aquele cheirinho de terra gostoso, tudo isso... ah, não tem dúvida." (12.16)

\section{$\underline{\text { Associando Instabilidade climática ao adoecimento }}$}

Julgam que a instabilidade atual em relação as estações do ano favorece o adoecimento e a mortalidade mais precoce (quadro 14).

"Eu acho que é... A natureza, como se diz - ela é variável, né, variável como se diz, uma ora é calor, outra ora frio, não tem aquela temperatura certa né."(10.7) 


\section{Categoria C3 - Sentindo prazer nas ações realizadas}

Julgam que, se as pessoas fizerem só as atividades que gostam e dão prazer, tendo lazer também, aumentam as possibilidades de se viver mais, assim como os ferroviários desempenhavam suas funções na ferrovia com prazer e amor (quadro 15).

"...o segredo de viver bem, comigo eu trago isso da minha avó, minha vó gostava de tudo que era bom sabe, ela as vezes até tomava um golinho de pinga mesmo, 95 anos, ela ia pescar, ela gosta de andar, ela gostava de passear, ela gostava de comer bem, criava os frango dela próprio né, tinha pomar, sempre fruta, então eu acho que isso é a vida né." (25.9)

"Eu acho que é... se pudesse soltar mais a vida, solta mesmo, pra vale, a gente ia vive mais né. Soltar a vida de que jeito assim? É, fazer o que quiser." (6.3)

\section{Categoria C4 - Envolvendo-se com o trabalho e tendo renda para se sustentar}

Acreditam que o trabalho é importante no processo da longevidade, pois distrai e não permite que fiquem com pensamentos ruins. Além disto, julgam essencial ter uma remuneração e não ter dívidas. Ressaltam o papel negativo da aposentadoria na vida e destacam a questão da sabedoria como componente que leva a maior longevidade (quadro 16).

As subcategorias que compõem esta categoria são: - Aposentadoria gerando desestímulo à vida, - Valorizando o conhecimento adquirido (diagrama 18)

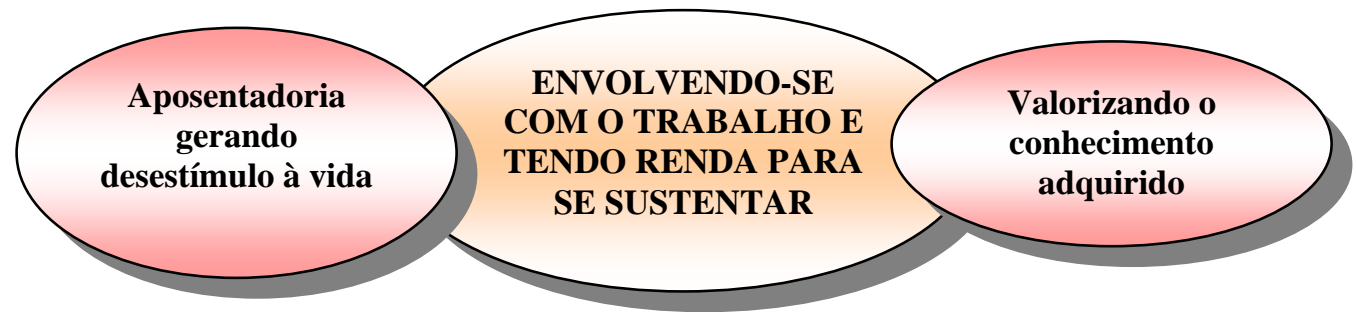

Diagrama 18. Categoria C4 - Envolvendo-se com o trabalho e tendo renda para se sustentar: Subcategorias.

\section{$\underline{\text { Aposentadoria gerando desestímulo à vida }}$}

Observam o papel negativo da aposentadoria, percebendo que muitos morrem logo que se aposentam, porque perdem a coragem, as amizades, começam a ter uma vida mais extravagante, bebendo, e vão perdendo a vida mais rápido (quadro 16). 
“...porque o camarada não queria aposentar, porque logo morria, é ferroviário é assim: ih! Vai aposentar, então vai morre logo, ... mais sabe que eu acho, o doutora, porque a pessoa aposenta fica sem fazer nada, fica abandonada, não é abandonada, perde a coragem, é como meu pai falava, já pensou perde a coragem? Aí não reanima mais, aí não tem. Então meu pai tem esse modo de pensar, num é porque, veja bem, o ferroviário na época aposentava, vivia de qualquer jeito, manda arruma, não sabia se era aposentado ou não, coisa e outra. Então meu pai foi contra sempre contra isso. Aposentou teria que continuar, não impecavelmente, mas sempre certinho, para nunca perder a coragem de boas amizades, uma coisa ou outra, então é isso aí que vai aniquilando a pessoa, agora fora isso aí, ter a vivacidade de como acabei de falar pra senhora, não (nt) mais normalmente uma coisa ou outra, vai daqui vai de lá bem arrumadinho, agora pega aí..., senta no jardim fica lá.... não é verdade? Fazendo o quê? Chega na hora lá vem almoçar, depois chega lá fica lá no jardim, fica lá vendo livro, vendo besteira, ouvindo conversa que num precisa ouvir... uma coisa ou outra...uma coisa ou outra...., agora não, agora por exemplo vai lá, vai em tal lugar, mas vai mais ou menos certinho, tudo bem, agora vai de qualquer jeito, não gostava disso, meu pai falava: olha Nestor, você se aposentando, meu filho, tenha cuidado viu, ande certinho, tudo bem, uma coisa ou outra, mas homem perdeu a coragem ele está liquidado." (17.7)

"Não, que o ferroviário poderia chegar num ponto aí pra ele se aposentar, ele já estava quase morto, muito serviço..." (19.6)

\section{Valorizando o conhecimento adquirido}

Acreditam que é importante para a longevidade ter sabedoria, ir adquirindo conhecimentos ao longo da vida para viver mais (quadro 16).

“... ter mais sabedoria, aquela coisarada toda, está dentro da... dos limite da gente de viver melhor..." (26.6)

\section{Categoria C5 - Crendo na espiritualidade e na sorte}

Associam a maior longevidade ao desígnio divino e à sorte (quadro 17).

"Aí, você fez uma pergunta difícil de responder. A minha irmã morreu com 55 anos, meu irmão morreu com 60, (nt) mas eu tenho muita fé de Deus, (nt). Mas, então tem uma verdade absoluta: só Deus." (20.5)

“...muitos colegas meu morreram tudo cedo, foi uma graça que Deus deu pra mim, porque o resto morreu muito cedo. Muitos colegas... " (1.2)

“... criançada tudo de um pai só uma mãe só, eles todos não chegaram na idade que eu cheguei, estou com 88, Deus é bom, eles deram menos sorte né, tiveram mais doença né." (16.6) 


\section{Categoria C6 - Sendo e estando tranqüilo e feliz}

Percebem o valor de ser e estar mais tranqüilo, mais sossegado, e criticam a correria diária das pessoas. Procuram ser e estar felizes, alegres, de bem com a vida, pois a tristeza representa a morte para eles (quadro 18).

"Sossego de vida, sossego de vida, você não pode prestar (nt), eu presto muita atenção nas coisa, invocar com as coisa eu num gosto... por exemplo minha filha faz um erro eu fico invocado com aquilo, em um estado de nervo, aquilo perde possibilidade de vida..." (27.10)

"Não ser muito alvorado, agora hoje em dia está ruim, porque sai na rua aí tem que correr e tudo, num tem mais jeito." (11.5)

"Pra viver bastante... olha pra dizer a verdade, tem que estar sempre alegre, disposto né, na nossa vida tem as partes alegres e as partes mais tristes né, mas não pensa só na tristeza, pensar na alegria no dia de amanhã, num é isso? " (15.8)

"Ser feliz... sabe o que que é? O segredo é esse... estar de bem com a vida. Eu sempre falo em casa, minha filha reclama muito né: - aí porque a UTI está cheia de criança, porque num sei que lá, minha chefe... Confia em Deus, e ele vai melhora a sua situação, mas se você num confiar nele, ele não vai te ajudar, né... e tenha a vida por feliz. Ah, porque fulana me olhou com cara feia... num dá confiança pra ela, viva sua vida, né... eu vivo bem com a vida viu... tristeza é morte..." (25.8/9)

\section{Categoria C7 - Possuindo fatores biológicos e genéticos favoráveis}

Fazem associação da longevidade com a variabilidade genética e individual, observando pessoas de uma mesma família que viveram bastante e, ao mesmo tempo, irmãos que morreram com diferentes idades. Fazem associação direta entre longevidade e saúde, ou seja, constroem um raciocínio lógico: se a pessoa tem saúde e não tem doença, vive mais. Destacam a importância de controlar e conservar a própria saúde, fazendo exames regularmente, cuidando do corpo, principalmente quando ficam doentes (quadro 19).

"Bom, um dia me perguntaram aqui uns parentes: sabe, o que você faz que, prá...pra ficar sempre assim? Eu não faço nada! (risos) Então é isso aí né. Eu acho que é, é isso aí, é, é congênito né. Que meu pai 96 anos, minha mãe 92, né, meus irmão também foram longe! E eu também estou indo, viu..." (2.4)

“... então acho que isso aí, vai de cada uma das pessoas né, que eu penso isso, sou eu que penso, a nossa vida é um livro cada dia passa uma página né. Uns o livro é menorzinho (nt). Minha mãe com 21 anos, minha mãe gostava da vida, eu me lembro de muita coisa que ela falava pra mim, apesar de eu ser muito novo, mais acho que o livro dela era tão pequeno que acabou logo né, e já minha irmã também morreu com 35 anos, agora eu já vivi mais do que meu avô, meu avô paterno, materno, meus filhos, ninguém chegou aonde eu cheguei, eu estou 
pensando que eu vou chegar aonde minha avó chegou né... pelo menos eu estou pensando assim." (25.9)

"O segredo... o segredo é a saúde né, o que interessa é saúde, saúde é o que interessa o resto não tem pressa, né." (19.6)

\section{Categoria C8 - Controlando a própria saúde}

Acreditam que é importante cuidar da própria saúde e do corpo, fazendo um checape, quando possível (quadro 20).

"A gente tem que se conserva né, o que estraga muito é extravagância, a gente se relaxa com o corpo né, fica resfriado num cuida dele né, aquilo vai aumentando e... isso aí prejudica bastante né, quer dizer, tem que se cuidar né..." (16.6)

“...e fazer que nem eu faço, de vez em quando, porque tem o que pode e o que não pode, fazer um checape lá pra saber se tem alguma coisa, né..."(15.8)

\section{Categoria C9 - Percebendo vários fatores associados}

Percebem que existem vários fatores, um conjunto de elementos, que podem garantir uma maior longevidade (quadro 21).

"Tomar um ventinho de vez em quando, se alimentar bem, andar um pouco também, não ficar feito coruja... é isso aí, ter uma... participa de uma boa sociedade, pra conversar, ter mais sabedoria, aquela coisarada toda, está dentro da... dos limite da gente de viver melhor..." (26.6)

“Ter tranqüilidade, saúde e dinheiro (risos). Tranqüilidade, saúde e dinheiro, que mais que quer? Mais nada!" (13.7)

O segundo tema que aparece dentro deste fenômeno, GERANDO VIDA, é: SENDO A SAÚDE INFLUENCIADA PELO MEIO AMBIENTE (Tema D).

\section{TEMA D - PODENDO A SAÚDE SER INFLUENCIADA PELO MEIO AMBIENTE}

Colocam que a saúde pode ser influenciada pela qualidade da água, pela poluição e contaminações que fazem mal, afirmando que o ar puro e onde tem maior área verde são melhores para a saúde. Entretanto, alguns acham que o meio ambiente pode influenciar na saúde, e outros não. Os que julgam que não pode influenciar 
justificam que existe variabilidade genética e individual, e que as pessoas têm mais cuidado com a saúde individual e coletiva atualmente e os indivíduos eram mais saudáveis no passado.

As categorias que emergiram foram: - Podendo o meio ambiente influenciar a saúde, - Podendo o meio ambiente não influenciar a saúde, - Poluição e contaminação prejudicando a saúde, - Qualidade da água e do ar influenciando a saúde, - Sendo melhor para a saúde locais com mais área verde (diagrama 19).

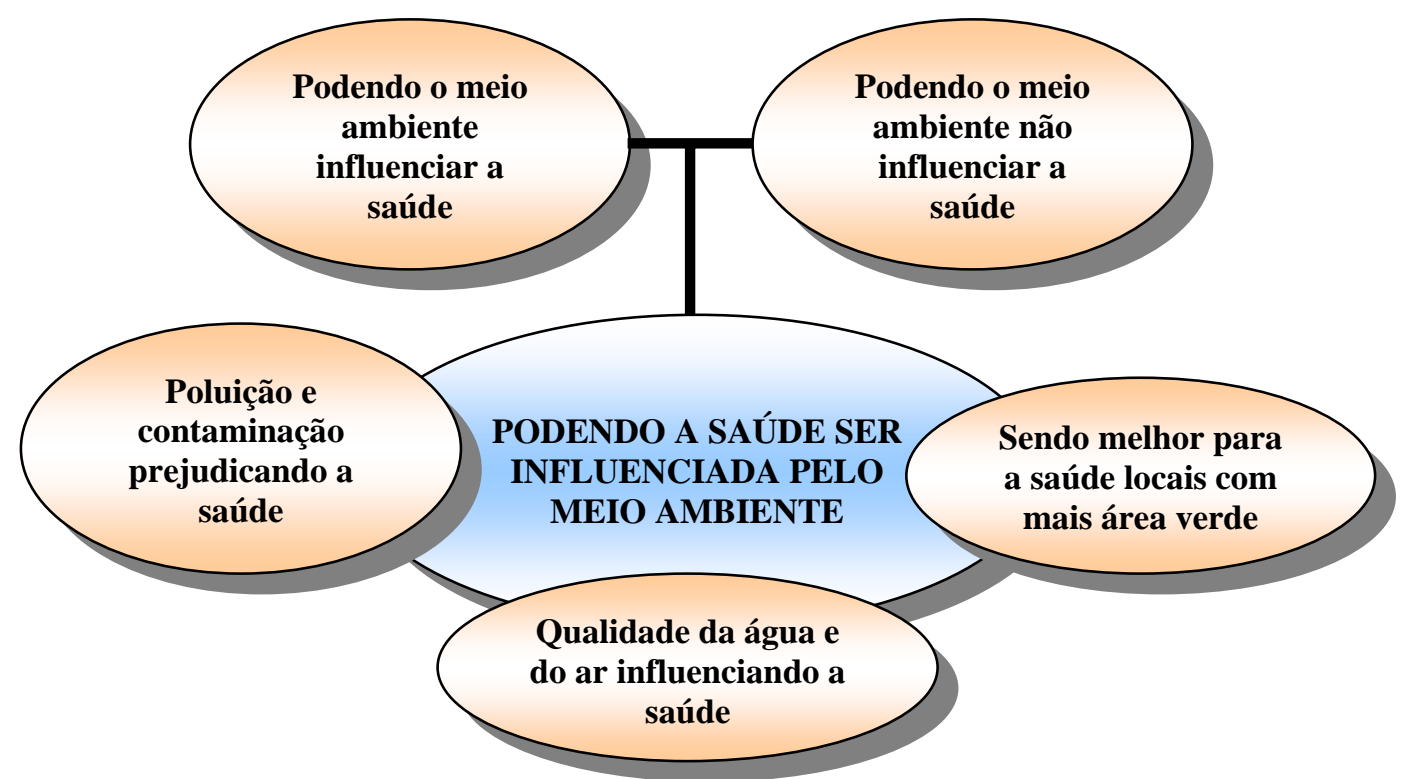

Diagrama 16. Tema D - Podendo a saúde ser influenciada pelo meio ambiente: Categorias

\section{Categoria D1 - Podendo o meio ambiente influenciar a saúde}

Acreditam que o meio ambiente, a natureza, influencia a saúde das pessoas, havendo relação direta entre saúde e meio ambiente, mas crêem ainda existir o desconhecimento da ciência de como se dá toda esta interação, que pode ser uma relação positiva (gerando saúde) ou negativa (adquirindo doenças) (quadro 22).

"Ah, não tem dúvida, influencia..." (18.4)

"Eu acho que influi e muito. Acho que muita coisa ainda aqui que intervem neste relacionamento não está descoberta..." (24.5)

"Mais é o tudo nosso né. Porque, eu na minha opinião, porque a gente tem assistido tantas coisas tristes, de doenças, tudo, tudo pela natureza que estão destruindo, estão destruindo totalmente a natureza..." (5.4) 
"Tem. A gente se sente é, mais, mais aberto mais alegre né, é assim, a natureza que manda, a natureza é fora de série viu". (12.13)

\section{Categoria D2 - Podendo o meio ambiente não influenciar a saúde}

Outros acreditam que não existe relação entre meio ambiente e saúde, em face à existência de variabilidade genética e individual, e julgam-se leigos no assunto. Ressaltam o maior controle atual da saúde individual e coletiva e julgam que, antes, as pessoas eram mais saudáveis (quadro 23).

As subcategorias que aparecem são: - Cuidando mais da saúde individual e coletiva atualmente, - Sendo as pessoas mais saudáveis no passado (diagrama 20).

“...mas eu num, não acredito que tivesse, tivesse tanta influencia assim viu, eu acho que isso aí, é da natureza de cada um. Eu tinha uns colegas fortes viu, que pescavam comigo e que já foram né, e eu estou aqui..." (2.6)

"Num sei, não posso falar pra senhora, nessa parte eu num... eu sou meio leigo... leigo não, eu sô inteiramente lego nessa parte..." (30.14)

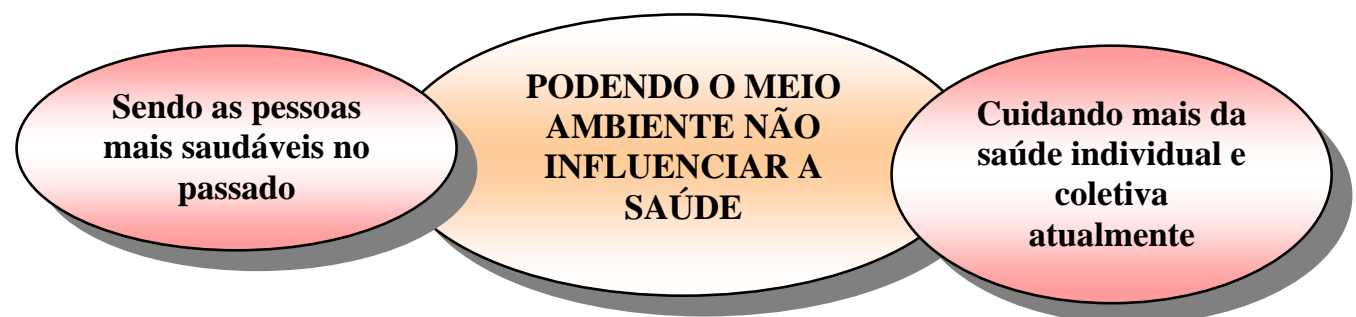

Diagrama 20. Categoria D2 - Podendo o meio ambiente não influenciar a saúde: Subcategorias.

\section{Cuidando mais da saúde individual e coletiva atualmente}

Julgam que as pessoas atualmente têm cuidado mais de sua própria saúde e da saúde pública, notando a erradicação de doenças que existiam no passado (quadro 23).

"Não, acho que não, né Karina, não. Acho que o povo sabe se tratar, né. Naquele tempo tinha muita maleita, essas coisa, hoje você não vê falar em Maleita, né. (...) Tinha bastante, hoje não se vê falar em maleita, febre amarela. Não se vê fala mais nisso. Antigamente tinha muito disso." (22.5)

Sendo as pessoas mais saudáveis no passado

Julgam que as pessoas eram mais fortes e mais saudáveis no passado (quadro

“...era mais, mais saudável a gente ...” (23.8)

“Era, a saúde era outra, né. Era mais forte a saúde..." (28.4) 


\section{Categoria D3 - Poluição e contaminação prejudicando a saúde}

Julgam que todo tipo de poluição e contaminação por produtos químicos prejudicam a saúde, e sentem-se melhor em locais sem poluição. Referem que já existia a utilização de agrotóxicos, mas que as pessoas não sabiam que aqueles produtos químicos pudessem fazer mal à saúde e não se protegiam, ficando doentes (quadro 24).

“Ah! Tratando de poluição, prejudica a saúde da gente..." (19.5)

"Porque tem muita relação e é influenciável devido, devido a muito, muito veneno, muitas drogas que põem nesses alimentos e a droga, sabe como é, até parece que ela morre, mais num morre, num desaparece..." (27.6)

"Hoje em dia usa, é química, é química pra tudo.(...) Não, ninguém pensava que fazia mal, não pensava. Ou fazia mal e a gente não percebia.(...) É depois que começou a prevenção da vista, daquilo, aí ..." (6.3)

"O que eu vi, que até hoje eu fico pensando: - puxa por isso que está todo mundo doente. Ali perto de Cambará, o ar daquelas fazendas, ali você enxergava a lavora de café, aquela colônia, aquele colosso de casa de empregado e o aviãozinho jogando BHC no café, que eu e o meu foguista precisamos fechar, fechar a janela da locomotiva, com aquele calor, e tapava o nariz um pouquinho e destapava, de tanto cheiro de...de veneno, os médico diz que demora 10 anos para sumir né. De veneno, por isso que eu falo, estou sempre comentando isso aí, por isso que está todo mundo doente e eu vi, não é que contaram pra mim, eu vi, né. Eu estava até sofrendo lá, eu e o foguista, porque não agüentava ficar com o nariz tapado, tampava um pouco, destampava, tirava a mão e tudo aquele sofrimento dentro da locomotiva, era um dia quente né e ele passava (rarararararar) aquela rajada de BHC. Aquela criançada tudo lá, mulherada, tudo mundo trabalhando, andando por lá. Onde que era isso? Lá perto de Cambará, é no Paraná." (12.10)

"Deixava o vagão lá e eles que descarregavam, os funcionários dessa empresa lá que descarregavam. Mas eles não usavam máscara não, eu tenho certeza, eu via quando ia trabalhar com o vagão, né." (5.8)

\section{Categoria D4 - Qualidade da água e do ar influenciando a saúde}

Percebem que o ar tem influência na saúde, sendo melhor o ar puro, sem poluição e mau cheiro. Avaliam que o ar era melhor antigamente, assim como no sítio. Em relação à água, destacam que, se esta for mais limpa, a saúde melhora, e se esta for suja, ninguém consegue viver bem (quadro 25).

"Deve influir, deve influir, porque, o que traz pra nós... você é médica, você sabe o que eu não sei,... o que traz esse conforto, esse ar puro pra gente é justamente isso aí né. Você fica aqui na rua sente, se você for num lugar onde (nt)você sente até um ambiente mais gostoso, entendeu?" (15.6) 
"Oh! Sente a diferença, do ar do sítio com o daqui (...) Melhor né. É por que, como era? Porque não tem poluição nenhuma, num tem. Sempre aquele ar gostoso, ar suave, num tem. E daqui da cidade? Já tem, tem gente pensando que num tem mais tem." (14.3)

"É lógico, a natureza, o rio, tinha árvore por ali, a água era cristalina, a gente bebia água do rio. Não tinha esgoto, nada disso. Depois o bairro passou a ter casa por lá e despejava esgoto no rio. Então aquilo foi estragando tudo..." (29.2)

\section{Categoria D5 - Sendo melhor para a saúde locais com mais área verde}

Relatam que a mata influencia a saúde, achando haver relação direta entre quantidade de área verde e melhor saúde. Justificam isto pelo fato de o ar ser melhor em áreas com mais verde, amenizando a temperatura e trazendo mais conforto para as pessoas. Julgam que o desmatamento e a destruição geram descontrole ambiental e, por conseguinte, da saúde (quadro 26).

"Olha, eu tenho a impressão que onde há mais verde há mais saúde né, favorece mais né. É a impressão que eu tenho e eu também já li, os campos de futebol são fechados de eucalipto, plantados em volta por causa do ar, fica mais puro né... e os jogadores precisam de muito ar né, então sinal que o verde é melhor pra saúde né."

(25.8)

"Num é, porque as matas que refrescam tudo, não é? E agora do jeito que tão devastando, acabando com tudo então... realmente isso influência." (23.4)

"Porque, eu acho que tem o descontrole da natureza, porque hoje em dia... antigamente eu me lembro que o frio chegava naquela época de frio, ia frio certo pra aquele tempo (...) eu acho que tudo isso é tudo descontrole, agora o tempo não estando correndo bem, a nossa saúde não pode correr bem também né? Isso você sabe bem mais do que eu (risos)." (5.4)

"As matas trazem bastante vida, trazem sombra né, protegem o corpo das intemperes do calor, de mal de sol e as árvores protegem, fazem bastante sombra."

O terceiro tema do segundo fenômeno, GERANDO VIDA (fenômeno 2) é: OBSERVANDO FATORES QUE PODEM TER CONTRIBUÍDO PARA MAIOR LONGEVIDADE DOS FERROVIÁRIOS (Tema E).

Acreditam que os ferroviários podem ter sido favorecidos a alcançar maior longevidade por terem tido maior controle de saúde e boa assistência por meio da ferrovia; pelo fato de o trabalho exigir atividade física; por serem pessoas ativas e se 
relacionarem bem com os colegas. A maioria deles também considera que tinham um bom salário e crédito em toda a cidade, podendo adquirir bens, possuindo emprego estável com possibilidade de desenvolver carreira e fazer horas extras; no entanto, dedicavam-se muito ao trabalho, mas com prazer e orgulho. Este orgulho está associado aos seguintes fatos: o ferroviário ser muito conhecido e estimado; ser considerado um dos melhores empregos; por ter prestígio entre as mulheres; ser uma profissão seguida pelas gerações da família, e pela ferrovia representar tudo na vida do ferroviário. Para fazer jus a essa profissão, vestiam-se bem e, para completar, o ambiente ferroviário era considerado ótimo.

Também existe a percepção de que os ferroviários não vivem mais que as outras pessoas, uma vez que existem outros fatores ligados à variabilidade individual, por morrerem cedo devido aos vícios. Outros atribuem a longevidade ao desígnio divino.

As categorias que formam este tema são: - Ferroviários alcançando ou não maior longevidade, - Tendo um emprego com estabilidade e carreira, - Desfrutando de benefícios como ferroviários, - Convivendo em um bom ambiente de trabalho, Exigindo muita atividade física no trabalho, - Tendo um bom salário e crédito na cidade, - Dedicando-se e sentindo prazer no trabalho, - Contando com controle periódico e assistência a saúde, - Orgulhando-se de ser ferroviário (diagrama 21).

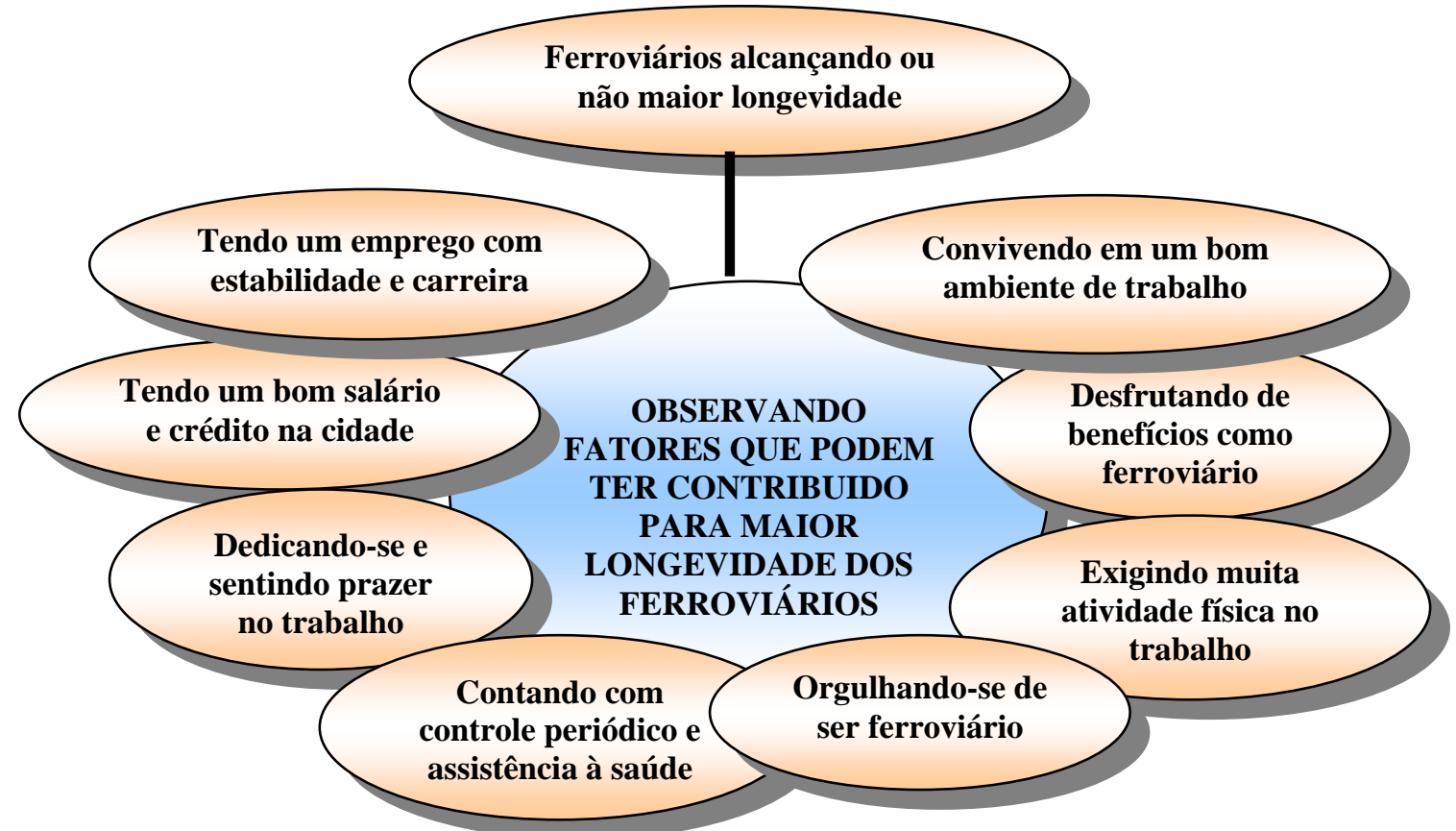

Diagrama 217. Tema $\mathrm{E}$ - Observando tatores que podem ter contribuído para maior longevidade dos ferroviários: categorias. 


\section{Categoria E1 - Ferroviários alcançando ou não maior longevidade}

Existe a crença de que os ferroviários vivem mais que outras pessoas, por observarem que vários amigos ainda estão vivos ou morreram com idade avançada, mas percebem que isto acontecia mais no passado, com os ferroviários mais antigos. Ao mesmo tempo, também apareçe a crença de que os ferroviários vivem o mesmo tempo que as demais pessoas. Argumentam dizendo que isto depende de cada um, da saúde, de Deus, sendo todos iguais (quadro 27).

"Ah! Vivia né, eu tenho colega daquele época, daquele tempo, que eu trabalhava, ainda encontro com eles aqui em Botucatu, muitos já morreram né, mais ainda tem bastante. Mas aqueles que morreram eles bebiam, né bem, eram extravagantes, tem outros que eram mulherengo." (11.5)

"Não. Acho que aí, acho que regula, é mesma coisa. E agora os ferroviários estão acabando tudo." (9.4)

"Olha isso é, uma coisa que... teve ferroviários, amigos da gente, que morreram muito novo, então eu acho que não tem nada a ver né. Fora os que morreram de acidente né, mais mesmo de doenças aí teve ferroviários que morreram muito novinho..." (25.9)

"Depende, depende, depende de, porque desses individuo que eu falei com a senhora que entraram comigo, a maioria morreu tudo novo, porque nunca se cuidaram, tá entendendo? Bebiam, fumavam, então, a maioria morreu tudo novo, entendeu?" (3.6)

\section{Categoria E2- Tendo um emprego com estabilidade e carreira}

Relatam que as pessoas queriam trabalhar na Sorocabana, porque ela oferecia emprego com maior estabilidade e possibilidade de progredir por meio da política de carreira que adotava (quadro 28).

"Tinha serviço! O pessoal achava serviço melhor, saía. Já passava por lá, porque quem mantinha empregado era a Sorocabana. Entrou na Sorocabana não saia..." (29.3)

“... e outra, uma coisa também: você para ter uma promoção, não era fácil não, tinha um almanaque, se você tirasse licença, você perdia pontos no almanaque viu.Se ficasse doente... eu que passava na sua frente, para ser promovido. É ...não era fácil não."(12.9) 
"Oh! Em tudo, porque a pessoa trabalhava, gostava de trabalha, atento, sempre pensando desde moço, de progredir, de ser promovido. Era sempre promovido, tinha estímulo, tinha incentivo né. Ficava contente, uma promoção, voltava alegre, pagava cerveja pros colega - ele foi promovido! Fulano lá vai se promovido, vai se removido, porque sempre que você era promovido era removido né..." (12.16)

\section{Categoria E3 - Tendo um bom salário e crédito na cidade}

Lembram que os ferroviários podiam comprar onde queriam, porque tinham crédito em toda a cidade por ganharem bem, melhor do que nos outros empregos do município, além de terem possibilidade de ganhar mais por meio de horas extras. Isto permitiu que eles adquirissem bens. Lembram que o pagamento era feito utilizandose o trem pagador, mas sempre existiam atrasos.

As subcategorias que aparecem são: - Conquistando bens, - Existindo descontentamento em relação ao salário, - Podendo fazer hora extra e ganhar mais (diagrama 22).

"Era um dos empregos melhores que existiam naquela época, né. Então a gente comprava o que queria em qualquer lugar... tinha, tinha tudo o ferroviário. Agora nem falo isso mais (risos)." (4.3)

“... pessoal tudo de carreira né. Carreira que a gente chama é a gente trabalha como maquinista, foguista, chefe de trem, ajudante de trem, e além do ordenado só havia hora extra, e fazia hora extra, ganhava mais, aí hora extra tinha um acréscimo né..." (30.12)

"Ganhava mais, ganhava mais e que nem eu disse pra você, a estrada sempre pago bem, porque tudo que você fizesse ela pagava pra você! Se você, se você fizesse estágio lá, você ganhava, se você fizesse uma hora extra, você ganhava, se ganhava, se ganha... se trabalhasse de noite, recebia a hora, de tudo, tudo ela pagava. Tudo ela pagava. E já o particular não paga, que nem o Blasi, Milaesi que nem, a serraria, a serraria ali... É tudo não pagava o ordenado que nós ganhávamos. Não pagava não!" (8.7)

"É o pagamento num é que nem hoje, que o você, no dia do pagamento, você vai lá no banco, está lá o dinheiro. O trem pagador, contaram pra você? O pagamento, tinha o trem pagador, é (...) ele chamava, fulano, fulano, ciclano,ía chamando (...). Atrasava!... eih! Natal, ixiii, quantos natal passava fora, o pessoal,...o pessoal lá em Assis, ficava falando: é... o pagador vai vim agora antes do natal vai vim, quando era, não vinha né, ficava todo mundo sem nada..." (12.7) 


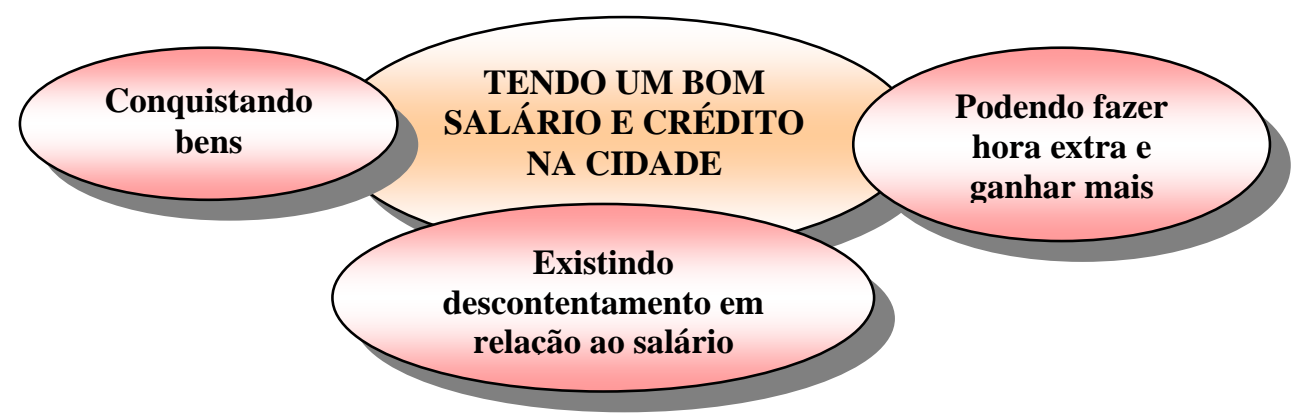

Diagrama 22. Categoria E3 - Tendo um bom salário e crédito na cidade: Subcategorias.

\section{Conquistando bens}

Por receberem bem, os ferroviários contam que puderam adquirir a casa própria e propiciar estudos aos filhos (quadro 29).

"Eu tenho saudade porque,foi uma graça de Deus, o que eu tenho, estudei minhas filhas, meu filho (se emociona), estudei minha filha, tenho minha casa, estudei minha filha, minhas duas filhas, meu filho, com o meu salário que eu trabalhava na ferrovia." (3.2)

"Então a gente comprava o que queria em qualquer lugar, tinha, tinha tudo o ferroviário." (4.3)

\section{Existindo descontentamento em relação ao salário}

Alguns ferroviários avaliam que não recebiam tão bem assim, pois não sobrava dinheiro no final do mês. Contam que sempre havia algum descontentamento entre os ferroviários, dizendo que uns ganhavam melhor do que os outros. Ressaltam que o custo de vida era menor e tinham muitos benefícios que compensavam o salário (quadro 29).

"Não, porque nosso custo de vida era bem barato né." (19.3)

"Há era bom viu, porque a Sorocabana, a gente tinha de tudo, ganhava pouco, mas a gente tinha médico, tinha hospital, tinha cooperativa, tinha farmácia, farmácia, cooperativa vinha tudo descontado em folha... tinha biblioteca para as crianças em

São Paulo, tinha tudo, dentista, ampla assistência viu..." (18.3)

"Era bom, era bom, quer dizer, sempre há um descontentamento né, qualquer, qualquer ramo de atividade, um está contente outro não está, um ganha mais... eu deveria ganhar também, mais ganhei pouco..." (13.3) 


\section{Podendo fazer hora extra e ganhar mais}

Relembram que as pessoas de carreira (maquinista, foguista) recebiam mais devido às horas extras que tinham de fazer durante o trabalho (quadro 29).

"Abria o X, vamos supor agora, que hora nós temos agora, faz favor? É... 15:15. Quinze e quinze eles abriam o $X$ e ia fechar quando você voltasse de viajem, quer dizer que aquelas horas você ganhava tudo direto. la contando o mês intero. Eu tive um mês, que eu fiz quatrocentas e poucas horas, tempo da locomotiva a vapor que lá trabalhava, que... a gente fazia muita hora extra. O pessoal da carreira tinha essa vantagem, e ganhava mais, sempre ganhava mais (...) É que nós não tínhamos,

vamos supor, que nem vocês que trabalham num lugar, que você trabalha no sábado e no domingo, nós não tínhamos isso. O pessoal da carreira só tinha dia pra trabalhar, não tinha hora." (5.5)

"Ah! Olha, nós trabalhávamos muito, para tirar um ordenado bom tinha que trabalhar assim, bastante viu, extra,fazer muita hora de serviço para tirar um ordenado, razoável né. Mas a gente, ói...os pernoite, nós num tinha regalia nenhuma...Doutora sabe o que eu fazia no pernoite? O pernoite só tinha a cama e o colchão né. O pernoite era em São Paulo? Não! São Paulo não tinha, a pernoite era em Bernardino... Na cidade, perto da estação tinha o pernoite do pessoal de trem, e perto do depósito do pessoal da locomotiva. Então a gente chegava, levava.... quantas vezes eu levava, pegava um pau e levava para por por baixo do colchão para servir de travesseiro, porque travesseiro não tinha, então eu falo muitas vezes a gente reclama de dormir ou coisa assim....ei quantas vezes que eu dormi com um travesseiro, um pau feito travesseiro, era desse jeito." (12.6)

"Era a vapor, a vapor acabava lenha no trecho, faltava água, quebrava isso, quebrava aquilo, meu Deus do céu... soltava, o maquinista num sei como é que... o

foguista também, a gente soltava um trem aqui, saía cedo, folgava outro dia, entrava as 11 hora no outro dia, o coitado ainda tava na linha... acabava lenha, acabava isso, acabava aquilo ( $n t)$... estou cansado, vou fazer o que? Mais ganhava por hora né, ganhava por hora e ganhava muito bem pessoal de máquina. Esse

pessoal padeceu, principalmente foguista, chuva em cima, boca de fornalha. Gastava 2, 3 tender de lenha para ir daqui e voltar até Iperó...E agora os homens não reconhece nada disso, né!" (18.7)

\section{Categoria E4 - Desfrutando de benefícios como ferroviários}

Revelam que os ferroviários desfrutavam de vários benefícios. Alguns moravam em casas da ferrovia, sendo o aluguel, a luz e a água gratuitos. Existia uma cooperativa que fornecia todo tipo de mantimento, suficiente para passar o mês inteiro, e entregava em casa, descontando do pagamento. Existia uma caixa dos ferroviários por meio da qual podiam fazer empréstimos financeiros. Havia também uma farmácia, de onde retiravam medicamentos que eram descontados do pagamento. Além disso, lembram que a ferrovia fornecia material para construção com melhor preço (quadro 30). 
"Onde eu morei, lá na Victor Atti, o serviço de água, tudo, era por conta da ferrovia, vinha por intermédio da ferrovia. A água? É, Até a luz era da ferrovia (...).

Da sorocabana mesmo, a gente comprava remédio lá e tinha uma cadernetinha própria da farmácia né, aí comprava, assinava e mandava aquela conta lá pra chefia, vinha descontado no pagamento." (3.4)

“... aí a gente chegava na época do pedido, fazia o pedido, tinha caderneta, levava a caderneta, dava uns sacos vazios, sacos de... de... farinha de trigo né, conforme 4 sacos, 5 sacos e eles punham toda mercadoria naquele saco, e depois de uns 10, 15 dias, tinha data certa de entrega, o carroceiro levava em casa, levava em casa, e entregava lá. (...) o chefe passava o visto, que a gente tava trabalhando tudo certo, levava lá eles forneciam, e descontavam em folha de pagamento, em folha. Mais era bem barato? Era, era mais era uma beleza, era um, olha tenho saudade, é muito bom, boa mesmo, era uma cooperativa bem montada mesmo, tinha de tudo, a gente não passava necessidade de nada, tinha tudo..." (30.15)

“... nós tínhamos uma caixa dos ferroviários, fazia empréstimo, naquele tempo três....três contos de reis, você pagava tabela, era tabela 'price', era uma porcaria, eu comprava casa, financiava casa,(nt), até hoje estou pagando a casa né." (9.6)

“... material para o pessoal construir casa, fornecia tijolo, e... um preço razoável né. Não era dado, era cobrado, mas era um preço mais baixo, e a serraria anônima fornecia madeiramento, a serraria anônima ajudou muita gente a construir casa naquele bairro lá." (30.18)

\section{Categoria E5 - Exigindo muita atividade física no trabalho}

Lembram que o trabalho na ferrovia era muito pesado, exigindo grande esforço

físico, mais que em outros serviços (quadro 31).

"É do foguista, ele ficava de pé, porque a locomotiva tinha um avental, que era para a radiação, então, ficava aqui de pé em cima da...daquele avental, aquela avental ficava fazendo assim ho (Mímica) e o foguista então vinha pegar a lenha do graxeiro aqui e jogar aqui dentro da fornalha. Muitas vezes um metro, um metro e meio de lenha enchendo dentro da fornalha. Oh! Era um preparo físico que eu vou falar pra você, coisa...coisa bárbara viu." (10.2)

"Nossa! Olha, o funcionário da Sorocabana, da carreira de locomotivas, de trem, do pessoal de estação, trabalhou! Olha trabalhador de turma, nossa senhora! Ói, vou te dizer, lá em (risos) Salto Grande, lá em Salto Grande tinha que carregar muito dormente né, aqueles dormente... em Salto Grande? É... O dormente era pesado pra chuchu, o dormente de peroba, favero né, pesado. (...) É, carregava muito dormente, uma vez estavam carregando dormente lá, o feitor, o mestre de linha, que dirigia tudo, aquele pessoal tudo carregando dormente para por em cima da gôndola, tinha um rapaz lá com o ombro aqui (mímica) até vertendo sangue de tanto carregar dormente. Aqueles dormente pesado assim. Um homem carregando um dormente que pesava $70 \mathrm{~kg}$ sozinho né. Então, depois quando acabaram de carregar a gôndola, ele (o feitor) falou assim para a turma: - vão, embarquem em paz. Subiam em cima da gôndola Então ele falou assim: - essa mamata de andar em cima de gôndola vai acabar, essa mamata. Mas, meu Deus do céu, carregando dormente desse jeito, ainda acha que é mamata?! (risos). Carregando dormente com o ombro vertendo sangue, ...ele falou de brincadeira essa mamata vai acaba...." (12.7) 
“... eu fui trabalha em Presidente Prudente, e me disseram, me avisaram. Disseram: - olha você vai trabalha lá com um homem lá, que o homem é horrível hein, o homem é tremendo. E eu fui trabalhar, fui trabalhar, mas o serviço lá era muito pesado sabe, era sacaria o dia inteiro, e um calor que a gente ficava molhado de suor o dia inteiro." (25.3)

\section{Categoria E6 - Contando com controle periódico e assistência à saúde}

Contam que para entrar na Sorocabana era preciso passar por vários exames de saúde antes. Referem que os ferroviários tinham boa assistência à saúde através da Sorocabana e quando eram casos mais graves eram encaminhados para São Paulo. Revelaram que os ferroviários de carreira, como o maquinista e seu ajudante, tinham de fazer exames completos anualmente em São Paulo (quadro 32).

“... sabe que ferroviário, acontece o seguinte, o ferroviário para ele entrar na ferrovia, ele fazia um colosso de exame, então quando ele entrava, já entrava sabendo que estava bom..." (15.9)

"Para os caso, para os casos que tinham problema assim encaminhava pra São Paulo, encaminhava pra São Paulo, encaminhavam muitos ferroviários. Foram operados de úlcera no estomago em São Paulo." (20.5)

"Era maquinista, ajudante, esses daí iam todo ano, tiravam chapa de pulmão tudo, um exame completo faziam, né." (5.6)

\section{Categoria E7 - Convivendo em um bom ambiente de trabalho}

Referem que o ambiente da ferrovia e do bairro de ferroviários era muito bom, com muitas amizades, sendo diferente dos dias atuais. Relatam que entre os ferroviários havia muita amizade e cooperação, assim como respeito ao chefe, sem competição, valendo a pena o trabalho somente por esta amizade (quadro 33).

"O ambiente era cheio, mas era o dia inteiro aquele bairro, bacana, ficava sentado ali em frente. Hoje não tem nada né." (1.1)

“... que nem eu disse pra você, fui criado no bairro, o bairro era um bairro onde vivia de ferroviário, e todos eles ganhavam bem. Então era um bairro de coisa - de ambiente bom, e os comerciantes que se estabeleciam, sempre tinha conversa, porque recebia bem e o camarada comprava, comprava e exigia mercadoria boa, porque ele tinha poder. Então, era ambiente bom e tudo que você via era ambiente bom e (...) ...vou falar pra você, o bairro da estação, quando eu fui criado, desde

que eu fui criado, quando saí de lá, nunca teve pessoa que pedisse esmola..." 
"Era gostoso, porque parecia que a gente, quanto mais trabalhava, mais boas amizades se tinha. A gente era todo mundo amigo, não existia aquele que... um querer ser mais do que o outro, porque, aquele tempo trabalhava mesmo, principalmente num trem de passageiro, você tinha que dá a conta do recado, porque se não, atrasava o trem de passageiro por falta de vapor, atrasava o trem de passageiro, a gente era até punido..." (5.2)

“... era um respeito todo mundo, com chefe também. Hoje não. Eu sempre respeitei meu chefe viu, eu sempre respeitei..." (10.1)

"Era muito bom, muito bom mesmo, acho que por causa mesmo dos ferroviários, eles eram muito dedicados sabe, muito dedicados, dedicação assim extremada mesmo..." (24.1)

\section{Categoria E8 - Dedicando-se e sentindo prazer no trabalho}

Gostavam muito do trabalho que desempenhavam na Sorocabana, sentindo prazer e satisfação, trabalhando com muito amor e dedicação, como se a ferrovia fosse propriedade deles mesmos. Ressaltam que o trabalho era pesado, mas valia a pena, e que ninguém deve se queixar, pois ganhavam bem (quadro 34).

"Era um serviço pesado, mas a pessoa se habituava com aquele andamento, aquele serviço, então para ele era comum. Agora eu gostava muito do que fazia, eu gostava, eu tinha muita dedicação no serviço e para mim era fácil de fazer o serviço porque tinha dedicação..." (8.2)

"Ah! Era uma riqueza viu, vou falar pra você, eu... eu gostava como fosse uma propriedade minha, eu trabalhava como se fosse uma propriedade minha e graças a Deus eu sempre fui bem estimado pelos... pelo chefe..." (10.1)

"Aqui era importante, eu não posso ter queixas e acho que nenhum dos meus amigos pode ter queixas, nenhum. Era pesado mais ganhava também..." (14.5)

“... e a gente batendo papo com eles, a gente vê que eles gostavam muito da ferrovia, por exemplo, gozado... um negócio meio místico viu, você não observou isso conversando com o pessoal? Gostam da ferrovia que é uma loucura, parece que a ferrovia é deles. Os ferroviários, eles eram muito satisfeitos viu..." (24.11)

"Era gostoso. Eu gostava da Sorocabana mais do que ficar em casa. A gente tinha amor àquilo, gostava..." (29.1)

“...a gente ia trabalhar, trabalhava com fé mesmo, agora, ultimamente que estão colocando essa rapaziada nova, que não quer mais nada, não é que nem os antigos que gostavam, que trabalhavam com amor..." (28.5) 


\section{Categoria E9 - Orgulhando-se de ser ferroviário}

Sentiam um grande orgulho de serem ferroviários, pois eram conhecidos em toda a cidade e disputados pelas mulheres; o trabalho na ferrovia era considerado um dos melhores empregos e seguido pelos descendentes, desejando esta profissão desde criança. Para fazer jus a essa posição, os ferroviários sempre se vestiam bem para o trabalho. Destacam como era linda a história da ferrovia, sentindo também orgulho disto.

As subcategorias que se agregam a esta categoria são: - Sendo o ferroviário conhecido e estimado, - Considerando um dos melhores empregos na época, - Tendo prestígio com as mulheres, - Sendo uma profissão seguida pelas gerações da família, - Vestindo-se bem, - Sendo linda a história e a ferrovia, - Sonhando em ser ferroviário (diagrama 23).

"Ah! Era até um orgulho ser ferroviário. Eu, eu gostava de ser ferroviário! Gostava mesmo, eu me sentia até orgulhoso de saí pra cidade aí, que eu era ferroviário, era

moço, tudo, aquela coisarada. O ferroviário, certas épocas, é o ferroviário era desprestigiado e depois... entendeu? Quando a ferrovia evoluiu, aí o ferroviário ficou valorizado, entendeu? liiiiiiiii a gente que era moço, por exemplo, era negócio ser ferroviário, era negócio ser ferroviário (risos) e depois..." (2.1/2)

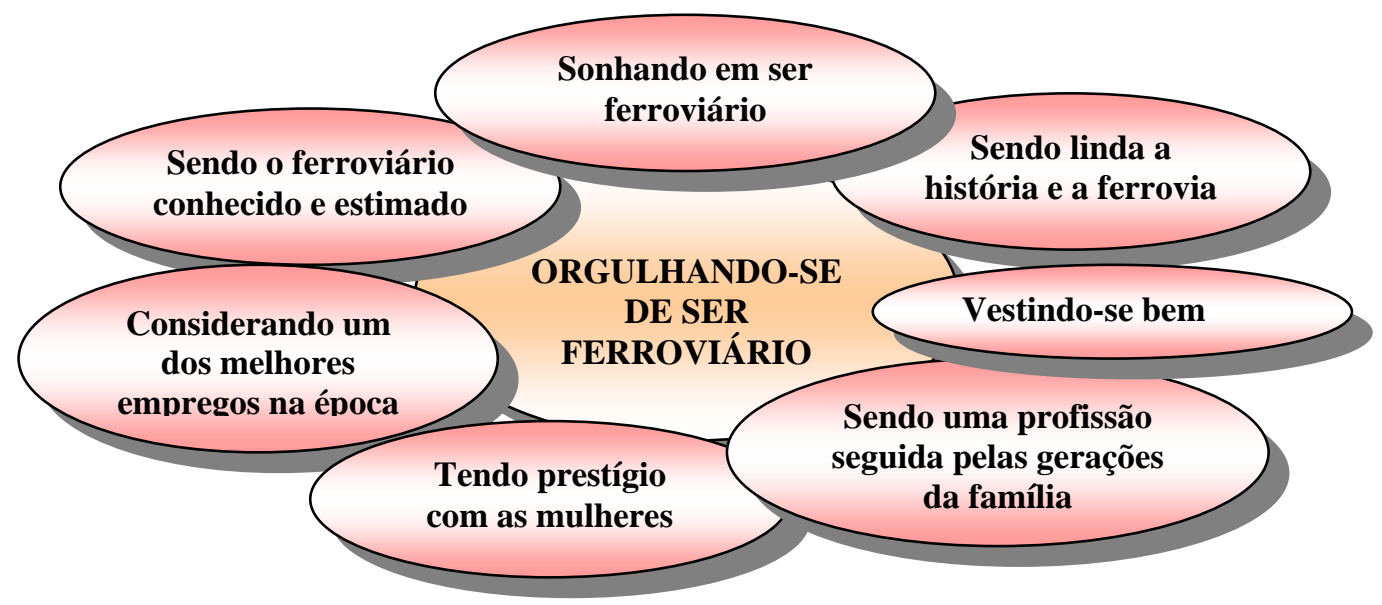

Diagrama 23. Categoria E8 - Orgulhando-se de ser ferroviário: Subcategorias.

\section{$\underline{\text { Sendo o ferroviário conhecido e estimado }}$}

Naquele tempo, lembram que o ferroviário era conhecido em toda a cidade e todos de Botucatu gostavam dos ferroviários (quadro 35).

"Era, o movimento da...eu me lembro, ou melhor, o ferroviário dentro, naquele tempo ele era conhecido na cidade toda, né." (4.3) 
"Tudo gostava do...do ferroviário viu (...) Em função da ferrovia, mais aqui tudo era, principalmente aqui no Bairro, você, de noite você saia, via uma pessoa lá longe,você via, estava com uma malinha para ir trabalhar..." (12.9)

\section{Considerando um dos melhores empregos na época}

Ser ferroviário era um dos melhores empregos que existia na época, e até considerado um empreendimento (quadro 35).

“Era um dos empregos melhores que existia naquela época, né.” (4.3)

“...era negócio ser ferroviário, era negócio ser ferroviário (risos) e depois...” (2.2)

\section{Tendo prestígio com as mulheres}

Contam que as mulheres consideravam um privilégio conseguir casar com um ferroviário, era um bom negócio, porque eles ganhavam bem. Comparam, que hoje, ninguém quer mais casar com ferroviário (quadro 35).

“... que a maior parte era ferroviário, naquele tempo, o ferroviário tudo falava um a um de casar com uma moça, se era filha de ferroviário podia casar que era gente que podia, mais infelizmente hoje." (5.2)

“... a turma falava:- você é ferroviário, ferroviário ganha bem, minha filha vai casar com o senhor (...) As moças queriam casar com ferroviário, hoje se fala pra casar com ferroviário, não casa mais." (22.5)

\section{Sendo uma profissão seguida pelas gerações da família}

Lembram que os filhos também procuravam seguir a carreira de ferroviário, como o pai (quadro 35).

"Os filhos continuaram, esse que tava aqui, ele era maquinista também, ele foi a maquinista, agora o Helio já era truqueiro, e o Jair também..." (10.8)

\section{$\underline{\text { Vestindo-se bem }}$}

Relatam que os ferroviários se arrumavam bem para trabalhar, sendo que o maquinista andava muito bem vestido, de terno azul e lenço no bolso, embora as roupas estragassem e rasgassem muito durante o serviço (quadro 35). 
"De domingo, de sábado, era moço, descia bem para ir trabalhar, colocava gravata, aquela cor ali, gravata..." (12.3)

"Meu pai ia trabalhar, não ricamente, era maquinista, não assim de terno mais ia de terninho, tudo direitinho, certinho. Na época, no paletó, tinha o lencinho, ele gostava muito de perfume, então ele chamava minha mãe: - Bárbara vem cá, põe o perfume aqui no lenço, Bárbara! Minha mãe chegava lá, botava o perfume, então está bom

Bárbara. Era azul marinho, a sorocabana dava 2 terno pra ele, pra todos os ferroviários. A camisa era branca por baixo? Branca, e o boné." (13.7)

\section{$\underline{\text { Sendo linda a história e a ferrovia }}$}

Consideram linda a história da ferrovia e procuravam deixar as estações bonitas e floridas (quadro 35).

“... eu comecei implantar lá sabe o que? Concurso de plantas, é, eu bolei umas florendas de dormentes pra por na estação, concurso das estações pra ver quem

que deixava a estação mais enfeitada né, e (nt), então fale: puxa vida, sujeito passa a maior parte da vida da gente no trabalho né, então eu queria ver todas as sessões lá bem arrumadas, bem enfeitada, principalmente com plantas, né." (24.12)

“... a estação de Botucatu era muito bonita, linda, linda, tinha até som: - tal hora vai partir tal trem, RL num sei o que vai pra Ourinhos, os passageiros podem vir comprar seus bilhetes..." (27.5)

\section{$\underline{\text { Sonhando em ser ferroviário }}$}

Desejando ser ferroviário desde a infância (quadro 35).

“É, era obrigação minha né. Desde pequeno, vivia apitando no sítio, queria ser maquinista. Desde criança. Depois que eu fui, que eu falei da porcaria que eu fui escolher né... (Risos) Sofri pra burro..." (1.1)

O último tema que emerge interagindo com o segundo fenômeno (GERANDO VIDA) é : - FERROVIA GERANDO RIQUEZAS (tema F).

Ressaltam os benefícios que a ferrovia proporcionava, gerando o desenvolvimento das cidades por onde passava, sendo que a EFS destacava-se mais ainda dentre as outras, pelo seu desempenho, organização e pelos funcionários. Relembram a importância do trabalho sofrido que desempenhavam, mas que era importante. Consideram que a ferrovia foi muito importante para o progresso, importando e exportando mercadorias e levando pessoas, facilitando a comunicação e implantando novas tecnologias. 
Este tema agrega as seguintes categorias: - Desenvolvimento da cidade favorecido pela ferrovia, - Sendo a ferrovia importante para o progresso, Relembrando a importância do trabalho na ferrovia (diagrama 24).

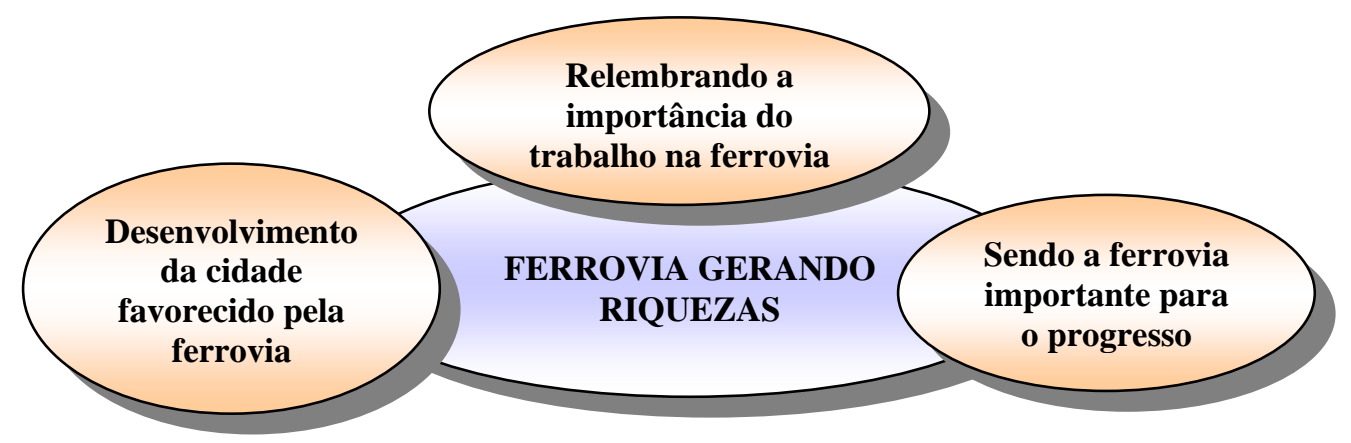

Diagrama 24. Tema F - Ferrovia gerando riquezas: Categorias.

\section{Categoria F1 - Desenvolvimento da cidade favorecido pela ferrovia}

Contam que o desenvolvimento da cidade foi favorecido pela ferrovia, que funcionava intensamente dia e noite, gerando muitos empregos e renda ao município, proporcionando o crescimento da cidade, inclusive, com bairros formados por ferroviários. Lembram que a EFS de Botucatu também se destacava, entre as ferrovias, por ser referência como oficina mecânica de trens; por ter uma extensa linha férrea; por ser muito organizada, possuindo uma grande frota de máquinas e diversificado almoxarifado. A ferrovia também contribuiu para o estabelecimento de uma rede de saúde no município. Por outro lado, colocam que a cidade já dispunha de uma boa infra-estrutura e boas escolas, além de ser um centro cultural, comercial e industrial.

Esta categoria apresenta as seguintes subcategorias: - Estabelecendo sistema de saúde, - Ferrovia funcionando intensamente dia e noite, - Apresentando boa infraestrutura e boas escolas em Botucatu, - Gerando muitos empregos e renda, - Sendo a cidade um centro cultural, comercial e industrial, - Proporcionando crescimento da cidade, - EFS de Botucatu recebendo destaque entre as ferrovias (diagrama 25). 


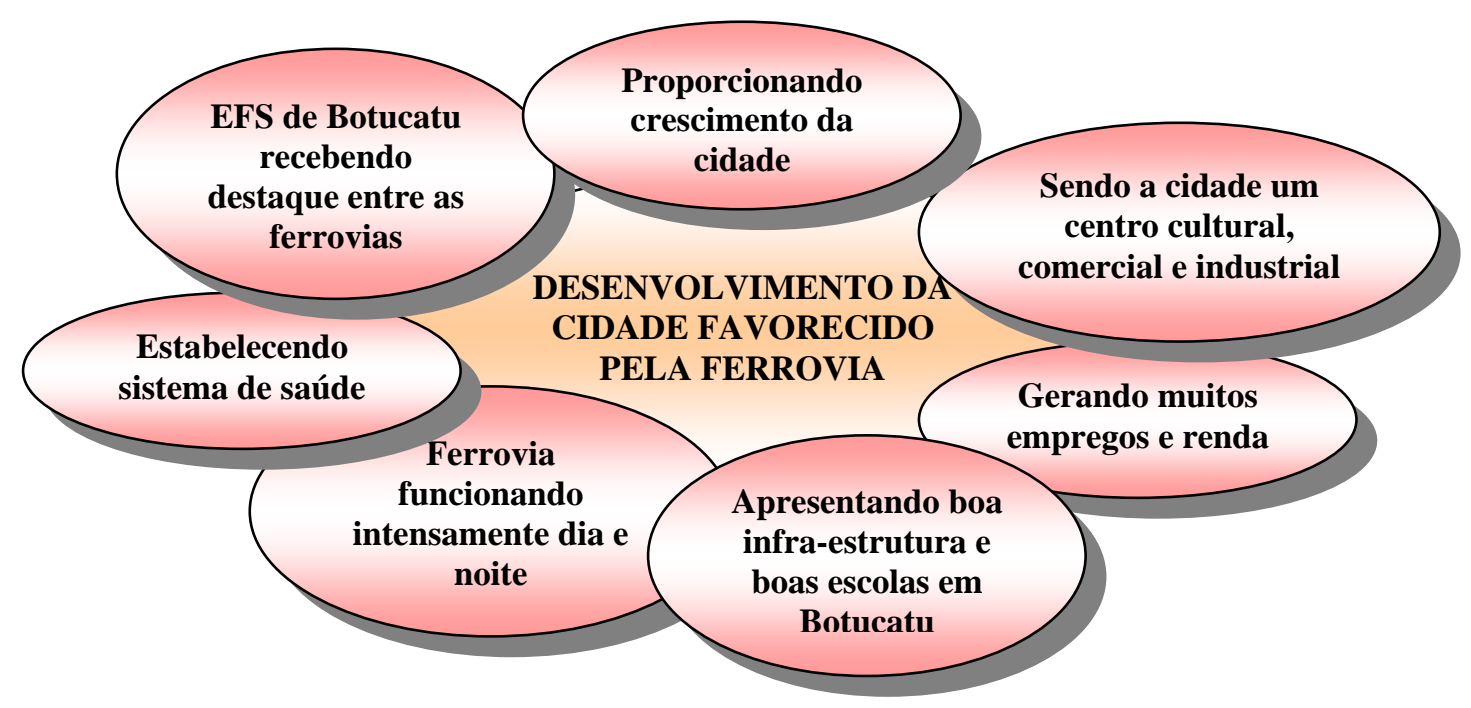

Diagrama 25. Categoria F1 - Desenvolvimento da cidade favorecido pela ferrovia: Subcategorias.

\section{Proporcionando crescimento da cidade}

Consideram que a cidade de Botucatu era provinciana, com população pequena e poucas casas. Depois, a cidade passa a ter mais movimento, desenvolvendo-se à custa da ferrovia, e formam-se bairros de ferroviários. A cidade de Botucatu se desenvolveu por causa da ferrovia, uma vez que a maior parte dos moradores era ferroviário, os quais moviam e a cidade e a mantinham economicamente. Lembram que existia um grande movimento em torno da ferrovia (quadro 36).

Os elementos que compõem esta subcategoria são: - Formando bairros de ferroviários, - Sendo a cidade de Botucatu desenvolvida à custa da ferrovia.

"Era bem menor, bem menor, essas, todas essas vilas aí aquele tempo tinha lá uma, duas, por exemplo, só né, a cidade era menor..." (7.2)

"... aqui foi em torno da ferrovia também, foram fazendo casa, casa, casa, até se transformar em cidade, aqui começo em 89... a ferrovia chegou aqui em 89, 1889..."

"Porque tem muito movimento de, do pessoal que ia trabalhar. Você via homem aqui, é indo trabalhar, você via outro, era indo trabalhar, porque aqui era muito movimento, principalmente esse bairro aqui, principalmente dessa rua pra lá era só ferroviário, Vila Maria foi só Ferroviário..." (14.2)

“... ali, quando era a ordem de chegada de trens de passageiro, essas coisas, nossa tinha um rio de gente barbaridade, aí servia café, bolinho, salgadinho, era doce, era de tudo, e vendiam ali viu. E ficava cheio? Nossa, ficava tapado de gente ali, e todo dia, num era de vez em quando, era todo dia, todo dia, é era uma beleza tinha um movimento muito grande aqui, é muito grande."(comentário sobre o bar da estação) (30.9) 
"Botucatu, praticamente, naquele tempo vivia da ferrovia, que a maior parte era ferroviário, naquele tempo..." (5.2)

"Uh! Se era, aquele tempo, aqui quem mandava era a ferrovia..." (6.3) “... q que movia, porque o bairro era ferroviário, mesmo a cidade era ferroviário que movia, porque o ferroviário, aqui, tinha bastante ferroviário, bastante empregado, tinha mesmo, bastante mesmo, tinha mesmo, vamos dizer assim, só o ferroviário garantia aqui tudo." (13.3)

Ferrovia funcionando intensamente dia e noite

Lembram o intenso movimento que existia em torno da ferrovia, 24 horas. Por dia, saíam cerca de 40 locomotivas, sendo que só em Botucatu existiam 36 locomotivas, cinco eram de passageiros, com 10 a 12 vagões cada, e para carga transportavam de 30 a 40 vagões. As reservas de cabine e para transportar mercadorias tinham de ser feitas com antecedência para se conseguir vaga (quadro 36).

"Era aquela locomotiva. Tinha, é trinta e seis locomotiva, é trinta e seis, e cada uma arrastava vinte, trinta metro de lenha por dia, e saia muita locomotiva daqui? Quarenta locomotiva por dia, quarenta? Quarenta Todo dia?, todo dia." (6.1)

"Não, naquele tempo não, é porque 4, 5 passageiro naquele tempo, 4, 5 passageiro. São cinco máquinas, cinco mais cinco dá dez, só de passageiro né. Em 10 vagões? É trem de carga tinha 30,40 vagão..." (6.4)

"Fazia....ohhhhhhhh, chegava a hora do trem, a estação tava lotada de gente e hoje não tem mais nada..." (10.7)

"Eram doze carros super lotados, tinham os carros, três carros sempre de segunda classe, dois de primeira. Fim de ano aumentava, era sempre quatro de segunda, três de primeira, tinha o restaurante e três dormitórios...ah! Os carros dormitórios...Você tinha que ir na estação, que nem lá em Presidente Prudente, você ía na estação fazer o pedido, você pedia uma cabina para vir para São Paulo, só se fizesse com oito dias antes para conseguir, e vagões também, você queria despachar sua mercadoria, você não ía lá na estação - ah! Eu quero um vagão prá...pedia antes? Tinha que fazer o pedido, tinha o livro de pedido, você pedia e assim por diante." (12.3)

"Bastante, bastante, bastante movimentada, era, para dizer a verdade, a ordem de chegada de trem de passageiro era um movimento grande, porque num era só aqui em Botucatu, em outros lugares que eu trabalhei também, era praxe as moças, moços irem ver o trem passar..." (30.7)

\section{$\underline{\text { EFS de Botucatu recebendo destaque entre as ferrovias }}$}

Contam que a Estrada de Ferro Sorocabana (EFS) de Botucatu era um centro importante dentre as ferrovias, por ser um local de entroncamento e vários ramais, passando tudo por Botucatu o que vinha do Paraná, de Bauru e de São Paulo. Tinha 
uma extensa linha férrea, por volta de 5 mil $\mathrm{Km}$ a FEPASA. Referem que a EFS de Botucatu destacava-se pela manutenção, desempenho dos funcionários e organização, não podendo haver nenhum tipo de atraso, senão o responsável era punido com multa ou suspensão. O almoxarifado era muito grande, tendo por volta de 2.500 itens e a frota de trens de Botucatu também era enorme, com quase 150 máquinas a vapor. Lembram que em Botucatu ainda existia oficina mecânica que fazia a reparação parcial de locomotivas, tendo uma oficina maior em Sorocaba e na Barra Funda (quadro 36).

Os elementos que aparecem são: - Sendo bem diversificado o almoxarifado, Sendo referência como oficina mecânica, - Tendo extensa linha férrea, - Sendo muito organizada, - Tendo grande frota de máquinas.

"Tudo! Descia tudo, Paraná, aquela, a Paulista, descia tudo que vinha para Bauru passava aqui e ia tudo para São Paulo." (4.3)

"Daí passou pra super intendente, chefe da regional tudo. Um ano eu fui a São Paulo, responsável pela Fepasa inteira, $5 \mathrm{mil} \mathrm{Km,} 5 \mathrm{mil} \mathrm{Km}$, parte da via permanente né, fiquei um ano lá." (24.2)

"...a regional, aqui de Botucatu, ela se projetou em relação as outras regionais pela... por ser uma regional assim no tocante a manutenção, desempenho dos funcionários né, assim ela se projetou." (24.15)

“...óia Karina a Sorocabana foi um exemplo de organização viu. Aí...é...o foguista de primeira, era o foguista que...que trabalhava só nos trem de passageiro né, o foguista de segunda era...as vezes eles escalavam também foguista de segunda, porque tinha foguista de primeira que num... num dava conta do serviço viu. Aí ficava no carga né, porque o empregado na sorocabana, o empregado que era bom de serviço era respeitado e a administração conhecia, porque quem não era bom de serviço aparecia, então a ferrovia naquela época, do tempo da máquina a vapor, todo mau empregado, em tudo quanto era repartição aparecia, aparecia o serviço dele, que ele não era bom. Você tinha que ser mesmo bom de serviço." (12.2)

“... as locomotivas, os vagões todos eram sediados aqui, eram reparados aqui, tinha uma... tinha uma sessão de reparação de vagões aqui, pintura de vagões aqui, o escritório era, o depósito de Botucatu era muito grande, era muito grande o depósito aqui, e tinha o depósito, tinha um inspetor engenheiro..." (20.1)

"Ah! Eu tinha que fiscalizar, além de fiscalizar as passagens, ver se estavam certas, e muita vezes algum passageiro entrava sem passagem e eu tinha que cobrar, eu estava preparado pra cobrar a passagem da onde embarcasse pra onde quisesse ir. Então cada passageiro que embarcasse sem passagem, onde havia estação aberta a gente cobrava uma multa, a multa era 25 cruzeiros na primeira classe e 20

na segunda, entendeu? Além da passagem ainda pagava essa multinha, aí já cobrava a passagem até o destino que a pessoa ia." (21.2) 
“...trabalhar como chefe de estação, você recebia os trens de passageiro e soltava os trem de passageiro, acompanhava o movimento dos trem de carga, horário é... tomava conta dos atraso dos trens, quando atrasava o trem tinha que procurar saber o motivo do atraso e transmitia pra sessão de movimento, dá o motivo do atraso do trem né, trem era tudo no horário, e... não podia atrasar, mais atrasava sempre um motivo tinha né, mais atrasava, algum motivo a gente encobria e passava por uma mentirinha também..." (22.2)

Gerando muitos empregos e renda

Contam que na ferrovia Sorocabana existiam muitos funcionários, sendo só na estação uns 200, no depósito e de carreira mais uns 300, e da Barra Funda até Porto Epitácio tinham 18 mil em 1941 e em 1960 eram 22 mil funcionários na EFS. Na superintendência de Botucatu eram 3 mil funcionários. A Sorocabana era tida como a rainha do emprego no Estado de São Paulo e, na cidade de Botucatu só depois foram aparecendo outros campos de trabalho. A ferrovia também era rentável, sendo que o trem de carga dava lucro, mas o de passageiros não, inclusive a ferrovia auxiliava anualmente com uma verba o pagamento do professorado e da polícia do Estado (quadro 36).

"É, tinha, trabalhava muito, uma média, acho, entre o pessoal de carreira e do depósito eram uns 300 homens mais ou menos." (4.1)

"Quando eu entrei falaram pra mim, não sei, eram 18 mil empregados, da Barra Funda até Porto Epitácio, da Barra Funda até Porto Epitácio, quando eu entrei em 41, depois foi indo foi diminuindo, eram 18 mil empregados." (14.1)

" A Sorocabana toda né, até tinha o trecho de Piracicaba, São Paulo a Santos né, São Paulo a Santos, São Paulo a Itararé, São Paulo a Itararé e São Paulo a Santos. De São Paulo a Porto Epitácio que era mil quilometro, era, na barranca do rio do Porto Epitácio estava a placa, 999, de São Paulo a Porto Epitácio era 999, agora já diminuiu bem, que depois que eu entrei na estrada de ferro fez outra linha."

"A Sorocabana foi a primeira, depois veio a, a medicina né, veio a medicina, depois da medicina veio a Duratex aí foi..." (17.7)

“... assim era na Sorocabana, naquele tempo a Sorocabana aqui no estado de São Paulo era o rei do emprego né." (28.2)

“... todo mundo queria viajar ali, porque ali era confortável, era gostoso né, mais a ferrovia achava que não dava lucro, mas num era pra dá lucro, aquilo era pra dá conforto né, a carga que dava lucro né, bruto, era carga que dava lucro né, e quantos trens tinha... Olha vinha trem de boi, vinha 20, 30 gaiolas cheias de bois pra São Paulo, vinha lá de Presidente Epitácio, vinham toras, 30, 40, gôndolas de toras né, e ia pra São Paulo." (25.11) 
“... o dinheiro ia tudo pra... tinha umas...que nem um cofre grandão, a estrutura de um latão, uma coisa, então ele era um cofre, então você pegava um funcionário da estação, todos pegavam e punham tudo dentro de uma bolsa e ia, punha aquele, levava pro chefe de trem, punha lá naquela, na caixa, uma caixa de metal, punha lá e chegava em São Paulo aquele colosso, ia pegando, pegava aqui em Botucatu, aí....conforme ia passando na estação que tinha dinheiro, ia....já punha naquela ... naquele coiso, que nem uma bolsa de zíper bem fechada e jogava lá, o nome tudo, chegava até lá em São Paulo, chegava tudo lá em São Paulo. Aí, dois funcionário ia lá e pegava aquela bolsa que tinha uma alça, pegava um de cada lado e levava pra tesouraria e o dinheiro ia para a tesouraria, ou o diretor da Sorocabana, aquele dinheiro ele tirava a parte do movimento da ferrovia e o resto ia lá pra tesouraria do estado que aí o estado com aquele dinheiro, dizem, não sei se é verdade, que pagava o professorado e a polícia, era arrecadação da Sorocabana, é, você vê como a Sorocabana, como rendia, como rendia a Sorocabana, é dava resultado que era uma maravilha." (12.10/11)

Estabelecendo sistema de saúde

Reconhecem que a ferrovia contribuiu para o estabelecimento de uma rede de assistência à saúde dos ferroviários no município de Botucatu, contando inicialmente com um posto médico, com três médicos e uma farmácia anexa, que aviava as receitas dos ferroviários. Depois foi construído o hospital Sorocabana, para o qual os ferroviários contribuíam com dinheiro para sua construção (era doado um dia de serviço por mês) (quadro 36).

“... na época eram 3 médicos, tinham 3 médicos: Arnaldo Moura Reis, João Reis, Doutor Araújo, depois veio o Doutor Darvi, aí veio o Vino, mais na época, doutora, da saúde, vamos dizer, a parte da empresa que era ferroviário tinha mais assistência, assistência na casa..." (13.5)

"A farmácia funcionava ali em frente ao antigo Lunardi, ali, que era aquela farmácia de fórmula, eu entrei ali, era só pra ferroviário. (...) Não, aí... aí por exemplo se houve a receita médica, porque ali em anexo, tinham 3 médicos na época, e o posto médico era anexo junto (...), então saía do posto médico e já entrava na farmácia mas só com receita médica, só com receita médica, só." (13.2)

"Ah! Nós que fizemos o hospital, nós é que fizemos, nós que bancamos com hospital, pagava mensalidade, pra consultar, pra tudo é, nós pagávamos mensalidade." (8.8)

\section{$\underline{\text { Apresentando boa infra-estrutura e boas escolas em Botucatu }}$}

Revelam que Botucatu já era uma cidade desenvolvida, contando com uma boa infra-estrutura. A luz chegou ao município em 1907, sendo que a primeira usina hidrelétrica do Estado foi construída no município pelo Bacchi. No município existiam duas companhias de luz, a do Bacchi e da Eletro Paulo. A rede de 
abastecimento de água era muito boa, sendo a água sempre de boa qualidade. O lema da cidade era: cidade dos bons ares e das boas escolas. Vinham estudantes de várias regiões para estudarem nas famosas escolas de Botucatu (quadro 36).

“Não! Ali tinha uma caixa d'água, aquele quarteirão inteiro era uma caixa d'água, mas a piscina e aí o Emilio Pedutti foi a prefeito falou não, vou fazer uma caixa d'água que vai dar pro ano de dois mil, vou fazer uma caixa bem feita pra essa água que tá aí... até dois mil garanto que tem água em Botucatu (nt) água e esgoto em tudo lugar." (8.6)

"É o Bacchi... a luz dele era das casa, que ele demando pra companhia paulista e ganhou a causa, então a companhia ficou com os poste, e o Bacchi ficou aqui com as casas, mas ele não aguentou porque o... a Eletro Paulo era muito forte sabe, e ele estava velho e os filhos não acompanharam ele." (17.6)

“É, em 1907 foi um grande, uma grande festa aqui, a chegada da luz elétrica, 1907."

(17.16)

"O lema era: Botucatu, cidade dos bons ares e boas escolas. Quando eu tomei posse em Candido Mota, quando eu disse da onde eu vinha, a inspetora de ensino, na época, ela me disse: a senhora me trouxe um cartão de visitas." (13.4)

“... vinham de toda a região, estudantes da Santa Marcelina também. Vinham estudar aqui? Nada... vinha da região, Mato Grosso, alta Sorocabana, eles vinham de todo o canto... Moravam na escola e cursos bons, muito bons. Botucatu era famosa justamente por causa das escolas. É... Botucatu tinha muitas escolas famosas né, mas gozado que não ficaram aqui saíram, algumas voltaram..." (24.4)

\section{$\underline{\text { Sendo um centro cultural, comercial e industrial }}$}

Relembram que Botucatu era uma cidade com várias atividades culturais, tendo bastante divertimento nos bailes e sendo a capital do cinema. Existiam 3 cinemas em Botucatu e a ferrovia era o centro distribuidor, sendo que o Emílio Pedutti, morador e ex-prefeito de Botucatu, era dono de uma grande rede de cinemas. O comércio da cidade era bem desenvolvido, mas praticado a preços elevados e dominado por um grupo de italianos. Existiam também várias fábricas na cidade: de chapéu, macarrão, bolachas, balas, cerveja, guaraná, e serrarias. Um outro passeio era ir até a estação esperar os trens chegarem (quadro 36).

“... mas tinha os divertimentos da gente né, tinha baile, tinha tanta coisa por aí. Aquele sábado, era baile na Vila Maria, baile não sei aonde! À fantasia! Aquele tempo era gafieira, né." (2.2) 
"Nossa vida! Era tulha de café, era salão grande, então, lotava viu, pegava o sanfoneiro aqui de Botucatu, que era, eu não me recordo o nome dele agora, era o Ferdinando, parece uma coisa assim, e ele ia lá tocava sanfona e nós dançávamos e tinha um senhor lá que era muito amigo nosso na fazenda também, morava lá junto com nós, ele tocava violão e cantava e tinha sanfona também. Hei! Mas era, era divertido viu!" (10.3)

"O cinema! Aqui, aqui era a capital do cinema aqui! Aqui chegou a ter parece que 4 ou 5 cinemas, aqui! Toda a distribuição de filmes para o Estado de São Paulo, Mato Grosso e tudo era feito por aqui, entendeu? Todas as companhias de Filmes: Paramon, éh, e todas elas, entendeu? Tinha o escritório aqui e cedo vinha aquele monte de latas de filmes, entendeu? Entregava a noite depois de tarde voltava tudo pra ser distribuído, tudo pela ferrovia.(...) cinema tinha 4 ou 5 como já falei, 4 ou 5 cinemas, entendeu? Era, hoje tem um e oiá lá (risos). Uma sessão e olha lá." (2.2)

' O Emílio Pedutti tinha 25 cidades com cinema, ele então é exibidor, então eu ia pra fiscalizar a renda quanto deu, metade dele metade da companhia..." (17.5)

"Tinham 3, o Cassino, o Pavilhão e o Glória que era no bairro. Era uma empresa só. Passava uma primeira parte do filme aqui, terminava e o carregador já levava para o outro cinema. Tinha um mensageiro. Punha na lata e ia a pé correndo. Então os cinemas começavam em horários diferentes, tipo seis horas, seis e meia e sete horas. No Cassino duas sessões, nos demais uma..." (29.2)

"O que estragou Botucatu foi meia dúzia de italianos que tomaram conta daqui e não deixaram entrar indústrias aqui. Esses... Blasi..." (29.1)

"... tinha a industria Petrarca Bacchi, era na esquina. Ele tinha fábrica de cerveja, guaraná, fábrica de macarrão, bolacha, fábrica de chapéu, serraria, tudo ali perto."

“Era o Milanezi, o Bacchi. O Bacchi era carroceiro, ele foi o Matarazzo de Botucatu. Era uma potencia. Tinha máquinas, tinha fazenda. Faziam máquinas de beneficiar café e exportavam. Esta máquina foi para o mundo inteiro. O Milanezi era serraria, fazia peças, equipamentos" (29.3)

\section{Categoria F2 - Relembrando o tipo de trabalho realizado na ferrovia}

Ao relembrarem como era o trabalho na ferrovia relatam que era sofrido, ficando longe de casa por longos períodos e não tendo descanso para o almoço, dormindo e alimentando-se mal. Para facilitar a vida recebiam ajuda de suas mulheres para preparar e levar as refeições. O trabalho exigia muita responsabilidade e treinamento, sendo difícil e trabalhoso, tendo longa jornada de trabalho, enfrentando muito barulho, tendo que ficar a disposição do serviço e trabalhar por escala, privando-se de datas comemorativas com a família. 
As subcategorias são: - Sendo sofrida a vida do ferroviário, - Recebendo auxílio das mulheres na alimentação, - Sendo difícil e trabalhoso o serviço, Exigindo muita responsabilidade e treinamento (diagrama 26).

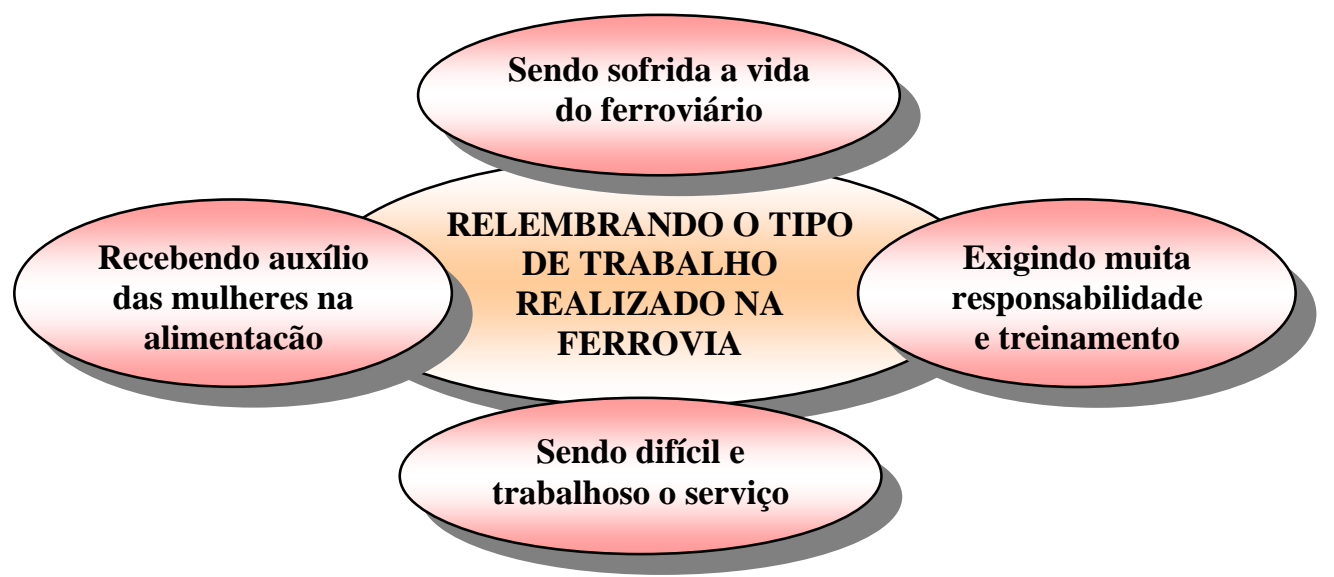

Diagrama 26. Categoria F2 - Relembrando a importância do trabalho na ferrovia: Subcategorias.

Sendo sofrida a vida do ferroviário

Revelam que não era tão bom assim ser ferroviário por trabalhar muitas horas seguidas, dia e noite, passar fome, sofrer com o intenso barulho, trabalhar longos períodos longe de casa e dormir pouco na própria casa. Não tinham nem descanso para o almoço, tendo que comer na própria locomotiva em movimento. Contam que tinha muito trabalho e que todo os dias faziam hora extra para adiantar o serviço, que era pesado com muitas funções difíceis, exigindo treinamento e dedicação intensa. Relatam que as jornadas de trabalho eram enormes, fazendo viagens com a locomotiva a vapor que demoravam 24, 30 horas sem parar. Eles trabalhavam por escalas e muitos tinham que ficar constantemente a disposição, tendo que ir trabalhar e resolver problemas sempre que eram chamados, perdendo várias datas comemorativas com a família.

Os elementos que agregam-se a esta categoria são: - Não tendo descanso para o almoço, - Ficando longe de casa, - Sendo a jornada de trabalho enorme, Trabalhando por escala e perdendo datas comemorativas com a família, - Ficando a disposição do serviço, - Trabalhando com muito barulho (quadro 37).

"Puxado, chegava a fazer dois meses, três meses num só, 700 horas, pegava aquele prêmio né, depois de 16 hora, um xis de 16 hora dava 4 horas de premio.(nt), dava para fazer 600, 700 horas por mês..." (1.1) 
"Sim, dormia 5 noites na minha cama só por mês, você vê! E ficava sem comer 24 horas e passava fome lá, trabalhava (nt), vinha em casa e eu num vinha, ficava lá, as vezes passageiro atrasava, acidente, qualquer coisa, fez 24 horas, era comida azeda, sem dinheiro, comia aquilo." (1.3/4)

"Ah sim, passava, principalmente em cima de locomotiva, porque quando a gente trabalhava com locomotiva, aqui de manhã saía uns trenzinhos pequenos que a gente chamava Misto, levava tudo misturado, então era o Misto, então faziam a comida em casa, minha mulher fazia a comida e eu pagava um menino para levar a comida pra mim na estação e eles mandavam no trem, mas as vezes a gente tava muito longe e esse trem demorava pra encontrar. A gente pegava comida, pra fazer é feito fresquinho, mas o calor né, então tava azeda, pegava aquela comida cheirava, num dava, jogava fora, fazia o que? Tomava água da locomotiva, água de tender né, aquela água morna, num tinha outra, e ficava sem comer, então as vezes eu fico lembrando né, como a coisa mudou. A gente podia chegar numa cidade, que o trem passava na cidade e pedia pro movimento: nós vamos parar tantos minutos para comer alguma coisa né, mas aquele tempo a pessoa parece que morria de medo de vir um chefe, aquele parece que tava vendo um Deus no vagão né, de medo, e a gente ficava as vezes aí é... 10, 12 horas sem comer nada, comida tava estragada e ficava por isso mesmo. Por exemplo maquinista, o maquinista pegou a comida dele, a dele estava boa, a minha estava azeda, ele comia a dele, agora ele não tinha obrigação de dar pra mim né, ou podia falar, então vamos parar em tal lugar, pelo menos um café você vai tomar né, mais que... num tinha... num tinha esse negócio não, a gente tinha uma resistência por demais." (25.7)

"Eu cheguei a ficar até 3 meses fora de casa, mandava ordenado ai para minha mulher e eu ficava por lá... trabalhando. As vezes a gente armava uma república, então ali a gente cozinhava, a república tinha cozinheiro, tinha tudo, tinha cama, tinha tudo, uma casa grande, sempre moravam uns 20 homens, alugavam 3 casas, tinha cama tinha tudo." (19.2)

"Dava porque fazia força né, porque a locomotiva a vapor tem um negócio, pra você fazer fogo nela, a lenha não era só você jogar a lenha dentro dela de qualquer jeito, você tinha que jogar ela enfiada assim (mímica), uma em cima da outra certinho, porque senão ela não produzia vapor suficiente, se você ver a boca da fornalha é assim (mímica), em pé as laterais, tinha que joga pelas laterais, não podia deixar lugar sem lenha, era trabalhoso viu." (5.6)

"A noite era bom, mas quando era o contrário, você voltava trabalhar depois das duas horas, você voltava cansado com sono, porque de dia o sono não era bom que nem a noite né, não sustentava parece que a gente não... a gente sentia, voltava trabalhar com sono. Doze horas sem parar. Isso só no pátio aqui, no pátio.

Fazendo manobra? Fazendo manobra, Nossa demorava tudo isso? Ficava o dia intero, porque não era um trem só, eram formados os trem tudo em seguida, quer dizer, eram os trens que formavam, eles formavam, os vagões, vamos supor, tinham os destinos certos. Eu trabalhava na locomotiva, a manobra era puxar os vagão pra cá, levar pra lá na linha, acertando os trem e tinham os manobradores que eram os que trabalhavam no chão lá acertando, engatando, desligando o vagão." (5.7) 
“...ah! outra coisa, o natal, dificilmente nós passávamos o natal, eu com as criança, ele tem duas dele e mais três meu né, mas quando eu morava lá embaixo eu tinha dois e nós ficamos natal sozinhos em casa, nunca... ficava viajando? Ficava viajando, ah! Ía viaja. Nunca, porque tinha sempre aqueles que escalava, e o Ary não era assim, gostava, ficava ajudando né. Ė ficava trabalhando. Dia de ano, tudo! Dia de ano, sempre sozinha." (12.7)

"De dia, de noite, era uma, duas, quatro horas da manhã, chegava aquela horinha estava lá, tinha que já ir direto, chegava aquela hora você ia embora direto, e outra, os trens, vamos supor, que nem de passageiro, vem vindo atrasado ia um chamador em casa, avisava que tal hora só que vinha chegar o trem, pra você ir lá, de madrugada era ruim, então eles faziam isso. Isso eles chamavam chamador. Que vinha na casa? Vinha na casa, rodava Botucatu intera, a noite intera, a noite intera, chovendo, com frio o jeito que tivesse. $\boldsymbol{E}$ vinha a pé? Algum tinha bicicleta." (5.5)

“... exaustor atrás da cabine, o compressor tudo barulho, tudo pe pe pe pe pe, era uma barulheira lá trás, ba ba ba na cabeça da gente viu, a viagem inteira, compressor tocando, é...parava, depois tocava outra vez." (10.3)

$\underline{\text { Recebendo auxílio das mulheres na alimentação }}$

Lembrando o trabalho e o auxílio desempenhado pelas mulheres dos ferroviários, que tinham que levantar de madrugada para fazer comida para eles levarem ou mandavam até a estação para ser despachada para o marido, onde ele estivesse trabalhando. Algumas também prestavam serviço para a ferrovia, lavando roupas e colocando os filhos pequenos para ajudarem (quadro 37).

"Mandava, tinha um trem de passageiro que saía de manhã, ele levava as marmitas lá, agora minha falecida esposa, por isso que eu digo que ela ajudou eu a ganhar minha vida porque, se eu fosse sair ás 2 horas da manhã, 3 horas da manhã, uma e meia ela estava levantada, ela fazia a comida pra mim levar, porque ela sabia que eu não gostava de comprar comida assim na vila, então ela fazia a comida assim pra mim levar, levantava cedinho." (5.5/6)

“... as mulheres, elas quantas vezes de madrugada no fogão a lenha fazendo comida prá mim levar. É a gente levava ou então mandava na linha prá mim, levava a pé, a gente morava perto, mandava levar na estação; a mulher de ferroviário, dos ferroviário da carreira - maquinista e foguista- sofreram barbaridade. De madrugada estava fazendo comida no fogão a lenha né. Que nem eles chegavam em São Paulo, que saía daqui e levava comida, tinha uma folha de zinco cheia de areia, embaixo era o fogo e esquentava e punha a vasilha de comida ali pra esquentar (risos)." (12.6/7)

“...minha mãe lavava roupa pra estrada sorocabana, minha mãe ficou viúva nova, com 34 anos, meu pai morreu com 38 e eu tinha dez anos e aí arrumaram o serviço pra ela lavar essa roupa aí né, lençol, fronha, as capa dos trens de primeira classe né e com isso, com esse serviço da Sorocabana que a minha mãe criou nós, mas todos nós trabalhávamos, um estendendo roupa, outro ía recolhendo, outro ía passando, as criança, as quatro trabalhando, até a pequenininha tinha serviço, que como com 3 ano e meio ela tinha o serviçinho dela também..." (12.70 


\section{Exigindo muita responsabilidade e treinamento}

O trabalho na Sorocabana era rigoroso, sendo que os ferroviários tinham de trabalhar corretamente e com muita atenção e não podiam atrasar nenhum minuto, principalmente no trem de passageiro, senão recebiam multa ou suspensão, conforme a infração. Algumas funções exigiam treinamento, existindo um mestre que ensinava ou o próprio colega mais experiente. Também era importante conhecer muito bem o percurso (quadro 37).

"É, de lá pra cá, aí pelos pingos que a gente controlava pros carga correr. Tinha que estar com o percurso na cabeça, aqui né, pra controlar todo o movimento, para não atrasar ninguém, e aquele tempo era uma beleza que era difícil ocorrer acidentes né, e a gente, quando o trem perdia 2, 3 minutos tinha que saber o motivo que perdeu. Tinha que fazer o boletim de ocorrência: tal trem perdeu dois minuto de Oiti a Embaúba por esse, esse motivo, fazia ocorrência, coisa, depois a chefia que ia ver, que ia julgar eles, (nt) as vezes atrasava trazendo bagagem, então era um serviço intenso..." (18.6)

“... o maquinista precisava saber o que estava fazendo, ter cuidado, conhecer a sinalização direito. Passava um sinal a perigo batia, não podia passar um sinal a perigo, se você passasse um sinal a perigo eram 15 dias suspenso, eu nunca tive essa suspensão, de passar um sinal a perigo. O maquinista tinha muita responsabilidade, era muita responsabilidade, qualquer coisa ia em cima do maquinista, e tinha que responder bem se não tomava na cabeça, ficava suspenso, multa, pagava multa, era multado." (16.3)

"Oitocentas, a marcha dela pra o você puxa é pesada viu. Não, você abrindo o regulador, daí na entrada de vapor ela ia aumentando a velocidade pelo regulador, agora a locomotica elétrica eram 3 marchas, primeira, segunda e terceira. A vapor não, a gente que regula. Era difícil? Muito mais difícil, o maquinista, o maquinista da máquina a vapor tem que ser, como se fala, que ele é bom, ele tem que saber

trabalhar mesmo, é difícil trabalhar com máquina a vapor. Conforme puxa o regulador, ele vai devagarzinho, devagar né, vai puxando (nt)uma pressão que nem, você num aguenta de tanto fazer pressão, é difícil sim. Ah! Tinha que ter experiência pra trabalhar, conhecer muito bem a linha, saber onde é mais, a linha é mais reta, aonde é menos, onde desce, sobe." (12.12)

\section{Categoria F3 - Sendo a ferrovia importante para o progresso}

Contam que a ferrovia gera progresso, na medida em que promove o crescimento das regiões por onde passa, facilita a comunicação, implementa novas tecnologias, possibilitando desenvolver parceiras com outros países. Além disso, configura-se como um importante meio de transporte de pessoas e de mercadorias, mais barato e com grande capacidade de transporte, importando e exportando produtos. Classificam a ferrovia também como um bem social, extremamente importante para 
o país e o transporte de pessoas, mesmo sem lucro. Ela também serviu como modelo para movimentos grevistas, por ser uma classe de trabalhadores bem organizada (quadro 38).

Encontram-se, aqui, as seguintes subcategorias: - Promovendo o crescimento dos locais por onde passava a ferrovia, - Possibilitando trabalhar com outros países, Facilitando a comunicação, - Sendo a ferrovia um bem social, - Implementando novas tecnologias, - Organizando movimentos grevistas, - Sendo importante meio de transporte de pessoas e mercadorias (diagrama 27).

"O mundo viveu em torno da ferrovia viu, o mundo..." (17.8)

"Naquela época dava gosto, se trabalhava com gosto de trabalhar,você só via progresso ali..." (22.2)

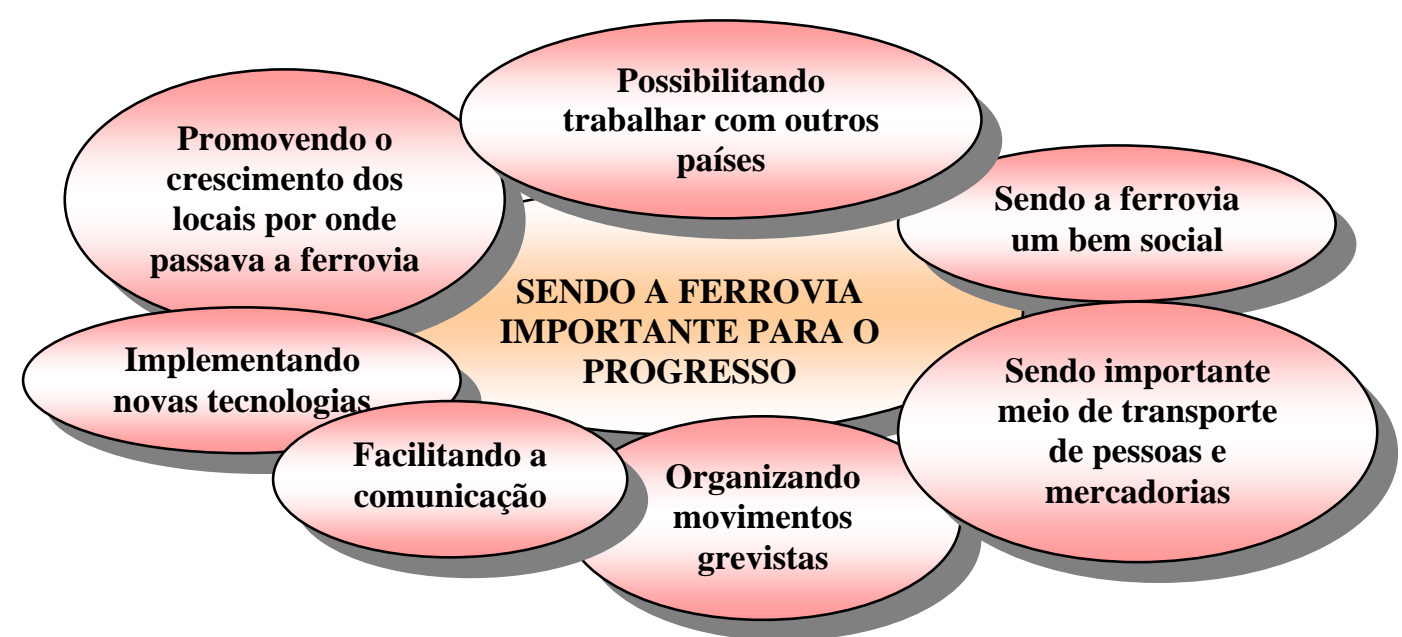

Diagrama 27. Categoria F3 - Sendo a ferrovia importante para o progresso: Subcategorias.

Promovendo o crescimento dos locais por onde passava a ferrovia

Referem que a ferrovia promovia o desenvolvimento das cidades por onde passava, levando o progresso. Observam que as ferrovias sempre passavam no centro das cidades, pois a ferrovia chegava primeiro e os centros das cidades iam se formando ao seu redor. Relatam que todo o crescimento do Estado de São Paulo e Paraná se deu à custa das ferrovias. Comparando com as rodovias, observam que estas não contribuíram para o crescimento das cidades assim como as ferrovias (quadro 38). 
"Na época, a ferrovia era o principal meio de transporte do estado, depois que vieram os transportes rodoviários..."

"A ferrovia é diferente da estrada de rodagem. A Estrada de rodagem passa, mas não deixa rastro, a ferrovia deixou tudo... essa alta Sorocabana e o resto Paulista tudo cresceram. Se a Sra. imagina o progresso que trouxe a ferrovia, basta dizer que a ferrovia passou por quase todo centro né. Aqui em Botucatu mesmo ela chegou no centro da cidade, Assis no centro da cidade, Presidente Prudente no centro da cidade, por que? Porque num tinha, num tinha nada, então a ferrovia foi a razão do grande progresso da alta Sorocabana, da Paulista, da Noroeste. A ferrovia... se tivesse criado uma ferrovia de Brasília a Belém, hoje o movimento lá seria muito maior..."

“... o Paraná foi se desenvolvendo graças a ferrovia, o norte do Paraná cresceu graças a ferrovia, é aquela madeira do Paraná, até que se pode vê que o norte do Paraná é a região mais desenvolvida, o sul de Minas, Uberlândia, Uberaba, tudo isso aí..." (20.2/3)

\section{$\underline{\text { Sendo importante meio de transporte de pessoas e mercadorias }}$}

Contam que a ferrovia era um importante e quase único meio de transporte de pessoas e de mercadorias na época. Tudo era transportado pela ferrovia: café, milho, arroz, feijão, açúcar, sal, mandioca, cereais, cerveja, gado, madeira, areia, pedra britada, óleo diesel, gasolina, soda cáustica, sendo que todo o traçado inicial das ferrovias foi feito para escoar a produção de café do Estado de São Paulo. Consideram que o transporte ferroviário era mais barato e com grande capacidade para cargas, bem superior à dos caminhões. Para o transporte de passageiros, existiam vários tipos de trens, como o Ouro Branco e o Ouro Verde, que eram trens de luxo, só para passageiros mais abonados (quadro 38).

Os elementos que compõem esta subcategoria são: - Importando e exportando mercadorias, - Tendo grande capacidade para transporte, - Sendo o transporte mais barato.

"Ah, tinha bastante, o número de passageiro, o número de carga né, tinha os de passageiro e os trens de carga, que transportavam mercadorias né, era feito tudo por estrada de ferro, num tinha caminhão..." (7.2)

"Transportava gado, transportava o café, soja, cereais de toda natureza, madeira, madeira também vinha um colosso do norte do Paraná, nossa era muita madeira tirada de lá, muita madeira tirada..." (20.3)

"Tudo: arroz, feijão, milho, soja, semente de girassol, é fazenda, ferragem, cimento, cal, né, era bastante, num era pouco não...(nt) eu levei oito vagões de soda cáustica, essa soda de fazer sabão, oito vagões de soda cáustica pra usina..." 
"Mandavam pra cá e a gente mandava daqui pra lá, tinha a sessão de bagagem de importação e exportação, depois seguia e mandava..." (22.1)

“... porque você vê, uma locomotiva de Ourinhos ao Porto leva mil tonelada, precisa 200 caminhões, os caminhões, esses monstros de caminhões aí nas estradas aí, estragando as estrada, porque o asfalto num aguenta..." (12.17)

“... num tinha um meio de transporte mais barato né, o primeiro foi fluvial, depois veio o marítimo né, e depois veio o ferroviário..." (24.9)

"É, branco era a óleo sabe, aquele era acima de super luxo, aquele embarcava só gente grossa, operário num tinha condição, nem ferroviário..." (17.8)

“...tinha o P1 e o P2 que era carro de madeira que pegava os passageiros lá em Assis, descia tudo do Ouro Verde, passa Prudente, lá pra Sorocabana,(...) a estação, ficava super lotada! A gente que embarcava ali, aquele povo tudo de cabina, esse povo rico da alta sociedade, era deputado tudo, andava no trem ôôô. Tinha o carro A15, o carro da inspeção, da diretoria de São Paulo, volta e meia tinha um deputado que ia, era lá de José Teodoro.." (12.5)

“... ouro verde, a composição era verde mesmo, era tudo verde, aí depois de tempos veio o ouro branco, aí era uma com posição pequena, era uma composição com uma máquina de duas frente né, uma virava, o maquinista mudava de um lado pra outro, eram 2 carros e um restaurante, era um trem mais rápido um pouco." (30.50)

Implementando novas tecnologias e possibilitando trabalhar com outros países

Contam que novas tecnologias se desenvolveram por intermédio da ferrovia, com o uso de locomotivas a vapor, depois, diesel e elétrica, sendo algumas importadas da Alemanha e EUA. A linha férrea foi eletrificada aos poucos, de São Paulo para o interior, recebendo ajuda externa de americanos para essa implantação (quadro 38).

“... aí em 47 eu fui a maquinista das locomotiva a vapor, aí trabalhei até 52 com locomotiva a vapor, aí de 52 pra cá começou a vir locomotiva a diesel e as elétrica. A elétrica corria de São Paulo, começou a correr de trecho em trecho, de São Paulo a Sorocaba, de são Paulo a Iperó depois de São Paulo a Juquiratiba, depois em 52 que veio pra Botucatu a elétrica, aí foi avançando..." (16.1)

"Companhia americana, pediu licença pra fazer trem aqui também né, eles fizeram, vieram porque não pensavam que nós podíamos fazer. Quando ficou pronto nosso luxo, foi um assombro, o nosso luxo, recebeu o nome de super luxo, mas os americanos não deixaram..." (17.7)

“... a Sorocabana eletrificou de São Paulo a Sorocaba, depois de Sorocaba ela veio a Iperó, de Iperó ela veio a Laranjal, de Laranjal ela veio a Botucatu, depois aqui de Botucatu foi a Manduri, ela foi fazendo todos os trechos conforme ia passando..." (8.4) 
"Não daqui mesmo, daqui mesmo, a não ser as locomotivas que vinham é... aquelas locomotivas Crupi, eram fabricação alemã, então eles importavam as peças né, e tinham as locomotivas americanas, essas já eram mais fáceis, porque locomotivas nacionais mesmo nós não tínhamos nenhuma aqui,aliás, começamos a

ter depois, umas locomotivas que eram montadas em Campinas, as elétricas, algumas eram da GE, e outras eram Westingauss..." (30.3)

“... umas par de subestações nacionais e umas par delas Americanas, junto com americano, junto com americano, porque o americano, o americano já ia com os desenhos da América, dos Estados Unidos, então ia dentro do transformador, cheio de óleo..." (19.1)

“... montamos uma subestação em Palmital, aquela subestação já era de outro tipo de subestação, já não era mais nem nacional nem americana, já era Suíça. Não, inglesa não, era só americana, nacional e essa suíça e... o suiço era um baixinho, pesava 110 quilo, inteligente pra dana viu, o suíço, onde ele ia eu tinha que ir junto com ele..." (19.2)

\section{Facilitando a comunicação}

Relembram que a comunicação naquela época era difícil e feita, principalmente, por meio da ferrovia, por intermédio do telégrafo, que transmitia e recebia as notícias. Não existia ainda televisão e os rádios pegavam muito mal. O jornal era trazido pelos trens e também vendido dentro dele. No entanto, o mais eficaz era o 'boca-a-boca', pois os ferroviários conversavam bastante e ficavam sabendo de tudo (quadro 38).

"Vinha, o telégrafo é que comunicava com tudo, naquela época para acertar os relógios, quando faltava 5 pra o meio dia: tempo, tempo, tempo, tempo, tempo, pra toda estação, ligava tudo o telégrafo, aí acertava o relógio, quando parava todo mundo acertava o relógio: meio dia em ponto. Naquele tempo o telégrafo, antes do telefone, (...) então era tudo telégrafo, desde estação grande... (nt) 1940, 40, 41... telegrafando congratulações, fulano morreu, isso aquilo, festa e tal, tudo pelo telégrafo, tudo pelo telégrafo..." (18.4)

"É tudo. Tinha o telégrafo né, telégrafo tinha o seletivo, naquele tempo era que nem um telefone né, comunicava de lá de Bauru, comunicava aqui em Botucatu com a seção despachadora aqui, né, fazia tudo que precisava, de um recado passava por ali também, né." (11.5)

“... não tinha televisão pra gente ver futebol, aqui não tinha, nem rádio, nem televisão, no interior não pegava nem rádio não pegava..." (2.5)

“Jornais, vinham jornais né, jornais assim, o trem que saía de São Paulo de manhã ele trazia jornais, o estado de São Paulo, diário de São Paulo, correio paulistano, tinha gente que assinava né, e tinham outros que compravam lá na estação." (7.5) 
"O trem trazia o jornal, aqui não existia banca de jornal. Eu era menina e era minha obrigação, todo domingo, até hoje se lê o jornal de domingo, mas 4 horas da tarde....estação oh (mímica, mostrando o caminho). Chegar lá e esperar o trem chegar, pegar o jornalzinho de domingo pro meu pai ler. E outro detalhe: não eram todas as casas que tinham rádio aquele tempo, eram poucas as casas. Outra coisa: a própria ferrovia era boca-a-boca, sabiam tudo de tudo. Era uma coisa assim muito bonito isso aí, que existiu. Lá em Assis, eu já namorava Nestor na época, eu chega aqui e ele dizia: tal dia você sai com tal vestido, você parou em tal lugar. O boca a boca era maravilha. Entendeu agora. Os ferroviários nesse ir e vir eles eram amigos, não faziam isto por maldade. Eu ia descer do trem, por exemplo, vinha o chefe de trem com aquele cuidado pra gente descer.Eu, por exemplo, que morei em lugarejo, qual era o meu passeio: a estação. Então naquele passar via um conhecido, trocava informação." (13.5)

\section{$\underline{\text { Sendo a ferrovia um bem social }}$}

Consideravam a ferrovia um bem social, por transportar pessoas com conforto e sem ter lucro, por meio dos trens de passageiros, sendo um serviço prestado à nação (quadro 38).

“...porque o trem de passageiro não foi feito pra dar lucro, ele foi feito pra dar conforto pras pessoas né. Olha a gente tinha aí um trem, não sei se a senhora conheceu, isso num é de muito tempo, o trem de luxo de ar condicionado, a gente saía de São Paulo com aqueles carros fresquinhos, com luz fluorescente, com tudo, aquilo era uma maravilha né, e ia lá em Presidente Epitácio né, lá com 40 graus de calor e a gente dentro daquele carro de ar condicionado, todo mundo queria viajar ali, porque ali era confortável era gostoso né, mais a ferrovia achava que não dava lucro, mas num era pra dá lucro, aquilo era pra dá conforto né, a carga que dava lucro né..." (25.11/12)

“... nós prestamos um serviço pra nação...” (26.7)

\section{Organizando movimentos grevistas}

Contam que a associação de classe dos ferroviários era bem organizada e controlava as greves, que tinham de ser curtas, pois a ferrovia não podia ficar parada. Os ferroviários são lembrados, por outros movimentos grevistas, como bom exemplo de mobilização em greves (quadro 38).

"Tinha, inclusive a última greve foi de 63 né, 18 dias parado, 18 dias, a famosa greve dos 18 dias. Parou tudo, tudo, tudo, mas também não ganhamos nada, perdemos né, perdemos, voltamos a trabalhar sem nada. Não conseguiram aumento? Não, mas isso aí, em parte o governo tinha razão, a gente tem que ser justo, porque foi por causa daquele famoso decreto 209, a senhora num deve de

lembra disso, ele deu o decreto 209, era um aumento que ele dava para o funcionalismo público e o movimento de classe da Sorocabana achou que nós também tínhamos direito ao 209, mas antes ele já havia dado um aumento pra nós, foi o Ademar de Barros que era o governador, ele falo: - não dou, que eu já dei pra vocês um aumento, o 209 é para o funcionalismo. (...) perdemos 18 dias de serviço 
e voltamos a trabalhar sem nada, a sorte que era em novembro, dezembro décimo terceiro. Ficamos, corto 18 dias de serviço de cada um, todo mundo, eu participei dessa greve também, foi em 63. E tiveram outras também? Há teve, teve, teve, tinha, tinha sim, só que, como por exemplo, Botucatu é considerado um lugar de grande importância né... então a greve durava 2, 3 dia, no máximo 4, 5 dia e já resolvia o assunto hein, e punha a turma pra trabalhar né, corre bem, pra correr bem..." (30.16)

"Ah sim, que vinha das associações de classe que comandava a greve né, era bem feito." (30.17)

"Eu acho que era, porque teve uma greve de estudante aqui uma vez, estava na catedral ali e chegou uma hora que o estudante lá falou assim: - Ferroviários obrigado por ensinar nós lutarmos... " (17.14)

\subsection{3 - Fenômeno 3 - FALTANDO CONTROLE SOCIAL E DO ESTADO}

O terceiro e último fenômeno é: - FALTANDO CONTROLE SOCIAL E DO ESTADO (fenômeno 3).

Este último fenômeno aparece como causa dos dois anteriores (Aniquilando a vida e Gerando a vida), pois o controle social e do Estado podem contribuir para gerar ou aniquilar a vida, o meio ambiente, a ferrovia e os ferroviários. Os entrevistados cobram a falta de controle social e do Estado sobre o meio ambiente, que gera a autodestruição do ser humano, uma vez que os cidadãos não têm conscientização de preservar perante a não-valorização dos recursos naturais e da própria história da ferrovia. Apontam que a definição de meio ambiente é algo amplo e de difícil definição, sendo outro problema que pode levar a esta falta de controle. Associadas à falta de controle, eles denunciam as ações ineficientes por parte do Estado, havendo corrupção, falta de recurso humano e não-preservação da ferrovia e do meio ambiente, sendo também mais recente a implantação de políticas ambientais.

A este fenômeno estão associadas três categorias: - Faltando conscientização de preservar o meio ambiente e a ferrovia, - Sendo difícil definir meio ambiente, Agindo o Estado de forma ineficiente (diagrama 28). 


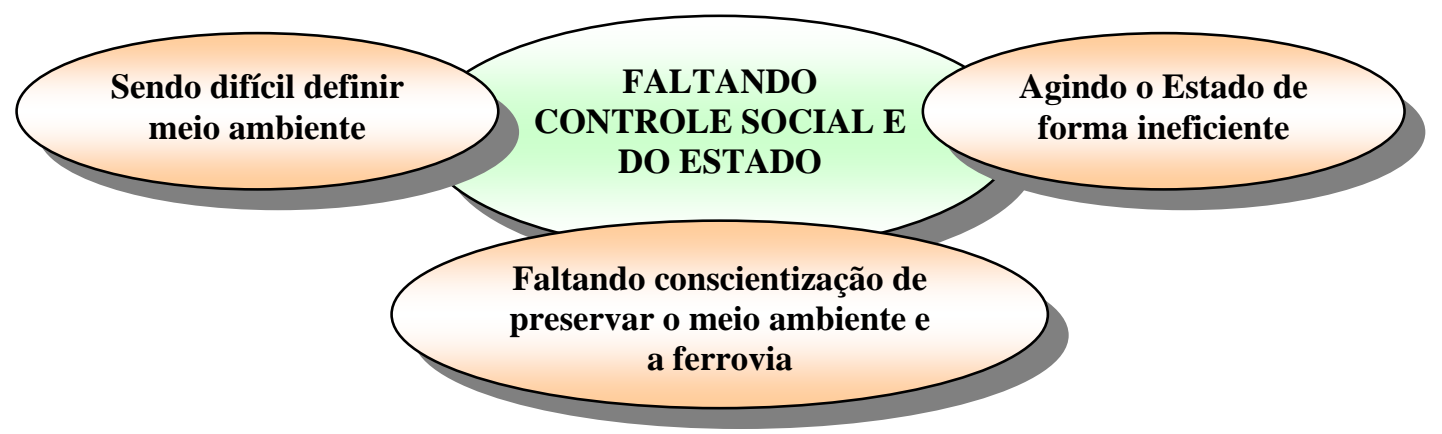

Diagrama 28. Fenômeno 3 - Faltando controle social e do Estado: Categorias.

\section{Categoria 3.1 - Faltando conscientização de preservar o meio ambiente e a}

\section{ferrovia}

Percebem que antigamente não existia a conscientização a respeito da necessidade de preservação ambiental e da própria ferrovia. Somente depois que já havia ocorrido uma extensa devastação, com prejuízo para a sociedade, é que começaram a perceber a importância de se preservar o meio ambiente. No entanto, esta conscientização de preservação ainda não atinge todas as pessoas, embora ressaltem a importância da participação dos cidadãos e a não-valorização dos recursos naturais e da ferrovia, pensando até que não vale a pena lutar pelo passado e pela ferrovia. Tudo isto acaba gerando a autodestruição do ser humano (quadro 39).

Os fatores associados à questão da não-conscientização de preservação aparecem ligados a quatro subcategorias: - Não valorizando os recursos naturais e a ferrovia, - Sendo importante a participação social, - Não valendo a pena lutar pelo passado e pela ferrovia, - Gerando a autodestruição do homem (diagrama 29).

“...nossa era muita madeira tirada de lá, muita madeira tirada, a gente não sabe, nem pensava, hoje que a gente vê como devastaram nosso país." (20.3)

“...tinham os trens de lenha que vinham com a locomotiva a vapor, é lenha aqui, Barra Grande, Vitoriana, Bernardino, em todo lugar tinha um lenheiro. É lenha de mato... Depois que preservaram com os hortos, tinha lá em Avaré, aí as pessoas parecem que vão se conscientizando pra num corta as matas..." (18.4). 


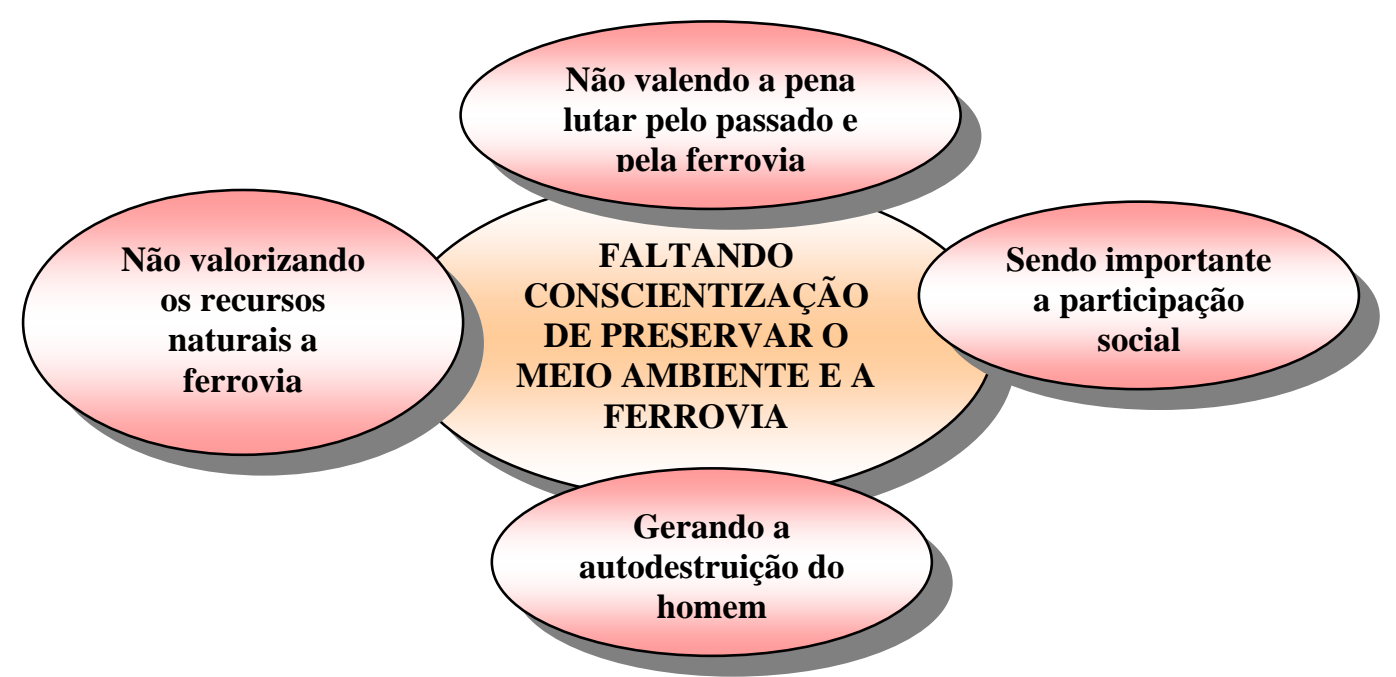

Diagrama 29. Categoria 3.1 - Faltando conscientização de preservar o meio ambiente e a ferrovia: Subcategorias

Não valorizando os recursos naturais e a ferrovia

Criticam as pessoas por não valorizarem os recursos naturais, dizendo que o Brasil destaca-se pela sua grande diversidade, mas mesmo assim vão destruindo tudo. Em relação à ferrovia, criticam o não-reconhecimento, por parte dos governantes, do papel desempenhado pelos ferroviários e que o Brasil não investe no desenvolvimento das ferrovias como os outros países (quadro 39).

“... ainda estão destruindo o pouco que tem, né. Não é todo país que tem o que nós temos aqui, o pessoal não entende isso e aí ainda continua destruindo o que nós temos né. Por isso que eu acho que deveria se chamar bom ambiente, meu modo de pensar é isso aí." (15.6)

"E agora os homens não reconhecem nada disso né." (dizendo do trabalho da ferrovia) (18.7)

"... mas sempre ficou a quem do que poderia ter sido por falta de investimento, ferrovia desenvolveu em todo o mundo, mas aqui não..." (24.15)

“... sendo que nos Estados Unidos, trem lá é aquele transatlântico né, é uma beleza uma maravilha, e nós aqui ficamos a zero, mais porque, sucatearam tudo por interesses próprios deles né." (25.11)

Sendo importante a participação social

Acreditam que o meio ambiente deve ser construído pelas próprias pessoas, as quais tornam-se úteis à sociedade ao contribuírem para um melhor meio ambiente. Julgam que é importante a participação de cada cidadão, cuidando de sua parte, pois 
sozinhos os governantes não dão conta, mas com a ajuda de todos ninguém será sacrificado. Em relação à ferrovia, também destacam a importância do controle social, mas acham que ela foi prejudicada pela grande dispersão dos funcionários, que não lutaram contra o seu fim (quadro 39).

“Meio ambiente, a gente tem que fazer o ambiente, não é? Se não fizer o ambiente a gente fica inútil na sociedade, tá certo? Então a gente faz o ambiente da gente, pra gente associa dentro dele aqueles critérios que a gente tem que ter disciplina né. Um é católico, um é protestante, um é sei lá... judeu,(...) a gente procura ser útil no ambiente favorável e gostoso pra gente né, num é isso? (26.4)

"Hoje estão cuidando mais, tem o Tanquinho, estão plantado. Todo mundo tem que cuidar de um pedacinho. Hoje estão cuidando." (18.8)

“... e agora você vê, depende muito das pessoas, porque a pessoa tem que ajudar, vamos supor, um prefeito foi um lixeiro, foi tudo ele. Tá certinho, está trabalhando, mas ele sozinho não vai vencer tudo isso aí. Cada um tem que ajudar um pouco né, porque todo mundo fazendo um pouco, ninguém sacrifica. $E$ as pessoas não colaboram, né? Não, não colaboram não..." (5.9)

“... a ferrovia, ela tinha o corpo de empregados esparramado. Eram 5 mil quilômetros né! Um pouco em Botucatu, um pouco aqui, outro lá, Bauru e assim por diante né, e então é diferente de uma indústria em que todo mundo está se encontrando, trocando idéia, e bolando, bolando coisas em conjunto né e constituindo uma força e pressionando a administração. A ferrovia não, você ficava aqui trabalhando, não tinha tempo pra mais nada, só pra trabalhar, num dava pra saí, e coisas para o nosso benefício né, e nos benefícios da empresa num modo conjunto... Porque o seu parceiro estava lá distante, conversava uma vez ou outra com ele, nas reuniões né,(nt) então... eu acho que o ferroviário deixou as coisas acontecerem, principalmente os da cúpula né, os engenheiros, sem tomar providencia, sem tomar providencia por causa desses motivos que eu falei pra você, por causa da separação e da distância e por isso a política foi tomando conta né e... a empresa não progrediu como podia progredi né!" (24.10/11)

Não valendo a pena lutar pelo passado e pela ferrovia

Acham que as ações na tentativa de recuperar a ferrovia são em vão, pois é impossível fazer a ferrovia voltar ao que era ou recuperá-la. Julgam que seria preciso construir tudo de novo, pois ninguém tem força para recuperar a ferrovia (quadro 39).

"Ah era bom, era bom, era muito melhor do que Fepasa, e agora que não tem mais nada acabou tudo, não tem mais nada, tem só lá a estação lá, que também não vai dá em nada, entendeu como é que é?" (21.2) 
“... e hoje não tem mais força, pessoa pra melhorar isso aí está pra nascer, num tem mais jeito não. Você passa lá, você acaba chorando, dá desgosto de vê..."

“... mas sei que isso jamais vai voltar né, não tem mais, não tem mais. Eu, do jeito que eu vejo isso aí, não tem mais recuperação, já tem que fazer tudo de novo, que infelizmente nosso governo acabo com isso aí, acabou, acabou, acabou. A senhora não viu lá onde era o depósito... se a senhora visse como é que está, se a senhora visse, se a senhora visse o que era aquilo, se a senhora visse o que era aquilo... Olha, é uma judiação o que aconteceu viu, judiação, agora eles tão lutando aí pra, até tem uma reportagem disso aqui pra senhora vê que querem a recuperação da estação aqui..." (30.8)

Gerando a autodestruição do homem

Percebem que toda essa destruição do meio ambiente provocada pelo ser humano é prejudicial a ele próprio, gerando sua autodestruição, acabando com a natureza e um bom ambiente. Consideram o capitalismo a mola propulsora de toda essa destruição (quadro 39).

“... porque a própria população, a própria população está acabando com aquilo que seria um bom ambiente, num é isso? Entendeu? As árvores, tudo que existia, tudo, hoje não, hoje é a gente vê, por exemplo, a maldade que tem lá, não só com o pessoal da cidade não, em todo lugar, cortam árvores, cortam isso porque né? Tudo isso aí eu acho que é prejudicial para a própria humanidade né..."

"Não pode abusar das coisas, é isso que a gente tem, não tem nada mais nada gostoso também. Está tudo destruído, destruíram tudo, não pode deixar destruir o mundo, o resto está destruído... a humanidade é destruidora das coisas, da natureza. Tinha jabuticaba no meio do mato, assim gostoso né, uma água cristalina que descia, hoje não, hoje desapareceu tudo viu, destruíram (nt), mas é a evolução das coisas sei lá, (nt) a natureza das coisas, está estragando tudo porque aumenta, hoje aqui tem, por exemplo, num sei quantos habitantes né, daqui a pouco está mais 10 , já num é 30 , já é 40 , é 50 , é isso aqui. O povo está se destruindo a si próprio (...) pode ser o progresso né... mas pode ser destruição, quem que pode... isso infelizmente é nosso..." (26.4)

“Eu acho que está muita judiação... uma judiação... está uma judiação, e num é aquele lá o culpado não, somos nós mesmo que somos culpados... nós mesmo somos culpados, você sabe muito bem disso, é professora, sabe muito bem disso aí, é nós mesmo que estragamos isso aí... nós no sentido, no sentido, os homens estragaram muito, muito..." (27.8)

“... o que que é o comércio, o comercio destrói tudo... infelizmente é isso aí, porque, num tem lei pra isso..." (26.5) 


\section{Categoria 3.2 - Sendo difícil definir meio ambiente}

Os ferroviários, ao serem solicitados para dizer o que era meio ambiente, conforme o entendimento pessoal de cada um deles, tiveram dificuldade, dizendo não saber definir teoricamente, por não compreenderem ou não saberem seu significado; por acharem difícil definir, ou tendo ouvido falar, mas não sabendo expressar o significado. Justificam este ‘desconhecimento’ pelo fato de só terem pouco tempo de estudo escolar. Tentam definir meio ambiente utilizando o raciocínio semântico da palavra (quadro 40).

Outros conceitos associados à definição de meio ambiente foram agrupados nas seguintes subcategorias: - Não sabendo definir, - Sendo o lugar onde se vive e adapta-se, - Sendo o ecossistema, - Podendo ser algo bom ou ruim, - Sendo o ambiente de trabalho, - Compreendendo através dos componentes bióticos e abióticos (diagrama 30).

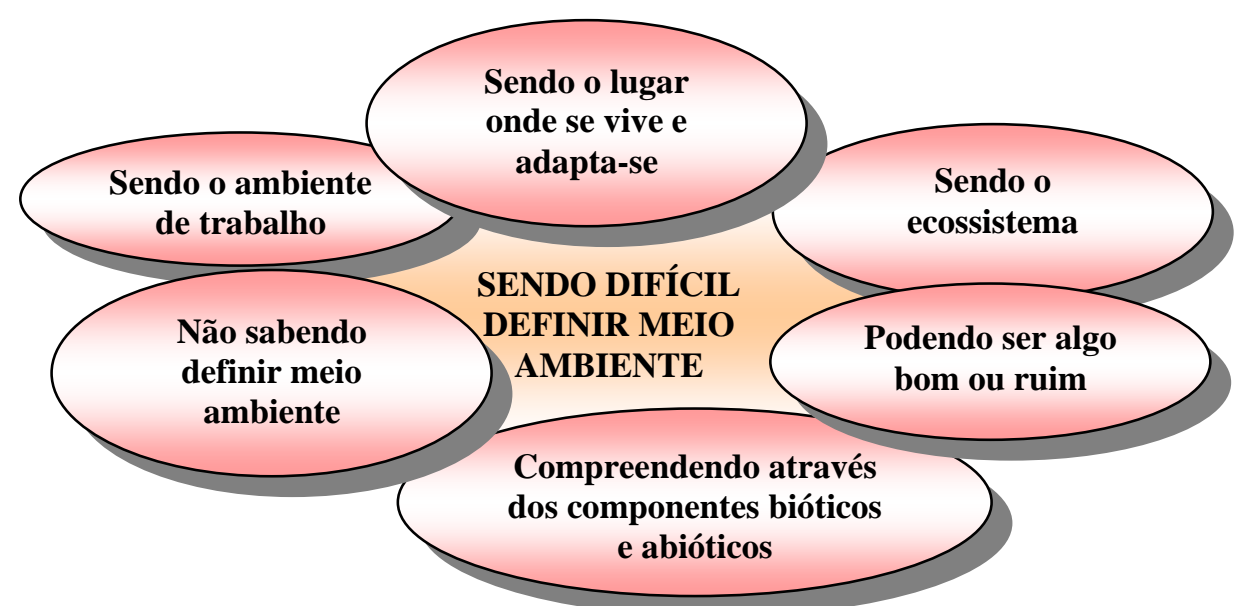

Diagrama 30. Categoria 3.2 - Sendo o meio ambiente algo muito amplo e de difícil definição: subcategorias

\section{Não sabendo definir meio ambiente}

Ao serem questionados diretamente e teoricamente, não conseguem definir o que é meio ambiente, achando difícil conceituar, embora já tenham ouvido falar bastante. Ficam confusos e justificam que têm pouca escolaridade. Outros tentam explicar pensando pelo lado semântico da palavra, ou seja, dizendo que é algo que não é inteiro, que não é completo e até criticam a adoção deste termo, dizendo que deveria ser 'bom ambiente’ e não ‘meio ambiente’. Além disso, pensam conceituá-lo por acreditarem que meio ambiente é a totalidade, o viver das pessoas (quadro 40). 
"Eu não, não vou dizer pra senhora, não acho nada porque eu não sei o que representa isso, não sei" ( 30.9).

“Meio ambiente? Hum...meio dificil né?" (6.4).

“....olha! eu não sei, eu não....é meio difícil de falar viu, eu vejo que fala muito, falam muito do meio ambiente, mas...o meio ambiente é o viver né? " (8.5).

"Meio ambiente, como é que eu posso dizer meio ambiente pra você...meio ambiente quer dizer que não é uma coisa, uma coisa completa, meio ambiente, mas, como é que eu vou dizer pra você..." (27.6).

"Bom, tem muito meio de, de repetir meio ambiente né, eu acho que não é meio, tem que ser bom ambiente, não é o mesmo que meio ambiente? Por que que é meio ambiente? Porque a própria população, a própria estão acabando com aquilo que seria um bom ambiente, não é isso, entendeu? " (15.6).

"Meio Ambiente? É. Eu acredito é o que não toma a totalidade da vida da gente, eu... também, eu só fiz 3 anos de grupo" (7.3).

\section{$\underline{\text { Sendo o lugar onde se vive e se adapta }}$}

Definem meio ambiente como sendo o lugar onde se vive, como a rua, a casa, o quintal, e no qual se adaptam e estabelecem o convívio com outras pessoas. Colocam que meio ambiente é o próprio modo de vida das pessoas (quadro 40).

"Meio ambiente, eu acho que é o lugar que a gente vive né, por exemplo, por exemplo pra mim, aqui a minha casa, o meu quintal é o meio ambiente, então o que eu faço, eu procuro preserva pra mim tê sempre em ordem né, eu penso assim, por exemplo o meio ambiente, a rua aí é um meio ambiente né, eu não posso ta jogando lixo na rua ou então na casa do vizinho né, eu penso isso né" (25.7).

"Meio ambiente? É o conviver com o pessoal né, é isso aí, é, eu penso assim." (10.3)"

"Meio ambiente é o lugar, é o meio também onde a gente se adapta com o meio ambiente no lugar onde a gente vive..." (20.4).

\section{$\underline{\text { Sendo o ecossistema }}$}

Aparece a definição de que meio ambiente é o próprio ecossistema (quadro 40).

“... é o meio... o ecossistema né.." (20.4). 


\section{$\underline{\text { Podendo ser algo bom ou ruim }}$}

Acham que meio ambiente pode ser algo bom ou ruim, podendo ser benéfico ou, até mesmo, maléfico às pessoas (quadro 40).

"De um lado pode se bom, do outro lado pode ser ruim, não é verdade? Então eu acho isso aí, pode favorecer algum, mais algum coitado vai... passa mal..." (28.3)

$\underline{\text { Sendo o ambiente de trabalho }}$

Relacionam meio ambiente ao próprio ambiente de trabalho, que pode também ser melhor ou pior conforme a dedicação dos funcionários (quadro 40).

“... mas como é que eu vou dizer pra você... até serviço, um serviço tem um... o serviço, é as vezes trabalha com meio ambiente mas... um meio ambiente, um meio ambiente de serviço... tem ambiente de serviço né, tratamento, tratamento de serviço é... tratamento em todos os sentidos né, se você é um empregado bom, então tem aquele ambiente de serviço, ambiente de serviço é, como é que se diz... constancia no serviço, pontualidade no serviço, ... acho isso aí o meio ambiente...(27.6).

Definindo através dos componentes bióticos e abióticos

Definem meio ambiente através de seus componentes bióticos e abióticos, como a água, as plantas, animais, etc. (quadro 40).

"Meio ambiente é aquele meio que está relacionado com a vida do homem... é... é a relação entre, relação entre homem e ar, terra, mar, água, sol" (24.5)

\section{Categoria 3.3- Agindo o Estado de forma ineficiente}

Denunciam que faltam ações de preservação do meio ambiente e da ferrovia por parte do Estado. Dizem que as políticas ambientais foram implantadas mais recentemente, dificultando alcançar grandes impactos. Além disso, existe a corrupção e poucos recursos humanos para estas ações ambientais.

As subcategorias que formam esta categoria são: - Faltando ações de preservação do meio ambiente e da ferrovia por parte do Estado, - Sendo mais recente a implantação de políticas ambientais, - Tendo corrupção e falta de recursos humanos (diagrama 31). 


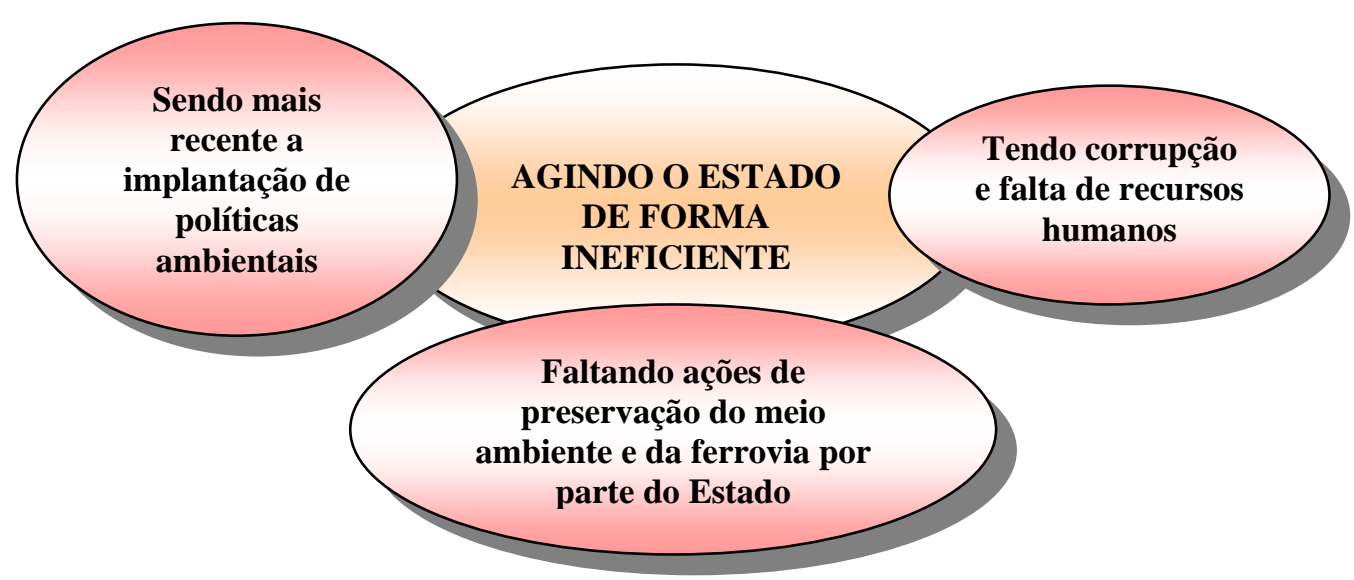

Diagrama 31. Categoria 3.3 - Agindo o Estado de forma ineficiente: subcategorias

Faltando ações de preservação do meio ambiente e da ferrovia por parte do Estado

Observam a falta de ações do governo na preservação dos rios, deixando-os ficar muito poluídos, sendo difícil sua recuperação. Criticam que não tomam providências em relação à poluição, pois zelam por seus interesses pessoais. Em relação ao desmatamento, denunciam que não se tomam providências eficazes. Colocam que algumas ações estão sendo realizadas, mas que deveriam melhorar muito mais. Essas ações ineficientes por parte dos governantes levaram à destruição da ferrovia (quadro 41).

“... a poluição desse rio aí, ninguém resolve nada.” (4.3)

"Agora, que nem eu sempre falo viu, não sei se eu estou errado, eu falo isso, tem quem sabe e vê que a poluição está maior, fora dos, dos parâmetros, mas ele não faz.... sabe porque ele não faz? Porque se ele faz, ele tem que parar o carro, e se parar o carro ele tem que andar a pé que nem nós, então ele não faz, então ele não fala porque ele tem que parar o carro, se ele parar o carro e ele vai faze o que? Vai andar de ônibus? Não vai. É por isso que não faz." (8.7)

"Eu acho que, acho a respeito, já acho que o governo devia tomar uma providência mais séria, porque eu vejo aquelas motoserras derrubando aqueles monstros daquelas árvores, me dá um aperto no coração, eu fico com dó, fico com dó mesmo, de ver o que eles fazem, uma árvore daquela que levou uns 300, 200 anos pra se formar, 5 minutos está no chão, eu acho que o governo tem que tomar uma providência séria, por que isso aí é o que nós estamos vendo, e o que estão tirando que ninguém vê, isso é, é coisa, é coisa de loco viu!" (5.3)

"Eu acho que está... vamos dizer (nt) merecia um tratamento bem melhor. A gente vê alguma coisa sendo feita nesse sentido, mais deveria ser muito melhor a coisa né, principalmente, no tocante a zelar pelos rios, eu acho uma judiação o que fazem com os rios, eu acho, principalmente o cuidado com as águas, eu acho que está sendo muito descuidado né." (24.8) 
"Eu acho que foi desmanzelo do governo né, acho que foi falha do governo, eles que acabaram com a ferrovia, infelizmente..." (22.3)

“... a empresa não progrediu como podia progredir né, tinha que existir um governo que falasse: - não, a ferrovia está aqui, ela vai ter que funcionar..." (24.10)

“... que infelizmente o nosso governo acabou com isso aí, acabou, acabou, acabou..." (referindo-se a ferrovia) (30.8)

$\underline{\text { Sendo mais recente a implantação de políticas ambientais }}$

Acham que, atualmente, estão cuidando mais do meio ambiente, havendo mais limpeza dos córregos, das ruas, e que antes tudo isto ficava abandonado. Observam, também, o surgimento de órgãos fiscalizadores e leis implantadas mais recentemente para controle ambiental (quadro 41).

“Era, a natureza era boa, agora também, está melhor agora também, porque agora estão cuidando, antes não cuidavam nada né, ninguém cuidava da natureza de primeiro. É? Por quê? O que que acontecia? É ninguém, era tudo abandonado, agora hoje não, hoje está mais cuidado." (6.4).

"Porque, a gente vê mais limpeza né, entendeu? Essas ruas aí mesmo quase, aqui na Vila Maria não tem, mais aí pra cidade, quase todo lugar tem pessoa limpando, num é verdade? Naquele tempo não tinha isso não, num tinha." (21.4).

"Cortou pouco (lenha), depois veio o Ibama, essas coisas aí, aí acabou tudo, né." (17.6).

“É, cortaram muitas árvores, judiação, aquele tempo num tinha lei que era proibido cortar árvores, podia cortar naquele tempo, mais agora cortar uma árvore dá cana, né..." (19.3)

Tendo corrupção e falta de recursos humanos

Criticam que existem poucos policiais para controlar todo este processo de desmatamento e, além de serem poucos, ainda existe a corrupção nesse meio, dificultando ainda mais o controle. Denunciam a existência do comércio clandestino de madeira em regiões do Brasil (quadro 41).

"Ainda não destruíram o meio ambiente, mas já tiraram bastante. A Amazônia, eu estava vendo, também estão destruindo. Quantas, quantas partes já foram destruídas por homens clandestinos, que roubam. Nós não temos fiscais suficientes e alguns são corruptos. A pior coisa que eu já vi foi é corrupção, em todo lugar, em todo o setor da vida, a coisa mais desagradável, mais horrível, é a corrupção. E o homem se corrompe facilmente, a corrupção do jeito que está não dá né..." (20.4).

"O mais que não dá é que os pescadores passam a rede no rio né. Você está pescando aqui o nego está passando no rio na sua frente, isso num tem... não acha pessoa para reclamar, não acha para reclamar, não sei o que que é, o que está por traz disso." (22.5) 


\section{2 - Descobrindo a categoria central}

A estratégia utilizada para descobrir a categoria central foi inter-relacionar os três fenômenos - ANIQUILANDO A VIDA, - GERANDO VIDA e - FALTANDO CONTROLE SOCIAL E DO ESTADO. Buscamos compreender como se dava a interação entre seus componentes e quais as suas conseqüências, procurando observar uma seqüência de acontecimentos inter-relacionados, o seu movimento. Esta estratégia nos permitiu identificar as categorias e subcategorias-chave, que evidenciassem a vivência dos ferroviários longevos entrevistados em relação ao meio ambiente, à saúde e à longevidade.

Por meio da coleta de dados das longas, mas prazerosas entrevistas, comecei a perceber que a história era muito rica e cheia de pequenos detalhes, que me encantavam, mas parecia que, a cada entrevista, novos fatos surgiam e eu não conseguiria nunca alcançar a saturação de minha amostra. Depois, por volta da $23^{\circ}$. entrevista, os dados foram se encaixando e começaram a se repetir, embora ainda existissem assuntos que eu não considerava que estivessem esgotados e que eram pontos-chave na pesquisa, como a relação da saúde e longevidade com o meio ambiente. A princípio, fiquei preocupada no estudo-piloto (três entrevistas), pois parecia que eles não sabiam discutir essas idéias centrais que eu buscava. Perguntava: - O que o Sr. acha que é meio ambiente, no entender do Sr.? Respondiam: - Ah, não sei. Outros respondiam: - A casa, os amigos, a ferrovia? E quando perguntava: - E a natureza, o que o Sr. acha? - 'Ah, isto vareia, tem uns que são mais nervosos, outros mais tranqüilos'. Ao discutir com minha orientadora, com o Prof. Marcos Reigota e recorrer à literatura, percebemos que o caminho estava completamente correto. Meio ambiente estava sendo considerado por eles como algo mais amplo e de difícil definição. Isto me aliviou e iniciei o trabalho de campo, gravando todas as entrevistas. Confesso que, às vezes, torcia para que a minha amostra nunca saturasse e, quando finalizei a $30^{\circ}$. entrevista, senti uma tristeza grande, pois não precisaria mais ter aquelas conversas tão agradáveis com aqueles maravilhosos cidadãos. Queria voltar à casa de cada um sempre, assim como eles pediam. Com alguns criei amizade e os encontro freqüentemente, mas precisava 
produzir minha tese e reencontrá-los para mostrar um bonito resultado, dividindo este trabalho que eles ajudaram a desvendar e construir.

De posse dos diagramas(que auxiliam muito na visualização e compreensão de todo o processo), trabalhando através da Grounded Theory, e com a ajuda imprescindível da Profa. Dra. Silvia Cristina Mangini Bocchi (Curso de enfermagem da Faculdade de Medicina da UNESP de Botucatu), que domina este referencial metodológico e com muita dedicação, fui percorrendo os trabalhosos passos desta metodologia. Conseguimos, aos poucos e com bastante angústia, ir descobrindo as peças e montando este grande ‘quebra-cabeça'. Por meio desta metodologia, tudo vai se encaixando, com um significado, uma seqüência, lembra mesmo a composição de música. As palavras vão tímidas, sem sentido, mas depois parece que formam versos, que constroem uma letra, com tons diferentes, compondo uma melodia.

Construímos uma matriz que facilitou observar todo o processo, com os três fenômenos, 6 temas e suas diversas categorias (matriz geral). Conseguimos visualizar que os dois fenômenos: ANIQUILANDO VIDA e GERANDO VIDA eram claramente opostos, inclusive, seus temas e categorias: Ferrovia gerando riquezas $x$ aniquilando a ferrovia e desolando os ferroviários. O primeiro bloco estava associado ao lado negativo, à morte: aniquilando a ferrovia e desolando os ferroviários e degradando o meio ambiente. E do outro lado, um bloco que conduzia ao lado positivo, a vida: Favorecendo alcançar maior longevidade, Sendo a saúde influenciada pelo meio ambiente, Observando fatores que podem ter contribuído para maior longevidade dos ferroviários, Ferrovia gerando riquezas. Tínhamos o lado negativo e o positivo, mas o que conduzia à vida ou ao aniquilamento? Precisávamos descobrir, por meio das vivências desses ferroviários, o que os conduzia de um lado para o outro, do ANIQUILAMENTO à VIDA. Emergiu, então, o terceiro fenômeno: FALTANDO CONTROLE SOCIAL E DO ESTADO, que aparecia como componente essencial, tanto para o resgate do meio ambiente mais harmônico, como para a revitalização da ferrovia. Essa falta de controle dos cidadãos como do Estado gerava o aniquilamento do meio ambiente e da ferrovia. E o que era necessário para que os entrevistados tivessem este “emporwerment”? Sim, eles precisavam ter a conscientização de preservação, como os ferroviários colocavam, se 'não tiver 
consciência, nada muda', definir melhor o que era meio ambiente e o Estado agir de forma mais eficiente (diagrama 32)

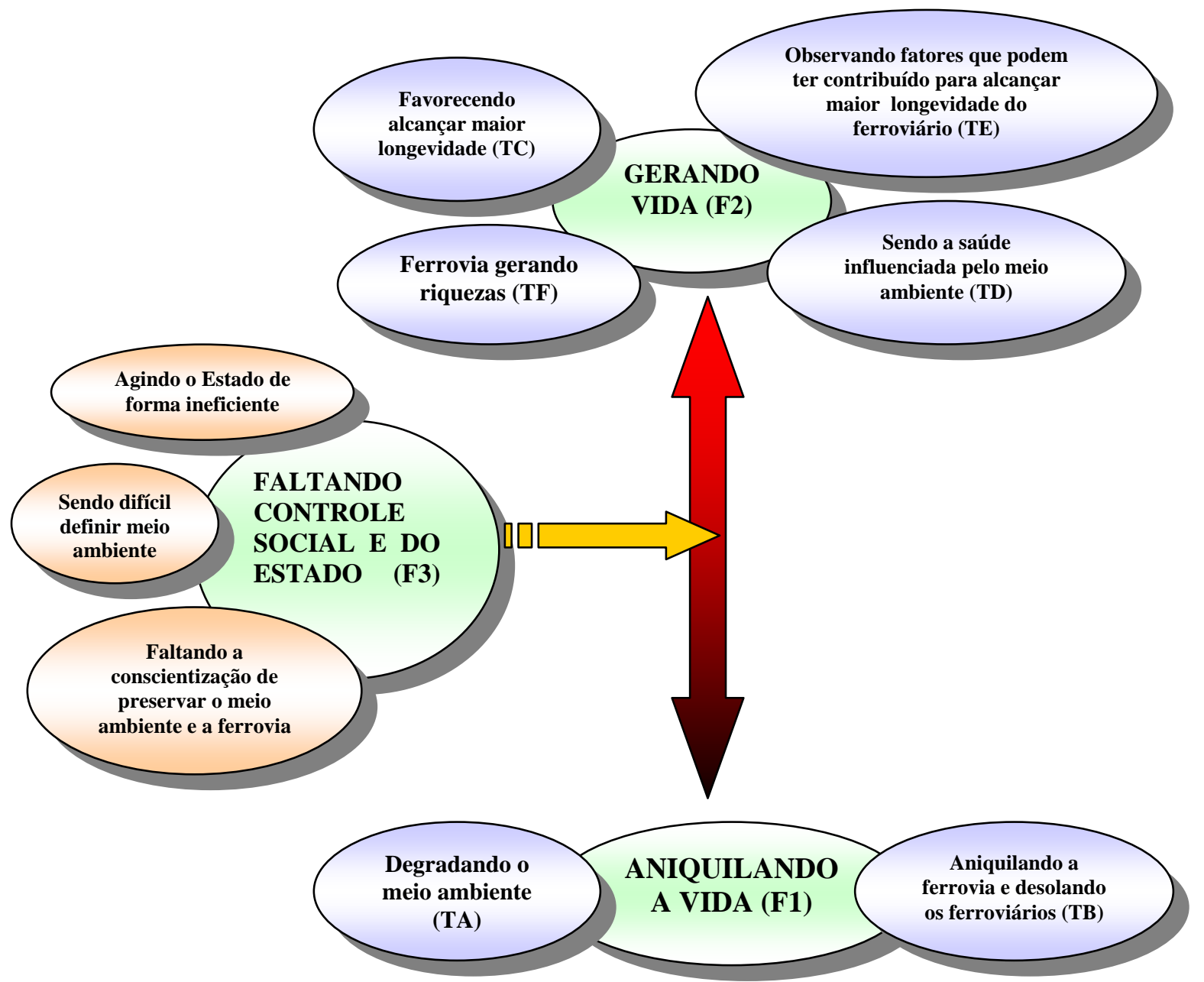

Diagrama 34 - Fenômenos, Temas e categorias gerais.

Voltando este diagrama geral (34), o bloco de baixo referia-se mais ao presente, e o de cima, mais ao passado. Então, o que movimenta para baixo (MORTE) ou para cima (VIDA)? Começamos a associar com o desenho de uma linha férrea, um trilho, uma locomotiva e um desvio (desenho A). No início do trilho, temos o passado, representado pelo depósito no tempo áureo da ferrovia, quando a ferrovia gerava riquezas, o meio ambiente era melhor, a longevidade dos ferroviários e da população era favorecida, GERANDO VIDA. Ao fim do desvio, temos o presente, representado pelo atual estado do depósito, depredado, ANIQUILANDO A VIDA. E o que poderia impulsionar a locomotiva para continuar no seu trilho normal (VIDA)? E o que levava a locomotiva a ir para o desvio, ficando à deriva, desativada 
e enferrujando (MORTE)? Novamente, aparece a FALTA DE CONTROLE SOCIAL E DO ESTADO, segundo a experiência desses informantes, como sendo responsável para que a locomotiva tomasse outro rumo, levando ao aniquilamento do meio ambiente, da ferrovia, dos ferroviários, enfim, da vida, impedindo que ela seguisse seu trilho de gerar vida.

Desta forma, finalmente, chegamos à grande categoria central, que expressa um modelo teórico representativo de todas essas experiências dos ferroviários, denominada: DA VIDA AO ANIQUILAMENTO: O CONTROLE SOCIAL E DO ESTADO EM DEFESA DA VIDA. 


\section{DESENHO A}

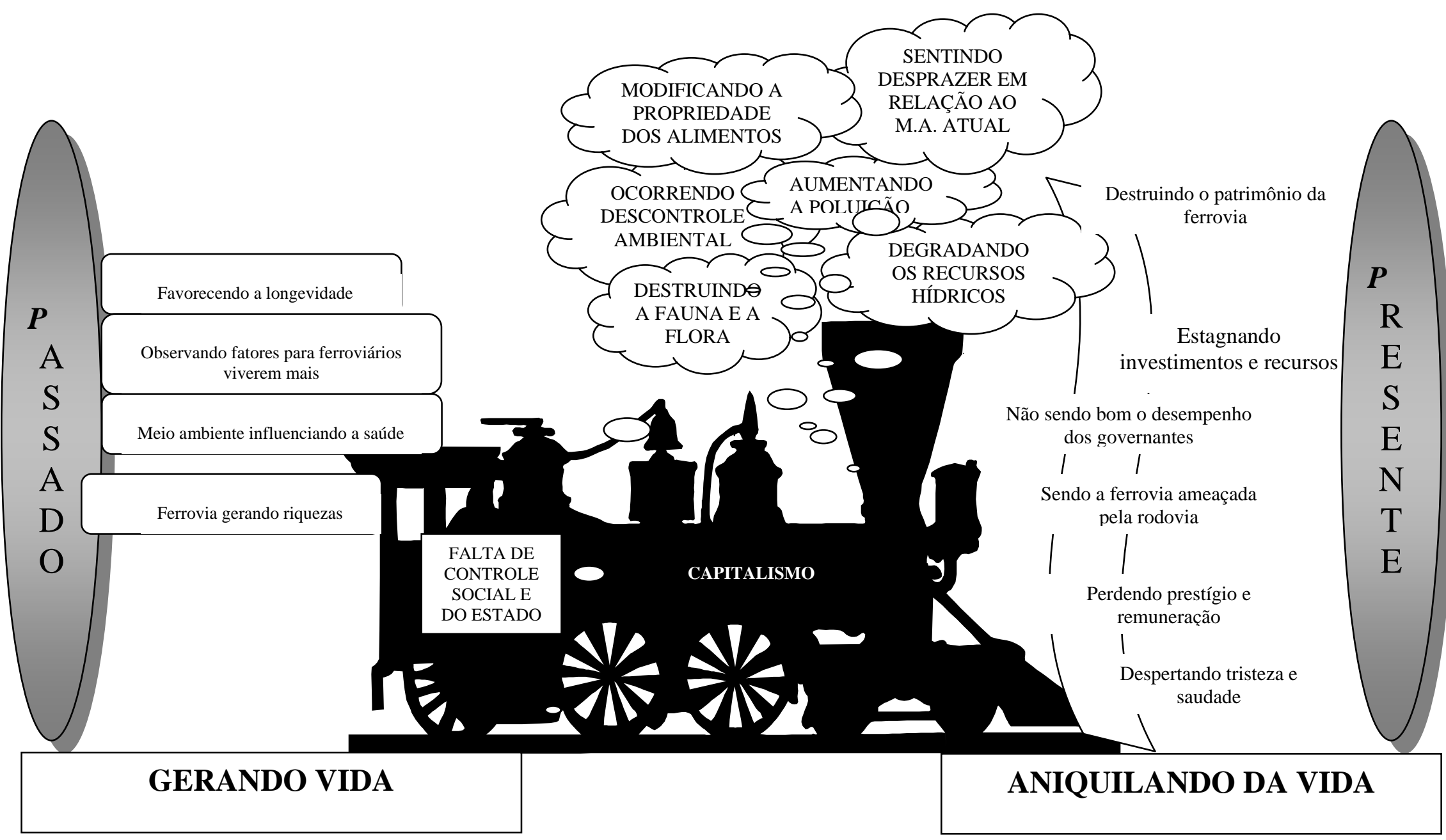

Desenho do modelo teórico representativo: DA VIDA AO ANIQUILAMENTO: O CONTROLE SOCIAL E DO ESTADO EM DEFESA DA VIDA 


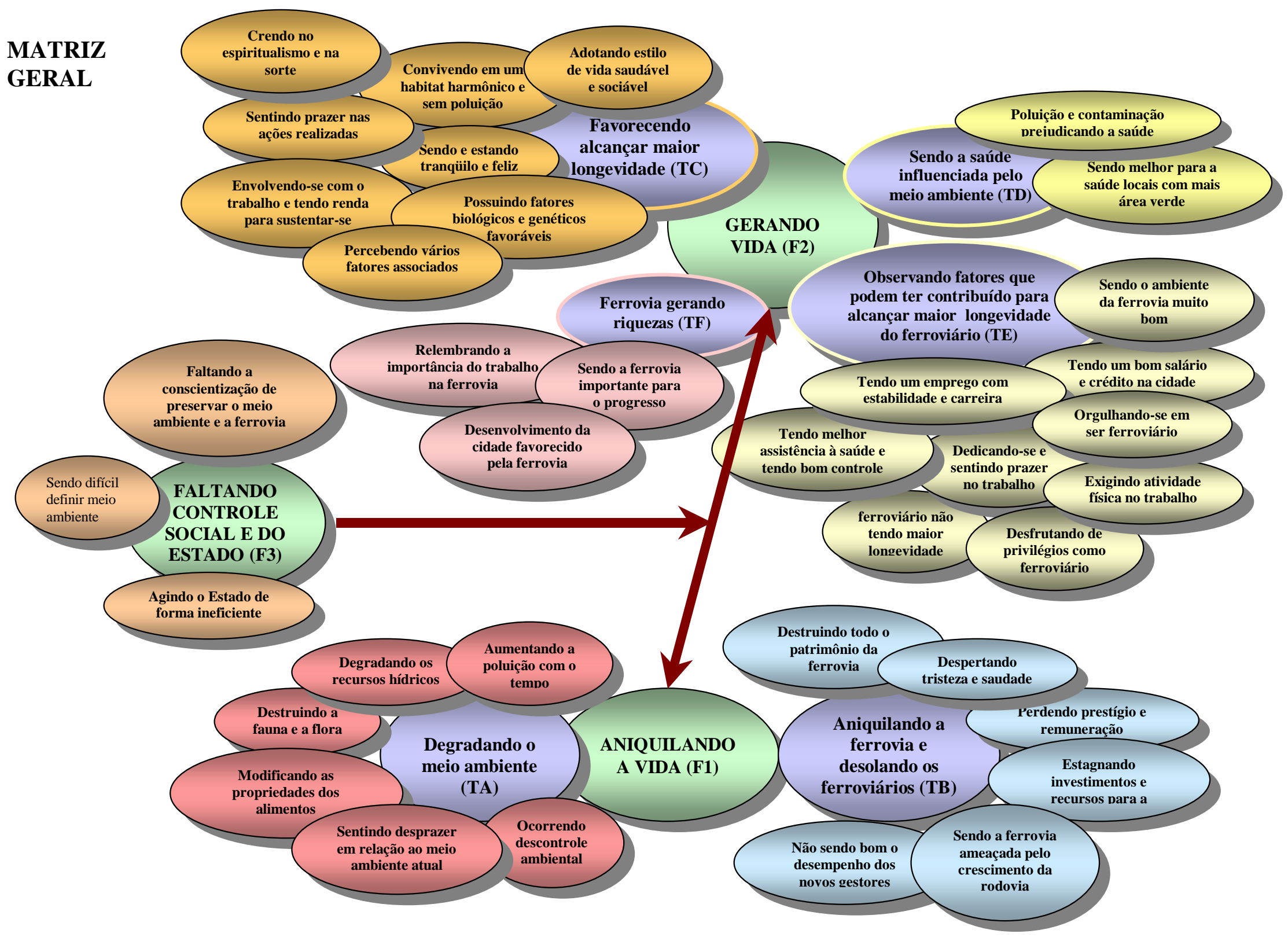




\section{CONSIDERAÇÕES FINAIS}

Ao percorrer os trilhos da Estrada de ferro Sorocabana de Botucatu, por meio dos relatos e das lembranças dos 30 longevos ferroviários entrevistados, foi possível obter aspectos relatos apontando para possível associação entre meio ambiente e longevidade humana. Os resultados obtidos, analisados por meio do referencial metodológico da Grounded Theory, mostraram que os longevos ferroviários reconhecem o papel do meio ambiente sobre a saúde e sobre a longevidade. Eles destacam componentes do meio ambiente, que podem garantir uma maior longevidade, como: boas sensações despertadas pela natureza (ver, ouvir, sentir), mantendo boas relações afetivas e sociais, estabilidade climática, e ausência de poluição do ar e da água. Os entrevistados descrevem com detalhes como era toda a natureza no passado e valorizam (ou hipervalorizam) as boas qualidades da natureza e os benefícios que esta trazia para suas vidas. No entanto, os aspectos negativos do meio ambiente também se sobrepõem nas falas dos entrevistados. Eles fazem sempre comparações entre o passado e o presente, apontando os aspectos negativos do meio ambiente atual, embora não exista consenso. Ressaltam a degradação do meio ambiente atual, associada à destruição das matas, poluição dos rios, aumento da poluição aérea, ao número excessivo de veículos nas cidades, acarretando descontrole ambiental com temperaturas variáveis, piorando o convívio entre as pessoas, prejudicando a saúde e a longevidade. Em relação ao desmatamento, chama muito a atenção a grande contribuição dada pela ferrovia para a destruição das matas. Logo nas primeiras falas dos entrevistados, eles começam a contar e quantificar o desmatamento pelo qual a ferrovia foi responsável, consumindo muita lenha nas máquinas a vapor. Foi necessário que a EF Sorocabana começasse a criar hortos florestais em vários locais, para obter madeira, que já era escassa na região. No entanto, o intenso desmatamento já tinha se estabelecido e suas conseqüências passaram a ser sentidas pelos próprios ferroviários, que sentem falta das grandes matas e de suas boas sensações, dizendo que atualmente é necessário construir parques e hortos artificiais para as pessoas poderem apreciar a natureza, dizendo que foi preço do progresso que a natureza pagou. Esta descrição dos aspectos negativos do meio ambiente sobre a saúde e a longevidade é encontrada na literatura, como os 
vários estudos que apresentamos no capítulo 1, item 3, que demonstram associação entre os problemas ambientais e seus riscos à saúde.

Procurando resgatar as características ambientais a que estes longevos foram expostos ao longo de suas vidas por meio da metodologia qualitativa emergem aspectos positivos do meio ambiente apontados como favorecendo a saúde e a longevidade. Aspectos, estes, não capturados por meio de indicadores ambientais quantitativos, como: sentir-se bem com o contato da natureza, ficando feliz, ouvindo os sons da natureza podendo apreciar suas belezas. Reforçamos aqui a necessidade real de rediscutir os indicadores ambientais utilizados, baseados somente em aspectos quantitativos, limitando por demais a compreensão global do processo que atinge um grupo populacional. Além disso, os resultados expressam que estas representações sociais de meio ambiente não se resumem apenas no cognitivo, mas emergem como conhecimento cognitivo-afetivo, como também defende SPINK (1995). Ao apreciar a natureza, dizem esquecer das preocupações da vida, respiram um ar mais puro e acabam vivendo mais, segundo seus valores. Estas questões estão ligadas à qualidade de vida e a um ambiente livre de estresse, que pode inclusive interferir no sistema imune e favorecer o aparecimento de patologias associadas ao estresse. Notamos algumas práticas atualmente que reforçam um pouco estas sensações apresentadas por esses longevos. Tem ocorrido um crescimento atual das empresas que oferecem o turismo ecológico, por meio do qual as pessoas procuram estar em contato com a natureza, podendo apreciar e desfrutar destes benefícios levantados pelos entrevistados. Assim como o surgimento de novos empreendimentos imobiliários oferecendo locais com grandes áreas verdes ou próximo a essas, destinados a classes sociais mais favorecidas. Parece-nos que tudo isso faz sentido, mas seria interessante desenvolver outros trabalhos que tentassem avaliar a contribuição desses fatores ambientais ligados as sensações e a afetividade que foram colocados como positivos para a longevidade.

Em relação aos indicadores ambientais quantitativos aplicados nesta pesquisa, seguindo os recomendados pela literatura, eles mostraram-se muitos frágeis no presente estudo. Fruto de diversos vieses existentes que prejudicaram sua aplicação, como lapsos de memória do entrevistado, tendo que lembrar como eram as condições ambientais a que foram expostos ao longo de suas vidas, e também aspectos muitas 
vezes subjetivos (água limpa nem sempre é sinônimo de boa qualidade). Perante a inexistência destes dados ambientais oficiais para a época, esta foi a maneira que buscamos levantá-los, através do relato dos próprios sujeitos expostos.

Dentre a multiplicidade de fatores associados a longevidade, os próprios idosos atribuíram a sua longevidade a: adotar um estilo de vida saudável e sociável; sentir prazer nas ações realizadas; envolver-se com o trabalho e ter renda para se sustentar; modo de ser e estar (tranqüilo e feliz); desígnio divino; ter fatores biológicos e genéticos favoráveis. Notamos um grande discernimento dos entrevistados (considerando que praticamente a totalidade freqüentou até a $4^{\circ}$. ano do ensino fundamental, evidenciando que a escolaridade não é apenas o único fator associado ao conhecimento adquirido) ao levantarem todos esses fatores associados à longevidade, sendo que os mesmos constam da literatura científica, como discutimos no capítulo 1, item 2 (atividade física, genética e hereditariedade, hábitos de vida, atividade mental, fatores biológicos). Estes dados fortificam a discussão da legitimidade do conhecimento advindo do senso comum, no sentido de retratar a realidade social e mostrar-se como uma rede de saberes e significados.

Na análise dos dados quantitativos, foi possível encontrar características, nesse grupo investigado, associadas a longevidade, tais como: bom relacionamento familiar, hereditariedade, estabilidade no serviço e boa remuneração, boa inserção social, intensa atividade física no trabalho, boas condições de saúde pregressas e atuais, boa assistência à saúde no passado, bom padrão alimentar e sem excessos, e convivendo em um ambiente mais equilibrado no passado. No entanto a amostra não foi significativa em termos estatísticos (uma vez que adotamos o princípio da saturação para investigação qualitativa) e não podemos inferir maiores associações, apenas pontuar o que apareceu como característica neste pequeno grupo. Esta pesquisa fornece subsídios para projetos futuros com maior representação estatística, inclusive com um instrumento, o questionário, desenvolvido e aplicado, podendo estes dados quantitativos servirem como estudo piloto para outros.

Esta pesquisa também possibilitou concluirmos que, ao se trabalhar com as temáticas de meio ambiente e longevidade, devemos partir de três premissas básicas: a complexidade e inter-relação dos fatores, o envolvimento de diversas áreas de 
conhecimento (transdisciplinariedade), e a necessidade de 'internalizar' a natureza nos processos investigados.

Em relação à primeira premissa, podemos perceber a enormidade de fatores que interferem no processo de envelhecimento-longevidade, alguns já descritos, outros ainda não elucidados, e que estão estreitamente inter-relacionados. Notamos que é praticamente impossível seccionar os fatores que interferem nesse processo. Eles estão imbricados, e ao se estudar e analisar um componente, automaticamente este se vincula e remete a outro. Além disto é necessário ter a visão global do processo que se quer analisar, para poder analisar cada elemento. Além disso, essa interação se dá de forma inter e intra-elementos, muitas vezes se contrapondo, aproximando-se da dialética. Toda esta complexidade de fatores não segue um único perfil de manifestação, ou seja, existem contradições e, às vezes, até conflitos entre os determinantes (uns dizem que o meio ambiente interfere na saúde e na longevidade, outros não); no entanto, segundo o materialismo dialético, essas contradições contribuem para a compreensão da realidade, podendo facilitar a elucidação das modificações constantes que ocorrem no meio (TRIVIÑOS 1987). Em relação ainda a complexidade dos fatores envolvidos na temática de meio ambiente e longevidade não podemos esquecer de outros elementos, às vezes tidos como subjetivos, que interagem nesse contexto, sendo necessário incorporá-los (como aspectos emocionais, comportamentais e o modo de ser), além do componente histórico. E nesta pesquisa isso ficou muito claro. Os elementos emocionais e comportamentais, trazidos pelos longevos entrevistados, foram de fundamental importância para alcançarmos o objetivo da pesquisa, compreendendo as possíveis associações entre meio ambiente e longevidade, aproximando-nos da realidade social.

Já na segunda premissa, estes temas - longevidade e meio ambiente - nos remetem ao envolvimento e estudo de diversas áreas do conhecimento, como: ciências da saúde, biologia e ecologia, sociologia e antropologia, história, entre outras. Embora divulgue-se o termo 'transdisciplinariedade', na prática as ações na área da saúde acabam acontecendo mais de forma multiprofissional. Ou seja, numa equipe de saúde temos a presença de profissionais de diferentes formações, mas as suas condutas acabam sendo tomadas separadamente e muitas vezes 
individualizadas. Julgamos que o trabalho transdisciplinar não é uma prática a ser desenvolvida facilmente, mas que se poderia refletir a respeito de como colocá-lo em prática, aceitando os conhecimentos dos outros e elaborando um projeto de intervenção conjunta.

A última premissa relaciona-se à temática ambiental. Discutimos, inicialmente, a tendência que existe de se trabalhar e analisar o meio ambiente como um elemento externo ao sistema ou, às vezes, como mero cenário, colorindo os eventos que ali ocorrem e que podem levar ao adoecimento e envelhecimento da população. Este processo de ‘externalizar' o meio ambiente, de ‘desnaturalização da natureza', como denominado por BECKER (1992), compromete a compreensão do fenômeno. Além disso, como ressaltado por LIEBER (1998), para que um problema tenha solução, ele precisa estar dentro do sistema, ou seja, internalizado, se estiver fora, não faz sentido intervir no meio. É essencial partir do principio de que o meio ambiente já é um elemento, um fator inserido e inter-relacionado no contexto que se pretende investigar. Outro elemento, associado a esta premissa do meio ambiente como algo externo, está ligado, direta ou indiretamente, à dificuldade de se conceituar meio ambiente. Nas falas dos entrevistados, notamos esta dificuldade. Muitos não conseguiram expressar em palavras sua definição, aparecendo, portanto, as mais variadas conceituações: o ambiente sendo o 'tudo', a casa, o quintal, o vizinho, o trabalho, onde se adapta, o viver. No entanto, nessas percepções, eles internalizam o conceito de meio ambiente à vida. Para compreendermos as associações com o meio ambiente, a fim de implantarmos ações eficazes, é necessário adentrá-lo. É essencial poder ver internamente como as relações se processam, determinando o processo meio ambiente/longevidade. UCHOA (2003) enfatiza que “O pesquisador deve penetrar o interior de uma cultura para descobrir como os dados relativos à velhice e ao envelhecimento são organizados e adquirem significado".

Assim sendo, para se abordar o processo saúde-doença, em nosso caso associado ao envelhecimento, é condição essencial: partir do princípio de que todos os componentes interagem e são interdependentes, devendo considerar este binômio saúde-doença como um sistema aberto e dinâmico, além de incorporar historicidade e subjetividade dos problemas socioambientais. No entanto, surge uma grande 
dificuldade: que instrumentos adotar para se analisar esta imensidade de variáveis? Como analisá-las e interpretá-las? Daí resulta a dificuldade de se criarem métodos epidemiológicos e indicadores ambientais que consigam abarcar todos esses elementos.

Em relação às metodologias adotadas, deparamos inicialmente com dificuldades conceituais, como a definição de longevo (e onde localizá-los) e de meio ambiente, assim como as dificuldades metodológicas para medirmos as relações entre meio ambiente e longevidade, e quais indicadores ambientais adotar. Ao optarmos por definir longevo como sendo aquele indivíduo com idade igual ou superior ao último quartil da população idosa (acima de sessenta anos), levamos em consideração a variabilidade de envelhecimento populacional de cada área, diante da heteregoneidade que existe em nosso país. No entanto, este também passa a ser um critério arbitrário, sendo difícil definir uma idade exata em que a pessoa possa ser considerada longeva, assim como idosa. Mas era preciso estabelecer uma faixa etária para a pesquisa. A inexistência de uma definição precisa de longevo para fins práticos, embora cause frustração, não deve ser motivo de desalento, mas motivação para a busca de outras soluções alternativas.

Por meio da utilização da Grounded Theory, foi possível averiguar como se processaram os fenômenos a partir das vivências dos ferroviários longevos entrevistados. Também conseguimos abarcar a noção da totalização, percebendo que, ao mesmo tempo em que as falas eram recortadas, passando por uma microanálise, tínhamos de manter a visão do conjunto, sem contudo esgotá-lo. Era necessário recortar em partes para chegar ao todo, mas em contraposição, não tendo o todo, não era possível visualizar as partes que o compunham. Ao compararmos todas as partes com o todo e vice-versa, chegamos às categorias, aos temas e aos três fenômenos: ANIQUILANDO A VIDA, GERANDO VIDA e FALTANDO CONTROLE SOCIAL E DO ESTADO, como discutido no capítulo anterior. No processo de validação, ao retornar aos dados brutos iniciais (entrevistas transcritas na íntegra) percebemos que o modelo teórico representativo explicava a maioria dos relatos, as suas vivencias. Também tivemos a oportunidade de convidar todos os ferroviários que participaram da pesquisa e reuni-los na própria estação da E.F Sorocabana (no bar da estação - local um pouco menos depredado) e apresentar os resultados finais, 
no dia 11/03/2006. Todo este processo foi repleto de emoções, tanto para os ferroviários, quanto para a pesquisadora. Ao agendar o encontro por telefone, felicidades em escutar as vozes novamente e tristezas ao descobrir que alguns já tinham falecido. Na ida a antiga estação ferroviária, muitas lembranças boas e o pesar por verem o local que trabalharam tantos anos naquele estado. A apresentação dos resultados foi feita em forma de projeção de slides, seguido por outra de fotos antigas da ferrovia. Os ferroviários entrevistados presentes concordaram com a forma como suas experiências foram agrupadas chegando a este modelo teórico representativo. Vale ressaltar que foi um momento muito especial e emocionante, no qual todos ficaram extremamente agradecidos pela pesquisa e apresentação, pelo reconhecimento do seu papel. Vislumbraram a importância em continuarem lutando, mas abatendo-se por todas as dificuldades existentes, como falta de apoio dos governantes locais e estaduais e da não valorização deste passado pela sociedade.

No processo de descobrir a categoria central, fazendo sempre comparações entre as categorias que emergiram das falas, dois aspectos importantes, ligados à longevidade, foram identificados: o papel da memória no processo da longevidade e outro, mais claramente apontado pelos longevos, o da falta de controle social, levando-nos a refletir sobre empoderamento desta população.

O primeiro aspecto, relacionado à memória, pôde ser descoberto por meio das falas dos entrevistados, ao recorrerem às suas lembranças que exaltavam o passado. Mostrando os dados ao Prof. Titular Katsumasa Hoshino (Faculdade de Ciências da UNESP de Bauru), ele questionou: “- Não é uma contradição eles dizerem que o meio ambiente do passado é melhor que o do presente? Ou seja, é o passado bom que faz ver o atual como ruim ou é o ambiente atual ruim que evoca a defesa do passado?" Existe o componente idílico, ou seja, valorizam o que eles viveram no passado. O ferroviário longevo percebe o aniquilamento do meio ambiente e da própria vida, imposto pela ideologia capitalista do lucro a qualquer custo. Esta degradação é percebida em comparação a um meio ambiente idealizado, de uma época onde ele próprio tinha vida e saúde. Contra esta tristeza do aniquilamento, ele hipervaloriza o trabalho (que não deixa de ser como o de outros e com problemas: passando fome, trabalhando horas seguidas e de forma intensa, perdendo o sono) e o seu passado (tempo áureo da ferrovia e de sua vitalidade), apegando-se às suas 
lembranças, ao seu passado. Assim, ele acaba relembrando o trabalho na ferrovia, $\underline{\text { a }}$ importância da ferrovia no progresso e no desenvolvimento das cidades. Pois o seu presente é repleto de perdas pessoais: de salário e de prestígio; de saúde; morte de familiares e amigos, causando tristeza e saudade; e perdas coletivas: gerando menos emprego e comprometendo o crescimento das cidades, com o fim da ferrovia, levando ao aniquilamento daquilo que eles mais amavam, a ferrovia, que teve todo seu patrimônio destruído. Para sobreviverem, acabam se apegando ao passado, às suas lembranças, hipervalorizando tudo do seu passado, época áurea de suas vidas, quando tinham vigor, prestígio, dinheiro e família estável. BOSI (1987) e BEAUVOIR (1990), em suas importantes obras, ressaltam o papel maléfico da sociedade industrial capitalista sobre a memória dos idosos, dizendo, respectivamente: "Eis um dos mais cruéis exercícios da opressão econômica sobre o sujeito: a espoliação das lembranças.” e que "a sociedade industrial é maléfica à velhice...”.

Bosi afirma que a lembrança não é um ‘fio de Ariadne”. Ela compõe-se de um emaranhado de fios de diferentes meadas, sendo um ponto de convergência dos muitos planos do nosso passado. E questiona como transmitir às gerações a imagem de algo que hoje não existe mais, que foi destruído. E é exatamente nesta situação que os ferroviários se encontram, como relembrar e contar toda a imponente história da EF Sorocabana, se hoje ela está completamente sucateada? Vale a pena 'perder tempo' com esse passado destruído? Sim, pois somente eles detêm esse conhecimento e vivência que estão ameaçados de serem enterrados junto com os poucos ferroviários restantes. Por tanto, esta história encontrou lugar para ser guardada somente na memória destes ferroviários, que se tornou um grupo ‘ameaçado de extinção’. Resta-nos apenas 19 anos (tempo estimado no qual ainda teremos ex-ferroviários vivos em Botucatu) para resgatarmos a história viva da EFS de Botucatu guardada na memória deles, uma vez que os documentos foram 'queimados', destruídos pela falta de valorização histórico-cultural que a atual sociedade vivencia.

Dentro das categorias que emergiram, tínhamos um bloco que lembrava mais o presente, e o outro mais o passado. Se colocássemos na horizontal, à esquerda teríamos o passado, representado pelos aspectos positivos: meio ambiente 
preservado, vitalidade, crescimento tecnológico e econômico, boa situação socioeconômica $=$ VIDA. À direita, teríamos o presente, representado pelos entrevistados com aspectos negativos: perdas salariais e de prestígio, fim da ferrovia, degradação ambiental = MORTE. E o que movimentava de um lado (PRESENTE) para o outro (PASSADO)? Voltamos à imagem de uma locomotiva no seu trilho, mas desta vez, em um trilho com suas linhas. A 'reta'16 levando ao passado, a linha duas $^{17}$ ao presente e a linha três ${ }^{18}$ à desativação (trens danificados, incapazes de prosseguir a viagem). Quem manipulava a chave de direção ${ }^{19}$ para mudar de linha, fazendo o trem tomar a reta, linha duas ou três? E o que o levava à linha três, incapacitando-os de prosseguir a viagem? As suas boas recordações, de um tempo áureo que eles viveram com prazer, e que, hoje, só há perdas. Como, atualmente, a grande maioria desses ferroviários não tem mais nenhuma atividade de trabalho ou lazer intenso, eles vivem das recordações do passado, que acaba sendo o mecanismo de defesa para sobreviverem a esse meio ambiente atual degradado, aniquilado. Talvez, os ferroviários que não conseguiram desenvolver algum mecanismo de defesa para sobreviver neste presente tão rude e adverso, acabaram indo para este desvio, adoecendo e esperando a morte. BOSI (1987) destaca que, no momento em que o ser humano se aposenta, deixando de ser um membro ativo da sociedade, restalhe uma função própria: ‘a de lembrar’, tornando-se a memória da família, do grupo, da instituição, da sociedade. Essa autora nos faz lembrar que, em tribos primitivas, se valorizava muito o saber dos mais velhos, que eram os guardiões. E finaliza: “Hoje, em nossa sociedade, estimamos um velho porque, tendo vivido muito tempo, ele tem muita experiência e está carregado de lembranças. Como, então, os homens idosos não se interessariam apaixonadamente por esse passado, tesouro comum de que se constituíram depositários, e não se esforçariam por preencher, em plena consciência, a função que lhes confere o único prestígio que possam pretender daí em diante?"

Associados ao papel da memória, que pode ter contribuído para a longevidade dos ferroviários, não podemos esquecer dos fatores biológicos, os quais a ferrovia

\footnotetext{
${ }^{16}$ Linha principal, que passava próximo à plataforma.

${ }^{17}$ Linha secundária, utilizada mais para manobrar os trens.

${ }^{18}$ Linha utilizada para deixar trens danificados à espera dos artífices para fazerem os reparos.

${ }^{19}$ Chave de direção compunha o aparelho de mudança de linha que era manipulado pelo ferroviário (guarda- chave), após a autorização do Centro de Controle de tráfego (CTC), para mudar de linha.
} 
favoreceu, oferecendo boa assistência à saúde, intensa atividade física e outros fatores que podem ter contribuído para maior longevidade dos ferroviários.

CHAUI (1987), no livro de Bosi: Memórias de Velhos, faz quatro questionamentos bastante pertinentes, com as respectivas respostas, que podemos aplicar para nossas considerações finais:

"Por que temos de lutar pelos velhos? - Porque são fontes de onde jorra a essência da cultura, ponto onde o passado se conserva e o presente se prepara...”

“Mas se os velhos são os guardiões do passado, por que nós é que temos de lutar por eles? Porque foram desarmados. (...) uma ferida aberta em nossa cultura: a velhice oprimida, despojada, banida.”

“Que é ser velho? ... em nossa sociedade, ser velho é lutar para continuar sendo homem."

“Que é ser velho na sociedade capitalista? É sobreviver. Sem projeto, impedido de lembrar, de ensinar, sofrendo as adversidades de um corpo que se desagrega à medida que a memória vai-se tornando cada vez mais viva, a velhice, que não existe para si mas somente para o outro. E este é um opressor.”

"Destruindo os suportes materiais da memória, a sociedade capitalista bloqueou os caminhos da lembrança, arrancou seus marcos e apagou seus rastros.”

O outro aspecto levantado, que emergiu como um fenômeno, foi a FALTA DE CONTROLE SOCIAL E DO ESTADO. Um tema extremamente atual, que foi apontado por estes ferroviários, mostrando novamente o grande discernimento deste grupo e o poder de retratar a realidade social. O controle social é um tema discutido e colocado como um dos princípios do SUS, como uma importante questão para promover a saúde. O empoderamento é um termo abrasileirado derivado de 'empowerment', adotado por vários pesquisadores, podendo ser compreendido como: “... a habilidade de pessoas conseguirem um entendimento e um controle sobre suas forças pessoais, sociais, econômicas e políticas, para poderem agir de modo a melhorar sua situação de vida. A meta do empoderamento é ajudar pessoas, organizações e comunidades a serem mais independentes; gerar autoconfiança e senso de governabilidade, mais do que se sujeitar à força de alguma coisa ou de alguém do exterior ” (TEIXEIRA 2002). 
Entretanto, deve-se tomar cuidado, pois o empoderamento pode levar a uma conotação dúbia: dar poder a outros e capturar poder. Além de abolir o saber próprio de cada comunidade e indivíduo. No Brasil, algumas ações ditas como de empoderamento resumem-se em promover a integração dos excluídos, ainda que de forma individualizada e assistencialista, estabelecendo intermináveis projetos de ações sociais assistenciais (GONH 2004).

Desta forma, deve-se evitar dar poder. Em saúde, deve-se procurar facilitar as pessoas a se tornarem capazes ou aprimorarem suas habilidades para que elas possam obter poder por seus próprios esforços, a fim de terem poder sobre suas próprias vidas. E para o idoso, estas questões são fundamentais, principalmente em relação à longevidade. Autores alertam que a longevidade leva ao desempoderamento, ou seja, as mudanças sociais, comportamentais e biológicas, pelas quais os longevos passam, acabam comprometendo sua autonomia e independência individual. MYERS (1993) coloca que a velhice torna as pessoas particularmente vulneráveis à análise e percepções sociais, existindo uma perda real do poder pessoal, levando a uma vulnerabilidade psicológica e emocional, perante a falência social. Este processo denominado de falência social, estudado inicialmente por J. KUYPERS e VERN BENGTSON (1973), englobaria quatro estágios. No primeiro, o idoso passa a ser alvo de preconceitos e sofrer atitudes negativas, e acaba interiorizando estes valores negativos. Muitos, com a aposentadoria e perda do status social, acabam incorporando dúvidas sobre suas próprias capacidades. Este estágio predispõe à depressão. O segundo estaria associado ao fato de que pessoas começam a duvidar das capacidades e comportamentos dos idosos, e, assim, os idosos também passam a duvidar realmente de suas capacidades. No terceiro estágio, começam a surgir as doenças e a dependência, e os idosos, em vez de se adaptarem, acabam se entregando e se atrofiando. No último estágio, os fatores anteriores são intensificados, os idosos passam a incorporar todas as percepções negativas, sentindo-se inadequados e dependentes.

Sugere-se que, para tentar evitar esta falência, deveria se trabalhar com a 'reconstrução social' ou 'empoderamento'. Na reconstrução social, pretende-se aumentar a competência dos idosos, por meio de ações psicológicas, sociais e ambientais. MYERS, citado por TEIXEIRA (2002: 36) coloca: “o desafio das 
sociedades é desenvolver atividades para as pessoas idosas nas quais elas possam encontrar um senso de significado e perspectiva, atividades estas que sejam respeitadas pelos demais e que ofereçam uma barreira efetiva para a vulnerabilidade que existe para a maioria das pessoas idosas”. Já o empoderamento, pode ser desenvolvido antes que os estágios negativos se incorporem nos idosos, preparando-os para enfrentarem estes fatores negativos ao envelhecimento. É importante empoderá-los para que consigam fazer suas próprias escolhas, de forma a alcançar uma melhor saúde e bem-estar (TEIXEIRA 2002). Para essa população específica de idosos ferroviários, já toda cadastrada para esta pesquisa, surgiram idéias e projetos futuros por nós vislumbrados, como a criação de um museu interativo (com sugestão de nome: 'Estação Museu-Escola'), administrado pelos próprios ferroviários aposentados,a orientação técnica de um grupo transdisciplinar. Possibilitaria resgatar a história da ferrovia e as experiências desses cidadãos, repassando a outras gerações, por meio de parcerias com secretaria de educação, de cultura e de turismo, valorizando o papel desempenhando pelos ferroviários e preservando a vida com uma qualidade mais digna. 


\section{CONCLUSÃO}

Os fatores apontados, pelos próprios longevos ferroviários, como sendo o segredo para se alcançar a longevidade, fortalecem algumas teorias que discutem a respeito da função da existência do idoso e do longevo humano. Como discutimos, é um contra-senso biológico manter, na natureza, por muito tempo, um animal idoso, que não mais se reproduz, tem habilidades e capacidades comprometidas e acaba apenas sendo mais um para dividir o alimento disponível. Para a espécie humana, estas características soam eticamente inadequadas, mas por que esta espécie tem o privilégio de viver tanto tempo após cessar o período reprodutivo? As teorias que argumentam a favor do conhecimento (teoria do educador) e da função (teoria da avó) parecem ser bem plausíveis (cap 1, item 1.2). No entanto, estas duas teorias valorizam mais o papel da figura materna, auxiliando nos cuidados da prole, no sucesso reprodutivo dos filhos e na sobrevivência dos netos. No caso da atual pesquisa, este conhecimento e função estão relacionados à sociedade, e não à família. Os ferroviários longevos lembram como eram valorizados pela sociedade e como era importante a transmissão de conhecimentos entre eles. Existiam os mestres, que eram responsáveis por ensinar os iniciantes, sendo muito respeitados e admirados. Todos sentem-se muito orgulhosos, até hoje, de serem ferroviários, pois, se voltarmos no tempo, na década de 1930/40, as ferrovias tinham grande papel no progresso das cidades e até do Brasil. Como eles mesmos colocam, ser ferroviário 'era um negócio’, e também sentiam-se responsáveis por aquele progresso, visto que cuidavam da ferrovia como lhes pertencesse. Esta valorização do tempo áureo da ferrovia e este orgulho em relação à função exercida podem ter desempenhado papel positivo para a longevidade desses ferroviários. Quando comparamos a mortalidade do grupo de ferroviários idosos com o da população idosa geral do município de Botucatu, foi possível encontrar significância estatística em dois anos (2001 e 2002), sendo que os dois grupos de idosos estavam sob condições ambientais semelhantes no município, embora não controladas no estudo. Destacamos outros componentes responsáveis por esta maior longevidade dos ferroviários, como: maior assistência à saúde, emprego estável, com bom salário, moradia e boa alimentação - sendo difícil dizer quanto realmente este papel social os favoreceu a alcançar a longevidade. Por 
outro lado, em todas as entrevistas, prevaleceu o saudosismo, a hipervalorização do trabalho na ferrovia. Em pouquíssimas falas, aparecem críticas ao serviço e à ferrovia, que era um trabalho extenuante, e prevalece o lado glorioso de ser ferroviário. Ficavam horas sem se alimentar e sem dormir. Trabalhavam até 30 horas seguidas sem descanso, com o barulho do manômetro na cabeça, o calor da fornalha em suas costas, a força exigida e a responsabilidade com pouca tecnologia. No entanto, o papel desempenhado para a sociedade superou tudo e, hoje, vivem dessas recordações, que provavelmente são outra força para sua longevidade.

Isto posto, podemos propor uma outra hipótese, baseando-se na teoria das Avós, do Educador e da Crença na importância social (como os Mórmons, Adventistas do Sétimo Dia e da Suprema Corte), apresentadas no capítulo 1, item 1.1. Nesta pesquisa atual, existe um diferencial em relação a estas teorias, pois este papel social não é mais desempenhado, foi destruído atualmente, ou seja, com o fim da EF Sorocabana, essa valorização do ferroviário foi perdida e seus conhecimentos ficaram obsoletos e sem utilidade. Estes longevos ferroviários não tem mais espaço nesta sociedade capitalista atual e nem são valorizados pela comunidade, ou mesmo acolhidos. Assim, propomos uma nova hipótese da "valorização das funções desempenhadas” (VFD), destacando a importância de o longevo ter desenvolvido um papel de destaque em sua vida no passado, fundamentando-se na memória, e fazendo desta lembrança sua força para sobreviver e alcançar a longevidade, vivendo dessas boas e importantes funções desempenhadas ao longo de sua vida ativa. Sugerimos que novas pesquisas sejam feitas nesta esfera a fim de corroborar ou descartar esta nova hipótese. Sendo verdadeira, ressalta-se ainda mais a importância de se resgatar o papel social desempenhado pelos idosos ao longo de suas vidas, como mais um mecanismo de auxílio à longevidade. Nota-se este movimento em alguns municípios do Brasil, o movimento de grupos de 'terceira idade', universidade aberta a terceira idade e muitos outros, mas deve-se ter o cuidado de proporcionar atividades que resgatem o seu real papel, não 'reenquadrá-los' em nossos novos valores atuais. Fatos que favorecem esta hipótese podem ser encontrados principalmente nas culturas orientais, onde existe uma valorização dos conhecimentos dos idosos e, sobretudo, dos centenários. As pessoas procuram ouvi-los, garantindo espaços para que esses conhecimentos e experiências vividas sejam transmitidos, valorizando e 
respeitando o papel que desempenharam. Assim como em comunidades tribais, indígenas ou não, que têm os seus 'pajés ou gurus’, que, apesar da idade avançada, ainda têm seus antigos conhecimentos valorizados. Esta valorização do papel desempenhado passa a ser tão fundamental, que conforme PENNIX e col. (1997) relataram, houve ocorrência de ‘suicídio programado’ de idosos que não se sentiam mais úteis socialmente, abatendo-se psicologicamente. Em Botucatu, logo após a privatização da ferrovia e sucateamento total da EF Sorocabana, ocorreram 8 suicídios de ferroviários ${ }^{20}$, fortalecendo a necessidade de se criarem espaços para resgatar e valorizar este papel por eles desempenhado.

Em relação aos indicadores ambientais, reforçamos a necessidade de rediscuti-los, incorporando elementos qualitativos, além de englobar técnicas e instrumentos apoiados em metodologias qualitativas. Entendemos que estas práticas podem auxiliar na compreensão do processo, não somente a sua descrição e quantificação (dentro ou não dos limites quantitativamente aceitos), aproximando o olhar dos grupos vulneráveis.

A análise a partir da Gronded Theory possibilitou concluirmos, para o grupo investigado, que os fatores associados ao aniquilamento da vida são mecanismos de agressão e caminham para o lado negativo, para a morte. Já o conviver em meio ambiente harmônico, com todos os outros componente positivos para a saúde e longevidade, que aparecem num modelo idealizado e recordado do passado, gera vida. Desta forma, a recordação e hipervalorização do passado mostram-se como mais um mecanismo de defesa, garantindo a vida. O meio ambiente do passado é bom realmente e de forma idealizada, pois esta hipervalorização do meio ambiente do passado garante a sobrevivência desses ferroviários hoje. Talvez esses longevos ferroviários tenham lapidado melhor este mecanismo de defesa, da memória, garantindo maior longevidade. Enquanto aqueles que não o conseguiram, sofrendo com a visão de um presente representado por perdas, podem ter se abatido mais cedo, vindo até mesmo a apresentar doenças associadas mais à esfera mental, como depressão e demência, que são freqüentes nesse grupo etário.

Sugerimos que atividades voltadas ao estímulo da memória dos idosos sejam adotadas, resgatando o seu importante papel e garantindo, no mínimo, sua cidadania.

\footnotetext{
${ }^{20}$ Collenci CA, em reunião sobre restauração do prédio da Estação, Botucatu, comunicação pessoal,
} 2004. 
Para esta população estudada de ferroviários, a idéia de um museu interativo da ferrovia poderia ser uma das formas de se trabalhar o empoderamento, mas outros tantos projetos podem e devem ser desenvolvidos no município, valorizando o controle social dos idosos.

A partir da experiência dos longevos, destacando o papel da memória, denotase a importância de subsidiar a população a empoderar-se, para que possa lutar contra a degradação ambiental e da própria vida, contra esta cultura do imediatismo e da etnodesvalorização, que faz o passado representar a vida (ganhos = trabalho, tempo áureo da ferrovia), e o presente a morte (perdas = degradação ambiental, aniquilamento da ferrovia e ferroviários, doenças). 


\section{REFERÊNCIAS}

Abercrombie GF. December fog in London and emergency bed service. Lancet 1953; 1: 234-5.

Abrams WB, Berkow R. Manual Merck de geriatria. São Paulo: Roca; 1994.

Aguiar MA. Botucatu: imprensa e ferrovia. São Paulo: Arte \& Ciência; 2001.

Anderson HR, Ponde-deLeon A, Bland MJ, Bower JS, Strachan DP. Air pollution and daily mortality in London: 1987-92. BMJ 1996; 312(7032): 665-9.

Augusto LGS, Branco A. Política de informação em saúde ambiental. Rev Bras Epidemiol 2003; 6: 150-7.

Augusto LGS, Camara VM, Carneiro FF, Câncio J, Gouveia N. Saúde e ambiente: uma reflexão da Associação Brasileira de Pós-Graduação em Saúde Coletiva ABRASCO. Rev Bras Epidemiol 2003; 6: 87-94.

Ferreira ABH. Novo Aurélio Século XXI: o dicionário da língua portuguesa. $3^{\circ}$. ed. Totalmente revisada e ampliada - Rio de Janeiro: Nova Fronteira, 1999.

Ballester DF, Merino EC, Perez HS. Association of air pollution and mortality: a review of recent epidemiological studies. Rev Esp Saude Publica 1995; 69: 177-88.

Ballester F, Corell D, Perez H, Hervas A. Air pollution and mortality in Valencia, Spain: a study using the APHEA methodology. J Epidemiol Community Health 1996; 50: 527-33.

Barata RCB. O desafio das doenças emergentes e a revalorização da epidemiologia descritiva. Rev Saúde Pública 1997; 31(50): 531-7.

Barzilai N, Shuldiner AR. Searching for human longevity genes: the future history of gerontology in the post-genomic era. J Gerontol A Biol Sci Med Sci 2001; 56(2): M83-7.

Bates DV. Adverse health impacts of air pollution-continuing problems. Scand $\mathbf{J}$ Work Environ Health 1995; 21: 405-11.

Beauvoir S De. A velhice. Tradução de Maria Helena Franco Martins. Rio de Janeiro: Nova Fronteira, 1990.

Becker BK. Repensando a questão ambiental no Brasil a partir da geografia política. In: Leal MC, organizador. Saúde, ambiente e desenvolvimento. Rio de Janeiro: Hucitec; 1992. v.1, p.127-52. 
Belmar R, Hofmeister VA, Michaels D, Moreno AR, Romieu I. Air pollutants. In: Finkelman J, Corey G, Calderon R. Environmental epidemiology: a project for Latin America and the Caribbean. Metepec: OPAS, WHO; 1993. p. 37-94.

Beregi E, Klinger A. Health and living conditions of centenarians in Hungary. Int Psychogeriatr 1989; 1: 195-200.

Berg BN, Simms HS. Nutrition and longevity. II. Longevity and onset of disease with different levels of food intake. J Nutr 1960; 71: 255-63.

Berkson J. Mortality and marital status: reflection on the devivation of etiology from statistics. Am J Public Health 1962; 52: 1318-29.

Bocchi SCM. Movendo-se entre a liberdade e a reclusão: vivendo uma experiência de poucos prazeres ao vir a ser um familiar cuidador de uma pessoa com AVC. São Paulo; 2001. [Tese de Doutorado - Escola de Enfermagem da USP].

Bonilla WR. Entre el recuerdo y el olvido - las memorias de los exiliados antiturjillistas. Rev Mex del Caribe 2003; 15: 79-105.

Borja Aburto VH, Loomis DP, Bangdiwala SI, Sky CM, Pascon-Pacheco RA. Ozone, suspended particulates and daily mortality in México City. Am J Epidemiol 1997; 145: 258-68.

Borja PC, Moraes LPS. Sistema de Indicadores de Saúde Ambiental e Saneamento em Políticas Públicas. Anal Dados 2001; 10: 229-44.

Bosi E. Memória e sociedade: lembranças de velhos. $2^{\text {a }}$ ed. São Paulo: TA Queiroz, Editora da Universidade de São Paulo; 1987.

Brasil Ferrovias [online]. Disponível em URL:http:// www.brasilferrovias.com.br [2005 nov 5]

Brewer R. Science of ecology. Fort Worth, Saunders; 1994.

Briggs D. Environmental pollution and the global burden of disease. Br Med Bull 2003; 68: 1-24.

Camarano AA, organizador. Muito além dos 60: os novos idosos brasileiros. Rio de Janeiro: Instituto de Pesquisas Econômicas Paliçada; 1999.

Cançado FAX. Noções práticas de geriatria. São Paulo: Coopmed; 1994.

Carandina L, Sanches O, Carvalheiro JR. Análise das condições de saúde e de vida da população urbana de Botucatu, SP. I - descrição do plano amostral e avaliação da amostra. Rev Saúde Pública 1986; 20: 465-74. 
Caruso C, Candore G, Romano GC, Lio D, Bonafe M, Valensin S, et al. Immunogenetics of longevity. Is major histocompatibility complex polymorphism relevant to the control of human longevity? A review of literature data. Mech Ageing Dev 2001; 122: 445-62.

Carvalho Filho ET, Papaleo Neto M. Geriatria: fundamentos, clínica e terapêutica. São Paulo: Atheneu; 1994.

Carvalho JAM, Garcia RA. O envelhecimento da população brasileira: um enfoque demográfico. Cad Saúde Pública 2003; 19: 725-33.

Caspari R, Lee SH. Older age becomes common late in human evolution. Proc Natl Acad Sci USA 2004; 101(30): 10895-900.

Chaimowicz F. A saúde dos idosos brasileiros às vésperas do século XXI: problemas, projeções e alternativas. Rev Saúde Pública 1997; 31(2): 184-200.

Chandra V, Szklo M, Goldberg R, Tonascia J. The impact of marital status on survival after myocardial infarction: a population based study. Am J Epidemiol 1983; 177: 320-5.

Charmaz K. The grounded theory method: an explication and interpretation. In: Emerson RM, editor. Contemporary field research. Boston: Little, Brown; 1983.

Chauí MS. Os trabalhos da memória. In: Bosi E. Memória e sociedade: lembranças de velhos. $2^{\text {a }}$. ed. São Paulo: TA Queiroz, Editora da Universidade de São Paulo; 1987. p.XVII XXXII.

Chenittz WC, Swanson JM. From practice to grounded theory. Reading: AddisonWeslwy; 1986.

Christen Y. Les facteurs environnementaux de la longevite. Presse Med 2003; 32: 370-6.

Christensen K, Vaupel JW. Departments of longevity: genetic, environmental and medical factors. J Intern Med 1996; 240: 333-41.

Cifuentes L, Borja-Aburto VH, Davis DL, Gouveis N, Thurston G. Hidden health benefits of greenhouse gás mitigation. Science 2001; 293(5533): 1257-9.

Community of environment health. Pediatrics 2004; 114(6): 1699-1707.

CNUMAD (Conferencia de las Naciones Unidas sobre el Meio Ambiente y el Desarrollo). Jornal da Conferencia das Nações Unidas para o Meio Ambiente. Rio de Janeiro; 1992. 
Cooper EL. Invertebrates can tell us something about senescence. Aging Clin Exp Res 1994; 6: 5-23.

Coravalán C, Briggs D, Kjellstrom T. Development of Environmental and health anlysis, general guidelines. A report of the Health and Environment Analysis for Decision-making (HEADLAMP) project. Geneva: WHO; 1996.

Cordeiro R. Ocupação e mortalidade em Botucatu. Botucatu; 2001. [Tese de livre docência - Departamento de Saúde Pública, Faculdade de Medicina de Botucatu, UNESP].

Creswell JW. Qualitative inquiry and research desing: choosing among five traditions. Thousand Oaks: Sage; 1998.

Cristensen K, Vaupel JW. Determinants of longevity: genetic, environmental and medical factors. J Intern Med 1996; 24: 333-41.

Davis Jr GE, Lowell WE. The Sun determines human longevity: teratogenic effects of chaotic solar radiation. Med Hypotheses 2004; 63: 574-81.

De Benedictis G, Tan Q, Jeune B, Christensen K, Ukraintseva SV, Bonafe M, et al. Recent advances in human gene-longevity association studies. Mech Ageing Dev 2001; 122: 909-20.

Delmanto AM. Memórias de Botucatu. Botucatu: Vanguarda de Botucatu; 1990.

Delmanto AM. Memórias de Botucatu II. Botucatu: Vanguarda de Botucatu; 1993.

Delmanto AM. Memórias de Botucatu III. Botucatu: Delmanto; 2000.

Demo P. Elementos metodológicos da pesquisa participante. In: Brandão CR, organizador. Repensando a pesquisa participante. $2^{\mathrm{a}}$ ed. São Paulo: Brasiliense; 1985.

Denzin NK, Lincoln YS, editors. The handbook of qualitative research. $2^{\text {nd }}$ ed. Thousand Oaks: Sage; 2000.

Dixon JK, Dixon JP. An integrative model for environmental health research. Adv Nurs Sci 2002; 24: 43-57.

Dockery DW, Schwartz J, Spengler JD. Air pollution and daily mortality: association with particulates and acid aerosols. Environ Res 1992; 59: 362-73.

Donato H. Achegas para a história de Botucatu. $3^{\mathrm{a}}$ ed. Botucatu: Prefeitura Municipal de Botucatu, Banco Sudameris; 1985.

Ellison CG, Levin JS. The religion-health connection: evidence, theory, and future directions. Health Educ Behav 1998; 25: 700-20. 
EPA (Environmental Proteccion Agengy). Indoor air pollution: an introduction for health professionals. Washington: EPA; 1993.

Estações da Estrada de Ferro Sorocabana [online]. Disponível em URL:http:// geocities.yahoo.com.br/efsorocabana [2005 nov 5]

Farr RM. Representações sociais: a teoria e sua história. In: Guareschi P e Jovchelovitch S (org). Textos em Representações Sociais. 2a ${ }^{\mathrm{a}}$. ed. Petrópolis, RJ: Vozes, 1995, p.31-59.

Fielding JE. Public Health in the twentieth century: advances and challenges. Annu Rev Public Helth 1999; 20: xiii-xxx.

Firmo JO, Lima-Costa MF, Uchôa E. Projeto Bambuí: maneiras de pensar e agir de idosos hipertensos. Cad Saude Publica 2004a; 20:1029-40.

Firmo JO, Uchôa E, Lima-Costa MF. Projeto Bambuí: fatores associados ao conhecimento da condição de hipertenso entre idosos. Cad Saúde Pública 2004b; 20: 512-21.

Friedman GD, Kannel WB, Dawber TR, McNamara PM. An evalution of follow-up methods in the Framingham Heart Study. Am J Public Health Nations Health 1967; 57: 1015-24.

FUNASA (Fundação Nacional de Saúde). Curso Básico de Vigilância Ambiental em Saúde - CBVA. Brasília; 2003.

Galvão LA, Oliveira MLC, Augusto LGS, Cancio J. Indicadores de saúde e ambiente - relatório da oficina de trabalho realizada durante o IV Congresso Brasileiro de Epidemiologia - Epi-RIO-98. Inf Epidemiol SUS 1998; 7(2): 46-53.

Garcia R. Interdisciplinaridad y sitemas complexos. In: Leff E, organizador. Ciências sociais y formación ambiental. Barcelona: Gedisa; 1994.

Gavrilov LA, Gavrilova NS. Etude biodemographique des determinants familiaux de la longevite humaine. Population (Paris) 2001a; 56(1-2): 225-52.

Gavrilov LA, Gavrilova NS. Epidemiology of human lonvevity: The search for appropriate methodology. J Anti Aging Med 2001b; 4: 13-30.

Gawain M, Jenkins NL, Walker DW, Lithgow GJ. Testing evolutionary theoris of aging. Ann N Y Acad Sci 2000; 908: 319-20.

Giesbrecht RM. Estações ferroviárias do Estado de São Paulo [online]. Disponível em URL:http://www.estacoesferroviarias.com.br [2005 nov 5]

Gimenez AS. Ferrovias em Sorocaba e região [online]. Disponível em URL:http://www. geocities.com/trens_efs [2005 nov 5] 
Glaser B, Strauss A. The discovery of grounded theory. Chicago: Aldine; 1967.

Glaser BG. Basics of grounded theory analysis: emergence vs forcing. Mill Valley: CA Sociology Press; 1992.

Godoy OP. A história do Capitão José Gomes Pinheiro. Botucatu: Santana; 2000.

Gohn MG. Empoderamento e participação da comunidade em políticas sociais. Saúde Soc 2004; 13: 20-31.

Goldberg MS. Particulate air pollution and daily mortality: who is at risk? J Aerosol Med 1996; 9: 43-53.

Goldman N, Korenman S, Weinstein R. Marital status and health among the elderly. Soc Sci Med 1995; 40: 1717-30.

Goodwin JS, Hunt W, Key R, Samet JM. The effect of marital status on stage, treatment, and survival of cancer patients. JAMA 1987; 258: 3125-30.

Gorni AA. E.F. Brasil: a primeira comunidade virtual de fãs ferroviários brasileiros [online]. Disponível em URL:http://www.efbrasil.eng.br [2005 nov 05]

Gouveia N, Fletcher A. Times series analysis of air pollution and mortality effects by cause, age and socioeconomic status. J Epidemiol Community Health 2000; 54: 750-5.

Granville GC, Gephart LA, Keefe RT. Urban air pollution and mortality. Can J Public Health 1998; 89: 152-6.

Gudmundsson H, Gudbjartsson DF, Kong A, Gudbjartsson H, Frigge M, Gulcher JR, et al. Inheritance of human longevity in Iceland. Eur J Hum Genet 2000; 8: 743-9.

Haguette TMF. Metodologias qualitativas na sociologia. $7^{\mathrm{a}}$. ed. Petrópolis: Vozes; 2000.

Houaisss A, Villar MS. Dicionário Houaiss da Língua Portuguesa. Elaborado no Instituto Antonio Houaiss de Lexicografia e banco de dados da Língua Portuguesa S/C Ltda - Rio de Janeiro: Objetiva, 2001.

Hawkes K, O’Connell JF, Blurton Jones NG. Hadza women's time allocation, offspring provisioning, and the evolution of long postmenopausal lifespans. Curr Anthropol 1997; 38: 551-7.

Hawkes K, O’Connell JF, Blurton Jones NG, Alvarez H, Charnov EL. Grandmothering, menopause and the evolution of human life histories. Proc Natl Acad Sci USA 1998; 95: 1336-9.

Hawkes K. The grandmother effect. Nature 2004; 428: 128-9. 
Hayflick L. The future of ageing. Nature 2000; 408(6809): 267-9.

HO SC. Health and social predictors of mortality in an elderly Chinese cohort. Am J Epidemiol 1991; 133: 907-21.

House JS, Landis KR, Umberson D. Social relationships and health. Science 1988; 241: 540-5.

Instituto Brasileiro de Geografia e Estatística. Censo demográfico 2000: características demográficas da população e dos domicílios (resultado do universo). Rio de Janeiro: IBGE; 2000.

Iyda M. Mudanças nas relações de produção e migração: o caso de Botucatu e São Manuel. São Paulo; 1979. [Dissertação de Mestrado - Faculdade de Saúde Pública da USP].

Izzoti A, Parodi S, Quaglia A, Fare C, Vercelli M. The relationship between urban airbone pollution and short-term mortality: quantitative and qualitative aspects. Eur J Epidemiol 2000; 16: 1027-34.

Jazwinski SM. Aging and Longevity genes. Acta Biochim Pol 2000; 47: 269-79.

Jerret M, Burnett RT, Brook J, Kanaroglou P, Giovis C, Finkelstein N, et al. Do socioeconomic characteristics modify the short termassociation between air pollution and mortality? Evidence from a zonal time series in Hamilton, Canadá. J Epidemiol Community Health 2004; 58: 31-40.

Jones TF, Eaton CB. Exercise prescription. Am Fam Physician 1995; 52: 543-50, 553-5.

Kalache A, Veras RP, Ramos LR. O envelhecimento da população mundial; um desafio novo. Rev Saúde Pública 1987; 21(3): 200-10.

Kark JD, Shemi G, Friedalnder Y, Martin O, Blondheim SH. Does religious observance promote health? Mortality secular vs religius kibbutzim in Israel. Am J Public Health 1996; 86: 341-6.

Keber RA, O’Brien E, Smith KR, Cawthon RM. Familial excess longevity in Utah genealogies. J Gerontol A Biol Sci Med Sci 2001; 56: B130-9.

Kinsella Kevin GMA. Future longevity: demographic concerns and consequences. J Am Geriatr Soc 2005; 59 Suppl 9: S299-303.

Kirkwood TBL. Genetics and the future of human longevity. J R Coll Physicians Lond 1997; 31(6): 669-73.

Kirkwood TBL, Austad SN. Why do we age? Nature 2000; 408(6809): 233-8. 
Kirkwood TBL. Evolution of ageing. Mech Ageing Dev 2002; 123: 737-45.

Konder L. O que é dialética. $28^{\circ}$. ed, $2^{\circ}$. reimpressão. Coleção Primeiros Passos, São Paulo: Editora Brasiliense S.A., 1999.

Krause N. Religion, aging, and health: current status and future prospects. J Gerontol Ser B 1997; 52: S291-3.

Lahdenpera M, Lummaa V, Helle S, Tremblay M, Russell AF. Fitness benefits of prolongel post-reproductive lifespan in women. Nature 2004; 428(6979): 178-81.

Lee JT, Kim HO, Cho YS, Hong YS, Ha EH, Park H. Air pollution and hospital admissions for ischemic heart diseases among individuals 64+ years of age residing in Seoul, Korea. Arch Environ Health 2003; 58: 617-23.

Instituto Brasileiro de Geografia e Estatística. Pesquisa Nacional de Saneamento básico. 2000. Rio de Janeiro: IBGE; 2000.

Levenson RW, Carstensen LL, Gottman JM. Long-term marriage: age, gender and satisfaction. Psychol Aging 1993; 8(2): 301-13.

Lewis K. Human longevity. An evolutionary approach. Mech Ageing Dev 1999; 109: 43-51.

Lieber RR, Romano-Lieber NS. Riscos, incerteza e as possibilidades de ação na saúde ambiental. Rev Brás Epidemiol 2003; 6: 121-34.

Lieber RR. Teoria e metateoria na investigação da causalidade. São Paulo; 1998. [Tese de Doutorado - Departamento de Saúde Ambiental da Faculdade de Saúde Pública da USP].

Lima e Costa MFF, Uchoa E, Guerra HL, Firmo JOA, Vidigal PG, Barreto SM. The Bambuí health and ageing study (BHAS): methodological approach and preliminary results of a population-based cohort study of the elderly in Brazil. Rev Saúde Pública 2000; 34(20): 126-35.

Lima-Costa MF, Barreto SM, Firmo JO, Uchoa E. Socioeconomic position and health in a population of Brazilian elderly: the Bambuí Health and Aging Study (BHAS). Rev Panam Salud Publica 2003; 13: 387-94.

Lima-Costa MF, Firmo JO, Uchôa E. A estrutura da auto-avaliação da saúde entre idosos: projeto Bambuí. Rev Saúde Publica 2004; 38(6): 827-34.

Lima-Costa MF, Veras R. Saúde pública e envelhecimento. Cad Saúde Pública 2003; 19: 700-1.

Lincoln R, Boxshall G, Clark P. A dictionary of ecology, evolution and systematics. $2^{\text {a. }}$ ed. Cambridge: Cambridge University Press; 1998. 
Lipfert FW. Air pollution and human health: perspectives for the '90s and beyond. Risk Anal 1997; 17: 137-46.

Losnak CJ, coodernador. Trabalho e sentimentos: histórias de ferroviários da Companhia Paulista e Fepasa. Bauru: Prefeitura Municipal de Bauru, Secretaria de Cultura; 2003.

Manton KG, Stallard E, Tolley HD. Limits to human life expectancy: evidence, prospects, and implications. Popul Dev Rev 1991; 17: 603-37.

Mar TF, Norris GA, Koening JQ, Larson TV. Association between air poluttion and mortality in Phoenix, 1995-1997. Environ Health Perspect 2000; 108: 347-53.

Marafon LP, Cruz IBM, Schwanke CHA, Moriguchi EH. Preditores cardiovasculares da mortalidade idoso longevos. Cad Saúde Pública 2003; 19: 799-807.

Marigliano V, Bauco C, Campana F, Cacciafesta M, Bagagliani C, Fritz C, et al. Normal values in extreme old age. Ann N Y Acad Sci 1992; 673: 23-8.

Martins MC, Fatigati FL, Vespoli TC, Martins LC, Pereira LA, Martins MA, et al. Influence of socioeconomic conditions on air pollution adverse health effects in elderly people: an analysis of six regions in São Paulo, Brazil. J Epidemiol Community Health 2004; 58(10): 41-6.

Masoro EJ, Yu BP, Bertrand HA, Lynd FT. Nutrition probe of the aging process. Fed Proc 1980; 39: 3178-82.

Masoro EJ. Influence of caloric intake on aging and on the response to stressors. $\mathbf{J}$ Toxicol Environ Health B Crit Rev 1998; 1: 243-57.

McCay CM, Crowell MF, Maynard LA. The effect of retarded growth upon the length of life span and upon the ultimate body size. J Nutr 1935; 10: 63-79.

Medvedev ZA. An attempt at a rational classification of theories of aging. Biol Rev 1990; 65: 375-98.

Meza C, Gershwin ME. Why is asrthma becoming more of a problem? Curr Opin Pulm Med 1997; 3(10): 6-9.

Minayo MCS. $O$ desafio do conhecimento: pesquisa qualitativa em saúde. $4^{\mathrm{a}}$. ed. São Paulo: HUCITEC; 1996.

Minayo MCS, Miranda A, organizadores. Saúde e ambiente sustentável: estreitando nós. Rio de Janeiro: FIOCRUZ; 2002.

Minayo MCS. Enfoque ecossistêmico da Saúde e Qualidade de vida. In: Minayo MCS, Miranda A, organizadores. Saúde e ambiente sustentável: estreitando nós. Rio de Janeiro: FIOCRUZ; 2002. Parte III.2, p.173-189. 
Ministério da Saúde. Sistema Nacional de Vigilância Ambiental em Saúde. Brasília, DF: Fundação Nacional de Saúde; 2001.

Mitchell BD, Hsueh WC, King TM, Pollin TI, Sorkin J, Agarwala R, et al. Heritability of life span in the old order amish. Am J Med Genet 2001; 102: 346-52.

Moscovici S. Prefácio. In: Guareschi P e Jovchelovitch S (org). Textos em Representações Sociais. 2a . ed. Petrópolis, RJ: Vozes, 1995, p.7-16.

Myers J. Personal empowerment. J Int Fed Ageing 1993; 20: 3-8.

Nações Unidas. Informe da Assembléia Mundial sobre o envelhecimento da população. A/Conf/31. Viena; 1982.

Neidell MJ. Air pollution, health, and sócio-economic status: the efect of outdoor an quality on childhood asthma. J Health Econ 2004; 23: 1209-36.

Neupert RF. Nova projeção da população brasileira: hipóteses baseadas em informações recentes. In: Wong LLR, Hakkert R, Lima R, organizadores. Futuro da população brasileira: projeções, previsões e técnicas. Embu: ABEP; 1987.

Nevalainen J, Pekkanen J. The effect of particulate air pollution on life expectancy. Sci Total Environ 1998; 217(1-2): 137-41.

Novaes TCP. Bases metodológicas para abordagem da exposição ao benzeno. São Paulo; 1992. [Dissertação de Mestrado - Instituto de Química da USP].

Olsen O. Immpact of social network on cardiovascular mortality in middle aged danish men. J Epidemiol Community Health 1993; 47: 176-80.

Olshansky SJ, Carnes BA, Desesquelles A. Prospects for human longevity. Science 2001; 291: 1491-2.

Organização Mundial de Saúde. Definition of environmental health developed at WHO consultation in Sofia, Bulgária, 1993 [online]. Disponível em URL:http://health.gov/environment/definitionenvhealth/ehdef2.htm [2005 nov 05]

Organización Panamericana de la Salud. Protección ambiental. In: Anais da 23a Conferencia Sanitaria Panamericana, 42a. Reunión del Comité Regional (CCPS23/16); 1990; Washington , DC (USA). Washington, DC: OPS; 1990.

Packer C, Tatar M, Collins A. Reproductive cessation in famale mammals. Nature 1998; 392: 807-11.

Pádua JA. Dois séculos de crítica ambiental no Brasil. In: Minayo MCS, Miranda A, organizadores. Saúde e ambiente sustentável: estreitando nós. Rio de Janeiro: FIOCRUZ; 2002. Parte I.1, p.27-35.

Pádua JA. Um sopro de destruição: pensamento político e crítica ambiental no Brasil escravista. Rio de Janeiro: Zahar; 2002. 
Palloni A, Peláez M. Histórico e natureza do estudo. In: Lebrão ML, Duarte YMO. SABE - Saúde, Bem Estar e Envelhecimento - O projeto Sabe no município de São Paulo: uma abordagem inicial. Brasília: Organização Pan-Americana de Saúde; 2003. p.15-32.

Parsons PA. The limit to humana longevity: an approach through a stress theory of ageing. Mech Ageing Dev 1996; 87: 211-8.

Patrício KP. Função adaptativa da longevidade induzida pela restrição alimentar: avaliação dos aspectos metodológicos envolvidos no estudo comparativo em idosos humanos. Botucatu; 1998. [Dissertação de Mestrado - Instituto de Biociências da Universidade Estadual Paulista].

Patton MQ. Qualitative evolution and research methods. $3^{\text {rd }}$ ed. Newbury Park: Sage; 2001.

Pearl R, Pearl RW. The ancestry of the long-lived. Baltimore: Johns Hopkins University Press; 1934.

Penninx BW, van Tilburg T, Kriegsman DM, Deeg DJ, Boeke AJ, van Eijk JT. Effects of social support and personal coping resources on mortality in older age: the longitudinal aging study Amsterdam. Am J Epidemiol 1997; 146: 510-9.

Pereira MG. Epidemiologia: teoria e prática. São Paulo: Guanabara Koogan; 1992.

Perls T. The oldest old. Sci Am 1995; 272: 70-5.

Perls T, Alpert L, Fretts R. Middle aged mothers live longer. Nature 1997; 389: 133.

Perls T, Wager C, Bubrik E. Siblings of centenarians live longer. Lancet 1998; 351: 1560 .

Perls T, Kunkel LM, Puca AA. The genetics of exceptional human longevity. J Am Geriatr Soc 2002; 509: 359-68.

Perls T, Terry D. Understanding the determinants of exceptional longevity [miscellaneous]. Ann Intern Med 2003; 139 (5 Part 2): 445-9.

Petropoulou C, Chondrogianni N, Simões D, Agiostratidou G, Drosopoulos N, Kotsoda V, et al. Aging and longevity: a paradigm of complementation between homeostatic mechanisms and genetic control?. Ann N Y Acad Sci 2000; 908: 13342.

Pinto SA. No velho Botucatu. $2^{\text {a }}$ ed. São Paulo: Paulicéia; 1994.

Pope CA, Schwartz J, Ranson MR. Daily mortality and PM10 pollution in Utah Valley. Arch Environ Health 1992; 47: 211-7. 
Pope CA, Bates DV, Raizenne ME. Health effects of particulate air pollution: time for reassessment? Environ Health Perspect 1995; 103: 472-80.

Possas CA. Epidemiologia e sociedade: heterogeneidade estrutural e saúde no Brasil. São Paulo: Hucitec; 1998.

Ramos LR, Veras RP, Kalache A. Envelhecimento populacional: uma realidade brasileira. Rev Saúde Pública 1987a; 21: 211-24.

Receputo G, Rapisarda R, Motta L. Centenari: stato di salute e condizioni di vita. Ann Ital Med Int 1995; 10: 41-5.

Reigota M. Meio ambiente e representação social. São Paulo: Cortez; 1995. (Questões da nossa época; v.41).

Ribeiro Sobral H. Poluição do ar e doenças respiratórias em crianças da Grande São Paulo: um estudo de geografia médica. São Paulo; 1988. [Tese de Doutorado Departamento de Geografia da USP].

Ribeiro Sobral H. Globalização e meio ambiente. In: Dowbor L, Ianni O, Resende PE. Desafios da globalização. Petrópolis: Vozes, 1998. p.140-6.

Ribeiro H. Saúde Pública e meio ambiente: evolução do conhecimento e da prática, alguns aspectos éticos. Revista Saúde e Sociedade 2004; v13, no. 1: 70-80.

Rickfles RE. A economia da natureza: um livro texto em ecologia básica. $3^{\circ}$. ed. Rio de Janeiro: Guanabara Kogan; 1996.

Robine JM, Michel JP. Looking forward to a general theory on population aging. $\mathbf{J}$ Gerontol A Biol Sci Med Sci 2004; 59: M590-7.

Romn JJ, Ervin CA. How energy policies affect public health. Public Health Rep 1996; 111: 390-9.

Ross MH. Life exctancy modification by change in dietary regimen of the mature rat. In: Proceedings of the $7^{\text {th }}$ International Congress of Nutrition; New York. New York: Pergamon; 1966. v.5.

Roth GS, Ingram DK, Lane MA. Calorie restriction in primates: will it work and how will we know? J Am Geriatr Soc 1999; 47: 896-903.

Ruiz T. Estudo da mortalidade e dos seus preditores na população idosa do município de Botucatu - SP. Campinas; 1996. [Tese de Doutorado - Faculdade de Ciências Médicas da Universidade de Campinas].

Saad PM. O idoso na Grande São Paulo. São Paulo: Fundação SEADE; 1990. p.17. 
Sahl J, Mezeni G, Kavet R, McMillan A, Silvers A, Sastre A, et al. Occupational magnetic field exposure and cardiovascular mortality in a cohort of eletric utility workers. Am J Epidemiol 2002; 156: 913-8.

Saldiva PHN, Pope CA, Schwartz J, Dockery DW, Lichtenfelds PSO, Salge JM, et al. Air pollution and mortality in elderly people: a time series study in São Apulo, Brazil. Arch Environ Health 1995; 50: 159-64.

Samaja J. Desafios a la epidemiologia (pasos para una epidemiologia 'Miltoniana”). Rev Bras Epidemiol 2003; 6: 105-20.

Samet JM, White RH. Urban air pollution, health, and equity. J Epidemiol Community Health 2004; 58: 3-5.

Sanhueza P, Vargas C, Jimenez J. Daily mortality in Santiago and its relationship with air pollution. Rev Med Chil 1999; 127: 235-42.

Santos E. Relatório Parcial do Projeto Mercúrio/IEC. Grupo de Trabalho da Coordenação de ecologia Humana e Meio Ambiente [mimeografado]. Belém: Instituto Evandro Chagas; 1997.

Santos M. Metamorfose do espaço habitado. São Paulo: Hucitec; 1997.

Sartor F, Demuth C, Snacken R, Walckies D. Mortality in the elderly and ambient ozone concentration during the hot summer, 1994, in Belgium. Environ Res 1997; 72: 109-17.

Schachter F, Cohen D, Kirkwood T. Prospects for the genetics of human longevity. Hum Genet 1993; 91: 519-26.

Schwanke CH, Cruz IB, Leal NF, Scheibe R, Moriguchi Y, Moriguchi EH. Analysis of the association between apolipoprotein E polymorphism and cardiovascular risk factors in an elderly population with longevity. Arq Bras Cardiol 2002; 78: 561-79.

Schwartz J, Dockery DW. Increase mortality in Philadelphia associated with daily air pollution concentrations. Am Rev Respir Dis 1992; 145: 600-4.

Schwartz J, Morris R. Air pollution and hospital admissions for cardiovascular disease in Detroit, Michigan. Am J Epidemiol 1995; 142: 23-35.

Schwartz J. What are people dying of on high air pollution days? Environ Res 1994; 64: 26-35.

SEADE (Fundação Seade). Perfil municipal [online]. Disponível em <URL:http://www.seade.gov.br> [2005 nov 05]

Seeman TE, Berkman LF, Kohout F, Lacroix A, Glynn R, Blazer D. Intercommunity variation in the association between social ties and mortality in the elderly: a comparative analyses of three communities. Ann Epidemiol 1993; 3: 325-66. 
Shanley DP, Kirkwood TBL. Caloric restriction and aging: a life history analysis. Evolution 2000; 54: 740-50.

Signorelli C, Limina RM. Environmental risk factors and Epidemiologic study. Ann Ig 2002; 14: 253-62.

Silva AS. Resíduos industriais organoclorados em Samaritá: um problema de saúde pública. São Paulo; 1994. [Dissetação de Mestrado - Faculdade de Saúde Pública da USP].

Simpson R, Williams G, Petroeschevksy A, O’Farrell T, Denison L, Hinwood A, et al. The short-term effects air pollution on cardiovascular admissions: meta-analysis for 4 Australian Cities. Epidemiology 2003; 14 Suppl 5: S33-4.

Sinclair J. Environmental effects on health. Nurs Stand 1999; 13(26): 42-6.

Smith DWE. Centenarians: human longevity outliers. Gerontologist 1997; 37: 2006.

Spink MJ. Desvendando as teorias implícitas: uma metodologia de análise das Representações Sociais. In: Guareschi P e Jovchelovitch S (org). Textos em Representações Sociais. 2 ${ }^{\mathrm{a}}$. ed. Petrópolis, RJ: Vozes, 1995, p.117-145.

Sri-Kantha S. Total Immediate Ancestral Longevity (TIAL) score as a longevity indicator: an analysis on Einstein and three of his scientist peers. Med Hypotheses 2001; 56: 519-22.

Strauss AL, Corbin J. Basics of qualitative research: techniques and procedures for developing grounded theory. $2^{\text {nd }}$ ed. California: SAGE Publications; 1998.

Stuchlikova E, Juricova-Horakova, Deyl Z. New aspects of the dietery effect of life prolongatiion in rodents. What is the role of obesity in aging ? Exp Gerontol 1975; 10: 141-4.

Tambelini AT, Câmara VM. A temática saúde e ambiente no processo de desenvolvimento do campo de saúde coletiva: aspectos históricos, conceituais e metodológicos. Ciência e Saúde Coletiva 1998; 3(2):47-59.

Tambellini AT. Notas provisórias sobre uma tentativa de pensar a saúde em suas relações com o ambiente. Por uma rede trabalho, saúde e modos de vida no Brasil. Rio de Janeiro: FIOCRUZ; 1996. v.2, n.1-2, p.12-6.

Tan Q, De Benedictis G, Ukraintseva SV, Franceschi C, Vaupel JW, Yashin AI. A centenarian-only approach for assessing gene - gene interaction in human longevity. Eur J Hum Genet 2002; 10: 119-24.

Teixeira CF, Paim JS, Vilas Boas AL. SUS, modelos assistenciais e vigilância da saúde. Inf Epidemiol SUS 1998; 7(2): 7-27. 
Teixeira MB. Empoderamento dos idosos em grupos direcionados à promoção da saúde. Rio de Janeiro; 2002. [Dissertação de Mestrado - Escola Nacional de Saúde Pública da Fundação Oswaldo Cruz].

Torres HG. Desigualdade ambiental na cidade de São Paulo. Campinas; 1997. [Tese de Doutorado - IFCH da Universidade de Campinas].

Touloumi G, Pocock SJ, Katsouyanni K, Trichopoulos D. Short-term effects of air pollution on daily mortality in Athenas: a time-series analysis. Int J Epidemiol 1994; 23: 957-67.

Turner L. Life extension research: health, illness, and death. Health Care Anal 2004; 12: 117-29.

Uchoa E, Lima-Costa MFF. Contribuição da antropologia para a abordagem da saúde do idoso. Gerontologia 1999; 7: 32-6.

Uchoa E. Contribuições da antropologia para uma abordagem das questões relativas à saúde do idoso. Cad Saúde Pública 2003; 19: 849-53.

Valadão AD. Fepasa 20 anos. Revista Comemorativa do $20^{\circ}$ Aniversário da Fepasa. São Paulo: Ferrovia Paulista S/A; 1991.

Van der Molen YF. Ecologia. São Paulo: EPU; c 1981.

Veras RP, Ramos LR, Kalache A. Crescimento da população idos no Brasil: transformações e conseqüências na sociedade. Rev Saúde Pública 1987; 21(3): 22533.

Veras RP. País jovem com cabelos brancos: a saúde do idoso no Brasil. Rio de Janeiro: Relume Dumará; 1994.

Verhoeff AP, Hoek G, Schwartz J, Van Wijnen JH. Air pollution and daily mortality in Amsterdam. Epidemiology 1996; 7: 225-30.

Veronese B, Oortgiesen M. Neurogenic inflamation and particulate matter (PM) air pollutants. Neurotoxicology 2001; 22: 795-810.

Vita AJ, Terry RB, Hubert HB, Fries JF. Aging, health risks, and cumulative disability. N Engl J Med 1998; 338: 1035-41.

Vorcaro CM, Rocha FL, Uchoa E, Lima-Costa MF. The burden of social phobia in a Brazilian community and its relationship with socioeconomic circumstances, health status and use of health services: the Bambuí study. Int J Soc Psychiatry 2004; 50: 216-26.

Walford RL, Spindler SR. The response to calorie restriction in mammals shows features also common to hibernation: a cross-adaptation hypothesis. J Gerontol 1997; 52: B179-83. 
Wardlaw AJ. Air pollution and allergic disease. Report of o Working Party of the British Society for Allergy and Clinical Immunology. Clin Exp Allergy 1995; 25 Suppl 3: 6-8.

Weindrunch $\mathrm{R}$, Walford RL. The retardation of aging and disease by dietary restriction. Springfield: Charles C. Thomas; 1988.

Weindrunch, R. Caloric restriction and aging. Sci Am 1996; 274: 46-52.

Westendorp RGJ, Kirkwood TBL. La transmission hereditaire de la longevite en lignes maternelle et paternelle. Population (Paris) 2001; 56(1-2): 253-68.

Wong LR, organizador. O envelhecimento da população brasileira e o aumento da longevidade: subsíduos para políticas orientadas ao bem-estar do idoso. Belo Horizonte: Centro de Desenvolvimento e Planejamento Regional, Universidade Federal de Minas Gerais, Associação Brasileira de Estudos Populacionais; 2001.

Wordley J, Walters AJP. Short term variations in hospital admissions and mortality and particulate air pollution. Occup Environ Med 1997; 54: 108-16.

Yu BP, Masoro EJ, Murata L, Bertrand HA, Lynd FT. Life span study of SPF fischer 344 male rats fed ad libitum or restricted diets: longevity, growth, lean body mass an disease. J Gerontol 1982; 37: 130-41. 


\section{ANEXO 1 - PARECER DO COMITÊ DE ÉTICA EM PESQUISA}

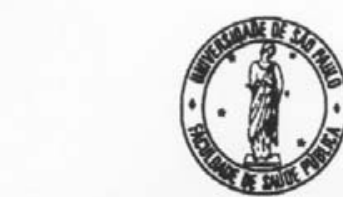

29

\section{Universidade de São Paulo \\ Faculdade de Saúde Pública}

COMITE DE ÉTICA - COEP

Av. Dr. Arnaldo, 715 - CEP 01246-904 - São Paulo - Brasil

Telefones: (55-11)3066-7734 - fone/fax (55-11)3064-7314-e-mail: mdgracas@usp.br

\section{Of.COEP/052/03}

12 de março de 2003

Pelo presente, informo que o Comitê de Ética em Pesquisa da Faculdade de Saúde Pública da Universidade de São Paulo-COEP, analisou e aprovou, em sua $02 .{ }^{\mathrm{a}} / 03$ Sessão Ordinária, realizada em 11.03.03, de acordo com os requisitos da Resolução CNS/196/96, o Protocolo de Pesquisa n. ${ }^{\circ} 925$, intitulado: "PERCORRENDO OS TRILHOS DA FERROVIA EM BUSCA DE FATORES AMBIENTAIS ASSOCIADOS À LONGEVIDADE HUMANA", apresentado pela pesquisadora Karina Pavão Patrício.

Atenciosamente,

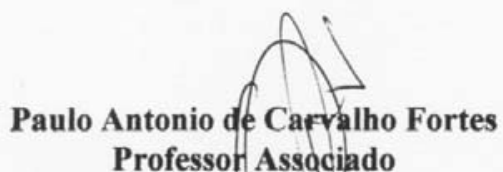

Coordenador do Comitê de Ética end Pesquisa da FSP-COEP 


\section{ANEXO 2 - CONSENTIMENTO LIVRE E ESCLARECIDO DE PARTICIPAÇÃO}

$\mathrm{Eu}$, declaro que concordo em ser entrevistado para participar voluntariamente da pesquisa científica sobre "envelhecimento, ferrovia e meio ambiente", que vem sendo realizada sob responsabilidade da Dra. Karina Pavão Patrício. Estou ciente de que os resultados serão utilizados em pesquisa científica. Autorizo a publicação dos resultados para efeito público. Os resultados poderão ser comunicados para minha pessoa.

Estou ciente de que posso, a qualquer momento, abandonar esta pesquisa sem qualquer tipo de prejuízo pessoal.

Botucatu, de de 200

Assinatura do entrevistado Assinatura do pesquisador

Observação: em caso de dúvida entrar em contato com a pesquisadora no telefone 38116080 ou 3882-8755 


\section{ANEXO 3 - Questionário}

Universidade de São Paulo - Faculdade de Saúde Pública - FSP

Pesquisa: "Percorrendo os trilhos da ferrovia rumo à associação entre fatores ambientais e longevidade humana" Departamento de Saúde Ambiental

Questionário de caracterização dos idosos ferroviários e fatores ambientais

Entrevista no:

Data: $/ 200$

I - Apresentação do entrevistador e do objetivo da pesquisa (termo de consentimento)

II - Identificação do Entrevistado

Vamos falar primeiro um pouquinho do Sr. e da sua família

1 - Nome:

2 - Data de Nascimento: anos)

3 - Endereço atual:

4- Telefone: Bairro:

5- Estado marital atual: ( ) 1. Casado - Há quanto tempo?
( ) 2. Viúvo Há quanto tempo?
( ) 3. Solteiro
( ) 6. Outros

( )4. Amasiado

( ) 5. Divorciado

6- Como era seu relacionamento com sua esposa?
( ) Ótimo
( ) Bom
( ) Médio
( ) Ruim
( ) Péssimo

7- O Sr. freqüentou a escola?
( ) 1 . Não

( ) 2. Sim. Por quantos anos?

8 - O Sr.teve filhos? (Enteados)

( ) 1 . Não

( ) 2. Sim. Quantos?

Vivos: __ Falecidos: __uando?

Convive com eles? ( ) Diariamente ( ) várias vezes na semana ( ) uma vez por mês

( ) Algumas vezes por ano ( ) Muito raramente

9 - O Sr. tem netos? ( ) 1. Não

( ) 2. Sim. Quantos?

10 - E bisnetos?
( ) 1 . Não
( ) 2. Sim. Quantos?

11- Em relação a sua família o Sr. Sempre teve um relacionamento:
( ) Ótimo
( ) Bom
( ) Médio
( ) Ruim
( ) Péssimo

12 - Na sua família tem pessoas que viveram bastante?

( ) 1. Não

( ) 2. Sim. Quem: (idade que faleceu: (idade que faleceu: (idade que faleceu:

13 - Se fosse para descrever que tipo o Sr. Costumava ser na maioria do tempo seria:
( ) Bem Calmo/tranqüilo
( ) Calmo
( ) Normal
( ) Nervoso/agitado
( ) Bem nervoso/ agitado 
14 - Qual a sua religião?
( ) Católica
( ) Protestante/ evangélica
( ) Judaica
( ) Outros cultos
sincréticos
( ) Outra
( ) Nenhuma
( ) NR

\section{III- Procedência}

15 - $\quad$ Agora vamos falar dos locais onde o Sr. já morou

a)nasceu em:

b) mudou-se para:

c) mudou-se para:

d) mudou-se para:

e) mudou-se para:

f) mudou-se para:

(morou até

(período/idade: (período/idade:

(período/idade:

(período/idade:

(período/idade:

$\left[\begin{array}{l}{ }^{a} \_ \\ a \\ a \\ a\end{array}\right.$

(Na tabela da página seguinte, se a pessoa morou em mais que 4 cidades, preencher os dados referentes as duas primeiras (ou até completar no mínimo 10 anos) e as duas últimas.

16 - Imigrante: ( )1- Não （ ） 2 - Sim

Ano que veio para Brasil:

Por quê veio?

17- Para o Sr. o que acha que é meio ambiente?

(gravar resposta)

(se não sabe o que é explicar e continuar as perguntas)

18- Como era o meio ambiente no local onde morava na época em que o Sr. trabalhava na ferrovia? (gravar)

19- Como o Sr. vê o meio ambiente hoje? (gravar)

20- O Sr. acha que meio ambiente tem alguma coisa a ver com a saúde? De que maneira? (gravar)

\section{IV - Profissões}

Agora vamos falar sobre as profissões que o Sr. Já exerceu.

21- Com que idade o Sr. começou a trabalhar? anos

22 - Quais os empregos/trabalhos que Sr. já teve?

\begin{tabular}{|l|l|l|l|}
\hline \multicolumn{1}{|c|}{ Local de trabalho } & \multicolumn{1}{c|}{ Função } & \multicolumn{2}{c|}{ Período/idade } \\
Inicial
\end{tabular}

23 - Em que ano o Sr. começou a trabalhar na ferrovia? 
27- Em relação ao trabalho que exercia, o Sr. Sentia-se:

( ) muito satisfeito/feliz com o trabalho ( ) Satisfeito

( ) Muito insatisfeito/ infeliz

28 - O Sr. já sofreu algum acidente no trabalho quando era ferroviário?
$\square 1$.Não
$\square$ 2. Sim

29 - Qual foi o tipo de acidente? (Pode-se assinalar mais de uma alternativa).
$\square$ 1. Caiu de veículo em movimento
$\square$ 11. Choque elétrico
2. Atropelamento
$\square$ 12. Manuseio de máquina
3. Colisão de veículo
$\square$ 13. Bala de arma de fogo
4. Queda da pessoa
5. Atingido por um objeto em movimento
$\square$ 14. Vazamento/inalação de gases
6. Manipulação de ferramentas cortantes ou perfurantes
15. Explosões
7. Transporte de equipamento
$\square$ 16. Incêndio
8. Contato com substância química
17. Ficou prensado
9. Contato com substância quente
18. Contaminação com material biológico
$\square$. 19. Outra. Especificar:

10. Contato com superfície aquecida ou muito fria

30- O sr já trabalhou com alguma substância química na ferrovia ou em qualquer outro serviço?
$\square$ 1.Não
$\square$ 2. Sim Quantas vezes?

Qual o tipo de substância?

Em que período? a

Que tipo de contato?

Costumava usar agrotóxicos, adubos em alimentos que comia?

31- O Sr. recebia algum desses benefícios quando trabalhava na ferrovia? (pode ser mais que uma alternativa)
1. Cesta básica
2. Vale refeição
3. Décimo terceiro
4. Assistência médica de convênio
5. Férias anuais

6. Nenhum

7. Outro. Qual?

32 - Comparando-se com outras pessoas de Botucatu, o Sr. considerava que a sua situação financeira era:
( ) Ótima

Por quê?

33- Qual era a jornada de trabalho do Sr na ferrovia?

Horário de entrada: Horário de saída:

Descanso do almoço:

Descanso semanal:

34- Com que idade o Sr. se aposentou da ferrovia? Em que ano? 
35 - Atualmente o Sr está:

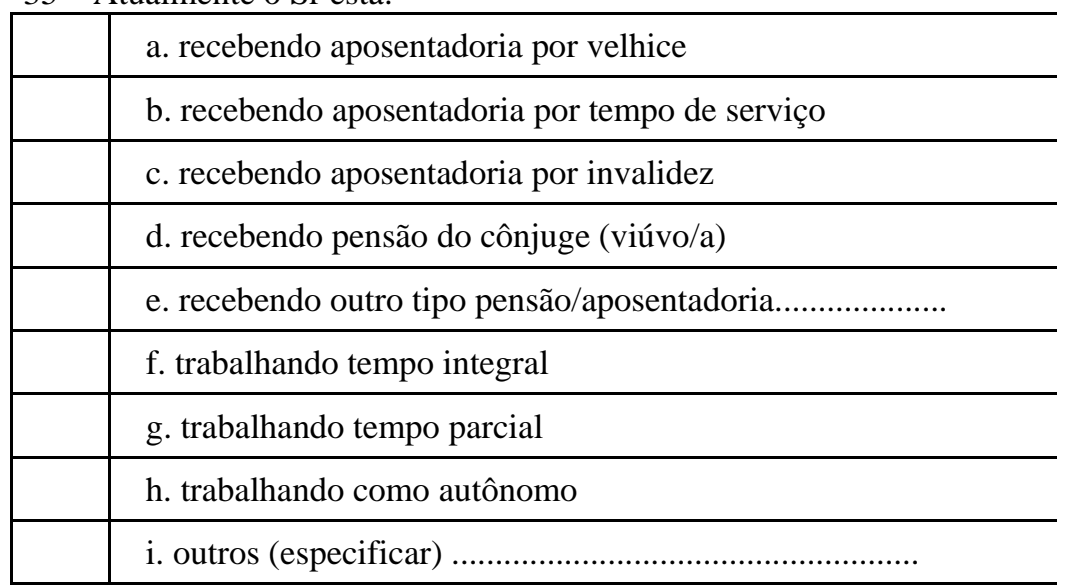

36. O Sr. poderia me dizer de onde regularmente recebe seu dinheiro?

\begin{tabular}{|l|l}
\hline & \\
\hline & a. trabalho (salário, negócios) \\
\hline & b. pensão (aposentadoria, benefício de seguro social) \\
\hline & c. investimentos, aluguel, juros, dividendos etc. \\
\hline & d. dinheiro da esposa \\
\hline & e. dinheiro dos filhos \\
\hline & f. dinheiro de outros familiares \\
\hline & g. dinheiro de não-familiares \\
\hline & h. dinheiro de instituição de caridade \\
\hline & i. outras fontes..........................................................
\end{tabular}

37 - Quantas pessoas moram na casa?

(Preencher quadro familiar)

38 - Quantas pessoas dependem financeiramente do Sr. , de seus ganhos?

39 - Considera, hoje, que a sua situação financeira é :

( ) Ótima ( ) Boa ( ) Média （）Ruim （）Péssima Por quê?

\section{V - HÁBITOS DE VIDA}

As perguntas agora são sobre alguns dos seus hábitos de vida.

40. O Sr. fuma?

$\square$ 1.Não - nunca

2.Sim - quantos cigarros por dia?

$\square$ 3.Já fumei - Por quanto Há quanto tempo? tempo?

41. O Sr. Costumava ingerir bebida alcoólica?
1.Não - nunca
$\square$ 2. Raramente
3. Um dia por semana
4. Mais de um dia por semana. Quanto por dia?
$\square$ 5. Já utilizei. Por quanto tempo? 
42. O Sr pratica alguma atividade física hoje em dia?

$\square$ 1.Não $\quad \square$ 2. Sim. Qual(is):

43. Quantas vezes por semana o Sr. pratica essa atividade?

$\begin{array}{ll}\square \text { 1. Todo dia ou quase todo dia } & \square \text { 2. Mais de } 4 \text { vezes por semana } \\ \square \text { 3. De } 2 \text { a } 3 \text { vezes por semana } & \square \text { 4. Um dia por semana }\end{array}$

$\square$ 5. Raramente

44. O Sr praticava alguma atividade física na época em que trabalhava na ferrovia?

$\square$ 1.Não $\quad \square$ 2. Sim. Qual(is):

45. Quantas vezes por semana o Sr. praticava essa atividade?

$\square$ 1. Todo dia ou quase todo dia $\square$ 2. Mais de 4 vezes por semana

$\square$ 3. De 2 a 3 vezes por semana $\square$ 4. Um dia por semana

$\square$ 5. Raramente

46. No trabalho da ferrovia qual era o esforço físico? Quantificar de 0 a 10.

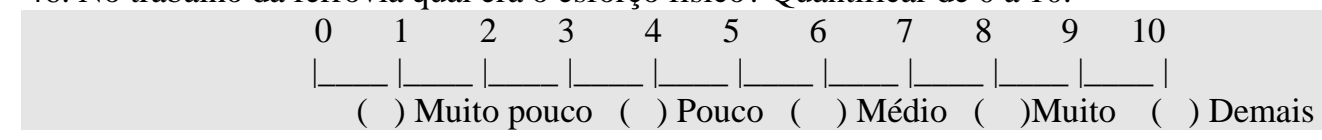

47. O que o Sr.normalmente faz como lazer hoje? (e na época em que trabalhava na ferrovia?

\begin{tabular}{|c|c|c|}
\hline HOJE & & ANTES \\
\hline & 1. ouvir rádio & \\
\hline & 2. assistir à televisão & \\
\hline & 3. ler jornal, revistas e livros & \\
\hline & 4. receber visitas & \\
\hline & 5. ir ao cinema, teatro, etc. & \\
\hline & 6. andar pela vizinhança & \\
\hline & 7. ir à igreja (serviço religioso) & \\
\hline & 8. fazer as compras & \\
\hline & 9. sair para visitar os amigos & \\
\hline & 10. sair para passeios longos (excursão) & \\
\hline & 11. sair para encontro social ou comunitário & \\
\hline & 12. coser, bordar, tricotar & \\
\hline & $\begin{array}{l}\text { 13. alguma atividade para se distrair (jogos de carta, xadrez, jardinagem, } \\
\text { etc) }\end{array}$ & \\
\hline & 14.pescar & \\
\hline & 15. ir a clubes de terceira idade & \\
\hline & 16. bailes & \\
\hline & 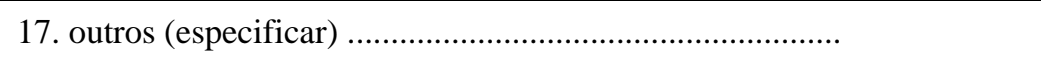 & \\
\hline
\end{tabular}

48 - O Sr. Sempre foi uma pessoa:

( ) Muito ativa, com muitas atividades

( ) Pacata, só as atividades do trabalho

( ) Médio, com algumas atividades

( )NS 
49 - Em relação a amizade, o Sr. Sempre teve:
( ) Muitas amizades
( ) Algumas amizades
( ) Poucas
( ) Bem poucas ( ) Nenhuma

VI - SAÚDE

Agora vamos falar da sua saúde

50. Em comparação com as outras pessoas da sua idade, o(a) Sr.(a) diria que sua saúde está:

1. muito pior

2. pior

3. igual (na média)

4. melhor

5. muito melhor

9. Não sabe

51. O Sr. tem algum problema de saúde?
$\square$ 1. Não
$\square$ 2. Sim. Qual(is) e ano/idade de aparecimento de cada:

52 - O Sr. Já teve algum problema respiratório?

$\square$ 1.Não $\quad \square$ 2. Sim. Qual(is):

53. O Sr. Já teve asma ou rinite?

$\square$ 1.Não $\square$ 2. Sim. Qual(is) e em que época:

54. O Sr. Já teve algum problema de coração?

$\square$ 1.Não $\square$ 2. Sim. Qual(is)e em que época:

55. O Sr. usa alguma medicação constantemente?

$\square$ 1.Não $\quad \square$ 2. Sim. Quantas, quais e ano de início:

56. O Sr. tem algum convênio de saúde?

$\square$ 1.Não $\quad \square$ 2. Sim. Qual(is) ?

57 - Em qual(is) instituição(ões) o(a) Sr.(a) tem direito a atendimento médico?

\begin{tabular}{|l|l|}
\hline a. & \\
\hline b. & \\
\hline c. & \\
\hline
\end{tabular}

58 - Qual nota que o Sr.daria à assistência à saúde que tem hoje em dia ? Marque na régua abaixo com um $\mathrm{X}$ em cima do número

\begin{tabular}{lllllllllll}
0 & 1 & 2 & 3 & 4 & 5 & 6 & 7 & 8 & 9 & 10 \\
\hline & & & & &
\end{tabular}

58. O Sr tem algum dos problemas abaixo na(s) instituição (ões) que utiliza?

$\square$ 1. o entrevistado não relata problemas importantes

$\square$ 2. problema com o custo dos serviços médicos

$\square$ 3. problema em obter atenção médica quando necessário (tempo de espera para marcar consulta e demora para ser atendido no dia, outras emergências)

$\square$ 4. problema com o tratamento oferecido pelos médicos (competência, atenção, relação médicopaciente)

$\square$ 5. problema com o tratamento oferecido pelo pessoal não-médico

$\square$ 6. problema com a localização da instituição

7 . outros problemas (especificar)

9. Não sabe 
59. O Sr. utiliza outros tipos de remédios ou ajudas para melhorar a sua saúde? Quais?

$\square$ 1. Plantas medicinais. Quais?

2. Benzedeiras

3. Promessas

4. Outras

60. O Sr. ficou doente no último ano?

$\square$ 1.Não $\quad \square$ 2. Sim . Qual(is) doença(s)?

Precisou internar?

$\square$ 1.Não $\quad \square$ 2. Sim . Quantos dias?

O seu problema foi resolvido?

$\square$ 1.Não. Por quê?

$\square$ 2. Sim

61. Quando o Sr. trabalhava na ferrovia tinha assistência médica?

$\square$ 1.Não $\quad \square$ 2. Sim. Onde?

62. Quando ficava doente , na época em que trabalhava na ferrovia, onde o Sr. Ia em primeiro lugar?
$\square$ 1. Posto de Saúde
2. UNESP
3. Hospital Sorocabana
$\checkmark$ 4. Médico particular
5. Santa Casa (qual
$\checkmark$ 6. outro (especifique)

63. Qual nota que o Sr.daria à assistência à saúde que tinha naquela época ? Marque na régua abaixo com um $\mathrm{X}$ em cima do número.

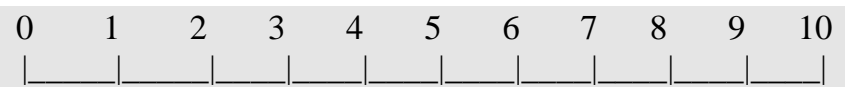

64. - Costumava freqüentar o médico, na época em que trabalhava na ferrovia, quantas vezes por ano?

$\square 1 \mathrm{vez}$

$\square 2$ vezes

$\square 3$ a 4 vezes

$\square$ mais que 5 vezes

$\square$ raramente

$\square$ nunca

65 - A saúde do Sr. , comparada com a de outros ferroviários era:
( ) Muito melhor
( ) Melhor
( ) Igual
( ) Pior
( ) muito pior

66 - Fale-me quais são os principais problemas que o Sr. enfrenta nesta questão de atenção à saúde aqui no município de Botucatu como ferroviário aposentado?

\section{VII- Alimentação}

Conte-me um pouco sobre a alimentação do Sr.na época em que trabalhava na ferrovia

67- Quantas vezes comia por dia?

68 - Comia leite, queijo ou outros produtos do leite quantas vezes por dia?

69 - Comia ovos, feijão ou lentilha (leguminosas) quantas vezes na semana?

70 - Comia carne, peixe ou ave quantas vezes na semana?

71 - Comia fruta ou verduras quantas vezes por dia? 
72 - Quantos copos ou xícaras de líquido consumia diariamente?

73- O Sr. Considera que tinha uma alimentação:
( ) Ótima
( ) Boa
( ) Média
( )Ruim
( ) Péssima

74. De onde vinham os alimentos que consumia?
$\square$ 1. comprava no armazém da ferrovia
$\square$ 2. comprava em outro armazém
$\square$ 3. hortas e/ou pomares em casa ou sítio
$\square$ 4. outros (especifique)
$\square$ 9. não sabe

75- Usava adubos químicos ou agrotóxicos?
( ) Não
( ) Sim

76. Comparando-se com outras pessoas da mesma idade, que trabalhavam igual e tinham mesmo tamanho que o $\mathrm{Sr}$, (colegas da ferrovia) durante a época em que trabalhava na ferrovia, sempre costumava comer:
$\square$ 1. Muito menos
$\square$ 2. Menos
3. Igual
$\square$ 4. Mais
5. Muito mais

77- Em relação ao sono, o Sr. Sempre foi uma pessoa que:

( ) Dormia muito bem ( ) Dormia bem ( ) Dormia normal

( ) Dormia não muito bem ～( ) Dormia muito mal

\section{VIII- CONSIDERAÇÕES PESSOAIS:}

Agora queria que o Sr. falasse qual a opinião do Sr. a respeito das seguintes perguntas (entrevistador deve gravar as respostas)

78 - Para o Sr., qual é o segredo para viver bastante? (gravar resposta)

79 - O Sr. acha que os ferroviários da Estrada de Ferro Sorocabana de Botucatu costumam viver mais tempo que as outras pessoas em geral? Por que o Sr. acha que isto acontece? (gravar resposta)

80 - Viver bastante tem alguma coisa a ver com o meio ambiente ou não? Fale-me o que o Sr. acha sobre isto (gravar resposta)

\section{IX - Grau de satisfação com a vida}

Para acabarmos gostaria de perguntar mais 5 coisas sobre o que o Sr. Acha de sua vida.

81 - Como o(a) Sr.(a) se sentia em relação à sua vida em geral?

$\square$ 1. Muito satisfeito

$\square$ 2. satisfeito

$\square$ 3. insatisfeito

$\square$ 4. muito satisfeito

$\square$ 9. não sabe

82 - O Sr. Se considerava uma pessoa:
1. Muito feliz
2. Feliz
3. Indiferente
4. Infeliz
5. Muito infeliz 
83. Gostaria que o(a) Sr.(a) me informasse qual é o problema mais importante do seu dia-a-dia

$\square$ 1. entrevistado não relata problemas importantes

$\square$ 2. problema econômico

$\square$ 3. problema de saúde (deterioração da saúde física ou mental)

$\square$ 4. falta de serviços ou programas de serviço social

$\square$. problemas de moradia

$\square$ 6. problemas de transporte

7. problemas familiares (conflitos)

8. problemas de isolamento (solidão)

$\checkmark$ 9. problemas de rejeição social (pessoas consideram a velhice de um modo negativo; a pessoa idosa se sente rejeitada)

$\square$ 10. outros problemas (especificar)

$\square$ 11. Não sabe

84 - Quais são os planos do Sr. Para o futuro (próximo)?

( ) Não tem ( ) NS

85. Como o Sr. se sente em relação ao meio ambiente em que vive hoje em dia?

$\square$ 1. Muito satisfeito

$\square$ 2. satisfeito

$\square$ 3. insatisfeito

$\square$ 4. muito satisfeito

$\square$ 9. não sabe

86. Qual é o principal motivo pelo qual o(a) Sr.(a) não se sente satisfeito(a) com o meio ambiente em que vive?

1. problema poluição aérea

2. problema de poluição sonora

3. problema de poluição visual

4. problema de poluição das águas

$\square$ 5. outro problema (especificar)

$\square$ 9. não sabe

Observações do entrevistador sobre o entrevistado: 
Continuação da questão 11

\begin{tabular}{|c|c|c|c|c|c|c|c|}
\hline 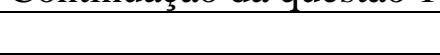 & Período: $\quad \mathrm{a}$ & Período: & $\mathrm{a}$ & Período: & $\mathrm{a}$ & Período: & $\mathrm{a}$ \\
\hline $\begin{array}{l}\text { I - AGUÁ } \\
\text { 1- Encanada dentro de casa } \\
\text { 2- Mina } \quad 3 \text { - Poço } \\
\text { 4- Açude } \quad \text { 5- Outro } \\
6 \text { - N.S. } \\
\text { Como era a água para o seu } \\
\text { consumo? } \\
\begin{array}{ll}\text { ( ) Muito Limpa } \\
\text { ( ) Limpa } \\
\text { ( ) ) Média } \\
\text { ( ) Suja } & \text { ( ) Imunda }\end{array}\end{array}$ & & & & & & & \\
\hline $\begin{array}{l}\text { II - AR } \\
\text { Havia poluição do ar no local } \\
\text { onde morava (ou em sua } \\
\text { cidade?) } \\
\text { 1- Não 2- Sim - Qual(is)? } \\
\text { Considera que o ar que } \\
\text { respirava era: } \\
\begin{array}{lll}\text { ( ) Muito puro } & \text { ( ) Puro } \\
\text { ( ) Médio } & \text { ( ) Poluído } \\
\text { ( ) Muito poluído }\end{array} \\
\end{array}$ & & & & & & & \\
\hline $\begin{array}{l}\text { III - LIXO } \\
\text { 1- Coleta municipal } \\
\text { 2- Composto orgânico } \\
\text { 3-Enterrava (próximo da casa } \\
\text { - quanto?*) } \\
\text { 4-Queimava* } \\
\text { 5- Jogava terreno baldio* } \\
\text { 6 - Outro (qual) } 7 \text { - N.S } \\
\text { A região onde morava, em } \\
\text { relação ao lixo, era: } \\
\begin{array}{ll}\text { ( ) Muito Limpa } \\
\text { ( ) Limpa } & \text { ( )Média } \\
\text { ( ) Suja } & \text { ( ) Imunda }\end{array}\end{array}$ & & & & & & & \\
\hline
\end{tabular}




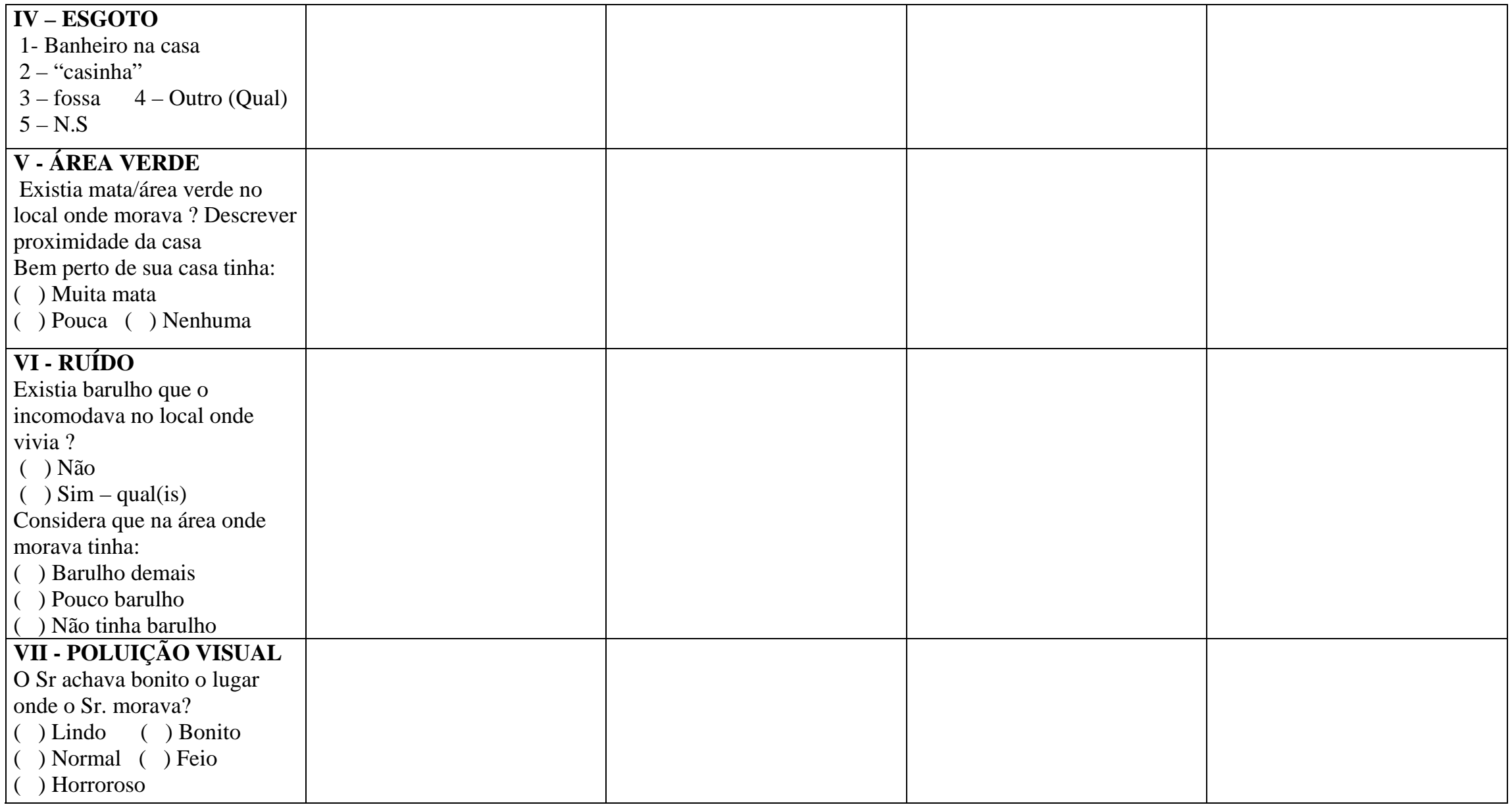




\begin{tabular}{|l|l|l|l|}
\hline VIII - UMIDADE & & & \\
No local onde morava era & & & \\
mais, na maior parte do & & & \\
tempo: & & & \\
( ) Muito Seco (pouca chuva) & & & \\
( ) Seco ( ) Normal & & & \\
( ) Úmido & & & \\
( ) Muito úmido (muita & & & \\
chuva) & & & \\
\hline IX TEMPERATURA & & & \\
No local onde morava & & & \\
costumava ser mais: & & \\
( ) Muito quente & & \\
( ) Quente ( ) Normal & & & \\
( ) Frio ( ) Muito frio & & & \\
Tinha mudança brusca de & & & \\
temperatura? ( ) Não & & & \\
( ) Sim ( & & \\
\hline
\end{tabular}

a) O Sr já vivenciou algum desastre ambiental?
( ) Não
( ) Sim - descreva:

b) O Sr. já passou por situações de contaminação ambiental?
( ) Não
( ) Sim - descreva:

c) O Sr. já morou em algum local que tenha acontecido algum tipo de contaminação do solo?

$$
\text { ( ) Não ( ) Sim - descreva: }
$$

d) De onde vinha a madeira que era utilizada nos trens da ferrovia?

e) A ferrovia teve alguma contribuição para o desmatamento?

f) Naquele tempo, como chegavam as informações a respeito das coisas que estavam acontecendo no Brasil e no mundo? A ferrovia tinha influência nisto? De que maneira?

g) Naquela época vocês já tinham conhecimento que os agrotóxicos faziam mal? Como ficaram sabendo disso? Passavam estas informações para outras pessoas? 
Quadro familiar - continuação da questão 31

\begin{tabular}{|l|l|l|l|l|l|}
\hline No. & Nome & Idade & Sexo & Relação com o longevo & Ocupação \\
\hline & & & & & \\
\hline & & & & & \\
\hline & & & & & \\
\hline & & & & & \\
\hline & & & & & \\
\hline & & & & & \\
\hline & & & & & \\
\hline
\end{tabular}




\section{ANEXO 4 - QUADROS}

\section{ANEXO - QUADROS}

\section{Quadro 1. Categoria A1 - Degradando os recursos hídricos: subcategorias, elementos e} códigos

\section{DEGRADANDO OS RECURSOS HIDRICOS}

Desmatando a mata ciliar e provocando riscos à população e às nascentes

- Associando o desmatamento de uma grota ao secar de uma nascente - 5.4

- Criticando que estão desmatando as matas e as nascentes vão secando - 7.4

- Relacionando lugar onde se corta mata a água seca - 17.13

- Referindo que o homem esta destruindo a natureza, principalmente a mata ciliar - 18.4

- Criticando as pessoas por morarem nas beiras dos rios -1.3

- Morando na beira do rio pode-se morrer durante as enchentes - 1.3

- Criticando as pessoas que constroem casas em barrancos - 1.3

Desperdiçando água

- Criticando o uso inadequado da água para lavar calçada - 24.8

- Contando que dá muito trabalho tratar da água para depois as pessoas lavarem calçada - 24.8

Poluindo rios

- Relatando que os rios são sujos e que ninguém vive assim - 4.4

- Achando que a poluição dos rios contamina a água que todos irão beber- 1.3

- Lembrando que o rio Lavapés era mais preservado - 15.5

- Lembrando que no rio Lavapés não tinha esta poluição de hoje - 15.5

Desprezando esgoto sem tratamento

- Lembrando que o esgoto era transportado por meio de canos que não contaminavam os rios, passavam por cima -4.3

- Reconhecendo que as pessoas antigas eram inteligentes, que sabiam fazer as coisas certas, pois todo o esgoto era bem controlado e passa por tubulações que eram despejados na rede pública sem contaminar -4.4

- Lembrando que o resíduo do esgoto era levado por carrocinha para ser aproveitado como adubo em jardins -4.4

- Relatando que a água do esgoto era jogada fora da cidade - 4.4

- Relembrando que todo o processo de tratamento de esgoto era feito automático e que hoje as pessoas manipulam isto -4.4

- Criticando o fato de jogarem todo o esgoto da cidade nos rios -4.4

- Criticando que agora todo o esgoto é jogado nos rios - 4.3

- Relacionando que hoje a água dos rios esta poluída com esgoto que as casas jogam e foi estragando tudo -29.2

Contaminando os rios com produtos químicos

- Contando ter havido tombamentos de tanques com produtos químicos nos rios - 24.14

- Contando que após a normatização de cargas especiais tinham toda a segurança no transporte 24.14

- Criticando que o veneno que jogam nas plantações acabou com o s peixes do rio pardo - 30.14 Jogando lixo nos rios

- Criticando as pessoas por jogarem lixo no rio - 1

- Criticando que as pessoas que as pessoas jogam lixo nos rios -5.4

- Associando à utilização excessiva de plásticos as enchentes dos rios - 9.4

Piorando a qualidade da água

- Avaliando como melhor a água de antes - 4.3

- Avaliando a água como boa naquela época - 15.5

- Avaliando a água de hoje como péssima podendo até morrer se beber água de rio - 2.5

- Acreditando que a água já não é mais igual a antigamente - 14.4

- Lembrando que a água era cristalina - 26.3

- Avaliando a água do poço como gelada e gostosa - 6.2

- Lembrando que depois foram fechando todos os poços -6.2

- Avaliando a água de hoje que vem do rio podre - 26.7

- Avaliando o rio Tietê como podre - 9.4 
- Relacionando que antes a água do rio era cristalina e eles bebiam - 29.2

- Julgando a água do rio Tietê, antes, como limpa e não tendo problema em bebê-la - 30.14

- Podendo beber água do rio antigamente - 2.5

- Lembrando que a água era cristalina e eles bebiam água do rio - 29.2

- Achando que a água que corre no rio é mais saborosa - 14.4

- Relatando que pegavam água da mina que era muito limpa - 10.5

Não podendo desfrutar dos benefícios

- Lembrando que no tempo de moleque era possível tomar banho, brincar e pescar no rio de Botucatu -4.3

- Comparando que nos rios que passam pela cidade, podia-se beber a água e pescar, mas agora nem o peixe pode sobrevier- 5.4

- Contando que nadava nos rios de Botucatu e pescava - 26.3

- Lembrando que ia brincar no riozinho quando criança - 29.1

- Lembrando que as mulheres iam lavar a roupa no rio Lavapés - 29.2

- Referindo que antes tinha mais peixe pequeno e não graúdo como hoje - 11.4

- Lembrando que havia peixe nos rios - 15.5

- Achando que antes tinha muito peixe - 22.5

- Gostando mais de antigamente porque tinha mais peixe -22.5

- Contando que hoje está muito ruim para pescaria - 23.7

- Lembrando que ia pescar no rio Tietê e que tinha muito peixe - 28.4

- Contando que ia pescar nos rios de Botucatu -26.3

- Lembrando que os rios eram cheios de peixinhos que dava para comer - 26.3

- Criticando que hoje não tem mais peixe - 28.4

- Lembrando que no rio da cidade tinha peixinhos - 29.2

- Lembrando que o Tietê era limpinho e dava peixe - 30.12

- Podendo pescar pois o rio era limpo - 2.5

- Lembrando que tem que passar bem no filtro a água de hoje para poder tomá-la - 14.4

- Preferindo comprar água mineral - 26.7

- Achando que não se deve tomar água que vem da prefeitura, preferindo a água mineral - 3.4

Quadro 2. Categoria A2 - Destruindo a fauna e a flora: subcategorias, elementos e códigos.

\section{DESTRUINDO A FAUNA E A FLORA}

Avanço intenso da tecnologia e do progresso

- Criticando que a motosserra pode derrubar uma árvore que demorou 300, 200 anos para se formar em apenas 5 minutos -5.3

- Associando o desmatamento ao progresso - 5.3

- Criticando que hoje estão destruindo para outras coisas, que antes o desmatamento era resultado do progresso, do transporte- 11.3

- Lembrando que existe a parte benéfica e a parte ruim do desmatamento - 20.4

- Dizendo que os avanços de hoje podem ser avaliados como progresso, mas podem ser também destruição - 26.4

\section{Tendo menos área verde atualmente}

- Achando que a natureza era bem melhor do que hoje por ter bastante verde - 25.8

- Observando que hoje o Brasil inteiro tem bem pouco mato - 28.7

- Lembrando que envolta da cidade tinha mata de todo lado - 29.1

- Observando que hoje o que mais tem é eucalipto - 28.7

- Lembrando que Bauru tinha locais bonitos cheios de árvore e comparando que hoje não tem mais $-11.3$

- Lembrando-se da mata grota que existia próximo de Salto Grande -12.13

- Lembrando-se que antes existia muita mata - 12.13

- Lembrando que próximo a Maringá havia uma Mata margeando o rio muito bonita - 12.17

- Lembrando-se que depois de alguns anos passou neste local de Maringá e já haviam cortado toda a mata para plantar café - 12.17

- Lembrando que para ir para a sua cidade era tudo mata, hoje não tem mais nada - 14.2

- Revelando que próximo a Vitoriana tinha uma grande mata que foi toda derrubada - 16.7

- Lembrando que existia bastante mata, bastante água e pasto nesta área - 8.6 
- Lembrando que antes tinha mata virgem e com árvores frutíferas - 16.10

- Contando que eram muitas matas virgens - 16.8

- Lembrando que do Hospital Sorocabana ao Lageado era só café - 8.3

- Relembrando que o Jardim Paraíso era só cafezal - 9.2

- Revelando que antigamente não havia uma casa que não tivesse horta ou jardim - 13.4

- Dizendo que depois as pessoas foram cimentando toda as casas - 13.4

Piorando o meio ambiente atual

- Achando que onde tem mais matas o meio ambiente é melhor - 3.5

- Avaliando o ambiente antes como bom - 1

- Comparando que antes o meio ambiente era bom - 9.3

- Avaliando o meio ambiente atual como muito ruim - 2.5

- Avaliando a ambiente atual como pior que antigamente - 3.4

- Avaliando o ambiente como muito ruim - 4.3

- Avaliando ambiente atual como não muito bom - 4.4

- Avaliando a mata como produzindo uma temperatura suave - 10.7

- Achando que é melhor viver onde tem árvore, água - 11.4

- Achando que no sítio é melhor que na cidade - 27.13

- Acreditando que antes a natureza era melhor - 13.4

Não vendo diferença no meio ambiente atual

- Lembrando que já não existiam muitas árvores - 15.5

- Revelando que aqui já não tinha mais mata - 16.7

- Achando que já tinham poucas árvores naquele tempo - 21.4

- Contando que antes havia plantação de café para todos os lados - 24.6

- Comparando a natureza de antes e de hoje como semelhantes - 2.5

- Achando que a natureza esta da mesma forma que antes - 3.4

- Não se lembrando de como era a natureza anteriormente - 3.4

Sendo $o$ acesso mais difícil aos alimentos atualmente

- Lembrando que antes todas as pessoas tinham pés de frutas nos quintais, não era necessário comprar - 28.4

- Contando que envolta da idade tinham árvores frutíferas como pitanga, tamburi - 29.1

- Lembrando que tinha bastante árvore e Jabuticabeiras no mato - 26.3

- Lembrando que ia chupar muita jabuticaba do mato - 5.3

- Observando que antes tinha mais mato, mais pesca e caça - 30.8

- Lembrando que tinha muita caça (perdiz e codorna) - 30.8

- Comparando que antes não havia esta miséria tão grande, podia faltar dinheiro mas tinha fartura em alimentos -9.4

Desenvolvimento intenso da ferrovia:

- Lembrando que a linha passou quase no meio da mata e que foram derrubando e acabando com tudo -5.3

- Encurtando o caminho da ferrovia, mas tendo que cortar o meio da mata e acabar com tudo - 5.3

- Justificando o movimento dos trens cheios de lenha com o desmatamento - 11.3

- Lembrando que para a ferrovia eles iam cortando todas as matas, fazendo uma devastação 12.14

- Referindo que para a ferrovia ia uma grande quantidade de lenha - 14.6

- Referindo que a ferrovia foi acabando com todas as matas daqui - 14.6

- Revelando que por conta de estar acabando a lenha que começaram as crises da ferrovia - 16.7

- Revelando que as locomotivas a diesel vieram para substituir a vapor porque não tinha mais lenha $-16.7$

- Culpando a estrada de ferro por ter destruído a mata virgem - 26.5

- Referindo que a ferrovia era responsável por ir cortando todo o mato - 26.5

- Culpando a estrada de ferro por consumir muita lenha - 26.5

- Referindo que acabaram com as matas virgens e que não tem mais dormente - 26.7

- Relatando que cortaram muitas matas para a ferrovia - 5.1

- Lembrando que era uma quantidade intensamente grande de lenha que era consumida - 8.1

- Revelando que muita mata foi destruída antes da construção do horto - 9.5

- Referindo que se utilizava muita lenha - 9.5

- Lembrando que iam cortando a mata - 14.2

- Lembrando que a locomotiva a vapor consumia muita lenha - 14.2

- Lembrando que o consumo de lenha era bastante - 16.8 
- Lembrando que ia muita lenha na ferrovia- 17.6

- Contando que a locomotiva a vapor consumia muita lenha - 19.3

- Referindo que ia muita madeira na ferrovia - 20.3

- Referindo que ia muita lenha para a locomotiva - 21.4

- Confirmando que consumia muita lenha - 24.7

- Achando um absurdo a quantidade de madeira transportada - 24.10

- Contando ir muita lenha na locomotiva - 25.5

- Lembrando que as fornalhas eram enormes - 27.9

- Lembrando que na Sorocabana gastava muita madeira - 28.1

- Lembrando que ia muita lenha na sorocabana - 30.9

- Contando que a Sorocabana comprava lenha do mato dos empreiteiros que cortavam a lenha do mato - 28.1

- Revelando que seu pai comprava as matas das pessoas e derrubava tudo para vender para a ferrovia -7.3

Sendo intenso e acelerado consumo de madeira

- Cada locomotiva arrastava vinte ou trinta metros de lenha por dia - 15.8

- Contando que daqui a Laranjal se queimava 20 metros de lenha e que cada vez iam 4 metros de lenha na fornalha -5.2

- Contando que na Serra de Vitoriana era difícil a subida e consumia o dobro de lenha - 5.2

- Lembrando que cada tender da locomotiva comportava 20 m de lenha - 9.5

- Revelando que em cada estação, quando fosse necessário, paravam para reabastecer o tender com lenha -10.5

- Contando que um container levava 18 metros de lenha e mais 20 caixas de carvão- 12.8

- Contando que as locomotivas mil levavam 22 metros de lenha - 12.8

- Lembrando que consumia muito lenha - 11.4

- Sinalizando que daqui a Iperó gastava 40 a 50 metros de lenha - 16.8

- Contando que no tender da locomotiva cabe 25 metros de lenha - 16.8

- Referindo que para fazer $120 \mathrm{Km}$ gastava uns 40 a 50 metros de lenha - 16.8

- Lembrando que para ir daqui até Avaré as vezes tinha que abastecer novamente de lenha - 25.5

- Lembrando que em cada máquina ia 30 a 40 metros de lenha - 28.1

Sendo a lenha transportada por caminhões ou ramais provisórios

- Contando que as árvores eram cortadas, transportadas por caminhões até as estações (Botucatu, Bernardino de Campos, Assis, Santo Anastácio) 7.3

- Revelando que em tempo de chuva era difícil o caminhão chegar para retirar lenha do mato - 8.1

- Lembrando que a lenha era cortada e deixada próximo a linha e depois carregava as gôndolas 11.3

- Contando que a Sorocabana chegava a fazer trilhos provisórios para poder pegar a lenha, encher as gôndolas -16.7

- Contando que tinha um ramal de $40 \mathrm{Km}$ que foi construído para pegar lenha em Borebi - 16.7

Empilhando lenha no depósito, já cortada no tamanho certo

- Revelando que a lenha vinha toda em gôndolas que eram descarregadas no depósito - 6.1

- Revelando que a lenha era empilhada no depósito e depois abasteciam as locomotivas - 10.5

- Revelando que o pátio da ferrovia ficava lotado de pilhas altas de lenha para poderem trabalhar 25.5

- Referindo que os lenheiros eram muito grandes, perdiam de vista - 27.9

- Revelando que existia um lenheiro enorme próximo ao depósito de Botucatu - 30.9

- Revelando que no depósito tinha 50 mil metros de lenha - 6.1

- Lembrando que existia um machado a vácuo para diminuir o tamanho da lenha para colocar na máquina -9.5

- Contando que a madeira já vinha do mato, mas tudo cortada certinha para abastecer a locomotiva $-22.4$

- Lembrando que as lenhas já vinham prontas, cortadas - 23.3

- Lembrando que os empreiteiros já cortavam a lenha no tamanho certo - 28.1

- Lembrando que os fornecedores de lenha já mandavam cortada , com 6 a $22 \mathrm{~cm}$ de espessura 29.1

- Referindo que a lenha tinha que ser bem empilhada para fazer pressão e não entrar ar - 16.8

- Revelando que os dormentes já vinham prontos das serrarias - 10.5

Utilizando todo tipo de madeira 
- Revelando que se usava favero e peroba para fazer dormente - 7.2

- Lembrando que o dormente era feito de peroba que vinha da serralheria do Bacchi - 9.5

- Lembrando que o dormente era de peroba e favero - 12.7

- Lembrando que cada dormente pesa uns $70 \mathrm{Kg}-12.8$

- Revelando que se usava Arueira, Cabreúva, Peroba, Angico para fazer dormentes - 14.5

- Relatando que até árvores do cerrado, que são tortas, duras, inapropriadas para o uso nas fornalhas, tiveram que ser utilizadas - 5.1

- Revelando que toda a madeira do mato era cortada não importando a espessura - 8.1

- Lembrando que usavam qualquer tipo de madeira para se tornar lenha (pau de sebo) -10.3

- Revelando que pegavam lenha grande para colocar na fornalha, eram de árvores bem grandes 10.6

- Lembrando que para queimar era qualquer uma - 14.5

- Lembrando que até madeira boa era queimada: pinho, peroba, canela - 22.4

- Lembrando que cortavam todo tipo de madeira até de lei, como Ipê - 29.1

- Contando que vinha madeira de campo também - 30.9

- Avaliando a lenha de Laranja Doce como muito fraca, sendo que a locomotiva consumia rápido 25.5

- Contando que a lenha de eucalipto era melhor - 25.5

- Contando que a lenha de eucalipto era mais firme e o fogo já não consumia tão rápido -25.5

- Relatando que a lenha de campo não era tão boa pra fazer pressão, gastava lenha e não fazia pressão -30.9

- Contando que o carvão era melhor porque dava mais pressão para a locomotiva - 30.9

- Contando o carvão era mais para trem de passageiro - 17.6

- Revelando que a lenha de eucalipto do horto era ruim por ser verde, sendo difícil trabalhar com ela- 8.1

Vindo lenha de diversas áreas e provocando desmatamento

- Revelando que a madeira era cortada no Mato Grosso, umas toras, eram transportadas para SP, nas serrarias e depois voltavam para o interior - 24.10

- Lembrando que as madeiras vinham do Paraná, atravessam a ponte de Porto Epitácio iam para SP e Santos, fabricavam móveis que iam para exportação - 25.11

- Relatando que a lenha vinha de vários lugares - 5.1

- Relembrando que a lenha vinha de Cerqueira César - 6.1

- Relatando que a lenha vinha muito de Paula Souza e era lenha do mato - 5.1

- Contando que a lenha vinha de Virgílio Rocha e do Mato Grosso - 8.1

- Revelando que a lenha para a ferrovia vinha de Andrade e Silva, próximo a Avaré - 9.5

- Lembrando que só mais tarde a Sorocabana montou um horto florestal de eucalipto em Itatinga e Mairinque -9.5

- Lembrando que a lenha para as serralherias vinha do Mato grosso e do Paraná - 9.5

- Revelando que a lenha vinha de Paula Souza - 10.5

- Lembrando que a lenha vinha de perto de Santa Cruz - 11.3

- Revelando que a Lenha e o carvão vinham do Paraná - 11.3

- Revelando que a madeira para os dormentos vinha de Salto grande - 12.7

- Lembrando que a lenha vinha de Andrades e de Itatinga, onde tinha ramal para pegá-la - 14.2

- Relatando que a madeira para fazer o dormente vinha de Rancharia - 14.5

- Lembrando que a lenha vinha de vários lugares - 15.6

- Lembrando que em Avaré havia um lenheiro - 15.6

- Contando que a lenha vinha de toda a redondeza - 16.6

- Lembrando que a Sorocabana tinha muitos hortos florestais - 16.7

- Lembrando que em vários lugares tinha lenheiro: Barra grande, Vitoriana, Bernardino -18.4

- Lembrando que vinha muita madeira do Paraná - 20.3

- Referindo que vinha muita madeira da Alta Sorocabana - 20.3

- Lembrando que em Barra grande tinha um depósito de lenha -21.4

- Revelando que a lenha vinha do pessoal do mato que vendia para a Sorocabana - 21.4

- Referindo que o Dormente vinha de fornecedor de Porto Epitácio e Presindente Bernardo - 21.4

- Revelando que tinha muito lenheiro em Botucatu - 22.3

- Revelando que a madeira vinha de todos os lados - 22.4

- Revelando que os dormentes vinham de Candido Mota - 22.4

- Achando que em Candido Mota tinha muito mato - 22.4 
- Contando que a lenha vinha de vários locais - 23.3

- Contando que em cada região tinha um centro fornecedor de lenha - 24.7

- Contando que em Virgílio Rocha tinha um grande lenheiro -24.7

- Lembrando que as pedras - paralelepípedo para as ruas da cidade vinham de Laranjal Paulista 22.4

- Contando que o eucalipto vinha de Ourinhos, Muambi, Bernardino de Campos - 25.5

- Lembrando que a lenha de mato vinha de vários lugares e de longe também - 25.5

- Contando que a lenha vinha da Alta Sorocabana, de um lugar chamado Laranja Doce - 25.5

- Revelando que cortavam muita madeira do mato no Paraná - 20.3

- Revelando que as matas vizinhas de Botucatu foram todas derrubadas para serem utilizadas pela ferrovia -7.3

- Referindo que daqui até Presidente Epitácio foram cortando toda a mata - 26.5

- Lembrando que as matas que eram cortadas eram muito exuberantes - 12.7

- Relatando que do começo da linha até Rubião era mata fechada - 5.3

- Dizendo que não é só as pessoas da cidade que cortam árvores, é em todo lugar - 15.6

Consumindo carvão importado e areia dos rios

- Lembrando que também utilizava muito carvão que vinha da Inglaterra - 30.9

- Referindo que o carvão que ia junto da lenha era importado, pois o nosso era ruim - 16.8

- Lembrando que o carvão era descarregado no porto de Santos e trazido pela ferrovia - 16.8

- Lembrando que existiam carro de passageiros que eram conduzidos só com carvão - 16.8

- Revelando que a locomotiva também consumia muita areia que vinha do rio Tietê - 30.9

- Revelando que muitas gôndolas cheias de areia vinham do rio Tietê - 30.9

- Lembrando que as locomotivas elétricas eram as que mais consumiam areia - 30.10

Tendo que construir parques artificiais e hortos

- Achando que por não ter mais mata bonita é que se tem que construir os jardins Botânicos -16.10

- Relatando que mata bonita só tem hoje no Amazonas e no Mato Grosso -16.10

- Lembrando que foram acabando com as matas e só depois vieram os Hortos com plantação de eucalipto (como de Itatinga - 5.1)

- Revelando que frente a dificuldade de conseguir lenha fez-se o horto de eucalipto em Itatinga 8.1

- Contando que havia horto florestal de onde vinha a lenha - 19.3

- Lembrando que existiam vários lenheiros da Sorocabana que plantavam eucalipto: Itatinga, Itapetininga - 27.9

- Lembrando que a Sorocabana plantava eucalipto - 28.1

- Referindo que a Sorocabana tinha horto florestal em Itatinga, no ramal Galvão - 30.9

- Referindo que a madeira vinha do horto de Itatinga e de outros - 30.9

- Revelando que a Sorocabana plantava eucalipto - 17.6

- Lembrando que a Sorocabana plantava eucalipto - 30.9

- Contando que a Sorocabana tinha hortos em tudo quanto é lugar - 28.1

- Lembrando que existia horto em Andrade e Silva, em Sorocaba, Itatinga, Piraju, Salto Grande, Virgílio Rocha, Borebi - 16.7

- Lembrando que o eucalipto veio só mais tarde - 14.6

- Lembrando que nos hortos era primeiro de mata e depois que começaram a plantar eucalipto 16.7

- Revelando que no Horto de Itatinga era mato e depois que acabaram com as árvores começaram a plantar eucalipto - 10.5

- Lembrando que os hortos eram em grandes áreas que eram compradas pela Sorocabana - 16.7

- Lembrando que tinha lenha que era eucalipto e do mato também - 19.3

- Contando que no início a lenha era do mato e depois veio de eucalipto - 25.5

- Acreditando que as árvores fazem parte da boa conservação das cidades - 14.4

- Acreditando que árvore nas cidades as vezes não é muito boa, pois junta muito bicho - 14.4

- Acreditando que na fazenda as árvores não tem problema - 14.4 
Quadro 3. Categoria A3 - Aumentando a poluição com o tempo: subcategorias, elementos e códigos.

\section{AUMENTANDO A POLUIÇÃO COM O TEMPO}

- Revelando que antes não tinha poluição - 26.3

- Vendo a poluição depois de velho, pois antes refere não existir - 28.8

- Avaliando que sempre teve poluição, mas que antes as pessoas não ligavam para isto - 6.4

- Avaliando a poluição atual como fora dos limites - 8.7

- Avaliando a natureza atual como muito poluída - 19.4

- Lembrando que a palavra poluição nem existia - 2.5

- Referindo que antes não havia poluição e hoje tem em qualquer lugar - 12.16

Aumentando a frota de carros e caminhões

- Criticando a intensa poluição do ar atual pelo grande número de carros - 9.4

- Dizendo que sempre existiu poluição de caminhões -19.4

- Achando que o meio ambiente de Botucatu é carregado por causa dos carros - 17.6

- Contando que agora estão substituindo o combustível de carros e ônibus por gás, principalmente em SP - 17.6

- Criticando que agora é muito poluído, com muito carro - 23.4

- Criticando a poluição dos ônibus em SP - 19.4

- Revelando que na época já existia um pouco de poluição dos caminhões e trator - 7.4

- Criticando a quantidade de ônibus que existe hoje em Botucatu e o movimento da cidade por conta deles -8.3

- Achando que não existia poluição, pois não tinham carros - 105

- Lembrando que tinha poucos carros na época e tinham que ir a pé para a ferrovia - 21.3

- Achando que Botucatu tem muitos carros - 24.4

- Achando que Botucatu está muito movimentada - 22.2

- Criticando que acabaram com as ferrovias, que poluíam menos - 9.4

- Avaliando que os trens não poluíam tanto como os carros - 23.4

- Lembrando que a ferrovia poluía pouco - 7.4

Utilizando abusivamente produtos químicos

- Criticando o adubo que colocam que vai acabando com tudo -23.7

- Avaliando a terra de hoje como muito contaminada - 27.7

- Referindo que por Botucatu passavam muitas gôndolas de enxofre - 5.8

- Revelando que era transportado adubo ultrafertil a granel que corroíam todo o vagão e ficavam inutilizados (depósito em Avaré ) - 5.8

- Referindo que os trabalhadores da ferrovia não manipulavam os adubos, eram os funcionários da empresa de adubo (Avaré e Assis) - 5.8

- Achando que o adubo vinha do Porto de Santos, pois era importado - 5.8

- Contando que usavam roupa especial de amianto para manipular os produto dos trens especiais 24.14

- Contando que transportavam soda caústica, mas era pouco, mas não tinham contato porque vinha em tambor - 25.6

- Lembrando que o adubo ia direto para os armazéns que distribuíam na região - 25.6

- Não observando as pessoas ficarem doentes por mexerem com adubos, porque talvez fossem mais fortes no passado - 5.8

Aumentando a produção de lixo:

Utilizando mais produtos descartáveis

- Criticando a utilização de sacos plásticos para comprar e transportar mantimentos - 9.3

- Avaliando que os sacos plásticos poluem muito o solo e a água - 9.3

- Comparando os brasileiros com os americanos que saem dos seus supermercados com sacos de papel - 9.3

Crescimento populacional

- Associando poluição com lixo produzido hoje, pois antes não tinham estas latinhas de bebidas 2.5

- Criticando ter muito lixo -18.4

- Achando que antes as pessoas eram mais educadas ou porque não tinham tantos moradores nas cidades e não faziam tanta sujeira - 11.3

Tendo maior poder aquisitivo

- Relacionando maior poder aquisitivo a maior produção de lixo - 7.4 


\section{Prejudicando a saúde e o bem-estar}

- Revelando que a respiração fica prejudicada pela poluição do ar - 9.4

- Achando que tudo que respira vai pro pulmão e prejudica a saúde -19.5

- Criticando a poluição gerada pelos ônibus de Botucatu que fazem mal para a população e para o pulmão -4.4

- Achando que a poluição, fumaça do ônibus, dá problema na garganta das pessoas -19.4

- Achando que toda poluição prejudica a saúde - 19.5

- Achando que a poluição faz mal para a saúde - 17.13

- Achando que a poluição interfere na saúde - 18.4

Sendo pior a poluição em cidades de maior porte e menor altitude

- Acreditando que quem mora em São Paulo está envenenado - 1.3

- Acreditando que a poluição de Botucatu ainda não prejudica a saúde - 4.4

- Comparando a poluição de Botucatu com a de São Paulo, a qual é bem pior - 4.4

- Comparando a poluição de Botucatu como menor por estar em cima do morro e ter ventilação 4.4

- Achando que aqui em Botucatu não tem problema com a poluição, pois vive em um lugar calmo e rua sem muito movimento -3.6

Quadro 4. Categoria A4 - Ocorrendo descontrole ambiental: subcategorias e códigos.

\section{OCORRENDO DESCONTROLE AMBIENTAL}

- Achando que o meio ambiente esta mudando - 18.4

- Achando que a natureza modificou muito - 22.5

- Achando que as culpadas pelas mudanças ambientais são as indústrias de materiais elétricos 27.8

Sendo as terras mais ressecadas hoje

- Contando que as terras eram boas e todo mundo tinha horta no quintal - 29.4

- Referindo que a terra não ficava tão ressecada como agora - 27.8

- Referindo que o eucalipto puxa muita água deixando a terra ressecada - 27.9

Morando em local privilegiado

- Lembrando que o clima de Botucatu sempre foi bom - 15.6

- Lembrando que o clima de Botucatu é bom mesmo com tudo que existe hoje - 15.5

- Acreditando que o clima de Botucatu é excelente - 15.8

- Referindo que o ar de Botucatu era muito bom- 29.2

- Sendo o céu de Botucatu um dos mais iluminados do mundo, com céu aberto, daí a indústria de aviões aqui -24.11

- Achando que a proximidade da cuesta proporciona um vento que limpa as nuvens e deixa o céu limpo - 24.12

- Revelando que pessoas com maior poder aquisitivo tinham casa em Botucatu para passar temporada - 8.9

Indefinição do ciclo da florada

- Lembrando que as flores floresciam na época certa e perfumavam (cafezal, laranjeira, mexeriqueira) - 28.4

Estando as estações do ano maldefinidas

- Avaliando que antes as estações do ano eram mais bem definidas - 7.4

- Achando que antes as estações do ano eram mais bem definidas - 10.4

- Observando que as estações não estão tão definidas mais - 25.8

- Lembrando que as estações do ano eram mais definidas - 27.8

- Referindo que antes as estações do ano eram mais definidas - 30.8

- Acreditando que as estações do ano estão descontroladas pelo desequilíbrio da natureza - 5.4

- Achando que hoje a natureza esta muito mudada, chovendo em época não esperada - 8.6

- Comparando a natureza anterior como mais controlada que a de hoje - 10.4

- Observando que o meio ambiente esta descontrolado, não tendo mais as estações do ano bem definidas 
Quadro 5. Categoria A5 - Modificando as propriedades dos alimentos: subcategorias e códigos.

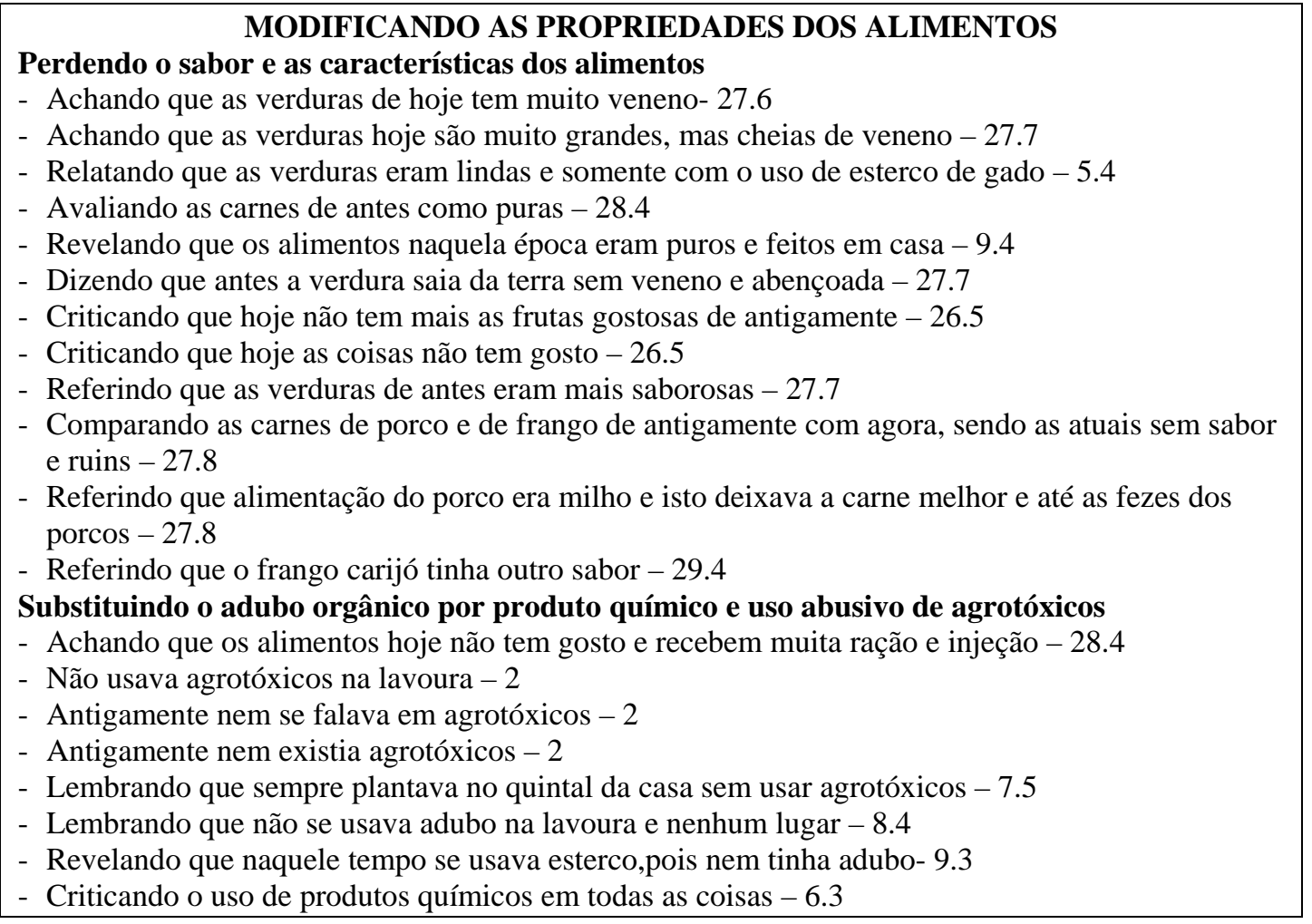

Quadro 6. Categoria A6 - Sentindo desprazer em relação ao meio ambiente atual: subcategorias e códigos.

\begin{tabular}{l} 
SENTINDO DESPRAZER EM RELAÇÃO AO MEIO AMBIENTE ATUAL \\
- Achando que agora não tem nada gostoso no ambiente, pois está tudo destruído - 26.4 \\
Aumentando a violência \\
- Criticando a violência do dia a dia que se vê na televisão - 9.4 \\
- Criticando a maldade que existe hoje em tudo - 15.6 \\
- Lembrando que antes se podia brincar na rua e aproveitar a infância - 9.3 \\
- Criticando que muitas pessoas ficam brigando por conta de ter terra, como os índios e os \\
garimpeiros - 11.4 \\
- Revelando que a cidade era um sossego e que não se ouvia falar em assalto - 10.1 \\
- Dizendo que antes você andava tranqüilo pelas ruas, hoje não dá - 14.2 \\
- Achando que agora tem muito banditismo e antes não tinha - 22.2 \\
- Reclamando que antes podia sair e deixar a casa aberta, hoje não - 22.2 \\
- Criticando que hoje somos prisioneiros da própria casa -22.2 \\
- Comparando as crianças de hoje que ficam na cidade já bebendo e tendo vícios, antes ficavam nas \\
fazendas brincando - 27.8 \\
Perdendo o respeito entre as pessoas e a liberdade \\
- Criticando os vizinhos por perturbarem a vida dos outros - 2.5 \\
- Criticando que hoje não existe o respeito de um para o outro - 2.5 \\
- Criticando que hoje não se tem tranqüilidade em casa pois sempre aparecem as pessoas pedindo \\
coisas - 9.4 \\
- Acreditando que o hoje esta pior o ambiente pois não se tem liberdade como antes - 3.4 \\
- Referindo que existia muito respeito entre as pessoas e que hoje não tem - 10.1 \\
- Referindo que não havia mendigo antigamente em Botucatu - 29.3 \\
Sentindo falta das boas sensações despertadas pela natureza \\
- Achando que hoje em dia esta fazendo falta a natureza - 28.4 \\
\hline
\end{tabular}


- Achando que antes a natureza tinha outro aroma, cheirava flor - 28.4

- Reclamando que hoje a natureza não tem cheiro de nada - 28.4

- Referindo que o aroma do mato era outro - 28.7

- Referindo que o mato legítimo tem outro sabor - 28.7

- Achando que a Natureza é fora de série - 12.13

- Classificando a Natureza como muito linda -16.10

- Avaliando a natureza como muito bonita - 2.5

- Achando que a natureza antes era muito bonita -12.13

- Achando que antes a natureza era mais linda porque via o passarinho cantando e mais matas 16.10

- Lembrando que as matas por aqui eram muito bonitas, fechadas com muitos animais silvestres, quase toda espécie de passarinho - 7.3

- Gostando muito de apreciar a natureza daqui até Corumbá, naquela época - 12.13

- Referindo que a natureza é muito bonita -16.10

- Achando que antes a natureza era mais linda - 16.10

- Avaliando que hoje a natureza esta feia, tudo morrendo - 12.13

- Avaliando que hoje esta tudo triste - 12.13

- Referindo que hoje a natureza esta ficando desativada -16.10

- Acreditando que a natureza vai ficando velha e cansada de tanta maldade - 27.12

- Referindo que as matas trazem vida -7.4

- Achando que o meio ambiente influencia no modo de viver das pessoas - 26.5

Deixando as pessoas tristes, fracas $e$ insatisfeitas

- Acreditando que a natureza preservada deixa as pessoas mais alegres -12.13

- Achando que a natureza não preservada deixa as pessoas tristes, aborrecidas, parecendo que estão morrendo - 12.14

- Achando que o aroma das frutas, das árvores e das flores fortalecia as pessoas- 28.4

- Achando que poucas pessoas são satisfeitas hoje em dia - 26.5

- Lembrando que antes as pessoas se contentavam com pouca coisa - 27.8

- Achando uma judiação o que estão fazendo com o meio ambiente - 4.3

- Sentindo-se triste ao ver o desmatamento - 5.3

- Sentindo-se penalizado com a destruição da natureza - 5.4

- Achando uma judiação a quantidade de árvores cortadas - 19.3

- Achando uma judiação como está a natureza hoje - 27.8

- Achando uma judiação terem cortado tudo - 29.1

- Avaliando como fracassado o meio ambiente, pela água estar toda poluída - 7.4

Sendo o meio ambiente atual melhor

- Avaliando a natureza de agora como melhor do que antes - 6.4

- Acreditando que o meio ambiente hoje em dia esta muito bom - 13.5

- Avaliando o meio ambiente como bom - 2.5

- Achando que o meio ambiente hoje esta melhor -21.3

- Achando que o meio ambiente de hoje, em termos, esta melhor do que antes, pois a população tem mais assistência -12.13

\section{TEMA B - ANIQUILANDO A FERROVIA E DESOLANDO OS FERROVIÁRIOS}

Quadro 7. Categoria B1 - Destruindo todo patrimônio da ferrovia: códigos.

\begin{tabular}{|l|} 
ANIQUILANDO A FERROVIA E DESOLANDO OS FERROVIÁRIOS \\
- Lembrando que a maioria já morreu - 2 \\
- Vivenciando que os ferroviários estão acabando - 9.7 \\
- Queixando-se que o governo quer tirar complementação salarial, mas não é necessário, pois todos \\
já estão muito velhos e logo morrerão - 2.4 \\
DESTRUINDO TODO O PATRIMÔNIO DA FERROVIA \\
- Contando o cuidado que se tinha antes com a ferrovia, tudo bem conservado e hoje tudo \\
abandonado - 5.2 \\
- Criticando que hoje não existe mais nem os fios da linha elétrica -22.4 \\
- Criticando que roubaram até os fios dos trens elétricos hoje - 25.11 \\
\hline
\end{tabular}


Quadro 8. Categoria B2 - Não sendo bom o desempenho dos novos gestores: subcategorias e códigos.

\begin{tabular}{|l} 
NÃO SENDO BOM O DESEMPENHO DOS GOVERNANTES \\
- Acreditando que as ferrovias acabaram por conta dos péssimos governos do país - 12.17 \\
- Referindo que quem acabou mesmo com as ferrovias foi o Mário Covas - 12.17 \\
- Acreditando que a ferrovia acabou por conta de política - 19.4 \\
- Revelando que com o Quércia começaram a roubar - 19.4 \\
- Revelando que Ademar de barros e Getúlio Goulart ajudaram muito a ferrovia - 19.4 \\
- Relatando que do governo Mario Covas pra frente a ferrovia foi perdendo a vitalidade -20.2 \\
- Achando que a ferrovia acabou por desmanzelo do governo - 22.3 \\
- Referindo que foi a má administração que deixou a ferrovia morrer - 25.10 \\
- Culpando os vereadores e presidentes por serem muito ruins e terem deixado acabar a ferrovia - \\
- 28.3 \\
- Culpando o governo por ter acabado com a ferrovia - 30.7 \\
- Referindo que na Sorocabana tinha muita política - 15.3 \\
- Criticando a péssima administração da FEPASA (73/74) que fez tudo acabar depois - 12.17 \\
Aumentando desnecessariamente o número de funcionários \\
- Lembrando que se criaram muitos cargos e depois acabou tudo em nada - 6.3 \\
- Referindo que com a FEPASA encheram de chefe, mesmo sem precisar - 12.17 \\
- Referindo que na época da Sorocabana só tinha o cargo se realmente precisasse - 12.17 \\
- Queixando que agora a ferrovia esta sucateada - 18.3 \\
- Indo a Barra Funda e ficando impressionado com a quantidade de pessoas trabalhando lá - 17.11 \\
- Lembrando que eram muitos empregados não necessários -17.12 \\
- Revelando que na década de 80 antes da ferrovia acabar, eles foram contratando muitas pessoas, \\
foram enchendo a Sorocabana - 17.12 \\
- Contando que a comissão dos ferroviários advertiu que não a folha de pagamento não ia dar - \\
- Lembrando que muitos entravam na Sorocabana por força política - 17.12 \\
- Revelando que era muito difícil demitir alguém que entrou por força política - 17.12 \\
Difamando a ferrovia \\
- Descordando do que os políticos diziam que a ferrovia dava prejuízo - 19.4 \\
- Criticando por falarem que a Sorocabana dava prejuízo - 15.3 \\
- A ferrovia sendo vista pelos outros como centro de despesas - 24.6 \\
\hline
\end{tabular}

Quadro 9. Categoria B3 - Estagnando investimentos e recursos para a ferrovia: subcategorias, elementos e códigos.

ESTAGNANDO INVESTIMENTOS E RECURSOS PARA A FERROVIA
Recebendo menor verba e tendo pouca propaganda
- Contando que a ferrovia não recebia tanto investimento como a rodovia - 24.6
- Criticando que a ferrovia sempre ficou a quem do que poderia ter sido por conta da falta de
investimentos - 24.15
- Comparando que a ferrovia nunca teve muita propaganda como a rodovia - 24.6
- Avaliando que o desmonte da ferrovia se deu por conta de problema político: rodovia todo mundo
vê, ferrovia não - 24.10
Sendo subtilizada a ferrovia atualmente e sem manutenção
- Referindo que a ferrovia hoje só transporta carga - 17.11
- Lembrando que a estação de Botucatu foi inaugurada em 1934 - 17.15
- Criticando que agora ainda transportam combustível pela ferrovia, mas que esta uma bagunça -
19.4


- Alertando para o perigo de dormentes podres que fazem descarrilhar trens - 11.2

Utilizando tecnologia ultrapassada e demorando o transporte

- Acreditando que poderiam modernizar hoje as ferrovias - 12.16

- Acreditando que até hoje o subúrbio de SP é semelhante a estas unidades japonesas - 16.5

- Avaliando que o desmonte da ferrovia se deu por conta do traçado antigo da ferrovia contra o moderno da rodovia -24.10

Demorando no transporte e na construção

- Lembrando que demorava 16 horas de Assis a SP - 12.5

- Revelando que de Botucatu a SP demoravam 5 horas e cinco minutos no trem elétrico -16.4

- Contando que por conta das muitas curvas não consegue se concorrer com a rodovia no tempo que leva para transportar os passageiros pela ferrovia -24.7

- Contando que o serviço do carro restaurante era terceirizado - 25.6

- Relatando que as viagens de trem eram muito demoradas, mas que era uma alegria e ninguém achava ruim, pois tinha restaurante e até orquestra lá - 25.10

- Revelando que tinha um trem que tinha ar condicionado dentro, ai de SP a Presidente Epitácio 25.11

- Referindo que daqui a SP demoravam 8 horas - 30.5

- Lembrando que o Ouro verde saia a 00:00 e chegava as 8:00 em SP - 30.5

- Revelando que a locomotiva a vapor fazia $30 \mathrm{KM} / \mathrm{h}$, a americana $35 \mathrm{Km} / \mathrm{h}$ e de passageiro $40 \mathrm{Km} / \mathrm{h}$ $-8.4$

- Revelando que de Botucatu a SP demoravam 8 horas e com as máquinas novas 6 horas e 15 minutos -8.4

- Não havendo maquinário de terraplanagem para fazer o traçado da ferrovia melhor - 24.6

- Revelando que as firmas procuravam esticar o máximo o traçado, com sinuosidades para poder receber mais, pois era por trecho construído - 24.7

Existindo acidentes e problemas no transporte ferroviário.

- Contando que a locomotiva a vapor quebrava muito e dava problemas -18.7

- Dizendo que as vezes o maquinista saía cedo e ainda no outro dia não tinha chegado, pois teve problema na máquina -18.7

- Lembrando que as vezes acabava a lenha da locomotiva e atrasava - 18.7

- Contando ter mais deslizamentos em períodos de chuva e interrompia os trechos - 24.3

- Deslocando mais funcionários em tempo de chuva para irem a frente para verificar se a linha estava com algum problema -24.3

- Referindo que era freqüente ter acidentes, tombamentos e descarrilamento de trens - 30.4

\section{Gerando menos emprego}

- Referindo que hoje só precisa de um homem para transportar e controla tudo por rádio - 17.11

- Lembrando que antes os serviços precisavam de mais gente trabalhando, hoje tem máquinas e precisam de poucos homens trabalhando -27.10

- Lembrando que com a máquina elétrica não precisava do serviço do depósito, apenas para as cargas -8.4

- Criticando que hoje querem que uma pessoa controle um trem inteiro sozinho para economizar 26.7

Quadro 10. Categoria B4 - Sendo a ferrovia ameaçada pelo crescimento das rodovias: subcategorias e códigos.

\begin{tabular}{l} 
SENDO A FERROVIA AMEAÇADA PELO CRESCIMENTO DAS RODOVIAS \\
Avanço das rodovias prejudicando as ferrovias \\
- Referindo que a rodovia começou a adquirir mais velocidade que a ferrovia, a qual foi acabando - \\
6.5 \\
- Achando que a Sorocabana foi decaindo por conta dos ônibus -17.7 \\
- Referindo que a indústria automobilística foi culpada por ter acabado com a ferrovia - 18.7 \\
Tendo interesse político nas rodovias \\
- Avaliando que o desmonte da ferrovia se deu por conta de problema econômico: interesses \\
inclusive internacional por conta do petróleo que os caminhões circulem - 24.10 \\
- Criticando que os governantes enterraram as ferrovias para poder sustentar as companhias de \\
ônibus - 25.10 \\
- Criticando que sucatearam tudo por interesses próprios - 25.11 \\
\hline
\end{tabular}




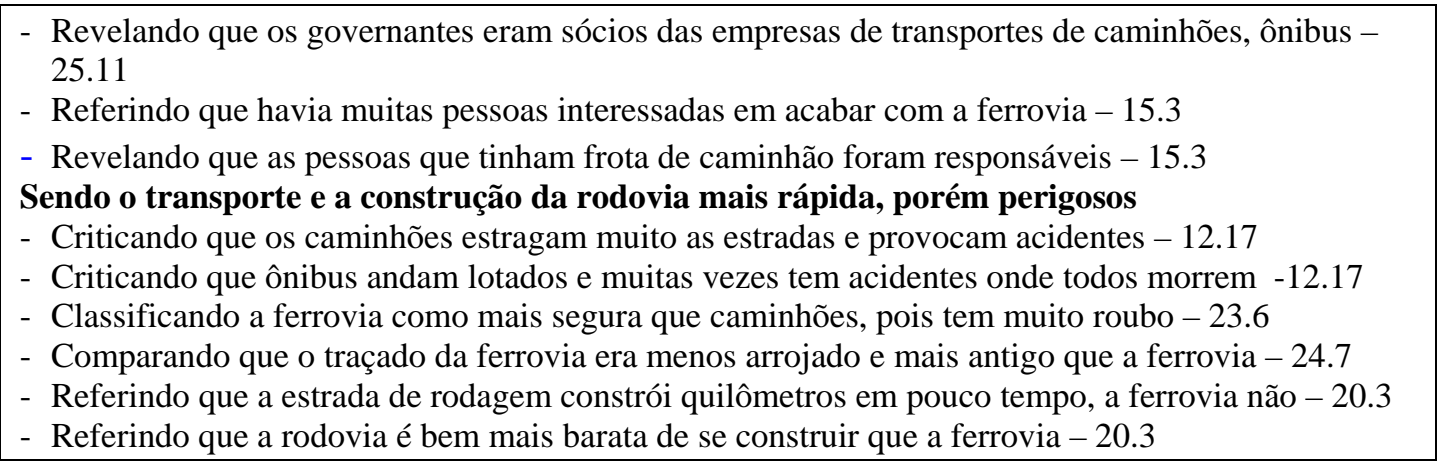

Quadro 11. Categoria B5 - Perdendo prestígio e remuneração: códigos.

\section{PERDENDO PRESTÍGIO E REMUNERAÇÃO}

- Anteriormente o ferroviário era desvalorizado, mas com o crescimento da ferrovia ele tornou-se valorizado -2

- Comparando com hoje e nem querendo se identificar como ferroviário - 4.3

- Lembrando que o ferroviário era uma pessoa com estatus na cidade - 5.2

- Comparando com hoje que o ferroviário não tem mais bom estatus social

- Revelando que os ferroviários eram valorizados naquela época - 10.2

- Lembrando que o ferroviário tinha uma boa posição na sociedade - 30.10

- Comparando que hoje o ferroviário não é ninguém - 30.10

- Reclamando que há tempo não recebe aumento no salário - 3.3

- Reclamando que o ferroviário faz 11 anos que não tem aumento - 5.2

- Reclamando que a 8 anos não tem aumento - 18.3

- Criticando o governo que não dá aumento para os ferroviários há anos - 26.7

- Reclamando que o ferroviário há 8 ano não tem aumento - 30.14

- Criticando que o governador não quis dar aumento justificando que o Estado não tinha mais ferrovia - 30.14

- Reclamando que o salário reduziu pela metade - 5.2

- Revelando que o ordenado começou a ficar defasado e esta até hoje - 19.2

- Lembrando que na época do Collor perdeu ordenado - 12.12

Quadro 12. Categoria B6 - Despertando tristeza e saudade: Categoria e códigos.

\section{DESPERTANDO TRISTEZA E SAUDADE}

- ficando com dó de ver a ferrovia abandonada -1

- Referindo que quem trabalhou e viveu esta história da ferrovia nem dá para acreditar que tudo acabou- 12.15

- Entristecido por lembrar que hoje não tem mais nenhum movimento - 14.1

- Reclamando que agora não tem mais nada , esta tudo acabado -21.2

- Ficando triste e chorando ao ver o estado da Sorocabana hoje - 22.3

- Ficando com dó de ver a ferrovia neste estado - 28.2

- Achando uma judiação o que fizeram com a ferrovia - 30.7

- Magoado pro ter trabalhado 30 anos e ver a situação da ferrovia hoje - 10.7

- Ficando triste de ver a Sorocabana hoje - 15.3

- Sentindo saudade da época em que trabalhava na ferrovia - 3.2

- Sentindo saudade até hoje do trabalho - 22.2

- Sonhando todos os dias com o serviço que fazia na ferrovia - 22.2

- Sonhando até hoje com os amigos de trabalho -22.6

- Tendo grandes recordações daquele tempo - 24.2

- Ficando com saudade da ferrovia - 24.11

- Achando que o tempo da ferrovia era bom- 27.3

- Tendo saudade da cooperativa - 30.13

- Lembrando-se emocionado dos tipos de apitos que cada maquinista fazia - 10.7

Querendo voltar a trabalhar se tudo fosse como antes

- Sentindo vontade de trabalhar novamente - 22.1

- Referindo que se a Sorocabana não tivesse acabado estaria trabalhando ainda lá -22.2 
- Dizendo que voltaria a trabalhar na ferrovia se ela voltasse a ser o que era - 30.7

- Indo todos os dias até a Estação para ver como as coisas estão indo - 19.5

TEMA C - FAVORECENDO ALCANÇAR MAIOR LONGEVIDADE

Quadro 13. Categoria C1 - Adotando estilo de vida saudável: subcategorias e códigos.

\section{ADOTANDO ESTILO DE VIDA SAUDÁVEL}

Mantendo-se ativo física e mentalmente e com pensamentos positivos

- Não ficando o dia inteiro na TV - 15.8

- Procurando fazer outras atividades - 15.8

- Acreditando que não pode parar -18.7

- Não ficar fechado (feito coruja) - 26.6

- Acreditando que estar sempre disposto - 15.8

- Acreditando que sempre deve ter alguma preocupação, pois assim o cérebro funciona - 18.7

- Achando que o segredo é usar a mente - 24.11

- Achando que o importante é ter consciência, é o pensamento - 28.6

- Relatando que nunca fez nada para viver mais, nem esporte - 2.5

- Achando que é por fazer exercícios físicos - 15.8

- Acreditando que o segredo é se movimentar, andar - 18.7

- Achando que o segredo é andar bastante - 23.6

- Achando que não se deve ficar pensando em coisas importantes, devendo procurar esquecer 22.7

- Achando que não deve esquentar a cabeça com as coisas - 24.11

- Acreditando que não se deve invocar com as coisas, ficar pensando muito numa coisa errada 27.10

- Achando que não pensar em coisas ruins vive um século - 28.6

- Achando que o que deixa as pessoas fracassadas é o pensamento - 28.6

- Acreditando que a mente influencia muito na saúde, que não deve ficar pensando em doença porque senão fica doente mesmo - 24.11

Tendo um sono regrado

- Não ficando sem dormir - 1.2

- Associando ao fato de não ficar passeando durante as noites - 3.6

- Associando a descansar e dormir bem - 5.9

- Não passando noite sem dormir -14.6

- Achando que deve dormir cedo - 27.10

- Acreditando que o segredo é dormir cedo - 29.2

- Acreditando que não pode faltar o dormir - 17.12

- Achando que o segredo é dormir bem -23.5

Não tendo vícios e não sendo extravagante

- Não fumando - 1.2

- Associando ao fato de não beber, não fumar - 3.6

- Acreditando que o que debilita uma pessoa é a bebida e o cigarro - 3.6

- Associando viver mais com o fato de evitar o cigarro, a bebida forte, pois isto estraga a saúde das pessoas -4.5

- Lembrando que a "droga” não existia naquele tempo - 4.5

- Associando a evitar a bebida e o cigarro - 5.9

- Associando a não fazer extravagância, não beber demais - 7.6

- Associando ao fato de não beber, não fumar - 8.8

- Acreditando que a bebida prejudica muito a saúde das pessoas - 8.9

- Associando ao fato de não beber e não fumar - 11.5

- Acreditando que o fumo e a bebida encurtam o tempo de vida - 16.6

- Achando que o fumo é prejudicial assim como a bebida -19.6

- Achando que quem bebe estraga a vida e morre cedo - 27.11

- Acreditando que o segredo é não beber e não fumar - 29.2

- Acreditando que a mulher vive um pouco mais que o homem porque é mais difícil beber - 27.12

- Referindo que o cigarro sempre fez mal, mas as pessoas não evitavam e hoje se evita mais - 4.5

- Acreditando que a extravagância prejudica a longevidade - 3.6

- Acreditando que se a pessoa se comportar ela vive mais - 3.6 
- Avaliando que tem boa saúde porque não faz extravagâncias - 5.9

- Associando ao fato de não fazer extravagâncias: sair, bagunçar, beber, não ser promiscuo - 9.7

- Acreditando que se deva ao fato de não fazer extravagância, não beber - 10.6

- Não fazendo extravagância - 14.6

- Julgando a extravagância como causa de estragar a vida - 16.6

- Achando que as pessoas devem ter disciplina em certas coisas (fumo e bebida) - 21.5

- Achando que se as pessoas começam a fazer extravagância encurta o período de vida - 27.12

- Achando que as pessoas já nascem com um tempo certo para viver e se for fazendo extravagância isto diminui - 27.12

- Achando que se o homem não fosse extravagante viveria mais (bebida, farras, jogo) - 28.7

- Acreditando que as extravagâncias enfraquecem as pessoas - 28.7

- Achando que o principal é que as pessoas devem andar direito - 19.6

- Associando morrer cedo com a extravagância (fumar) - 1

- Lembrando que a maioria dos ferroviários gostavam de beber - 4.6

- Acreditando que depende da pessoa e da bebida - 8.9

- Associando que quem bebia bastante já morreram todos - 8.9

- Associando o óbito dos colegas mais jovens ao fato de beberem - 11.5

- Associando que o ferroviário mais velho nunca bebeu e nem fumou -16.6

Tendo hábito alimentar saudável

- Relacionando com a alimentação: fruta, leite - 17.12

- Achando que tem ligação, se alimentando bem e tendo uma vida ordeira - 26.7

- Verificando que os mais gordos morrem primeiro - 4.6

- Verificando que os gordos se aposentavam e não se mexiam, iam engordando mais como porco e morrendo mais cedo -4.6

- Achando que antes os ferroviários viviam mais, pois as coisas eram melhores: fumo, bebida, alimento - 28.7

- Associando a alimentar-se bem - 5.9

- Associando a se alimentar direito, comendo frutas - 7.6

- Achando que a primeira coisa é comer bem - 14.6

- Achando que é comer a comida que gosta e que não faz mal - 14.6

- Acreditando que não pode faltar comida - 17.12

- Achando que o segredo é comer bem - 23.5

- Achando que o segredo é comer bem - 30.13

- Descobrindo que a gordura faz mal para o coração - 4.6

Relacionando-se bem com as pessoas e com a família

- Acreditando que é não fazer o mal - 12.15

- Não se deve desejar mal para os outros, se não dá para fazer o bem, não se deve fazer o mal 28.6

- Procurar melhorar o que esta fazendo de mal - 25.9

- Andando com a consciência limpa -12.15

- Não arrumando encrencas - 12.15

- Não explorando as pessoas no trabalho, principalmente quem irá trabalhar para você - 12.16

- Achando que é participar de uma boa sociedade - 26.6

- Achando que é conversar - 26.6

- Tendo boa convivência com a família - 15.8

- Ter boas amizades - 15.8

- Achando que o segredo é não ligar para vida dos outros - 25.9

- Aconselhando a olhar a própria vida - 25.9

- Achando que as pessoas devem cuidar de suas próprias vidas - 19.6

Quadro 14. Categoria C2 - Não existindo consenso se habitat harmônico e sem poluição é positivo para a longevidade: subcategorias e códigos.

NÃO EXISTINDO CONSENSO SE HABITAT HARMÔNICO E SEM POLUIÇÃO É POSITIVO PARA A LONGEVIDADE

- Acreditando que depende do jeito que cada pessoa foi criada - 8.5

- Acreditando que foi criado em um bom ambiente no bairro - 8.5

- Achando que o meio ambiente influencia a saúde das pessoas - 10.4

- Acreditando que meio ambiente contribui para a pessoa viver mais - 10.7 


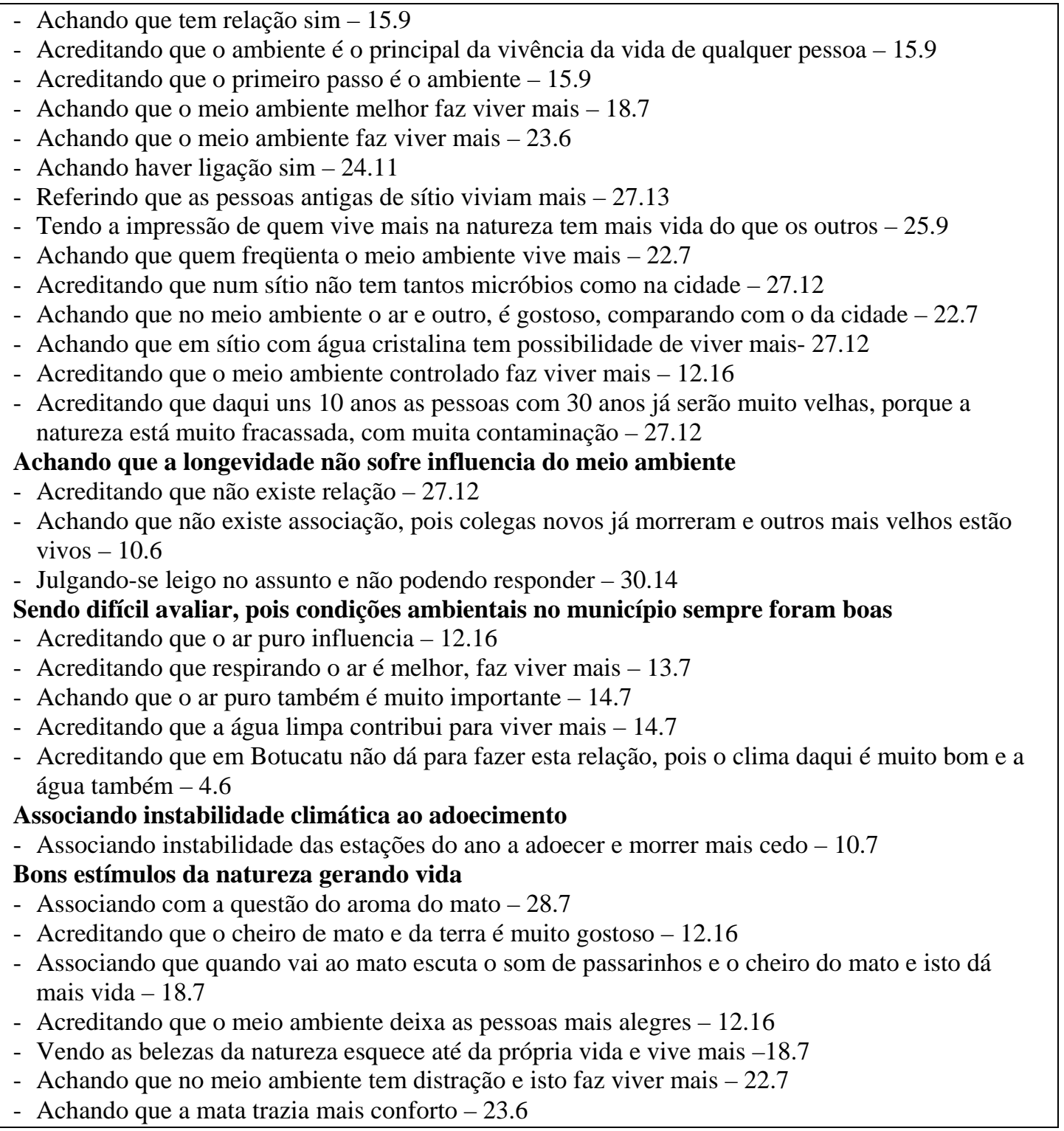

Quadro 15. Categoria C3 - Sentindo prazer nas ações realizadas: códigos.

\begin{tabular}{|l|}
\hline \multicolumn{1}{c|}{ SENTINDO PRAZER NAS AÇÕES REALIZADAS } \\
- Acreditando que se fizer o que quer, vive mais - 6.3 \\
- Achando que deve ter lazer, fazendo as coisas que gosta -22.7 \\
- Referindo que avó morreu com 95 e só gostava de coisa boa - 25.9 \\
\hline
\end{tabular}

Quadro 16. Categoria C4 - Envolvendo-se com o trabalho e tendo renda para se sustentar: subcategorias e códigos.

\author{
ENVOLVENDO-SE COM O TRABALHO E TENDO RENDA PARA SE SUSTENTAR \\ - Associando ao fato de trabalhar -1 \\ - Associando ao fato de trabalhar - 3.6 \\ - Acreditando que trabalhar ajuda a viver mais - 16.6 \\ - Acreditando que enquanto está trabalhando não se pensa em coisas ruins - 16.6 \\ - Achando que trabalhar é muito gostoso - 16.6 \\ - Achando que o segredo é trabalhar - 30.13 \\ - Ter dinheiro - 13.7 \\ - Achando que as pessoas que vão se endividando, vão perdendo possibilidade de vida - 27.11
}




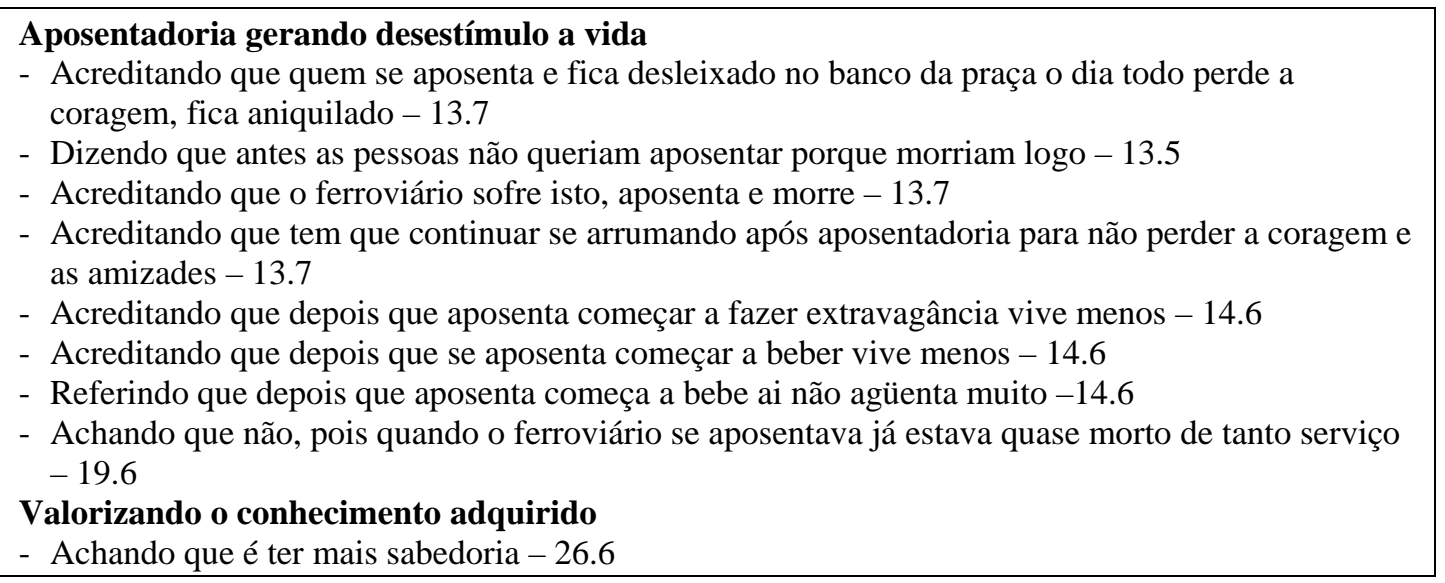

Quadro 17. Categoria C5 - Crendo no espiritualismo e na sorte: códigos.

- Acreditando numa força superior - 20.5

\section{CRENDO NO ESPIRITUALISMO E NA SORTE}

- Achando que foi uma graça de Deus ele viver tanto - 1

- Achando que depende de sorte -16.6

- Referindo que tem pessoas que estão bem e de repente morrem - 21.5

Quadro 18. Categoria C6 - Sendo e estando tranqüilo e feliz: códigos.

\section{SENDO E ESTANDO TRANQÜILO E FELIZ}

- Associando a longevidade ao fato de viver mais tranqüilamente - 6.3

- Acreditando que o segredo para viver mais é ter tranqüilidade - 13.7

- Achando que é ser tranqüilo - 22.7

- Achando que é ser folgado - 22.7

- Achando que o segredo é ser sossegado - 27.10

- Achando que ficar nervoso perde possibilidade de vida - 27.10

- Associando ao fato de não fazer tudo na correria - 11.5

- Criticando que as pessoas fazem tudo correndo na rua hoje em dia - 11.5

- Acreditando que deve relaxar o corpo - 16.6

- Acreditando que é estar sempre alegre - 15.8

- Não pensar na tristeza - 15.8

- Pensar na alegria do dia de amanhã - 15.8

- Achando que o segredo é ser feliz - 25.8

- Achando que o segredo é estar de bem com a vida - 25.8

- Dizendo que tristeza é morte - 25.9

Quadro 19. Categoria C7 - Possuindo fatores biológicos e genéticos favoráveis: códigos. POSSUINDO FATORES BIOLÓGICOS E GENÉTICOS FAVORÁVEIS

- Acreditando que é congênito, pois tem pessoas na família que viveram bastante - 2.4

- Associando com a questão genética - 3.6

- Observando que na própria família as pessoas viveram bastante - 3.6

- Acreditando que é genético, varia com a natureza de cada um - 28.7

- Comparando com os demais irmãos, com a mesma genética que morreram antes - 16.6

- Comparando-se com irmãos e vendo que depende de cada pessoa - 20.5

- Acreditando que longevidade esta associada a genética, pois tinham pessoas fortes que já morreram - 2.6

- Ter saúde - 13.7

- Achando que é ter uma vida saudável - 24.11

- Achando que ter mais doença morre antes - 16.6

- Achando que o segredo é ter saúde - 19.6

- Achando que depende do organismo da pessoa - 10.4 


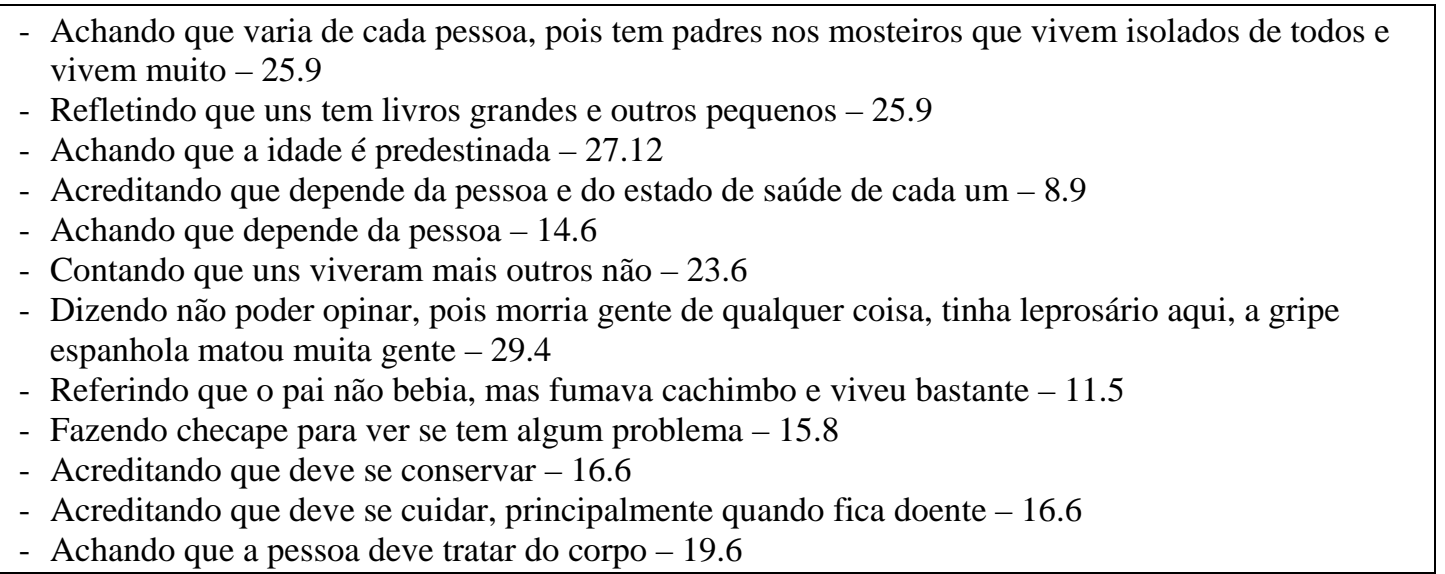

Quadro 20. Categoria C8 - Controlando a própria saúde: códigos.

\begin{tabular}{l} 
CONTROLANDO A PRÓPRIA SAÚDE \\
- Fazendo checape para ver se tem algum problema - 15.8 \\
- Acreditando que deve se conservar - 16.6 \\
- Acreditando que deve se cuidar, principalmente quando fica doente - 16.6 \\
- Achando que a pessoa deve tratar do corpo - 19.6 \\
\hline
\end{tabular}

Quadro 21. Categoria C9 - Percebendo vários fatores associados: códigos.

\section{PERCEBENDO VÁRIOS FATORES ASSOCIADOS}

- Achando que é necessário, ter água, comida, ar e dormir - 17.12

- Achando que tomar um ventinho, alimentando-se bem, andando um pouco -26.6

\section{TEMA D - PODENDO A SAÚDE SER INFLUENCIADA PELO MEIO AMBIENTE}

Quadro 22. Categoria D1 - Podendo o meio ambiente influenciar a saúde: códigos.

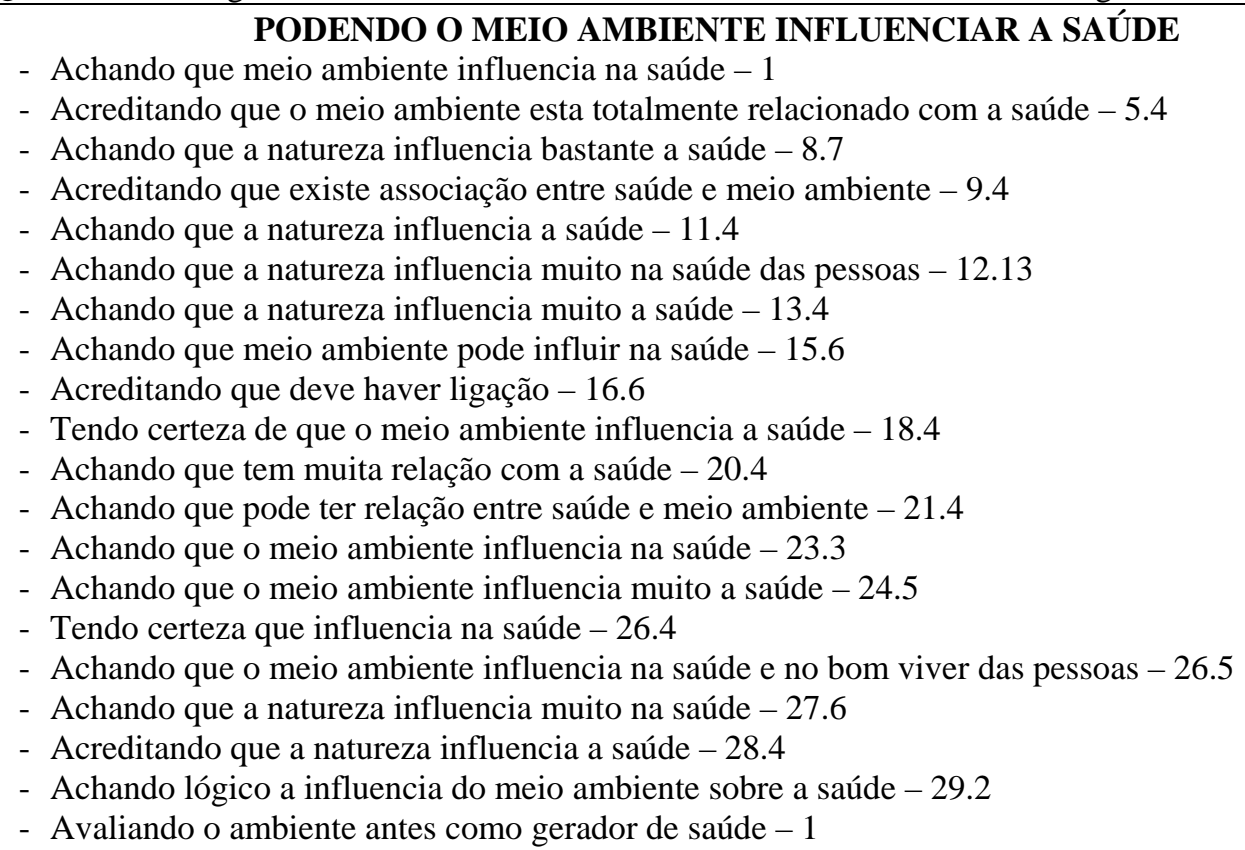




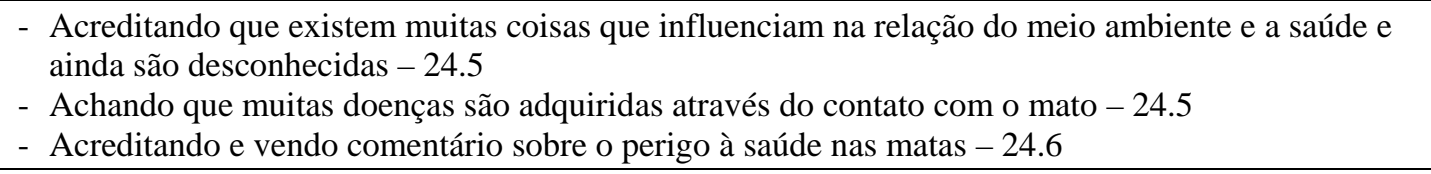

Quadro 23. Categoria D2 - Podendo o meio ambiente não influenciar a saúde: subcategorias e códigos.

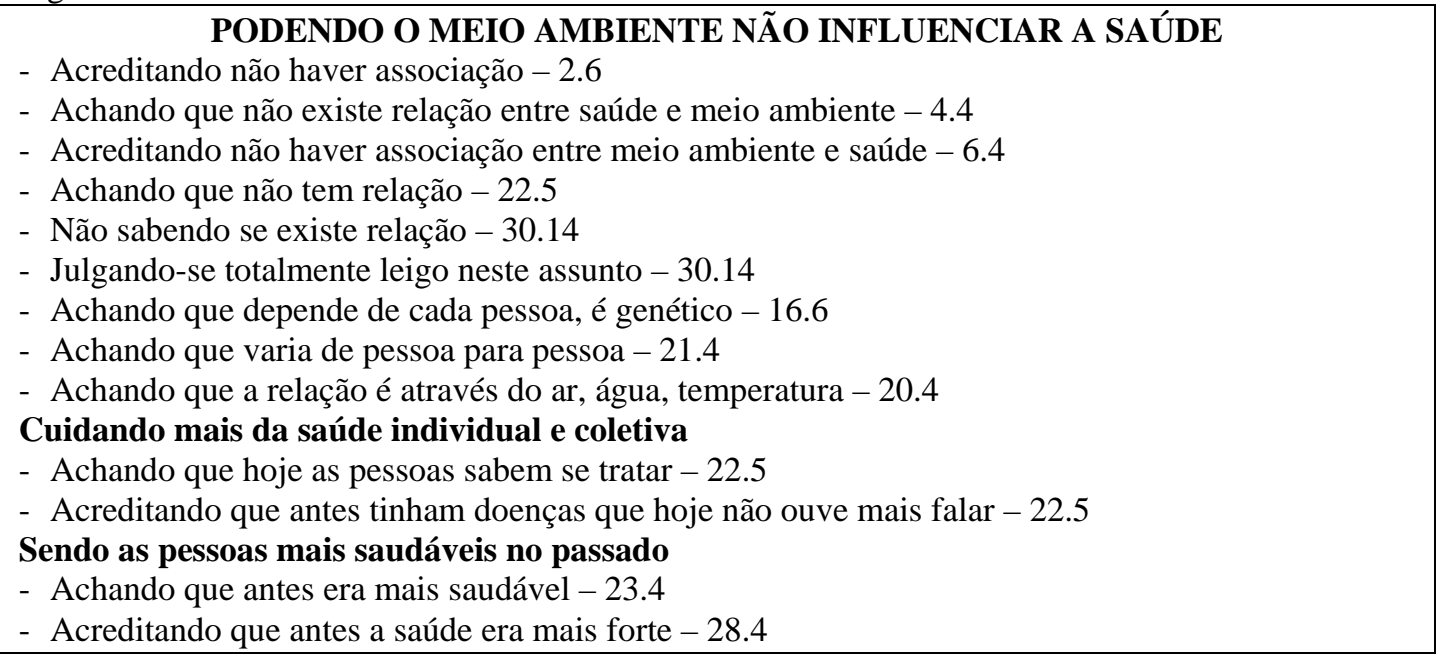

Quadro 24. Categoria D3 - Poluição e contaminação prejudicando a saúde: categoria e códigos.

\section{POLUIÇÃO E CONTAMINAÇÃO PREJUDICANDO A SAÚDE}

- Achando que toda poluição prejudica a saúde - 19.5

- Achando em ambiente sem poluição sente-se melhor - 15.6

- Achando que influencia porque tem colocado muito veneno - 27.6

- Referindo que naquele tempo as pessoas nem pensavam que os produtos químicos podiam fazer mal para a saúde -6.3

- Pensando que talvez os produtos químicos já fizessem mal e ninguém percebesse - 6.3

- Relatando que só posteriormente vieram as preocupações em uso de equipamento para prevenção $-6.3$

- Vendo o agrotóxico, pensou: por isto que está todo mundo doente - 12.10

- Dizendo que já existiam produtos químicos e adubos - 19.5

- Dizendo que as pessoas já sabiam que estes produtos faziam mal e usavam máscaras - 19.5

- Antigamente não se tinha esta preocupação com agrotóxicos - 2

- Acreditando que estes adubos deveriam fazer mal a saúde pois o cheiro era muito forte - 5.8

- Lembrando que viu pela primeira vez jogarem veneno em lavoura com avião em Presidente Prudente - 12.10

- Lembrando que viu jogarem BHC no café perto de Cambará (PR) e ao redor várias casas de empregados -12.10

Quadro 25. Categoria D4 - Qualidade do ar e da água influenciando a saúde: códigos.

QUALIDADE DO AR E DA ÁGUA INFLUENCIANDO A SAÚDE
- Achando que um bom ar puro traz conforto - 15.6
- Achando que o ar puro influencia na saúde - 8.7
- Achando que o ar exerce influencia sobre a saúde - 13.4
- Acreditando que o ar influencia a saúde - 18.4
- Comparando que antes o ar era mais limpo - 23.4
- Achando que o ar que se respira hoje não é puro - 8.7
- Criticando mal cheiro do curtume - 4.4
- Achando que o ar do sítio era melhor por não ter poluição - 14.3
- Achando que o ar do sítio era gostoso e mais suave - 14.3
- Avaliando Botucatu como um bom lugar para a saúde devido ao ar - 1




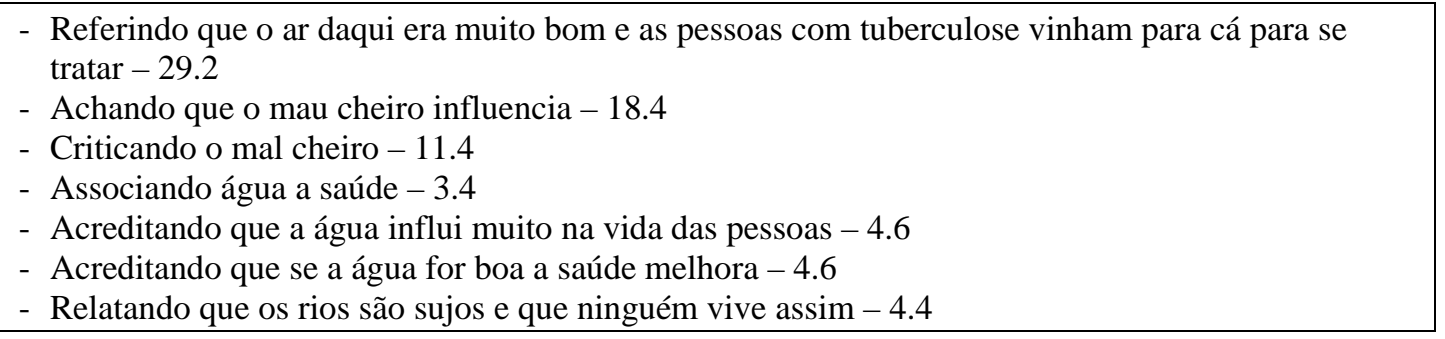

Quadro 26. Categoria D5 - Sendo melhor para a saúde locais com mais área verde: códigos.

\section{SENDO MELHOR PARA A SAÚDE LOCAIS COM MAIS ÁREA VERDE}

- Achando que a mata influencia a saúde - 3.5

- Achando que as árvore favorecem a saúde -13.4

- Acreditando que o fato de diminuir a área verde das casas influencia na saúde - 13.5

- Tendo a impressão de que onde há mais verde há mais saúde - 25.8

- Comparando que em lugar com arvoredos o ar é mais gostoso - 16.6

- Achando que as matas refrescam - 23.4

- Achando que a devastação influencia nisto e assim na saúde - 23.4

- Associando as doenças atuais com a destruição da natureza - 5.4

- Associando que quando a natureza esta descontrolada a saúde se comporta da mesma forma - 5.4

- Achando que onde tem mata tem mais oxigênio -17.13

- Referindo que as matas trazem sombra, protegendo o corpo das intempéries do calor do sol - 7.4

- Achando que o sol era mais fraco e agora o sol vem direto nas pessoas, porque cortaram as matas $-23.4$

\section{TEMA E - OBSERVANDO FATORES QUE PODEM CONTRIBUIR PARA A MAIOR LONGEVIDADE DO FERROVIÁRIO}

Quadro 27. Categoria E1 - Ferroviário alcançando ou não a longevidade: subcategorias e códigos.

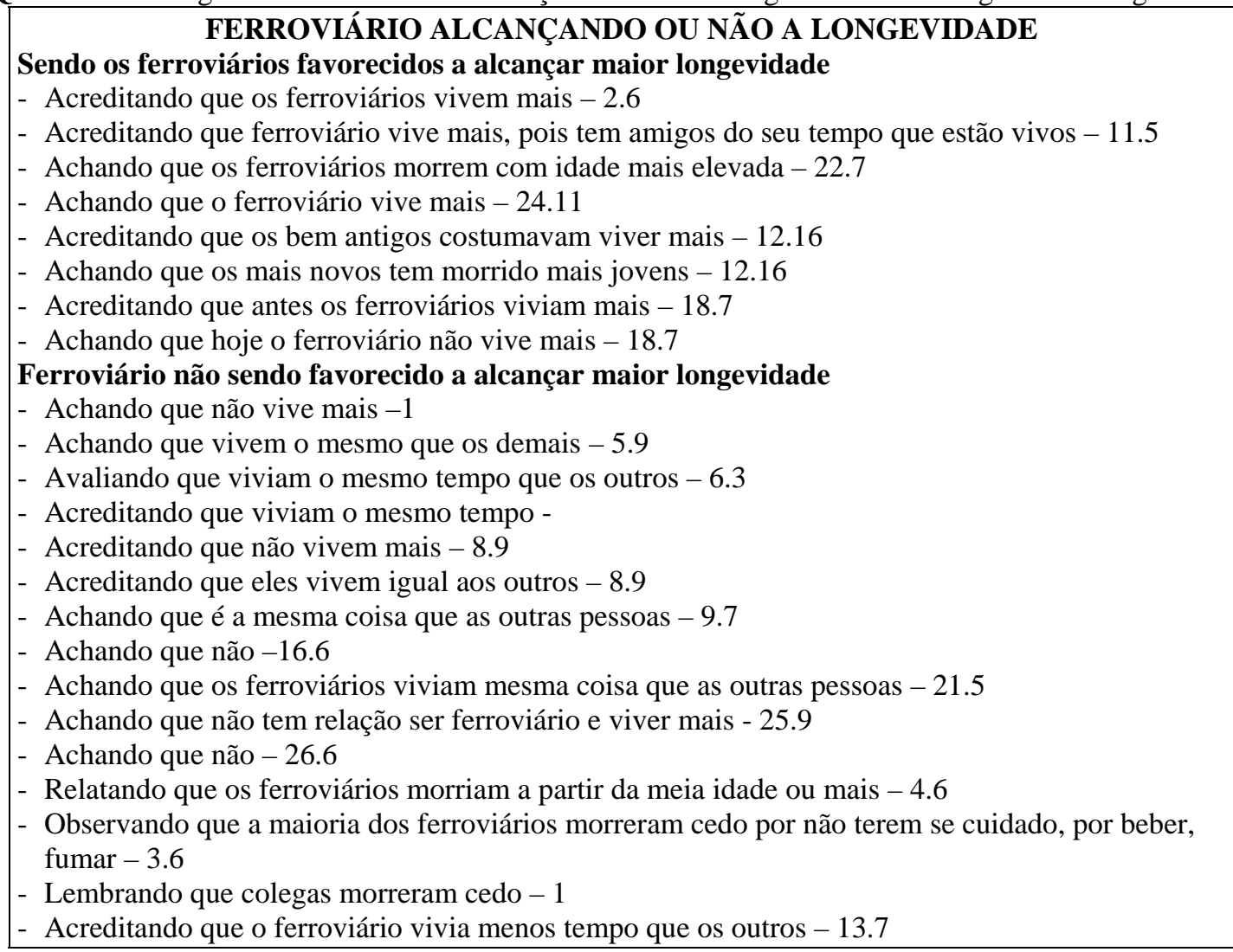




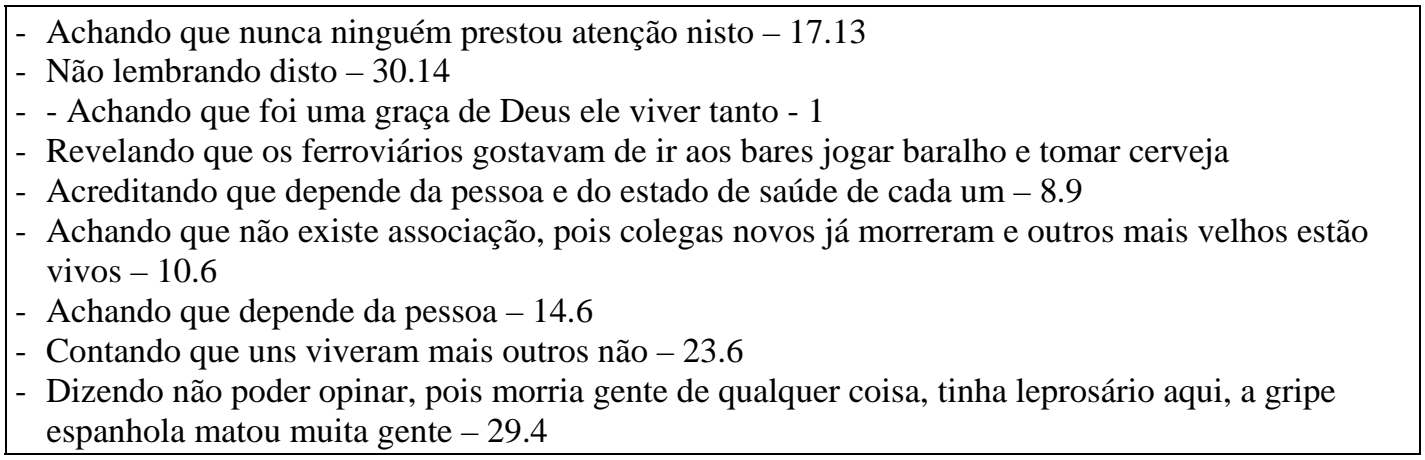

Quadro 28. Categoria E2 - Tendo um emprego com estabilidade e carreira: códigos.

TENDO UM EMPREGO COM ESTABILIDADE E CARREIRA
- Contando que quem dava emprego era a Sorocabana e o comércio, mas na Sorocabana era mais estável - 29.3

- Lembrando que as pessoas queriam trabalhar na Sorocabana porque faziam carreira - 29.3

- Revelando que quem entrava na Sorocabana não saia mais - 29.3

- Lembrando que cada ferroviário tinha um almanaque onde ia marcando pontos para ser promovido -12.9

- Tirando licença descontava pontos e se ficasse doente também, assim outro passava na sua frente $-12.9$

- Revelando que as pessoas casavam, conseguiam emprego e iam fazer carreira na Sorocabana 29.4

- Revelando que as pessoas ficavam na ferrovia até se aposentarem - 16.4

- Dizendo que na ferrovia quem trabalhava mais, ganhava mais - 13.3

- Contando que o pessoal de máquina ganhava bem, porque fazia extra - 18.7

- Lembrando que quem era da carreira ganhava mais - 30.10

Quadro 29. Categoria E3 - Tendo um bom salário e crédito na cidade: subcategorias e códigos.

TENDO UM BOM SALÁRIO E CRÉDITO NA CIDADE
- Lembrando que podia comprar o que queria e em qualquer lugar - 4.3
- Revelando que o ferroviário tinha crédito em todos os lugares - 8.3
- Revelando que os ferroviários tinham crédito em todos os lugares - 10.2
- contando que o ferroviário podia comprar em qualquer lugar - 19.2
- contando que o ferroviário podia comprar fiado - 19.2
- Dizendo que o ferroviário tinha crédito no comércio - 22.5
- Relatando que o ferroviário tinha crédito em todos os lugares - 28.2
- Lembrando que o ferroviário tinha crédito no comércio - 30.10
- Revelando que todo ferroviário ganhava muito bem - 6.3
- Revelando que o ferroviário ganhava mais do que outras pessoas - 8.7
- Revelando que a ferrovia sempre pagou bem - 8.7
- Revelando que qualquer serviço prestado a ferrovia era remunerado - 8.7
- Revelando que nem o Blasi, Milanesi e a Serraria pagam bem - 8.7
- Lembrando que os ferroviários ganhavam mais do que outros empregos em Botucatu - 10.2
- Revelando que ser ferroviário naquele tempo era um cargo importante e que recebia bem, como
bancário hoje em dia - 11.1
- Lembrando que sempre ganhou bem, até melhor que outros - 13.3
- Dizendo que ganhava bem, pois dava para sustentar muito bem uma família de 4 pessoas-29.3
- Revelando que ganhavam bem - 30.10
- Elogiando que ganhava certinho na ferrovia - 30.10
- Lembrando que o pagamento vinha direitinho - 15.4
- Avaliando como melhor o tempo anterior, pois conseguia comprar o que precisava - 10.4
- Lembrando o dia do trem pagador que chegava a estação trazendo o dinheiro do salário dos
- ferroviários, que iam lá receber - 11.2
- Dizendo que o pagamento sempre atrasava 5 ou seis dias - 12.7
- Lembrando que o pagamento era trazido pelo trem pagador- 12.7




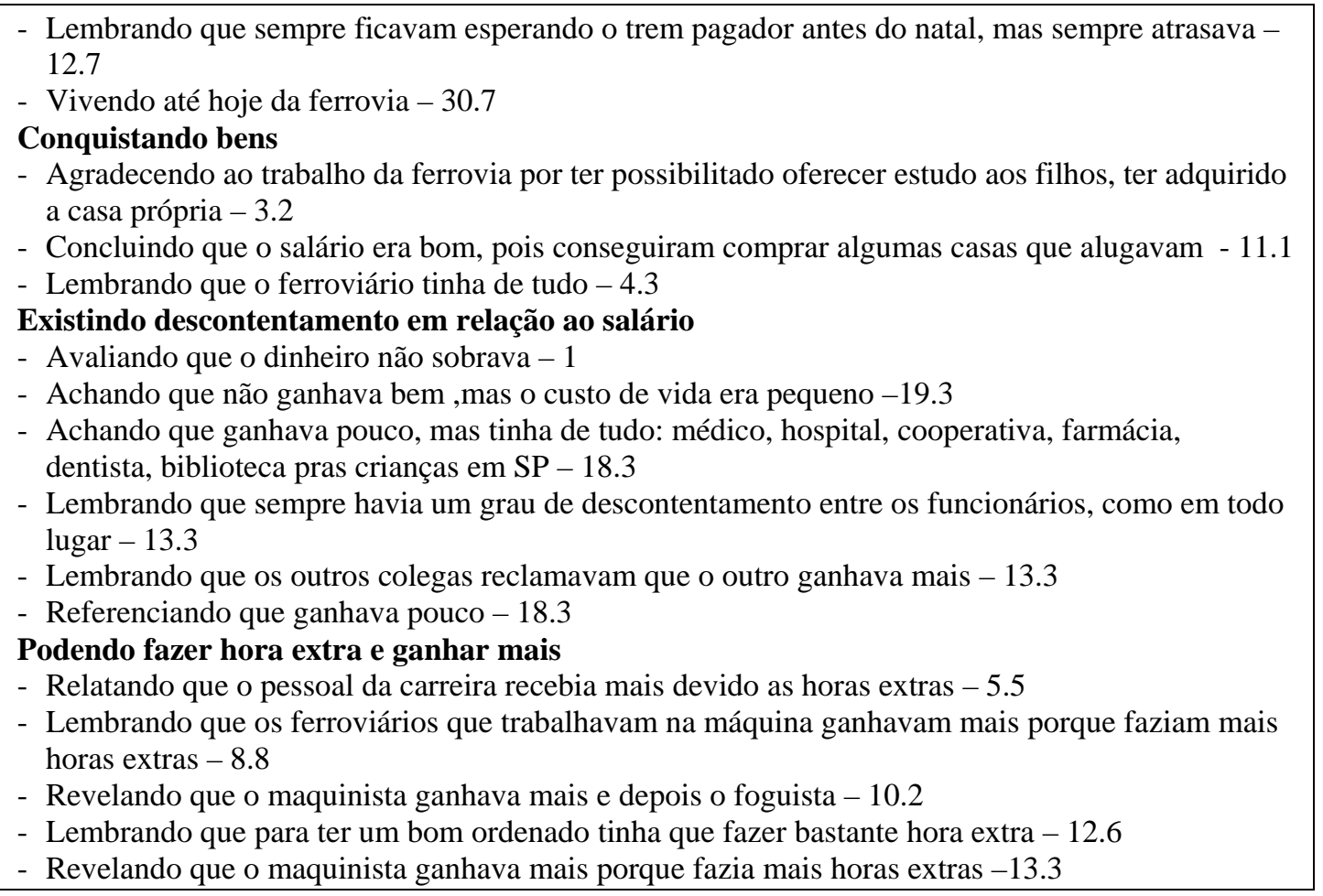

Quadro 30. Categoria E4 - Desfrutando de benefícios como ferroviários: códigos.

\section{DESFRUTANDO DE BENEFÍCIOS COMO FERROVIÁRIOS}

- Relatando que a água e a energia de sua rua - Vitor Atti, eram por conta de ferrovia - 3.4

- Relatando que depois a energia foi transferida para uma companhia e a água vinha do curtume 3.4

- Relatando que nas residências da ferrovia não se pagava aluguel e que eram casa boas - 3.5

- Lembrando que a cooperativa fornecia de tudo que era descontado e anotado em caderneta -28.2

- Referindo que a Sorocabana foi uma mãe - 28.2

- Lembrando que a Sorocabana era bem diferenciada, com colônia de férias - 29.3

- Referindo que tinham cooperativa que compravam mercadoria que eram anotadas na caderneta e descontadas do salário - 30.13

- Lembrando que o pedido da cooperativa demora 10 a 15 dias para ser entregue nas casas - 30.13

- Revelando que a cooperativa tinha de tudo - 30.13

- Lembrando que no dia primeiro de maio havia um dia especial, passeios oferecidos aos ferroviários e familiares - 30.15

- Lembrando que a serralheria anônima fornecia madeira para construção de casas aa um preço muito bom -30.15

- Lembrando que vinham tijolos muito bons de Conchas através da ferrovia - 30.16

- Relatando que alguns tinham direito a moradia em vilas de ferroviários beirando a estação - 2

- Relembrando o papel da cooperativa dos ferroviários que fornecia de tudo para eles - 4.3

- Lembrando que compravam tudo na cooperativa da ferrovia e vinha descontado em folha - 5.7

- Revelando que a cooperativa entregava os produtos nas casas dos ferroviários por meio de carroças -5.7

- Referindo que existia o armazém de abastecimento que fornecia tudo que já vinha descontado em folha -7.5

- Revelando que existia uma caixa dos ferroviários onde podiam fazer empréstimos financeiros 9.6

- Revelando que comprou a casa com este empréstimo e até hoje esta pagando - 9.6

- Revelando que retiravam tudo o que precisavam do armazém da ferrovia - 9.6

- Referindo que o que retiravam no armazém dava para passar o mês - 9.6

- Lembrando que existia a cooperativa para a qual faziam os pedidos que eram entregues em casa no outro mês e descontados do salário, através de uma caderneta - 11.2

- Contando que o décimo terceiro começou a vir em 1960/61 - 12.11 


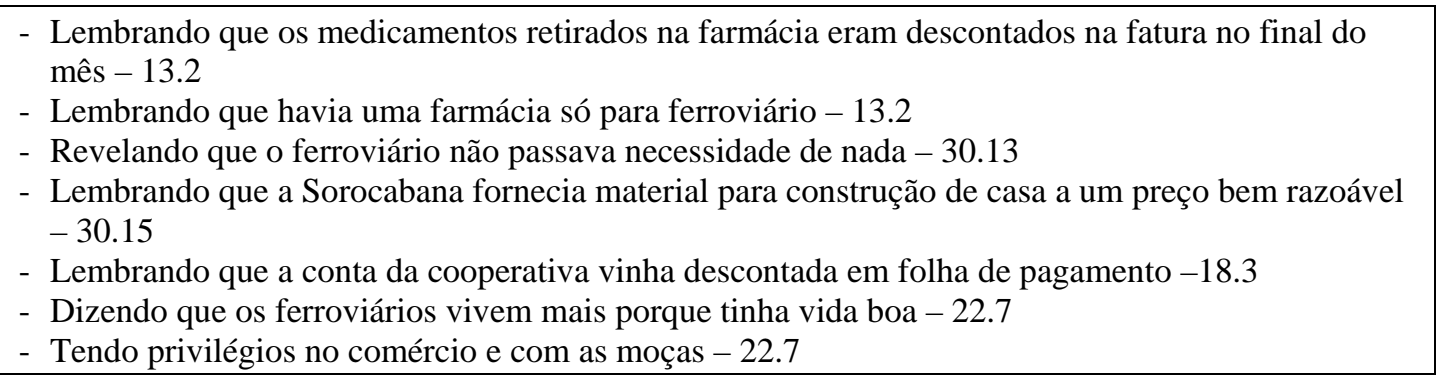

Quadro 31. Categoria E5 - Exigindo muita atividade física no trabalho: códigos.

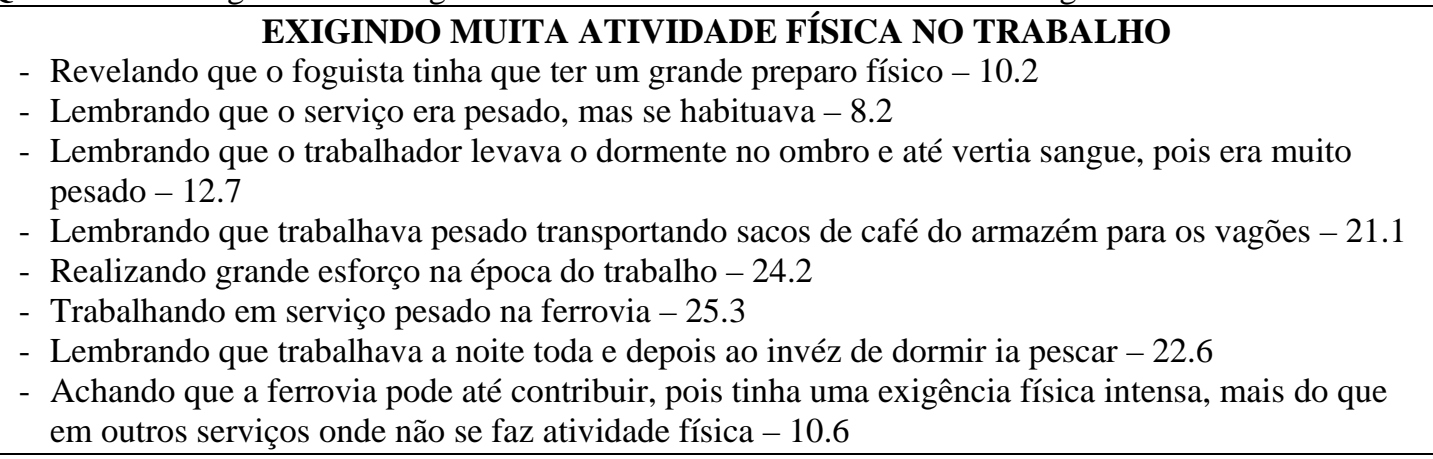

Quadro 32. Categoria E6 - Contando com controle periódico e assistência à saúde: códigos.

\begin{tabular}{|l|}
\hline CONTANDO COM CONTROLE PERIÓDICO E ASSISTÊNCIA À SAÚDE \\
- Revelando que o pessoal da carreira, maquinista e ajudante faziam exames completos anualmente \\
- 5.6 \\
- Revelando que o maquinista fazia exames periódicos em $\mathrm{Sp}-15.4$ \\
- $\quad$ Revelando que se o maquinista apresentasse alterações no exame não podia mais exercer \\
- a função - 15.4 \\
- Lembrando que o maquinista que não podia mais exercer função e já tinha tempo para se \\
- Relatantar ia trabalhar em algum outro cargo estadual - 15.4 \\
- Referido que os ferrocabana tinha muita tinham assistência a saúde e quando eram casos mais graves eram \\
encaminhados para SP - 20.5 \\
- Lembrando que os ferroviários tinham assistência no hospital daqui e de SP- 29.4 \\
- Lembrando que o ferroviários fazia vários exames antes de entrar na ferrovia - 15.9 \\
- Lembrando, então que o ferroviário já entrava sabendo que estava bom - 15.9 \\
\hline
\end{tabular}

Quadro 33. Categoria E7 - Convivendo em um bom ambiente de trabalho: códigos.

\footnotetext{
- Relembrando que o ambiente era bom - 1

- Avaliando como muito bom antigamente por ter muitas amizades, diferente de hoje - 2.3

- Lembrando que o ambiente do bairro era muito bom - 8.6

- Lembrando que no bairro não existia pessoas que pediam esmola - 8.6

Relacionando-se bem com os colegas no trabalho

- Relacionando quanto mais trabalho mais amizades -5.2

- Relatando que os ferroviários eram muito amigos - 5.2

- Dizendo que ao vir um novo colega todos mundo ajudavam, eram amigos 12.12

- Contando que todo mundo era amigo na Sorocabana - 22.6

- Referindo que não havia competição entre eles - 5.2

- Lembrando que sempre teve bom relacionamento entre os colegas - 10.1

- Avaliando como muito bom trabalhar na ferrovia por conta dos próprios ferroviários mesmo 24.1

- Lembrando que existia muito respeito para com o chefe - 10.1
} 
Quadro 34. Categoria E8 - Dedicando-se e sentindo prazer no trabalho: códigos.

\section{DEDICANDO-SE E SENTINDO PRAZER NO TRABALHO}

- Avaliando como prazeroso trabalhar na ferrovia - 5.2

- Revelando que gostava muito do serviço que fazia- 8.2

- Achando muito prazeroso trabalhar na ferrovia - 10.1

- Trabalhando com muito amor em sua profissão - 10.7

- Gostando muito do trabalho desempenhado - 10.7

- Gostando de ver a locomotiva bem limpinha e bonita - 12.3

- Revelando que era bom trabalhar na Sorocabana - 13.3

- Achando o trabalho gostoso - 14.3

- Achando bom trabalhar na Sorocabana - 21.2

- Achando muito melhor trabalhar na Sorocabana que na FEPASA - 21.2

- Achando muito gostoso trabalhar na Sorocabana - 22.2

- Achando que era um trabalho divertido e prazeroso - 22.2

- Gostando muito do serviço que fazia - 23.2

- Gostando muito de trabalhar na Sorocabana - 23.2

- Avaliando como muito bom trabalhar na Sorocabana - 24.1

- Observando que os ferroviários faziam muito satisfeitos o seu serviço - 24.11

- Achando gostoso trabalhar na Sorocabana - 26.3

- Achando gostoso trabalhar na Sorocabana- 29.1

- Gostando de trabalhar na sorocabana - 30.6

- Não tendo queixas de trabalhar na ferrovia - 30.6

- Achando bom trabalhar na Sorocabana - 16.2

- Relatando que o trabalho era pesado - 16.2

- Achando bom trabalhar na Sorocabana - 18.3

- Dedicando-se ao trabalho a atividade ficava fácil - 8.2

- Dedicando-se ao trabalho como se a ferrovia lhe pertencesse - 10.1

- Não se arrependendo do trabalho que exerceu - 14.3

- Acreditando que nenhum ferroviário pode se queixar do emprego que teve, era pesado, mas se ganhava bem - 14.5

- Avaliando os ferroviários como tendo dedicação extrema ao trabalho - 24.1

- Gostando de trabalhar e fazendo com amor e fé - 28.4

- Criticando os trabalhadores jovens que fazem tudo sem compromisso - 28.5

- Vendo como os ferroviários gostavam muito da ferrovia-24.11

- Achando que parece até meio místico este gostar - 24.11

- Observando que os ferroviários gostavam da ferrovia como se fosse deles - 24.11

- Dizendo que gostava mais de ficar na Sorocabana do que em casa - 29.1

- Apreciando até hoje a ferrovia - 30.6

- Julgando que a ferrovia foi tudo na vida dele - 30.7

Quadro 35. Categoria E9 - Orgulhando-se em ser ferroviário: subcategorias e códigos.

\section{ORGULHANDO-SE EM SER FERROVIÁRIO}

- Relatando que era um orgulho ser ferroviário - 2.1

- Sentindo-se satisfeito de ser ferroviário - 2.2

- Lembrando-se com detalhes do uniforme que usavam e com orgulho -10.7

- Avaliando com muito bom ser ferroviário, porque a única coisa melhor que existia em Botucatu era a ferrovia - 11.1

- Achando muito bom ser ferroviário - 15.4

Sendo o ferroviário conhecido e estimado

- Relembrando que o ferroviário era conhecido em toda a cidade naquele tempo - 4.3

- Dizendo que todos de Botucatu gostavam dos ferroviários - 12.9

Considerando um dos melhores empregos na época

- Ser ferroviário era um dos melhores empregos que existia na época - 4.3

- Lembrando que era um empreendimento ser ferroviário - 2 


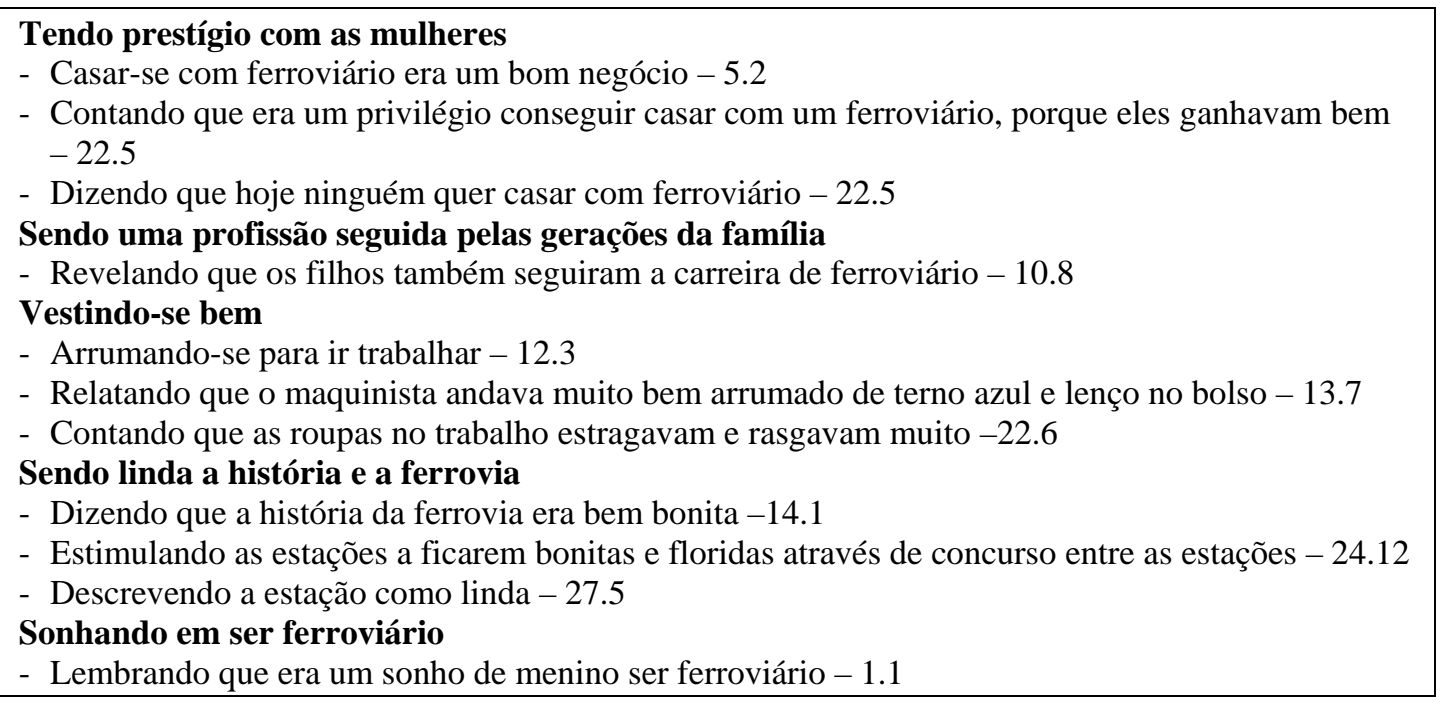

\section{TEMA F - FERROVIA GERANDO RIQUEZAS}

Quadro 36. Categoria F1 - Desenvolvimento da cidade favorecido pela ferrovia: subcategorias, elementos e códigos.

\begin{tabular}{|l} 
DESENVOLVIMENTO DA CIDADE FAVORECIDO PELA FERROVIA \\
Proporcionando crescimento da cidade \\
- Avaliando Botucatu como uma cidade provinciana - 2 \\
- Lembrando que a cidade era bem menor - 7.2 \\
- Comparando que Botucatu era bem diferente por ter uma população pequena e poucas casas - 8.3 \\
- Lembrando que em 1909 veio o Bispo Dom Lucio para Botucatu e a cidade na época tinha 6 mil \\
- habitantes - 17.16 \\
- Contando que antes já existiam jezuítas em Botucatu e tinham fazenda de gado de leite - 17.16 \\
- Referindo que Botucatu era uma cidade provinciana com poucos bairros- 18.3 \\
- Classificando Botucatu como provinciana para a época - 26.3 \\
- Referindo que Botucatu era pequena - 27.5 \\
- Lembrando que Botucatu não tinha nada - 28.3 \\
- Relatando que Botucatu era uma cidade bem movimentada - 4.3 \\
- Achando a cidade movimentada - 6.2 \\
- Comparando o movimento de Botucatu como maior que o de Bauru - 11.1 \\
- Acreditando que antes Botucatu tinha mais movimento das pessoas que iam trabalhar - 14.2 \\
- Achando que Botucatu muito movimentada na época - 23.3 \\
- Referindo que tinha muito movimento em Botucatu - 30.9 \\
- Achando que antes a cidade de Botucatu era feia, que hoje é mais bonita - 16.3 \\
- Lembrando que só existia a rua Amando de Barros, o resto era feio - 16.3 \\
- Referindo que o comércio não era bonito - 16.3 \\
- Lembrando que a ferrovia veio para Botucatu em 1889 -17.8 \\
- Referindo que a população a de Botucatu em 1950 não chegava a 50 mil -16.3 \\
Formando bairros de ferroviários \\
- Revelando que os moradores do bairro não se davam muito bem com os do centro - 8.6 \\
- Contando que a vila dos lavradores foi formada pela ferrovia - 2 \\
- Relembrando que a rua Vitor Atti era uma vila dos ferroviários - 3.4 \\
- Revelando que o bairro era a moradia dos ferroviários - 8.6 \\
- Revelando que o bairro era o núcleo ferroviário, onde morava a maioria dos ferroviários - 9.2 \\
- Dizendo que a maioria dos ferroviários moravam no bairro - 12.9 \\
- Contando que depois eles começaram a morar também na Vila Maria - 12.9 \\
- Lembrando que no bairro eram só ferroviários - 13.3 \\
- Lembrando que o bairro era só de ferroviários indo trabalhar - 14.2 \\
- Lembrando que na Vila Maria também tinha muito ferroviário - 14.2 \\
\hline
\end{tabular}


- Referindo que a Vila dos Lavradores era o chamado bairro da estação - 30.5

Sendo a cidade desenvolvida a custa da ferrovia

- Referindo que Botucatu vivia a custa da ferrovia - 5.2

- Lembrando que a maior parte dos moradores da cidade eram ferroviários - 5.2

- Relatando que existia um grande movimento na cidade em torno da ferrovia - 5.2

- Entristecido de ver tudo abandonado hoje - 5.2

- Revelando que quem mandava na cidade naquela época era a ferrovia - 6.3

- Revelando que quem mantinha economicamente a cidade eram os ferroviários -9.2

- Dizendo que a cidade girava em torno da ferrovia - 12.9

- Dizendo que o ferroviário é quem movia a cidade - 13.3

- Revelando que o ferroviário é quem garantia tudo em Botucatu- 13.3

- Classificando Botucatu como um meio ferroviário -13.3

- Revelando que tudo girava em torno da Sorocabana - 13.4

- Referindo que Botucatu também viveu em torno da ferrovia - 17.8

- Referindo que tudo que tem é graças a ferrovias- 27.4

EFS de Botucatu recebendo destaque entre as ferrovias

- Avaliando Botucatu como um centro importante da ferrovia - 2

- Referindo que todo transporte passava pro Botucatu, o que ia para o Paraná, que vinha de Bauru e ai para são Paulo -4.3

- Revelando que Botucatu era o tronco e que existiam os ramais (Itatinga, Pirajuí, Treze de Maio e Porto Martins) -7.2

- Revelando que a ferrovia tinha 5 divisões: São Paulo, Campinas, Botucatu, Assis e Santos - 9.1

- Referindo que Botucatu liberava trens para vários locais, inclusive para Bauru - 11.1

- Revelando que em Botucatu era o entroncamento das ferrovias - 11.1

- Revelando que em Rubião é que fazia a separação dos trens para outras ferrovias, como para noroeste e alta sorocabana - 11.1

- Comparando que o depósito de Botucatu era o maior e que depois veio o de Assis - 16.3

- Referindo que tudo que vinha dos lados de Itapetininga parava em Botucatu para descansar e depois continuava -17.16

- Referindo que Botucatu era ponto de passagem - 17.16

- Revelando que Botucatu era o maior centro ferroviário que tinha no interior de SP - 20.2

- Lembrando que depois de Botucatu vinha Assis e Bauru- 20.2

- Referindo que Bauru era maior porque tinha Paulista e Noroeste - 20.3

- Contando que Botucatu era bem importante dentro da ferrovia - 23.2

- Contando que a regional de Botucatu se projeta em relação as outras regionais no tocante a manutenção e desempenho dos funcionários - 24.15

- Botucatu sendo considerado um local de grande importância - 30.15

Sendo bem diversificado o almoxarifado

- Lembrando que o almoxarifado das locomotivas tinha 2500 itens -30.2

Sendo referência como oficina mecânica

- Contando que aqui e em Sorocaba havia oficina mecânica, mas de Sorocaba era maior - 14.1

- Referindo que em Botucatu havia um grande depósito para repara vagões - 20.1

- Relatando que na Barra funda tinha um depósito grande de locomotivas que recebiam reparos 16.3

- Lembrando que a oficina de Sorocaba era para fazer manutenção anual ou semestral das locomotivas -30.2

- Referindo que a oficina de Botucatu fazia reparações parciais - 30.2

Tendo extensa linha férrea

- Lembrando que as estações eram as seguintes: Iperó, Ourinhos, Candido Mota, Boituva, Porto feliz, Cerquilho, Botucatu, Manduri, Piraju, Americano, Santa Cruz do Rio Pardo, Assis, Porto Epitácio - 9.1

- Lembrando que São Paulo a Porto Epitácio eram 1000 Km de estrada - 16.1

- Contando que a linha férrea da Fepasa tinha 5 mil Km - 24.2

Sendo muito organizada

- Relatando que a Sorocabana era um exemplo de organização - 12.2

- Enfatizando que a ferrovia funcionava que era uma maravilha - 12.10

- Referindo que a ferrovia entregava tudo certinho, até a casa da pessoas -19.4

- Referindo que a ferrovia funcionava muito bem - 19.4 
- Contando que se passageiro tentasse embarcar sem passagem pagava multa -21.2

- Lembrando que os trens não podiam atrasar - 22.2

- Lembrando se os trens atrasassem tinha que justificar o porque e transmitir para a seção de movimento -22.2

- Lembrando ser rigoroso o controle de mercadorias - 23.5

- Podendo falar com o movimento através de telefones nas cabinas nas estradas e saídas de pátio 24.3

- Lembrando que o conferencista conferia as mercadorias e as pessoas iam retirar na estação ou tinha serviço rodoviário de entrega domiciliar - 11.1

- Achando bom o serviço da ferrovia porque era tudo organizado pro escala- 23.2

- Contando que o dinheiro arrecadado em cada estação era levado para uma espécie de cofre e depois para SP- 12.10

- Havendo concorrência para ver quem construiriam a linha férrea pelo menor valor - 24.7

- Lembrando que o bom empregado era respeitado e a administração conhecia.-12.2

- Revelando que o mau empregado em todas as repartições aparecia - 12.2

- Lembrando que o ferroviário tinha que ser bom de serviço - 12.2

- Lembrando que o mal ferroviário era removido para Jupiá e Santo Anastácio, ninguém gostava de lá (tinha muito pernilongo) - 12.16

- Revelando que o mal funcionário na Sorocabana era duro de subir na profissão, ficava parado 16.2

Tendo grande frota de máquinas

- Contando que existiam 150 máquinas a vapor em Botucatu - 30.9

Estabelecendo sistema de saúde

- Lembrando que os ferroviários ajudaram a construir o hospital sorocabana pagando mensalidade $-8.8$

- Revelando que tinham parteiras famosíssimas em Botucatu - 13.5

- Lembrando que Ademar de Barros construiu o Centro de Saúde na Avenida Santana - 8.8

- Lembrando que os ferroviários tinham atendimento médico no Posto médico (dr. Jorge, Arnaldo, João Reis) -10.3

- Revelando que Dr. João Reis dava licença médica para quem pedisse - 10.3

- Lembrando que o posto médico era em anexo a farmácia - 13.2

- Contando que no posto médico da ferrovia tinham 3 médicos - 13.2

- Revelando que na farmácia só poderia retirar o medicamento com receita médica - 13.2

- Lembrando que a farmácia fazia 700 a 800 faturas/mês - 13.2

- Revelando que a farmácia não podia atender fora de horário - 13.2

- Revelando que quando a farmácia da Sorocabana estava fechada haviam duas outras farmácias que recebiam as receitas da Sorocabana -13.2

- Lembrando que após a construção e funcionamento do hospital a farmácia foi fechada - 13.2

- Lembrando que o médico ia até a casa do ferroviário quando precisava - 13.5

- Lembrando que se o médico não tivesse carro o paciente tinha que mandar um buscá-lo - 13.5

- Lembrando que quando era uma parturiente pedia para o trem trazê-la para Botucatu - 13.5

- Referindo que a assistência médica naquela época era boa - 13.5

- Avaliando como tendo muito bons médicos em SP - 29.4

- Revelando que quando tinham atendimento médico através da caixa de aposentadoria era bom 30.12

- Lembrando que depois passou a ser IAPEFESP e depois INSP e ai virou bagunça - 30.12

Ferrovia funcionando intensamente dia e noite

- relembrando que a estação ficava cheia de gente o dia todo - 1

- Relembrando que saiam 40 locomotivas por dia - 6.1

- Revelando que existiam 36 locomotivas em Botucatu - 6.1

- Lembrando que tinham 5 locomotivas de passageiros com 10 vagões - 6.4

- Lembrando que as locomotivas de carga transportavam 30 a 40 vagões - 6.4

- Lembrando que quando era a hora do trem chegar a estação ficava cheia de pessoas - 10.7

- Lembrando que eram doze carros de passageiros para SP super lotados - 12.3

- Lembrando que se não fizesse a reserva da cabina para SP com oito dias de antecedência não conseguia vaga -12.3

- Dizendo que no final do ano aumentavam os números de carros de passageiros - 12.3 
- Lembrando que para despachar mercadoria também precisava fazer o pedido com antecedência 12.3

- Lembrando que se via uma pessoa a noite andando com uma malinha era porque ia trabalhar na ferrovia - 12.9

- Lembrando que tinha bastante movimento aqui na ferrovia - 14.1

- Lembrando que a ferrovia funcionava 24 horas - 14.1

- Lembrando que a Sorocabana trabalhava 24 horas -17.6

- Lembrando que os trens foram ficando super lotados, levando 15, 20 carros - 17.8

- Contando que tinham 12 trens de passageiro de Botucatu para SP -23.2

- Dizendo que havia muita circulação de trem dia e noite -23.3

- Revelando que a estação tinha muito movimento e era muito bonita - 29.3

- Revelando que iam 3 trens de passageiros diariamente lotados para São Paulo - 29.3

- Dizendo ser uma beleza, uma maravilha o movimento da ferrovia - 30.4

- Lembrando que o movimento da estação era bem grande - 30.6

- Lembrando que o movimento na estação era muito grande - 30.7

- Lembrando que o serviço era 24 horas - 8.4

Apresentando boa infra estrutura e boas escolas em Botucatu

- Revelando que existiam duas companhias elétricas em Botucatu, a do Bacchi e da Eletro Paulo 8.9

- Lembrando que fizeram a primeira usina hidrelétrica aqui em Botucatu - 17.6

- Lembrando que em Botucatu havia a companhia de eletricidade do Bacchi, que atendia as casas, e a companhia paulista que atendia os potes das ruas - 17.6

- Lembrando que a luz elétrica chegou em Botucatu em 1907 - 17.16

- Contando que Botucatu tinha duas companhias de luz, para as casas era do Blasi e para as ruas uma companhia contratada pela prefeitura - 29.3

- Classificando Botucatu como uma cidade fabulosa - 13.4

- Lembrando do lema de Botucatu: “cidade dos bons ares e das boas escolas” - 13.4

- Achando que hoje a cidade esta bem cuidada porque o prefeito é muito bom- 29.2

- Lembrando que as pessoas que estudavam aqui eram bem respeitas nos demais municípios - 13.4

- Contando que vinham estudantes de várias regiões estudar em Botucatu ( Mato Grosso, Alta Sorocabana - 24.4

- Contando que os estudantes moravam nas escolas - 24.4

- Tendo bons cursos em Botucatu - 24.4

- Contando que Botucatu era famosa pelos cursos que tinham aqui - 24.4

- Contando que Botucatu tinha escolas famosas, mas que foram saindo daqui - 24.4

- Lembrando que Botucatu tinha boas escolas - 29.1

- Contando que teve um engenheiro que projetou e planejou a cidade de Botucatu - 24.5

- Referindo que a água de Botucatu sempre foi boa - 8.9

- Lembrando que a água sempre foi boa em Botucatu - 8.6

- Acreditando que a água de Botucatu é a melhor - 15.8

- Lembrando que o Emílio Pedutti fez uma grande caixa d água para Botucatu - 8.6

- Dizendo que a água para abastecer a cidade vinha do Rio Pardo - 15.5

- Lembrando que as caixas dágua ficavam num local mais alto - 15.5

- Acreditando que existia um poço artesiano para abastecer o bairro - 15.5

Gerando muitos empregos e renda

- Lembrando que só na estação tinham uns 200 funcionários - 2

- Lembrando que entre o pessoal do depósito e da carreira eram uns 300 homens - 4.1

- Revelando que quando se criou o serviço de recursos humanos criaram-se muitos cargos na ferrovia -6.3

- Lembrando que a Sorocabana tinha uns 4 mil funcionários - 6.5

- Lembrando que tinha muito ferroviário e todos empregados em Botucatu - 13.3

- Contando que na Sorocabana, da Barra funda até porto Epitácio, tinham 18 mil funcionários, em $1941-14.1$

- Relatando que a Sorocabana em 1960 tinha 22 mil funcionários - 16.1

- Lembrando que a Sorocabana tinha 22 mil empregados - 17.5

- Lembrando que deviam ter uns 3 mil e poucos funcionários na Superintendência de Botucatu 23.2

- Revelando que a Sorocabana era o rei do emprego no Estado de São Paulo - 28.2 
- Contando que quase Botucatu toda trabalhava para a ferrovia- 254.11

- Lembrando que na seção de escritório haviam uns 15 a 20 funcionários - 9.2

- Ouvindo dizer que parte da arrecadação da ferrovia ia para pagar o professorado e a polícia do Estado - 12.10

- Revelando que a ferrovia dava uma verba anual para a polícia e o professorado do Estado - 22.3

- Enfatizando que a ferrovia rendia muito - 12.10

- Referindo que a ferrovia não dava prejuízo, pois tinha frete mais barato - 19.4

- Avaliando que a ferrovia dá lucro-23.6

- Revelando que a ferrovia dava muito lucro - 24.9

- Revelando que o trem de carga é que dava lucro - 25.11

- Relembrando que a ferrovia dava lucro naquele tempo - 28.1

- Dizendo que as pessoas faziam 14 anos e já iam trabalhar na Sorocabana - 13.3

- Lembrando que os filhos acabavam o normal e os pais desejavam que eles fossem trabalhar na Sorocabana ou ser professor primário (as mulheres) - 13.3

- Lembrando que a Sorocabana foi a primeira empresa a dar muitos empregos em Botucatu - 17.7

- Lembrando que depois da Sorocabana veio a FCMBB, a Duratex - 17.7

- Dizendo que todo mundo tinha trabalho na cidade - 29.3

- Comparando que hoje Botucatu tem poucos locais que empregam -25.11

- Lembrando que existiam muitas pessoas formadas, com nível superior, na Sorocabana - 13.4

Sendo um centro cultural, comercial e industrial

- tendo divertimento em Botucatu, como os bailes - 2.2

- Avaliando Botucatu como a capital do cinema -2.2

- Lembrando que não tinha muito divertimento - 2.5

- Relatando que todo Sábado tinha baile com sanfoneiro na Fazenda - 10.3

- Lembrando que o Emílio Pedutti tinha cinema em 25 cidades, Paraná, SP, Mato grosso - 17.5

- Contando que Botucatu tinha 3 cinemas enormes - 24.5

- Lembrando que em Botucatu tinham três cinemas: Cassino, Pavilhão e Glória - 29.2

- Lembrando que a praça central da cidade era muito bonita, cheia de árvores e bancos - 29.2

- ferrovia como centro distribuidor de filmes - 2.2

- Botucatu mandando filmes para todo o ESP e Mato grosso - 2.2

- Referindo que o comércio da cidade era bom naquela época - 5.3

- Lembrando que Petrarca Bacchi tinha fábrica de cerveja, guaraná, macarrão, bolacha, chapéu, serraria, vaca leitera -9.4

- Lembrando que em Botucatu tinham duas serralherias - 9.5

- Revelando que o Bacchi foi o primeiro capitalista daqui: fábrica de chapéu, serraria, fábrica de macarrão, de descaroçar algodão, a luz - 17.7

- Relembrando que Botucatu teve fábrica de cerveja, guaraná, chapéu, tecido e três serrarias, máquina de algodão, fábrica de bolacha, de macarrão, de balas - 25.11

- Comparando os Blasi com o Matarazzo, pois tinha máquinas de beneficiar café e exportavam 29.3

- Revelando que os produtos em Botucatu eram caros, então as pessoas iam comprar em Bauru 11.2

- Revelando que o que estragou Botucatu foram alguns italianos que não deixavam as indústrias virem para cá - 29.1

- Lembrando que o passeio era ir a estação ferroviária - 13.5

- Referindo que na chegada de trens de passageiro o movimento aumentava, pois em todas as cidades os moços e moças iam lá passear - 30.6

- Referindo que Botucatu foi uma cidade muito importante e ainda é - 17.16

Quadro 37. Categoria F2 - Relembrando o trabalho desenvolvido na ferrovia: subcategorias e códigos.

\section{RELEMBRANDO O TRABALHO DESENVOLVIDO NA FERROVIA}

\section{Sendo sofrida a vida do ferroviário}

- Avaliando que ser ferroviário não era tão bom, pois trabalhava muitas horas seguidas - 1

- Avaliando que ser ferroviário não era tão bom, pois muitas vezes passava fome ou tinha que comer comida estragada -1

- Avaliando que ser ferroviário não era tão bom, pois só dormia 5 noites por mês em casa - 1 
- Dizendo que sofria um pouco na ferrovia pois tinha que trabalhar a note, no frio, na chuva - 22.2

- Passando fome na locomotiva, ficando 10 a 12 horas sem comer - 25.7

- Reclamando que a vida na Sorocabana era sofrida, pois trabalhava de dia e de noite - 28.2

- Lembrando que o ferroviário sofria muito - 15.9

Não tendo descanso para o almoço

- Revelando que não tinha hora descanso para almoçar, retirava a comida na cidade ou no outro trem de passageiro que a esposa mandara a comida e ia comendo e andando - 5.6

- Revelando que também não paravam para almoçar - 10.2

- Lembrando que não tinha tempo para parar e comer - 10.6

Ficando longe de casa

- Chegando a ficar três meses fora de casa -19.2

- Morando em república com uns 20 homens da Sorocabana - 19.2

- Contando que alugavam casa e ficavam trabalhando em ouros lugares 19.2

- Contando que havia cozinheiro -19.2

Sendo a jornada de trabalho enorme

- Lembrando que em um mês trabalhou mais de 400 horas - 5.5

- Lembrando que fazia viagens com a locomotiva a vapor que demorava 24, 30 horas sem parar 5.6

- Avaliando o trabalho como pesado, pois entrava as 15:00 e saía as 7:00h - 6.2

- Lembrando que trabalhava a noite toda e só dava tempo de tomar um café e já voltava ao trabalho $-6.2$

- Revelando que sempre trabalhava mais que 30 horas direto - 8.4

- Revelando que trabalhava dia e noite - 10.1

- Revelando que trabalhava 20 a 25 horas - 10.1

- Revelando que trabalhava direto sem dormir, 2025 horas - 10.2

- Referindo que no trem de carga ficava mais horas trabalhando que no de passageiro - 21.3

- Referindo que o trem de passageiro tinha hora de sair e de chegar e o de carga não - 21.3

- Lembrando que existia o X50 , onde anotava as horas trabalhadas - 21.3

- Trabalhando 44 horas seguidas - 24.2

- Avaliando como sofrido por ter que trabalhar a noite toda, longas jornadas - 27.3

Trabalhando por escala e perdendo datas comemorativas com a família

- Referindo que ferroviário tinha que trabalhar na escala, chovendo, frio, de madrugada, estava escalado tinha que ir -5.2

- Revelando que trabalhava o ano todo sem ter natal ou outras datas comemorativas - 11.1

- Lembrando que trabalhava por escala, então um dia trabalhava de daí e o outro a noite - 11.1

- Relembrando que a mulher acabava passando Natal e dia de Ano sozinha com os filhos, pois estava trabalhando por escala - 12.7

- Lembrando que levantava de madrugada par ir trabalhar por escala - 21.3

Ficando a disposição do serviço

- Relembrando que trabalhava dia e noite na ferrovia, podendo ser chamado a qualquer hora pelo telefone que ficava na beira da cama - 3.2

- Relatando que o pessoal da carreira não tinha hora e nem dia para trabalhar - 5.5

- Relatando que existia um chamador que ia até as casas dos maquinistas avisar a respeito da hora que teriam que ir trabalhar - 5.5

- Lembrando que existia o chamador que ia na casa dos maquinistas chamar duas horas antes do trem sair- 12.11

Trabalhando com muito barulho

- Lembrando-se que na locomotiva fazia muito barulho que incomodava (do compressor) - 10.3

Recendo auxílio das mulheres na alimentação

- Relatando que as mulheres mandavam a comida por um outro trem de passageiro - 5.5

- Valorizando o papel das esposas que auxiliaram os ferroviários no trabalho - 5.5

- Lembrando que a esposa levantava de madrugada para fazer a comida para ser levada no trabalho $-5.6$

- Lembrando que levava a marmita pronta feita pela esposa para poder jantar - 6.3

- Lembrando que levava a comida de casa logo cedo - 10.6

- Revelando que a mulher do ferroviário sofreu barbaridade,pois tinha que acordar de madrugada para fazer comida e leva-la -12.6 
- Revelando que as mulheres de Botucatu também prestavam serviço para a ferrovia, como lavando roupas, e até os filhos pequenos ajudavam - 12.7

Sendo difícil e trabalhoso o serviço

- Revelando que tinha serviço pesado (na linha, trabalhadores de lenha, cortador, manobrador) 17.6

- Avaliando como muito bom o tempo anterior, embora trabalhoso - 4.3

- Trabalhando muito na época da ferrovia - 23.4

- Avaliando o trabalho como difícil - 5.2

- Relatando que a profissão de chamador era difícil, pois andavam a cidade toda de madrugada a pé ou de bicicleta -5.5

- Relembrando que era muito trabalhoso trabalhar com a locomotiva a vapor, pois a lenha tinha ser distribuída de forma homogênea senão não produzia vapor suficiente - 5.6

- Revelando que ficava o dia todo para manobrar os vagões e montar os trens para os seus destinos $-5.7$

- Lembrando que para vir de Manduri para Botucatu existia um trecho que era muito difícil (serra)12.8

- Revelando que era muito mais difícil ser maquinista da máquina a vapor - 12.12

- Dizendo não ser fácil trabalhar na ferrovia - 14.1

- Achando difícil baldear as pessoas de carros de passageiros quando tinha trecho interrompido 24.3

- Revelando que os tatus de turma e o foguista desempenhavam um serviço muito difícil - 30.11

- Comparando que era mais difícil de lidar com a locomotiva a vapor por ser mais complicada 16.4

- Avaliando o tempo anterior como difícil - 6.1

- Revelando que tinha muito trabalho e que todo os dias fazia hora extra para adiantar o serviço 7.2

- Lembrando que se trabalhava muito, o de carreira de locomotivas, o trabalhador de turma - 12.7

- Dizendo que o serviço era bem puxado - 14.1

- Dizendo que os ferroviários padeciam, principalmente o foguista - 18.7

- Revelando que o dinheiro que ganhavam era muito bem ganho, a custa de muito trabalho - 30.11

- Lembrando que muitos trabalharam direto sem folga até se efetivarem durantes meses ou 1 ano 12.6

Exigindo muita responsabilidade e treinamento

- Lembrando que o ferroviário tinha que trabalhar corretamente, principalmente no trem de passageiro que não podia atrasar senão recebiam multa ou suspensão- 5.2

- Revelando que o maquinista não podia atrasar de jeito nenhum - 12.5

- Revelando que o trabalho na Sorocabana era rigoroso - 12.6

- Lembrando que o ferroviário não podia atrasar um minuto, se não tinha que pagar multa e suspensão - 12.14

- Contando se atrasasse 2,3 minutos tinha que justificar e fazer boletim de ocorrência que era julgado pela diretoria - 18.6

- Lembrando que havia censura, multa ou suspensão conforme a infração que cometiam no trabalho - 30.11

- Revelando que não se devia passar nenhum sinal a perigo senão era multado - 16.3

- Lembrando que o maquinista tinha muita responsabilidade - 16.3

- Revelando que se o maquinista tinha que respeitar os sinais senão era multado e/ou suspenso 16.3

- Lembrando que no depósito haviam várias funções: torneiro mecânico, ajustador ferreiro, carpinteiro -7.2

- Revelando que o maquinista tinha que ter muita atenção no seu trabalho, na máquina - 10.2

- Tinha que ter muita experiência para ser maquinista - 12.12

- Tinha que conhecer muito bem o trecho que seria percorrido (subidas, curvas, retas) -12.12

- Lembrando que existia um mestre que saia junto com o maquinista novo, ensinando como fazer 12.12

- Lembrando que quem ensinava o foguista era o próprio maquinista -12.12

- Contando que tinha que fazer dois anos de escola de telégrafo aqui em Botucatu para seguir a carreira -18.2

- Lembrando que era muito fácil aprender as funções, era só querer - 14.2 
Quadro 38. Categoria F3 - Sendo a ferrovia importante para o progresso: subcategorias, elementos e códigos.

\begin{tabular}{|l} 
SENDO A FERROVIA IMPORTANTE PARA O PROGRESSO \\
- Referindo que o Mundo viveu em torno da ferrovia - 17.8 \\
- Achando que trabalhar na ferrovia dava para sentir o progresso - 22.2 \\
Promovendo crescimento dos locais por onde passava a ferrovia \\
- Comparando a ferrovia com estrada de rodagem: onde a ferrovia passa deixa rastro (crescimento), \\
a rodovia não - $20.2 / 3$ \\
- Referindo que a ferrovia deixou muita coisa, muito progresso - 20.3 \\
- Revelando que a alta sorocabana e o resto paulista cresceram a custo da ferrovia - 20.3 \\
- Lembrando que todas as ferrovias passaram no centro, ou seja, o centro das cidades se \\
desenvolveram em torno da ferrovia - 20.3 \\
- Referindo que a ferrovia foi a razão do grande progresso da alta Sorocabana, da Paulista, da \\
- Noroeste - 20.3 \\
- Referindo que a ferrovia traz progresso - 20.4 \\
- Revelando que em todo lugar importante a ferrovia chegou antes - 20.4 \\
- Relacionando o crescimento e desenvolvimento do Estado por conta da ferrovia - 30.14 \\
- Lembrando que o Paraná se desenvolveu graças a ferrovia - 20.3
\end{tabular}

\section{Sendo importante meio de transporte de pessoas e mercadorias}

- Relembrando que na época não existia caminhão e tudo era transportado pela ferrovia: gado, porco, madeira, tudo -4.3

- Lembrando que transportavam milho, café, açúcar, mandioca, gado que iam para São Paulo -6.4

- Lembrando que todo o transporte de mercadorias e passageiros era feito pela ferrovia, pois não existia caminhão -7.2

- Lembrando que a ferrovia até chegou a fornecer pedra britada de uma pedreira de Lençóis Paulista- 7.2

- Revelando que transportavam soja, muita madeira e gado - 10.3

- Lembrando que muitas gaiolas de gado eram levadas para Osasco e depois transportadas - 10.3

- Lembrando que transportavam todos os tipos de mercadorias nos trens - 11.1

- Lembrando-se que existia um trem só de primeira classe de São Paulo a Araçatuba - 11.1

- Revelando que em Rejente Feijó carregava muito boi, sendo em 1948 embarcaram 10 mil cabeças. -12.4

- Lembrando que o Ouro verde era o trem de Luxo para passageiros - 12.4

- Dizendo que o Ouro Branco era um trem de Luxo para passageiros e só fazia SP Bauru - 12.5

- Lembrando que no Ouro Branco só viajou gente rica - 12.5

- Lembrando que transportavam também cobras para o Butantã - 12.10

- Referindo que a ferrovia despachava muita mercadoria - 17.8

- Contando que a ferrovia transportava gasolina, óleo diesel e óleo de queimante em tanques - 19.3

- Referindo que o combustível ia para o Paraná, para a alta Sorocabana, para Bauru, de lá Três lagoas -19.4

- Cotando que tudo vinha pela ferrovia - 20.2

- Referindo que o armazém ficava super lotado de mercadorias - 20.2

- Revelando que as ferrovias eram o principal meio de transporte do Estado -20.2

- Lembrando que transportavam café, soja, cereais, madeira, gado -20.3

- Contando que a ferrovia transportava de tudo - 22.1

- Referindo que na ferrovia transportava de tudo: suíno, madeira, boi, cereais - 22.3

- Contando que transportava muito café e açúcar - 23.4

- Contando que no começo transportavam muito gado - 24.10

- Vendo o gado ficar judiado, 2 a 3 dias viajando sem beber água, caindo e as vezes até morrendo 24.10

- Lembrando que separavam as mercadorias e entregavam com o caminhão na casa das pessoas25.3

- Lembrando que a ferrovia transportava: tecidos, vidrarias, cerveja, sal - 25.6

- Contando que vinham 20 a 30 gaiolas de bois em cada locomotiva e 30 a 40 gôndolas de toras de madeira - 25.11

- Lembrando que a ferrovia transportava milho pra fabricar maisena, areia - 25.11 
- Referindo que na ferrovia transportava: arroz, feijão, milho, soja, semente de girassol, ferragem, cimento, cal, soda caústica -27.4

- Lembrando que levavam 150 passageiros para SP - 10.3

- Contando que a ferrovia foi implantada para escoar a produção de café até o porto, todo o seu traçado -24.6

Importando e exportando

- Contando que a ferrovia importava e exportava para qualquer município - 22.1

- Referindo que não deixavam malandro entrar na cidade, o delegado mandava pra outro lugar 29.3

Tendo grande capacidade para transporte

- Lembrando que uma locomotiva de Ourinhos a Porto Epitácio levava mil toneladas - 12.17

- Comparando que precisariam de 200 caminhões para levar mil toneladas -12.17

- Lembrando que naquele tempo levava 700 toneladas, uns 14 vagões de café - 16.5

- Revelando que hoje uma máquina quer puxar muito mais, uns 100 vagões - 16.5

- Lembrando que na serra ficava tão pesado que tinha que ir outra locomotiva para auxiliar na subida -17.8

- Revelando que a máquina a vapor (1000 a 1022) puxava 500 toneladas e a elétrica 2 mil toneladas $-8.4$

Sendo mais barato

- Sendo a ferrovia o meio de transporte mais barato, depois do fluvial - 24.9

Implementando novas tecnologias

- Lembrando que a locomotiva a diesel veio em 1942 - 16.1

- Lembrando que as locomotivas elétricas vieram em 1952 - 16.1

- Revelando que a Sorocabana conseguiu construir um trem super luxo e que a companhia americana ficou com medo de nossa capacidade-17.7

- Contando que a locomotiva elétrica veio na década de 40 - 19.1

- Lembrando que existiam muitos tipos de trem: de passageiro, de carga, noturno, carro motor, unidades japonesas - 16.5

- Comentando que as unidades japonesas eram um motor e três carros e elas faziam o subúrbio de $\mathrm{SP}-16.5$

- Lembrando que o Ouro Branco era a diesel - 17.8

- Lembrando que o Ouro Branco só transportada gente de posses - 17.8

- Lembrando que Ademar de Barros comprou 20 máquinas elétricas - 28.2

- Lembrando que Ademar de Barros eletrificou primeiro de SP a Sorocaba - 28.2

- Lembrando que a eletrificação de Sp até Botucatu foi feita aos pedaços - 28.2

- Lembrando que primeiro se eletrificou o trecho de São Pualo a Sorocaba, depois a Iperó, Iperó laranjal, Laranjal Botucatu, Botucatu a Manduri. - 8.4

- Lembrando que o Ouro branco era pequeno, 2 carros e 1 restaurante - 30.5

- Lembrando que o Ouro verde era grande, com carro correio, 14 ou 16 carros, dormitório, restaurante -30.5

- Revelando que as locomotivas elétricas mudaram tudo - 8.4

Possibilitando trabalhar com outros países

- Revelando que a rede elétrica foi construída com a ajuda de americanos que já tinham os desenhos -19.1

- Ajudando na construção da rede elétrica de Iperó a Assis - 19.1

- Contando que a subestação em Palmital era suíça - 19.2

- Lembrando que as locomotivas a vapor eram alemãs e americanas - 30.3

Facilitando a comunicação

- Queixando-se que não tinha televisão e rádio não pegava no interior - 2.5

- Revelando que os trens traziam os jornais (Estado de São Paulo, diário de SP, correio paulista) e que tinham pessoas que assinavam ou outros iam até estação comprar - 7.5

- Relatando que a notícia chegava através do telégrafo 9.6

- Avaliando como difícil para a notícia chegar a Botucatu - 9.6

- Referindo que a informação circulava pela ferrovia através do telégrafo - 9.6

- Revelando que não ligavam muito para as notícias - 10.6

- Referindo que o jornal que circulava mais era a "ultima hora" - 10.6

- Referindo que sempre tinha alguém que vendia jornal dentro do trem e que as pessoas ficavam sabendo das informações - 10.6 
- Lembrando-se que as informações eram passadas pelo seletivo (tipo de telégrafo) - 11.5

- Contando que todo o domingo tinha que ir até a estação buscar o jornal para o pai ler- 13.5

- Lembrando que o jornal era trazido pelo trem - 13.5

- Revelando que na ferrovia de sabia de tudo pelo boca a boca - 13.5

- Lembrando que o jornal mais forte era o diário do Estado - 14.6

- Lembrando que na época só tinha radinhos- 14.6

- Lembrando-se que pelo seletivo dava para saber tudo que acontecia daqui até porto Epitácio 14.6

- Revelando que o meio de comunicação na época era o telégrafo - 18.4

- Revelando que para acertar os relógios era através do telégrafo - 18.4

Sendo a ferrovia um bem social

- Referindo que a ferrovia é um bem social, pois transportava passageiros sem dar lucro, o que dava lucro eram as cargas -20.3

- Contando que o trem de passageiro dava prejuízo - 24.9

- Revelando que a firma que fez a privatização cortou logo o trem de passageiros, pois não dava lucro -24.9

- Revelando que o trem de passageiro não foi feito para dar lucro e sim conforto aos passageiros 25.10

- Enfatizando o serviço prestado para a nação pelos ferroviários - 26.7

Organizando movimentos grevistas

- Lembrando que em 63 fizeram uma greve de 18 dias para pedir aumento e não conseguiram 30.15

- Lembrando que as greves eram curtas, 4 a 5 dias pois a ferrovia não podia ficar parada - 30.15

- Revelando que a associação de classe dos ferroviários era bem organizada e controlava as greves $-30.15$

- Lembrando que tinham aumento, mas as vezes tinham que fazer greve para conseguir - 30.10

- Lembrando que haviam algumas greves - 17.11

- Lembrando que a maior greve ficou 15 dias parado, reivindicando que não passasse para uma companhia americana -17.11

- Revelando que durante uma greve estudantil, os ferroviários foram lembrados por serem exemplos de mobilizações em greve -17.14

\section{FENÔMENO 3 - FALTANDO CONTROLE SOCIAL E DO ESTADO}

Quadro 39. Categoria 3.1 - Faltando a conscientização de preservar o meio ambiente e a ferrovia: subcategorias e códigos.

\section{FALTANDO A CONSCIENTIZAÇÃO DE PRESERVAR O MEIO AMBIENTE E A} FERROVIA

- Referindo que antes cortava muito mato, mas as pessoas foram se conscientizando e começaram a plantar os hortos -18.4

- Referindo que só hoje as pessoas vêem como devastaram o nosso país - 20.3

- Referindo que antes nem se pensava na quantidade de madeira retirada - 20.3

- Revelando que antes se cortava e estragava tudo - 6.4

- Associando que se for uma pessoa desleixada ela não se importa com o desmatamento- 5.9

- Associando que se uma pessoa é sensível ela se preocupa com o desmatamento - 5.9

- Criticando as pessoas por jogarem lixo no rio - 1.3

- Criticando que as pessoas que as pessoas jogam lixo nos rios -5.4

- Associando à utilização excessiva de plásticos as enchentes dos rios - 9.4

Não valorizando os recursos naturais e a ferrovia

- Criticando que as pessoas não valorizam tudo o que tem no país e continuam destruindo tudo o que temos -15.6

- Avaliando que não é todo o país que tem tudo que nós temos aqui - 15.6

- Criticando as autoridades que hoje não reconhecem o grande trabalho desenvolvido e sofrido pelos ferroviários - 18.7

- Comparando que todas as ferrovias se desenvolveram no mundo, menos aqui (lembrando que a topografia de certas regiões dificulta) -24.15 
- Comparando que os EUA tem trens lindos - 25.11

Sendo importante a participação social

- Conceituando meio ambiente como a gente tendo que fazê-lo - 26.4

- Achando que se não fizermos nosso meio ambiente nos tornamos inútil na sociedade - 26.4

- Procurando ser útil no ambiente favorável - 26.4

- Achando que cada pessoa deve cuidar de um pedacinho - 18.8

- Procurando preservar o seu meio ambiente para tê-lo sempre em ordem - 25.7

- Associando poluição a culpa das pessoas não ajudarem - 5.9

- Avaliando que o prefeito sozinho não pode resolver o problema da poluição, todos teriam que ajudar -5.9

- Havendo o cooperação de cada um ninguém será sacrificado - 5.9

- Criticando que as pessoas não colaboram - 5.9

- Vendo outro problema na não centralização dos empregados em um só local, como uma empresa, que podem se mobilizar e pressionar a administração - 24.10

- Achando que os ferroviários , engenheiros e principalmente a cúpula deixou as coisas acontecerem desta forma -24.10

Não valendo a pena lutar pelo passado e pela ferrovia

- Descrente que as ações da ferrovia vão dar alguma coisa - 21.2

- Achando que hoje ninguém tem força para recuperar a ferrovia, que não adianta mais - 22.3

- Percebendo que a ferrovia não pode voltar a ser o que era - 30.7

- Observando que a ferrovia não tem mais recuperação - 30.7

- Achando que teria que fazer tudo de novo - 30.7

Gerando a auto-destruição do homem

- Achando que toda esta destruição é prejudicial para a própria humanidade - 15.6

- Colocando que as pessoas estão se destruindo a si próprios - 26.4

- Julgando que a sociedade tem um pouco de culpa nisto, pois não sabem conservar - 5.4

- Dizendo que o homem esta destruindo a natureza - 18.4

- Julgando a humanidade como destruidora das coisas, da natureza - 26.4

- Achando que os homens estragaram muito - 27.8

- Achando que os homens são os próprios culpados de deixarem a natureza assim -27.8

- Homem fazendo muitas coisas ruins contra a natureza, porque ele já é ruim por natureza - 27.12

- Acreditando que a própria população esta acabando com o bom ambiente - 15.6

- Achando que ainda não destruíram o meio ambiente, mas já tiraram muito - 20.4

- Referindo que o comércio destrói tudo - 26.5

- Achando que o homem é quem prejudica a natureza - 1.3

- Achando que a poluição dos rios contamina a água que todos irão beber -1.3

Quadro 40. Categoria 3.2 - Sendo difícil de definir meio ambiente: subcategorias e códigos.

\section{Não sabendo definir o que é meio ambiente}

- Não compreendendo muito - 1.1

- Não compreendendo direito - 4.3

- Justificando que não sabe dizer o que é meio ambiente por ter freqüentado somente 3 anos de escola -7.3

- Não sabendo definir muito bem meio ambiente - 8.5

- Não compreendendo o que é meio ambiente - 11.4

- Dizendo que no momento foge de sua mente o que seja meio ambiente - 13.4

- Não sabendo o que é meio ambiente - 16.6

- Não sabendo o que significa meio ambiente, pedindo para explicar -22.4

- Não sabendo definir o que é - 23.3

- Ficando confuso ao conceituar meio ambiente - 27.6

- Não respondendo sobre a definição de meio ambiente - 29.2

- Não sabendo o que é meio ambiente - 30.8

- Não sabendo defini-lo - 30.8

- Não sabendo nada o que é meio ambiente - 30.9

- Achando difícil definir o que seja meio ambiente - 6.4

- Ouvindo falar muito sobre meio ambiente - 8.5 
- Ouvindo falar em meio ambiente - 30.9

- Achando que meio ambiente é mesma coisa que reforma agrária - 28.3

- Acreditando que existe muitas formas de conceituar meio ambiente - 15.6

- Acreditando que meio ambiente é o que não toma a totalidade da vida das pessoas - 7.3

- Achando que meio ambiente não e mais e nem menos, é a metade 19.4

- Conceituando meio ambiente como algo que não é completo - 27.6

- Achando que deveria ser bom ambiente, não meio ambiente - 15.6

- Achando que meio ambiente é tudo -21.3

- Achando que meio ambiente é o viver da pessoas - 8.5

Sendo o lugar onde se vive e adapta-se

- Questionando sobre o ambiente, a rua, a casa -4.3

- Acreditando que meio ambiente é o lugar - 20.4

- Acreditando que meio ambiente é o lugar onde a gente vive- 20.4

- Conceituando meio ambiente como o lugar onde as pessoas vivem, por exemplo, a casa, o quintal $-25.7$

- Acreditando que a rua também é o meio ambiente e então não deve jogar lixo nela ou na casa do vizinho -25.7

- Acreditando que meio ambiente é onde a gente se adapta com o meio ambiente - 20.4

- Acreditando que meio ambiente é o convívio com as pessoas - 5.3

- Definindo meio ambiente como o convívio com as pessoas - 10.3

- Definindo meio ambiente como o modo de viver - 9.3

- Conceituando meio ambiente como o meio de vida - 12.13

- Conceituando meio ambiente o que esta relacionando com a vida do homem - 24.5

Sendo o ecossistema

- Acreditando que meio ambiente é o ecossistema - 20.4

Podendo ser bom ou ruim

- Conceituando meio ambiente como uma boa coisa - 23.3

- Conceituando meio ambiente como algo que pode ser bom e ruim - 28.3

- Conceituando meio ambiente como algo que pode favorecer ou passar mal -28.3

Sendo o ambiente de trabalho

- Conceituando meio ambiente como o ambiente de serviço - 27.6

Compreendendo através dos componentes bióticos e abióticos

- Acreditando que meio ambiente é o ar, a água, as matas - 20.4

- Conceituando meio ambiente como a relação entre o homem e o ar, terra, mar, água e sol - 24.5

Quadro 41. Categoria 3.3 - Agindo o Estado de forma ineficiente: subcategorias e códigos.

AGINDO O ESTADO DE FORMA INEFICIENTE
Faltando ações de preservação do meio ambiente e da ferrovia por parte do Estado
- Acreditando que não tem como limpar a água corrente - 4.4
- Criticando que os pescadores passam com rede e isto vai diminuindo o número de peixes - 22.5
- Reclamando que não tem pessoas para quem possa reclamar das redes de outros pescadores -
22.5
- Criticando que ninguém resolve a poluição do rio de Botucatu - 4.3
- Achando que deveriam zelar mais pelos rios - 24.8
- Criticando por ninguém tomar providências a respeito da poluição - 8.7
- Criticando que ninguém faz nada para melhorar a poluição - 8.7
- Criticando que o governo não faz nada porque teria que parar os carros que e que eles próprios
não querem parara os seus - 8.7
- Comparando o ambiente com hoje e relatando estar sem cuidados por parte da prefeitura - 1
- Percebendo que hoje a rua esta cheia de mato - 1
- Dizendo que falta cuidado com as matas - 23.4
- Acreditando que a natureza merecia um cuidado melhor - 24.8
- Vendo alguma coisa ser feita pela natureza, mas acreditando que deveria ser muito melhor - 24.8
- Criticando o governo que deve tomar providências sérias a respeito do desmatamento - 5.3
- Achando que deveria ter um governo que insistisse que a ferrovia funcionasse - 24.10
Sendo mais recente a implantação políticas ambientais
- Achando que hoje estão cuidando mais do meio ambiente - 18.8


- Achando que hoje limpam mais as beiras dos córregos - 21.4

- Achando que o ambiente está melhor, com pontes - 21.4

- Achando que o ambiente esta melhor hoje porque tem mais limpeza, até nas ruas - 21.4

- Achando que agora a natureza esta melhor porque as pessoas cuidam mais - 6.4

- Revelado que antigamente não se cuidava da natureza, tudo abandonado - 6.4

- Lembrando que depois veio o IBAMA e começou a controlar os cortes de mata - 17.6

- Referindo que naquela época não existia lei que proibisse cortar árvores -19.3

Tendo corrupção e falta de recursos humanos

- Questionando a respeito do desmatamento que não se vê com facilidade, clandestinos - 5.3

- Referindo que até a Amazônia já teve muitas partes destruídas por homens clandestinos, que roubam - 20.4

- Criticando que temos poucos ficais para controlar este desmatamento e além disto muitos são corruptos -20.4 